SZEGEDI TUDOMÁNYEGYETEM

ÁLLAM- ÉS JOGTUDOMÁNYI

DOKTORI ISKOLA

dr. Nagy Éva

\title{
A VEVÖ-FOGYASZTÓ TRADICIONÁLIS JOGAI INGÓ ADÁSVÉTEL HIBÁS TELJESÍTÉSE ESETÉN
}

\section{PHD ÉRTEKEZÉS}

TÉMAVEZETŐ:

Prof. Dr. Jakab Éva

tanszékvezető egyetemi tanár, DSc.

Szeged

2014 


\section{Tartalomjegyzék}

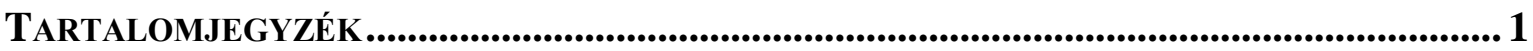

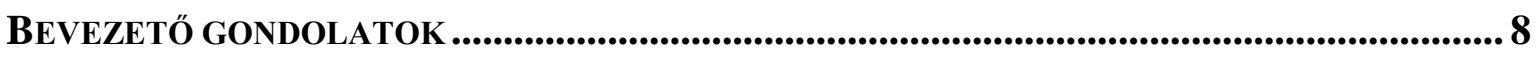

I. RÉSZ: AZ INGÓ ADÁSVÉTEL HIBÁS TELJESÍTÉSÉNEK TÖRTÉNETE ............................... 12

I. AZ INGÓ ADÁSVÉTEL HIBÁS TELJESÍTÉSÉNEK JOGKÖVETKEZMÉNYEI AZ ÓKORI

RÓMÁBAN - KÜLÖNÖS TEKINTETTEL A RABSZOLGÁK ADÁSVÉTELÉRE ............................. 12

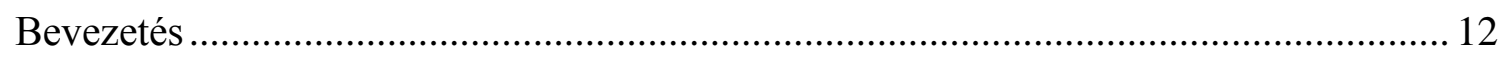

1. Exkurzus: a kellékszavatosság előzményei az archaikus Rómában - a XII táblás

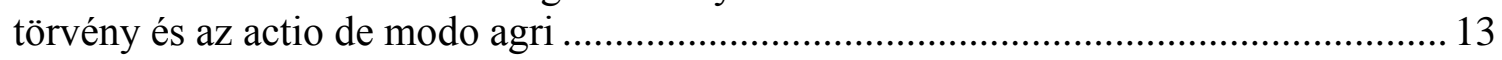

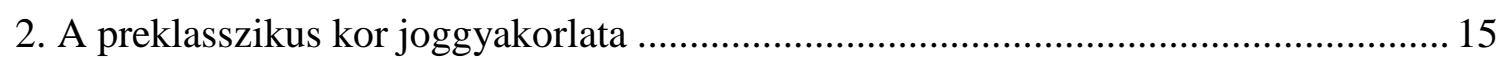

2.1. Az áruforgalom fellendülése - kereskedelmi és piaci szokások ......................... 15

2.2. Eladói garancia-stipulatiók ................................................................................ 17

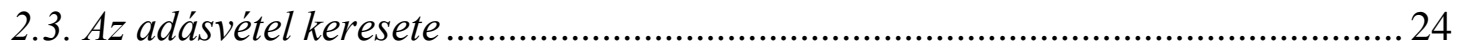

2.4. Az adásvétel különös fajtája: a „próbára vétel "................................................. 25

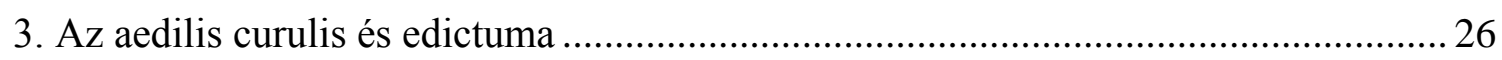

3.1. Az edictum aedilium curulium szerinti kellékhibák rabszolgák adásvétele esetén

3.2. Kellékhibák az igásállatok adásvételénél ......................................................... 32

3.3. Az aediliszi edictum alanyi és területi ,, hatálya" ............................................... 34

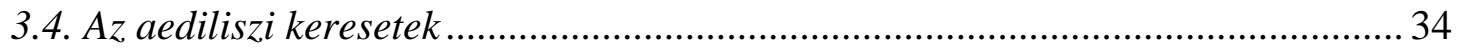

3.4.1. Actio redhibitoria - az elállás keresete ........................................................... 38

3.4.2. Actio quanti minoris - kereset a vételár csökkentése iránt ........................... 40

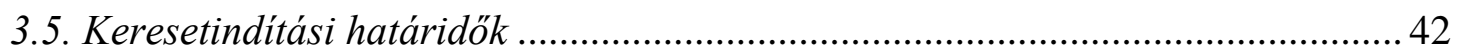

4. Az aediliszi és a praetori jogérvényesítési lehetőség párhuzamossága ...................... 43

5. A hibás teljesítés jogkövetkezményei a posztklasszikus korban................................ 45

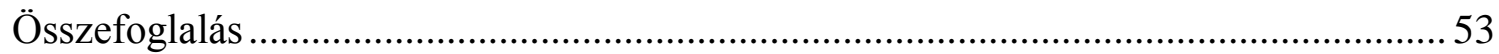

II. Az OSZTRÁK ÉS A NÉMET KODIFIKÁCIÓK A HIBÁS TELJESÍTÉSRŐL - A KORABELI MAGYAR JOGTUDOMÁNY TÜKRÉBEN....................................................................55

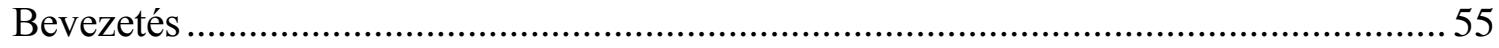

1. Az osztrák Allgemeines Bürgerliches Gesetzbuch szabályai hibás teljesítés esetén .. 56

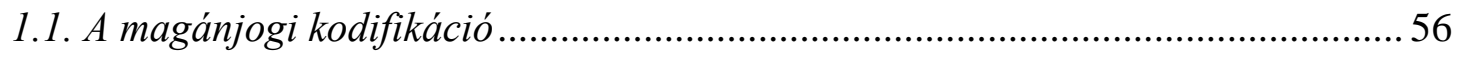

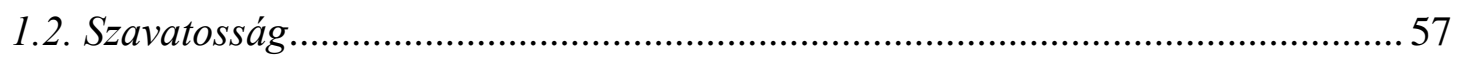

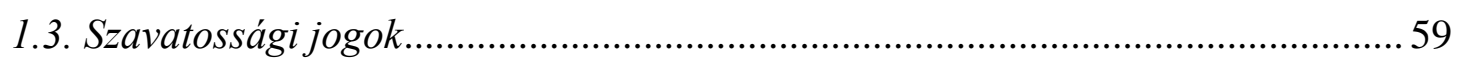

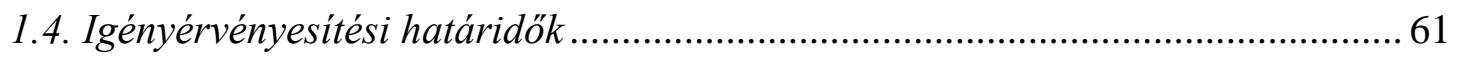

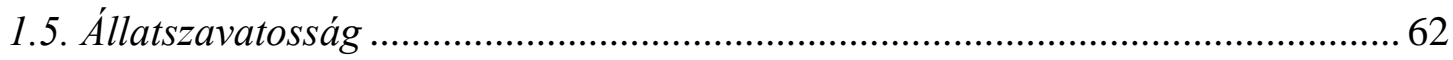

2. A hibás teljesítésre vonatkozó szabályok a német Bürgerliches Gesetzbuchban......... 62

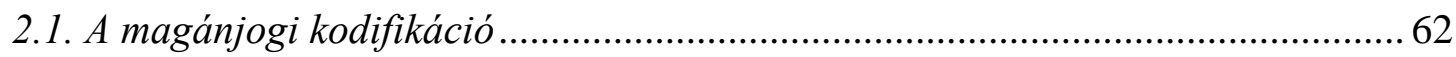




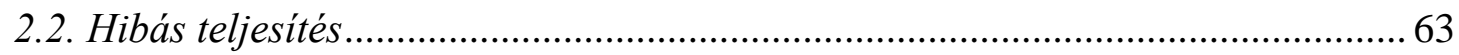

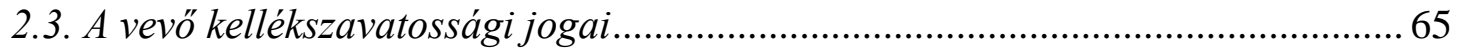

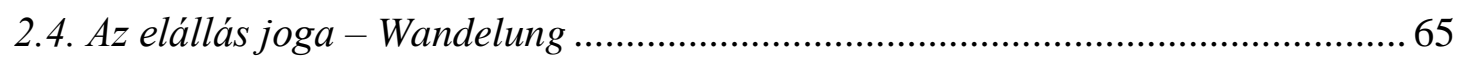

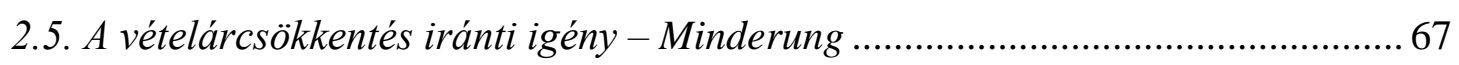

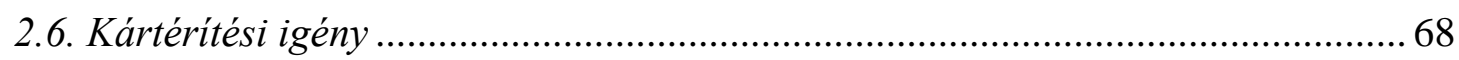

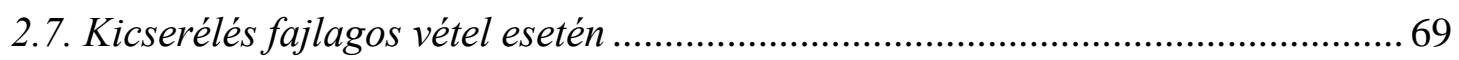

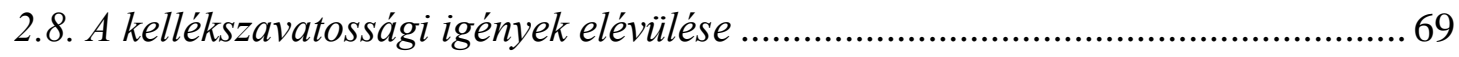

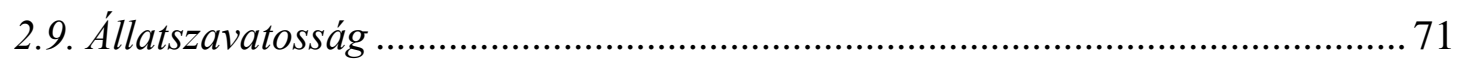

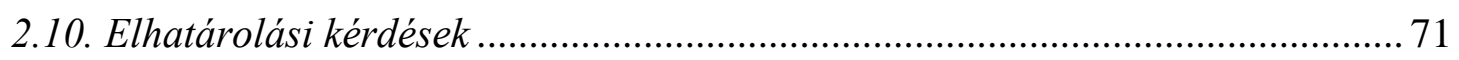

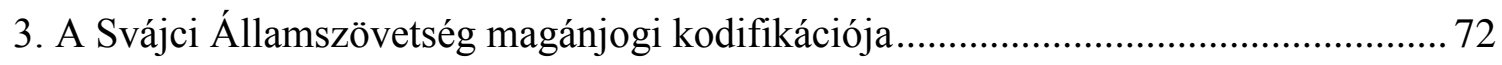

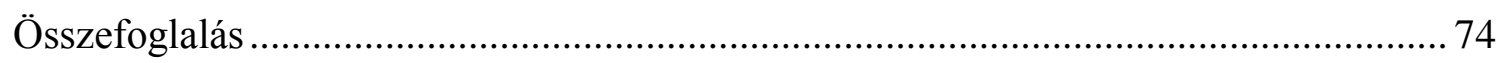

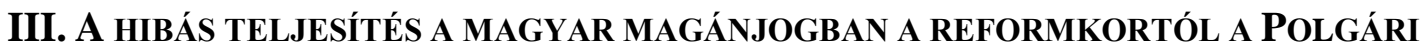

TÖRVÉNYKÖNYV MEGALKOTÁSÁIG ........................................................................... 75

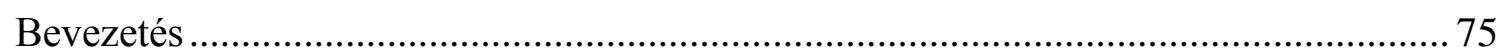

1. A kellékhibás teljesítés a reformkori hazai magánjogban és a jogirodalomban........... 75

2. Kellékszavatosság az 1875-ös Kereskedelmi törvényben és a korabeli

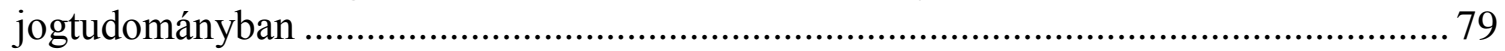

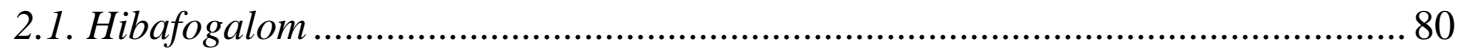

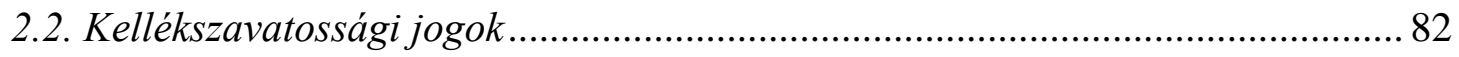

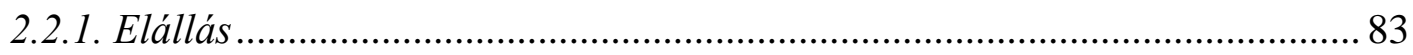

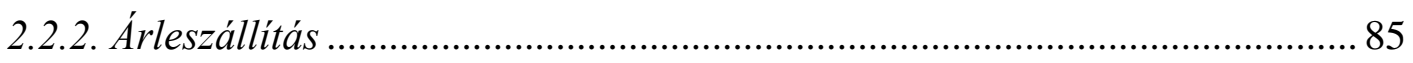

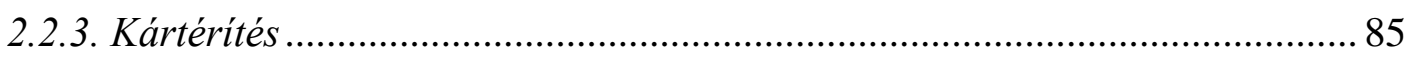

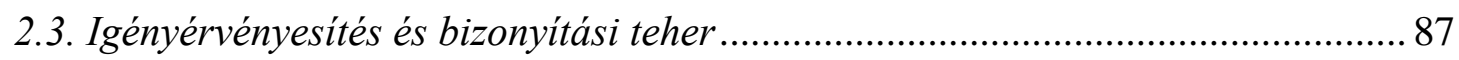

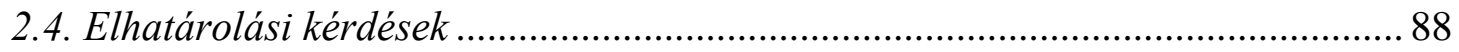

2.5. Hibás teljesités az állatok adásvételénél .......................................................... 90

3. Az ingó dolog adásvételének hibás teljesítése az 1928-as Magánjogi

Törvényjavaslatban és a korabeli jogirodalomban, joggyakorlatban ............................. 93

3.1. Hibás teljesités, kellékszavatosság, hibafogalom .............................................. 94

3.2. A szavatossági helytállás jogalapja és a szabályozás diszpozitiv jellege............. 98

3.3. A vevö tudomása a hibáról ............................................................................. 98

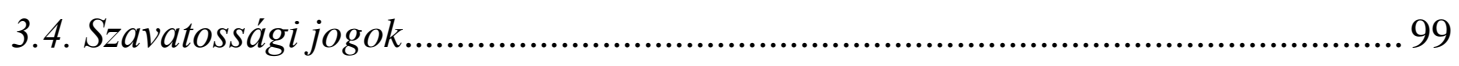

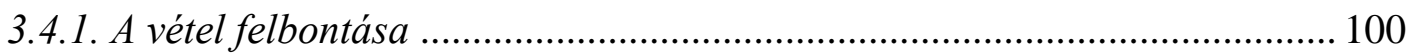

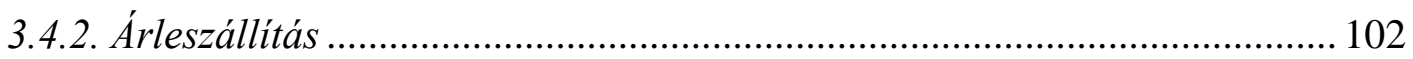

3.4.3. Hiánymentes dolog szolgáltatása fajlagos vétel esetén .............................. 103

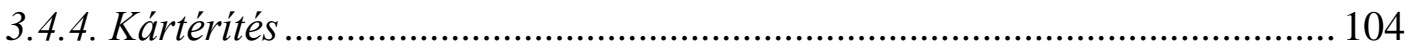

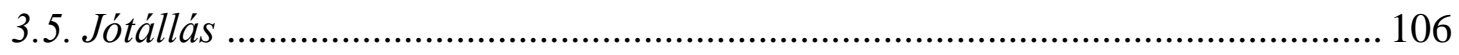

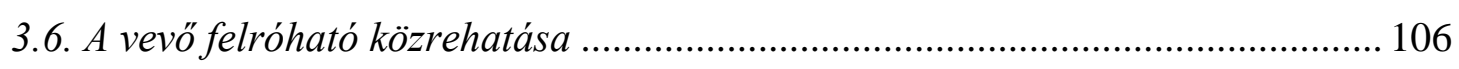

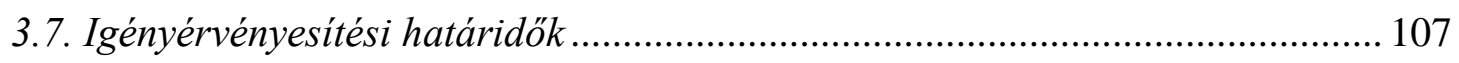




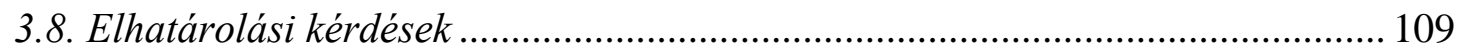

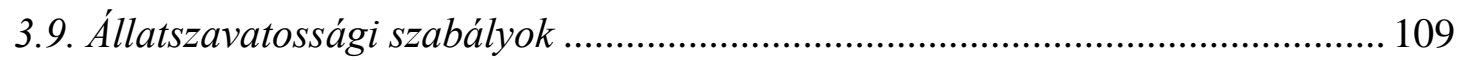

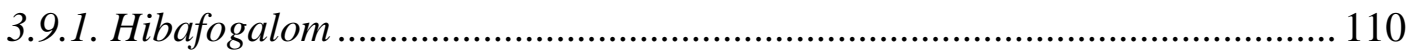

3.9.2. Főbb eltérések az általános szavatossági szabályokhoz képest................... 111

3.10. Exkurzus: „,szédelgö feldicsérés (reklámszédelgés) ”, ..................................... 112

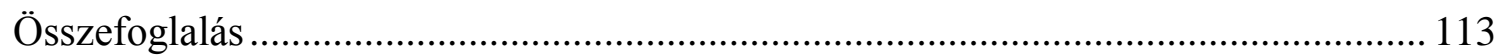

IV. AZ INGó ADÁSVÉTEL HIBÁS TELJESítÉSÉNEK SZABÁlyOZÁSI TÖRTÉNETE A PolgÁRI TÖRVÉNYKÖNYV HATÁLYBA LÉPÉSÉTÖL AZ EZREDFORDULÓIG ..................................... 115

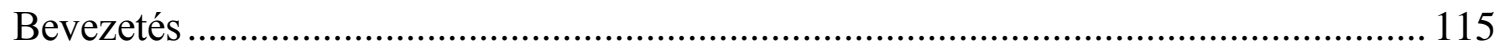

1. Az 1959. évi IV. törvény megalkotásának előzményei ........................................ 115

2. Gazdaság, szerződések és adásvétel a Ptk. megalkotásának idején ......................... 116

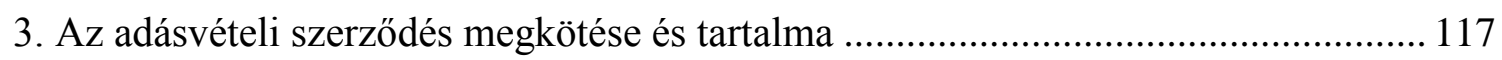

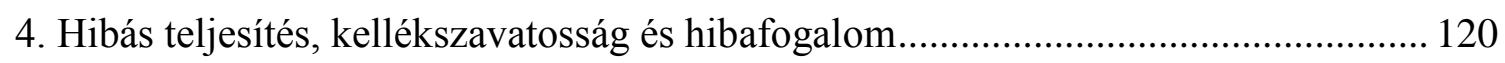

4.1. A védett vagyoni érdek, a szabályozás jogalapja és diszpozitivitása ................. 122

4.2. A vevö tudomása a hibáról ........................................................................... 123

4.3. A hibás teljesités jogkövetkezményei ................................................................ 124

4.3.1. Egyedileg meghatározott dolog szolgáltatása .......................................... 125

4.3.2. Fajta és mennyiség szerint meghatározott dolog szolgáltatása .................. 127

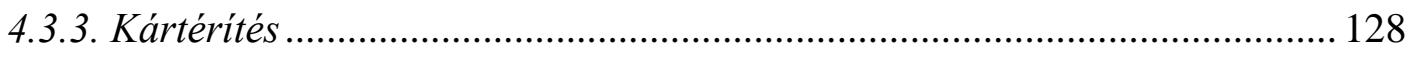

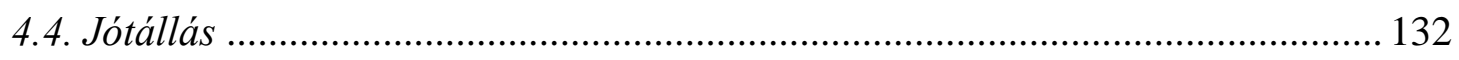

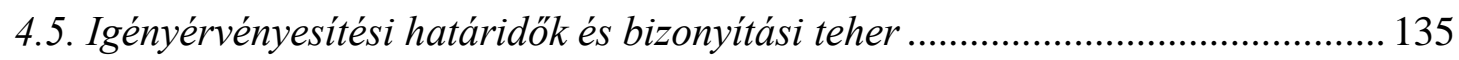

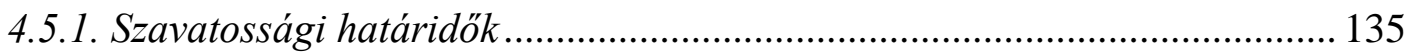

4.5.2. A kártéritési igény érvényesitésének határideje ........................................ 139

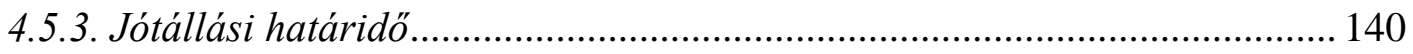

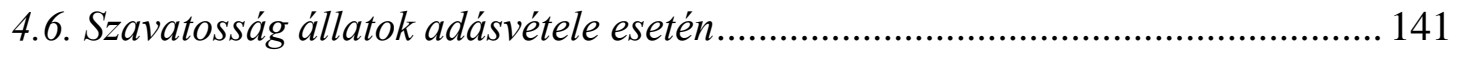

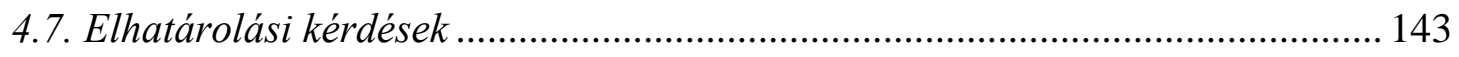

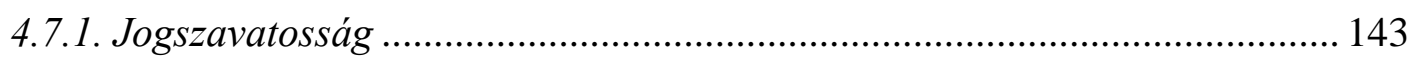

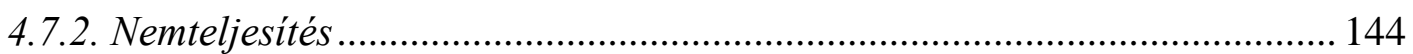

4.7.3. A szerzödés teljesitése alkalmával a jogosult egyéb - nem szerződési érdekeinek sérelme .................................................................................... 145

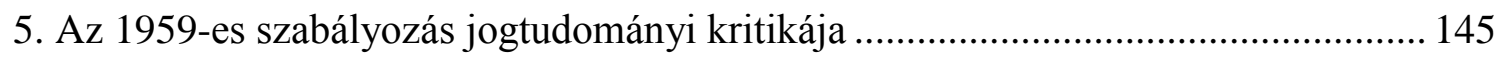

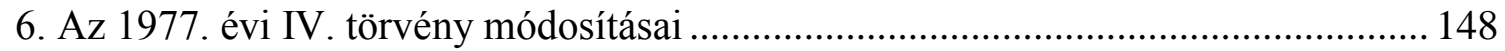

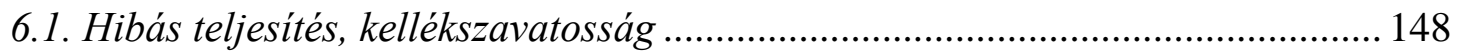

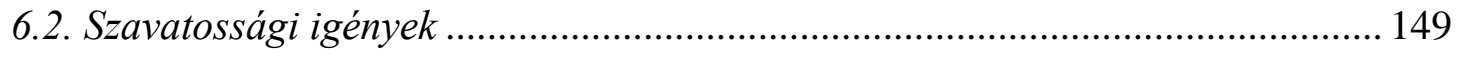

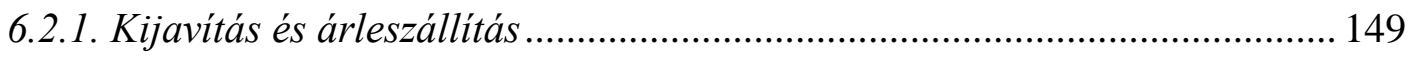

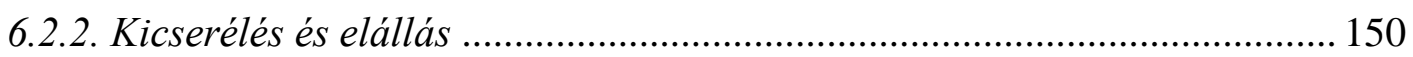

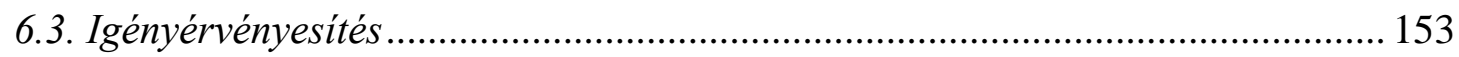

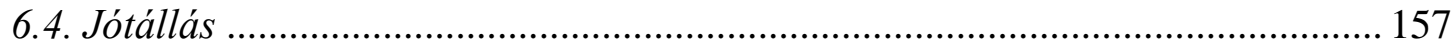




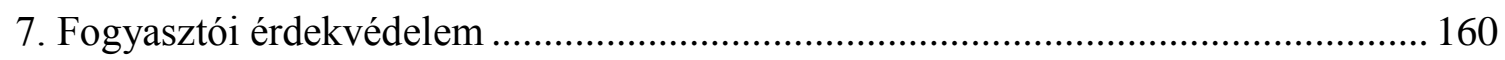

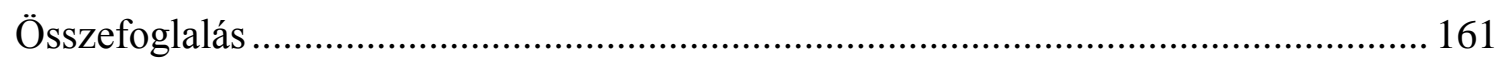

II. RÉSZ: AZ INGÓ ADÁSVÉTEL HIBÁS TELJESÍTÉSE A HATÁLYOS JOGBAN .................... 163

I. FoGYASZTÓVÉDELEM ÉS AZ INGÓ ADÁSVÉTEL HIBÁS TELJESÍTÉSE AZ EURÓPAI UNIÓ

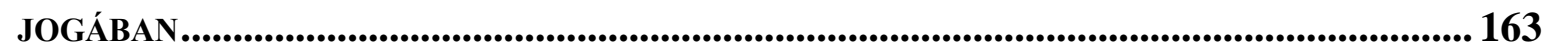

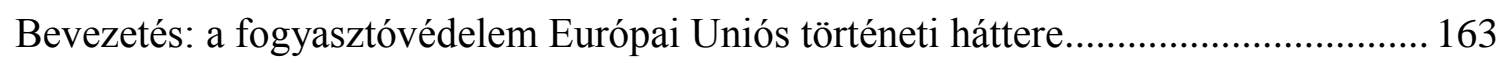

1. Az EU-s fogyasztóvédelem jelenlegi állapota és jellemzői........................................ 166

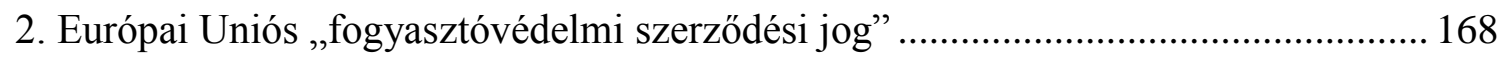

3. A fogyasztó EU-s fogalma és a vele szerződő fél kategóriája ................................ 171

4. Az 1999/44/EK Irányelv a fogyasztási cikkek adásvételének és a kapcsolódó

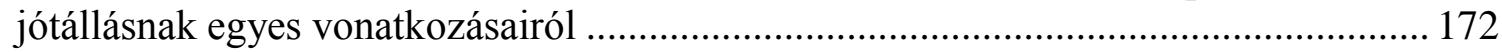

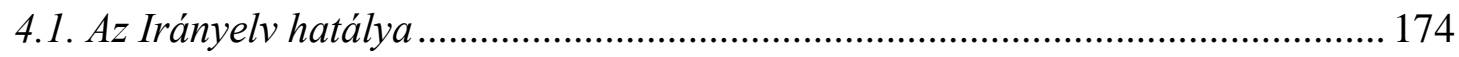

4.2. A védett vagyoni érdek és a jogintézmény jogalapja ........................................ 176

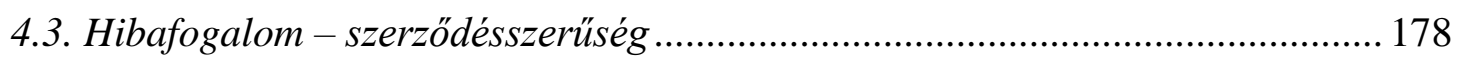

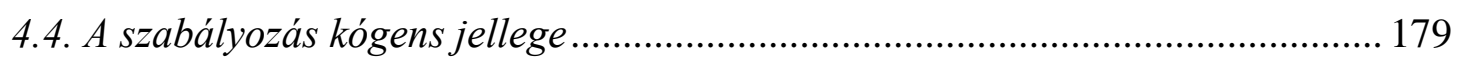

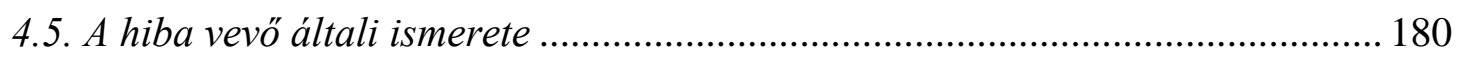

4.6. A hibás teljesitésböl fakadó jogkövetkezmények ........................................... 180

4.6.1. Első lépcső - kijavitás vagy kicserélés iránti igény ................................... 181

4.6.2. Második lépcső - vételárcsökkentés vagy elállás iránti igény .................... 182

4.7. Igényérvényesitési határidök - bizonyitási teher ........................................... 183

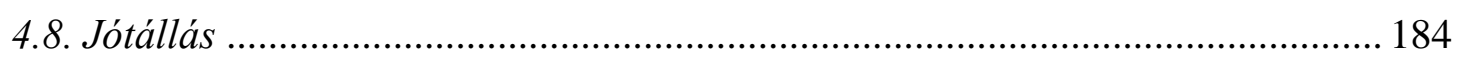

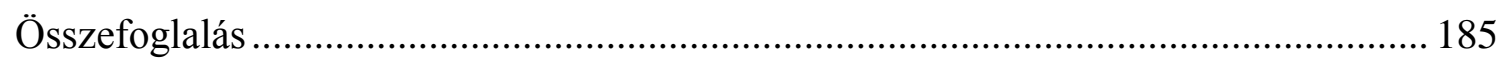

II. AZ INGÓ ADÁSVÉTEL HIBÁS TELJESÍTÉSÉNEK SZABÁLYAI A HATÁLYOS NÉMET,

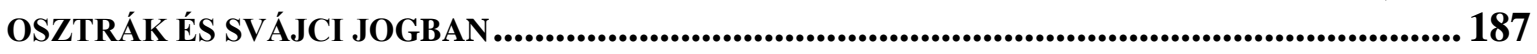

1. Bevezetés: fogyasztóvédelem és az adásvétel hibás teljesítése............................... 187

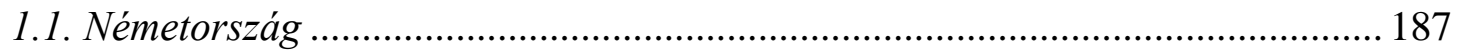

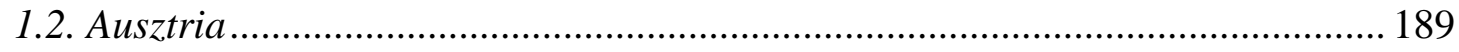

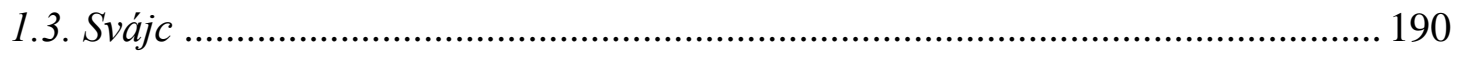

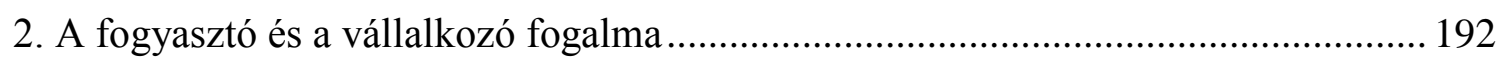

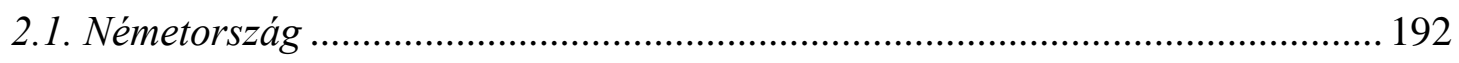

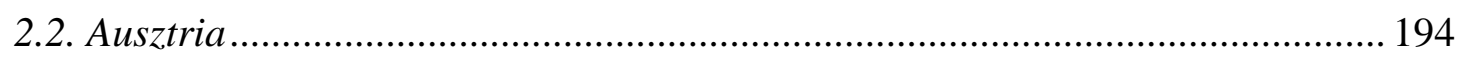

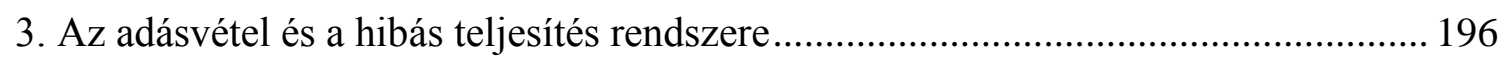

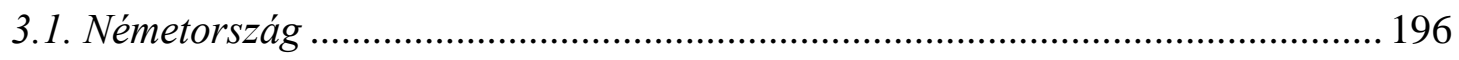

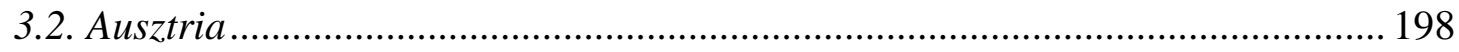

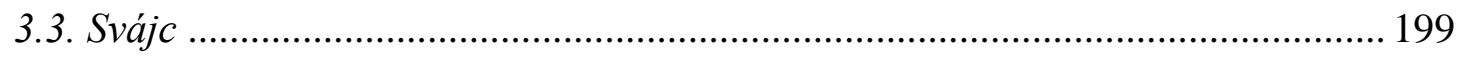

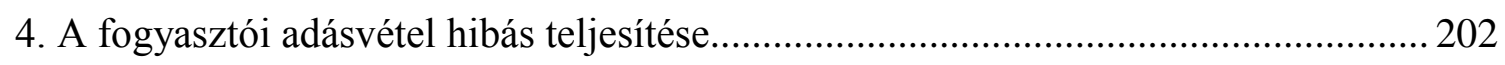

4.1. Kellékszavatosság és hibafogalom a német jogban........................................ 202

4.2. Kellékszavatosság és hibafogalom az osztrák jogban .................................... 205 
4.3. Kellékszavatosság és hibafogalom a svájci jogban ....................................... 207

5. A védett vagyoni érdek, a jogintézmény jogalapja és a szabályozás jellege............. 209

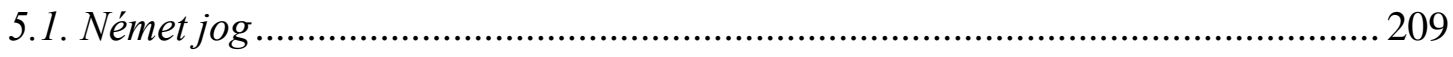

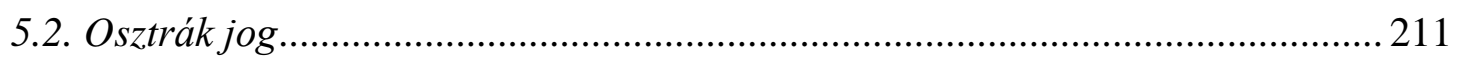

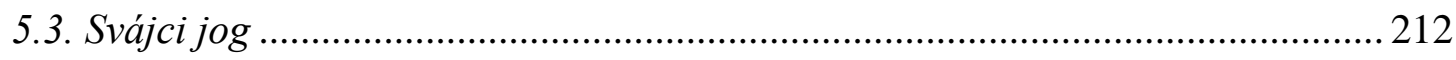

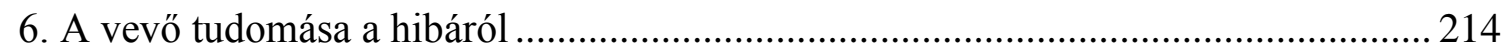

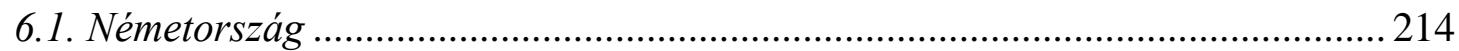

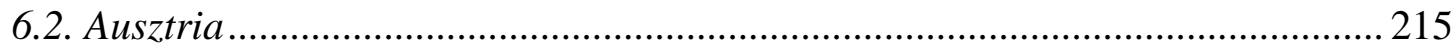

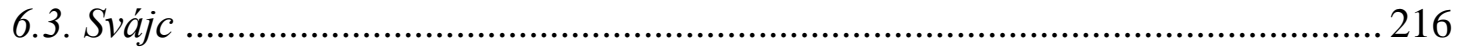

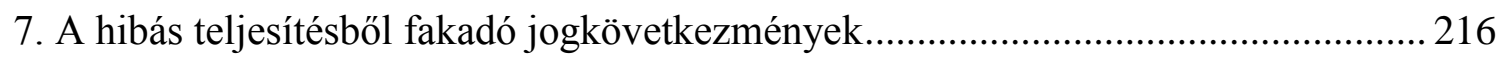

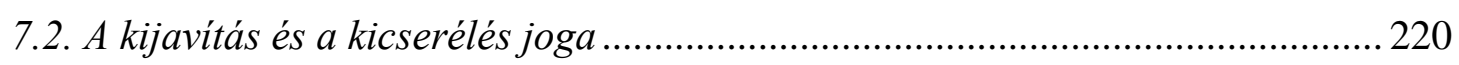

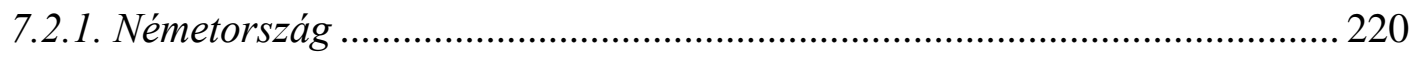

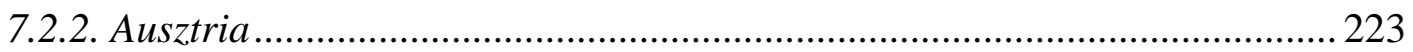

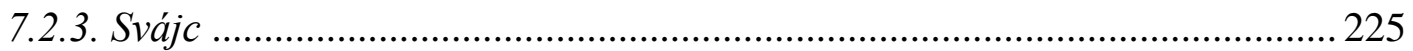

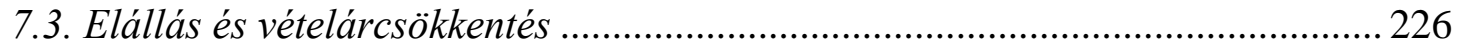

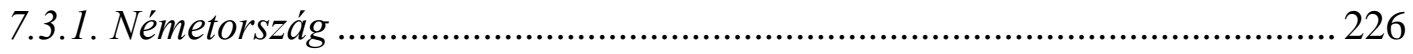

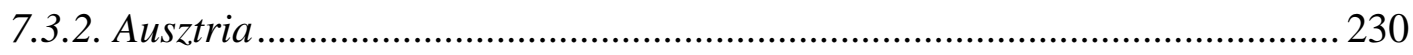

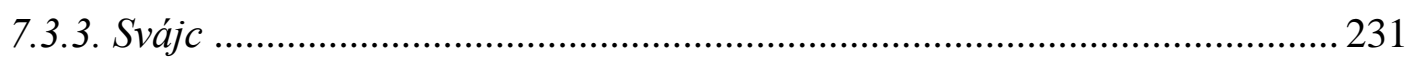

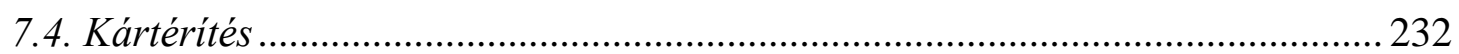

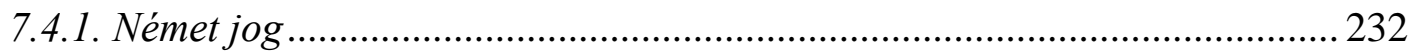

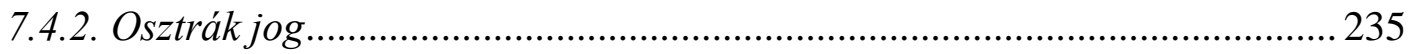

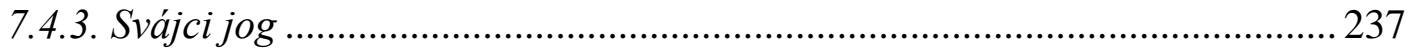

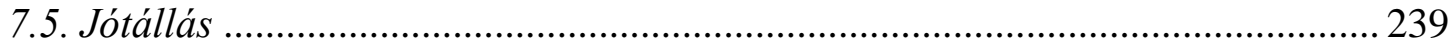

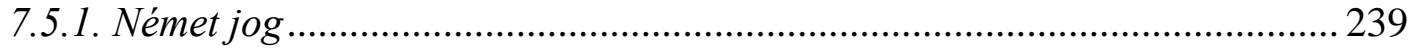

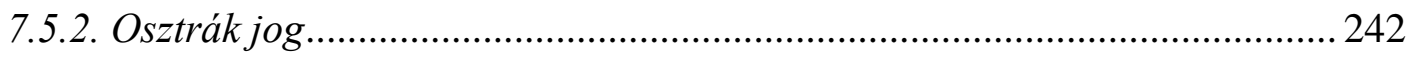

8. Kellékszavatossági jogok az Európai Bíróság gyakorlatában: a kicserélési jog és az arányosság mércéje - a C-65/09. számú egyesített ítélet ................................................ 243

8.1. Az alapügyek és az elözetes döntéshozatal iránti kérelmek .............................. 244

8.1.1. A C-65/09. számú ügy ................................................................................... 244

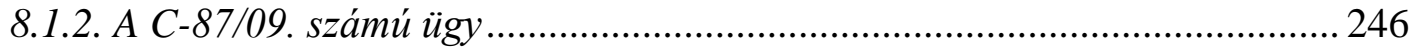

8.2. Az elözetes kérdések jogi kontextusa .................................................................. 247

8.2.1. Az 1999/44/EK irányelv és a német $B G B$................................................. 247

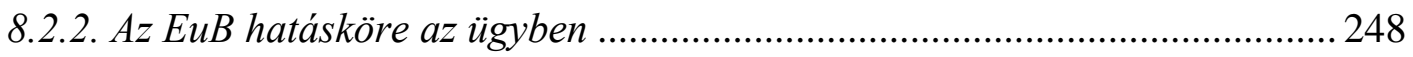

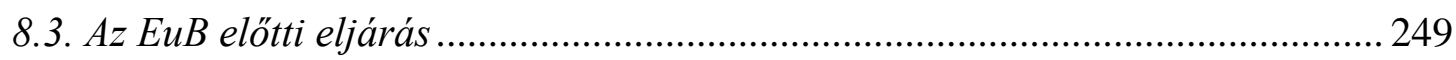

8.3.1. A beadványok és az elöterjesztett álláspontok ......................................... 249

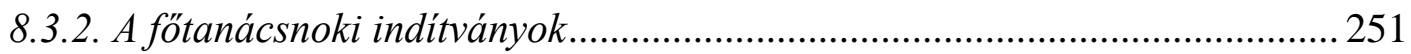

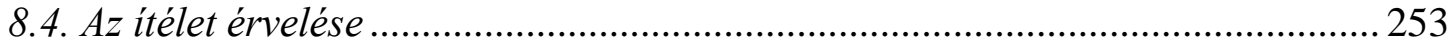


8.4.1. Az eladó kötelezettségei a kicserélési jog érvényesitése során 253

8.4.2. Az eladó számára aránytalan költségvonzatú jogorvoslati mód 255

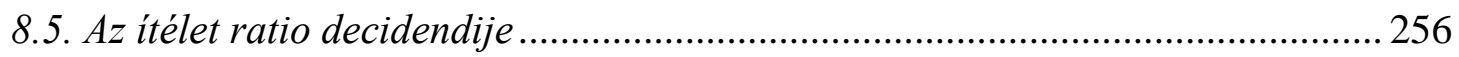

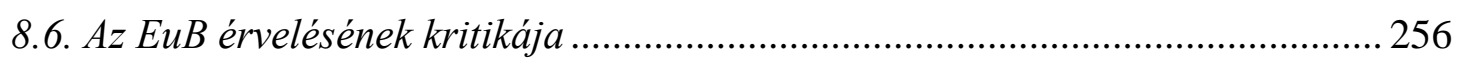

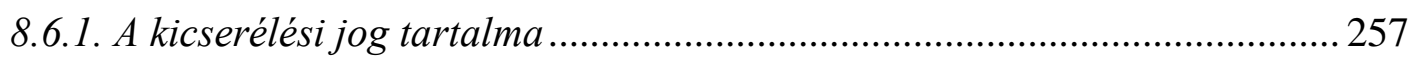

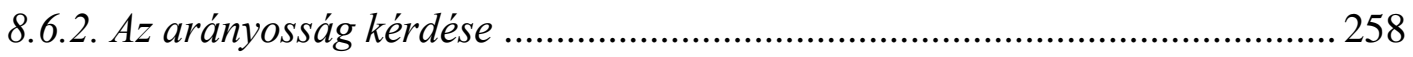

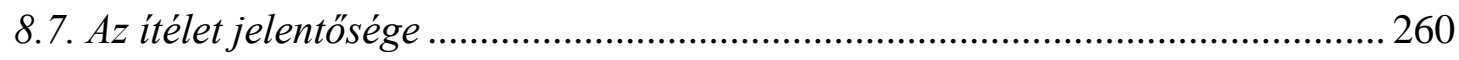

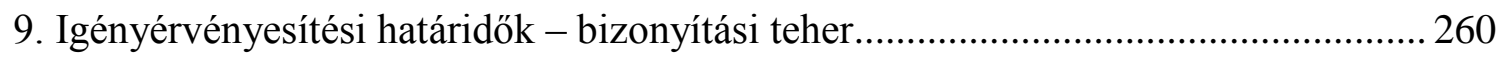

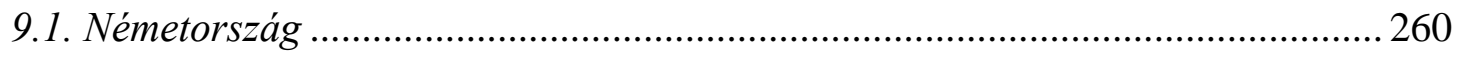

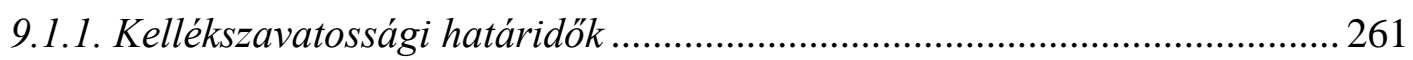

9.1.2. A hibás teljesitésböl eredő kártéritési igény érvényesitésének határideje .. 264

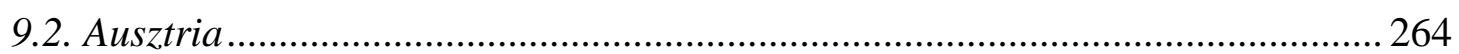

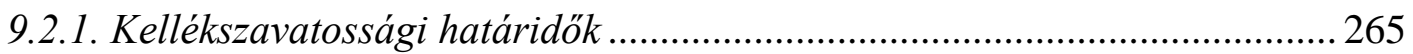

9.2.2. A hibás teljesités miatti kártérités érvényesitésének határideje .................. 267

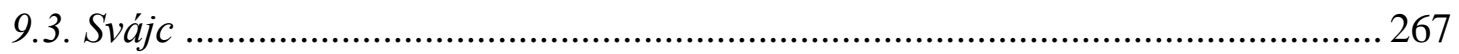

10. Kellékszavatosság állatok adásvétele esetén .................................................... 270

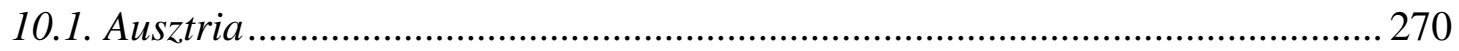

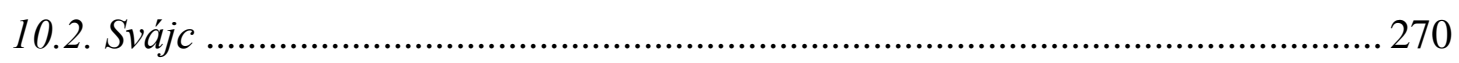

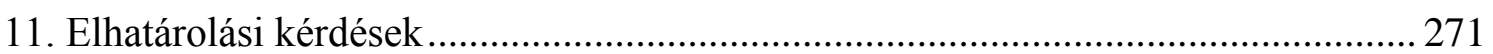

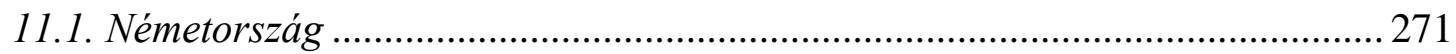

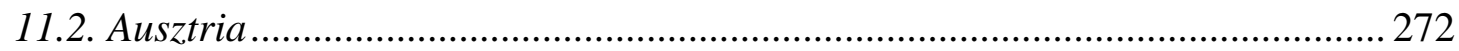

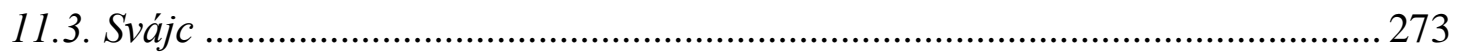

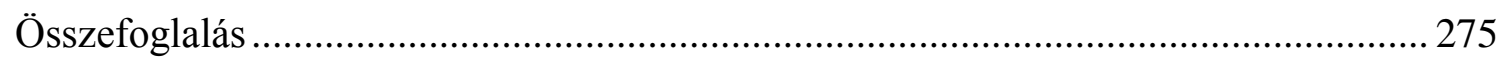

III. A FOGYASZTÓ TRADICIONÁLIS JOGAI INGÓ ADÁSVÉTEL HIBÁS TELJESÍTÉSE ESETÉN A MAGYAR JOGBAN - AZ IRÁNYELV IMPLEMENTÁCIÓJA 2002-BEN .................................. 278

1. Bevezetés - fogyasztóvédelmi szerződési jog a hazai polgári jogban ..................... 278

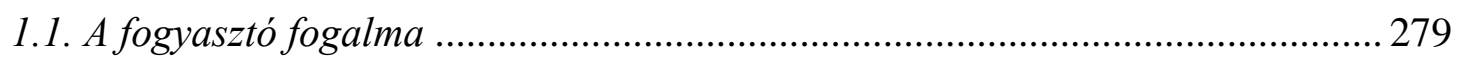

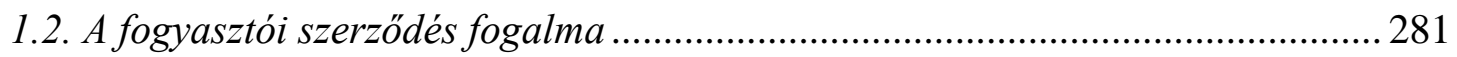

2. A hibás teljesítés rendszere és a „fogyasztói adásvétel” a Ptk.-ban ........................... 282

2.1. Az adásvételi szerzödés tartalma és teljesitése ............................................... 282

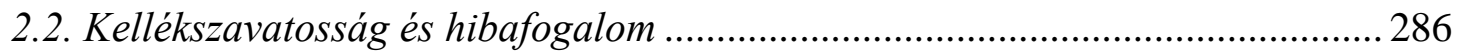

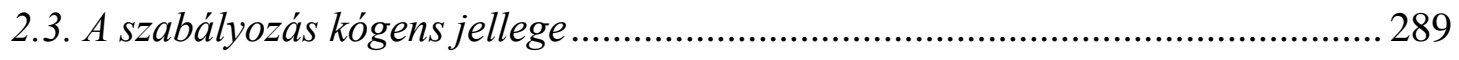

2.4. A hiba vevö általi ismerete - az eladó ,,mentesülése” "...................................... 290

2.5. A hibás teljesitésböl fakadó jogkövetkezmények ............................................... 293

2.5.1. Első lépcsőben érvényesithető igények - kijavitás, kicserélés ................... 293

2.5.2. Második lépcsőben érvényesithető igények - árleszállitás és elállás.......... 295

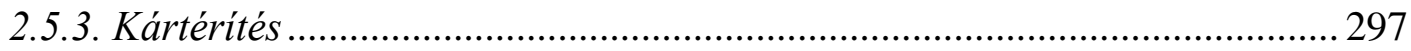




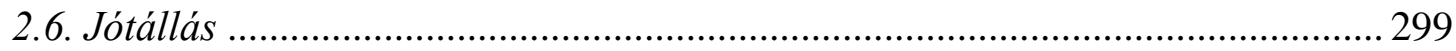

2.7. Igényérvényesitési határidök - bizonyítási teher .............................................. 302

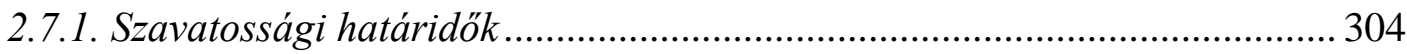

2.7.2. A hibás teljesités miatti kártérités érvényesitésének határideje .................. 307

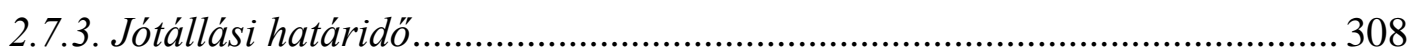

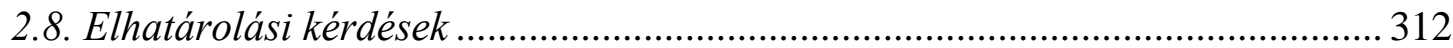

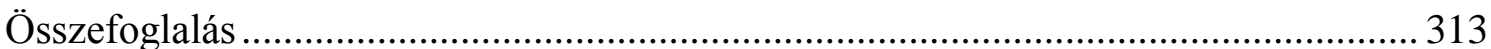

IV. AZ ÚJ PTK. RENDELKEZÉSEI A HIBÁS TELJESÍTÉSRÖL - KÜLÖNÖS TEKINTETTEL A FOGYASZTÓ ÉS VÁLLALKOZÁS KÖZÖTTI ADÁSVÉTELRE .................................................... 314

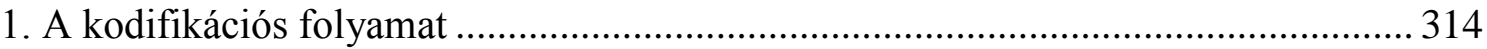

2. Fogyasztóvédelmi magánjog és fogyasztófogalom az új Ptk.-ban........................... 315

3. A hibás teljesítés rendszere - a fogyasztó és vállalkozás között kötött ingó adásvétel

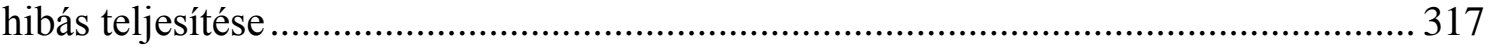

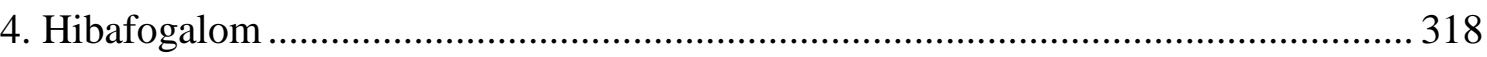

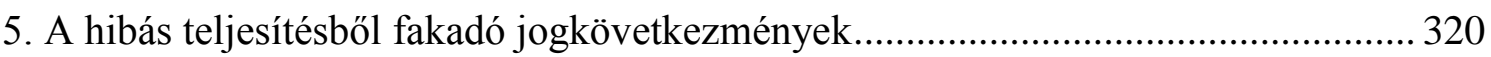

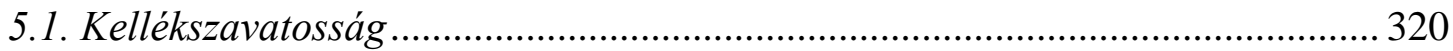

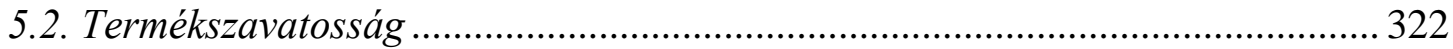

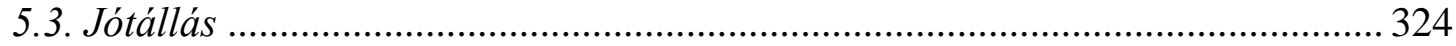

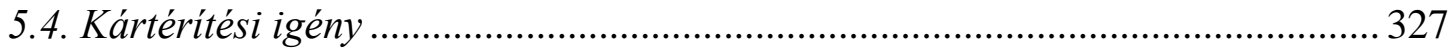

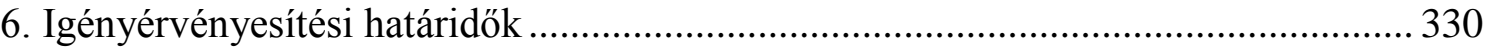

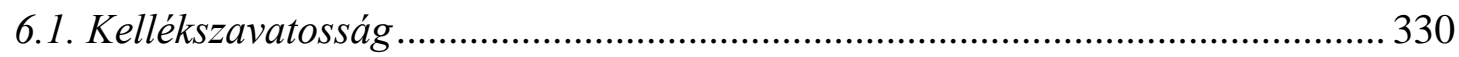

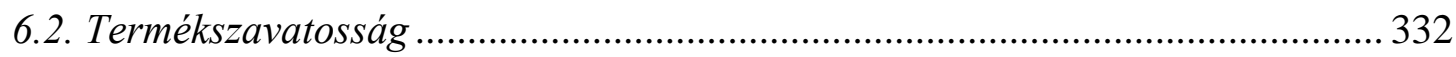

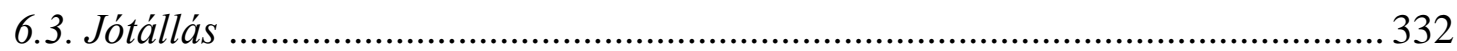

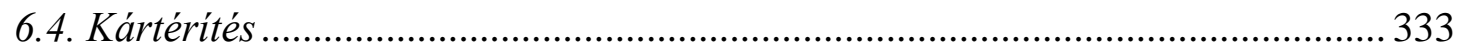

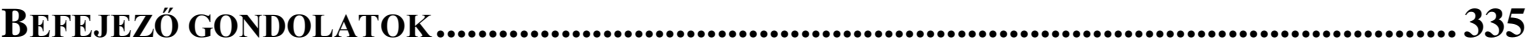

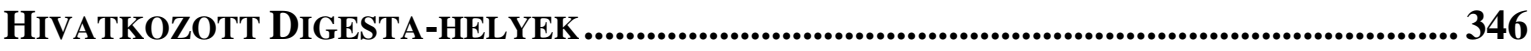

HIVATKOZOTT BÍRÓSÁGI HATÁROZATOK, ÁLLÁSFOGLALÁSOK ...................................... 348

HIVATKOZOTT JOGSZABÁLYOK, JOGSZABÁLYTERVEZETEK .............................................. 353

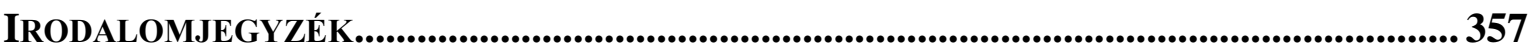




\section{Bevezető gondolatok}

Korunkban a szerződéses kapcsolatokban a kötelezett olyan szolgáltatással tartozik, amely megfelel a jogszabályi elöírásoknak, továbbá alkalmas a rendeltetésszerü használatra, és eleget tesz a szerződésben foglaltaknak. ${ }^{1}$ A kikötött minőségnek és tulajdonságoknak megfelelő dolog szolgáltatásához füződő érdek sérelme, a hibás teljesítés az adásvételben az ár-érték kikötött arányát is megbontja, ezért a jog a hibás teljesítést szankcionálja. A legtöbb európai ország hatályos magánjogában az adásvétel kellékhibás teljesítése esetén a törvényileg szabályozott objektív jogalapú kellékszavatosság, az önkéntesen felvállalható, ugyancsak objektív jogalapú jótállás, valamint a szubjektív jogalapú kártérítés áll rendelkezésre a jogosult hibátlan és szerződésszerü teljesítés iránti igényének az érvényesítésére.

A vásárolt dolog megfelelő minőségéhez füződő vevői érdek védelme nem mai keletủ kérdés. Az ókori Rómában olyan piaci, kereskedelmi szokások, majd jogalkalmazási elvek, jogpolitikai törekvések és azok nyomán olyan keresetek alakultak ki, amelyek a vevő hibás teljesítésből fakadó érdeksérelmét igyekeztek reparálni. A római jog recepciója az egyes újkori magánjogi kodifikációkban éreztette hatását a hibás teljesítés szabályozásánál is. E törvénykönyvek, különösen a német, az osztrák és a svájci kódex szabályai a magyar magánjogi dogmatikára is nagy hatást gyakoroltak a XIX-XX. században. ${ }^{2}$ Hazánkban az 1959. évi Polgári Törvénykönyv emelte először törvényi eröre a hibás teljesítés minden visszterhes szerződésre kiterjedő szabályait.

Az Európai Gazdasági Közösség 1957-es megalapításával, az egységesedő piac és a piacgazdasági struktúra kiépülésével Európában fokozatosan terjedni kezdett a fogyasztóvédelem eszméje a magánjogi jogalkotással összefüggésben is. A piacgazdaság és a kiépült belső piac által generált gazdasági, kereskedelmi folyamatoknak az átlagemberek szerződéses pozícióját kedvezőtlenül érintő hatása indokolja napjaink Európájában a különleges jogi védelmet.

A múlt század végének Európai Uniós fogyasztóvédelmi jogalkotása jelentős változást hozott az adásvételi jog és a kapcsolódó kellékszavatosság és jótállás tagállami szabályozásában is; a hibás teljesítés miatti kártérítés rendezését azonban tagállami hatáskörben hagyta. A fogyasztási cikkek adásvételének és a kapcsolódó jótállásnak egyes vonatkozásairól szóló 1999/44/EK irányelv magánjogi jogegységesítést célzó

\footnotetext{
${ }^{1}$ FAZEKAS (2007), 122. és 125. p.

2 MÁdL (2002), 71. p.
} 
rendelkezéseit minden tagállam egyéni módon valósíthatta meg az irányelvi szabályozás koncepciójának megfelelően. ${ }^{3}$ A jogszabály legfontosabb újítása mindenütt egyezik: a fogyasztói érdekvédelem eszméjének megfelelően a magánjogi szabályozástól idegen, kógens szabályok elöírása. A cél mindemellett azonos a történeti jogalkotói és jogalkalmazói törekvéssel: segíteni az ingó dolog vevőjét, és védeni az áru minőségéhez és a vételárban megtestesülő ár-értékarányhoz füződő vagyoni érdekét.

A dolgozat fő célkitüzése, hogy a hibás teljesítés fent említett három „tradicionális” jogkövetkezménye, a kellékszavatosság, a jótállás és a kártérítés jogtörténelmen átívelő szabályozásának fejlődési útját bemutassa ingók adásvétele esetén. Az ingók adásvétele a jogfejlődés kezdete óta az egyik leggyakoribb jogügylet a piaci kereskedelemben. Az esetek nagy hányadában az egyik szerződő fél hivatásos kereskedő, a másik pedig a dolgot saját, végső felhasználás céljából megvásárló személy. Az is indokolja a téma e jogügyletre szükített vizsgálatát, hogy az említett jogintézmények jogtörténeti gyökerei az ingó adásvétel hibás teljesítésének szabályozásánál fejlődtek ki, és egyes nemzeti jogokban rendszertanilag ma is ott szerepelnek.

A dolgozat a célkitűzésének megfelelően két nagy részből épül fel. Az első rész a hibás teljesítésből fakadó kellékszavatosság, jótállás és kártérítés jogintézményeinek jogtörténetét kívánja bemutatni. Az ókori római kereskedelmi szokásokat, szabályokat és joggyakorlatot tárgyaló fejezet az első. A szerződésszerű teljesítéshez füződő érdek védelme mindig az adott kor gazdasági, társadalmi körülményei és jogpolitikai célkitüzései szerint alakult a jogtörténetben, és ezek határozzák meg a hatályos jogi szabályozást is. A dolgozat fö hipotézise mindemellett az, hogy már az ókorban kialakultak a tárgyalt kérdéskör egyes dogmatikai jellemzői, amelyek a kellékhibás teljesítés korokon átívelő szabályozásában, így a hatályos európai szabályozási koncepcióban és a tagállami magánjogokban is fellelhetőek.

Az első rész második fejezete a római jogi kellékhibás teljesítésre vonatkozó szabályoknak a német és osztrák újkori magánjogi kodifikációkban megjelenő kivetülését vázolja. E két nemzeti kódex szabályainak ismertetése nem csak a római jog recepciója, hanem a magyar magánjogi dogmatikára gyakorolt jelentős hatásuk okán is indokolt. A harmadik fejezet azon időszak magyar jogéletét és hibás teljesítésre vonatkozó joggyakorlatát mutatja be, amelyben annak centrális jogkövetkezménye, a

\footnotetext{
${ }^{3}$ Az irányelv, mint Európai Uniós jogi norma a célkitüzések tekintetében kötelezi a tagállamokat, de az implementáció tekintetében szabad kezet ad nekik. Emellett a fogyasztóvédelmi célú irányelvek eredendő koncepciója a minimum-harmonizáció, azaz a szabályozott terület legfontosabb, legalapvetőbb szabályainak közelítése; lásd többek között: BLUTMAN (2010), 229. p.; RÖSLER (2004), 201. p.
} 
kellékszavatosság ${ }^{4}$ már a magánjog jelentős jogintézményét jelentette, de szabályai még nem emelkedtek a minden ingó adásvételére kiterjedő hatályos jogszabály rangjára. ${ }^{5} \mathrm{Az}$ első rész negyedik fejezete a hazai Polgári Törvénykönyvről szóló 1959. évi IV. törvény hibás teljesítésről és jótállásról szóló eredeti rendelkezéseit tekinti át az 1977-es Ptk.novella módosításaival együtt. Ezt a fejezetet azért tartottam szükségesnek, hogy a nemzetközi kitekintés mellett a hazai szabályozás története napjainkig - kronologikus sorrendben - teljes egészében bemutatásra kerüljön.

A dolgozat második fő része az ingó adásvétel hibás teljesítésének tradicionális jogkövetkezményeit a hatályos szabályozás tükrében vizsgálja, nemzetközi jogösszehasonlító aspektusból. A hazai jogon és a történeti részben már hivatkozott német és osztrák szabályozáson kívül a svájci magánjog vonatkozó hatályos rendelkezéseinek bemutatását is célul tűzi ki. Az utóbbi azért is érdekes a téma komplex tárgyalásánál, mert nem EU-s tagállam, de az EU fogyasztóvédelmi magánjogi szabályozásának indirekt átvételére utalnak az utóbbi évtized svájci jogalkotási törekvései és fejleményei. A terjedelmi korlátok mellett az a már említett körülmény indokolja csupán a fenti jogrendszerek megoldásainak összehasonlító vizsgálatát, hogy a hazai magánjogra ezek meghatározó hatást gyakoroltak a jogfejlődés során. Ennek fényében az összehasonlító vizsgálatra egyébként ugyancsak érdemes brit common law szabályainak és a francia Code Civil rendelkezéseinek, illetve a többi EU-s tagállam szabályozásának bemutatása nem képezi a kutatás tárgyát.

Minden fejezetben kitérek a hibás teljesítés miatti kártérítés szabályaira is, annak ellenére, hogy a fent idézett irányelv hatálya arra nem terjed ki. Indokolt e vevői igény funkcionális összehasonlítása is, mert a harmonizációs kényszer hiányában ezt a kérdést a vizsgált nemzeti jogokban más-más módon szabályozzák.

A második rész első fejezetében az Európai Uniós fogyasztói adásvétel ${ }^{6}$ és az ahhoz kapcsolódó szavatosság és „kereskedelmi” jótállás kérdéseiről rendelkező 1999/44/EK irányelv szabályozásának ismertetésére kerül sor.

A második fejezet a fogyasztói adásvétel hibás teljesítésének német, osztrák és svájci szabályozását vizsgálja, és kitekint az Európai Bíróságnak az 1999/44/EK irányelv

\footnotetext{
${ }^{4}$ A találó, materiálisan hibás teljesítésre utaló kifejezést elöször Grosschmid Béni alkalmazta, lásd: ZsöGöD (1900), 1232. p.

${ }^{5} \mathrm{Az} 1853-1959$. közötti időszak.

${ }^{6}$ A fogyasztói adásvétel fogalma nem szerepel minden tárgyalt állam dogmatikájában és kódexében. A meghatározáskor a fogyasztó illetve a fogyasztói szerződés magánjogi meghatározásából, és különösen abból indulok ki, hogy a vételt az ilyen jogügyletek esetén az ingó dolog végső felhasználása érdekében kötik a hivatásos eladóval, kereskedővel.
} 
és a német implementáció összhangjának kérdésében állást foglaló egyik jelentős ítéletére is. E külföldi szabályozási koncepciók több ponton jelentősen eltérnek egymástól, ezért érdekes következtetésekre adnak lehetőséget a jogösszehasonlítás a magyar szabályozás fényében.

A harmadik fejezet a magyar 1959. évi Polgári Törvénykönyvnek a fogyasztói adásvételi szerződés hibás teljesítése esetén irányadó, az említett EU-s irányelv nyomán 2003-ban módosult rendelkezéseit veszi górcső alá. Az utolsó, negyedik fejezet az új Polgári Törvénykönyv 2014. március 15-én hatályba lépett vonatkozó szabályozásának módosult rendelkezéseit mutatja be.

A dolgozat témájának tárgyalása nagy időintervallumot ölel fel. Az ókori és XIXXX. század eleji viszonyok esetén, sőt még a múlt század második harmadát illetően sem lehet a mai értelemben vett fogyasztói adásvételről beszélni. A tárgyalt problémakör azonban kétségtelenül az átlagember és a hivatásos kereskedő jogviszonyában jelent meg a jogtörténelemben, és a hatályos európai szabályozás is erre koncentrál. A címben tehát erre utal a „vevő-fogyasztó” kifejezés. A dolgozat a választott téma anyagi jogi kérdéseivel foglalkozik. Mivel a kiválasztott országok rendszertanilag máshogy közelítik meg az ingó, illetve a fogyasztói adásvétel hibás teljesítésének kérdését, ezért gyakran a példák igyekeznek rávilágítani a szabályozás e szerződések esetén releváns rendelkezéseire és jellemzőire.

A célkitüzésnek megfelelően a dolgozatban elsősorban a leíró és a dogmatikai elemző módszert, valamint a jogtörténeti és a nemzetközi jogösszehasonlító módszert alkalmazom a vizsgálódásaim során. A dolgozat készítése folyamán a jogszabályi környezet elemzése mellett lehetőség szerint figyelmet fordítottam a jogalkalmazói gyakorlat, és a vonatkozó jogtudományi álláspontok bemutatására is. 


\section{RÉSZ: AZ INGÓ ADÁSVÉTEL HIBÁS TELJESÍTÉSÉNEK TÖRTÉNETE}

\section{AZ INGÓ ADÁSVÉTEL HIBÁS TELJESÍTÉSÉNEK JOGKÖVETKEZMÉNYEI AZ ÓKORI RÓMÁBAN - KÜLÖNÖS TEKINTETTEL A RABSZOLGÁK ADÁSVÉTELÉRE}

\section{Bevezetés}

A modern kor folyamatainak megértéséhez a jogtudomány területén is szükséges az egyes jogintézmények történeti hátterének feltérképezése. A dolgozat központi célkitüzésének megfelelően e fejezetben az ingó adásvétel hibás teljesítésének jogkövetkezményeit a történeti jogösszehasonlítás és a dogmatikai elemző módszer segítségével vizsgálom az ókori római szabályozásban és a joggyakorlatban.

Az ókori Róma társadalmi és gazdasági fejlettsége tette lehetővé, hogy jogrendszere olyan magas szintre jusson, amilyet a fennmaradt okiratos emlékekből és a Jusztiniánusz császár nevéhez füződő Kr.u. VI. századi birodalmi kodifikációból, különösen a jogtudósok magyarázatait tartalmazó Digestából megismerhetünk. Az egyes jogintézmények szabályainak precíz kidolgozottsága és a korabeli jogtudomány magas színvonalú müvelése miatt a római magánjog túlélte a Birodalom bukását, és nem csak a középkorban tükröződött a hatása a gyakorlatban és a jogi oktatásban, de azon átívelve az újkorban megvalósult a közvetett illetve közvetlen recepciója is több európai államban. ${ }^{7}$ $\mathrm{Az}$ ókori római magánjog szerves részét képező és jogforrási rangra is emelkedő jogtudomány rendkívül nagy hatást gyakorolt az újkori jogtudomány és dogmatika fejlődésére. Mindezek fényében a római jog az európai ún. kontinentális jogrendszerek anyajogának tekinthető. ${ }^{8} \mathrm{~A}$ hibás teljesítés ma is centrális jogkövetkezményének, a kellékszavatosságnak a példája ezt különösen jól szemlélteti.

Az egyes történeti korszakok jogpolitikája mindig az aktuális történelmi eseményekhez, társadalmi és gazdasági folyamatokhoz igazodott Rómában is, és ez tükröződött a jogalkotásban és a jogalkalmazásban egyaránt. Már az ókori Rómában fellelhetőek azon jogalkotói törekvések, melyek a kereskedelmi kapcsolatokban a gazdasági pozícióját tekintve gyakran „gyengébb” felet, a vevőt kívánták megvédeni a hivatásos kereskedőkkel szemben. ${ }^{9}$ A hibás teljesítés fő jogkövetkezménye, az eladói

\footnotetext{
${ }^{7}$ Lásd: STEIN (1959), 102-111.p.

${ }^{8}$ MOLNÁR - JAKAB (2010), 17. p.; FÖLDI - HAMZA (2013), 9. p.; BENEDEK - PÓKECZ KovÁCS (2013), 13. p.

9 Lásd például: KASER - KNÜTEL (2014), 255. p. szóhasználatát: „,...dient das Edikt dem Verbraucherschutz”, valamint JAKAB (2013), 198. p. Az ókori Rómán kívül más ókori forrásokat is találunk „vevővédelmi” tartalommal: Hammurappi törvénykönyvének 278. szakasza így szólt: „Ha valaki rabszolgát
} 
kellékszavatosság az árucserejog központi intézményévé fejlödött, amely a jogosultnak a hibátlan teljesítéshez füződő érdekét védte már az ókori Rómában is. ${ }^{10}$ Mivel a kellékszavatosság jogintézménye az ókori rabszolgavételi ügyletekkel összefüggésben fejlődött ki, ${ }^{11}$ és sokáig a rabszolgák jelentették az egyik legjelentősebb adásvételi tárgyat a fellendülő kereskedelemben, ezért a rabszolga-adásvételi ügyletekre fókuszálok a téma tárgyalásánál. ${ }^{12}$

A jogintézmény a jogalkotásban és jogalkalmazásban, valamint a szerződési gyakorlatban is szép fejlődési utat járt be, amelynek bemutatása a jelen fejezet célja a Római Birodalomban fellelhető okirati emlékek, és főként a Digesta jogeseteinek felhasználásával és elemzésével.

\section{Exkurzus: a kellékszavatosság előzményei az archaikus Rómában - a XII táblás törvény és az actio de modo agri}

Az áruforgalom a dinamikusan fejlődő ókori római civilizációban már az archaikus korban, azaz a város monda szerinti, Kr. e. 753-as alapítását követő évszázadokban kezdett kibontakozni. A korabeli gazdasági viszonyokról a legtöbbet az árucsere alapviszonya, az adásvétel lebonyolításának és szerkezetének sajátosságai tudósítanak bennünket. ${ }^{13}$

$\mathrm{Az}$ adásvétel az archaikus korban ún. készvétel volt, az áru és vételár azonnali kicserélése jellemezte, a dologi és kötelmi jogi vetület pedig még nem vált szét a jogügyletben. $^{14}$ A gazdasági szempontból legjelentősebb dolgok, a res mancipi ${ }^{15}$ adásvételének lebonyolítására a mancipatio ${ }^{16}$ formalitásokhoz kötött tulajdonátruházó aktusa szolgált.

\footnotetext{
vagy rabszolganőt vesz, akin egy hó leforgása alatt kitör a „,bennum” (= nyavalyatörés), betegség, adja vissza a rabszolgát, s kapja vissza pénzét.”, lásd: SAN NICOLO (1922), 222-223. p. Lásd továbbá a Leviták Könyvét: „Ne legyetek igazságtalanok az ítélkezésben, hosszmérték, súlymérték és az ürmérték használatában. Legyen hiteles a mérleged, a súlyod, hiteles a mértéked és a vékád.” lásd: FAZEKAS (2007), 19. p. hivatkozása a Bibliára.

${ }^{10}$ Lásd: JAKAB (1993), 5. p. A fogyasztóvédelem egyik ókori előképeként említi a kellékszavatosságot Aldo Petrucci, lásd: PETRUCCI (2007), 207. p. Lásd továbbá: JAKAB (2003), 33. p. szóhasználatát.

${ }^{11}$ JAKAB (2013), 192. p. A rabszolgák kereskedelméhez vö. BRADLEY (2011), 241. p.

${ }^{12}$ A rabszolgákat az ókori Rómában jogi értelemben ingó dolgokként kezelték, figyelembe véve azonban emberi mivoltukból fakadó tulajdonságaikat, lásd: MOLNÁR - JAKAB (2012), 122-123. p.

${ }^{13}$ Pólay (1953), 115. p.

${ }^{14}$ MOLNÁR - JAKAB (2012), 299. p.; FÖLDI - HAMZA (2013), 508. p.; BENEDEK - PóKECZ KovÁCS (2013), 284-285. p.

${ }^{15} \mathrm{Az}$ itáliai telek, a rabszolga, az Itáliában honos igásállatok és a kültelki szolgalmak, MOLNÁR - JAKAB (2012) 173.p.

16 „Az ún. res mancipi átruházására szolgáló ünnepélyes formában lezajló ősi szerző ügylet... Eredeti formájában készvétel (adásvétel), azonnal kifizetésre kerülő vételár (nyersérc) eszközlésével.”, lásd: MOLNÁR - JAKAB (2012), 206. p.
} 
A res mancipi, azaz a mancipálható dolgok közül a föld, az itáliai telek (fundus Italicus) kereskedelmi forgalma a nemzetségi közös földek felosztása után, valószínüleg a királykor végétől kezdődően indult meg. ${ }^{17}$ A kor legjelentősebb jogforrása a Kr.e. 451-ben megalkotott XII táblás törvény volt, amelynek a kérdéshez kapcsolódó rendelkezéseit Cicero írásaiból ismerhetjük meg. ${ }^{18}$ A vonatkozó szövegrészlet a mancipatiós telekeladással kapcsolatos eladói helytállási kötelezettségről szól, és a nuncupatioba felvett téves vagy hamis eladói ígéretek kérdéskörét tárgyalja.

A nuncupatioban az eladó valószínüleg kifejezetten megígérte, hogy a telek nagysága határozott méretü (például 100 iugerum). ${ }^{19}$ Amennyiben utóbb kiderült, hogy a telek az eladó által állítottnál kisebb, a vevő a duplumra, azaz a hiányzó terület vételárának kétszeresére irányuló keresettel élhetett az eladóval szemben akkor, ha a telek ára nagyságának arányában, azaz iugerumonként került meghatározásra. ${ }^{20} \mathrm{~A}$ vevő keresete a praetori jogalkalmazásban az actio de modo agri néven ismert. ${ }^{21}$ A keresetet alapító tényállás alapján az eladó tehát a nuncupatioban a telket nagyobbnak jelölte meg a valóságosnál. ${ }^{22}$ A kereset deliktuális jellegü volt, azonban a régi jog felelősségi rendje nem fejlödött még arra a szintre, hogy elkülönítse az objektív és szubjektív elemeket a helytállás tekintetében. Ha az eladó kifejezetten kijelenti, hogy az eladásra szánt dolog bizonyos tulajdonságokkal rendelkezik (például a telek bizonyos nagyságú), köteles ezért helytállni - ez is azt mutatja, hogy nem vizsgálták a jó- illetve rosszhiszemüségét, azaz felróhatóságtól független, objektív volt a helytállás jogalapja. ${ }^{23} \mathrm{Ez}$ az eladói helytállás a kellékszavatosságnak még csak egy kezdetleges „elődje”, és a római jogi tankönyvek sem kezelik feltétlenül a kellékszavatossághoz tartozóként. ${ }^{24}$ A kereseti lehetőség megadásának valószínü jogpolitikai indoka, és az objektív jellegü helytállás megjelenése miatt azonban kapcsolódik a kérdéskörhöz.

\footnotetext{
${ }^{17}$ PÓLAY (1953), 121. p.

${ }^{18}$ Cicero: De officiis (a továbbiakban: De off.) 3.16.65: „Ac de iure quidem praediorum sanctum apud nos iure civili, ut in his vendendis vitia dicerentur, quae nota essent venditori. Nam cum ex duodecim tabulis satis esset ea praestari, quae essent lingua nuncupata, quae qui infitiatus esset, dupli poenam subiret, a iuris consultis etiam reticentiae poena est constituta; quidquid enim esset in praedio vitii, id statuerunt, si venditor sciret, nisi nominatim dictum esset, praestari oportere.".

${ }^{19}$ PÓLAY (1953), 119. p.

${ }^{20}$ PÓlAY (1953), 116. p., MOLNÁR - JAKAB (2012), 304. p. Lásd még: Paulus: Sententiae (a továbbiakban: PS) 2.17.4.: „,... in duplo eius, quod mentitus est, officio iudicis aestimatione facta convenitur... ”.

${ }^{21}$ PÓLAY (1953), 120. p.

${ }^{22}$ Lásd: PS 1,19,1 és 2,17,4; PÓlAY (1953), 123. p.

${ }^{23}$ PÓlAY (1953), 124. p.; erre utalhat Pomponius Sabinushoz füzött Digesta-kommentárja is, lásd: D. 19,1,6 pr.

${ }^{24}$ Lásd: MOLNÁR - JAKAB (2012), 304. p., illetve KASER - KNÜTEL (2014), 253. p.
} 
A kereseti követelés a duplumra irányult; erről tudósít Paulus az egyik Digestafragmentumban. ${ }^{25}$ Ha a telek kisebbnek bizonyult, mint a nuncupatióban megadott iugera, akkor az összes eladott földterület átlagos minőségü termőföldjének egy iugerumra eső árából kiindulva kellett kiszámítani a hiányzó iugera átlagárát: így nyert megállapítást egy iugerum értéke, amelyből pedig ki lehetett számítani a hiányzó rész értékét, illetve annak kétszeresét. ${ }^{26} \mathrm{Ha}$ egy ingatlan két (vagy több) részét egy árért adták el, és különbség volt a két ingatlanrész ígért méretében, akkor a föld minősége alapján lehetett becsülni, és így került megállapításra, hogy mennyi esne az egységes vételárból az ígértnél kisebbnek bizonyuló telekre. ${ }^{27}$ A mancipatio és a hozzá köthető actio de modo agri valószínűleg a Kr.u. IV. században kopott ki végleg a gyakorlatból. ${ }^{28}$

\section{A preklasszikus kor joggyakorlata}

\subsection{Az áruforgalom fellendülése - kereskedelmi és piaci szokások}

Számos korabeli forrás szerint bizonyos, hogy már az archaikus korszakban is müködött az itáliai városokban heti piac, a preklasszikus korban pedig a szárazföldi kereskedelem is fellendült, és kereskedelmi kapcsolatok már gyakran köttettek különböző nemzetiségüek között is. ${ }^{29}$

A kedvező földrajzi adottságoknak és a rómaiak terjeszkedésének köszönhetően korán megkezdődött a tengeri kereskedelem is; a Kr. e. II-I. században Delos lett a Földközi-tenger egyik legforgalmasabb kereskedelmi központja. ${ }^{30}$ Ezzel egy időben az egyfajta tengeri rendfenntartó szerepet betöltött Rhodosz hanyatlásával teret nyert a kalózkodás. ${ }^{31} \mathrm{Ez}$ a tevékenység és a Kr.e. II. században egyre gyakoribbá váló hódító háborúk ${ }^{32}$ - amelyek révén Róma új tartományokra és számtalan hadifogolyra is szert tett a rabszolga-kereskedelem felvirágozásához vezettek. ${ }^{33}$ A rabszolgák iránti igény különösen azért nőtt meg a piacokon, mert ők jelentették a korszakban felvirágzó

\footnotetext{
25 D. 19,1,4,1 Paulus: Si modus agri minor inveniatur, pro numero iugerum auctor obligatus est, quia ubi modus minor invenitur, non potest aestimari bonitas loci, qui non exstat. Sed non solum si modus agri totius minor est, agi cum venditore potest, sed etiam de partibus eius, ut puta si dictum est vineae iugera tot esse, vel oliveti et minus inveniatur: ideoque his casibus pro bonitate loci fiet aestimatio.

${ }^{26}$ PÓLAY (1953), 125. p.

${ }^{27}$ PÓLAY (1953), 127-128. p.

${ }^{28}$ PÓLAY (1964), 6. p.

${ }^{29}$ Kereskedelmi kapcsolatok például Etruriával, lásd: JAKAB (1993), 9. p.

${ }^{30}$ Lásd: SCHUMACHER (2001), 51-53. p.; MARÓTI (1962), 1. p.

${ }^{31}$ FiNLEY (1977), 186. p.

32 A legnevezetesebbek a Karthágóval folytatott és győzelemmel végződött pun háborúk Kr.e. 264-146. között, lásd: MOLNÁR - JAKAB (2012), 29. p.; FÖLDI - HAMZA (2013), 30. p.

${ }^{33}$ PÓlAY (1964), 4. p.; PINTÉR (1986), 312. p.
} 
árutermelő gazdaságban a legfőbb munkaerőt. ${ }^{34}$ A tengeri kereskedelemnek köszönhetően jutottak el a rabszolgák árucikként az egyik legnagyobb felvevőpiacra, Rómába is. ${ }^{35} \mathrm{~A}$ rabszolgaforgalom felélénkülésével igen gyakran peregrinusok, azaz nem római polgárok voltak a kereskedők. Ök gyakran specializálódtak valamilyen árura, és általában ugyanazokra a piacra tértek vissza, így nagyrészt ugyanazzal a vevőkörrel érintkeztek, mintegy személyes kapcsolatban álltak velük, ezért a bizalom fokozott jelentőséget játszott a kereskedésben. ${ }^{36}$

A Kr. e. II. században Rómában már sok piac müködött: nem központi, hanem több kisebb, egyfajta árura specializálódott piacok voltak ezek. ${ }^{37}$ Rómában a rabszolgapiacokon belül is differenciálódás mutatkozott: egyes helyeken kifejezetten olcsó árura szakosodtak, máshol például kizárólag női rabszolgákat árultak. ${ }^{38}$ Így sokszor már maga a piac is árulkodott a rabszolgák minőségéről. A kereskedők megítélése és piaci gyakorlata azonban egy adott piacon belül is nagyon eltérő lehetett. ${ }^{39}$ A magasabb vételárár kicsikarása érdekében a kereskedők bizonyosan a kisebb csalásoktól sem riadtak vissza. ${ }^{40} \mathrm{~A}$ kereskedői gyakorlat ellenőrzésének igénye mellett a rabszolgának, mint árucikknek a speciális fizikai és szellemi tulajdonságai hívták életre az állami kontrollját a rabszolgapiacokon, ${ }^{41}$ amely a régi - funkciójukban a kellékszavatossághoz hasonló szabályok megreformálását igényelte. ${ }^{42}$

A kereskedelmi gyakorlatban az áru minőségét illetően nem csak az eladóra hárultak kötelezettségek, hanem a vevő viselkedésére is vonatkoztak bizonyos elvek. Az adásvétel alapelvévé vált caveat emptor nem csak az ókori Róma, hanem minden korai jogrendszer adásvételi jogát jellemezte és igazgatta. ${ }^{43}$ Az elv azt jelentette, hogy azoknál az adásvételeknél, amelyek esetén a megállapodás (consensus) és az áru-vételár cseréje egyazon időpontban ment végbe, a vevőtől el lehet várni, hogy körültekintően járjon el, és

\footnotetext{
${ }^{34}$ PÓLAy (1964), 5. p.; PINTÉR (1986), 312. p.

${ }^{35}$ FINLEY (1977), 156. p.

${ }^{36}$ FINLEY (1977), 28. p.; JAKAB (1993), 15-16. p.

${ }^{37}$ SCHUMACHER (2001), 44. p.; JAKAB (1993), 10. p.

${ }^{38}$ Lásd: JAKAB (1993), 16. p.

${ }^{39}$ Cicero például egyenesen piszkosnak nevezte a kiskereskedelmet, míg a nagykereskedőket illetően úgy véli, hogy lehetnek köztük kétes személyiségüek, de ugyanúgy tisztességesek egyének is, lásd: De off. 1.151.; WESTERMANN (1955), 98. p.

${ }^{40}$ PEKARY (1979), 99. p.

${ }^{41}$ JAKAB (1993), 23. p.

${ }^{42}$ PÓlAY (1964), 5. p.

${ }^{43}$ A régi germán jogban: „Augen auf, Kauf ist Kauf”, ,, Wer die Augen nicht auftut, der tue den Beutel auf”, „,Wer närrisch kauf, muss weislich bezahlen”, az angolszászoknál: ,let their eye be their chapman”, a franciáknál: , qui n'ouvre pas yeux doit ouvrir la bourse”, lásd: ZIMMERMANN (1996), 307. p.
} 
alaposan megvizsgálja az árut, mielőtt megkötné az ügyletet. ${ }^{44}$ A piaci gyakorlatban a rabszolgákat általában kőtömbre vagy emelvényre állítva kínálták a kereskedők, így a potenciális vevők meg tudták vizsgálni a testüket, és a megfontoltabbak ki is kérdezték a megvenni kívánt rabszolgát annak múltjáról, képzettségéről, stb. ${ }^{45}$

Bizonyos külső jelek már előre világosan utalhattak az eladásra szánt rabszolga tulajdonságaira. Ilyen volt a fejére tett kalap (pilleatos servos), ami a gyenge minőségről árulkodott, és arról, hogy emiatt az eladó nem vállal helytállást az esetleges hibákért. ${ }^{46} \mathrm{~A}$ koszorúval a fejükön ( sub corona) eladandó rabszolgák hadifoglyok voltak. ${ }^{47}$ Ha az eladó megkötözve vitte a piacra a rabszolgát, az általában a szökésre való hajlamot, vagy bármilyen más veszélyes tulajdonságot jelölt. ${ }^{48} \mathrm{~A}$ fehérre festett láb arról árulkodott, hogy frissen importált rabszolgáról van szó. ${ }^{49}$ A kereskedők gyakran kis táblácskát akasztottak a rabszolga nyakába annak legfontosabb tulajdonságairól. ${ }^{50}$ A rabszolgák tulajdonságaira vonatkozó eladói információközlésnek tehát számtalan módja lehetett. Ezek a szokások mind azt a célt szolgálták, hogy már a vételi aktus előtt információt nyújtsanak a potenciális vevőknek a rabszolga egyes tulajdonságairól.

\subsection{Eladói garancia-stipulatiók}

Az áruforgalom fellendülésével a preklasszikus korszakban már a praetor peregrinus volt a római polgárok és idegenek közötti jogvitákban jogot szolgáltató magistratus. Az ő jogalkotó és jogalkalmazó tevékenységének is köszönhetően az adásvétel fokozatosan elvált az áru átruházásának dologi jogi aktusától, és kötelmet keletkeztető szerződéssé vált, amelynek már a felek közti megegyezés (consensus) a forrása, annak létrejöttével a szerződés kikényszeríthetővé vált. ${ }^{51}$

Már ebben az időszakban fellelhetőek annak írásos nyomai, hogy az adásvétel megkötése esetén az eladók ún. garanciaígéretet tettek a vevőknek ünnepélyes szóbeli

\footnotetext{
${ }^{44}$ ZIMMERMANN (1996), 307. p. Lásd ehhez: ADOMEIT - HÄHNCHEN (2011), 1-9. p.

45 Erről tanúskodik többek között Titus Maccius Plautus: Bacchides című műve, valamint Persa címü komédiája is, lásd: JAKAB (1993), 26-27. p.

${ }^{46}$ Lásd Gell. NA 6.4.1.

${ }^{47}$ Lásd Gell. NA 6.4 .

${ }^{48}$ Erröl tanúskodik a D. 21,1,48,3 Pomponius: Ei, qui servum vinctum vendiderit, aedilicium edictum remitti aequum est: multo enim amplius est id facere, quam pronuntiare in vinculis fuisse. A fragmentum szerint nem vonható felelősségre az, aki megkötözve viszi ki a piacra a rabszolgáját adásvétel céljából, mivel az egyértelműen utal a rabszolga bizonyos tulajdonságára.

${ }^{49}$ Lásd Plin. nat. 35.199.

${ }^{50}$ Lásd Gell. NA 4.2.1.

${ }^{51}$ ERNST (2013), 38. p.
} 
formában. ${ }^{52}$ Az eladó ennek keretében megígérte a vevőnek egy stipulatioban, hogy a vétel tárgyát nem fogják tőle részben vagy egészben elperelni harmadik személyek olyan jog alapján, ami a vétel megkötésének pillanatában már fennállt. ${ }^{53}$ Ez volt az evictióért való helytállás, modern kifejezéssel a jogszavatosság intézménye. ${ }^{54}$

Gyakorlattá vált az evictiós helytállás felvállalása mellett, hogy ugyanabba a stipulatióba foglalták az ígéretet arra nézve, hogy a vétel tárgya bizonyos tulajdonságokkal rendelkezik, illetve még gyakrabban azt, hogy nem rendelkezik bizonyos negatív fizikai, illetve a múltját és jellemét érintő hibákkal. ${ }^{55}$ Mivel az evictiós helytállást keletkeztető ígéretben az eladó a duplumot, azaz a vételár vagy a dolog objektív értéke kétszeresének a megfizetését vállalta magára az esetleges jogi hiba miatt, az a stipulatio duplae elnevezéssel jelenik meg a forrásokban. A jogügylet helytállást keletkeztetett az eladó oldalán, aki mindenért felelt, amit ünnepélyesen kijelentett. ${ }^{56} \mathrm{Az}$ ilyen ún. garanciastipulatiókat a gyakorlatban egyre gyakrabban alkalmazták a rabszolgák adásvételének megkötésénél is. Erről tanúskodnak a formulás gyüjtemények, mint például Marcus Terentius Varro Kr. e. I. századból származó műve a mezőgazdaságról, a De Rerum Rusticarum Libri Tres. ${ }^{57}$ A következő idézet példa az eladói garanciá́géretre Varro müvéböl:

Varro rust. 2.10.5:

In horum emptione solet accedere peculium, aut excipi et stipulatio intercedere, sanum eum esse, furtis noxisque solutum aut si mancipio non datur, dupla promitti, aut si ita pacti simpla.

„Vásárlásuknál szokásos, hogy a peculiumot járulékként hozzáveszik vagy kizárják, és hogy stipulatiót kötnek arról, hogy [a rabszolga] egészséges, lopás vagy noxa nem terheli, ha nem mancipációval adják át, akkor vagy a duplumot ígérik vagy az egyszeresét." ${ }^{, 58}$

\footnotetext{
${ }^{52}$ Lásd: ERNST (2013), 79. p.

${ }^{53}$ Lásd: PÓlAY (1953), 123. p.

${ }^{54}$ KASER - KNÜTEL (2014), 249-253. p.; MOLNÁR - JAKAB (2012), 303. p. A stipulatio az ókori római magánjog azon jogügylete volt, amelyben a hitelező ünnepélyes formában feltett kérdésére az adós azzal egybevágó szóbeli választ adott. A formai kötöttségeket leszámítva ez volt a korának egyik legelterjedtebb és legrugalmasabb jogügylete, lásd: Lásd: MOLNÁR - JAKAB (2012), 287. p.; FÖLDI - HAMZA (2013), 489. p.; BENEDEK - PÓKECZ KOVÁCS (2013), 275. p.; FinKENAUER (2010), 60. és 77. p.

${ }^{55}$ HONSELl (1969), 63. p.

${ }^{56}$ Lásd: JAKAB (1993), 80. p.

57 PINTÉR (1986), 318. p.; PÓLAY (1953), 128. p. Pólay Elemér szerint a müben szereplő formulák szövegeinek konstrukcióiból valószínúsíthető, hogy ily formában már a Kr. e. II. században is alkalmazták őket, lásd: PÓLAY (1964), 8. p.;

${ }^{58}$ Lásd: JAKAB (1993), 69. p.
} 
Az idézet Varro müvének második könyvében található, ahol a szerző a nyáj őrzése céljából juhászok beszerzéséről ír, és röviden megemlíti a rabszolgák vásárlásánál szokásos szerződési kikötéseket is. A szöveg szerint a rabszolgát eladhatták a peculiumával, azaz a különvagyonával együtt vagy anélkül is. ${ }^{59}$ A peculium a rabszolga saját rendelkezési joga alatt álló vagyontárgyakat jelentette, és - ha azt a rabszolgával együtt eladták, akkor vagy határozott összegben, vagy relatíve határozták meg. ${ }^{60}$ Az utóbbi esetben a peculium mindent magában foglalt, ami annak részét képezte a vétel megkötésekor a rabszolga házikönyve, könyvelése alapján. ${ }^{61}$

Egy ilyen adásvétel során az eladó és a vevő gyakran stipulatiót kötött: a vevő kérdésében ígéretre szólította az eladót arra vonatkozóan, hogy a rabszolga bizonyos negatív attribútumokkal nem rendelkezik, és a kérdéssel pontosan megegyező válaszban az eladó megígérte a negatív tulajdonságok hiányát. Az idézet alapján feltehető, hogy a stipulatio a rabszolgára vonatkozó legfontosabb jellemzőket általában magába foglalta: az egészségi állapotát (sanum eum esse) és a jogilag releváns előéletét, azaz, hogy lopás vagy noxa nem terhelte (furtis noxisque solutum). Mivel a rabszolgák gyakran gazdaságilag jelentős munkaerőt jelentettek a földeken vagy a domiunus háza körül, ezek a fenti tulajdonságok voltak a legfontosabbak a rabszolgák munkaképessége, „használhatósága” tekintetében: jelentős hatást gyakoroltak a vevő vételi szándékára. ${ }^{62}$ Az egészséges állapotra vonatkozó ígéret nem csak elterjedt, hanem ajánlott is volt a kereskedelmi gyakorlatban, amit más Varro-források is megerősítenek. ${ }^{63}$

Ha a rabszolga idegen személynek deliktuális jellegü kárt okozott (például őt meglopta, vagy vagyontárgyát megrongálta), akkor a károsult kártérítést illetve büntetést követelve a rabszolgatartó ellen fordulhatott noxális actióval. ${ }^{64}$ A rabszolgatartó ilyen esetben válaszhatott, hogy kártérítést fizet, vagy átadja a károsultnak a rabszolgát a kár ledolgozására. ${ }^{65} \mathrm{Az}$ ilyen noxális kötöttség hiánya ezért szintén fontos tulajdonság volt, mert a noxával terhelt rabszolgát a vevő akár el is veszíthette. ${ }^{66}$

A fenti idézet második mondata azt mutatja, hogy a rabszolga átadására (tulajdonátruházás) két eset létezett az adásvétel mellett: a rabszolgát vagy a mancipatio

\footnotetext{
${ }^{59}$ Lásd ehhez: WACKE (2002), 831. p.

${ }^{60}$ Lásd: JAKAB (2013), 200. p.

${ }^{61}$ Lásd: JAKAB (2013), 200. p.; hasonló garancia-ígéretekhez Varro művében vö. FINKENAUER (2010), 57. p.

${ }^{62}$ Ez megjelenik a Digestában is, lásd: D. 21,1,1,8: Proinde si quid tale fuerit vitii sive morbi, quod usum ministeriumque hominis impediat.

${ }^{63}$ Lásd például: Varro rust. 2.1.15: In emptione alias stipulandum esse, alias e sano pecore, alias neutrum.

${ }^{64}$ Lásd: FÖLDI (2004), 103. p.

${ }^{65}$ FÖLDI (2004), 103. p.

${ }^{66}$ FÖLDI (2004), 103-104. p.
} 
aktusával adták át, ${ }^{67}$ vagy az elmaradt; mind a két átadási mód elfogadott volt már Varro korában. ${ }^{68}$ Amikor a mancipatio nem volt része az ügylet lebonyolításának, akkor az eladó más módon akarta a vevőt biztosítani, hogy bár a rabszolga felett a civiljogi tulajdont formálisan nem szerzi meg azonnal, mégsem fogják a rabszolgát elperelni tőle, ezért ígérte meg neki a duplumot az elperlés esetére. ${ }^{69}$ Mivel azonban a stipulatio az alku részét képezte, a duplum helyett megállapodhattak a vételár egyszeri visszafizetésében is. ${ }^{70}$

A garancia-stipulatio gyakorlatát a Kr. u. I. és II. századból származó ókori írásos dokumentumok is igazolják. Ezeket az okiratokat viaszos táblákon rögzítették Itáliában, Herculaneumban és jó néhány provinciában, többek között Dáciában, Kilikiában, Pamphyliában és Egyiptomban. ${ }^{71}$ Az alábbi egy a dáciai viaszostáblák okiratai közül, amely egy rabszolga-vételről tanúskodik:

FIRA III 88:

"Dasius Breucus emit mancipioque accepit puerum Apalaustum, sive is quo alio nomine est, n(atione) Graecum, apocatum pro uncis duabus, (denariis) DC Bellico Alexandrini, fide rogato $M$. Vibio Longo. Eum puerum sanum traditum esse, furtis noxave solutum, erronem fugitivum caducum non esse praestari: et si quis eum puerum quo de agitur partenue quam quis ex eo evicerit, quo minus emptorem supra scriptum eunue ad quem ea res pertinebit uti frui habere possidereque recte liceat, tunc quantum id erit, quod ita ex eo evictum fuerit, tantam pecuniam duplam probam recte dari fide rogavit Dasius Breucus, dari fide promisit Bellicus Alexandri, idem fide sua esse iussit Vibius Longus. Proque eo puero, qui supra scriptus est, pretium eius denarios DC accepisse et habere se dixit Bellicus Alexandri ab Dasio Breuco. Actum kanabis legionis XIII. geminae, XVII kal Iunias, Rufino et Quadrato cos. ..."

Dasius Breucus megvette és mancipatióval átvette az Apalaustus nevü rabszolgafiút, vagy ahogy éppen hívják, görög nemzetiségü, két unciáért nyugtázva, 600 dénárért Bellicustól, Alexander fiától, M. Vibius Longus kezességével. Dasius Breucus hite alatt kérdezte és Bellicus, Alexander fia hite alatt ígérte, hogy helytáll azért, hogy ezt a fiút egészségesen adta át, lopás vagy más delictum miatt nem áll fenn teljesítetlen követelés ellene, nem csavargó, nem szökött, nem epilepsziás; és ha valaki a szóban forgó fiút egészben vagy részben tőle elperli, aminek következtében a fentírt vevő ill. akihez a dolog éppen tartozik azt jogosan használni, bírni, birtokolni nem tudja, akkor amennyit az ér, ill. amennyit így elperelnek belöle, annak az összegnek a kétszeresét megfizeti.

Ugyanezért kezességet vállalt Vibius Longus. Bellicus, Alexander fia kijelentette, hogy a fent írt rabszolgafiúért a vételárat, 600 dénárt, átvette Dasius Breucustól.

\footnotetext{
${ }^{67}$ Ami formálisan biztosította a tulajdonának átruházását is, lásd: MOLNÁR - JAKAB (2012), 206. p.

${ }^{68}$ JAKAB (1993), 68. p.

${ }^{69}$ KASER - KNÜTEL (2014), 249. p.

${ }^{70}$ Ehhez lásd: PÓlAY (1965), 208-216. p.; JAKAB (1993), 78. p.

71 Ezek közül a FIRA III 87., 88., 89. és 132. számú okiratok tipikusnak tekinthetőek, és római hatást mutatnak, lásd: JAKAB (1993), 76-77. p.; CAMODECA (2000), 74-75. p.; FINKENAUER (2010), 60-62. p.
} 
Kelt a XIII. ikerlégió tábora melletti polgári telepen, május 16-án, Rufinus és Quadratus konzulságának évében..."72

Az okirat egy rabszolga adásvételéröl szól, amelyet a 13. ikerlégió melletti polgári településen (canabae) kötöttek meg Dácia provinciában Kr. u. 142-ben. A canabae a katonai tábor melletti olyan polgári település volt, ahol gyakran a rabszolgakereskedők is letelepedtek, mert a katonákkal is kereskedtek. ${ }^{73}$ A canabae lakossága az Apulumbeli 13. ikerlégiós tábor mellett is jórészt kereskedőkből, iparosokból, veteránokból és a legionáriusok családtagjaiból állt. ${ }^{74}$

Alapvetően kétfajta okirat létezett az ókori üzleti gyakorlatban: az egyes szám első személyben írtakat chirographumnak nevezik, az egyes szám harmadik személyben írtaknak pedig testatio a nevük. ${ }^{75}$ A fenti okirat egy testatio, amelyet a vevő kérésére foglaltak írásba egy viaszostáblán a jegyzőnél (tanúk jelenlétében) latin nyelven a szerződés teljesítését követően, ${ }^{76}$ így bizonyítéki funkciót töltött be az esetleges későbbi jogvitában. $^{77}$

A rabszolga vevője Dasius Brecus (aki valószínüleg illír származású volt), az eladó pedig egy Bellicus nevü férfi, akit az „Alexander fia” jelzővel illettek (ami esetleg a görög származására utal): a nevük alapján mindketten peregrini voltak. A kezesként fellépő Vibius Longus tipikus római nevéből arra lehet következtetni, hogy ő valószínűleg római polgár volt. $^{78}$

Az okirat tanúsága szerint a felek elöször a rabszolga legfontosabb tulajdonságaiban állapodtak meg, a nemében, a nevében és a nemzetiségében: egy görög nemzetiségü Apalaustus nevű fiú rabszolga került eladásra. Ezek a tulajdonságok elengedhetetlenek voltak a vétel tárgyának azonosításához. ${ }^{79}$ A nemzetiséget azért is volt fontos közölni, mert a minőségre vonatkozó jelentése is volt: már az ókorban is sztereotípiák alakultak ki az egyes nemzetekről, így a nemzetiség meghatározó volt annak a munkának a tekintetében, amelynek elvégzésére a rabszolgát szánták. ${ }^{80}$

\footnotetext{
${ }^{72}$ A fordítást lásd: JAKAB (2012), 127. p.

${ }^{73}$ Lásd: PÓlAY (1972), 25. p.

${ }^{74}$ Lásd: PÓLAY (1972), 25. p.

${ }^{75}$ Lásd: JAKAB (2011), 275-276. p.

${ }^{76}$ Lásd: PÓLAY (1972), 149. p.

${ }^{77}$ Lásd: JAKAB (1993), 82. p.

${ }^{78}$ A nevek problematikájához lásd részletesen: PóLAY (1972), 70., 72. és 128-129. p.

79 JAKAB (1993), p. 78.

${ }^{80}$ Ez megjelenik a D. 21,1,31,21 Ulpianus fragmentumban is: Qui mancipia vendunt, nationem cuiusque in venditione pronuntiare debent: plerumque enim natio servi aut provocat aut deterret emptorem: idcirco interest nostra scire nationem... (,Akik rabszolgákat adnak el, kötelesek az eladáskor közölni annak a
} 
A mancipatio aktusának említése az okiratban megtévesztő, mert mancipatiós tulajdonátruházás csak ius commerciivel, azaz vagyonjogi jogképességgel rendelkező személyek között mehetett végbe, amellyel az itt szerződő peregrinus felek nem voltak felruházva. ${ }^{81}$ A szóhasználat annak tulajdonítható, hogy a jegyző hivatalában valószínűleg gyakori volt a római formulagyüjtemények alkalmazása a testatio lejegyzésének alkalmával az idegenek jogügyleteinél is. ${ }^{82}$

A jogi és fizikai hibákért való helytállás egy kombinált stipulatio duplae-ben szerepel az okiratban. A vevő megkérdezte az eladót, hogy megígéri-e neki, hogy a rabszolgafiút egészséges állapotban adja át, és a rabszolgával szemben nem áll fenn teljesítetlen követelés, lopás vagy más delictum miatt. Az egészségi állapotra vonatkozó ígéret itt is megjelenik, mivel ez volt a rabszolga legfontosabb tulajdonsága a munkaképessége és a piaci értéke tekintetében. ${ }^{83}$ Varro a fenti idézetben a "sanum eum esse, furtis noxisque solutum" kifejezéseket használta, itt pedig a "sanum traditum esse, furtis noxave solutum” szerepel. A FIRA III 87., 89. és 132. számú okiratok ugyanezt a fenti sémát követik, és a Herculaneumban fennmaradt viaszostáblák okirataiban is hasonló klauzulák szerepelnek, ami azt mutatja, hogy ezeket a fenti tulajdonságokat valószínüleg mindig belefoglalták a kellékhibákért vállalt stipulatióba. ${ }^{84}$

Az eladó az okirat tanúsága szerint további hibák hiányát is megígérte, amelyek fennállása nem csupán a rabszolga fizikai vagy mentális állapotát, és annak munkaképességét (használhatóságát) érintették, hanem a vevő birtokláshoz való jogára nézve is veszélyt jelenthettek. Megígérte az eladó a stipulatióban, hogy a rabszolga nem szökött (fugitivus), nem csavargó (erro) és nem caducus.

A fugitivusszal a Digestában a jogtudósok hosszan foglalkoznak. ${ }^{85}$ A kortárs jogirodalomban vita folyik a fugitivus megítéléséről: az objektív megközelítés szerint „szökött” az a rabszolga, aki akár csak egyszer is megszökött, és e cselekedete miatt megbélyegzetten kezelik: ilyenkor az eladó azért állt helyt, amit a rabszolga a vétel előtt a múltban ténylegesen elkövetett. ${ }^{86}$ A szubjektív megközelítés abból indul ki, hogy a

nemzetiségét: a rabszolga nemzeti hovatartozása ugyanis vagy vásárlásra csábítja vagy elriasztja a vevőt: ezért érdekünkben áll, hogy ismerjük a nemzetiséget...”), lásd: JAKAB (2012), 122. p.

${ }^{81}$ MOLNÁR - JAKAB (2012), 206. p.; BENEDEK - PÓKECZ KOVÁCS (2013), 115. p.

${ }^{82}$ Lásd: PÓLAY (1972), p. 67.; JAKAB (1993), p. 78.

${ }^{83}$ Lásd: JAKAB (1993) 80. p.; DONADIO (2004), 57. p. 41. lj.

${ }^{84}$ Lásd: PÓLAY (1972), 152-153. p.; JAKAB (1993), 78-79. p.; CAMODECA (2000), 74-75. p.

${ }^{85}$ Lásd: D. 21,1,17 pr.-13. fragmentumok.

${ }^{86}$ Lásd: JAKAB (2003), 39. p. és JAKAB (2013), 194-195. p. 
szökevény rabszolga jellemhibás, és már a szökésre való hajlam is megalapozza a kellékhibát. ${ }^{87}$

Az erro olyan rabszolgát takar, aki nem akart ugyan megszökni, de ,gyakori szokása a céltalan kóborlás, és gyakran tér haza késői órán" ${ }^{88}$ A caducus valószínűleg epilepsziást jelent, ${ }^{89}$ amely egyértelműen egy olyan súlyos betegséget takart már az ókorban is, ami jelentős mértékben kihatott a rabszolga használhatóságára. ${ }^{90}$

A fenti tulajdonságok hiányára vonatkozó ígéretet a vételár kétszeresének, vagy a rabszolga részbeli elperlése esetén az elperelt összeg kétszeresének az ígérete követte az okirat szerint. A duplum odaígérése biztosítékot jelentett a vevőnek a jogilag tökéletes teljesítésre: az actio auctoritatis keresetét helyettesítette. ${ }^{91} \mathrm{Az}$ okiratnak ez a része ugyancsak nagyon hasonló ahhoz, ami a Varro-idézetben szerepelt. Nem utal azonban az okirat a stipulatiós garanciaígéretből fakadó keresetre, és annak tartalmára kellékhiba esetén.

A garancia-stipulatio keresete nyilvánvalóan a stipulatio általános keresete, az actio ex stipulatu volt. A vevő vagyoni érdeksérelmet szenvedett a kellékhiba miatt, emellett pedig a rabszolga sem ért annyit a hibából kifolyólag, mint amennyi a kifizetett vételár volt. $^{92}$ A kellékhibák miatt indított actio ex stipulatu célja így a vevő teljes érdeksérelmének, az interessének a megtérítése volt. ${ }^{93}$ A bírósági eljárásban az esküdtbírónak (arbiter) le kellett folytatnia egy becslőeljárást, hogy megállapítsa az interesse pontos értékét. ${ }^{94}$

\footnotetext{
${ }^{87}$ Lásd: Gamauf (1999), 110-111. p. és Gamauf (2006), 95-96. p. Erre utal az alábbi fragmentum: D. 21,1,17 pr. Ulpianus: Quid sit fugitivus, definit Ofilius: fugitivus est, qui extra domini domum fugae causa, quo se a domino celaret, mansit. („Fugitivus az, aki szökési szándékkal a dominus házán kívül marad azért, hogy elrejtözzön.”; saját fordítás).

${ }^{88}$ Ez szerepel az alábbi fragmentumban: D. 21,1,17,14 Ulpianus: Erronem ita definit labeo pusillum fugitivum esse, et ex diverso fugitivum magnum erronem esse. sed proprie erronem sic definimus: qui non quidem fugit, sed frequenter sine causa vagatur et temporibus in res nugatorias consumptis serius domum redit.

${ }^{89}$ Lásd: MEMMER (1990), 15. p.

${ }^{90}$ Lásd: D. 21,1,53.

${ }^{91}$ Lásd: JAKAB (2003), 41. p.; KASER - KNÜTEL (2008), 232. p. Az actio auctoritatisszal az archaikus jog mancipatiós vételénél a dolog szerzője az eladót perbe hívhatta, ha harmadik személy el akarta tőle perelni a dolgot, lásd: MolnÁR - JAKAB (2012), 303. p.; BENEDEK - PÓKeCZ KovÁCs (2013), 288. p.; FÖLDI HAMZA (2013), 517. p.

${ }_{92}$ Az ár-érték kérdéséhez lásd: JUSZTINGER (2012), 136. p.

${ }^{93}$ Lásd: HONSELL (1969), 26., 63. és 70. p.; ZIMMERMANN (1996), 310. p., valamint D. 21,2,31. Ha pontos összegre ment a stipulatio alapján fennálló követelés, akkor a jogosult keresete a condictio volt, fizikai hibák esetén azonban nem volt elsőre rögtön meghatározható, konkrét összegü a követelés, így a vevő keresete az actio ex stipulatu volt, lásd: KASER - KNÜTEL (2014), 235. p.

${ }^{94}$ Lásd: KASER - KNÜTEL (2014), 235. p.
} 
A stipulatio alapján az eladó minden esetben helytállni tartozott a hibátlanságért, illetve az esetlegesen kikötött tulajdonságokért. ${ }^{95}$ A helytállása így objektív jogalapú volt: az eladó tudattartalma a stipulatio esetén nem volt releváns, attól függetlenül felelt, hogy a hibáról tudott (tudhatott) vagy sem. ${ }^{96} \mathrm{Ez}$ azzal is indokolható, hogy az eladó kifejezett ígérete ésszerü bizalmat generálhatott a vevőben.

A kereskedelmi gyakorlattá váló garancia-stipulatiók főként a rabszolgák adásvételénél voltak szokásosak. ${ }^{97}$ Nagy hátrányuk volt az, hogy megkötésük a vevő és az eladó alkujának eredménye volt, de mivel befolyásolta a vételárat, azaz jelentős árképző szerepe volt, gyakran az eladó önkényén múlt a stipulatiós ígéret felvállalása. ${ }^{98}$

\subsection{Az adásvétel keresete}

A praetor jogalkalmazását (és jogalkotását) a bona fides, mint a magánfelek jogviszonyainak - különösen szerződéses viszonyainak - rendező elve határozta meg. ${ }^{99} \mathrm{~A}$ vevő keresete az adásvételi szerződés alapján az actio empti volt, amelynek kialakításánál szintén ez volt a vezérelv. ${ }^{100} \mathrm{Az}$ actio empti a konszenzuális szerződés jellemzőinek megfelelően egy szubjektív jogalapú kereset volt, azaz a bírósági eljárás során és az ítélet meghozatalánál tekintetbe vették az eladó jó- illetve rosszhiszemüségét is. ${ }^{101}$ Szépen demonstrálja a vételi kereset jellegét az alábbi fragmentum:

D. 19,1,11 pr.-1 Ulpianus

Ex empto actione is qui emit utitur. Et in primis sciendum est in hoc iudicio id demum deduci, quod praestari convenit: cum enim sit bonae fidei iudicium, nihil magis bonae fidei congruit quam id praestari, quod inter contrahentes actum est. quod si nihil convenit, tunc ea praestabuntur, quae naturaliter insunt huius iudicii potestate.

„A vételből eredő kereset [azaz az actio empti] a vevőnek áll rendelkezésére. És mindenekelőtt azt kell tudni, hogy ennek a keresetnek csak az lehet a tárgya, amiről [a felek] megállapodtak, hogy azért helytállnak: mivel [ez] a kereset bonae fidei

\footnotetext{
${ }^{95}$ Lásd: JAKAB (1993), 80. p.

${ }^{96}$ Lásd: MOLNÁR-JAKAB (2012), 304. p.

${ }^{97}$ Varro a hivatkozott müvében a szokásos adásvételi formulákat közli, amelyekből kiderül, hogy ,,a rejtett hibákért való helytállás vállalása [...] szokásos volt az eladó részéről”, lásd: JAKAB (1996), 118. p.; Varro gyakran hivatkozik egy Manilius nevü, a Kr. e. II. században hivatalban lévő hispániai praetor adásvételi szabályokat összefoglaló formuláskönyvére, lásd: JAKAB (1993), 71. p. Az általánosan előforduló formulákat lásd például: Varro rust. 2.1.15; 2.2.5; 2.5.11;2.6.3; 2.10.5.

${ }^{98}$ PÓLAY (1953), 128. p.

${ }^{99}$ Lásd ehhez: FöLDI (2001), 16-19. p.

${ }^{100}$ MANTHE (1976), 142. p.; MOLNÁR - JAKAB (2012), 302. p.

101 Lásd: D. 19,1,11 pr. és D. 19,1,6,8. és a jogirodalomban lásd többek között: HonsELL (1969), p. 79.; ZIMMERMANN (1996), 308-309. p.; MOLNÁR - JAKAB (2012), 304-305. p.
} 
kereset, és semmi más nem felel meg jobban a bona fidesnek, mint helytállni azért, amit a szerződö felek kikötöttek. Ha [pedig a felek] semmit nem kötöttek ki, akkor azért kell helytállni, ami természetszerüleg ennek a keresetnek a hatáskörébe tartozik."102

A fragmentum az adásvételből eredő vevői keresetről szól. Az adásvétel megkötése alkalmával a felek a szerződéses szabadság elvéből fakadóan elvileg bármiben megállapodhattak. ${ }^{103} \mathrm{Az}$ adásvételi szerződés lényeges tartalmi elemei közé az adásvétel tárgyának, azaz az árunak és a vételárnak az adekvát meghatározása tartozott. ${ }^{104} \mathrm{~A}$ szerződésből eredő főkötelezettségek ennek alapján abban álltak, hogy a vevőnek meg kellett fizetnie a kikötött vételárat (dare szolgáltatás), az eladó pedig kötelezte magát arra, hogy az áru birtokát átadja a vevőnek (facere típusú szolgáltatás). ${ }^{105}$ A bona fides elve a fragmentum szerint az actio empti céljában mutatkozik meg leginkább: a vevő ennek megfelelően a jóhiszemüség és tisztesség elvéből fakadóan követelheti a szerződésben meghatározottnak tökéletesen megfelelő áru birtokának az átadását. A fragmentum utolsó mondata azt tükrözi, hogy olyan eset is elöfordulhatott, amikor a felek nem rögzítették egzaktan a szerződés tartalmát; ilyenkor Ulpianus megoldása alapján ugyancsak a vételi kereset eredendő céljának megfelelően az ügyletből természetszerüen következő követeléssel élhet a vevő, azaz követelheti az áru birtokának átadását. ${ }^{106}$ A szerződés tartalmát ilyen esetben nyilvánvalóan egyedileg kellett a peres eljárásban vizsgálni, és az alapján lehetett megállapítani a vevő konkrét érdeksérelmét (interesse) abból fakadóan, hogy nem kapta meg a dolgot vagy nem úgy kapta meg, mint ahogy az a szerződésben szerepelt. $^{107}$

\subsection{Az adásvétel különös fajtája: a „próbára vétel”}

A minőséghez füződő érdek kérdésköréhez kapcsolódik a pactum displicentiae, az eladó és vevő által „,nem tetszés esetére” kötött mellékegyezmény. ${ }^{108}$ A korabeli nem jogászi irodalom tanúsága szerint a pactum alapján a vevő nem tetszés esetén egy a felek által meghatározott határidőn belül visszaléphetett az ügylettől. ${ }^{109}$ A paktum egyértelmüen a

\footnotetext{
102 Pozsonyi Norbert fordítása.

${ }^{103}$ ZIMMERMANN (1996), 258. p.

${ }^{104}$ ERNST (2013), 38. p.

105 KASER - KNÜTEL (2014), 194. p.

${ }^{106}$ ZIMMERMANN (1996), 278. p.

${ }^{107}$ KASER - KNÜTEL (2014), 203. p.; ERNST (2013), 81. p.

${ }_{108}$ MiSERA (1982), 524. p.; MOLNÁR - JAKAB (2012), 305. p.

${ }^{109}$ PÓKECZ KOVÁCS (2012), 202. p.
} 
vevő javára szolgált, és már elég korán megjelent az ügyletkötési szokások között. ${ }^{110}$ A Digestában is találunk erre vonatkozó forrást:

\section{18,5,6 Paulus}

Si convenit, ut res quae venit, si intra certum tempus displicuisset, redderetur, ex empto actio est, ut sabinus putat, aut proxima empti in factum datur.

„Ha úgy állapodtunk meg, hogy az eladott dolgot egy meghatározott időpont után vissza kell adni, ha neked nem tetszik, Sabinus úgy gondolja, a vevőt actio empti illeti meg, vagy legalább egy in factum actio, ami az actio emptihez hasonló."111

A fragmentum egyike a csupán néhány Digesta-helynek, amely említi a pactum displicentiae-t, a nem jogászi irodalmi müvek azonban arról tanúskodnak, hogy elterjedt volt az ilyen kikötés az eladó és a vevő jogviszonyában. ${ }^{112}$ A tetszőlegesen megállapítható határidőt valószínűleg a kereskedő adott piacon tartózkodásának tervezett idejéhez szabták a felek. ${ }^{113}$ A nem tetszés esetére kötött pactum displicentiae kérdése az igényérvényesítési határidőket illetően jelent meg a piaci adásvétellel kapcsolatos magistratusi szabályozásban. ${ }^{114}$

\section{Az aedilis curulis és edictuma}

Az aedilis curulis magistratusi tisztségét Kr.e. 367-ben alapították. Az ö feladata többek között a városrendészeti teendők ellátása volt, és a kereskedelem felvirágozásával az ő hatáskörébe került a piacfelügyelet, a forgalom biztonságának ellenőrzése, és a piaci adásvétellel összefüggő kérdések szabályozása is. ${ }^{115}$ Rendelkezett ius edicendivel, azaz edictumában kibocsáthatta éves hivatali programját. ${ }^{116}$ Ebben tette közzé a piaci kereskedésre vonatkozó szabályokat is, amelyeket az eladóknak be kellett tartaniuk. ${ }^{117} \mathrm{~A}$ szabályozás kialakítása visszavezethető a piacokon már spontán kialakult kereskedelmi

\footnotetext{
${ }^{110}$ Lásd: PETERS (1973), 82. p.

${ }^{111}$ Lásd: PÓKECZ KovÁCS (2012), 204. p.

112 Lásd: PÓKECZ KovÁCs (2012), 204. p. A pactum gyakorlati jelentőségét bizonyítja, hogy az aedilis curulis is felvette azt az edictumába, lásd később. JAKAB (1993), 28. p.

${ }^{113}$ Lásd: JAKAB (1993), 27. p.

${ }_{114}$ A kérdéskör ezért az igényérvényesítési határidőkről szóló pontban kerül tárgyalásra.

115 Az aedilis curulis tisztségének jellemzéséhez lásd: JAKAB (1993), 33-65. p.; PóLAY (1964), 8-9. p.; valamint KASER (1963), 173-176. p.

${ }^{116}$ MOLNÁR - JAKAB (2012), 56. p.; FÖldi - HAMZA (2013), 83. p.; BENEDEK - PÓKECZ KovÁCS (2013), 55. p.; JAKAB (1993), 43-45. p.

117 JАКАВ (1993), 43. p.
} 
gyakorlatra, valamint arra, hogy a hivatásos kereskedők gyakran próbálták kihasználni a piaci szokásokkal és a minőséggel kapcsolatban tájékozatlan vevőket. ${ }^{118}$

A piaci adásvételt és annak hibás teljesítését szabályozó aediliszi edictum megalkotásánál az eladói garancia-stipulatio gyakorlata állt a magistratus rendelkezésére példaként. ${ }^{119} \mathrm{Az}$ utóbbinak számos előnye volt: rugalmas volt, bármilyen egyezséget, jogügyletet tartalmazhatott, és az áru valamely tulajdonságának, vagy az áru hibamentességének garantálására is alkalmazhatták. ${ }^{120}$ Emellett az eladói garancia-stipluatiók tükrözték leginkább a jogéletet, a kereskedelmi gyakorlatot, szerződési praxist, így az aediles curules feltehetően ezek alapján konstruálták meg rendelkezéseiket. ${ }^{121}$ Az edictum szabályai a Kr.e. I. századra már kikristályosodott formában próbálták rendezni a piaci áruforgalmat. ${ }^{122}$ Mivel az egyik legjelentősebb árucikk a piacokon a rabszolga volt, az edictum kezdetben csak annak adásvételéröl rendelkezett.

\subsection{Az edictum aedilium curulium szerinti kellékhibák rabszolgák adásvétele esetén}

A Digestában szereplő kommentárok csak részben tartalmazzák az edictum eredeti szövegét, de a jogászoknak az edictumhoz, mint jogforráshoz füzött magyarázatai a kereskedelmi gyakorlatban kialakult szokásokat és az aediliszi joggyakorlatot részletesen mutatják be, így azokból számos következtetés levonható. Ulpianus megfogalmazásában ismerjük az edictum korabeli szövegét:

\section{21,1,1,1 Ulpianus}

Aiunt aediles: Qui mancipia verdunt certiores faciant emptores, quid morbi vitive cuique sit, quis fugitivus errove sit noxave solutus non sit: eademque omnia, cum ea mancipia venibunt, palam recte pronuntiatio. Quodsi mancipium adversus ea venisset, sive adversus quod dictum promissumve fuerit cum veniret, fuisset, quod eius praestari oportere dicetur: emptori omnibusque ad quos ea res pertinet iudicium damibus, ut id mancipium redhibeatur...

Item si quod mancipium capitalem fraudem admiserit, mortis consciendae sibi causa quid fecerit, inve harenam depugnandi causa ad bestias intromissus fuerit, ea omnia in venditione pronuntiatio: ex his enim causis iudicium dabimus. Hoc amplius si quis adversus ea sciens dolo malo vendidisse dicetur, iudicium dabimus.

„Az aediliszek elrendelik: akik rabszolgákat adnak el, hozzák a vevő tudomására, melyiknek mi a betegsége vagy hibája, melyik szökött vagy csavargó és melyiket terheli noxa; mindezt, amikor rabszolgákat adnak el, kötelesek helyesen és

\footnotetext{
${ }^{118}$ Lásd: ROGERSON (1959), 116. p.

${ }^{119}$ PÓLAY (1964), 6. p.

${ }^{120}$ PÓLAY (1964), 6. p.

${ }^{121}$ JAKAB (1993), 28-29. p. és 47. p.

${ }^{122}$ PÓLAY (1964), 11. p.
} 
nyilvánosan kijelenteni. Ha egy rabszolgát ezekkel [az előírásokkal] ellenkezően adnak el, vagy nem olyan állapotban volt, amit [az eladó] az eladáskor mondott vagy ígért, ami miatt [a vevő] állítja, hogy [az eladó] helytállni köteles: akkor a vevőnek és mindazoknak, akikhez a dolog tartozik, megadjuk a perlési lehetőséget arra, hogy a rabszolga visszvétessék...

Ugyanúgy, ha a rabszolga halálbüntetéssel fenyegetett büncselekményt követett el, öngyilkosságot kísérelt meg vagy az arénában vadállatokkal való harcra ítélték, mondják meg mindezt eladáskor; ezen okok miatt ugyanis megadjuk a perlési lehetőséget. Azonkívül akkor is megadjuk a perlési lehetőséget, ha [a vevő] állítja, hogy [az eladó] tudva csalárdul ezekkel [az előírásokkal] ellenkezően adott el."123

E lemmatikus kommentáron ${ }^{124}$ kívül további, az áruról kötelezően szolgáltatandó információkat az alábbi két fragmentum jelez. Ezek valószínűsíthetően még nem képezték az első aediliszi edictum részét, hanem később, fokozatosan kerültek felvételre: ${ }^{125}$

D. 21,1,31,21 Ulpianus

Qui mancipia verdunt, nationem cuiusque in venditione pronuntiare debent: plerumque enim natio servi aut provocat aut deterret emptorem: idcirco interest nostra scire nationem...

„Akik rabszolgákat adnak el, kötelesek az eladáskor közölni annak a nemzetiségét: a rabszolga nemzeti hovatartozása ugyanis vagy vásárlásra csábítja vagy elriasztja a vevőt: ezért érdekünkben áll, hogy ismerjük a nemzetiségét..."

\section{21,1,37 Ulpianus}

Praecipiunt aediles, ne veterator pro novicio veneat. Et hoc edictum fallaciis venditorum occurrit: ubique enim curant aediles, ne emptores a venditoribus circumveniantur. Ut ecce plerique solent mancipia, quae novicia non sunt, quasi novicia distrahere ad hoc, ut pluris vendant...

„Az aediliszek elöírják, hogy ne adjanak el veteratort noviciusként. Az edictum igyekszik megelőzni az eladók csalárdságát: az aediliszek gondoskodnak arról, hogy a vevőket ne szedjék rá az eladók. Egyeseknek ugyanis az a szokása, hogy rabszolgákat, akik nem noviciusok, noviciusként adják el az okból, hogy többért tudják eladni..."

Az edictum a fenti források alapján az eladó tájékoztatási kötelezettségére vonatkozó elöírásokat tartalmazta taxatív felsorolás keretében. Ezek a kellékhibák az edictum történeti fejlödése alapján tehát a következő tulajdonságok voltak:

1. a rabszolga egészséges illetve beteg volta (morbi vitiique vagy sanum esse),

\footnotetext{
${ }^{123}$ A fordítást lásd: JAKAB (2012), 121. p. A továbbiakban a Digesta-források fordításait lásd: JAKAB (2012), 105-134. p.

${ }^{124}$ Lásd: HAUSMANINGER - SELB (1997), 88. p.

${ }^{125}$ A Kr. e. II. században már valószínúleg szerepeltek az edictumban, lásd: PólAY (1964), 24. p. Az edictum réteges szerkezetéhez vö. SELB (1986), 262-265. p.
} 
2. delictum elkövetése miatt vele szemben fennálló noxális követelés (noxave solutus non sit),

3. szökött volta (fugitivus),

4. csavargó volta (erro),

5. valaha súlyosabb büncselekmény elkövetése miatt elítélték (ad bestias damnatus),

6. korábban öngyilkosságot kísérelt meg (mortis consciendae sibi causa fecerit),

7. nemzetisége,

8. novitius volta, azaz hogy újonnan rabszolgasorba került rabszolga volt-e, vagy korábban már szolgált valakinél (veterator).

A hibák zárt, taxatív katalógusa tipikusan olyan tulajdonságokat tartalmazott, amelyek megléte vagy hiánya nagyban befolyásolta a vevő vételi szándékát, kihatott a rabszolga piaci értékére, használhatóságára és így a vételárra is. ${ }^{126} \mathrm{Az}$ mondható, hogy egyfajta minimum-szabályozást érvényesített az aedilis curulis, a legfontosabb tulajdonságokra vonatkozó tájékoztatást tette kötelezővé. ${ }^{127}$

$\mathrm{Az}$ aediliszi jogalkalmazást és az edictum meghirdetését is nagyban befolyásolta a vevő magatartására vonatkozó alapelv, a caveat emptor. Ebből fakadt az a megszorítás a szabályozásban, hogy az eladó csupán azon hibákért illetve hiányosságokért tartozott helytállni, amelyeket a vevő körültekintő eljárásával, az alkut megelőzően az áru megvizsgálásával sem ismert vagy ismerhetett volna fel, azaz csak az ún. rejtett hibákért kellett helytállnia. ${ }^{128} \mathrm{Az}$ elv érvényesülése kitünik az alábbi aediliszi edictumhoz füzött kommentárból:

\section{21,1,1,6 Ulpianus}

Si intellegatur vitium morbusve mancipii (ut plerumque signis quibusdam solent demonstrare vitia), potest dici edictum cessare: hoc enim tantum intuendum est, ne emptor decipiatur.

„Ha a rabszolga betegségét vagy hibáját észre lehet venni, mint ahogy bizonyos jelek utalni szoktak a hibára, mondhatjuk, hogy az edictumot nem lehet alkalmazni: az edictum ugyanis arra az esetre vonatkozik, hogy a vevőt ne csapják be."129

E forráshely arra utal, hogy az aediliszi edictum kibocsátásának egyik célja a vevők védelme a csalárd piaci kereskedőkkel szemben. ${ }^{130}$ Erre figyelemmel az észrevehető hibák

\footnotetext{
${ }^{126}$ Lásd: D. 21,1,31,21. GAROFALO (2000), 5. p.

${ }^{127}$ Lásd: GAROFALO (2000), 5. p.; JAKAB (2003), 33. p.

${ }^{128}$ Lásd: MOLNÁR - JAKAB (2012), 304. p.; FÖLDI - HAMZA (2013), 518. p.

${ }^{129}$ Lásd továbbá: D. 21,1,14,10.

130 Lásd ezen kívül: D. 21,1,1,2, amelyben a circumvenire ige utal a megtévesztő, csalárd eladói magatartásra; JAKAB (1993), 49. p.
} 
esetére Ulpianus interpretációjának megfelelően nem biztosítható a védelem, mert az már túlmenne ezen a jogpolitikai szándékon. ${ }^{131}$ A vevőnek fennállt a megvizsgálási kötelezettsége, azaz az aediliszi szabályok a kockázattelepítés egyensúlyának elvén alapultak.

Az egyes aediliszi kellékhibákra nézve a Digestában található edictumkommentárok és források adnak részletesebb felvilágosítást. Az első négy kellékhiba egyértelműen tükrözi a kereskedelmi gyakorlatban előforduló eladói garancia-ígéretek tartalmát, jelölve a rabszolga leglényegesebb tulajdonságait. Az eladó egyik legfontosabb közlési kötelezettsége tehát a rabszolga egészségi állapotára (sanum esse) vonatkozott. A rabszolga esetleges betegségét jelző morbus és vitium kifejezések általában együtt, egy szókapcsolatban szerepelnek a forrásokban, ${ }^{132}$ de jelentésük szétvált. A morbus (betegség) a vonatkozó jogtudósi definíciók szerint egy természetellenes fizikai állapot volt, amely a test természetszerü „használatát” gátolta, és fennállhatott a rabszolga egész testén, vagy annak csupán egy részét is érinthette. ${ }^{133}$ A vitium (hiba) ezzel szemben csak a fizikai hibákat takarja. ${ }^{134}$ A mentális hibák nem képezték az aediliszi helytállás alapját, ezekért a helytállást legfeljebb külön stipulatióban, vagy formátlan ígéretben lehetett felvállalni. ${ }^{135}$ Így például nem tekintették fizikai hibának, ha a rabszolga babonás, lobbanékony természetü, makacs vagy könnyelmü volt, és az sem tartozott az edictum hatálya alá a jogtudósok kommentárjai alapján, ha a rabszolga félénk, kapzsi vagy fukar volt. ${ }^{136}$ Léteztek azonban olyan esetek, amelyeknél valamely mentális fogyatékosság generálta a fizikai hibát, ebben az esetben alkalmazható volt az edictum. ${ }^{137}$ A kisebb, jelentéktelen fizikai hibák, amelyek a rabszolga munkaképességét tartósan és visszafordíthatatlanul nem befolyásolták, mint például az enyhe láz vagy egy kisebb seb, nem tartoztak a szabályozási

\footnotetext{
${ }^{131}$ ROGERSON (1959), 130. p.

${ }^{132}$ Lásd fent a D. 21,1,1,1-ben: „morbi vitiive”.

133 Lásd: D. 21,1,1,7 Ulpianus: „, Sed sciendum est morbum apud sabinum sic definitum esse habitum cuiusque corporis contra naturam, qui usum eius ad id facit deteriorem, cuius causa natura nobis eius corporis sanitatem dedit: id autem alias in toto corpore, alias in parte accidere... ". Lásd még D. 21,1,5; D. 21,1,10 pr.; D. 21,1,12,1.

${ }^{134}$ Ez tünik ki kifejezetten a D. 21,1,1,9, a D. 21,1,1,10 és a D. 21,1,4,3 fragmentumokból. Ulpianus példája a dadogás a D. 21,1,1,7-ben; ZIMMERMANN (1996), 313. p.

${ }^{135}$ Lásd: D. 21,1,4,3. A különböző mentális hibák kizárásához lásd például: D. 21,1,1,9.

${ }^{136}$ Lásd: D. 21,1,1,11; D. 21,1,1,3.

137 Így például a rabszolga szökevény vagy csavargó volta, mint jellembeli tulajdonságok, a noxális kötöttség esetleges terhe, súlyos büncselekmény elkövetése; lásd még: D. 21,1,4,1.
} 
körbe. ${ }^{138}$ Az azonban megjelenik a kommentárokban, hogy az edictum hatálya alá tartozó betegség nem csak állandó jellegü, hanem időszakosan jelentkező is lehetett. ${ }^{139}$

A következő két aediliszi hiba, a rabszolga szökött (fugitivus) illetve csavargó (erro) volta részben már a fent említett jellembeli hibák közé sorolható, amelyek azonban olyan súlyosnak bizonyultak, hogy az aedilis curulis kiemelte őket. ${ }^{140}$ Ezek is általában egy szókapcsolaton belül szerepeltek a morbushoz és vitiumhoz hasonlóan, ${ }^{141}$ azonban a Digesta edictum-kommentárjai felvilágosítást adnak a jelentéskülönbségről. Ulpianus meghatározásában szökevény az a rabszolga, aki abból a célból marad távol ura házától, hogy elmeneküljön, elrejtőzzön elöle. ${ }^{142}$ A fugitivus objektív és szubjektív megítélésére vonatkozóan említettek itt is irányadóak. ${ }^{143} \mathrm{Az}$ objektív megközelítés helyesebbnek látszik, ${ }^{144}$ mert méltánytalan csupán a szökésre fennálló lehetőség, a szökevény hajlam miatt perbe vonni az eladót. Helyesebb a múltbeli tények alapján elbírálni a rabszolga e tulajdonságát, ${ }^{145}$ ennek fényében a ,szökött” megfelelőbb jelzőnek látszik a „szökevénynél”. A csavargó (erro) rabszolga ezzel szemben az, aki valójában nem szökik meg, hanem csak gyakorta kószál el céltalanul, majd az időpazarlás után egy kései órán hazatér ura házába. ${ }^{146}$

Ha a rabszolga idegen személynek büncselekménnyel kárt okozott, akkor a károsult kártérítést illetve büntetést követelve a rabszolgatartó ellen fordulhatott noxális actióval. ${ }^{147}$ Az ilyen noxális kötöttség hiánya éppen ezért szintén fontos tulajdonság volt, mert a noxával terhelt rabszolgát a vevő akár el is veszíthette. ${ }^{148} \mathrm{Az}$ aedilis curulis ebből a megfontolásból és a kereskedelmi gyakorlatnak megfelelően a noxális kötöttségre vonatkozó tájékoztatási kötelezettséget is elöírta, ami a gyakorlatban azt jelentette a jogtudósok szerint, hogy az eladónak kifejezetten azt kellett nyilatkoznia, hogy harmadik személy nem fog noxális keresettel élni a rabszolgával szemben. ${ }^{149}$

\footnotetext{
${ }^{138}$ Lásd: D. 21,1,1,8.

139 Lásd: D. 21,1,6 pr. Ulpianus: Pomponius recte ait non tantum ad perpetuos morbos, verum ad temporarios quoque hoc edictum pertinere. („Pomponius helyesen mondja, hogy az edictum nem csak a krónikus, hanem az időszakosan jelentkező betegségekre is vonatkozik.”, saját fordítás).

${ }^{140}$ PÓLAY (1964), 21. p.

${ }^{141}$ Lásd fent a D. 21,1,1,1-ben: ,fugitivus errove".

${ }^{142}$ Lásd: D. 21,1, 17 pr., valamint D. 21,1,17,1-13 fragmentumok.

143 Lásd: JAKAB (2003), 39. p. és JAKAB (2013), 194-195. p., valamint GAMAUF (1999), 110-111. p. és GAMAUF (2006), 95-96. p.

${ }^{144}$ Vö. JAKAB (2003), 39. p. és JAKAB (2013), 194-195. p.

145 Azaz helyesebb az objektív helytállásnak megfelelően a múltbéli szökésre, mint eredményre tekinteni.

${ }^{146}$ Lásd: D. 21,1,17,14.

${ }^{147}$ Lásd: MOLNÁR - JAKAB (2012), 331. p.; FÖLDI - HAMZA (2013), 561. p.; BENEDEK - PÓKECZ KovÁCS (2013), 316. p

${ }^{148}$ Lásd: a fent hivatkozott Varro-idézetnél (Varro rust. 2.10.5.) említettek.

${ }^{149}$ Lásd: D. 21,1,17,17; ZIMMERMANN (1996), 314. p.
} 
Azok a szintén jellembelinek tekinthető hibák, hogy a rabszolga halálbüntetéssel fenyegetett büncselekményt követett el, vagy súlyos büncselekmény miatt az arénában vadállatokkal való harcra ítélték, valamint ha valaha öngyilkosságot kísérelt meg, valószínűleg csak a principátus korában kerültek felvételre az edictumba. ${ }^{150} \mathrm{E}$ három hibára vonatkozóan nem találni számottevő jogtudósi kommentárt a Digestában. Egyedül Ulpianus tudósít arról, hogy az ad bestias damnatus azt jelenti, hogy a rabszolga olyan büncselekményt követett el szándékosan, amelyért akár halálra is ítélhető lenne; ha gondatlanul vagy véletlenül követett el ilyen büncselekményt, akkor nem volt alkalmazható az edictum. ${ }^{151}$ Az öngyilkossággal kapcsolatban szintén Ulpianus írja, hogy aki saját életét próbálta meg kioltani, azt „,rossz rabszolgának” tartották. ${ }^{152}$

Tárgyi hatályát tekintve az edictumra vonatkozó kiterjesztő értelmezést tartalmaz egy Gaiustól származó jogeset, miszerint akkor, ha a telek adásvételének részét, azaz annak alkatrészét képezi a rajta lévő összes rabszolga, abban az esetben is áll a rabszolgákra az eladó helytállási kötelezettsége (hogy ne lehessen így megkerülni az aediliszi szabályokat). ${ }^{153}$ Egy másik forrás szerint, ha egy rabszolgát a különvagyonával vagy az örökségével együtt adtak el, az edictum szabályai az utóbbiaknak az egyes, különálló részeire nem vonatkoztak. ${ }^{154}$

\subsection{Kellékhibák az igásállatok adásvételénél}

Az árutermelő Róma piaci kereskedelmében a rabszolgák gazdaságilag jelentős munkaereje miatti kelendősége vitathatatlan, azonban az igásállatok (iumenta) gazdaságilag ugyancsak fontosak voltak, így a piaci kereskedelemben azok is árucikként vettek részt. ${ }^{155} \mathrm{Az}$ igásállatok kereskedelme a Kr.e. I. században ugrásszerüen megnőtt a piacokon, valószínüleg ennek köszönhetően terjesztették ki az aediles curules edictumbeli

\footnotetext{
${ }^{150}$ Feltehetően közvetlenül Hadrianus előtt vagy Hadrianus korában, lásd: PÓLAY (1964), 22. p.

${ }^{151}$ Lásd: D. 21,1,23,2 Ulpianus: Excipitur etiam ille, qui capitalem fraudem admisit. capitalem fraudem admittere est tale aliquid delinquere, propter quod capite puniendus sit: veteres enim fraudem pro poena ponere solebant. capitalem fraudem admisisse accipiemus dolo malo et per nequitiam: ceterum si quis errore, si quis casu fecerit, cessabit edictum.

152 Lásd: D. 21,1,23,3. Ulpianus példálózva még az öngyilkosság egyes módjait is felsorakoztatja e fragmentumban.

${ }^{153}$ Lásd: D. 21,1,32 pr. Gaius: Itaque sicut superius venditor de morbo vitiove et ceteris quae ibi comprehensa sunt praedicere iubetur, et praeterea in his causis non esse mancipium ut promittat praecipitur: ita et cum accedat alii rei homo, eadem et praedicere et promittere compellitur. quod non solum hoc casu intellegendum est, quo nominatim adicitur accessurum fundo hominem stichum, sed etiam si generaliter omnia mancipia quae in fundo sint accedant venditioni. A fragmentum elemzéséhez lásd: WACKE (2002), 813-817. p.

${ }^{154}$ Lásd: D. 21,1,33 pr. A fenti és e fragmentum elemzésétől eltekintek.

155 JАKAB (1993), 29. p.
} 
szabályaikat az igásállatok adásvételére is. ${ }^{156}$ A iumentum-edictum szövegét szintén Ulpianus kommentárjából ismerhetjük meg:

D. 21,1,38 pr. Ulpianus

Aediles aiunt: Qui iumenta verdunt, palem recte dicunto, quid in quoque eorum morbi vitiique sit... Si quid ita factum non erit... morbi autem vitiive causa inemptis faciendis in sex mensibus vel quo minoris cum venirent, fuerint, in anno iudicium dabimus. Causa autem huius edicti eadem est, quae mancipiorum redhibendorum.

„Az aediliszek elrendelik: Akik igásállatot adnak el, mondják meg nyíltan és helyesen, melyiknek mi a betegsége vagy hibája, és ahogyan az eladáskor felszerszámozták öket, úgy adják át őket a vevőknek. ... Ha ez nem így történik, a felszerszámozás miatt a felszerelés kiadására hatvan napon belül, a betegség vagy hiba miatt hat hónapon belül keresetet adunk a vétel felbontására vagy egy éven belül arra, amennyivel kevesebb volt (a dolog értéke) az eladáskor."

Az igásállatok munkaképességének legfontosabb záloga az egészségi állapotuk volt, ezért az edictum-idézet is csak erre utal. A jószágok vételára azonban általában viszonylag magas volt, így betegségük esetén a vevőt a rabszolgákhoz hasonlatos jelentős érdeksérelem érhette. ${ }^{158}$ A rabszolgával kapcsolatos többi kellékhiba a jószágok esetén értelemszerüen nem volt releváns. A betegséget és hibát mindig egyedileg kellett megítélni; ${ }^{159}$ itt is az volt a döntő, hogy az mennyiben hat ki az állat használhatóságára: míg például a nemzőképességét elvesztett ló egészségesnek minősült (mert a mindennapi munkában ez nem hátráltatta, ha igáslónak, és nem fedezőménnek szánták), ${ }^{160}$ addig betegnek tekintették azt, amelynek kivágták a nyelvét (mert az ilyen sérülés miatt a ló alig tud enni). ${ }^{161}$

Az aedilisz a rabszolgavétellel kapcsolatos szabályozással egyezően két keresetet, az actio redhibitoriát és az actio quanti minorist bocsátotta a vevő rendelkezésére az igásállat hibája, betegsége esetére.

\footnotetext{
${ }^{156}$ GAROFALO (2000), 5-11. p.; MARÓTI (1962), 2-3.p.

${ }^{157}$ Lásd ezen kívül: D. 21,1,48,6.

158 JAKAB (1993), 31. p.

${ }^{159}$ Lásd: JAKAB (2003), 36. p.

${ }^{160}$ Lásd: D. 21,1,38,7.

${ }^{161}$ Lásd: D. 21,1,8. ZiMMERMANN (1996), 319. p.
} 


\subsection{Az aediliszi edictum alanyi és területi „hatálya”}

Területi hatályát tekintve az aedilis curulis hatásköréböl fakadóan az edictum csak a piacon megkötött adásvételekre vonatkozott. ${ }^{162}$ A szabályozás diszpozitív jellegét egy a Digesta második könyvében, a pactumokról szóló fejezetben található fragmentum jelzi, miszerint az edictum szabályaitól a felek egyező akarattal eltérhettek. ${ }^{163}$

Az aktív legitimációt illetően a D. 21,1,1,1 alapján megállapítható, hogy az aedilis előtti eljárásban a vevőn kívül mindazok állhattak a felperesi pozícióban, ,akikhez a dolog tartozott”, azaz akik a dolgot utóbb megszerezték (azaz a vevő vagy a jogutódja). Az aediliszi kellékszavatosság tehát tulajdonváltozást türő jogintézmény volt. Alapesetben az eladó került az alperesi pozícióba. Ha azonban egy rabszolga vagy egy hatalomalatti fiú bonyolította le az adásvételt, a hatalomfö vált kötelezetté az edictum alapján a peculium (a hatalomalatti vagy a rabszolga különvagyona) erejéig, és ugyanez érvényesült a hatalomalatti lány illetve rabszolganő ügyletkötésével kapcsolatban is. ${ }^{164} \mathrm{Az}$ eladó örökösei ellen is meg lehetett indítani az aediliszi kereseteket. ${ }^{165}$

\subsection{Az aediliszi keresetek}

$\mathrm{Az}$ aediles curules által biztosított első jogorvoslat az eladóval szemben az actio redhibitoria keresete volt. Erre vonatkozóan Ulpianusnak az aediliszi edictumot idéző D. 21,1,1,1 és a D. 21,1,38 pr. fragmentumai jelentik a kiindulópontot. Akkor folyamodhatott a vevő ehhez a keresethez, ha egy rabszolgát (igásállatot) az aediliszi előírásokkal ellentétesen adtak el. Ha az eladó nem tudott a hibáról, akkor is köteles volt helyt állni,

1. ha kiderült, hogy a rabszolga valamely ,,aediliszi kellékhibával” terhelt volt, és az eladó ezt nem közölte a vevővel, vagy

2. ha valamely negatív tulajdonság, amelynek hiányát az eladó garantálta, mégis megvolt benne, vagy

\footnotetext{
${ }^{162}$ Lásd: D. 21,1,48,8: Simplarium venditionum causa ne sit redhibitio, in usu est. („Az „,egyszerü [...] adásvételre szokásosan nem alapozható redhibitio.”). Lásd: ZIMMERMANN (1996), 319. p.

${ }^{163}$ D. 2,14,31 Ulpianus: Pacisci contra edictum aedilium omnimodo licet, sive in ipso negotio venditionis gerendo convenisset sive postea. Lásd: JAKAB (2003), 36. p.

${ }_{164}$ Lásd: D. 21,1,23,4. Ez tekinthetö quasi actio de peculionak is. Az actio de peculio a hatalomfö elleni olyan praetori járulékos kereset volt, amely akkor volt megindítható, ha a hatalomalatti vagy a rabszolga harmadik személlyel kötött valamilyen jogügyletet, és rendelkezett különvagyonnal, lásd: MOLNÁR - JAKAB (2012), 136. $\mathrm{p}$

${ }^{165}$ Lásd: D. 21,1,23,5; D. 21,1,48,5.
} 
3. ha valamely pozitív tulajdonság, amelynek meglétét kifejezetten ígérte az eladó, hiányzott.

4. Végül fennállt az aediliszi helytállási kötelezettség akkor is, ha az eladó rosszhiszemű volt, azaz tudott bármely kellékhibáról, de azt nem közölte a vevővel: “tudva csalárdul ezekkel [az előírásokkal] ellenkezően adott el”. ${ }^{166}$

Az első eset egyértelműen arra utal, hogy az edictumban foglalt tájékoztatási kötelezettség betartásáért az eladó objektív jellegű helytállással tartozott.

A második és harmadik esetkör a dicta et promissára, az eladó kifejezett ígéretére utal. A dicta et promissa azt jelentette, hogy az eladó az ediktális hibák körét kitágítva más tulajdonságok hiányát illetve fennállását is kijelenthette az adásvétel alakalmával, és ezen ígéretekért is helytállással tartozott az edictum alapján. ${ }^{167}$ Megállapítható, hogy az edictum a mai jótálláshoz hasonló eladói ígéretért való helytállást is szabályozta tehát, azonban dogmatikai különbség ${ }^{168}$ még nem mutatkozott a két jogintézmény között az ókorban.

A dicta et promissa kapcsán szólni kell arról, hogy a gyakorlat milyen kijelentéseket minősített ekként, és melyek voltak azok a nyilatkozatok, melyek csupán jogilag nem releváns dícséretként („reklámként”) értékelhetőek. Ezzel a kérdéssel kapcsolatos és a caveat emptor elvével (és a szemmel látható tulajdonságokkal) hozható összefüggésbe az alábbi fragmentum:

D. 18,1,43 pr. Florentinus

Ea quae commendandi causa in venditionibus dicuntur, si palam appareant, venditorem non obligant, veluti si dicat servum spenciosum, domum bene aedilficatam...

„Mindaz, amit az eladáskor [az áru] ajánlása végett mondanak, ha nyíltan felismerhető, nem kötelezi az eladót, így ha azt mondja, hogy a rabszolga szép alakú, a ház jól megépített..."

A tényállás szerint az eladó elad egy árucikket (rabszolgát illetve házat) a vevőnek. Az áru tulajdonságait felsorolva ajánlja az árut a vevőnek. Az eladó kijelentéseit nem szó szerint, hanem ésszerűen kellett értelmezni Gaius szerint, ${ }^{169}$ és ahhoz, hogy jogilag releváns

\footnotetext{
166 Lásd: D. 21,1,1,1 Ulpianus: „Quodsi mancipium adversus ea venisset, sive adversus quod dictum promissumve fuerit cum veniret..."; ZIMMERMANN (1996), 317. p.; KASER - KNÜTEL (2014), 253. p.

${ }_{167}^{16}$ Lásd: D. 21,1,17,20. A dicta et promissa kérdésköréhez részletesen lásd: JAKAB (1993), 56-64. p.

${ }^{168}$ A modern jogokban a dicta et promissa jegyeit a dolog minőségére vonatkozó eladói ígéret, a jótállási nyilatkozat hordozza magán, lásd később.

${ }^{169}$ Lásd: D. 21,1,18 pr.
} 
ígéretnek minősüljenek, azoknak mindig kifejezettnek kellett lennie. ${ }^{170} \mathrm{~A}$ kérdéshez kapcsolódik a következő forráshely is :

\section{4,3,37 Ulpianus}

Quod venditor ut commendet dicit, sic habendum, quasi neque dictum neque promissum est. si vero decipiendi emptoris causa dictum est, aeque sic habendum est, ut non nascatur adversus dictum promissumve actio, sed de dolo actio.

„Amit az eladó ajánlásként mond [az áruról], úgy tekintendő, hogy az nem (joghatályos) kijelentés vagy ígéret. Azonban ha a vevő megtévesztése céljából történt a kijelentés, akkor is úgy tekintendő, hogy nem keletkezik actio a dictum promissumve megszegése miatt, de [keletkezik] a megtévesztés miatt kereset."171

A tényállás szerint az eladó elad egy árut a vevőnek, amelyet a vevő vásárlási hajlamát serkentő kijelentésekkel kínál neki. Az egyik tényállási variációban ráadásul a megtévesztés célzata vezérli a kijelentéseit. Érdekes ez a jogeset abból a szempontból, hogy a jogász szerint a puszta dicséretnek minősülő eladói kijelentések kikényszeríthetetlenek. Azt, hogy mi minősült dicséretnek, a fentiek fényében esetenként kellett megállapítani, és összefüggésben volt a caveat emptor elvével. Valószínűleg ebből az elvből következtet úgy a jogász, hogy a kifejezetten megtévesztés céljából tett kijelentés esetén sem adható meg a kereset. Ha a vevő kellő körültekintéssel járt (volna) el az ügylet során, akkor az eladó ajánlattételekor észre kellett (volna) vennie, hogy adott esetben csupán puszta feldicsérésről van szó. Ilyen lehet például egy rabszolga esetén az a kijelentés, hogy az fizikailag nagyon erős, holott közelebbröl látszik, hogy bár magas, de vékony testalkatú, gyenge fizikumú. ${ }^{172}$ Ugyanaz tehát a jogász döntése ez esetben is: nem keletkezik kereset a dictum promissum megszegése miatt.

A jogeset a Digesta dolus malusról szóló titulusában szerepel, amint az a jogászi döntésből is kitünik. Az, hogy az adásvételből eredő szubjektív jogalapú kereset, illetve az ahhoz kapcsolódó objektív kellékszavatossági keresetek nem alkalmazhatóak ebben az esetben, nem zárja ki, hogy az eladó kifejezett rosszhiszemüsége esetén ilyen, ígéretnek nem minősülő kijelentések esetén a csalárd magatartás szankcionálásra kerüljön, joghátránnyal járjon. Ennek érdekében tehát Ulpianus megadja az actio de dolo keresetét a

${ }^{170}$ D. 21,1,19,3; példák az elhatároláshoz ezen kívül: D. 21,1,18 pr.; D. 21,1,18,1-2; D. 21,1,19 pr.; D. $21,1,19,1-2$.

${ }^{171}$ Saját fordítás.

172 Ellentétesen véli ZiMMERMANN (1996), 316. p. 176. lj. A jogesetet vö. D. 4,3,1,1. Medicus is úgy véli, hogy a forrás ellenére az actio empti indítható volt ilyen esetekben is, lásd: MEDICUS (1962), 125. p. 3. lj. 
vevőnek, aki valószínűleg kárt is szenvedett az eladó csalárd, a magasabb vételár elnyerése érdekében tett kijelentése miatt. ${ }^{173}$

A dicta et promissa esetkörében fokozottan érvényesült az edictum fent említett minimum-szabályozási jellege, hiszen ezen esetekben az ígéret megtétele alapozta meg az aediliszi helytállást. A gyakorlatban az ígéret tartalma az eladón és a vevőn múlott, az bármit tartalmazhatott a hibák, illetve a hibáktól való mentesség tekintetében. ${ }^{174}$ Ehhez kapcsolódik a következő jogeset :

\section{21,1,52 Marcianus}

Si furtum domino servus fecerit, non est necesse hoc in venditione servi praedicere nec ex hac causa radhibitio est: sed si dixerit hunc furem non esse, ex illa parte tenebitur, quod dixit promisitve.

„Ha a rabszolga meglopta a tulajdonosát, ezt nem muszáj a rabszolga eladásakor [a vevővel] közölni és ezen ok miatt nincs redhibitio (elállás). De ha [kifejezetten] kijelenti, hogy a rabszolga nem tolvaj, akkor [az edictumnak] a dictum promissum-ra vonatkozó része alapján felel."

A jogeset szerint az eladó adásvételi szerződést kötött a vevővel, amelynek egy olyan rabszolga a tárgya, aki korábban lopást követett el a tulajdonosa terhére. Marcianus döntésében két tényállási variáció szerepel: az első esetben az eladó nem közölte a lopás tényét a vevővel, hallgatott a rabszolga ezen tulajdonságáról (ugyanakkor nem garantálta a hibától való mentességet); a másik tényállási variációban az eladó határozottan kijelentette a vevőnek, hogy az eladásra szánt rabszolga nem tolvaj (dixerit hunc furem non esse).

Az eladni kívánt rabszolga tolvaj voltára vonatkozó konkrét közlési kötelezettség nem szerepel az aediliszi edictum által meghatározott zárt hibakatalógusban. Bár az edictum által elöírt egyik közlési kötelezettség a rabszolga esetleges noxális kötöttségére vonatkozik, ez ebben az esetben nem forog fenn. A noxális kötelezettség ugyanis csak harmadik személy irányában állhat fenn (ha a rabszolga harmadikat károsított a delictummal), ${ }^{175}$ a jogesetből azonban az tünik ki, hogy a rabszolga saját tulajdonosát lopta meg.

A második tényállási variáció szerint az eladó kifejezetten kijelenti, hogy a rabszolga nem tolvaj. A jogász ezt dictum promissumveként értékeli. Ez egyrészt azt jelenti, hogy amennyiben a rabszolga lop az adásvétel megkötése után, akkor a vevő élhet a kellékszavatossági keresetekkel. A dictum et promissum jellege és jelentősége miatt

\footnotetext{
${ }^{173}$ Honsell a D. 4,3,1,1-re hivatkozva azt írja, hogy az actio de dolo csak akkor alkalmazható, ha más kereset (beleértve a szubjektív actio emptit is) nem áll rendelkezésre, lásd: HONSELL (1969), 79. p. 63. lj., vö. KASER (1971), 488. p. 33. lj. Lásd továbbá: DONADIO (2004), 194. p.

${ }^{174}$ JAKAB (1993), 58. p. Lásd még: THIELMANN (1971), 495-496. p.

${ }^{175}$ Lásd: MOLNÁR - JAKAB (2012), 331. p.
} 
érvényesítheti a vevő az igényét akkor is, ha nem lopott ugyan tőle (vagy harmadik személytöl) a rabszolga, de utóbb kiderül, hogy a tulajdonosától igen. Indokolt ez a megoldás azért is, mert e tulajdonság hiányának konkrét eladói állítása - mint a legtöbb ehhez hasonló eladói magatartás - valószínűleg a minél magasabb vételár kialkudása érdekében történt. Ilyenkor véleményem szerint akár az actio emptivel is felelösségre lehetett vonni az eladót a csalárdsága miatt, ha sikerült bizonyítani a perben a felróhatóságot, azaz a szándékos megtévesztést, elhallgatást.

Végül az aediliszi jogorvoslatok alkalmazhatóságának negyedik esetkörében az aedilis az eladó minden csalárd, dolózus magatartására kiterjesztette a szabályozást, ez esetben azonban a felelősség jogalapja szubjektív volt.

\subsubsection{Actio redhibitoria - az elállás keresete}

Az actio redhibitoria célja egyfajta in integrum restitutio, azaz az eredeti állapot helyreállítása volt, hogy a felek az adásvételt megelőző vagyoni állapotba kerüljenek. ${ }^{176}$ Az in integrum restitutio megvalósításánál - Ulpianus magyarázata szerint - elsőként a vevőnek kellett teljesítenie az abból fakadó kötelességeit (előteljesítési kötelezettség). ${ }^{177}$ Ennek megfelelően a vevő köteles volt visszaadásra felajánlani a rabszolgát összes tartozékával együtt, az eladónak pedig vissza kellett szolgáltatni a kifizetett vételárat. Mindez ugyanakkor felvetette azt a kérdést, hogy a feleknek milyen bevételei vagy költségei, kárai merültek fel az adásvétel megkötése után, és ezeket meg kell-e téríteniük a szerződési partnerüknek az elállási jog gyakorlásakor. Amennyiben például a rabszolga lopott a vevőtől (vagy harmadik személytől), akkor az eladónak ezért kártérítéssel tartozott. ${ }^{178}$ A vevő pedig köteles volt visszatéríteni minden, a rabszolga birtoklásából származó bevételt, így például a hagyományt és az örökséget is. ${ }^{179} \mathrm{~A}$ vevő kötelezettsége volt továbbá, hogy ha ő, a háza népe vagy procuratora (képviselője) valamilyen fogyatkozást vagy sérülést okozott a rabszolgában a vétel megkötése és a rabszolga átvétele után, akkor megtérítse az ebből fakadó kárt. ${ }^{180}$ Az eladónak azonban nem kellett a

\footnotetext{
176 ThielmanN (1971), 487. p.; MANTHE (1976), 133. p.; GAROFAlo (2000), 39. p.; D. 21,1,23,7; D. $21,1,21$ pr.

${ }^{177}$ Lásd: D. 21,1,25,10. JAKAB (1996), 116. p.

${ }^{178}$ Lásd: D. 21,1,23,8. GAROFALO (2000), 16. p.

${ }^{179}$ Lásd: D. 21,1,23,9; ZIMMERMANN (1996), 317. p.

${ }^{180}$ Lásd: D. 21,1,25 pr.; D. 21,1,25,1-4. GAROFALO (2000), 47. p.
} 
vevő által a rabszolgára fordított szükséges tartási költségeket megtérítenie a vevő részére. ${ }^{181}$

Érdekes kérdés, hogy hogyan ítélték meg azt az esetet, amikor a visszaszolgáltatandó rabszolga (igásállat) az in integrum restitutio előtt meghalt. Ez az ún. mortuus redhibetur kérdésköre, ${ }^{182}$ amelyet többek között a következő jogeset is tárgyal:

\section{21,1,31,11 Ulpianus}

Si mancipium quod redhiberi oportet mortuum erit, hoc quaeretur, numquid culpa emptoris vel familiae eius vel procuratoris homo demortuus sit: nam si culpa eius decessit, pro vivo habendus est, et praestentur ea omnia, quae praestarentur, si viveret.

„Ha a rabszolga, amit vissza kellene venni (adni), meghalt, felmerül a kérdés, hogy a vevő, háza népe vagy procuratora culpája miatt halt-e meg a rabszolga. Ha ugyanis ezek gondatlan cselekménye folytán halt meg, élőnek kell tekinteni, és mindazt teljesíteni kell, amit teljesíteni kellene, ha még élne."

A tényállás alapján a redhibitio céljának elérése, azaz az eredeti állapot helyreállítása előtt meghalt a kellékhibás visszaadandó rabszolga. A rabszolga a vevő (annak „háza népe” illetve procuratora) gondatlanságából eredően halálozott el. A jogi probléma az, hogy gyakorolható-e ebben az esetben is az elállás joga, illetve amennyiben igen, akkor miként. A probléma elsősorban abban gyökerezik, hogy a dolog (rabszolga) halála idején már a vevő tulajdonát képezi, ezért főszabály szerint a casus nocet domino elvnek kellene érvényesülnie, azaz a vevő terhére esne a rabszolga halála miatti veszteség és kár a dolog vétlen pusztulása esetén (vis maior). ${ }^{183}$

A jogesetben ezért is vizsgálták a vevő oldalán a szubjektív elemet, az ő illetve háza népe (familia tágabb értelemben), procuratora ${ }^{184}$ esetleges felróható magatartását. Ulpianus válasza alapján lehetséges az elállás jogának gyakorlása ez esetben is, és úgy kell tekinteni, mintha élne a rabszolga. Ebből az következik, hogy a vevőnek úgy kell foganatosítani az elállást, mintha az élne, azaz felelős a rabszolga értékének megtérítéséért. ${ }^{185}$ Ezen kívül a fent említett releváns költségeket is meg kell térítenie, de cserébe visszakapja a vételárat. ${ }^{186}$ A gyakorlatban tulajdonképpen egy elszámolási procedúra megy végbe a felek között. A contrario arra lehet következtetni a jogászi

\footnotetext{
${ }^{181}$ Lásd: D. 21,1,25,9. GAROFALO (2000), 33. p.

182 A kérdéskörhöz részletesen lásd többek között: LEDERLE (1983).

${ }^{183}$ Lásd: THIELMANN (1971), 487-488. p.; LEDERLE (1983), 28-29. és 33-34. p.; GAROFALO (2000), 25-26. p.

${ }^{184}$ A procurator az, aki valaki perbeli képviselőjeként alakszerütlen megbízás alapján vagy megbízás nélkül lépett fel a perben, lásd: MOLNÁR - JAKAB (2012), 116. p.

${ }^{185}$ Lásd: LEDERLE (1983), 36-43. p.; ZIMMERMANN (1996), 333. p.

186 ZIMMERMANN (1996), 333. p.
} 
megoldásból, hogy ha a vevőt culpa nem terhelte a rabszolga elpusztulása tekintetében, akkor is gyakorolhatta a halott rabszolga esetén az elállás jogát, azaz a kockázatot minden olyan esetben az eladó viselte, amikor a vevő nem tanúsított felróható magatartást. ${ }^{187} \mathrm{~A}$ megoldás, és a mortuus redhibetur fictiójának indoka a hibás teljesítés által okozott vevői érdeksérelemben keresendő.

\subsubsection{Actio quanti minoris - kereset a vételár csökkentése iránt}

A kereskedelmi gyakorlatban felmerülő igények arra késztették a jogszolgáltató magistratust, hogy jogfejlesztéssel élve olyan esetre is keresetet nyújtson, amikor a vevőnek nem állt érdekében a hibás rabszolga visszaadása. ${ }^{188}$ Ilyenkor a vevő a kellékhibás árut megtartva kívánt szavatossági igényt érvényesíteni. ${ }^{189}$ Erre figyelemmel alkothatta meg az aedilis az actio quanti minoris nevü keresetet, amely a vételárnak a kellékhibával arányos csökkentésére irányult. ${ }^{190}$

A vételárcsökkentés mint szavatossági igény érvényesítése esetén központi kérdés annak mértéke. Erre nézve két számítási módszer kínálkozik: az egyik alapján a bíró csak egy becslést végez a hibás dolog értékére nézve objektív kritériumok alapján, és ezt vonja le a vételárból. ${ }^{191} \mathrm{~A}$ másik módszer alkalmazásáról tanúskodnak egyes Digesta-helyek: eszerint kettős becslőeljárás (actio aestimatoria) ${ }^{192}$ lefolytatásával állapította meg az esküdtbíró az eljárásban a vételárcsökkentés mértékét. ${ }^{193}$ A felek alkujaként megállapított vételárra is figyelemmel volt, és megbecsülte egyrészt a hibás dolog, másrészt az ugyanolyan hibátlan áru vételkori értékét. ${ }^{194} \mathrm{Ez}$ azt jelentette, hogy aránypárban gondolkozott a bíró: a leszállított vételárhoz a számítási módszere alapján úgy viszonyult a vételár, mint ahogy a dolog értéke hibás állapotban a hibátlan állapotbani értékéhez aránylott az adásvétel megkötésekor. ${ }^{195}$ A legfontosabb rációja az, hogy tekintettel van a felek által kialkudott ár-érték arányra. ${ }^{196}$

\footnotetext{
187 THIELMANN (1971), 489. p.; ZIMMERMANN (1996), 333. p.

${ }^{188}$ Lásd: D. 21,1,48,1; DONADIO (2004), 80-82. p.; KASER - KNÜTEL (2014), 254. p.

${ }^{189}$ KASER - KNÜTEL (2008), 254. p. Lásd: D. 21,1,19,6.

190 Lásd: JAKAB (2000) 327. p. Feltehetően a Kr. e. II. század végén vezette be az aedilis, lásd: PÓLAY (1964), 53. és 56. p.

${ }^{191}$ Lásd: HoNSELL (1969), 74-75. p.

192 ERNST (2013), 83. p.

193 JAKAB (2000), 328. és 332. p.

${ }^{194}$ Lásd: JAKAB (2000), 331. p. Az abszolút és relatív számítás összehasonlítását lásd még: JAKAB (2012), 123. p.

${ }^{195}$ Lásd: JAKAB (2000), 332. p.; HONSELL (1969), 75. p. Az abszolút számítási módszer a csökkentett vételárat a vételár és a dolog értékcsökkenésének különbségeként határozta meg, amely azonban adott
} 
A kereset alkalmazásának gyakorlati nehézségeit példázza az alábbi jogeset:

D. 21,1,31,16 Ulpianus

Si quis egerit quanto minoris propter servi fugam, deinde agat propter morbum, quanti fieri condemnatio debeat? Et quidem saepius agi posse quanto minoris dubium non est, sed ait iulianus id agendum esse, ne lucrum emptor faciat et bis eiusdem rei aestimationem consequatur.

„Ha valaki a rabszolga szökése miatt vételárcsökkentésre perel, majd később betegség miatt perel, mennyi legyen a marasztalás? Nem kétséges, hogy ismételten is lehet vételárcsökkentésre perelni, bár Iulianus azt mondja, hogy ügyelni kell arra, hogy a vevő ne gazdagodjon ebből eredően és ne kapja meg kétszer ugyanazon dolog becsértékét."

A tényállás szerint az eladó egy rabszolgát hibátlanként adott el a vevőnek. Később megtudja a vevő, hogy a rabszolga szökött, majd annak betegségére is fény derül. A vevő ezért két alkalommal, a rabszolga két különböző kellékhibája - először szökött volta, majd betegsége - miatt szeretne a vételárcsökkentésre irányuló szavatossági igényt érvényesíteni keresetével. A jogi probléma az, hogy hogyan határozható meg a vételárcsökkentés mértéke ilyen esetben, azaz, hogy a vevő gazdagodik illetve nyerészkedik-e.

A jogászi megoldás lehetségesnek véli a kétszeri (vagy többszöri), különböző hiba miatt indított actio quanti minorist azzal a korlátozással, hogy ez nem járhat jogtalan gazdagodással a vevő oldalán. A vevő tehát nem nyerészkedhetett az aediliszi keresetek által. A második esetben tehát fokozottan figyelembe kellett venni a becslőeljárás során azt, hogy milyen a hiba jellege, és azt is, hogy a megelőző igényérvényesítésnél mennyit kapott vissza a vételárból a vevő. Ulpianus indoklásában Iulianusra utal, aki szerint nem kaphatja meg a vevő többször is a dolog becsértékét. ${ }^{197} \mathrm{Ha}$ a fenti esetben a vételárat 100 nak vesszük, a hibás rabszolga becsült értéke mindkét esetben 80 , a hibátlan rabszolgáé pedig 110, akkor az alábbi aránypár állítható fel az arányos vételárcsökkentés képleteként, ahol $X$ a vételárcsökkentés mértéke: $X / 100=80 / 110$. Eszerint $X=72$, azaz az eladónak a kifizetett vételárból 28-at kell visszaadnia mindkét esetben. ${ }^{198}$

esetben - különösen alacsony vételár esetén - semmivel sem orvosolta volna a vevő hibából eredő érdeksérelmét. Az abszolút számítási módszert Bechmann, Haymann, illetve Medicus támogatták, lásd: JUSZTINGER (2012), 139. p.

196 JAKAB (2000), 332. p.

${ }^{197}$ Az idézett iulianuszi vélemény a D. 21,2,32,1-ban található, lásd: JAKAB (2000), 329. p.

${ }^{198}$ A képleteket lásd: JАKAB (2012), 123. p. 


\subsection{Keresetindítási határidők}

A római magánjogban a civiljogi keresetek indítása általában nem volt határidőkhöz kötve, e kereseteket így gyüjtőnéven actio perpetuaenak nevezik. ${ }^{199}$ Kivételt képeztek többek között az aediliszi kellékszavatossági keresetek is, mert ezek esetén a magistratus határidőhöz kötött rövid, jogvesztő igényérvényesítést írt elő (actiones temporales). ${ }^{200} \mathrm{Az}$ aediliszek által meghirdetett keresetindítási határidőkről tanúskodik az alábbi Ulpianustól származó fragmentum:

\section{21,1,19,6 Ulpianus}

Tempus autem redhibitionis sex menses utiles habet: si autem mancipium non redhibeatur, sed quanto minoris agitur, annus utilis est. Sed tempus redhibitionis ex die venditionis currit aut, si dictum promissumve quid est, ex eo quo dictum promissumve quid est.

„A redhibitio perlési határideje hat hónap (utilis): de ha a rabszolgát nem adják vissza, hanem a vételárcsökkentésre perelnek, egy év a határidő. A redhibitio határideje az eladás napjától folyik, vagy ha kijelentettek vagy megígértek valamit, attól a naptól, amikor a dictum promissumve történt."

Az actio redhibitoria az eladás napjától számított hat hónapon belül volt megindítható. A vételárcsökkentésre irányuló actio quanti minoris kezdeményezésének határideje pedig egy év volt. A vevőt az első hat hónapban tehát választási jog illette meg arra vonatkozóan, hogy melyik igényt kívánja érvényesíteni, ${ }^{201}$ illetve bármikor át is térhetett egyikről a másikra. ${ }^{202}$ Ulpianus tempus utileként jelöli meg a határidőket, ami azt jelentette, hogy a kezdőnap nem szükségképpen volt az eladás napja, mert ha a rabszolga átadása csak később történt meg, akkor az eladás és az átadás közötti időt nem számították bele a határidőbe. ${ }^{203}$

A határidők kérdéskörénél érdemes ismét szólni a pactum displicentiae gyakorlatáról, amely alapján a vevő egy bizonyos kikötött határidőn belül nem tetszés

\footnotetext{
199 MOLNÁR - JAKAB (2012), 110-111. p.; FÖLDI - HAMZA (2013), 157. p. A helyzet a keresetelévülés intézményesítésével változott csak meg Kr.u. 424-ben, amikor II. Theodosius császár 30 évet írt elő a korábbi actiones perpetuae érvényesítésére. Uo.

${ }^{200}$ DELI (2008), 39. p.

${ }^{201}$ DONADIO (2004), 108-109. p.

${ }^{202}$ Erre utal a D. 21,1,48,2: Non nocebit emptori, si sex mensum exceprione redhibitoria exclusus velit intra annum aestimatoria agere.

${ }^{203}$ JAKAB (1993), 56. p.; DELI (2008), 40. p.
} 
esetén visszaléphetett az ügylettől. ${ }^{204}$ Ezt a megállapodást az aedilis curulis is szabályozta, és felvette edictumába, ${ }^{205}$ amiről az alábbi jogeset tanúskodik:

\section{21,1,31,22 Ulpianus}

Si quid ita venierit, ut, nisi placuerit, intra praefinitum tempus redhibeatur, ea conventio rata habetur: si autem de tempore nihil convenerit, in factum actio intra sexaginta dies utiles accommodatur emptori ad redhibendum, ultra non. si vero convenerit, ut in perpetuum redhibitio fiat, puto hanc conventionem valere.

„Ha valamit azzal a feltétellel adtak el, hogy ha nem tetszik, határozott időn belül vissza lehet adni, ez a megállapodás érvényes. Ha azonban a határidőről semmiben sem állapodtak meg, a vevőnek in factum actio áll rendelkezésre a jogérvényesítésre alkalmas hatvan napon belül, de azon kívül nem. Ha azonban abban állapodtak meg, hogy az elállás határidő nélkül gyakorolható, akkor véleményem szerint ez a megállapodás érvényes."206

A korábban említettek szerint elfogadott volt az a gyakorlat, hogy a vevő és az eladó megállapodtak abban, hogy a vevő a rabszolgát (a vétel tárgyát) kipróbálhatja: ha a rövid használat során mégsem tetszene neki, elállhat a vételtől (nem tetszés esetére való visszalépés joga). A vevő elállási jogának határideje tekintetében a felek bármiben megállapodhattak, e fragmentum szerint akár abban is, hogy az elállási jog határidő nélkül gyakorolható. Jogi probléma lépett azonban fel az ilyen esetben, amikor a felek semmiben nem állapodtak meg a határidőt illetően. Ulpianus tudósítása szerint az aediliszek ebben az esetben is indokoltnak látták a jogvédelmet. Ha tehát a felek a pactumban az elállási jog gyakorlására semmilyen határidőt sem kötöttek ki, akkor az aedilis curulis in factum actiót adott a vevőnek. A magistratusok általában akkor adtak in factum actiót az adott igény érvényesítésére, ha a megfelelő kereset hiánya ellenére is jogpolitikai indokot láttak a per lefolytatására. ${ }^{207} \mathrm{Az}$ aedlisz hatvan napban korlátozta a keresetindítás lehetőségét ilyen esetekben.

\section{Az aediliszi és a praetori jogérvényesítési lehetőség párhuzamossága}

A piaci gyakorlatban az aediliszi edictum kibocsátása után is gyakori volt a garanciastipulatio vállalása. A vevő e kifejezett eladói ígéretből származó, az interessére irányuló

\footnotetext{
${ }^{204}$ Lásd: 2.4. pont. Lásd: JAKAB (1993), 27-28. p. Részletesen lásd: PóKECZ KovÁCS (2012), 202-223. p.

${ }^{205}$ Lásd: D. 21,1,31,22: Si quid ita venierit, ut nisi placuerit, intra praefinitum tempus redhibeatur, ea conventio rata habeatur: si autem de tempore nihil convenerit, in factum actio sexaginta dies utiles accomodatur emptori ad redhibendum, ultra non...

206 Saját fordítás.

${ }^{207}$ Lásd: MOLNÁR - JAKAB (2012), 96. p.
} 
igényét az actio ex stipulatuval érvényesíthette. ${ }^{208}$ Az eljárás a praetor előtt zajlott, így nem érvényesültek a rövid (aediliszi) határidők az igényérvényesítésre, ${ }^{209}$ a per azonban csak akkor volt megindítható, ha a vevőnek már konkrét kára keletkezett a fennálló kellékhiányból vagy kellékhibából kifolyólag. ${ }^{210}$

Amennyiben a kár fennállt, a vevő maga választhatott, hogy az aediliszi vagy a praetori jogorvoslattal szeretne-e élni: a két kereseti forma párhuzamosan állt rendelkezésre a jogkeresők számára. ${ }^{211}$ Az actio ex stipulatu esetén annak bizonyítása, hogy a kár a kellékhibából fakadóan fennállt, megnehezítette a vevő perbeli helyzetét.

A fentiek mellett a bona fides elve által determinált vételi kereset, az actio empti is a vevő rendelkezésére állt a fenti igényérvényesítési módokkal párhuzamosan. ${ }^{212} \mathrm{Ez}$ a kereset is a vevő érdeksérelmére, azaz az interessére ment, ${ }^{213}$ de szubjektív jogalapú volt, azaz csak akkor volt megindítható, ha az eladó szándékosan, azaz tudva hibás árut adott el. Az eladó felelőssége (a klasszikus kori kategorizálás szerint) érdekelt adósként valószínűleg kiterjedt nem csak a dolusra (azaz a szándékosságra), hanem a culpa latára és a culpa levisre, azaz az átlagember gondosságának valamint a jó és gondos családapa gondosságának elhanyagolása miatti helytállásra is. ${ }^{214}$

Egy jogeset, amely Paulusnak a Sabinushoz füzött kommentárjából származik, a párhuzamos igényérvényesítés lehetőségét demonstrálja:

D. 19,1,4 pr. Paulus

Si servum mihi ignoranti, sciens furem vel noxium esse, vendideris, quamvis duplam promiseris, teneris mihi ex empto, quanti mea intererit scisse, quia ex stipulatu eo nomine agere tecum non possum antequam mihi quid abesset.

„Ha eladod nekem a rabszolgát, holott tudod, hogy tolvaj vagy noxa terheli, én viszont nem tudom ezt, jóllehet megígérted a duplumot, megindíthatom ellened a vételi keresetet annyira, amennyi az érdeksérelmem abból eredően, hogy ezt tudnom kellett volna, mivel a stipulatio alapján nem perelhetlek be emiatt, mielőtt valamim hiányoznék."

\footnotetext{
${ }^{208}$ Honsell (1969), 69. p.

${ }^{209}$ Kezdetben nem voltak perlési határidők, majd a Kr. u. 424-ben a tartományi helytartók gyakorlatát általánossá téve II. Theodosius császár állapította meg az általános elévülési határidőt 30 évben, lásd: MolNÁR - JAKAB (2012), 111. p.; FÖLDI - HAMZA (2013), 157. p.; BENEDEK - PóKECZ KovÁCS (2013), 88. p.

${ }^{210}$ JAKAB (1993), 81. p.

${ }^{211}$ MANTHE (1976), 137. p.; JAKAB (1993), 81. p.; DONADIO (2004), 63. p.

${ }^{212}$ Lásd: D. 19,1,6,8. DONADIO (2004), 203-204. p.

${ }^{213}$ Lásd: 2.3. pont.

${ }^{214}$ KASER - KNÜTEL (2014), 256. p.
} 
A Digesta 19. könyv első titulusában, az adásvételi jogban elhelyezett forrás Paulustól, a Kr. u. III. században tevékenykedő remekjogásztól származik, és szemlélteti az igényérvényesítési módok párhuzamos fennállását. A jogesetben szereplő tényállás szerint az eladó elad a vevőnek egy rabszolgát, tudva, hogy az tolvaj vagy noxális kötelezettséggel terhelt, és e hibák hiányára vonatkozóan külön garancia-stipulatiót is ad. A vevő előtt viszont e kellékhibák ismeretlenek. Az eladó sciens a hiba tekintetében, azaz csalárdul (dolo malo) adta el hibásan a rabszolgát. ${ }^{215}$ A kérdés az, hogy milyen jogorvoslattal élhetett a vevő ebben az esetben.

A jogeset megoldásához meg kell jegyezni, hogy a „noxa terheli”, azaz itt a noxius latin szó kettős értelemben fordítható: jelenti egyrészt azt, hogy idegen (harmadik) személy sértelmére elkövetett bűncselekmény miatt noxa terheli, másrészt „bünöző hajlamú” is lehet a jelentése. ${ }^{216}$ Itt azonban az aediliszi edictum szövegéből kiindulva sokkal valószínűbb a „noxa terheli” jelentés-variáció.

A ,jóllehet megígérted a duplumot" fordulat jelzi, hogy a felek a konszenzuális vétel mellett stipulatio duplaet is kötöttek. A fordulat a garancia-stipulatio alkalmazására utal, de nem jelenti azt, hogy az eladónak kellékhiba esetén is duplumért kellett volna helytállnia, mert ez esetben (a korábban emítetteknek megfelelően) az interessére irányult az actio ex stipulatu. ${ }^{217}$

Paulus válasza alapján a vevő megindíthatja a vételi keresetet az interessére. Az actio ex stipulatu ebben az esetben azért nem alkalmazható, mert a fent említettek alapján az csak konkrét kár bekövetkezése után volt megindítható. Erről a forráshely ugyan nem tesz említést, de feltehető, hogy a vevő az actio empti helyett az actio redhibitoria vagy az actio quanti minoris jogorvoslati lehetőségével a határidők lejárta miatt nem élhetett. Az is elképzelhető, hogy a jogász csak az actio empti és az actio ex stipulatu közti opcióra koncentrál.

\section{A hibás teljesítés jogkövetkezményei a posztklasszikus korban}

A hibás teljesítésért fennálló eladói helytállás végső jogtörténeti állomásaként a klasszikus kor vége felé a praetor recipiálta saját edictumába és jogalkalmazásába az aediliszi kereseteket, és megadta azokat nem csak a rabszolgák és igásbarmok, hanem minden dolog

\footnotetext{
${ }^{215}$ Lásd: ZIMMERMANN (1996), 309. p. A dolushoz lásd még többek között: D. 21,1,1,10; D. 21,1,38,7.

216 Lásd: Finály Henrik: A latin nyelv szótára (http://latin.oszk.hu/cgi-bin3/index.cgi). Vö. például D. 19,1,11,8, ahol furtis noxisque solutum szerepel, ami egyértelmüen a noxális kötelemre utal.

${ }^{217}$ KASER (1971), 555. p.
} 
vétele esetén a piacokon kívül is. ${ }^{218}$ Természetesen az actio empti, mint a vevő szubjektív jogalapú keresete továbbra is rendelkezésre állt a felróható magatartást tanúsító eladó felelősségre vonására.

Idővel tehát az objektív jogalapon álló aediliszi jogsegélyek és a stipulatio alapján rendelkezésre álló actio ex stipulatu mellett az adásvétel keresete, az actio empti a jogorvoslati lehetőségek színes palettáját képezte; a keresetek konkuráltak egymással. ${ }^{219}$ Gyakran nem csak a vevőknek, hanem a jogvitában véleményt nyújtó jogászoknak is nehézséget jelenthetett eldönteni egy-egy hibás rabszolga adásvételével kapcsolatos, bonyolultabb jogesetet. Jól példázza ezt az alábbi Digesta-fragmentum:

\section{19,1,13,1 Ulpianus}

Item qui furem vendidit aut fugitivum, si quidem sciens, praestare debebit, quanti emptoris interfuit non decipi: si vero ignorans vendiderit, circa fugitivum quidem tenetur, quanti minoris empturus esset, si eum esse fugitivum scisset, circa furem non tenetur: differentiae ratio est, quod fugitivum quidem habere non licet et quasi evictionis nomine tenetur venditor, furem autem habere possumus.

„Ugyanúgy, aki tolvaj vagy szökött [rabszolgát] adott el, helytállással fog tartozni annyival, amennyi az eladó interesséje, hogy őt ne csalják meg. Ha [az eladó] erről nem tudva (ignorans) adná el a [a rabszolgát], annyira kötelezik a szökött [rabszolga] tekintetében, amennyivel kevesebbért vette volna meg [a vevő], ha tudta volna, hogy az szökött, a tolvaj [rabszolga] tekintetében nem kötelezik. A különbségnek az az oka, hogy a [vevö] a szökött rabszolgát nem tudja [zavartalanul] a birtokában tartani és az eladót quasi evictio címén kötelezik, a tolvajt azonban zavartalanul birtokolhatjuk."220

A forráshely Ulpianusnak az edictumhoz füzött kommentárjait tartalmazó müvéből származik a Kr. u. 3. századból. A Digesta adásvételi keresetekről szóló könyvében helyezték el a rabszolga adásvételét tárgyaló jogesetet a jusztiniánuszi kompilátorok. A jogesetben két tényállási variációt különíthetünk el, melyeken belül ugyancsak két-két alváltozat különböztethető meg:

1. Az első tényállási variációban a vevő megvett egy (a) tolvaj, illetve (b) szökött rabszolgát az eladótól; az eladó tisztában volt azzal, hogy a rabszolga a hibákkal terhelt: az eladó ezek tekintetében sciens volt.

2. A második variációban a vevő ugyancsak egy (a) tolvaj, (b) szökött rabszolgát vett az eladótól, aki azonban ezekről a hibákról nem tudott: az eladó ez esetben ignorans volt a hibák tekintetében.

\footnotetext{
${ }^{218}$ DONADIO (2004), 204. p.; DONADIO (2008), 67-68. p.; KASER - KNÜTEL (2014), 257. p.

219 Lásd: JAKAB (1993), 81. p.; ZIMMERMANN (1996), 319. p.

220 Pozsonyi Norbert fordítása.
} 
Néhány megfontolás a két variáció elkülönített tárgyalása előtt indokoltnak látszik. A rabszolga mind tolvaj, mind szökött mivolta döntő jelentőséggel bíró tulajdonságok voltak a vevő vételi szándéka tekintetében. Mindkettő előfordul az adásvételi okiratokban is. A rabszolga szökött voltát még az aedilisz is felvette edictumába, a releváns kellékhibák katalógusába; ${ }^{221}$ a tolvaj rabszolga szintén többször feltünik a Digesta 21 . könyvében, bár nem az aediliszi hibakatalógus részeként. ${ }^{222}$ Van azonban egy fontosabb különbség a két tulajdonság között: a fugitivus rabszolga e tulajdonsága érinthette a vevő birtokláshoz füződő jogát, és ha emiatt elveszítette a rabszolgáját, akkor soha többé nem hasznosíthatta annak munkaerejét, szaktudását. Ha azonban a rabszolga tolvaj volt, az közvetlenül nem érintette a munkaképességét és a vevő birtokjogát, mert még ha lopott is valamit a vevőtől (háza népétől) vagy harmadik személytől, akkor is folyamatosan tovább tudta használni a rabszolgát a vevő (de természetesen a hiba ekkor is fennállt). A két esetben az is hasonló, hogy egyik hibának sem kell ismétlődnie a vevőnél a kellékszavatossági igény érvényesítéséhez, hiszen a tolvaj nem biztos, hogy ismét lopni fog (nem szükségszerüen „tolvaj jellemü”), és a szökött sem biztos, hogy ismét szökni fog vagy szökni próbál majd. Itt is relevanciát nyer a korábban hivatkozott jogirodalmi vita az objektív és szubjektív fogalomértelmezéssel kapcsolatban. ${ }^{223}$ Az objektív megközelítés helytállóbbnak látszik épp emiatt, hogy a tulajdonság, bár egy múltbéli cselekményre utal, és ehhez kapcsolódik a rabszolga egyfajta megbélyegzettsége, és az eladói helytállás, de nem biztos, hogy újra megszökik majd a rabszolga (nem feltétlenül „szökevény jellemü”).

Az első tényállási variációban a jogász nem tesz különbséget a két hiba között a jogkövetkezményeket illetően. Az eladó a vevőt szándékosan megtévesztve, a szökött illetve tolvaj mivoltáról tudva (sciens) adta el a rabszolgát. A jogi probléma az, hogy kérdéses, hogy mit követelhetett, és melyik keresettel követelhette azt a vevő.

Ulpianus válasza szerint a vételi kereset szubjektív jogalapja megáll, így az eladó a vétel (actio empti) alapján felelős a dolózusan okozott kárért. Azt a megoldást javasolja, hogy a vevő jogosult a teljes kárát, azaz az interessét követelni, amely az eladó csalárd magatartásából fakadó érdeksérelme. Ez a megoldás több szempontból is helytálló: egyrészről az adásvételi szerződés konszenzuális jellege és az annak a hátterében álló bona fides elve igazolja, amely a vételi kereset kialakításának a vezérelve is volt a praetori

\footnotetext{
${ }^{221}$ Lásd: D. 21,1,1,1.

${ }^{222}$ Lásd például: D. 21,1,17,20 Ulpianus : Si quis adfirmaverit aliquid adesse servo nec adsit, vel abesse et adsit, ut puta si dixerit furem non esse et fur sit, si dixerit artificem esse et non sit: hi enim, quia quod adseveraverunt non praestant, adversus dictum promissumve facere videntur.; valamint: D. 21,1,19,1.

${ }^{223}$ Lásd: JAKAB (2003), 39. p. és JAKAB (2013), 194-195. p., valamint GAMAUF (1999), 110-111. p. és GAMAUF (2006), 95-96. p.
} 
jogalkalmazásban. ${ }^{224}$ Másrészt levezethető ez az aediliszi edictum közvetett jogpolitikai céljából, amelyet azért is alkottak meg, hogy meggátolják a ravasz, fortélyos, csalárd kereskedői magatartást, és segítséget nyújtsanak azoknak a vevőknek, akiket rászed a velük szerződő eladó. ${ }^{225} \mathrm{Az}$ interesse tartalmával kapcsolatban a jogeset Digesta-beli folytatását képező fragmentum nyújt eligazítást (D. 19,1,13,2), amelyben Ulpianus úgy értékeli, hogy az interessébe sokféle kár beletartozhat. Példaként említi az abból fakadó vevői érdeksérelmet, hogy a szökött rábír más rabszolgákat a vele való szökésre, valamint azt a kárt is, ami a rabszolga tényleges lopásából fakad. ${ }^{226}$

A második tényállási variáció szerint az eladó úgy adta el a rabszolgát, hogy nem tudta, hogy az (a) tolvaj, illetve (b) szökött. A tolvaj rabszolga esetén volt-e ezen magatartásának valamilyen jogkövetkezménye, és ha igen, akkor mit lehetett követelni az eladótól annak fényében, hogy a kellékhibát illetően ignorans volt? A korábban említetteknek megfelelően a fenti két tulajdonság egy lényeges pontban különbözik egymástól: a fuga ediktális hiba, míg a rabszolga tolvaj volta nem az. Ennek megfelelően az (a) esetben Ulpianus úgy dönt, hogy a tolvaj rabszolga tekintetében ignorans eladó nem felel, tőle semmi sem követelhető a vételi keresettel.

Nem zárnám azonban ki ez esetben az aediliszi objektív jogalapú jogorvoslatok lehetőségét az eladó kijelentéseivel és formátlan ígéreteivel összefüggésben. Ha a felek a konszenzuális vétel mellett dicta et promissa formájában kikötötték, hogy a rabszolga nem tolvaj, akkor a vevő ebben az esetben is élhet az aediliszi keresetekkel. A dicta et promissa a korábban említettek alapján szintén megalapozta az eladó aediliszi helytállását. ${ }^{227}$

Ulpianusnak az aediliszi edictumhoz füzött kommentárja szerint az eladó akkor is felel, ha nem tud a hibákról. Úgy véli, hogy ebben nincs semmi méltánytalan, mert az eladó megbizonyosodhatna az eladásra szánt áru tulajdonságairól, és egy esetben sem a vevő dolga, hogy kiderítse, hogy az eladó magatartása a nem tudásából (az ignorantiából)

\footnotetext{
${ }^{224}$ FÖLDI (2001), 16. p.

${ }^{225}$ Lásd: D. 21,1,1,2 Ulpianus: ...ut occurratur fallaciis vendentium et emptoribus succurratur, quicumque decepti a venditoribus fuerint... Vö. D. 19,1,11,1 Ulpianus (... cum enim sit bonae fidei iudicium) és D. 19,1,6,8 Pomponius (... dolum malum eo iudicio aestimari oportet, ut id, quod praestaturum se esse pollicitus sit venditor emptori, praestari oporteat).

${ }^{226}$ Lásd: D. 19,1,13,2: Quod autem diximus "quanti emptoris interfuit non decipi", multa continet, et si alios secum sollicitavit ut fugerent, vel res quasdam abstulit. KASER - KNÜTEL (2014), 256. p.; HONSELL (1969), 74. p.

${ }^{227}$ Lásd: D. 21,1,1,1; D. 21,1,19,2; DONADIO (2004), 157-158. p.; ZIMMERMANN (1996), 315-316. p.; JAKAB (2013), 195-196. p.
} 
vagy a csalárd üzleti gyakorlatából fakad. ${ }^{228}$ Bár a rabszolga tolvaj volta nem képezte az aediliszi taxatív hibakatalógus részét, de ha az eladó dictum promissum formájában megígérte, hogy a rabszolga nem tolvaj vagy nem tolvaj természetü, akkor a vevő követelhette az elállást az actio redhibitoriával 6 hónapon belül, és a vételárcsökkentést az actio quanti minorisszal egy éven belül. ${ }^{229}$ Ulpianus is így érvel:

D. $19,1,13,3$

Quid tamen si ignoravit quidem furem esse, adseveravit autem bonae frugi et fidum et caro vendidit? videamus, an ex empto teneatur. et putem teneri. atqui ignoravit: sed non debuit facile quae ignorabat adseverare. inter hunc igitur et qui scit praemonere debuit furem esse, hic non debuit facilis esse ad temerariam indicationem.

„Ha pedig [az eladó] nem is tudta ugyan, hogy a [rabszolga] tolvaj, de azt állította, hogy [a rabszolga] becsületes és hüséges és [ezért] drágán adta el. Megfontoljuk, hogy [az eladót] kötelezik-e ex empto. És én úgy vélem, hogy kötelezik. Pedig [az eladó] nem ismerte [a hibát], de nem szabad könnyelmüen állítani [olyan dolgokat], amiket [az eladó maga] nem ismert. Tehát e között és [azon személy között, aki tudta a hibát és hallgatott, nincs nagy különbség, ugyanis [aki tudja], annak meg kellett mondania elöre, hogy [a rabszolga] tolvaj, itt nem kellett könnyelmünek lenni a meggondolatlan árszabáshoz.” ${ }^{230}$

Az eladó e forrás alapján tehát felelt a vételből kifolyólag akkor is, ha nem tudott arról, hogy a rabszolga tolvaj, de kijelentette, hogy a rabszolga becsületes és hüséges (azonban nem ígérte kifejezetten, hogy nem tolvaj). Ennek az az oka, hogy a jogász értékítélete szerint az ilyen eladó csak nagyon kicsiben különbözik a csalárd eladótól, mert tartózkodnia kellett volna a rabszolgára vonatkozó meggondolatlan, gondatlan kijelentésektől. Úgy vélem, hogy ilyen esetben lényegében az eladó nem tekinthetö jóhiszemü ignoransnak. Szerintem bizonyos fokú culpa terheli, mert az elvárható gondosságot nem tanúsította a kijelentései alkalmával.

A (b) tényállási alvariációban szereplő fugitivus, azaz szökött rabszolga ignorans eladójának kérdése problematikusabb az előző esetnél. A jogi probléma ugyanaz: lehet-e jogkövetkezménye, és ha igen, akkor mit követelhet a vevő, ha az eladó nem tudott a rabszolga kellékhibájáról? A fugitivus fent említett objektív fogalma szerint nem számít, hogy hányszor szökött vagy akart elszökni urától a rabszolga, ha akár csak egyszer is megpróbálta, akkor már szököttnek tekintendő.

\footnotetext{
${ }^{228}$ Lásd: D. 21,1,1,2 Ulpianus: „,...dummodo sciamus venditorem, etiamsi ignoravit ea quae aediles praestari iubent, tamen teneri debere. nec est hoc iniquum: potuit enim ea nota habere venditor: neque enim interest emptoris, cur fallatur, ignorantia venditoris an calliditate."

${ }^{229}$ Lásd: JAKAB (2013), 195-196. p.

${ }^{230}$ Pozsonyi Norbert fordítása.
} 
Ulpianus úgy véli, hogy az ignorans eladó ebben az esetben azért felel, amennyivel kevesebbet adott volna vételárként a vevő a rabszolgáért, ha tudta volna annak szökött voltát. A jogalap itt is nyilvánvalóan objektív, független az eladó tudati állapotától, az actio empti viszont eredetileg szubjektív jogalapú. Ennek ellenére a jogász mégis odaítéli a keresetet olyan követelésre, amely ténylegesen az objektív jogalapú aediliszi actio quanti minorisnak felel meg. A kérdés az, hogy mi igazolhatja ezt az álláspontot.

Ulpianus a tolvaj és a szökött rabszolga kellékhibái közötti feltétlenül szükséges megkülönböztetésböl indul ki az indokláskor: szerinte a szökött rabszolga esetén potenciális veszélyben van a vevő birtokláshoz füződő joga, ${ }^{231}$ és ezért úgy véli, hogy az eladó olyan módon tartozik helytállni, mintha evictióért felelne. ${ }^{232}$ Ez elöször ide nem illő megállapításnak tűnhet, de érdemes megfontolni, hogy evictióért való helytállás, azaz jogszavatosság esetén valóban ugyanez a helyzet, hisz itt is végső soron a rabszolga eredeti tulajdonosa elperelheti azt a vevőtől: eljárásjogilag a két szituáció nagyon hasonló. ${ }^{233}$ Egy Neratiustól származó fragmentum is Ulpianus fenti megoldását támasztja alá: eszerint az eladónak felelnie kell a vevővel szemben azért, ha a rabszolga szökött, akkor is, ha az eladó erről a tulajdonságáról nem tudva adja azt el. ${ }^{234}$

Az Ulpianus által javasoltak szerint a per tárgya az actio quanti minoris céljának megfelelő vételárleszállítás az actio emptibe „bújtatva”, mondhatni quasi actio quanti minorisról van szó. Ha azt az érvet mérlegeljük, miszerint a szökött rabszolga a vevő birtokláshoz illetve tulajdonhoz füződő jogát veszélyezteti, ráadásul egy aediliszi kellékhibáról van szó, akkor megindokolható a megoldás azzal, hogy a rendes actio quanti minorisre irányadó rövid határidő megakadályozhatná a jogérvényesítést. ${ }^{235}$ Azt is fontolóra kell venni, hogy ha a vevő tudta volna a hibát, és mégis megvette volna a rabszolgát, akkor a hibás, szökött rabszolga piaci vagy kialkudott vételárát fizette volna meg érte. Ezért, az érdeksérelme, az interesse ebben az esetben valóban a hibátlan és a hibás rabszolga vételára közötti különbség lehet. ${ }^{236}$

Mi lehetett a helyzet azonban akkor, ha a rabszolga nem szökik meg ismét, illetve nem perlik el azt a vevőtől? Ilyen esetben a szökött és a tolvaj, mint tulajdonságok nem

\footnotetext{
${ }^{231}$ Lásd: „fugitivum quidem habere non licet”.

${ }^{232}$ Lásd: „quasi evictionis nomine tenetur venditor”.

${ }^{233}$ Lásd ehhez: JAKAB (2003), 39. p.

${ }^{234}$ Lásd: D. 19,1,11,8 Ulpianus: Idem neratius, etiamsi alienum servum vendideris, furtis noxisque solutum praestare te debere ab omnibus receptum ait et ex empto actionem esse, ut habere licere emptori caveatur, sed et ut tradatur ei possessio.

${ }^{235}$ Lásd: WACKE (2002), 824. p.; JAKAB (2003), 41. p.; DONADIO (2004), 174. p.

${ }^{236}$ Lásd: D. 19,1,13 pr. KASER - KNÜTEL (2014), 254-255. p.
} 
különböznek: sem kára és sem tényleges érdeksérelme nincs a vevőnek. ${ }^{237}$ Ennek fényében úgy vélem, hogy különbséget kell tenni az olyan esetek között, amelyekben a rabszolga megszökik a vevőtől vagy elperlik tőle, illetve amelyekben egyik sem következik be. Az utóbbi esetben a birtoklás joga nem sérül, ezért ilyenkor a tolvaj rabszolga esetével megegyező megoldás látszhat méltányosnak, azaz hogy az ignorans eladó nem felel.

Véleményem szerint azonban közvetett érdeksérelem jelenik meg a vevő oldalán abban, hogy potenciálisan még mindig fennáll a veszélye a szökött rabszolga elvesztésének, a tolvaj esetén pedig bármely házi vagy akár idegen vagyontárgy eltulajdonításának. Ez a közvetett érdeksérelem mutatja, hogy a rabszolga tulajdonságaival kapcsolatban milyen gondosság lenne elvárható az eladótól: eladóként meg kellene bizonyosodnia azokról. Ennek fényében az eladó nem tudása a hibákról értékelhető negligentiának is, és mint ilyen az eladó a klasszikus kori jogi értékelésnek megfelelően a culpáért, az elvárható gondosság elmulasztásáért is felelősségre vonható a vételi keresettel.

A jogeset és annak elemzése igyekezett bemutatni, hogy a hibás teljesítésből eredő jogkövetkezmények mennyire összefonódva jelentek meg a klasszikus kori joggyakorlatban. Látható, hogy a kifejezett, stipulatiós vagy akár a formátlan eladói ígéretnek (dicta et promissa) is mekkora jelentősége volt, és az objektív, felróhatóságtól független, valamint a szubjektív, felróhatóságon alapuló jogkövetkezmények közötti különbségtétel milyen kifinomult jogértelmezést igénylő problematikus kérdéskör volt.

Ugyanezt a problémakört érinti a következő jogeset, amely azonban nem rabszolgák adásvételével kapcsolatos, hanem igásállatokról illetve épületfáról szól. Jól prezentálja azt, hogy a praetor kiterjesztette az eladó objektív helytállását dolus és dictum esetén bármely dolog bárhol, azaz nem csak a piacon lebonyolódó adásvételére. ${ }^{238} \mathrm{~A}$ jogeset több ponton is kapcsolódik az előzőhöz, többek között ezért szerepel a fenti jogesetet tartalmazó bekezdés principiumaként a Digestában:

D. 19,1,13 pr. Ulpianus

Iulianus libro quinto decimo inter eum, qui sciens quid aut ignorans vendidit, differentiam facit in condemnatione ex empto: ait enim, qui pecus morbosum aut tignum vitiosum vendidit, si quidem ignorans fecit, id tantum ex empto actione praestaturum, quanto minoris essem empturus, si id ita esse scissem: si vero sciens reticuit et emptorem decipit, omnia detrimenta, quae ex ea emptione emptor traxerit, praestaturum ei: sive igitur aedes vitio tigni corruerunt, aedium aestimationem, sive pecora contagione morbosi pectoris perierunt, quod interfrui idonea venisse erit praestandum.

\footnotetext{
${ }^{237}$ Megjegyzendő ugyanakkor, hogy a vételárat illetően mégis felmerül érdeksérelem, mert az áru hibás, ezért az eladó valószínủleg többet kapott érte, mint amennyit ért.

${ }^{238}$ Lásd: DONADIO (2004), 7. és 203-204. p.
} 
„Iulianus 15. könyvében a vételi kereset alapján történő elítélésnél különbséget tesz, hogy valaki tudva adott el hibás dolgot vagy a hibáról nem tudva tette ezt. Azt mondja ugyanis, ha valaki beteg marhát vagy hibás épületfát adott el, ha nem tudva tette, csak annyit kell teljesítenie a vételi kereset alapján, amennyivel kevesebbért vettem volna meg a dolgot, ha valódi állapotát ismertem volna. Ha azonban az eladó tudott a hibáról, de elhallgatta és becsapta a vevőt, akkor minden olyan kárért felel a vevő fele, amely a vevőt érte ebből a vételből kifolyólag. Ha tehát az épületfa hibája miatt a ház összeomlott, a ház becsértékét, ha pedig a nyája elpusztult a beteg marha által okozott fertőzés folytán, annyit kell szolgáltatni, amennyi a vevő érdeksérelme abból, hogy az eladó nem megfelelő marhát adott el."

A jogesetben két tényállási variáció szerepel, melyeket az eladó felróható magatartása (sciens) különböztet meg egymástól a jogkövetkezmények tekintetében. Az első tényállási variációban az eladó a kellékhibáról nem tudva (ignorans) (a) beteg, azaz kellékhibás marhát, illetve (b) hibás épületfát adott el a vevőnek. A jogi probláma lényegében megegyezik az előző jogesetben tárgyaltakkal: ha az eladó ignorans a kellékhibák tekintetében, akkor felelősségre vonható-e a vételi keresettel? ? $^{239}$

Ulpianus mindenféle indokolás nélkül úgy véli, hogy megindítható a vételi kereset, és a vevő annyit követelhet, amennyivel kevesebbért vette volna meg a marhát illetve az épületfát, ha tudott volna annak hibás voltáról a vétel megkötésekor. Itt is, mint a fenti esetben, valójában az árleszállítási igény jogkövetkezményével állunk szemben, a jogász ezt felelteti meg a vevő interesséjének. ${ }^{240}$

A másik tényállási variációban az eladó magatartása felróható: a kellékhibáról tudva adta el (a) a beteg marhát, illetve (b) a hibás épületfát a vevőneknek, azaz rosszhiszemüen járt el. Az egyértelmü, hogy felelösségre vonható a vételi keresettel, a jogi probléma inkább a követelés összegszerüségében áll ebben az esetben. A jogász megoldása alapján minden olyan kárért felelősséggel tartozik az eladó, amely a hibás áru megvételének következményeként keletkezett. Így nem csak a dologban beálló károk, hanem a hiba folytán más vagyontárgyban bekövetkező károkért is felelt tehát az eladó. A utóbbihoz tartozhat például a hibás épületfa esetén az, ha a fa hibája miatt a ház, amelyet abból építettek, összeomlik: ilyenkor az eladó a ház becsértékét kell, hogy megtérítse a jogász szerint. A marha betegsége következményként okozhatja az egész nyáj elpusztulását is,

\footnotetext{
${ }^{239}$ Lásd: MANTHE (1976), 135. p.; JAKAB (2003), 46. p.; ERNST (2013), 81. p.

${ }^{240}$ Lásd: JAKAB (2003), 46. p.; KASER - KNÜTEL (2014), 252. p.
} 
ezért a fentiek szerint ebben az esetben a vevő követelhette akár a teljes csorda értékét is. $^{241}$

Látható, hogy az objektív helytállás esetén a vevő kevesebbet követelhetett, mint az eladó csalárd magatartása esetén, azonban az elöbbinél könnyebben érvényesíthette igényét, mert nem kellett bizonyítania az eladó felróhatóságát. A második esetben az interesse tartalma jóval tovább terjedt, az igényérvényesítést azonban megnehezítette a vevőre háruló bizonyítási teher a felróhatóságra vonatkozóan. ${ }^{242}$

\section{Összefoglalás}

Az ókori Rómában a spontán kialakult piaci szokások nyomán az áru (a rabszolga) minőségéhez füződő vevői érdek védelme materializálódott a piaci adásvételről szóló aediliszi edictumban. Az ókori szabályozási megoldás dogmatikai jellemzői közül kiemelendő néhány, amely a materiálisan hibás teljesítésért fennálló eladói helytállási kötelezettségnek korokon átívelő szabályozásában is minduntalan fellelhető.

1. A caveat emptor elve, azaz a készvétel esetén a vevő körültekintő eljárásának követelménye;

2. a caveat emptor elvével összefüggésben az áru minőségi hibájára utaló külső jelek és a rejtett minőségi hibák relevanciája (kockázattelepítés a szerződő felek között);

3. a minőséget már az adásvétel megkötése előtt demonstráló (tisztességes) eladói gyakorlat kívánalma;

4. az áru rendeltetésszerü használatát befolyásoló és piaci értékére is kiható kellékhibák relevanciája;

5. a gyakran tájékozatlan vevőnek a hivatásos (furfangos) kereskedőkkel szembeni védelme, mint jogpolitikai cél;

6. az áru tulajdonságait illetően önkéntesen felvállalt eladói ígéret (a jótállás előképe);

7. a hibás teljesítésért fennálló objektív - a kellékhiba ismeretétől független - eladói helytállás;

8. az objektív kellékszavatossági és a hibás teljesítés miatti szubjektív kártérítési igények párhuzamossága; és végül

9. a vevő választási joga a rendelkezésre álló igényérvényesítési eszközök között

\footnotetext{
${ }^{241}$ JAKAB (2003), 46-47. p.; ZIMMERMANN (1996), 309-310. p.

${ }^{242}$ MANTHE (1976), 145. p.
} 
mind nyomon kövehetőek az újkori magánjogok szabályozási megoldásaiban is. Minderre igyekeznek rámutatni a következő fejezetek. 


\section{AZ OSZTRÁK ÉS A NÉMET KODIFIKÁCIÓK A HIBÁS TELJESÍTÉSRÖL - A KORABELI MAGYAR JOGTUDOMÁNY TÜKRÉBEN}

\section{Bevezetés}

A római jog XI. századi itáliai recepciójával, a Bolognai Egyetem alapításával, a glosszátorok, majd a kommentátorok munkájával kezdetét vette az a folyamat, melynek során számtalan jogi kart alapítottak Európa-szerte. ${ }^{243} \mathrm{Az}$ egyetemeken kivétel nélkül a Digesta és a Codex Iustinianus volt a tananyag. ${ }^{244}$ Az 1583-ban a francia Dionysius Gothofredus által először összefoglalva kinyomtatott három jusztiniánuszi joggyüjteményt (Codex Iustinianus, Institutiones, Digesta) tartalmazó Corpus Iuris Civilis szövegei könnyítették meg a jogászok és az egyetemen jogot hallgatók munkáját.

A tudományos élet fellendülésével az újkorban meginduló különféle szellemi áramlatok és törekvések a kidolgozott római magánjogi rendszert igyekeztek életre kelteni az újkori jogtudományban és joggyakorlatban is. Az egyház, a német-római császárság és az európai egyetemek müködésének köszönhetően következett be a római jog recepciója Európában. ${ }^{245}$ A 16. században a humanizmus, majd a 17-18. században a természetjogi iskola hatására a Corpus Iiuris Civilis szerepe módosult, ratio scriptának, a természetjog lehetséges írott materializálódásának kezdték tekinteni, és az ennek hatására született római jogból táplálkozó művek ${ }^{246}$ nagy hatást gyakoroltak egyes európai államok magánjogi kodifikációs folyamataira, és azok szakmai vezetőire. ${ }^{247}$ Ezt tükrözi Balásfalvi Kiss Albert gondolata is: „...a latin népnek juttatta feladatul a világtörténelem oly magánjogi jogrendszer kialakítását, melynek alapelvei ma is élnek a világ valamennyi művelt országában." ${ }^{248}$ E hatás az osztrák, a német és a svájci magánjogi kódexek hibás teljesítésre vonatkozó szabályaiban is megmutatkozik.

Villányi László a XX. század derekán úgy vélekedett, hogy „a római jogot követik általában az európai kontinentális jogrendszerek” és ,az áru hibáiért való felelősség szabályait együttesen [...] a szavatosság gyüjtőfogalma alá szokás helyezni."249 Szladits

\footnotetext{
${ }^{243}$ PICHONNAZ (2012), 27. p.; KECSKÉS (2009), 105. p.

244 PICHONNAZ (2012), 28. p.

245 BALÁSFALVi KISS (1937), 44. p.

${ }^{246}$ Például: Jean Domat: Les loix civiles dans leur ordre naturel (1689.); Robert-Joseph Pothier: Pandectae Justinianeae in novum ordinem redactae (1748-1752.) és Traité des Obligations (1761.), lásd: PICHONNAZ (2012), 31.p.

${ }^{247}$ Többek között a porosz ALR (Friedrich der Zweite vezetésével, 1794.), a franica Code civil (1804.), az osztrák ABGB (Carl Anton von Martini vezetésével, 1811.) megszületésére, lásd: PICHONNAZ (2012), 29. p.

${ }^{248}$ BALÁSFALVI KISS (1937), 6. p.

${ }^{249}$ Lásd: ViLLÁNYI (1941), 332. p.
} 
Károly XX. század eleji tanulmányában pedig azt írta, hogy „avégből, hogy a kellékszavatosság intézményi jelentőségét tisztázhassuk és szabályait a magyar jog szempontjából tüzetesen kifejthessük, célszerü [...] előzetesen az intézmény alakulását azokban a jogrendszerekben bemutatni, amelyek hazai jogéletünkre hatást gyakorolnak". ${ }^{250}$ E gondolatmenetet követve kerülnek röviden ismertetésre az osztrák és a német polgári törvénykönyv kellékhibás teljesítésről szóló eredeti szabályai a magyar szabályozás történetének bemutatása előtt. ${ }^{251}$

\section{Az osztrák Allgemeines Bürgerliches Gesetzbuch szabályai hibás teljesítés esetén}

\subsection{A magánjogi kodifikáció}

A jogfejlesztés és a jogegységesítés iránti törekvés már a XVI. században megkezdődött Ausztriában a magánjogot illetően is. A joggyakorlatot előtérbe helyező jogtudósok különösen Azzoni, Martini és Zeiller - a tartományok jogszokásait és az érvényben lévő, a gyakorlatban alkalmazott római jogot és kánonjogot igyekeztek összhangba hozni egymással. ${ }^{252} \mathrm{E}$ folyamat hatására sorra születtek a szokásjogi gyüjtemények illetve tartományi rendeletek, amelyek a római jog kisegítő szabályaival együtt a jogegységesítés szolgálatában álltak. ${ }^{253}$

Az osztrák tartományokra kiterjedő magánjogi kodifikáció 1753-ban indult meg Mária Terézia rendelkezése nyomán, aki felállított egy kodifikációs bizottságot is. ${ }^{254} \mathrm{~A}$ több mint fél évszázados kodifikációs folyamat több periódusra bomlott, de az egyes résztervezetek megalkotásánál mindvégig meghatározó szerepe volt a római jognak. ${ }^{255} \mathrm{~A}$ polgári törvénykönyv, az Allgemeines Bürgerliches Gesetzbuch für die gesammten deutschen Erbländer der Österreichischen Monarchie ${ }^{256}$ végül 1811-ben került kihirdetésre, és 1812. január 1-jén lépett hatályba. ${ }^{257}$ A kódex megalkotói kimondottan a római jogi institúció-rendszer átvételére törekedtek, de a kodifikált joganyagra a római jog és az azon alapuló Gemeines Recht mellett a természetjogi eszmék és a tartományi jogok is

\footnotetext{
${ }^{250}$ Lásd: SZLADITS (1906), 285. p.

${ }^{251}$ Mádl Ferenc is utal rá, hogy a magyar kötelmi jog kodifikálásánál milyen nagy jelentőséggel bírtak az osztrák, német és svájci kódexek kötelmi jogi rendelkezései, lásd: MÁDL (2002), 71. p.

${ }^{252}$ HAMZA (2002), 111. p.

${ }^{253}$ HAMZA (2002), 112-113. p.

${ }^{254}$ GINYOVSZKY (1932), 4. p.; KECSKÉS (2009), 385-386. p.

${ }^{255}$ HAMZA (2002), 113. p.

${ }^{256}$ A továbbiakban: ABGB.

${ }^{257}$ HAMZA (2002), 113. p.
} 
hatást gyakoroltak. ${ }^{258}$ Szladits utóbb úgy jellemezte az ABGB-t, hogy az „egészséges, helyes középutat mutat a nagyszerü tudományossággal készült, súlyos, de éppen ezért nehézkes német törvénykönyvvel és a laikus bíróknak készült, nagyon rövid és szükszavú svájci törvénykönyvvel szemben". ${ }^{259}$

Az ABGB első része a „személyjogról”, második része a dologi jogról, harmadik része pedig a „személyi és dologi jogok közös meghatározásáról” szólt. ${ }^{260}$ Az institúciórendszer átvétele eredményezte azt az ABGB-ben, hogy a kötelmi jog általános részének megfeleltethető szabályok egy része a dologi és a kötelmi jogra vonatkozó közös szabályok részét képezte. ${ }^{261}$

Az ABGB második részének második alegysége így az ún. „dologhozi jogokról”

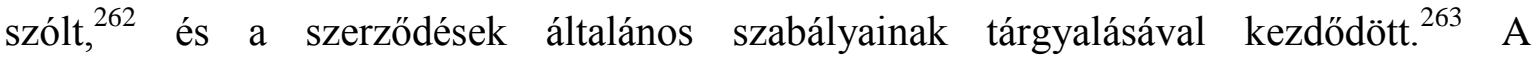
törvénykönyv megalkotói itt helyezték el a hibás teljesítés elsődleges jogkövetkezményének, a szavatosságnak a szabályait. ${ }^{264}$

\subsection{Szavatosság}

A szerződésszerü teljesítésre vonatkozóan az ABGB úgy rendelkezett, hogy „a szerződések azon időben, azon helyen és azon módon teljesítendők, mint az iránt a felek megegyeztek..." ${ }^{265}$ Ha mégsem ennek megfelelően történt a teljesítés, akkor az ABGB a követezőképpen rendelkezett:

„, Wenn Jemand eine Sache auf eine entgeltliche Art einem Anderen überlässt, so leistet er Gewähr, dass sie die ausdrücklich bedungenen, oder gewöhnlich dabei vorausgesetzten Eigenschaften habe, und dass sie der Natur des Geschäftes, oder der getroffenen Verabredung gemäss benützet und verwendet werden könne. "266

Szladits úgy fogalmaz, hogy az ABGB szerint a visszterhes szerződéseknél a teljesítés nem szünteti meg véglegesen a kötelmet, mert ahhoz, hogy a szerződés elérje a célját, a szolgáltatásoknak egyenértékűeknek kell lenniük. ${ }^{267}$ Ezért ha a szolgáltatott dolog hibás,

\footnotetext{
${ }^{258}$ GINYOVSZKY (1932), 7. p.; FÖLDI (2012), 337. p.

${ }^{259}$ Lásd: GINYOVSZKY (1932), 7. p.

${ }^{260}$ GINYOVSZKY (1932), 36. p.

${ }^{261}$ FÖLDI (2012), 342. p.

${ }^{262}$ Ezt latinul ,, ius ad rem”-ként említette Szladits (a mai kötelmi jog), olyan előny, amelyhez ,a jogosultat hozzá kell juttatni” (pl. a szolgáltatást teljesíteni kell), szemben a „dologbani joggal” (ius in rem), amely a mai értelemben vett dologi jogot takarta, lásd: GINYOVSZKY (1932), 274. p.

${ }^{263}$ MÁRKUS (1907), 185. p.

${ }^{264}$ MÁRKUS (1907), 185. p.

${ }^{265}$ ABGB § 902, lásd: MÁRKUS (1907), 194. p.

${ }^{266}$ ABGB $\S 922$.

${ }^{267}$ Lásd: GINYOVSZKY (1932), 279. p.
} 
akkor az azt nyújtó félnek szavatolnia kell; ${ }^{268}$ a szavatosság ezek szerint a „teljesítés szabályainak alkalmazása a minőségi kellékek szolgáltatására". ${ }^{269}$ A szabályozás tehát minden visszterhes szerződésre vonatkozott, és két irányban érvényesült: a dolog „átengedésére” kötelezett fél az arról „rendszerint feltett”, és a „világosan kikötött” tulajdonságokért felelt, és helyt kellett állnia az ügylet természetéből fakadó, valamint a konkrét megállapodásnak megfelelő használhatóságért is. ${ }^{270}$ Ezt a szabályt részletezte a következő szakasz a szavatosság eseteiről:

„,Wer also der Sache Eigenschaften beileget, die sie nicht hat, und die ausdrücklich oder vermöge der Natur des Geschäftes stillschweigend bedungen worden sind; wer ungewöhnliche Mängel oder Lasten derselben verschweiget; wer eine nicht mehr vorhandene, oder eine fremde Sache als die seinige veräussert, wer fälschlich vorgibt, dass die Sache zu einem bestimmten Gebrauche tauglich, oder dass sie auch von den gewöhnlichen Mängeln und Lasten frei sei; der hat, wenn das Widerspiel hervorkommt, dafür zu haften. "271

Az ABGB szabályozásában nem választotta el élesen a jogalkotó a kellékhibákért és a jogszavatosságért fennálló kötelezetti helytállást, amely utóbbira a terhektől mentes állapot említése utal. A meghatározás ex lege objektív helytállásra enged következtetni, megjelenik azonban a szabályozásban az aediliszi edictumból ismert kiterjesztés a szándékos, csalárd eladói magatartásra: a dolog átadója akkor is helytállni tartozott, ha elhallgatta a hibákat, illetve ha „hamisan” azt állította, hogy valamire alkalmas a dolog. A római jogból ismert caveat emptor elvének megfelelően úgy rendelkezett azonban az ABGB, hogy nincs helye szavatosságnak, ha a hiba felismerhetö, azaz csak a rejtett hibákért állt fenn a helytállási kötelezettség. ${ }^{272}$

Az ABGB szabályozásában megjelent a magánautonómia elismerése, amely a „dologhozi” (kötelmi) jogban a szerződési szabadságot jelentette. ${ }^{273}$ A kódex ennek megfelelően diszpozitív szabályozást alkalmazott a szavatosságnál is, ennek megfelelően akár ki is lehetett zárni a szavatossági helytállást. ${ }^{274}$ A szavatosság kizárása azonban

\footnotetext{
${ }^{268}$ Lásd: GiNYOVSZKY (1932), 279. p.

${ }^{269}$ SZLADITS (1906), 325. p.

${ }^{270}$ Lásd: KARVASY (1870), 238. p.

271 ABGB § 923: „Ki tehát a dolognak olly minőségeket tulajdonít, mellyekkel az nem bir, s a mellyek világosan, vagy az ügylet természeténél fogva hallgatagul kikötöttek; ki annak szokatlan hiányait vagy terheit elhallgatja; ki már meg nem lévő, vagy idegen dolgot magáé gyanánt árusit el; ki hamisan állitja, hogy a dolog meghatározott használatra alkalmas; vagy hogy az mentes a közönséges hiányoktól és terhektől is, az ha az ellenkező nem tünik ki, azért kezeskedni tartozik.”, lásd: Lásd: KARVASY (1870), 239. p. A definíció a római jogi szabályokat tükrözi, vö. I. fejezet 3.4. pont.

${ }^{272}$ ABGB § 928: „Fallen die Mängel [...] in die Augen [...] findet keine Gewährleistung statt.”. Vö. D. $21,1,14,10$.

${ }^{273}$ Lásd: GINYOVSZKY (1932), 50. p.

${ }^{274}$ ABGB § 929; KRAINZ (1900), 86. p. Így volt ez a római jogban is.
} 
semmis volt, ha a hibamentességet kifejezetten elvállalták (§ 928), illetve ha az átadó fél rosszhiszemü volt, azaz ha tudott a hibáról (§ 930).

\subsection{Szavatossági jogok}

Az ABGB általános kötelmi jogi szabálya szerint, „,ha az egyik fél a szerződést vagy éppen nem, vagy $[\ldots]$ nem a kikötött módon teljesiti; a másik félnek a törvényben meghatározott eseteken kívül, nem a szerződés megszüntetését, hanem csak annak pontos teljesitését és kártéritést van joga követelni."275 A szavatosság egy ilyen, a „törvényben meghatározott” esetkör volt, amely objektív helytállást keletkeztetett, és amelyre szigorúbb jogkövetkezményeket írt elő a kódex, mint általában a szerződéses felelősség eseteiben. A kellékszavatossági igényekről az ABGB a következőképpen rendelkezett:

„Ist der die Gewährleistung begründende Mangel von der Art, dass er nicht mehr gehoben werden kann, und dass er den ordentlichen Gebrauch der Sache verhindert, so kann der Verkürzte die gänzliche Aufhebung des Vertrages, wenn hingegen sich das Fehlende, z. B. an Mass oder Gewicht, nachtragen lässt, nur diesen Nachtrag, in beiden Fällen aber auch den Ersatz des weiteren Schadens, und daferne der andere Theil unredlich gehandelt hat, auch den entgangenen Nutzen fordern. ",276

Az ABGB tehát a kellékhibákkal egy tekintet alá vette a mennyiségi hiányt is, ${ }^{277}$ valamint különbséget tett az elhárítható és az elháríthatatlan hibák/hiányok között a jogkövetkezmények tekintetében. Ha a hiba elhárítható, akkor a jogosult a hiány szerződés szerinti pótlását igényelhette, ${ }^{278}$ fajlagos vétel esetén pedig a hibátlanra való kicserélést is kérhette. ${ }^{279}$

Ha a hiba a rendeltetésszerü használatot kizárta és azt elhárítani nem lehetett, akkor a dolog átvevője a szerződés megszüntetését követelhette, azaz elállhatott a szerződéstől. ${ }^{280}$ Ilyenkor az elállás jogkövetkezménye szerint a már nyújtott szolgáltatásokat a felek

\footnotetext{
275 „,Wenn ein Teil den Vertrag enweder gar nicht; oder nicht zu der gehörigen Zeit; an dem gehörigen Orte; oder auf die bedungene Weise erfüllet; so ist der andere Teil, außer in dem Gesetze bestimmten Fällen, oder einem ausdrücklichen Vorbehalte, nicht berechtiget, die Aufhebung, sondern nur die genaue Erfüllung des Vertrages und Ersatz zu fordern."(ABGB § 919), lásd: MÁRKUS (1907), 198. p.

${ }^{276}$ ABGB § 932.

${ }^{277}$ Lásd: KARVASY (1870), 243. p. Lásd továbbá: OGH 4514; SZLADITS (1906), 342. p. 1. 1j.

278 „Nachtrag des Fehlenden” és ,, somit Behebung des Mangels”, OGH. 31., 14852.; SzLADITS (1906), 326. p.

${ }^{279}$ SzLADITS (1906), 326. p.

280 „Wandelklage” vagy ,, actio redhibitoria”. Gyakran használták a latin terminológiát a jogtudósok és a bíróságok is, mert az igény megfelelt a római jogi elállásnak, lásd: KRAINZ (1900), 87. p. Ilyenkor tulajdonképpen a jogosult oldalán érdekmúlás állt fenn.
} 
kötelesek voltak egymásnak visszaadni, és ez érvényesült akkor is, ha a dolog véletlen folytán megsemmisült. ${ }^{281}$

Ha a hiány/hiba pótolható volt, akkor csak ,ezen pótlék” követelését tette lehetővé a kódex, tehát nem biztosította a jogosult római jogból ismert választási jogát. ${ }^{282}$ Ezzel kapcsolatban Szladits tudósítása szerint jelentős vita bontakozott ki a jogtudományban: az egyik felfogás szerint az igény pusztán a hiány pótlását jelentette, ${ }^{283}$ a másik megközelítés - amelyet a bírói gyakorlat is támogatott - kártérítési kötelezettségként értékelte a rendelkezést, ${ }^{284}$ a harmadik felfogás szerint pedig a római jogi actio quanti minoris elvei alkalmazandóak a szabály értelmében. ${ }^{285} \mathrm{~A}$ harmadik jogértelmezés Szladits szerint nem állja meg a helyét, mert míg a római szabályok szerint a vételár arányos csökkentésének volt helye, addig a fenti szabály egyszerűen azt az értéket rendelte „leszámítani”, amellyel a dolog kevesebbet ért, mint hibátlan állapotban, és így az szerinte sokkal nagyobb aránytalanságokhoz vezethet a gyakorlatban. ${ }^{286}$

A római jogi szabályokhoz hasonlóan a kártérités is a jogosult igényei közé tartozott: a megfogalmazás a hibán felüli, de a hiba következtében felmerült tényleges károk megtérítésének kötelezettségére utal. ${ }^{287}$ A hibás teljesítés miatti kártérítés jogalapja vita tárgyát képezte a jogéletben: a jogtudósok egyik tábora objektív jogalapot tulajdonított e kötelezettségnek, és csak a kártérítés mértékénél juttatta szerephez a felróhatóságot. ${ }^{288} \mathrm{~A}$ másik jogtudományi álláspont szerint az általános kártérítési szabályoknál irányadó szubjektív jogalap érvényesül a kellékhibás teljesítés esetén is. ${ }^{289}$ Pfersche közvetítő megoldása szerint a kötelezett csak akkor tartozott a hibás teljesítés miatti kártérítéssel szubjektív jogalapon, ha a dolog nem rendelkezett a konkrétan vagy a természetének megfelelően hallgatólagosan kikötött minőséggel, valamint ha a dolog „szokatlan hiányait” elhallgatta, illetve ha csalárdul azt állította, hogy a dolog meghatározott használatra alkalmas vagy mentes a közönséges hiányoktól. ${ }^{290}$

\footnotetext{
${ }^{281}$ Lásd: OGH 1761.; SZLADITS (1906), 331. p. Ez is a római jogi hatást tükrözi a szabályozásban.

${ }^{282}$ Lásd: KARVASY (1870), 243. p.

${ }^{283}$ Például Zeiller, lásd: SZLADITS (1906), 327. p.

${ }^{284}$ Lásd például: OGH 40., 2402.

285 Például Krainz, (,Minderungs-, Würderungsklage”, ,, actio quanti minoris”, ,judicium aestimatorium”), lásd: KRAINZ (1900), 87. p.; ZLINSZKY (1899), 654. p.; Magyar Jogi Lexikon (1907), 343. p.). Az álláspontok összehasonlítását lásd: SZLADITS (1906), 327. p.

${ }^{286}$ Lásd: SzLADITS (1906), 327-328. p.

${ }^{287}$ Ez tulajdonképpen a mai kijavítás igényét jelenti.

${ }^{288}$ Az elmaradt haszon eszerint csak a felróhatóan eljáró kötelezettől volt követelhető. Így vélekedett például: Hasenöhrl és Stubenrauch, lásd: SzLADITS (1906), 328. p.

${ }^{289}$ Lásd például: KRAINZ (1900), 87. p. Vö. ABGB §§ 1295 és 1306.

${ }^{290}$ Ezek tulajdonképpen a szavatosság esetei, lásd: SZLADITS (1906), 329. p., vö. ABGB § 923.
} 
Amennyiben a dolog átadója a hibás teljesítés tekintetében rosszhiszemüen járt el, az kétséget kizáróan szubjektív jogalapú, szigorúbb kártérítési szankciót eredményezett: nem csak a tényleges kárt, hanem az elmaradt hasznot is meg kellett térítenie a kötelezettnek. ${ }^{291}$

\subsection{Igényérvényesitési határidők}

A szavatossági jogok érvényesítését speciális határidőkhöz kötötte a kódex, csakúgy, mint az ókori aediliszi edictum. Azonban nem a szavatossági igények (redhibitio vagy quanti minoris), hanem a szerződés tárgya tekintetében differenciált: az ingó és az ingatlan dolgokra különböző perlési határidőt írt elő:

„Wer die Gewährleistung fordern will, muss sein Recht, wenn es unbewegliche Sachen betrifft, binnen drei Jahren, betrifft es aber bewegliche, binnen sechs Monaten geltend machen, sonst ist das Recht erloschen. "292

A kódex alkotói megtartották a római jogban gyökerező hat hónapos igényérvényesítési határidőt ingó dolgok visszterhes szerződéssel történő átengedése esetén. A törvény nem mondta ki, hogy a határidők elévülési jellegűek-e, és arról sem rendelkezett, hogy mikortól számítandóak, ami a joggyakorlatban zavart okozott. ${ }^{293}$ A törvény megfogalmazásból (erloschen) arra lehet következtetni, hogy a határidők jogvesztő jellegüek voltak. Krainz szerint attól az időponttól indult a határidők számítása, amikor a szerződéskötés befejezetté vált. ${ }^{294}$ Amennyiben azonban a hibát csak később lehetett felfedezni, a felfedezéstől indult a határidő, a hiba kiütközésének illetve felfedezésének (későbbi) időpontját azonban a jogosult volt köteles bizonyítani (§ 927). ${ }^{295}$

A fenti határidők Krainz szerint ugyanúgy irányadóak a kifogás megtételére is, ${ }^{296}$ Szladits azonban úgy vélte, hogy ha a határidő alatt a kifogásközlést az átvevő elmulasztotta, akkor annak letelte után is érvényesíthette az igényt a bíróságon. ${ }^{297}$

\footnotetext{
${ }^{291}$ KARVASY (1870), 243. p.

292 ABGB § 933.

293 A dogmatikai zavart mutatja az, hogy az osztrák legfelsőbb bíróság is egymással ellentétes döntéseket hozott a kérdés kapcsán, lásd: SZLADITS (1906), 332. p.

${ }^{294}$ KRAINZ (1900), 88. p.

${ }^{295}$ KRAINZ (1900), 88. p. Ez tulajdonképpen felfogható egyfajta nyugvási szabálynak is, ami azonban már a határidők elévülési jellegére enged következtetni.

${ }^{296}$ KRAINZ (1900), 88. p.

${ }^{297}$ Lásd: GINYOVSZKY (1932), 280. p.
} 
Ellentétes volt ezzel a felfogással az osztrák bírósági gyakorlat, amely kizárta a határidő utáni igényérvényesítést kifogás formájában is. ${ }^{298}$

Ha részletfizetésben állapodtak meg a felek, addig nem évült el a követelés, amíg a teljes vételár kifizetésre nem került. ${ }^{299} \mathrm{Ez}$ egy, a XIX. század második felében újonnan bevezetett bírói gyakorlat volt, amelyre Krainz szerint azért volt szükség, mert korábban a részletügyletet kötő kereskedők célzatosan hat hónap elteltével követelték a hátralékot, kizárva ezzel a szavatossági igény érvényesítését. ${ }^{300}$

\section{5. Állatszavatosság}

Olyan visszterhes szerződések esetén, amelyeknek állat volt a tárgya, az ABGB speciális rendelkezéseket is tartalmazott, egyebekben pedig az általános szavatossági szabályokat rendelte alkalmazni ( $§ 925)$. Az állat átadója is helytállással tartozott az ABGB $§ 922$ hatálya alá tartozó minden kellékhibáért. Úgy rendelkezett emellett a törvény, hogy rendelet állapítja meg, hogy melyek azok a betegségek és hibák, amelyeknek a rendeletben megállapított rövid határidőn belüli jelentkezése a hibásság megdönthető vélelmét állította fel (§ 925). Az átvevő fél számára e vélelmek könnyebbséget jelentettek a bizonyítást illetően, azonban csak akkor lehetett azokra hivatkozni, ha az átvevő a hibát a kötelezettel, vagy a községi illetékes eljáró hivatallal (hivatalnokkal) azonnal, késlekedés nélkül közölte. Ellenkező esetben neki kellett bizonyítania, hogy a hiba már az átadáskor megvolt az állatban (§§ 926-927).

\section{A hibás teljesítésre vonatkozó szabályok a német Bürgerliches Gesetzbuchban}

\subsection{A magánjogi kodifikáció}

A német magánjogi kodifikációt az országon belüli egység megteremtése, azaz a Német Szövetség létrejötte, a társadalmi fejlődés és a magánjogtudomány magas színvonala hívta életre. ${ }^{301}$ A német egyetemeken is a Digesta-szövegek, és különösen a német bíróságok által alkalmazott továbbélő római jog alapulvételével folyt a jogi oktatás. ${ }^{302} \mathrm{~A}$ tartományi jogterületekre tagolt Németországban tartományi jogszabályok voltak érvényben a XIX.

\footnotetext{
${ }^{298}$ Lásd: OGH 1148., 1597., 4862.; SZLADITS (1906), 381. p. 1. lj.

${ }^{299}$ Lásd: KRAINZ (1900), 88. p.

${ }^{300}$ Lásd: KRAINZ (1900), 88. p.

${ }^{301}$ 1814-1815-ben, lásd: RuSZOLY (2011), 95. és 97. p.

${ }^{302}$ Lásd: RUSZOLY (2011), 101-102. p.
} 
század első felében, és az egyes területeken egyénileg vették kezdetét a kodifikációs kísérletek. ${ }^{303} \mathrm{Az}$ 1871-es német birodalmi alkotmány rendelkezései nyomán kezdődött meg a kötelmi jog szövetségi kodifikációjának folyamata, amelyet 1873-ban kiterjesztettek a magánjog minden területére. ${ }^{304} \mathrm{~A}$ kódex hosszas, meghatározóan a pandektista Bernhard Windscheid vezette előkészítési munkálatok eredményeképp 1896. augusztus 18-án fogadták el a Bürgerliches Gesetzbuch für das Deutsche Reich elnevezésü egységes törvényt, amely 1900. január 1-jén lépett hatályba. ${ }^{305}$ A kodifikátorok a neves egyetemi professzorok jogtudományi müveire támaszkodva absztrakt, minden lehetséges esetet felölelő rendelkezések megalkotására törekedtek. ${ }^{306}$ Ennek fényében a kódex nem új megoldásokat vezetett be, hanem korábban kidolgozott eredményeket iktatott törvénybe. ${ }^{307}$

A BGB rendszere a precízen kimunkált pandekta-rendszert tükrözte, ${ }^{308}$ „,szelleme, technikája, tartalma alapján római jogi jellegü" volt. ${ }^{309}$ Ez megjelent a kódex kötelmi jogának rendszerében is, amelyben az első fő rész a kötelmekre vonatkozó általános tanokat tárgyalta, a második pedig az egyes szerződéstípusokat, valamint a deliktuális kötelmeket tartalmazta. A Schuldrecht Allgemeiner und Besonderer Teil elnevezések csak a BGB nyomán kialakuló magánjogi szakirodalomban váltak szokásossá. ${ }^{310}$

\subsection{Hibás teljesítés}

A BGB szabályai a hibás teljesítés és elsődleges jogkövetkezménye, a kellékszavatosság esetén is a pandekta-jog hatását tükrözték. A kodifikációt megelőző időszakban a pandektisztika képviselői már speciálisan foglalkoztak a kellékszavatosság problémakörével, és a római jogi hagyományoknak megfelelően - az ABGB-vel ellentétben - azt mindig az adásvételi jog részeként tárgyalták. ${ }^{311}$ A BGB ennek megfelelően ugyancsak az adásvételi jogba illesztette a kellékhibákért való helytállás szabályait, és lényegében átvette a Gemeines Recht, azaz a recipiált római jog szabályait azzal a kiegészítéssel, hogy fajlagos vétel esetén is kimondottan az egyedi vételre

\footnotetext{
${ }^{303}$ Lásd: RUSZOLY (2011), 101-102. p.

${ }^{304}$ RUSZOLY (2011), 102. p.

305 A továbbiakban: BGB. Lásd: RUSZOLY (2011), 103. p.; KECSKÉS (2009), 343. p.

${ }^{306}$ Lásd: KECSKÉS (2009), 353. p.

${ }^{307}$ Lásd: WIEACKER (1967), 472-478. p.

${ }^{308}$ FÖLDI (2012), 339. p.

${ }^{309}$ Lásd: RUSZOLY (2011), 103. p.

${ }^{310}$ FÖLDI (2012), 342-343. p.

${ }^{311}$ Lásd: SZLADITS (1906), 297-305. p.
} 
vonatkozó szabályokat rendelte alkalmazni. ${ }^{312}$ A kódex a kellékszavatossági jogokon és érvényesítési határidőkön kívül kitért a lehető legtöbb részletkérdésre is, amelyek a gyakorlatban felmerültek. Az eladónak a kellékhibákért fennálló szavatossági helytállásáról így rendelkezett:

„Der Verkäufer einer Sache haftet dem Käufer dafür, daß sie zu der Zeit, zu welcher die Gefahr auf den Käufer übergeht, nicht mit Fehlern behaftet ist, die den Wert oder die Tauglichkeit zu dem gewöhnlichen oder dem nach dem Vertrage vorausgeßesten Gebrauch aufheben oder mindern. Eine unerhebliche Minderung des Wertes oder der Tauglichkeit kommt nicht Vertracht. Der Verkäufer haftet auch dafür, daß die Sache zur Zeit des überganges der Gefahr die zugesicherten Eigenschaften hat. "313

Az eladó azért szavatolt, hogy abban a pillanatban, amikor a veszély átszáll a vevőre, az eladott dolog nem rendelkezik olyan hibával, amely a szokásos vagy a szerződésnek megfelelő értékét vagy használhatóságát kizárná vagy csökkentené. Ez ex lege helytállást keletkeztetett a fenti törvényi kellékek hiánya, és bármely kikötött szerződéses kellék hiánya esetén is. 314

A pandekta-joghoz képest változást hozott a BGB a veszélyátszállás idejét illetően: az irányadó időpont az ingók „helyi” adásvételénél az átadás, a „helykülönbségi vételeknél” pedig (amikor is az eladó a vevő kérésére a dolgot a szerződéskötés helyétől különböző helyre küldte neki), az áru feladásának időpontjában szállt át a dolog megrongálódásának illetve (vétlen) megsemmisülésének a veszélye a vevőre. ${ }^{315}$

Nem volt helye a szavatosságnak, ha a hiba miatt az érték- vagy használhatóság csökkenése jelentéktelennek bizonyult, illetve akkor, ha a hibát a vevő az adásvétel megkötésekor ismerte. ${ }^{316}$ Az utóbbi esetén vélelmezték, hogy a hiba ismeretében is meg akarta kötni a vevő a szerződést. ${ }^{317}$ A római jogi szabályok tehát e vonatkozásban is teljes mértékben érvényre jutottak. Ha a vevő a hiba ismeretében vette meg az árut, de kifejezetten fenntartotta a szavatossági jogát a szerződéskötéskor, akkor a vevő tudomása ellenére fennállt az eladó helytállási kötelezettsége a hibáért. ${ }^{318}$

\footnotetext{
${ }^{312}$ SZLADITS (1906), 305. és 308. p.

${ }^{313}$ BGB § 459, lásd: Rosenthal (1927), 147. p.

${ }^{314}$ ECK (1903), 446. p. A definíció többnyire a római jogi megközelítést és az aediliszi szabályozást idézi, vö. D. 21,1,1,1; lásd: I. fejezet 3.4. pont.

${ }^{315}$ Lásd: BGB § 446 (1) és 447. A pandekta-jog szerint ez az időpont a szerződés megkötése volt, lásd: SZLADITS (1906), 306. p.

${ }^{316}$ Lásd: BGB § 460: „, ...wenn der Kaufer den Mangel bei dem Abschlusse des Kaufes kennt.”.

${ }^{317}$ Lásd: SZLADITS (1906), 310. p.

${ }^{318}$ Lásd: BGB § 464, ECK (1903), 448. p.
} 
A caveat emptor ókori elve, illetve a germán jogokban is ismeretes „,Beim Kauf gelten Augen für Geld” és a ,Wer beim Kaufe die Augen nicht aufthut, der thue den Beutel auf ${ }^{, 319}$ szabályai a BGB-ben is szerepet kaptak: nem kellett az eladónak szavatolnia akkor sem, ha a vevő a hibát a kellően gondos megvizsgálás révén felismerhette volna, de gondatlansága folytán mégsem ismerte azt $(\S 460) .{ }^{320}$ Ez esetben csak akkor tartozott helytállással az eladó, ha csalárdul járt el, vagy a hiba egy kifejezetten kikötött tulajdonságot érintett $(§ 460){ }^{321}$

\subsection{A vevö kellékszavatossági jogai}

A BGB az aediliszi jogorvoslatokat biztosította a vevőnek hibás teljesítés esetén: ${ }^{322}$

„Wegen eines Mangels, den der Verkäufer nach den Vorschriften der $\S \S 459,460$ zu vertreten hat, kann der Käufer Rückgängigmachung des Kaufes (Wandelung) oder Herabsetzung des Kaufpreises (Minderung) verlangen."

A vevő tehát elállhatott vagy vételárcsökkentést követelhetett az eladótól, akárcsak az ókori Rómában, a kódex a szabad választás jogát biztosította a vevőnek az igények között az ABGB-vel ellentétben. ${ }^{323} \mathrm{Ha}$ a dologban már az adásvétel megkötésekor hiányzott valamely kikötött tulajdonság, vagy ha ugyanekkor az eladó a dolog valamely hibáját szándékosan (arglistig) elhallgatta, akkor a vevő azonnal visszautasíthatta azt, és követelhette a szerződésszerű teljesítést, vagy a teljesítési érdek megtérítését, azaz kártérítést. ${ }^{324} \mathrm{Az}$ igényérvényesítés során a teljesítés általános szabályának értelmében a vevőt terhelte a hibás minőség bizonyításának a kötelezettsége. ${ }^{325}$

\subsection{Az elállás joga - Wandelung}

A BGB a szerződéses elállási jogra vonatkozó szabályokat rendelte megfelelően alkalmazni a szavatossági elállási jogra, ami ugyanazt jelentette, mint a római jogban: helyre kellett állítani az eredeti állapotot, ezért mindkét fél köteles volt visszajuttatni a

\footnotetext{
${ }^{319}$ ECK (1903), 447. p.

${ }^{320}$ A BGB ,súlyos gondatlanság” kifejezést használja. Ez a rendelkezés is a római jogi szabályokat tükrözi.

${ }^{321}$ Ez a szabály hasonlít az ABGB azon megoldására, amely a szavatosság kizárásának semmisségéről rendelkezett a fenti esetekben, vö. ABGB $\S \S 928,930$.

${ }^{322}$ WINDSCHEID (1891), 437. p.

${ }^{323}$ Lásd: SZLADITS (1906), 319. p.

${ }^{324}$ SZLADITS (1906), 306-307. p.

${ }^{325}$ Vö. BGB § 363, lásd: SzLADITS (1906), 310. p.
} 
másiktól kapott főszolgáltatást, azaz a vételárat és a dolgot. ${ }^{326}$ Ezen kívül az eladónak a vételár után a fizetés napjától számított kamatot is ki kellett fizetnie, meg kellett térítenie a szerződéses költségeket és a vevőnek az eladott dologra fordított szükséges beruházásait is (§ 467). ${ }^{327} \mathrm{~A}$ vevő a vásárolt dolog mellett annak hasznait is köteles volt kiadni az eladó részére. ${ }^{328} \mathrm{Az}$ elállás általános szabályai értelmében a dolog vétlen megsemmisülése sem zárta ki az igény érvényesítését; a vevőnek felróható megromlás, megsemmisülés és átalakítás esetén azonban nem lehetett elállni (§ 350). A BGB tehát részletesen szabályozta a mortuus redhibetur ókori problémakörét is. Alkivétel volt, azaz elállhatott a vevő, ha a hiba az áru átalakítása során derült ki, mint például a vetőmagnak az elültetés következtében felmerülő csíraképtelensége. ${ }^{329}$ A vétlenül megsemmisült áru esetén a vevő anélkül volt jogosult visszakapni a kifizetett vételárat, hogy vissza kellett volna adnia a dolgot. $^{330}$

A BGB részletes számítási szabályokat fogalmazott meg azon esetekre, amelyekben több dolog együttesen került eladásra. Amennyiben az együttesen megvásárolt dolgok közül csak egy volt kellékhibás, csak erre nézve volt követelhető az elállás, még akkor is, ha az összes árura egy egységes vételár lett kifizetve. Csupán akkor lehetett minden egyes dologra kiterjedően követelni az elállást összetartozókként megvásárolt hibás dolgok esetén, ha aránytalan hátrány okozása nélkül nem volt lehetséges azokat szétválasztani ( $§$ 469). ${ }^{331}$ Rosenthal példája erre, ha két gyertyatartót egységes asztaldíszként, vagy négy nemes deres lovat egy fogatként adtak el. ${ }^{332}$ Ha a két (vagy több) együttesen megvásárolt dolog közül a fődolog minősült kellékhibásnak, az erre nézve gyakorolt elállási jog kiterjedt a „mellékdologra” (Nebensache) is, azonban ha csak a mellékdolog volt hibás, akkor az elállási jogot csupán erre nézve gyakorolhatta a vevő (§ 470).

Abban az esetben, ha több, egységes vételáron vásárolt áru közül csak egyre kívánták érvényesíteni az elállási igényt, akkor a vételár arányos részét kellett visszatérítenie az eladónak: amilyen mértékben a hibátlan állapotban lévő dolgok összértékéhez viszonyult az elállási joggal nem érintett hibátlan dolgok értéke (§ 471).

\footnotetext{
${ }^{326}$ Rückgängigmachung des Kaufes, lásd: BGB § 467; SzLADITS (1906), 305. p.; ECK (1903), 451. p.

${ }^{327}$ Lásd: BGB $\S 467$, ROSENTHAL (1927), 148. p. Az utóbbira példa a megvásárolt állat etetési költsége.

${ }^{328}$ ROSENTHAL (1927), 148. p.

${ }^{329}$ Vö. BGB § 467, lásd: SzLADITS (1906), p. 320. p.

${ }^{330}$ SZLADITS (1906), p. 320. p.

${ }^{331}$ E szabályok a római jogi megoldást tükrözik, vö. D. 21,1,38,13.

${ }^{332}$ Lásd: ROSENTHAL (1927) 148. p.
} 
Rosenthal példát is hoz erre: ${ }^{333}$ 'A' vett egy díványból és hat fotelből álló plüssgarnitúrát 900 márka összvételáron. Kiderült, hogy a hat közül két fotelben moly van. 'A' erre tekintettel a két fotel vonatkozásában elállást követelt, és az eladó vissza is vette őket. Ha a számításnál azt vesszük alapul, hogy a garnitúra ára hibátlan állapotban 1000 lett volna, akkor az elállási joggal nem érintett részei 800 márka értéket képviselnének, akkor e kettő aránya 900 (tehát a kifizetett vételár) és az ismeretlen (azaz az elállási joggal nem érintett garnitúra-részek tényleges értékének) hányadával. 900/x = 1000/800, azaz az ismeretlen 720. A két kellékhibás szék visszavételekor tehát a vevőnek 900 - 720, azaz 180 márka járt vissza a példa és a BGB számítási módszere alapján. ${ }^{334}$

\subsection{A vételárcsökkentés iránti igény - Minderung}

„Bei der Minderung ist der Kaufpreis in dem Verhältnisse herabzusetzen, in welchem zur Zeit des Kaufs der Wert der Sache in mangelfreiem Zustande zu dem wirklichen Werte gestanden haben würde. "335

Az árleszállítás számítása esetén olyan arányban kellett a vételárat csökkenteni, mint amilyenben a vétel megkötésekor a hibátlan dolog értéke a tényleges értékéhez viszonyulna. Így tehát az volt az irányadó, hogy hogyan viszonyul egymáshoz az adásvétel időpontjában az ugyanolyan, hibátlan állapotban lévő áru értéke és az eladott áru tényleges értéke. ${ }^{336}$ A számítás szabálya a római jogban is ismert relatív módszert követte. Amennyiben egy vételárért több dolgot vettek, és utóbb csak egy dolog vonatkozásában akarták érvényesíteni az árleszállítást, akkor az összes dolog összértékét kellett alapul venni. ${ }^{337}$

Ugyancsak a római jogban alkalmazott gyakorlatot rögzítette a BGB $§ 475$, amely alapján egy adott hiba vonatkozásában gyakorolt árleszállítási igény nem zárta ki, hogy később egy másik hibával kapcsolatban a vevő ismét éljen e jogával vagy elállási igényével. $^{338}$

\footnotetext{
333 ,, 'A' kauft eine Plüschgarnitur, bestehend aus Sofa und sechs Sesseln, für den Gesamtpreis von 900 RM. Es stellt sich heraus, daß in zwei Sesseln die Motten find. 'A'verlangt daher hinsichtlich dieser zwei Sessel Wandelung und der Verkäufer nimmt sie zurück.”, lásd: ROSENTHAL (1927), 148. p.

${ }^{334}$ Az eset elemzését lásd: RosenTHAL (1927), 148-150. p.

335 BGB $§ 472$.

${ }^{336}$ ECK (1903), 454. p.

${ }^{337}$ BGB § 472 második mondat, ugyanúgy, mint az elállási joggal kapcsolatos fenti jogesetben.

${ }^{338}$ Vö. D. $21,1,31,16$
} 


\subsection{Kártérítési igény}

Ha a dologban már az adásvétel megkötésekor hiányzott valamely kikötött tulajdonság, vagy ha az eladó a dolog valamely hibáját szándékosan (arglistig) elhallgatta, akkor a vevő követelhette a teljesítési érdekének a megtérítését, azaz kártérítést. ${ }^{339}$ Az objektív jogalapú kellékszavatossági helytállás mellett a római jogi megoldáshoz hasonlóan tehát kártérítési

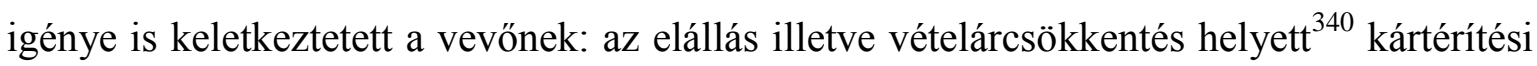
igénnyel léphetett fel:

„Fehlt der verkauften Sache zur Zeit des Kaufes eine zugesicherte Eigenschaft, so kann der Käufer statt der Wandelung oder der Minderung Schadenersatz wegen Nichterfüllung verlangen. Das gleiche gilt, wenn der Verkäufer einen Fehler arglistig verschwiegen hat. ,341

Akkor követelhette tehát a vevő a kártérítést, ha az adásvétel megkötésének idején a megvett dolog nem rendelkezett valamely kikötött tulajdonsággal, vagy ha az eladó egy hibát csalárdul elhallgatott. A vevő a kártérítés követelése esetén visszautasíthatta a hibás dolgot, és úgy követelhette kárainak megtérítését, mintha egyáltalán nem történt volna teljesítés, vagy meg is tarthatta azt, de ekkor csak a hiba folytán beálló kárát követelhette. ${ }^{342}$

A fentieken kívül a joggyakorlatban és a jogirodalomban elfogadottá vált az, hogy ha a hibás teljesítés az eladó szolgáltatási kötelezettségének felróható megszegéséből következett, akkor ő volt felelős az ezzel okozott kárért is. ${ }^{343}$ Ezt egyedi vétel esetén a szolgáltatás tulajdonképpeni lehetetlenülése, fajlagos vételnél pedig a „középminőségü” dolog szolgáltatásának a kötelezettsége indokolta. ${ }^{344}$ Szladits szerint azonban ez a lehetőség elállás esetén annak jogkövetkezményét megkérdőjelezi, mert akkor tulajdonképpen nem történik meg az eredeti állapot helyreállítása, ha a vevő egyúttal kártérítést is követel. ${ }^{345}$

A kártérítés fenti két esetében a jogalap különbözött: ha a kikötött tulajdonság hiánya állt fenn, akkor a törvényi megfogalmazás arra enged következtetni, hogy nem vizsgálták az eladó felróható magatartását, azaz objektív jogalapon felelt (a

\footnotetext{
${ }^{339}$ SZLADITS (1906), 306-307. p.

${ }^{340}$ Azaz nem a kellékszavatossági igények mellett, mint az osztrák kódexben.

${ }^{341}$ BGB $§ 463$.

${ }^{342}$ Lásd: SZLADITS (1906), 307-308. p.

${ }^{343}$ SZLADITS (1906), 308. p.

${ }^{344}$ Vö. BGB § 243. A középminőség a gyakorlatban hibátlan áru szolgáltatásának kötelezettségét jelentette, lásd: SZLADITS (1906), 308. p.

${ }^{345}$ Lásd: SzLADITS (1906), 309. p.
} 
kellékszavatossággal egyezően). ${ }^{346}$ A másik esetben a csalárd (arglistig) magatartása miatt a kódex azonban nyilvánvalóan szubjektív jogalapon teszi felelőssé az eladót a hibás teljesítésért.

\subsection{Kicserélés fajlagos vétel esetén}

Külön rendelkezett a BGB a fajlagos vétel kellékhibája esetén alkalmazható igényről:

„Der Käufer einer nur der Gattung nach bestimmten Sache kann statt der Wandelung oder der Minderung verlangen, daß ihm an Stelle der mangelhaften Sache eine mangelfreie geliefert wird. Auf diesen Anspruch finden die für die Wandelung geltenden Vorschriften der $\$ \$ 464$ bis 466, des $\$ 467$ Satz 1 und der $\S \S 469,470,474$ bis 479 entsprechende Anwendung. “347

Fajlagos, azaz fajta szerint meghatározott dolog vétele esetén a BGB tehát megadta a vevőnek azt a jogot, hogy elállás és árleszállítás helyett a hibás dologért cserébe új, hibátlan dolgot kérjen, ${ }^{348}$ és ezen igény érvényesítésére megfelelően alkalmazni rendelte az elállásra érvényes előírásokat.

Érdekes kérdés volt a fajlagos vételnél a hiányos teljesítés esete. Ha a teljesítés hiányos, de a hiány elhárítható volt, akkor a jogirodalomban megkülönbözették a felróhatóan és vétlenül okozott, vagy véletlen folytán beállt hiányok jogkövetkezményeit. ${ }^{349} \mathrm{Az}$ eladót felróható magatartásából fakadó hiány esetén kártérítésért is felelőssé tették, ha azonban vétlenül/véletlenül állt be a hiány, akkor csak az elállást és a vételárcsökkentést követelhette a vevő. ${ }^{350}$ Vitatott volt, hogy kérhet-e az eladó a „pótteljesítésre” határidőt: a jogtudomány többségi álláspontja szerint azon az alapon megillette őt a póthatáridő, hogy a nem vagy késedelmesen teljesítő eladó is rendelkezett e joggal. $^{351}$

\subsection{A kellékszavatossági igények elévülése}

Az elállási és árleszállítási jog gyakorlása, valamint a szubjektív jogalapú kártérítés követelése között az igényérvényesítési határidők tekintetében a BGB eredeti szövege nem

\footnotetext{
${ }^{346}$ Erre a kártérítési igényérvényesítési határidőből is lehet következtetni, lásd lent.

${ }^{347}$ Lásd: BGB $§ 480$ (1).

${ }^{348}$ Az ABGB szövegében ez az igény nem jelent meg konkrétan.

${ }^{349}$ SZLADITS (1906), 305. p.

${ }^{350}$ SZLADITS (1906), 315. p.

${ }^{351}$ SZLADITS (1906), 315. p.
} 
tett különbséget. A differenciát a dolog jellege alapján alakították ki, csakúgy, mint az ABGB-ben:

„Der Anspruch auf Wandelung oder auf Minderung sowie der Anspruch auf Schadenersatz wegen Mangels einer zugesicherten Eigenschaft verjährt [...] bei beweglichen Sachen in sechs Monaten von der Ablieferung, bei Grundstücken in einem Jahre von der Übergabe an. Die Verjährungsfrist kann durch Vertrag verlängert werden." 352

Ingó dolgok esetén tehát pusztán hat hónap állt a jogosult rendelkezésére bármilyen szavatossági jog és az objektív jogalapú, a megígért tulajdonságok hibája miatti kártérítés érvényesítésére is. A rövid határidők indokolása - az ókori római határidőkével egyezően az volt, hogy az idő múlásával a kellékhibák megállapítása és bizonyítása nehéz. ${ }^{353}$ Ezek a határidők azonban - az ABGB-vel ellentétben - eljárási (elévülési) jellegűek voltak, azaz csak a kereseti jog elévüléséhez vezettek, maga az igény nem enyészett el. ${ }^{354} \mathrm{Ez}$ a gyakorlatban azt is jelentette, hogy ha az elállást vagy vételárcsökkentést egy szerződés keretében foganatosították a felek, az egyfajta novációnak minősült, és attól kezdve a rendes, 30 éves keresetelévülési határidők érvényesültek. ${ }^{355}$ A felek a szerződésben hosszabb igényérvényesítési határidőben is megállapodhattak, azaz diszpozitív volt a szabályozás e tekintetben is. A BGB kifejezett rendelkezése hiányában a jogtudomány a fajlagos vételnél alkalmazható kicserélési igényre is irányadónak tekintette a fenti határidőket. ${ }^{356}$ A szubjektív jogalapú, csalárd eladói magatartás esetén fennálló kártérítés érvényesítési határideje - eltérő rendelkezés hiányában - a rendes, 30 éves elévülési idő volt.

Az elévülés ingó dolgok esetén az áru „leszállításával” (Ablieferung) vette kezdetét, amely a gyakorlatban azt az időpontot jelentette, amikor a vevőnek lehetősége nyílt megvizsgálni az áru esetleges hibáit. ${ }^{357}$

Az igényérvényesítés módjáról a BGB úgy rendelkezett, hogy az elállás és a vételárcsökkentés akkor joghatályos, ha az eladó a vevő kérésére beleegyező nyilatkozatát adta. ${ }^{358}$ Ez a jogalkotók szándéka szerint azt jelentette, hogy a vevőnek a törvény alapján pusztán arra keletkezett joga, hogy követelje ezen igények valamelyikének teljesítéséhez

\footnotetext{
352 BGB $\S 477$.

353 „,...die Feststellung, daß ein Mangel bestand, schwierig und unsicher wird.” lásd: ECK (1903), 455. p.

${ }^{354}$ Lásd: ECK (1903), 456. p.

${ }^{355}$ Lásd: ECK (1903), 456. p.

${ }^{356}$ Lásd: SZLADITS (1906), 320. p.

${ }^{357}$ ECK (1903), 456. p.

${ }^{358}$ Lásd: BGB § 465: „Die Wandelung oder die Minderung ist vollzogen, wenn sich der Verkäufer auf Verlangen des Käufers mit ihr einverstanden erklärt. ”.
} 
az eladó hozzájárulását; a jogirodalomban azonban vitatták e megszorító értelmezést. ${ }^{359}$ A jogtudósok szerint a vevőnek a választott jogát visszavonhatatlan nyilatkozatban kellett közölnie az eladóval, ${ }^{360}$ és úgy vélték, hogy a nyilatkozat megtétele után már nem térhet át másik szavatossági jogra. ${ }^{361}$

Amennyiben a vevő a hibával kapcsolatos kifogását még az elévülési határidőn belül bejelentette az eladónak, akkor kifogásként akkor is érvényesíthette szavatossági igényeit, ha a határidő egyébként már lejárt. Ez a szabály is jelzi a határidők elévülési jellegét. ${ }^{362}$

\subsection{Allatszavatosság}

A BGB eredeti szövege az ABGB-hez hasonlóan az állatok adásvétele esetére speciális szabályokat tartalmazott annak érdekében, hogy ezen ingók speciális (kóros) hibáira, betegségeire és azok bizonyítására nézve elejét vegye a jogbizonytalanságnak. ${ }^{363} \mathrm{~A}$ szabályokat meghatározott tenyésztett állatok: ló, szamár, öszvér, szarvasmarha, juh és sertés adásvétele esetén, külön rendeletben meghatározott föhibák (Hauptmängel) felmerülésekor lehetett alkalmazni meghatározott rövid (de meghosszabbítható), a veszélyátszállástól számított határidőkön belül. ${ }^{364} \mathrm{~A}$ határidőkön belül jelentkező hiba esetén fennállt a vélelem, hogy a hiba már a veszélyátálláskor fennállt. ${ }^{365} \mathrm{~A}$ vevő elállási jogot, illetve fajlagos vétel esetén kicserélési jogot is érvényesíthetett, ha a hibát és szavatossági igényét a határidő lejárta után, vagy az állat elhullása után legkésőbb két napon belül bejelentette az eladónak. ${ }^{366}$

\subsection{Elhatárolási kérdések}

Az aliud szolgáltatás, azaz ha az eladó a szerződésben kikötött egyedi dolog helyett teljesen mást szolgáltatott, jogilag nem minősült hibás teljesítésnek, hanem a nemteljesítés

\footnotetext{
${ }^{359}$ SZLADITS (1906), 316. p.

${ }^{360}$ Lásd: ECK (1903), 449. p., SzLADITS (1906), 316. p.

${ }^{361}$ Ezt szerintük a méltányosság követelménye indokolta, lásd: ECK (1903), 449. p.

${ }^{362}$ Lásd: BGB § 478 (1): „Hat der Käufer den Mangel dem Verkäufer angezeigt oder die Anzeige an ihn abgesendet, bevor der Anspruch auf Wandelung oder auf Minderung verjährt war, so kann er auch nach der Vollendung der Verjährung die Zahlung des Kaufpreises insoweit verweigern, als er auf Grund der Wandelung oder der Minderung dazu berechtigt sein würde.".

${ }^{363}$ Lásd: SZLADITS (1906), 322. p.

${ }^{364}$ Lásd: BGB $\S \S 481,482$. Ebben teljesen egyezett az osztrák megoldással.

${ }^{365}$ Lásd: BGB $\S \S 484,486$ és a 1899 . III/27. császári rendelet.

${ }^{366}$ Lásd: BGB $\S \S 485,487$. Árleszállítási igénye azonban ilyen esetekben nem volt.
} 
szabályai voltak alkalmazandóak. ${ }^{367}$ Fajlagos vétel esetén azonban lehetőség volt a kellékszavatossági szabályok alkalmazására, ${ }^{368}$ a ,középminőségü” áru követelményének értelmezéséből fakadóan akkor is, ha az eladó „silányabb fajú, de hibátlan dolgot szolgáltatott". 369

A vevőnek a dolog tulajdonságait illető és a dolog hibájában megnyilvánuló tévedése főszabály szerint akkor is kizárta az eladó szavatossági kötelezettségét, ha a vevő saját gondatlansága miatt nem tudott a hibákról, de ilyenkor tévedés miatti érvénytelenség címén megtámadhatta a szerződést. ${ }^{370}$

\section{A Svájci Államszövetség magánjogi kodifikációja}

A római jog és az abban gyökerező európai ius commune már a középkortól kezdve hatást gyakorolt Svájc jogtudományának és joggyakorlatának fejlődésére is. 1460-ban a svájci Basel városában is jogi kart alapítottak, és a XIII-XIV. században jelentős számú svájci hallgató tanult a Bolognai Egyetem jogi karán is. ${ }^{371}$ A többi európai egyetem tanrendjéhez hasonlóan a XV-XVI. században a svájci joghallgatók is a Digesta és a Codex Iustinianus joganyagát sajátították el az egyetemeiken. ${ }^{372}$

A svájci helyi jogok és a szokásjog területenként gyakran igen eltérő képet mutattak, azonban az itáliai hatásoknak köszönhetően az írott vagy szokásjogi szabályok alkalmazása és értelmezése területén a képzett jogászok ugyanazokat az elveket és jogi technikákat alkalmazták. ${ }^{373}$ Mivel a helyi szokásjogra jellemzőek volt a joghézag, azok kitöltésénél is jelentős szerepe volt az egyetemen tanított római jognak. ${ }^{374}$

Az 1848 óta alkotmányjogilag is szövetségi államként müködő Svájc kantonjainak joggyakorlata erősen eltérő képet mutatott, ugyanakkor egységesen felismerhető volt bennük a német szokásjog hatása a 19. században. ${ }^{375} \mathrm{Az}$ egyetemek jogi karain változatlanul a római jogot oktatták, a magánjogi kodifikációs folyamatokra pedig nagy hatást gyakoroltak a római jog erőteljes hatását magukon viselő európai magánjogi

\footnotetext{
${ }^{367}$ SZLADITS (1906), 309. p.

${ }^{368}$ SZLADITS (1906), 309. p.

${ }^{369}$ Lásd: SZLADITS (1906), 309. p.

${ }^{370}$ Vö. BGB § 119. és 121., lásd: SzLADITS (1906), 311. p.

${ }^{371}$ PICHONNAZ (2012), 27. p.

372 PICHONNAZ (2012), 28. p.

${ }^{373}$ HUBER (1893), 18. p.

${ }^{374}$ PICHONNAZ (2012), 28. p.

${ }^{375}$ BLUNTSCHLI (1855), 78. p.
} 
kodifikációk. ${ }^{376}$ Így Nyugat- és Dél-Svájc kantonjainak magánjogi törvényei meghatározóan a francia Code civil átdolgozásai, sokszor pedig fordításai voltak, míg például Bern, Luzern, Solothurn és Aargau magánjogi törvényeire az osztrák ABGB gyakorolt nagy hatást. ${ }^{377}$ Zürich kanton magánjogi kódexének elkészítésével Friedrich von Savigny egyik tanítványát, Johann Caspar Bluntschlit bízták meg, aki mesterének gondolkodásmódját képviselve a történeti jogi iskola és a pandektisztika elveit követte a kodifikáció során. Az elkészült törvénykönyv a pandekta-jog mellett a hagyományos zürichi jog és a modern kereskedelmi jog vonásait ötvözte, és ennek köszönhetően jelentős hatást gyakorolt Kelet- és Közép-Svájc kantonjainak magánjogi kodifikációs folyamataira is. 378

A kodifikációs folyamat végén a Svájci Államszövetség magánjogi kódexét, a Zivilgesetzbuch-ot ${ }^{379}$ 1907-ben fogadták el, és 1912. január 1-jén lépett hatályba. A törvénykönyvet az 1911-ben elfogadott, a kötelmi jogot magában foglaló résszel egészítették ki, amely azonban nem alkot szerkesztett egységet a ZGB-vel, így külön névvel is illetik. ${ }^{380}$

A svájci polgári jogi kódex és az OR is szerves terméke volt Svájc gazdasági és társadalmi körülményeinek. ${ }^{381}$ Bár a két svájci törvényt a BGB-vel egyezően a magánjogi jogegységesítés szükségessége hívta életre, a német jogtudósok közül is sokan a BGB „javított kiadásaként”, a „a XX. századi német nyelvü jogtudomány legérettebb gyümölcseként" értékelték. ${ }^{382}$ A hibás teljesítésre vonatkozó szabályainak kialakítására csakúgy, mint általában a magánjog fejlődésére kezdettől fogva nagy hatással voltak az egyes, római jogi gyökerekböl „táplálkozó” európai magánjogi kodifikációk - így az ABGB és a $\mathrm{BGB}$ is -, valamint az európai magánjogi hagyományok. A hibás teljesítés szabályai a közelmúltig egyáltalán nem is módosultak az OR-ben, ezért a rendelkezéseinek ismertetésére nem ehelyütt, hanem a második, hatályos jogösszehasonlító részben kerül sor. $^{383}$

\footnotetext{
${ }^{376}$ PICHONNAZ (2012), 32. p.

377 Lásd: PICHONNAZ (2012), 33. p.

378 Lásd: PiCHONNAZ (2012), 34. p.

379 A továbbiakban: ZGB.

${ }^{380}$ A kötelmi jogi rész szintén 1912. január 1-jén lépett hatályba Obligationenrecht néven, a továbbiakban: OR. Elérhetö: http://www.admin.ch/opc/de/classified-compilation/19110009/201401010000/220.pdf (2014. április 23.).

${ }^{381}$ KECSKÉS (2009), 404. p.

382 Lásd: WIACKER (1967), 491. p.

${ }^{383}$ Lásd: II. rész 2 . fejezet.
} 


\section{Összefoglalás}

Az ABGB és a BGB szabályozási koncepciója eltérően közelítette meg a kellékhibás teljesítést: az előbbi minden szerződésre kiterjedő hatállyal, az utóbbi azonban csak az adásvételi szerződésre vonatkozóan alakította ki a rendelkezéseket. Ebből és a kodifikátorok átfogó koncepciójából is fakad az, hogy míg az osztrák törvény meglehetősen absztraktan fogalmaz, a BGB alkotói igyekeztek minden, az adásvétel kellékhibás teljesítése kapcsán potenciálisan felmerülő részletkérdést - a pandekta hagyományoknak megfelelően - rendezni.

Az ABGB szükszavú szabályozása miatt a jogtudományban és a joggyakorlatban is vitatott volt a hibás teljesítés miatti kártérítés jogalapja, nem érvényesült a vevő (jogosult) római jogból is ismert árleszállítási igénye, valamint az igények közötti választási joga. Ezen kívül vitatott volt az igényérvényesítési határidők jogi jellege is.

A BGB a pandektisták munkája nyomán letisztult római jogi megoldásokat vezette be az adásvétel kellékhibás teljesítésének részletes szabályozásában. Az aediliszi kellékszavatossági igényeken kívül fajlagos vétel esetén biztosította a vevőnek a kicserélés jogát, és egyértelmüen utalt a kártérítés jogalapjára is. A két kódex hasonlóan szabályozta viszont a nagy gazdasági jelentőséggel bíró állatok adásvétele esetén fennálló kellékszavatosság kérdését. A következő fejezet igyekszik rámutatni arra, hogy a fenti két magánjogi kódex kellékhibás teljesítésre vonatkozó rendelkezései hogyan jelentek meg a XIX-XX. századi magyar jogéletben. 


\section{A HIBÁS TELJESÍTÉS A MAGYAR MAGÁNJOGBAN A REFORMKORTÓL A POLGÁRI TÖRVÉNYKÖNYV MEGALKOTÁSÁIG}

\section{Bevezetés}

A jogszavatosság, azaz a dolog elperlése esetén fennálló eladói helytállás intézménye korán megjelent jogrendszerünkben az örökbevallás szabályai között, ${ }^{384}$ de a kellékhibákért való helytállás szabályai nem kaptak olyan nagy hangsúlyt a hazai jogban az Osztrák Polgári Törvénykönyv ${ }^{385}$ magyarországi hatályba lépéséig. A rendi korban, sőt már az Árpád-korban is előfordultak azonban olyan jogesetek, amelyekben a jogi probléma az adásvétel tárgyának valamely minőségi fogyatékosságából, materiális hibájából adódott. ${ }^{386} \mathrm{~A}$ nemesi ingatlanok tulajdonjogának átruházását, az örökbevallást egy hiteles személy vagy hiteles hely előtt kellett lefolytatni. ${ }^{387}$ A kellékhibák jelentőségét mutatja, hogy a hiteles személy „minden jogilag releváns körülményt megvizsgálhatott” ingatlan eladása esetén, többek között a föld minőségét is. ${ }^{388}$ Az adásvétel tárgyának esetleges materiális hibája sohasem volt közömbös, de a gazdasági- és a tulajdonviszonyok szempontjából kiemelten jelentős jogszavatosság intézményének jogi szabályozása valószínüleg nagyobb hangsúlyt kapott.

Ez a fejezet a XIX-XX. századi magyar jogéletben a kellékhibás teljesítéssel összefüggő fejleményeket követi nyomon. Célja, hogy rávilágítson arra, hogy az előző fejezetben bemutatott kódexek szabályainak - közvetett vagy közvetlen - hatása illetve mintája mely kérdésekben mutatkozik meg a magyar jogfejlődésben.

\section{A kellékhibás teljesítés a reformkori hazai magánjogban és a jogirodalomban}

Az osztrák magánjog a történelmünk összefonódásának és a hazai tanult jogászoknak köszönhetően a XIX. században meghatározóan hatott magánjogunkra. ${ }^{389}$ Szladits Károly

\footnotetext{
${ }^{384}$ Szavatosság vállalása esetén, „ha a megvásárolt birtokra vonatkozóan a szerző ellen bárki pert indított és ezzel alperesi pozícióba került”, az alperes szerző oldalán köteles volt az eladó „,perbe lépni, minden tőle telhető segítséget megadni, hogy perét megnyerhesse"., lásd: HOMOKI NAGY (2005), 98. p. hivatkozása Werbőczy István: Hármaskönyv címü jogtörténeti jelentőségű munkájára (I., 74-75.).

385 Bár hazánkban ebben a korban az Optk. illetve Opt. rövidítést használták, az egységes megjelölés érdekében a teljes dolgozatban az ABGB rövidítést alkalmazom.

${ }^{386}$ Például amikor egy vevő az általa vett ló hibája, betegsége miatt perelte be az eladót, Váradi Regestrum 168. e. (Kandra 290. 1.), lásd: ILLÉS (1901), 293. és 302. p.

${ }^{387}$ HOMOKI NAGY (2005), 93. p.

${ }^{388}$ ILLÉS (1901), 254. p.

${ }^{389}$ BOZÓKY (1891), 1. p.
} 
szerint az ABGB ,a legnagyobb befolyást volt hivatva gyakorolni hazai jogfejlődésünkre” a XIX. században létező európai magánjogi kódexek közül. ${ }^{390}$ 1853-ban rövid időre hatályba is lépett hazánkban, amelynek előfeltétele és közvetlen előzménye az adományi és ősiségi rendszer 1848-as megszüntetése volt; az ABGB szabályozása már a korlátlan elidegenítés és terhelés elvein nyugodott. ${ }^{391}$ A hatályba lépés következtében a szavatossági szabályok is alkalmazhatóvá váltak hazánkban. A vonatkozó rendelkezés szerint:

„... ha vki vmely dolgot másnak visszteher mellett enged át, szavatol arról, hogy az a világosan kikötött vagy arról rendszerint föltett tulajdonságokkal bir, és hogy az ügylet természetéhez v. a történt egyezkedéshez képest használható és alkalmazható." 392

A hazai jogfejlődés következő jelentős állomása az volt, hogy az 1861-ben összeült, Apponyi György országbíró vezette Országbírói Értekezlet megalkotta az Ideiglenes Törvénykezési Szabályokat. ${ }^{393}$ Az Országbírói Értekezlet az ABGB-t nagy részben hatályon kívül helyezte (ami a szavatossági szabályokat is érintette), egyes régebbi magyar törvények hatályát visszaállította, és új intézkedéseket is bevezetett. ${ }^{394}$ Ez a magánjogi szabályok koherens rendszerét nélkülöző helyzet a jogbiztonság követelményének - „a szabályok rendszertelen sokasága" miatt - egyáltalán nem felelt meg. ${ }^{395}$ Sok helyütt a bírói gyakorlat által is betöltetlen joghézagok tátongtak, ami különösen igaz volt a kötelmi jogra. ${ }^{396}$ A kodifikáció szükségességét a kötelmi jog vonatkozásában jól tükrözi Biermann Mihály véleménye:

„... a forgalomnak csak bizonyos pontosan elhatárolt területet szabályozó kereskedelmi és váltótörvénytől eltekintve, nem létezik magyar kötelmi jog; a kötelmek tág mezeje eddigelé gazzal és bozóttal sürün ellepett vadon, melyben utakat vagy utjelzőket hiába keresnénk. [...] Ily kényszerhelyzetben ki-ki más expedienshez fordul: az egyik az osztrák polgári törvénykönyv, a másik a szász codex nyomdokain törekszik elöre hatolni, a harmadik a Gemeines Recht-ben, a negyedik a kereskedelmi törvényben keres útmutatást és ha mindez cserben hagyja, a maga egyéni belátása után indul. Igen természetes, hogy ily körülmények között útjaik iránya és végpontjai is vajmi ritkán esnek össze."397

\footnotetext{
${ }^{390}$ Lásd: GINYOVSZKY (1932), 3. p.

${ }^{391}$ GINYOVSZKY (1932), 20. p.

${ }^{392}$ ABGB § 922, MÁRKUS (1907.), 342-343. p., lásd: II. fejezet 1.2. pont.

${ }^{393}$ Lásd: BÓNIS (2011), 3. p.

${ }^{394}$ GINYOVSZKY (1932), 25. p

395 Indokolás Magyarország magánjogi törvénykönyvének a m. kir. igazságügyminiszter által 1928. március 1-én az országgyülés elé terjesztett törvényjavaslatához. I. kötet (A M. Kir. Igazságügyminisztérium, Budapest, 1929.), 5. p. A továbbiakban: Mtj. indokolás.

${ }^{396}$ BÓNIS (2011), 3. p.; Mtj. indokolás. 5. p.

${ }^{397}$ Lásd: BIERMANN (1884.), 1-2. p.
} 
$\mathrm{Az}$ ideiglenes törvénykezési szabályok ugyan sohasem léptek hatályba, de a joggyüjteményt mégis, közvetlenül és közvetve is, alkalmazni kezdték a gyakorlatban. ${ }^{398}$ Emellett azonban továbbra is nagy hatással volt magánjogunk fejlődésére az ABGB is. Ez annak köszönhető, hogy az 1848-as törvényhozás a korábbi magyar magánjog centrális intézményeinek nagy részét eltörölte, és a különösen a jogéletben egyre nagyobb jelentőségü kötelmi jog korábbi szabályai elavultakká váltak, amelyek a megváltozott gazdasági élet követelményeinek már nem feleltek meg. ${ }^{399}$ A jogalkalmazásban, a kereskedelmi gyakorlatban és a jogtudományban is nagy tekintéllyel bírtak az ABGB szabályai. $^{400}$

Az adásvétel korabeli szabályairól tudósít 1865-ben írt művében Kallós Lajos. ${ }^{401} \mathrm{~A}$ jogtudós az „eladási felelősség” kérdéskörében tárgyalja a csalás és a hibás teljesítés összefüggéseit. Úgy véli, hogy csalás állapítható meg többek között akkor, ha a vétel tárgyának tulajdonságait illetően kétértelmüen fogalmaz az eladó, illetve ha valamely tulajdonságot elhallgat. ${ }^{402}$ A hibás teljesítésért fennálló helytállás objektív jellegét jelzi, hogy Kallós arra utal, hogy az eladó a tudattartalmától függetlenül kicserélni tartozik például az arany müként eladott rézmüvet, illetve a hibás mű visszaadása ellenében vissza kell térítenie a vételárat. ${ }^{403}$ Különbséget tesz azonban a tudva hibásan eladott dolgokért való helytállás vonatkozásában, mivel ez esetben az eladó terhére rója a hiba folytán bekövetkezett összes kár megtérítését is. ${ }^{404}$ Kiemeli azonban, hogy ha az eladó az ajánlat és a dolog kelendőségének fokozása érdekében „rendes tulajdonságokat” közöl a vevővel, akkor azokért nem kell helytállnia. ${ }^{405}$ Ellenben ha valamilyen speciális jellemzőt nevez meg, így például azt, hogy a ló lovaglásra be van tanítva, és utóbb kiderül, hogy az adott tulajdonság mégsem áll fenn, akkor az eladó köteles azt a vételárkülönbözetet visszafizetni, amely a fizetett vételár és a tényleges érték között fennáll. ${ }^{406}$

A Kiegyezés után a jogtudósok szinte kivétel nélkül tárgyalták tudományos müveikben és tankönyveikben a kellékhibás teljesítés kérdéskörét. Figyelemre méltó, hogy

\footnotetext{
398 GINYOVSZKY (1932), 26. p.

${ }^{399}$ GINYOVSZKY (1932), 33. p.

${ }^{400}$ SZLADITS (1906), 336. p.

${ }^{401}$ Lásd: KALLÓS (1865), 673-725. p.

${ }^{402}$ Lásd: KALLÓS (1865), 677. p. Az utóbbira példa, ha a vevő konkrétan kérdezi a barom természete felől, és az eladó elhallgatja, hogy az makacs stb.

${ }^{403}$ KALLÓs (1865), 679. p.

${ }^{404}$ Lásd: KALLÓS (1865), 679. p. Ha például az eladó tudva hibás épületfákat adott el, aminek következtében az épület összeomlott, akkor az eladó terhére rója az épület újra-felépítésének a költségeit; ha pedig „ragályos” barmokat adott el, akkor mindazt a kárt is megtérítendőnek ítéli, amely abból ered, hogy a ragály átterjedt már barmokra is, amelyek azután elpusztultak.

${ }^{405}$ KALLÓS (1865), 679. p.

${ }^{406}$ KALLÓS (1865), 680. p.
} 
a kellékhibákért való helytállás még nem különült el élesen a jogszavatosságtól: ${ }^{407}$ a „szavatosság” címszó alatt a jog- és kellékszavatosságot egyaránt értették. Ezt példázza a következő, 1869-es idézet is:

„Szavatosság alatt értetik a jótállás a szerződéseknél a szerződés tárgyának hibáiért, vagy a tárgy kikötött tulajdonságának hiányaiért, végre egy harmadik által támasztható igények folytán a szerződő felekre hárulható sérelem következményeiért." ${ }^{, 408}$

Suhayda János meghatározása szerint a forgalom biztonsága iránti igény által életre hívott szavatosság - az ABGB nyomán - minden visszterhes szerződésből eredő helytállási kötelezettség volt, akár kikötötték a felek, akár nem. ${ }^{409}$ Kérdés, hogy ki lehetett-e zárni. A kellékszavatosság $^{410}$ az átadott dolog rejtett fizikai hibája, illetve az átadó fél által kijelentett tulajdonságok hiánya esetén állt fenn. ${ }^{411} \mathrm{Az}$ átadó helytállással tartozott mindezért, „különbség nélkül akár tudta, akár nem a dolognak rejtett hibáit, vagy a kikötött tulajdonság hiányát". ${ }^{412}$ Ez azt jelenti, hogy objektív jogalapú volt az átadó helytállási kötelezettsége.

A hiba „rejtett” volta a „közönséges vigyázat” melletti észrevehetetlenségét jelentette, ezért ha „az átvevő a szerződés megkötésekor, vagy a kimérés, kiválasztás alkalmával, vagy a föltétel teljesülésekor a hibát ismerte, vagy mint szakértőnek ismernie kellett", a dolog átadója nem tartozott szavatossági helytállással. ${ }^{413}$

A dolog átvevője kellékhiba esetén a római jogból már ismert aedilisi jogokkal élhetett, amelyek a német pandekta hagyományokban és az áruforgalmi gyakorlatban gyökereztek, és valószínüleg ezek közvetítésével kerültek át a magyar jogászképzésbe és a jogirodalomba; ehhez járult, hogy az ABGB is rendelkezett e jogokról. ${ }^{414}$ Suhayda úgy fogalmazott, hogy a vevő a szerződés megszüntetését kérhette, amelynek a jogkövetkezménye megegyezett az elálláséval, azaz az eredeti, szerződés megkötése előtti állapotot kellett helyreállítani (in integrum restitutio). ${ }^{415} \mathrm{Az}$ árleszállítás jogának

\footnotetext{
407 Az elkülönítés a kodifikációs folyamat megindulásával kristályosodott ki a XIX. és XX. század fordulóján, lásd: HOMOKI NAGY (2008), 109. p.

${ }^{408}$ SUHAYDA (1869), 259. p.

${ }^{409}$ SUHAYDA (1869), 259. p.

${ }^{410}$ Zsögöd Benő „Fejezetek kötelmi jogunk köréből” címü művében szerepelt először ez a kifejezés, lásd: ZSÖGÖD (1900), 1232. p. Vö.: NAGY (1913), 219. p. és RAFFAY (1909), 313. p.

${ }^{411}$ SUHAYDA (1869), 260. p.

${ }^{412}$ Lásd: SUHAYDA (1869), 260. p.

413 SuHAYDA (1869), 260. p. Erre a Curia is rámutatott egyik későbbi ítéletében, lásd: Jogtudományi Közlöny, 1888. 23. évfolyam 7. szám (február 17.), melléklet: Curiai Határozatok, 43. p., 1887. deczember 7., 917. sz. a. curiai határozat.

${ }^{414}$ Vö. ABGB $§ 932$.

${ }^{415}$ SUHAYDA (1869), 260-261. p.
} 
gyakorlása esetén a kikötött ár és a hibás áru értékének különbözete járt vissza a vevőnek, ${ }^{416}$ azaz az ún. abszolút számítási módszert alkalmazták. Emellett bármelyik jog választása esetén a vevő kártérítési igényét is érvényesíthette, amennyiben az eladó rosszhiszemü volt. ${ }^{417}$

\section{Kellékszavatosság az 1875-ös Kereskedelmi törvényben és a korabeli jogtudományban}

A bírói gyakorlat az 1861-es ideiglenes törvénykezési szabályok megalkotása és az ABGB hatályon kívül helyezése után is többnyire az osztrák kódex rendelkezéseit követte a kellékszavatossági ügyekben. ${ }^{418}$ Egyre nagyobb igény mutatkozott azonban a hazai jogalkotásban is a kellékszavatosság szabályozására, ezért az 1862. évi német általános kereskedelmi törvény alapulvételével ${ }^{419}$ megalkotott magyar Kereskedelmi törvény, az 1875. évi XXXVII. törvénycikk ${ }^{420}$ megszövegezésekor az is vezérelte a jogalkotót, hogy a kereskedelmi vétel szabályai között a kellékszavatosságot adekvát, a jogalkalmazást segítő módon szabályozza. ${ }^{421}$ A Kt. a kereskedelmi ügyletek egyik típusaként definiálta az ún. kereskedelmi vételt: ${ }^{422}$

„,Kereskedelmi ügyletnek tekintendők: 1. áruk, s általában ingó dolgok vétele [...] azon szándékkal, hogy azok természetben, át- vagy feldolgozva ismét tovább adassanak...",423

Az áru fogalma alól a Kt. kivette az ingatlanokat, és csak az olyan ingó dolgot tekintette árunak, amely ,a vételnek és a továbbadásnak rendszerinti tárgya. Itt is azonban szükséges, hogy a dolog a termelőtől a fogyasztóhoz jutás állapotában legyen. (A termelőnél még nem, a fogyasztónál már nem áru.) "424 A Kt. szabályai 1876. január 1-jén léptek hatályba, és a bírói gyakorlatban fokozatosan kiszorították az ABGB alkalmazását

\footnotetext{
${ }^{416}$ SUHAYDA (1869), 261. p.

${ }^{417}$ SUHAYDA (1869), 262. p.

${ }^{418}$ SZLADITS (1906), 336. p.

${ }^{419}$ A német kereskedelmi törvényt az osztrák kereskedelmi törvény is csaknem teljes egészében átvette, lásd: GINYOVSZKY (1932), 34. p. A magyar kereskedelmi jog fejlődéséhez lásd: NAGY (1913), 21-28. p. és KuNCZ (1922), 17-18. p.

${ }^{420}$ A továbbiakban Kt., elérhető: http://www.1000ev.hu/index.php?a=3\&param=5692 (2013. augusztus 8.).

A törvény előkészítésével 1872-ben bízták meg Apáthy Istvánt.

${ }^{421}$ SZLADITS (1906), 336-337. p.

${ }^{422}$ Kt. 336-367. §§.

${ }^{423}$ Kt. 258 . $\S$.

${ }^{424}$ Lásd: KUNCZ (1922), 24. p.
} 
kellékszavatossági ügyekben. ${ }^{425}$ Sőt, idővel nem csak a kereskedők egymás közötti vételeinél érvényesültek, hanem akkor is, ha csak az egyik szerződő fél minősült kereskedőnek. ${ }^{426}$ Mivel az üzleti forgalomban gyakoriak voltak e szerződések és az ezekből eredő jogviták, a bíróságok analógiával elkezdték alkalmazni a Kt. szabályait a közpolgári ügyekben is. ${ }^{427}$

\subsection{Hibafogalom}

Az eladó a teljesítési kötelezettségének csak olyan áru szolgáltatásával tett eleget, amely a szerződésben kikötött vagy a törvényi kellékeknek megfelelt. ${ }^{428} \mathrm{Kt}$. a kereskedelmi vétel szabályai között így rendelkezett a kellékszavatosságról:

„Ha az áru a kikötött vagy törvényi kellékeknek meg nem felel, a vevönek jogában áll az ügylettöl elállani, vagy a vételár aránylagos leszállitását igényelni. E mellett mindegyik esetben a netaláni kár megtéritését is követelheti. "429

A kellékszavatossági szabályok mind az egyedi mind a fajlagos vételre vonatkoztak (337.§). Az eladó akkor tartozott szavatossági helytállással, ha az áru a szerződésileg kikötött vagy a törvényes kellékeknek nem felelt meg. A szerződéses kikötések sokfélék lehettek a gyakorlatban: pozitív tulajdonságok meglétét és negatív tulajdonságok hiányát is jelenthették. ${ }^{430}$ Egy bírói döntés például kimondta, hogy olyan szerződési nyilatkozatok alapozzák meg a szavatossági helytállást, amelyek „a fennforgó körülmények józan méltatása mellett, az élet felfogása szerint" a felek szerződéses céljának megfeleltek. ${ }^{431} \mathrm{Az}$ áru ajánlása, dicsérgetése, mint például az a kijelentés, hogy „a motor feltűnően kevés benzint fogyaszt”, nem kötelezte az eladót. ${ }^{432}$ Egy bírói döntés alapján szavatolt az eladó,

\footnotetext{
425 SZLADITS (1906), 337. p.

${ }^{426}$ SZLADITS (1906), 337. p.

${ }^{427}$ STIASSNY (1904), 287. p.; NAGY (1913), 224. p.; Lásd például: Curia I. G. 96/1901. (1901. márczius 28.) számú ítélet; GoTTL (1902), 452-459. p.

${ }^{428}$ NAGY (1913), 219. p.

${ }^{429}$ Kt. 348. §.

${ }^{430}$ NAGY (1913), 221. p. Az utóbbi kérdés és a rosszhiszemű eladói magatartás problematikájához lásd például: Curia I . G. 490/1904. (1905. január 25.) számú ítélet; GoTTL (1906), 204-207. p.

${ }^{431}$ Lásd: D4f. 1/88. számú döntés, SzLADITS (1906), 338. p.; KolosvÁry (1904), 118. p. Lásd még a D3f. 17/245. számú döntést, amelyben a bíróság megállapította, hogy ha az eladó kijelenti ajánlatában, hogy az árpa elöreláthatólag zsizsikes, akkor következtetni lehet, hogy az dohos, de az nem következik belöle, hogy rothadt, tehát ez utóbbiért helyt kell állnia; lásd: NAGY (1913), 221. p.

${ }^{432}$ Lásd: D3f. 26/79. számú ítélet, SzLADITS (1906), 338. p. Ez a római jogi felfogást tükrözi, vö. D. 18,1,43 pr.
} 
ha „,egy adott festő névjegyével ellátott képet ilyenként adott el és a valódiságért jótállást is vállalt, ennek ellenére a festmény nem volt valódi”. 433

A törvényes kellék azt jelentette, hogy az árunak ,a rendszerint feltett tulajdonságokkal kellett rendelkeznie", és hogy nem szenvedhetett olyan hibában, amely a „természetszerü, közönséges használhatóságát” kizárta vagy lényegesen korlátozta. ${ }^{434}$ Külön kikötés nélkül is megállapította a bíróság az eladó szavatossági helytállását azért, hogy a vetési célra eladott árpamag őszi és tavaszi árpa keveréke. ${ }^{435}$ A kevert árpamag ugyanis vetési célra nem volt alkalmas. Ebben az esetben az eladó árumegjelölését (vetési árpa) hallgatólagos jótállásként értékelték azért, hogy a mag csíraképes, azaz alkalmas a szerződési célra. Ugyanígy annak, aki „gőbölyt”, azaz emberi fogyasztásra alkalmas marhát adott el, szavatolnia kellett azért, hogy a hús fogyasztásra alkalmas. ${ }^{436}$

Törvényes kelléket határozott meg a Kt. is fajlagos szolgáltatás esetére: „ha a szerződésben az áru faja és minősége iránt közelebbi meghatározás nem foglaltatik, az adós középfaju és minöségü árut tartozik szolgáltatni”, 437

Nem alapozta meg azonban a kellékszavatosságot a lényegtelen hiba, amely az áru vételárára nem hatott ki. ${ }^{438}$ Ugyanígy nem képezte a szavatossági helytállás alapját a „múlékony hiány” sem. ${ }^{439} \mathrm{Az}$ áru mennyiségi hiánya csak abban az esetben jelentett kellékhibát, ha „egy határozott súly az árúnak rendeltetése szerint használati értékére, kelendőségére lényeges befolyással van és az árú minőségének meghatározásánál tekintetbe veendő, például a búzánál a hektoliterenkénti súly egyszersmind minőségi kellék". 440 Nem állt fenn szavatosság a gyakorlat szerint az átalány-vétel és a bírói árverésen kötött vétel esetén sem. ${ }^{441}$

A joggyakorlat kizárta a kellékszavatosságot akkor is, ha a vétel alkalmával a vevő a dolgot megtekintette, és a hiba „kellő, rendszerinti gondosság [„,közönséges figyelem”] mellett felismerhető volt". ${ }^{442}$ A kellő gondosság fogalmába azonban nem tartozott bele az

\footnotetext{
${ }^{433}$ Lásd: 1886. január 26. 6222. számú curiai határozat, ZLINSZKY (1899), 650. p. Bár dogmatikailag nem különítették még el, de az egyes szerződéses kikötéseket gyakran önként vállalt jótállásként értékelték a jogtudományban.

${ }_{434}$ SzLADITS (1906), 339. p. Így rendelkezett az ABGB (§ 923), majd a BGB (§ 459) is.

${ }^{435}$ Lásd: SZLADITS (1906), 339-340. p.

${ }^{436}$ SZLADITS (1906), 340. p.

${ }^{437}$ Kt. 321. §.

${ }^{438}$ Lásd: D3f. 26/79. számú döntés, SzLADITS (1906), 341. p.; 866/1889., 7157/1890., 3672/1891. számú curiai határozatok, RAFFAY (1909), 315. p.; 1897. október 29. 463. sz. a., 1895 deczember 18. 1367/94 sz. a. curiai határozatok, lásd: KOLOSVÁRY (1904), 120-121. p.

${ }^{439}$ SzLADITS (1906), 341. p.

${ }^{440}$ Lásd: D3f. 5/339. számú döntés, NAGY (1913), 222. p.

${ }^{441}$ Lásd: Duf. 35/76. számú döntés, SzLADITS (1906), 341-342. p.

${ }^{442}$ Lásd: D3f. 25/140. és Duf. 9/19. számú döntések, SZLADITS (1906), 344. p.
} 
áru különleges szakértelmet igénylő vizsgálata. ${ }^{443}$ Erre példa az az eset, amelyben a megtekintés alapján rumburgi cérnavászonként vett áruról kiderült, hogy az szakértő által is nehezen felismerhető pamutvászon volt. ${ }^{444}$ Nyilvánvalóan nem tartozott szavatossággal az eladó akkor sem, ha a vevő a tudottan hibás árut jogfenntartás nélkül, teljesítésként átvette. $^{445}$

A legtöbb szerző rendszertanilag a visszterhes szerződésekből folyó kötelezettségként említi, de az adásvétel szabályai között tárgyalja a kellékszavatosságot. Zlinszky Imre a XIX. század legvégén így határozta meg annak fogalmát:

„... ha az átruházott dolog a kikötött, vagy a dolog természete szerint követelhető kellékekkel nem bír; vagy ha az oly hiányban szenved, melyektől való mentessége határozottan ki volt kötve; vagy ha az oly hiányok elhallgattattak, melyekröl önként érthetőleg feltételeztetik, hogy a dolog azoktól ment."446

A kellékszavatosságnak a szerződésszegés általában szubjektív jogalapú következményei alóli kivételes jellegét jól demonstrálja Raffay Ferenc megállapítása a XX. század legelején:

„Nem-teljesítés vagy nem-kellő teljesítés esetén az adós menekül exculpatio által, vagyis ha igazolja, hogy öt mulasztás nem terheli. Ha azonban a vagyontárgy visszterhes átruházásáról van szó [...], meg fennáll a szavatosság, mely alól exculpatioval menekülni nem lehet, mert ez nem a teljesítés körüli gondosságra vonatkozik, hanem az áru kellékszerüségére.”447

\subsection{Kellékszavatossági jogok}

A törvény alapvetően az elállás és a vételárcsökkentés igényeit és a közülük való szabad választás jogát biztosította a vevőnek az eladó hibás teljesítése esetére, ${ }^{448}$ tekintet nélkül arra, hogy a vevő ,szerződési érdeke a kettő közül melyikre irányult”. ${ }^{449}$ A bíróságok a Kt. e rendelkezését is kiterjesztették a köztörvényi vétel eseteire is, de a joggyakorlatban

\footnotetext{
${ }^{443}$ Lásd: D3f. 22/80; NAGY (1913), 222. p.

${ }^{444}$ Lásd: D3f. 24/43. számú döntés, SZLADITS (1906), 344. p.

${ }^{445}$ Lásd: 3365/1902. számú curiai határozat, lásd: RAFFAY (1909), 315. p.

${ }^{446}$ ZLINSZKY (1899), 650. p.

${ }^{447}$ RAFFAY (1909), 309. p. 2. lj.

448 Lásd fent: Kt. 348. §. A jogirodalomban adekvát magyar jogi terminológia helyett még gyakran használták a római jogi elnevezéseket a jogkövetkezményeket illetően, így az elállást redhibitióként, az árleszállítást pedig quanti minorisként említették; lásd például: ZLINSZKY (1899), 654. p.; KATONA (1904), 147. p.

${ }^{449}$ NAGY (1913), 227. p. Ez a megoldás a pandekta hagyományt tükrözi.
} 
következetesen kizárták az elállási jog alkalmazhatóságát a „múlékony hiba” esetén. ${ }^{450} \mathrm{~A}$ vevő ezek mellett kártérítést is követelhetett (Kt. 348. §). ${ }^{451}$

\subsubsection{Elállás}

Az elállás jogát a Kt. rendelkezései alapján a vevő elméletben bármilyen jellegü hiba és érdeksérelem esetén érvényesíthette. Ezt az elvet a joggyakorlat is messzemenőkig követte. Így például bírói döntés mondta ki, hogy ,a vevő nem volt köteles türni, hogy a felperes az illető árut, amely az átadáskor a törvényi vagy kikötött kellékeknek meg nem felelt, az emiatt történt rendelkezésre bocsátás után helyezze olyan állapotba". ${ }^{452}$ A jogirodalomban azonban ezzel ellentétes álláspontok is megfogalmazódtak. Szladits például úgy vélte, hogy a Kt. célja az absztrakt szabállyal csupán az volt, hogy a vevőt felmentse annak bizonyítási terhe alól, hogy az elálláshoz milyen érdeke füződik. De szerinte ez nem vezethet oda a gyakorlatban, hogy a vevő az elállási jogát ,ürügyül használja fel a szerződés alóli kibúvásra”, különösen, ha az eladó bizonyítani tudja, hogy nem éri a vevőt érdeksérelem a szerződés fenntartása esetén. ${ }^{453}$ Erre is figyelemmel vélte úgy Szladits, hogy a köztörvényi adásvételek esetén a megfelelő időben foganatosított eladói hiánypótlás az elállás jogának gyakorlását kizárja. ${ }^{454}$

Az elállás jogkövetkezménye az eredeti állapot helyreállítása volt. Egy bírói döntés szerint „mindkét fél visszaadni köteles mindazt, ami a hatályát vesztett szerződés alapján kezéhez jutott”" ${ }^{455}$ Egyéb, a szerződéses viszonyból eredő költségek visszatérítése is a felek kötelezettségei közé tartozott az eredeti állapot helyreállításának keretei között. ${ }^{456}$ Ezt Szladits azzal indokolta, hogy bár az eladó vétlen is lehetett a hibás dolog szolgáltatását illetően, a vevő még nála is kiszolgáltatottabb helyzetben van, ezért méltányos, ha a szerződés megkötésével kapcsolatos egyéb költségeket is megtéríti az eladó a vevőnek az elállás keretei között. ${ }^{457}$ Ennek megfelelően a vevőt megillette a kifizetett vételár annak kamataival együtt, a szerződéskötési költségek, így a levelezés, fuvar, küldöncdíjak, vizsgálati költség, bírói szemle költsége ${ }^{458}$ és a dolog fenntartásának a költsége is. ${ }^{459}$

\footnotetext{
${ }^{450}$ Lásd: SZLADITS (1906), 350. p.

${ }^{451}$ Lásd: Curia I. G. 96/1901. 1901. márczius 28. számú ítélet; GotTL (1902), 452-459. p.

${ }^{452}$ Lásd: Duf. 31/46. számú döntés, SzLADITS (1906), 373. p.

${ }^{453}$ SZLADITS (1906), 374. p.

${ }^{454}$ SZLADITS (1906), 374. p.

455 Lásd: D3f. 18/50. számú döntés, SzLADITS (1906), 367. p.

${ }^{456}$ SZLADITS (1906), 367. p.

${ }^{457}$ SZLADITS (1906), 367. p.

${ }^{458}$ Lásd: Drf. 21/60., Duf. 20/28. számú döntések, SZLADITS (1906), 368. p.
} 
A vevő kötelezettsége az volt, hogy visszaadja a dolgot és a dolog időközben keletkezett hasznait is. ${ }^{460}$ Szladits felvetette a mortuus redhibetur, azaz az elpusztult, megsemmisült dologgal kapcsolatos elállás problematikáját, amelyről tudósítása szerint nem állt rendelkezésre meghatározó bírósági döntés a XX. század elejéig. ${ }^{461}$ A jogi probléma a mortuus redhibetur esetén az, hogy a kárveszély átszállt a vevőre a dolog átvételével, ezért annak vétlen pusztulása is öt terhelné. Kivételt képez azonban az, ha a pusztulás a kellékhiba következményeként állt be. A nehézséget a hiba fennállásának és az okozati összefüggésnek a bizonyítása jelentette. ${ }^{462}$ A vevő érdekeit szem előtt tartó római jogi és az annak mintájára kidolgozott német BGB-beli szabályokból, valamint az elállás céljából arra következtetett Szladits, hogy a vevő a dolog vétlen vagy véletlen megsemmisülése esetén is visszakövetelheti a teljes vételárat. ${ }^{463}$ Azonban ha maga a vevő okozta a megsemmisülést, vagy a hibás dolgot „lényegesen átalakította” (például a hibás téglát beépítette vagy a rossz kukoricát összekeverte a saját, már meglévő kukoricájával), akkor nem gyakorolhatta az elállási jogot. ${ }^{464} \mathrm{Az}$ átalakítás esetén azonban Szladits szerint alkivétel volt az osztrák és német joggal egyezően, ha a hibára csak az átalakítás alkalmával derülhetett fény; ebben az esetben a vevő elállhatott a vételtől. ${ }^{465} \mathrm{~A}$ dolog puszta használata sem zárta ki az elállási jog gyakorlását. ${ }^{466}$

Ha az adásvételi szerződés egyszerre több különálló dologra irányult, amelyek közül csak egyes egyedek voltak kellékhibásak, akkor a bírói gyakorlat szerint még abban az esetben is csak a hibás dolgokra nézve gyakorolhatta a vevő az elállást, ha egységes vételárat fizetett a dolgokért, ${ }^{467}$ kivéve, ha bizonyította, hogy az áru egységes és nem megosztható. ${ }^{468} \mathrm{Az}$ áru egységes voltát a gyakorlat szerint a vétel kísérő körülményei alapján lehet megállapítani: egyes döntések az áru egységét állapították meg például egy pár hámos ló, egy pár ökör, két fekete ló egységes vételáron történő adásvétele esetén. ${ }^{469}$

\footnotetext{
459 Az utóbbihoz tartozott például az állat gyógykezelésének a költsége is az állat visszaadásáig, lásd: D3f. 10/349. számú döntés, SzLADITS (1906), 368. p.

${ }^{460}$ SZLADITS (1906), 368-369. p.

${ }^{461}$ SZLADITS (1906), 369. p.

${ }^{462}$ Lásd: ZIMMERMANN (1996), 330-334. p.

${ }^{463}$ SZLADITS (1906), 370. p.

${ }^{464}$ SZLADITS (1906), 370. p. Vö. BGB $§ \S 350$ és 467.

465 Lásd: SZLADITS (1906), 370. p. hivatkozása a német RG. 3/216. 1. számú döntésre.

${ }^{466}$ SZLADITS (1906), 370. p.

${ }^{467}$ Lásd: Drf. 27/43. számú döntés.

${ }^{468}$ Lásd: D4f. 2/131. számú döntés, SzLADITS (1906), 370. p. Mindez a BGB szabályait tükrözte, vö. BGB § 479.

${ }^{469}$ Lásd: D4f. 4/140. és Duf. 5/81. számú döntések, SZLADITS (1906), 372. p.
} 


\subsection{2. Árleszállitús}

A vevő az árleszállítás jogát ugyanúgy gyakorolhatta egyoldalú nyilatkozattal, mint az elállás jogát. ${ }^{470} \mathrm{~A} \mathrm{Kt}$. úgy rendelkezett, hogy az árleszállítás mértékének „, aránylagosnak” kell lennie. Szladits szerint olyan arányban kellett a vételárat csökkenteni, ahogyan a hibátlan dolog szerződéskötéskori valódi értéke a dolog tényleges értékéhez viszonyult, ${ }^{471}$ és erről tudósít Grosschmid Béni illetve Nagy Ferenc is. ${ }^{472}$ Szladits álláspontja szerint a több dolog összvételáron történt vétele esetére a német minta követendő, azaz ha a dolgok közül csak egyesek voltak hibásak, és a vételárcsökkentést a vevő csak ezekre nézve gyakorolta, akkor az árleszállításnál az összes dolog értékét kellett alapul venni. ${ }^{473}$

\subsubsection{Kártérítés}

A bírói gyakorlatban és a jogtudományban a legvitatottabb a szavatosság mellett esetlegesen felmerülő kártérítési igény volt. A Kt. szerint a vevő az elállás vagy a vételárcsökkentés érvényesítése mellett kártérítést is követelhetett. ${ }^{474}$ Bár a Kt. tömör szövegezéséből a kellékhiba miatti kártérítés objektív jogalapja látszik kitűnni, a jogirodalomban ez vitatott volt. ${ }^{475}$ Szladits a vevőnek okozott érdeksérelem tekintetében differenciált a szerződésileg kikötött kellékek és a törvényes kellékek rejtett hibája között. ${ }^{476} \mathrm{Az}$ elöbbi esetben úgy érvelt, hogy mivel az eladó saját magát kötelezi a szerződésben a dolognak bizonyos hiányoktól mentes szolgáltatására, illetve abban konkrét tulajdonságok fennállására, így ha e szerződéses kikötésekkel kapcsolatos kellékhiba lép fel, akkor a vevő kártérítési követelése esetén felróhatóságtól függetlenül kell helytállnia a vevő teljes ún. teljesítési érdekéért, és azért a kárét is, ami a hiba/hiány folytán őt éri. ${ }^{477} \mathrm{Az}$ egyéb, a hiba miatt beálló károkkal kapcsolatban egy bírói döntés kimondta, hogy ha az

\footnotetext{
${ }^{470}$ SzLADITS (1906), 372. p. Eltérő volt tehát a magyar bírói gyakorlat megítélése a BGB-től, amely az eladó hozzájárulását követelte meg, vö. BGB $§ 465$.

${ }^{471}$ Lásd: D3f. 25/140. számú döntés, SzladiTs (1906), 372. p. Lásd továbbá: Curia I. G. 259/1903. 1903. október 20.) számú ítélet; GOTTL (1904), 85-90. p. Vö. BGB § 472.

${ }^{472}$ Lásd: ZSÖGÖD (1900), 1036. p.; NAGY (1913), 226. p.: „ún relatív árleszállítás”.

473 SZLADITS (1906), 373. p. Vö. BGB § 472.

${ }^{474}$ Lásd: D. új f..40/171.; NAGY (1913), 227. p.

${ }^{475}$ SZLADITS (1906), 351. p.

${ }^{476}$ SZLADITS (1906), 352. p.

477 SzLADITS (1906), 352. p. Teljesítési érdeknek azt a szerződésből fakadó jogosulti érdeket tekintette, hogy a vevő megkapja mindazt, ami a szerződés alapján neki jár, az utóbbit pedig „megelőzési érdeknek” nevezte.
} 
eladó a búza üszökmentességéért jótállást vállalt, akkor köteles a mégis üszkös búza által okozott elmaradt haszon megtérítésére is. ${ }^{478}$

A rejtett törvényi - azaz szerződésileg külön ki nem kötött - kellékhiba esetén Szladits tovább differenciált a fajlagos és az egyedi vétel között. Fajlagos vétel esetén a Kt. szabályából kiindulva úgy vélte, hogy mivel a középminőségü áru szolgáltatásának a kötelezettsége magában foglalja a hibamentességet, ezért ha mégis kellékhibás az áru, akkor az eladó felróhatóságtól független kártérítési kötelezettséggel tartozik. ${ }^{479}$ Egyedi vétel esetén azonban szerinte az eladó kártérítési felelőssége a rejtett hibákért szubjektív, felróhatósági alapú volt. ${ }^{480}$ Grosschmid Béni épp ellenkezőleg, a Kt. fajlagos vételre vonatkozó szabályát kiterjesztve az egyedi vételre, helytállónak vélte az eladó objektív kártérítési helytállását. ${ }^{481}$

Egy bírói döntés a kártérítés mértékét illetően az ABGB szabályának alkalmazásáról tanúskodik. ${ }^{482}$ A bíróság itt a felróhatóság fokához igazította a kártérítés mértékét, így a vevő az elmaradt hasznot csak szándékos vagy súlyosan gondatlan eladói magatartás esetén követelhette, a felróhatóság enyhébb fokánál azonban csak a tényleges kárt kellett megtérítenie az eladónak. ${ }^{483}$

Az üzleti gyakorlatban az eladónak a fentieken kívül arra is lehetősége volt mind egyedileg mind fajlagosan meghatározott áru esetén, hogy az esetlegesen hibás dolog kijavítására vállaljon kötelezettséget. Gyakori lehetett az, hogy a gyáros vagy iparos az általa előállított dolog eladásakor jótállott érte egy bizonyos határidőn belül. ${ }^{484} \mathrm{Ez}$ rendszerint magában foglalta az e határidőn belül jelentkező hibák kijavításának a kötelezettségét is, függetlenül a hiba jelentőségétől és attól, hogy rejtett illetve már az átadáskor látható hibáról volt-e szó. ${ }^{485}$ A bírói gyakorlat alapján e ,jótállási nyilatkozatok”

\footnotetext{
${ }^{478}$ Lásd: Duf. 4/159. számú döntés. A római jogban a hibás gerenda eladásáról szóló jogeset is ezt a felfogást tükrözi, vö. D. 19,1,13 pr. Az elmaradt haszon kérdésével foglalkozik egy eladott gőzcséplőgéppel kapcsolatos curiai határozat is, lásd: Curia I. G. 96/1901. (1901. márczius 28.) számú ítélet; GoTTL (1902), 453. p.

${ }^{479}$ SZLADITS (1906), 352. p.

${ }^{480}$ SZLADITS (1906), 354-355. és 357-358. p.

${ }^{481}$ ZSÖGÖD (1900), 257. p.

${ }^{482}$ Vö. ABGB § 1324: ,,In dem Falle eines aus böser Absicht, oder aus einer auffallenden Sorglosigkeit verursachten Schadens, ist der Beschädigte volle Genugthuung: in den übrigen Fällen aber nur die eigentliche Schadloshaltung zu fordern berechtiget..." .

${ }^{483}$ Lásd: Duf. 25/102. számú döntés, SZLADITS (1906), 359. p.

${ }^{484}$ SZLADITS (1906), 357. p.

${ }^{485}$ SZLADITS (1906), 357. p.
} 
önmagukban nem eredményezték a szavatossági jogok kizárását, de azokban a kellékszavatossági igényeket kizáró kikötés is szerepelhetett. ${ }^{486}$

\subsection{Igényérvényesités és bizonyitási teher}

A Kt. „helykülönbség melletti” kereskedelmi vétel esetén (azaz amikor az eladó az árut köteles volt a vevő részére elküldeni ${ }^{487}$ előírta, hogy a szavatossági igényérvényesítés előfeltétele a kifogásközlés:

„A más helyröl küldött árút, a mennyiben ezt a rendes üzleti kezelés megengedi köteles a vevö az átvétel után nyomban megvizsgálni és ha a kellékeknek nem felel meg, kifogásairól az eladót azonnal értesiteni. Az értesités elmulasztása esetén, az árút kifogástalannak tekintjük, kivéve, ha utóbb oly hiányokról van szó, a minők az azonnal megtörtént megvizsgálás esetén sem voltak a rendes üzleti kezelés szerint azonnal felismerhetök.

...A később felfedezett hiányokról nyomban a felfedezés után köteles a vevö az eladót értesíteni, mert ellenkezö esetben az árút olyannak tekintik, a mely ellen kifogást nem emelnek. ",488

A megvizsgálás idejére és módjára is irányadó volt a „rendes üzleti kezelés” elve, figyelemmel kellett lenni az áru tulajdonságaira és az üzleti gyakorlatra is. ${ }^{489}$ A kellő időben tett értesítést a vevőnek kellett bizonyítania, ${ }^{490}$ azonban ha ő az átvételt megtagadta vagy azt követően nyomban kifogást tett, akkor ,az árú szerződés- illetve törvényszerü minőségét mindig az eladó tartozott bizonyítani", 491

Ha a helykülönbség melletti adásvétel nem minősült kereskedelminek a Kt. alapján, akkor nem érvényesült a gyakorlatban a kifogásközlés kötelezettsége, de ilyen esetben is mindig mérlegelték, hogy a kifogás elmaradása a hibás áru jóváhagyásának minősíthető volt-e. ${ }^{492}$ Kereskedelmi és köztörvényi helyi vétel esetén sem állt fenn a kifogásközlési kötelezettsége a vevőnek a Kt. alapján, de a joggyakorlatban irányadóvá vált az a szabály, hogy az ilyen ügyletek esetén sem hagyhatja a vevő az eladót „,hosszabb ideig kétségben a megrendelt áru sorsa iránt". 493

\footnotetext{
486 Lásd: Curia I. G. 68/1902. (1902. július 1.) számú döntés, GoTTL (1903), 541-542. p.; valamint lásd: Curia I. G. 426/1902. (1903. január 17.) számú ítélet, GOTTL (1904), 175-178. p.

${ }^{487}$ Lásd: NAGY (1913), 203-204. p.

${ }^{488}$ Kt. 346. §; BERÉNYI (1904), 65. p.

489 1295/1889. sz. curiai határozat, lásd: NAGY (1913), 220. p.

${ }^{490}$ Lásd: C. 1914. márczius 11. 609/913. v. sz. IV. p. t.; GRECSÁK - SÁNDOR (1916), 750. p.

${ }^{491}$ Lásd: NAGY (1913), 224-225. p. Az utóbbira Nagy Ferenc mint állandó magyar bírói gyakorlatra utal.

${ }^{492}$ Lásd: NAGY (1913), 219. p.; SZLADITS (1906), 349. p.

${ }^{493}$ Lásd: Duf. 29/51. számú döntés, valamint D3f. 6/34., D3f. 8/34. és D4f. 4/133. számú döntések, SzLADITS (1906), 350. p. Lásd továbbá: NAGY (1913), 219. p.
} 
A vevő peren kívüli és perbeli nyilatkozatban is gyakorolhatta a szavatossági igények közötti választás jogát, azonban ha a választott joghoz az eladó már hozzájárult, illetve ha a jogvitát jogerős bírói ítélet eldöntötte, akkor már nyilvánvalóan nem térhetett át másik jogra. ${ }^{494}$

A Kt. speciális elévülési határidőket állapított meg: a kellékhibára vonatkozó kifogás megtételére és a keresetindításra is hat hónap állt a vevő rendelkezésére, amelyet az áru átvételétől kellett számítani:

„A vevö azon kifogással, hogy az áru a kikötött vagy törvényi kellékeknek meg nem felel, nem élhet, ha a hiányokat az átvételtöl számítandó 6 hó eltelte után fedezi fel; vagy ha az eladót a hiányokról az átvételtöl számitandó 6 hó alatt nem értesiti. A vevőnek a hiányokra alapitott kereseti joga az eladó ellen, az átvételtöl számitandó 6 hó alatt elévül. Ezen határozatok által, a törvényes intézkedéseken, illetöleg a kereskedelmi szokásokon, melyek bizonyos üzletekre nézve rövidebb elévülési idöt állapitanak meg, változás nem történik. Ha az eladó felelössége szerzödésileg rövidebb vagy hosszabb idöre állapittatik meg, a megállapodás szolgál irányadóul. "495

A rövid határidő indoka a forgalom biztonsága és a jóhiszemü eladó érdekeinek a védelme volt. ${ }^{496}$ Egyetlen kivételként az eladó rosszhiszemüsége esetén a rendes elévülési határidő érvényesült. ${ }^{497}$ A Kt. fenti szabályai diszpozitívek voltak, amit a bírói gyakorlat is megerösített. ${ }^{498}$

A Kt. szavatossági határidőkre vonatkozó rendelkezései nem érvényesültek a kereskedelmi vételnek nem minősülő adásvétel hibás teljesítéséből fakadó jogvitáknál. ${ }^{49}$ Minden esetben, minden fajta adásvételből eredő szavatossági jogvitában a vevőt terhelte azonban a bizonyítási kötelezettség arra vonatkozóan, hogy az átvételkor, azaz a szavatosság kezdetén a kellékhiba már fennállt. ${ }^{500}$

\subsection{Elhatárolási kérdések}

A kötelmi általános szabályok közül a kellékszavatosság és a tévedés, mint a szerződés érvénytelenségének egyik oka közötti viszony gyakran okozott jogértelmezési problémákat

\footnotetext{
${ }^{494}$ Lásd: D4f. 1/88., 2/32, Duf. 30/56., 30/69., 37/38., 40/48. számú döntések, lásd: SzLADITS (1906), 365. p.

495 Kt. 349-350. §§, lásd: STIASSNY (1904), 290. p.; BERÉNYI (1904), 65. p.

${ }^{496}$ Lásd: NAGY (1913), 219. p.

${ }^{497}$ SzLADITS (1906), 381. p.

498 „Ha az eladó szavatosságát határozott időre korlátozza és a vevő ezen időn belül a hiányok miatt fel nem szólal, ugy az eladó szavatossága elévültnek tekintendő.” 1893. április 17. 3604. sz. a. curiai határozat, lásd: Jogtudományi Közlöny, 1894. 29. évfolyam 23. szám (junius 8.), melléklet: Curiai Határozatok, 169. p. ${ }^{499}$ SZLADITS (1906), 381. p.

500 KATONA (1904.), 147. p. Lásd továbbá: Curia I . G. 651/1901. (1902. április 9.) számú ítélet; GOTTL (1903), 413. p.
} 
a joggyakorlatban, és a jogtudományban is úgy tartották, hogy „,a szavatosság és a tévedés egy tőről szakadt két intézmény" ${ }^{501}$ A XX. század legelején Szladits arról tudósít, hogy a bírói ítéletekben kétfajta megközelítés lelhető fel: az egyik szerint a dolog minőségében való lényeges tévedés már megalapozza a szerződés érvénytelenségét, kivéve, ha az a vevő gondatlanságából származott. ${ }^{502}$ A másik álláspont szerint lényeges tévedés esetén a vevő csak akkor támadhatja meg a saját szerződési nyilatkozatát, ha „,a tévedést a másik fél okozta vagy felismerhette", az előbbi alatt értve azt, hogy - akár jó, akár rosszhiszemủen az eladó szolgáltatta azokat az adatokat, amik a tévedéshez vezettek. ${ }^{503}$ Ez viszont már megtévesztés lenne. A megosztott bírói gyakorlat következetlen ítéletekben lényeges minőségi hiba esetén hol tévedés miatti érvénytelenséget, hol az eladó szavatossági helytállását állapította meg. Olyan ellentmondás is előfordult, hogy egy jogesetben a Guarnerius-ként eladott hegedüről utóbb kiderült, hogy nem valódi, és a bíróság amellett, hogy a szerződést érvénytelennek mondta ki, az indoklásban mégis hivatkozott a szavatossági kötelezettségre is. ${ }^{504}$

A jogtudományban az volt a többségi álláspont, hogy a szavatosság a tágabb kategória, mivel ott semmilyen okozatosságot nem várnak el az eladó eljárása és a vevő minőséget illető tévedése kötött (objektív a helytállás), a tévedésnél azonban szükség van a kauzalitás bizonyítására is. ${ }^{505}$ Erre tekintettel köztörvényi vételek esetén, mivel azokra nem vonatkozott a Kt. szigorú igényérvényesítési határideje, Szladits szerint nem állt a vevő érdekében, hogy a szavatosság mellett a tévedés miatti megtámadási jogával is éljen. ${ }^{506}$

Gyakorlati szempontból a legfontosabb kérdés az volt, hogy a tévedés és a szavatosság a fenti megfontolásokra tekintettel érvényesíthetőek-e párhuzamosan. Ezzel kapcsolatban két álláspont állt egymással szemben: Grosschmid szerint a két igény halmozva is érvényesíthető, azonban a szavatossági igények elévülése után minőségi

\footnotetext{
${ }^{501}$ Lásd: SCHWARZ (1901), 273. p.

${ }^{502}$ Lásd: D3f. 18/32., D4f. 3/47. számú döntések, SZLADITS (1906), 375. p. Vö. BGB § 119 (1): „,Wer bei der Abgabe einer Willenserklärung über deren Inhalt im Irrtume war oder eine Erklärung dieses Inhalts überhaupt nicht abgeben wollte, kann die Erklärung anfechten, wenn anzunehmen ist, daß er sie bei Kenntnis der Sachlage und bei verständiger Würdigung des Falles nicht abgegeben haben würde.”.

${ }^{503}$ Lásd: D4f. 1/125., SzLADITS (1906), 375. p. Vö. ABGB § 871 (1): „, War ein Teil über den Inhalt der vor ihm abgegeben oder dem anderen zugegangenen Erklärung in einem Irrtum befangen, der die Hauptsache oder eine wesentliche Beschaffenheit derselben betrifft, worauf die Absicht vorzüglich gerichtet und erklärt wurde, so entsteht für ihn keine Verbindlichkeit, falls der Irrtum durch den anderen veranlaßt war, oder diesem aus den Umständen offenbar auffallen mußte, oder noch rechtzeitig aufgeklärt wurde.".

${ }^{504}$ Lásd: D3f. 19/61., SZLADITS (1906), 376. p.

${ }^{505}$ Lásd: SZLADITS (1906), 374-375. p.

${ }^{506}$ SZLADITS (1906), 376. p.
} 
tévedés miatt sem lehet már tévedés címén perelni. ${ }^{507}$ Az ellentétes tudományos álláspontot Szászy-Schwarz Gusztáv képviselte, aki úgy vélte, hogy a két igény egymás melletti követelése kizárt. ${ }^{508}$ Szladits is az utóbbi vélemény mellett voksolt a Kt. szövegének szigorú értelmezése alapján: úgy vélte, hogy a szavatosságra vonatkozó törvényi rendelkezések mindig érvényesen létrejött adásvételi szerződést tételeznek fel. ${ }^{509}$

\subsection{Hibás teljesítés az állatok adásvételénél}

Az állatok, mint ingók adásvétele gazdaságilag fontos, értékes jogügyletet jelentett az üzleti forgalomban. Mivel azonban az élő állatnak, mint dolognak speciális jellemzői vannak, különös szabályozás volt indokolt az állatok hibáiért fennálló kellékszavatosság esetén. A Kiegyezés utáni időszakban azonban az állatszavatosságra nem voltak egységes jogszabályi rendelkezések hazánkban, ezért - jótállás vállalásának hiányában - az állatszavatossági kérdések megítélése általában szakértők egyedi megítélésére tartozott. ${ }^{510}$

A XIX. század végén a bírói joggyakorlat ún. föhibák és az ezekhez kapcsolódó megdönthető vélelmek felállításával oldotta meg az állatszavatossági kérdéseket az ABGB § 924-925 alapján, annak ellenére, hogy állatok adásvételére gyakran lehetett alkalmazni a Kt. szabályait is. ${ }^{511}$ A szavatossági föhiba esetén a vevő egy bizonyos rövid határidőn belül hivatkozhatott a hibákra, és e határidőn belül ellenkező bizonyításig úgy kellett tekinteni, mintha a hiba már az átadáskor meglett volna az állatban. ${ }^{512} \mathrm{Ez}$ azt jelenti, hogy a bizonyítási teher megfordult. Az előnye e megoldásnak az volt, hogy az eladó pontosan tudta, hogy milyen hibákért kell szavatolnia, a vevőt pedig nem terhelte a költséges és bizonytalan kimenetelü bizonyítási procedúra. ${ }^{513}$ Hátránya volt viszont, hogy a vevő nem részesült kellő védelemben a föhibaként nem szabályozott betegségek esetében. ${ }^{514}$

A szavatossági határidők még sokáig nem voltak egységesek, ezért szakértői bizonyítást igényelt az egyes esetekben szereplő betegségek lappangási idejének

\footnotetext{
${ }^{507}$ Lásd: ZsÖGÖD (1900), 842. p. Ez érvényesült egyébként a BGB és az ABGB szabályozásában is, vö. ABGB $\S 933$ és BGB $\S 477$.

${ }^{508}$ Lásd: SCHWARZ (1901), 274. p.

${ }^{509}$ SZLADITS (1906), 378. p.

${ }^{510}$ Lásd például: SUHAYDA (1869), 262. p.

${ }^{511}$ KOLOSVÁRY (1904), 121. p. Az ABGB § 924 így rendelkezett: „Ha valamely barom az átvétel után 24 óra alatt megbetegszik vagy eldöglik, az vélelmeztetik, hogy már az árvétel előtt beteg volt." (ún. éjjeli kár esete), lásd: RAFFAY (1909), 316. p.

512 ZLINSZKY (1899), 652-653. p.

${ }^{513}$ MÁRKUS (1907), 345. p.

${ }^{514}$ MÁRKUS (1907), 345. p.
} 
megállapítása, mert csak ez alapján lehetett meghatározni a szavatossági jogok érvényesítési határidejét. ${ }^{515}$

Szavatossági főhibának az olyan lényeges hiba számított, ami az állatot a rendeltetésszerü használatra képtelenné tette. ${ }^{516}$ Azért szabályozta ezeket a hibákat már az ABGB is főhibaként, mert ezek voltak a leggyakrabban előforduló releváns betegségek. ${ }^{517}$ Az ún. mellékhibák esetében is szavatolnia kellett az eladónak, de ilyenkor nem állt fenn a hibásság vélelme (a fordított bizonyítási teher), így a vevőnek kellett bizonyítania, hogy már a vétel idején megvolt a hiba az állatban, és hogy a hiba gátolta az állat rendeltetésszerű használatát. ${ }^{518}$

Az állatszavatossági igényeket illetően a bíróságok általában az actio redhibitoriát, azaz az elállást ítélték meg a vevő javára, amennyiben azonban a hiba csak az állat értékére volt befolyással, de a használhatóságát nem érintette, helyt adtak az actio quanti minoris, azaz a vételárcsökkentés követelésének is. ${ }^{519}$ Ilyen jogeset volt az, amelyben a vevő tenyésztési célra vett meg egy lovat az eladótól 3000 forintért, a ló azonban „rekedt és hörgős" volt, ezért valós piaci értéke 1200 forint lett volna, de az eladó ezért a hibáért szavatosság alapján mégsem tartozott helytállással a bíróság ítélete szerint. ${ }^{520}$

Érdemes ehelyütt bemutatni további szemelvényeket a bírói gyakorlatból. A rejtett kellékhiba (betegség) követelményét példázza, hogy egy döntésben a Curia megállapította, hogy ló eladásánál, ha az olyan külső hibában szenved, amely megtekintésre felismerhető, az eladó csak abban az esetben tartozik kellékszavatossággal, ha az eladó a ló hibátlanságáért jótállást vállalt. ${ }^{521}$ Külön kikötés nélkül ugyancsak nem állapította meg a szavatossági kötelezettségét a bíróság annak az eladónak, aki idült „tüdőgumókórban” szenvedő szarvasmarhát adott el, ami azonban csak a vétel utáni harminc napon túl vált felfedezhetővé. ${ }^{52}$ Ezzel szemben egy másik ügyben azt állapította meg a Curia, hogy juhok adásvétele esetén, „,ha az átvételtől számított két hó alatt szőrféreg és métely vétetik észre, az vélelmezendő, hogy a megvett juhok már az átvételkor betegek voltak s e

\footnotetext{
515 ZLINSZKY (1899), 653. p.

${ }^{516}$ KOLOSVÁRY (1904), 121. p.

${ }^{517}$ KOLOSVÁRY (1904), 121. p.; MÁRKUS (1907), 347. p.

518 MÁRKUS (1907), 345. p. Az állatszavatossági hibákkal kapcsolatos jogesetekhez lásd: 33066/1885. sz.; 1886. decz. 16. 34.102. sz.; 1895. ápr. 4. 7475/1894. sz.; 1072/1889. sz.; 1898. aug. 31. I . G. 134. sz.; 1895. decz. 13. 8143/1894. sz. döntések; lásd: VAVRIK - GYOMAI (1906), 873-874. p.

519 1897. junius 24. 5178. számú curiai határozat, lásd: MÁRKUS (1907), 349. p. Így volt ez a római jogban is, vö. D. 18,1,43 pr., lásd: I. fejezet 3.4. pont és JAKAB (1993), 62-63. p.

${ }^{520}$ Lásd: Curia 1897. jun. 24. 5178/1896. sz. döntés; LÁNYI (1911), 250-251. p.

${ }^{521}$ C. 1900. márcz. 3. I. G. 5. sz. döntés; LÁNYI (1911), 249-250. p.

522 Curia 1897. deczember 20. 2553/1898. sz. döntés; LÁNYI (1911), 250. p. Erre a Curia mint „hazai jogszokásra" hivatkozott az ítélet indoklásában.
} 
lényeges hiba miatt a vevőnek joga van a szerződés felbontásához."523 A legkülönfélébb betegségekkel kapcsolatos jogeseteket - láthatóan - mindig egyedileg kellett megítélni.

Az állatszavatosságal kapcsolatos igények érvényesítési határidejével kapcsolatban egy bírói döntés kitért rá, hogy azt a magyar joggyakorlat és jogszokás a ragályos betegségekre, így például a sertésorbáncra 8 napban állapítja meg. ${ }^{524}$ Ennek fényében a fajlagos sertésvétellel kapcsolatos jogesetben megállapította a bíróság, hogy ha a szavatossági hiba az állaton 8 nap alatt észlelhetö, a törvényes vélelem az, hogy az állat már az átadás elött beteg volt. Mivel a jogesetben a szolgáltatás több sertés eladására vonatkozott, úgy ítélte meg a bíróság, hogy a felperes jogosult a betegségből kigyógyult és a hizlalás folytán értékesebbé vált sertéseket megtartani, az elhullottakért pedig kártérítést követelni. $^{525}$

Az állatszavatosságért való helytállás ex lege (de diszpozitív) jellegét példázza az a bírói döntés, amely így rendelkezett: ,az állat tulajdonosa, annak az eladás idejében már meglévő minden rejtett és külsőleg fel nem ismerhető hibájáért a vevőnek felelősséggel tartozik, hacsak a vevő ez alól az eladót kifejezetten fel nem menti, avagy ha a felek a szavatosságot kizárták. E szerint szavatossággal tartozik alperes a ló karórágós voltáért, tekintet nélkül arra, hogy a karórágás szavatossági főhibát képez-e vagy sem, avagy szervi baj-e az, vagy csak rossz szokás, akkor, ha ez a lóban az eladáskor már meg volt, de külsőleg felismerhető nem volt."

Egy ugyancsak lóvétellel kapcsolatos jogesetben szigorúan értelmezte a külsőleg látható (azaz a nem rejtett) kellékhiba kategóriáját a Curia. ${ }^{527} \mathrm{Az}$ ügyben a felperes vevő azért támadta meg a fellebbezési bíróság ítéletét, mert szerinte a külsőleg felismerhető hiba esetén kizárt eladói helytállás szabálya ${ }^{528}$ az esetben nem alkalmazható. A felperes arra hivatkozott, hogy a szakértő szerint a ló patájának csak a „gyürüzöttsége” látható kívülről, de annak következményét, a belső gyulladást csak a szakértő tudja megállapítani. Azt mondta továbbá, hogy nem azért kívánja a szerződést felbontani, mert a ló patája gyürüzött, hanem mert a ló „sánta és rokkant pataságban” (gyulladásban) szenved. Tanúival azt is bizonyította, hogy a vétel megkötésekor megkérdezte az alperes eladótól, hogy a lónak van-e valami hibája, azt azonban az alperes csalárdul elhallgatta. Ennek ellenére a Curia mégis úgy ítélte meg, hogy a fellebbezés nem alapos, és helyben hagyta a

\footnotetext{
${ }^{523}$ Curia I. G. 3/1896. sz. döntés; LÁNYI (1911), 250. p.

${ }^{524}$ Lásd: C. 1909. április 28. 5437/908. sz. a. V. p. t. számú döntés; LÁNYI (1911), 260-261. p.

525 Érdemes megemlíteni, hogy az ítélet indokolása a Kt. 358. §-ra hivatkozik.

${ }^{526}$ Lásd: Curia 1909. május 18. 308/909. sz. a. VI . p. t. számú ítélet; LÁNYI (1911), 261. p.

${ }^{527}$ Lásd: 1900. márcz. 3. I. G. 5. számú döntés; VAVRIK - GYOMAI (1906), 870. p.

${ }^{528}$ Ehhez lásd például: 1902. febr. 27. I . G. 332/1901. számú döntés; VAVRIK - GYOMAI (1906), 871. p.
} 
fellebbezési bíróság megállapítását, miszerint a ló „külső hibában szenved, mely megtekintésre felismerhető”. Ezért pedig az alperes szavatossággal csak abban az esetben tartozna, ha jótállást vállalt volna a hibátlanságért.

\section{Az ingó dolog adásvételének hibás teljesítése az 1928-as Magánjogi} Törvényjavaslatban és a korabeli jogirodalomban, joggyakorlatban

A magánjogi kodifikáció kérdése már a Kiegyezés után napirendre került az 1848. évi XV. törvénycikknek megfelelően, ${ }^{529}$ és az 1895 -ig terjedő időszakban több, a magánjog egyes főbb részeire vonatkozó törvénycikk született, ${ }^{530}$ de végül csak 1895-ben állították fel az állandó magánjogi kodifikációs bizottságot, amely az első egységes szövegtervezetet 1900ra készítette el. ${ }^{531}$ Grosschmid Béni „Fejezetek kötelmi jogunk köréből” címü művében figyelemre méltó megjegyzéseket tett a szavatosság jogi mibenlétére vonatkozóan, amelyet a kodifikáció folyamán is minden bizonnyal szem előtt tartott a jogalkotó:

„A szavatosság [...] egyik sajátos létszaka az obligácziónak. Megkérődzése. A consummatum, vagyis a lerótt kötelezettség a lerovásbeli fogyaték (jog- és kellékhiány) okából visszafordul nem consummátummá s az obligáczió életfolyása újra kezdődik."

Azt is megemlítette ugyanakkor a jogtudós, hogy nagyon nehéz meghatározni a szavatosság pontos fogalmát. ${ }^{533} \mathrm{Az}$ 1900. évi polgári törvénykönyv-tervezet a kötelmi általános szabályok között például így rendelkezett a kellékszavatosságról: ${ }^{534}$

„Az elidegenítő felel a megszerzőnek azért, hogy a megszerzett dolog a veszély átszállásának időpontjában nem szenved oly hiányban, mely értékét v. rendeltetésének megfelelő használhatóságát kizárja v. lényegesen csökkenti, továbbá hogy a dolog [...] a kikötött tulajdonságokkal bír."

A tervezetben a szavatosság alól mentesítő körülmények megegyeztek a korábbi gyakorlattal, a kellékszavatossági jogokat illetően pedig a Kt.-ben szereplő igényekről

\footnotetext{
529 1848. évi XV. törvénycikk az ősiség eltörléséröl, 1. §. A kodifikálási munkálatok 1869-ben indultak meg, lásd: VILLÁNYI (1941), 9. p.

${ }^{530}$ Többek között: a gyámságról és gondnokságról szóló 1877. évi XX. törvénycikk, a végrendeletek alaki kellékeiről szóló 1876. évi XVI. törvénycikk, a házassági jogról szóló 1894. évi XXXI. törvénycikk, lásd: Mtj. indokolás, 5. p.

${ }^{531}$ Mtj. indokolás, 5. p. A magánjogi kodifikáció egyes kérdéseihez és történetéhez lásd: HOMOKI NAGY (1998), 149-151. p.

${ }^{532}$ ZSÖGÖD (1900), 1224. p.

${ }^{533}$ ZSÖGÖD (1900), 1224. p.

534 1900. évi polgári törvénykönyv tervezet 1469. §, lásd: MÁRKUS (1907), 343. p.

535 MÁRKUS (1907), 343. p., 1900. évi polgári törvénykönyv-tervezet 1431. §.
} 
rendelkezett a tervezet, és az elévülési jellegü perlési határidőt is 6 hónapban állapította meg ingók esetén. ${ }^{536}$

A tervezetet nem tekintették alkalmasnak a törvényhozási vitára, mert szerkezete nem volt egységes, és a gyakorló jogászok erősen bírálták szabályozási megoldásait. ${ }^{537} \mathrm{~A}$ teljesen átdolgozott tervezet második szövege, az 1913-as polgári törvénykönyv-tervezet a kellékszavatosság szabályait finomította, de nem pontosította annak viszonyát más, hasonló kötelmi általános jogintézményekhez. ${ }^{538}$ Bírálat érte a kártérítési igény és a dolog megfelelőségének, a használhatóság kategóriájának a meghatározását is. ${ }^{539}$

Az I. világháború kitörése következtében ez az 1913-as törvénytervezet sem került országgyülési tárgyalásra, jelentőségét mégis mutatja, hogy a bíróságok a tervezet képviselőházi bizottságának a szövegét - különösen annak kötelmi jogi részét - mint hatályos jogot kezdték el alkalmazni. ${ }^{540}$

A kodifikáció szakmai előkészítése nem torpant meg a háború alatt sem, azonban az érdemi munka a háború befejezését követően, az 1920-as évek elején folytatódott. ${ }^{541} \mathrm{Az}$ 1928-as Magánjogi Törvényjavaslat ${ }^{542}$ megalkotását 1922-ben megkezdő szerkesztőbizottság új szöveget készített a törvénykönyv mind a négy förészéröl. ${ }^{543} \mathrm{~A}$ megelőző tervezetek átdolgozása során a jogalkotó célja „a fennálló magyar magánjog értékes elemeinek rendszeres egybefoglalása és eredeti jellegéhez hű továbbfejlesztése” volt. ${ }^{544}$ Emellett helyes rendszertani felosztásával, áttekinthető szerkezetével és „világos, szabatos és magyaros szövegezésével” elő akarták segíteni, hogy a kódex ,a nemzet széles rétegeinek közérthető törvénye legyen". 545

\subsection{Hibás teljesítés, kellékszavatosság, hibafogalom}

A hibás teljesítés a kötelmi jog egyik kardinális kérdésköreként a jogtudományban nagy figyelmet kapott az Mtj.-t megelőző időszakban is. Ez a felfogás jellemezte az Mtj. megszövegezését is. A kötelmi általános részében szerepelt a teljesítés módjának általános

\footnotetext{
${ }^{536}$ MÁRKUS (1907), 343. p., 1900. évi polgári törvénykönyv-tervezet 1435-1451. $\S$.

${ }^{537} \mathrm{Mtj}$. indokolás, 5. p.

${ }^{538}$ BÁRDOS (1914), 66-67. p.

${ }^{539}$ BÁRDOS (1914), 70. p.

${ }^{540}$ Mtj indokolás, 6. p.

${ }^{541} \mathrm{Mtj}$ indokolás, 7. p.

${ }^{542}$ A továbbiakban Mtj.

${ }^{543} \mathrm{Az}$ Mtj. 4 fö része: személyi és családjog, dologi jog, kötelmi jog és öröklési jog.

544 Magyarország Magánjogi Törvénykönyve. A m. kir. igazságügyminiszter által 1928. március 1 -én az országgyülés elé terjesztett törvényjavaslat (Budapest, 1928.), Bevezetés, IV. p. A továbbiakban: Mtj.

${ }^{545}$ Mtj. Bevezetés, IV. p.
} 
szabálya, amely szerint a kötelezettnek a méltányosságnak megfelelően, ${ }^{546}$ az adott jogviszony körülményeire és az „élet felfogására” tekintettel kell teljesítenie a szolgáltatást (1084. §). A kellékhibákért való helytállás szabályait azonban az Mtj. (a BGB pandektarendszerét követve), az adásvétel jogába illesztette be, de úgy rendelkezett, hogy az eladó szavatosságára vonatkozó szabályok alkalmazandóak mindazon szerződésekre, ,,amelyek valamely tárgynak ellenértékért elidegenitésére vagy megterhelésére irányulnak”. 547

Szladits Károly „A magyar magánjog vázlata” című müvében ${ }^{548}$ a kötelem tartalma címü fejezetben, azon belül is a kötelemszegés nevesített változatai között tárgyalta a hibás teljesítést, de annak centrális jogkövetkezményét, a kellékszavatosságot az Mtj.-nek megfelelően már ő is az adásvétel szabályai között elemezte, mert - ahogy fogalmazott annak szabályai „elsősorban a vételre nézve fejlődtek ki $\mathrm{s}$ annak körében leggyakorlatibbak". 549

Szladits kötelemszegésnek tartotta az adósnak minden olyan magatartását, amellyel a hitelezőnek a kötelemmel védelmezett érdekét sértette. ${ }^{550}$ Ebből kiindulva különbséget tett a kötelem szolgáltatása körében a „szolgáltatási kényszer”, azaz az elsődleges kötelezettség, valamint a kötelemhez füződő másodlagos, ,járulékos” joghatások között. ${ }^{551}$ A hibás teljesítés szerződésszegési esete és az ahhoz kapcsolódó jogkövetkezmények az utóbbiba tartoztak Szladits szerint. Úgy fogalmazott, hogy hibás teljesítés esetén az adós nem a kötelemből fakadó közvetlen érdeket, hanem a kötelem teljesítésére vonatkozó jóhiszeműség és tisztesség követelményét, és ezzel a jogosult ún. „oltalmi érdekeit” sérti meg. 552

A magánjogi dogmatika szerint ,a teljesítés az adósnak az a cselekménye, amellyel a kötelemnek megfelelő szolgáltatást véghezviszi,",553 a bíróságokon pedig „törvényes gyakorlat által elfogadott jogszabály” volt, hogy ,az eladó külön kikötés nélkül is felelős az eladott dolognak szerződésszerü szolgáltatásáért”. ${ }^{554}$ A kötelemnek megfelelő teljesítés, és az azzal ellenkező teljesítés jogkövetkezményeit a jogtudósok különböző elvekből vezették le, mint például a szerződési hüség (pacta sunt servanda), a „becsület és

\footnotetext{
${ }^{546}$ A méltányosságnak megfelelő teljesítés követelményét a bírói gyakorlat is hangsúlyozta, lásd: 1690/1925. döntés, lásd: SzLADITS - FÜRST (1935), 117. p.

${ }^{547}$ Mtj. 1407. §.

${ }^{548}$ SZLADITS (1933).

${ }^{549}$ SZLADITS (1933), 196. p.

${ }^{550}$ SZLADITS (1933), 85. p.

${ }^{551}$ SZLADITS (1933), 3-4. p.

${ }^{552}$ SZLADITS (1933), 105-106. p.

${ }_{553}$ Lásd: VILLÁNYI (1941), 257. p.

${ }^{554}$ Lásd többek között: 187/1901. számú döntés, SZLADITS - FÜRST (1935), 374. p.
} 
emberség”, vagy a ,jóhiszemüség és tisztesség” elve. ${ }^{555}$ A hibátlan teljesítés elősegítéséhez ezeken kívül több kötelezettség is kapcsolódott, mint például a teljesítést előkészítő teendők és a jogosult érdekeit érintő minden körülményre vonatkozó tájékoztatás. ${ }^{556}$ Ingó adásvétele esetén ilyen kötelezettség volt a dolog átadásáig az áru „gondozása”, és az esetleges hiányainak illetve hibáinak a közlése is. ${ }^{557}$

Az eladó szavatosságát a dolog hiánymentességéért az Mtj. a következőképpen határozta meg:

„Az eladó szavatol a vevőnek azért, hogy az eladott dolog a kárveszély átszállásának idejében hiánymentes. Hiánymentes a dolog, ha megvannak a kikötött tulajdonságai és nincs oly hibája, amely értékét vagy rendeltetésének megfelelö használhatóságát elenyészteti vagy számbavehetöen csökkenti. "558

A „szavatossági hiány” fennállása szempontjából tehát a kárveszély átszállása volt az irányadó időpont, amelyről úgy rendelkezett az Mtj, hogy ,, az eladott dolog átadásával a dolog véletlen elpusztulásának és rosszabbodásának veszélye - a kárveszély - átszáll a vevőre.". 559 A dolog átadásának idején fennforgó kellékhiba alapozta meg tehát a szavatossági helytállást. Az átadás ideje azonban különböző volt „helykülönbség melletti vétel” („distanc-vétel”) és „távolba eladás” (Fernverkauf) esetén. ${ }^{560}$ Ingó adásvétele esetén mindkét esetben a dolog elküldésének, feladásának az időpontja volt irányadó a kárveszélyátszállás, és így a kellékhiba fennállásának szempontjából is. ${ }^{561}$

Az Mtj. a hibát a hibamentesség aspektusából definiálta: a szerződésileg konkrétan kikötött tulajdonságok hiánya, és a dolog (piaci, objektív) értékére és rendeltetésszerü használhatóságára kiható hibák alapozták meg a kellékszavatossági helytállást. ${ }^{562}$

Az ingó árut a felek meghatározhatták egyedileg (pl. egy ló), fajlagosan (pl. 100 mázsa búza) vagy zártfajúan is (pl. 50 liter az eladó pincéjében készült vörösborból) ${ }^{563} \mathrm{~A}$ jogtudomány álláspontja szerint egyedi vétel esetén még a szerződéssel való tökéletesen azonos teljesítésnél is fontosabb volt az a követelmény, hogy az eladott dolog a

\footnotetext{
${ }^{555}$ SZLADITS (1933), 74-75. p.

${ }^{556}$ SzLADITS (1933), 76. p. Ezt a bírói gyakorlat is megerősítette: Kúria P. VI. 226/1931. (MD. XXIV. 122), lásd: SZLADITS - FÜRST (1935), 358. p.

${ }^{557}$ SZLADITS (1942), 258. p. Lásd: K. P. VI. 226/1931. számú döntés.

${ }^{558}$ Mtj. 1382. §. Ez részben egyezett a BGB szabályával, vö. § 459.

${ }^{559}$ Mtj. 1356. §. Ez azonos a BGB szabályával.

${ }^{560}$ Ezeknek az átadás ideje, és így a kárveszély átszállása miatt volt jelentősége a szavatosság szempontjából. Az előbbinél az eladó a teljesítés helyéről küldte el az árut a vevőnek, az utóbbinál pedig az eladó a teljesítési helytől különböző helyen lévő árut a teljesítés helyére küldte, lásd: SzLADITS (1933), 192-193. p.

561 Az elküldés a dolog fuvarozónak vagy szállítmányozónak (vagy egyéb megbízottnak) való átadásával vette kezdetét, lásd: Mtj. 1356. §.

${ }^{562}$ SZLADITS (1942), 286-287. p.

${ }^{563}$ SZLADITS (1933), 192. p.
} 
rendeltetésszerü használatra alkalmas legyen. ${ }^{564}$ Fajlagos vétel esetén „bizonyos mennyiségü helyettesíthető ingó dolog" szolgáltatandó. ${ }^{565}$ Ilyenkor a faj tulajdonságainak elvont megjelölése, és a középminőségü áru szolgáltatásának a követelménye a hiánymentesség kikötését is magában foglalta a korábbi jogértelmezésnek megfelelően. ${ }^{566}$ A fajlagos vételekre vonatkozó joggyakorlat és a jogtudomány szerint bizonyos tulajdonságokat az ügylet céljából kifolyólag kikötöttnek kellett tekinteni, így például a magkereskedő köteles volt helytállni a szavatossági szabályok alapján azért, ha a mag nem csíraképes, mert a csíraképtelen mag nem felel meg a közönséges rendeltetésének. ${ }^{567}$

A zártfajú szolgáltatás kapcsán is érvényesült ez a követelmény, de a zártfajúságot kiterjesztően értelmezték: egy precedens-értékű bírói döntés kimondta, hogy ha a vevő Singer típusú varrógépet rendelt, de nem kötötte ki külön, hogy annak eredeti Singernek kell lennie, akkor az eladó szerződésszerüen teljesített akkor is, ha egy Singer géprendszer szerint készített gépet szállított. ${ }^{568}$

A hiba fogalma minta szerinti vétel esetén kiegészült a mintának megfelelő tulajdonságok hiányával (Mtj. 1410. §), és az eladó szavatossága ilyen esetben fennállt azért, hogy az áru minőségében nem lesznek olyan hiányok, melyek a mustrán a szerződéskötéskor rendes kereskedői gondosság tanúsításával sem voltak felismerhetőek. ${ }^{569}$ Ez esetben sem volt azonban kizárt - a korábbi joggyakorlatnak megfelelően - bármely más minőségi jellemző külön kikötése, és az ilyen kikötésnek nem felelt meg a dolog, az is megalapozta a hibás teljesítést. ${ }^{570}$

A kikötött tulajdonságok esetén nem követelték meg, hogy azok hiánya a rendeltetésszerű használatra vagy a dolog értékére bármilyen hatást gyakoroljon, a kikötés puszta ténye megalapozta a szavatossági helytállást (Mtj. 1383. §) ${ }^{571}$ A hiba jelentékeny illetve jelentéktelen volta sem volt ez esetben mérvadó.

\footnotetext{
${ }^{564}$ Lásd többek között: SzLADITS (1933), 197. p.; VILLÁNYI (1941), 331. p.

565 Lásd: TóTH (1938), 141. p. 2. 1j. A fajlagos szolgáltatás azonban nem azonosítható a helyettesíthető dologgal. A problémakör tárgyalását lásd később.

${ }^{566}$ SZLADITS (1933), 197. p.; VILLÁNYI (1941), 332. p.

${ }^{567}$ Lásd: SzLADITS (1933), 200. p. 2. lj. hivatkozása a 115. E. H.-ra. Ez is egyezett a korábbi gyakorlattal.

568 80/1902. (Dt. 3. f. XXII. 194.) döntés, lásd: SZLADITS - FÜRST (1935), 122. p.

${ }^{569}$ Lásd: 6673/1917. (PHT. 661.) döntés; SZLADITS - FÜRST (1935), 381. p.

${ }^{570}$ Lásd: 621/1882. döntés, SZLADITS - FÜRST (1935), 381. p.

571 „Ha a felek között külön ki van kötve, hogy az eladott dolognak bizonyos tulajdonsággal bírnia kell, az eladó általában szavatol azért, hogy a dolog a kikötött tulajdonsággal bír, anélkül, hogy kérdés tárgya lehetne, hogy e tulajdonság hiánya érinti-e a dolog értékét vagy használhatóságát és hogy a hiány jelentékeny-e vagy jelentéktelen.”, lásd: P. V. 3778/1929. (MD. XXIII. 73. számú döntés, SZLADITS - FÜRST (1935), 372. p.
} 


\subsection{A szavatossági helytállás jogalapja és a szabályozás diszpozitív jellege}

Az Mtj. fogalmi meghatározásából és a jogtudományi álláspontokból, valamint a joggyakorlatból is következtetni lehet a jogintézmény objektív jellegére. Kötelmi jogi könyvében Tóth Lajos - Grosshmid Bénit idézve - így fogalmazott: „Ha nem volna szavatosság, a jóhiszemü forgalom sokat szenvedne [...] megbénulna, megállana a forgalom. [...] a szavatosság hiánya a rosszhiszemű emberek favorizálása lenne." ${ }^{, 572}$ Ez a vélekedés kifejezi a szavatosság szabályozásának jogpolitikai célját, amely a jogintézmény ókori kialakulásától kezdve irányadó a mindenkori szabályozásban: a jóhiszemű vevő (fogyasztó) védelmét.

Az Mtj. úgy rendelkezett, hogy a szavatosságot kizáró vagy korlátozó kikötés akkor hatálytalan, ha az ilyen kikötést, vagy a dolog hiányosságát az eladó a vevő előtt csalárdul elhallgatta. ${ }^{573}$ Ebböl a contrario arra lehet következtetni, hogy egyéb esetben lehetséges volt a szavatosság korlátozása és teljes kizárása is, azaz az Mtj. szabályai a gyakorlat igényeihez igazodva diszpozitívek voltak.

\subsection{A vevö tudomása a hibáról}

Úgy rendelkezett az Mtj., hogy ,olyan hiány miatt, amelyet a vevő a szerzödés megkötésekor ismert, az eladó nem szavatol." ${ }^{574}$ A római jog szabályaival és a BGB rendelkezésével megegyezően, ha a hiány „a vevö elött saját súlyos gondatlansága következtében maradt ismeretlen elötte, az eladó csak akkor szavatol, ha a dolog kikötött tulajdonsága hiányzik, vagy ha az eladó a hibátlanságért jótállott vagy a hibát csalárdul elhallgatta". ${ }^{775}$ Ez a szabály a venire contra factum proprium elvéböl is következett, miszerint ha a vevő (jogosult) a teljesítést a hibát ismerve elfogadta, akkor nem követelhet újbóli teljesítést, azaz nem érvényesítheti a hibás teljesítésből fakadó jogait sem. ${ }^{576}$ Ehhez kapcsolódóan rendelkezett úgy az Mtj., hogy „,ha a vevő, ismerve a hiányt, a hiányos

\footnotetext{
572 Tóth (1938), 306. p.

${ }^{573} \mathrm{Mtj}$. 1405. §. Bizonyára több jogesetben is jogi problémaként merült fel a csalárdság konkrét tartalma, mert több eseti döntések megfogalmazta azt a követelményt, hogy az eladónak a hibát/hiányosságot a csalárdság megállapításához már az ügylet megkötésekor ismernie kellett, lásd: P. VII. 3483/1917. (MD. XII. 16.) és P. II. 5445/1921. (MD. XVI. 11.) döntések, SZLADITS - FÜRST (1935), 372. p.

${ }_{574} \mathrm{Mtj} .1383$. §.

${ }^{575} \mathrm{Mtj} .1383$. §. Vö. BGB § 460.

${ }^{576}$ VILLÁNYI (1941), 258. p.; SZLADITS (1942), 290. p.
} 
dolgot teljesitésül mégis elfogadja, szavatosság alapján csak akkor támaszthat követelést, ha jogát ehhez az elfogadáskor fenntartotta", 577

\subsection{Szavatossági jogok}

A két elsődleges szavatossági jog - a pandekta hagyományoknak megfelelően - a vétel felbontása és a vételár leszállítása volt az Mtj.-ben:

„, Oly hiány miatt, amelyért az eladó szavatol (szavatossági hiány), a vevö a vétel felbontását vagy a vételár leszállítását követelheti. "578

Újdonság volt az Mtj.-ben fajlagos vétel esetén - a BGB-vel egyezően - a kicserélési igény: ${ }^{579}$

„Egyedileg meg nem határozott dolog vevöje vagy az 1. bekezdésben meghatározott jogok valamelyikét gyakorolhatja, vagy azt követelheti, hogy az eladó a hiányos dolog helyett hiánymenteset szolgáltasson. "580

Az eladó helyzetét könnyítette, és mindkét fél érdekeit szolgálta az a rendelkezés, amely alapján az eladónak lehetősége volt arra, hogy ha a teljesítésre tüzött határidő előtt szolgáltatott hibásan, akkor még a határidőn belül korrigálhatta ezt a hiány pótlásával, vagy fajlagos vétel esetén kicseréléssel is, de csak abban az esetben, ha nem hallgatta el csalárdul a vevő elől a kellékhibát (Mtj. 1390. §). ${ }^{581}$

Az Mtj. szerint a szavatossági jogok között a vevő szabadon választhatott, ugyanúgy, mint a római jogban, és választásától akár el is térhetett mindaddig, amíg az eladó nem egyeztetett vele, vagy ha egyeztetett ugyan, de a választott jogosultság teljesítésével a kötelezett „,vétkesen késlekedett” (1388. §). ${ }^{582}$ A már bírósági szakban járó kellékszavatossági jogvita esetén is változtathatott az érvényesíteni kívánt igényen, amíg a bíróságnak az ügyben hozott ítélete jogerőssé nem vált. ${ }^{583}$

Más volt a joggyakorlat akkor, ha a vevő közölte ugyan a szavatossági kifogását az eladóval, de azt nem mondta meg, hogy melyik szavatossági joggal akar élni: ekkor az

\footnotetext{
${ }^{577}$ Mtj. 1387. §. Ezt a szabályt a bírói gyakorlat is megerősítette, lásd: P. V. 5828/1928. (MD. XXIII. 118.) számú döntés, SZLADITS - FÜRST - UJLAKI (1934), 87. p.

${ }^{578} \mathrm{Mtj}$. 1385. $\S$ első mondat.

${ }^{579}$ Vö. BGB $§ 480$ (1) és ABGB $§ 932$.

${ }^{580} \mathrm{Mtj} .1385$. $§$ második mondat.

${ }^{581}$ Mtj. 1390. $\$$.

582 SzLADITS (1942), 297. p.

${ }^{583}$ Mtj. 1388. §. Ez megfelelt a korábbi és a korabeli bírói gyakorlatnak is, lásd többek között: P. VI. 1776/1931. (MD. XXVI. 121.) számú döntés, SZLADITS - FÜRST (1935), 372. p.
} 
eladót illette az igények közötti választás joga ${ }^{584}$ Ha azonban például az eladó az elállási jogot nem ismerte el, vagy annak lebonyolításával késlekedett, akkor nem kellett figyelembe venni az ő érdekeinek a védelmét. ${ }^{585}$

Az Mtj.-ben a szavatossági igények között ugyan nem szerepelt, de a gyakorlatban mégis elterjedt a kijavítás igényének követelése illetve teljesítésének felajánlása az eladó részéről, amennyiben az adásvétel tárgya alkalmas volt arra. ${ }^{586}$

\subsubsection{A vétel felbontása}

Az Mtj. az addigi jogirodalomban a római jog nyomán elállásként vagy redhibitióként említett igényt felbontásnak nevezte, feltehetően azért, mert az általános elállási joghoz képest speciális szabályokat határozott meg kellékszavatosság esetére. Utaló szabálya azonban arról rendelkezett, hogy a nem szabályozott kérdésekben a felbontásra a törvényes elállási jogra vonatkozó szabályokat kell alkalmazni (1394. §).

Az Mtj. alapján a vevő szavatossági panasza esetén az eladó határidő tüzésével felajánlhatta neki a vétel felbontására vonatkozó nyilatkozattételt, ami azt eredményezte, hogy a felbontás lehetőségével a vevő csak e kitüzött határidőn belül élhetett (1389. §). ${ }^{587}$

Ha több dolgot adtak el egyszerre, és azok közül csak egyes egyedek voltak hiányosak/hibásak, akkor rendszerint csak azokra vonatkozóan lehetett követelni a vétel felbontását, azonban ha mégis mint „együvé tartozókat adták el” őket, akkor bármelyik fél, akinek sértette az érdekeit a különválasztás, kérhette az egész vételre vonatkozó felbontást (Mtj. 1392. §). Ez a római jogot és a pandekta szellemü BGB rendelkezését ${ }^{588}$ idéző szabályt a korábbi joggyakorlatunk is megalapozta. Így például egy bírói döntés szerint „ha együttesen vásárolt egy pár hámos ló közül az egyik szenved olyan hibában, amelynek esetében a vételi ügylet felbontásának helye van, úgy ez a felbontás a párt képező másik egészséges lóra is kiterjed és az egész vételi ügylet felbontását vonja maga után." 589

Amennyiben több együttesen, egy összegben meghatározott vételárért eladott dolog esetén csak a konkrét hibás dolog vonatkozásában éltek a vétel felbontásának jogával, akkor az Mtj. rendelkezése alapján ,,a vételárt olyan arányban kell mérsékelni, amelyben

\footnotetext{
${ }^{584}$ SZLADITS (1933), 201. p.

${ }^{585}$ Lásd: SzLADITS (1933), 201. p. Az utóbbit az Mtj. is kimondta, lásd: 1388. § 2. mondat.

${ }^{586}$ Erre utal a G. 87/1904. (Dt. 3. f. XXVII. 128.) számú döntés is, lásd: SZLADITS - FÜRST (1935), 174. p. Ez esetleg visszavezethető az ABGB hatására.

${ }^{587}$ SzLADITS (1942), 299. p.

${ }^{588}$ Vö. BGB § 469.

${ }^{589}$ Lásd: 4706/1904. (Dt. 4. f. IV. 140.). Lásd ezen kívül: P. II. 2348/1917. (MD. XI. 227.) és 55/1917. (MD. XI. 226.) döntések, SZLADITS - FÜRST (1935), 379. p.
} 
valamennyi dolognak az eladásakor volt együttes értéke a nem kifogásolt dolgok ugyanakkori együttes értékéhez állana valamennyi dolog hiánymentessége esetén". ${ }^{590} \mathrm{Ez}$ a rendelkezés azt tükrözi, hogy a BGB vonatkozó szabályát a bírói jogalkalmazás segítésére bevezetni kívánták. ${ }^{591}$

A vétel felbontásának a jogkövetkezménye az elállással egyezően az eredeti állapot helyreállítása volt: a vevő köteles volt az eladónak visszaszolgáltatni a dolgot, az eladó pedig köteles volt a vevőnek visszaadni a kifizetett vételárat (Mtj. 1067. §). ${ }^{592}$ Köteles volt továbbá a szerződés megkötésével és a dolog átvételével kapcsolatos költségeit megtéríteni, és vissza kellett vennie a hibás dolgot, mégpedig azon a helyen, ahol a hiba kiütközött (1394. §) ${ }^{593}$ Ezzel a rendelkezéssel valószínűleg a vevő kellemetlenségektől és felesleges költségektől mentes igényérvényesítését akarta elősegíteni a jogalkotó.

A fent említett utaló szabály a törvényes elállási jogra vonatkozó rendelkezések alkalmazását rendelte el. ${ }^{594} \mathrm{Az}$ Mtj. ezek között az általános elállási szabályok között rendelkezett a mortuus redhibetur római jogból jól ismert esetéről is: az elállási jog gyakorlását nem zárta ki az, ha a dolog véletlen cselekménye folytán egészben vagy részben elpusztult vagy lényegesen rosszabbodott, valamint az sem, ha a tárgyat egészben vagy jelentős részben átalakították, és a hiányosság ezen átalakítás alkalmával tünt csak ki (1075. §). ${ }^{595}$ E rendelkezés is teljes egészében a BGB szabályát tükrözte. ${ }^{596}$

Az elállási jogot az Mtj. értelmében a vevő az eladóhoz intézett egyoldalú nyilatkozattal gyakorolhatta (1066. §). A jóhiszemű joggyakorlás elvéből fakadóan a gyakorlatban csekély jelentőségü, könnyen javítható hiba miatt továbbra sem volt helye elállásnak, hanem először is a hiány megfelelő pótlásának lehetőségét kellett biztosítania a vevőnek az eladó számára. ${ }^{597}$

A hiba jelentőségével és a vétel felbontásának jogával kapcsolatos a következő XIX. század végi jogeset. ${ }^{598}$ Az ügyben a vevők, egy asszony és a lánya alperesként, a ruhákkal kereskedő eladó pedig felperesként szerepelt. Az utóbbi azért indította a pert, mert úgy vélte, hogy az asszony nem jogszerűen élt a vétel felbontásának jogával, és

\footnotetext{
${ }^{590}$ Mtj. 1393. §. Egy számítási példához lásd: SzLADITS (1942), 300. p.

${ }^{591}$ Vö. BGB § 471, lásd: II. fejezet 2.4. pont, Rosenthal példája.

592 SZLADITS (1942), 298. p.

593 Különösen „,Fernverkauf” esetén fontos ez a szabály, de egyébként is előfordulhatott, hogy a vevő a dolgot nem a teljesítés helyén használja.

594 Mtj. 1394. § utalása az 1074-1078. §§-ra.

${ }^{595}$ SZLADITS (1942), 298. p.

${ }^{596}$ Vö. BGB §§ 350 és 467.

597 VILLÁNYI (1941), 333. p. A rendelkezés a római jogi szabályokat tükrözi: ez a „minima non curat praetor" elve.

${ }^{598}$ Lásd: 33.066/1885. döntés, SZLADITS - FÜRST (1935), 379-380. p.
} 
követelte a meg nem fizetett vételárat. Az adásvétel tárgyát két női ruha képezte, amelyek nem csak a vevő, hanem utóbb az eljárásban alkalmazott szakértők véleménye szerint sem feleltek meg a rendeltetésszerü használat követelményének, így szerintük az alperes jogosan küldte vissza az eladónak a ruhákat a vétel felbontása céljából. (A vételár ekkor még nem került kifizetésre.) A bíróság egyetértett a szakértői véleménnyel, és úgy ítélte meg, hogy az alperes vevő annak ellenére élt jogosan a vétel felbontásának jogával, hogy az eladó a ruhák visszaküldése után felajánlotta azok kijavítását, amit az alperes nem fogadott el. Az ítélet indoklása szerint az alperestől nem volt elvárható, hogy a ruhák utólagos kijavítására várakozzon, hanem jogosult volt a vételt felbontani.

Egy másik vonatkozó jogeset ugyancsak e probléma köré épült. ${ }^{599}$ Vételi szerződés jött létre egy gépre vonatkozóan, amelyet a szerződés szerint az eladó ,jó karban” tartozott átadni, valamint benne foglaltatott a megállapodásban, hogy a gép használhatóságát a hatósági kazánvizsgálat eredménye is tanúsítja. A bírósági eljárást ebben az esetben is az eladó indította, mert úgy vélte, hogy a vevő jogosulatlanul állt el a vételtől, és tagadta meg a vételár megfizetését. A bíróság véleménye szerint a fenti szerződési kikötések olyan lényegesek voltak, hogy nem teljesítésük már önmagában is feljogosította a vevőt, hogy a maga kötelezettségeit ne teljesítse, és elálljon a szerződéstől. Ezt - a bíróság érvelése alapján - akkor is megtehette, ha a szerződésben az is ki volt kötve, hogy nem lehet a vételt felbontani, mert az ilyen kikötést felülbírálja az eladó fenti szerződésszegése, a vétel tárgyának állapotában megmutatkozó hibás teljesítés ténye.

\subsection{2. Árleszállítás}

A vétel felbontása mellett a vevő másik általános szavatossági igénye a vételár leszállítása volt, amelyről az Mtj. így rendelkezett:

„Árleszállitás esetében a vételárt abban az arányban kell leszállitani, amelyben a szerzödés megkötésekor - vagy ha a vételárt későbbi idöpont szerint határozták meg, e későbbi idöpontban a dolognak hiánymentes állapotban való értéke a hiányos állapotban való értékhez állott. "600

A rendelkezés a német BGB-vel egyezően az arányos (relatív) árleszállítási módszert írja elő. ${ }^{601}$ Ennek alapján, ha például egy megvásárolt női ruha hibátlan állapotbani értéke 100

\footnotetext{
${ }^{599}$ Lásd: 173/1902. döntés, SZLADITS - FÜRST (1935), 380. p.

${ }^{600}$ Mtj. 1395. §.

${ }^{601}$ Vö. BGB § 472: „... ist der Kaufpreis in dem Verhältnisse herabzusetzen, in welchem zur Zeit des Kaufs der Wert der Sache in mangelfreiem Zustande zu dem wirklichen Werte gestanden haben würde.”.
} 
pengő, a vételár 90 pengő, a hibás állapotbani érték pedig 80 pengő volt, és X a vételárcsökkentés utáni vételár(maradvány)t jelöli, akkor a következő egyenlet vezet az árleszállítás helyes mértékéhez: $X / 90=80 / 100$, tehát $X=72$. Ez azt jelenti, hogy a vételárat 90 - 72, azaz 18 pengővel kellett leszállítani. ${ }^{602}$

Amennyiben több dolgot adtak el egy összegben meghatározott vételárért, de nem minden dolog volt kellékhibás, a vételárcsökkentés számításánál akkor is figyelembe kellett venni az összes dolog értékét (Mtj. 1397. §). ${ }^{603}$ Ugyanez volt a szabály akkor is, ha több dolgot külön-külön vételáron, de mint együvé tartozót adtak el, és a hiányos/hibás darabok csökkentették a többinek az értékét is (1397. §). ${ }^{604}$ Ennek a fenti aránypárnak a meghatározása a vétel felbontásánál szereplő szabályhoz hasonlóan valószínüleg ugyancsak az üzleti gyakorlat és a bírósági jogalkalmazás számára kívánt segítséget nyújtani.

Amennyiben a pénz mellett egyéb szolgáltatás is a vételár részét képezte, akkor az árleszállítás csak a pénzt érinthette. De ha a vételárcsökkentés mértéke a fenti számítási mód alapján kimerítené a pénzszolgáltatást, akkor az eladó köteles volt a különbözetet (pénzben) megtéríteni a vevő részére (Mtj. 1397. §). Az Mtj. úgy rendelkezett, hogy a valamely konkrét hiba illetve hiányosság miatt érvényesített árleszállítás nem zárja ki a vevő jogát arra, hogy a későbbiekben jelentkező más hiba vagy hiányosság esetén újra érvényesítse valamelyik szavatossági jogát (1399. §). ${ }^{605}$

A korábbi joggyakorlatnak megfelelően, ha a hiba csak az adásvétel tárgyának értékére volt hatással, azonban annak ellenére a dolog a vétel céljának megfelelt, akkor a vevő nem követelhette a vétel felbontását, hanem csak árleszállítás iránti igényével élhetett. ${ }^{606}$

\subsubsection{Hiánymentes dolog szolgáltatása fajlagos vétel esetén}

A fajlagos vétel esetén érvényesíthető kicserélést illetően az Mtj. utaló szabályokat adott a vétel felbontására vonatkozó rendelkezésekre. ${ }^{607}$ Ezek alapján az eladónak a hiánymentes dolog szolgáltatásának (kicserélésnek) a szavatossági igénye esetén is megvolt az a lehetősége, hogy a nyilatkozattételre vonatkozó határidő tűzésével felajánlja a vevőnek a

\footnotetext{
${ }^{602}$ Konstruált példa. Az aránypárokhoz lásd: SzLADITS (1942), 302. p.

${ }^{603} \mathrm{Ez}$ is a BGB szabályának átvétele volt, vö. BGB $§ 472$.

${ }^{604}$ Lásd: SzLADITS (1942), 303-304. p.

${ }^{605}$ Ez a szabály is a római jogi megoldást idézi.

${ }^{606}$ Lásd: 51/78/1897. döntés, SZLADITS - FÜRST (1935), 373. p.

${ }^{607}$ Lásd: Mtj. 1400. § utalása az 1389., 1392., 1398. és az 1399. §§-ra.
} 
hiánymentes áru szolgáltatását. Ugyanúgy érvényesült kicserélés esetén is az, hogy ha az együttesen és egy vételárért eladott több dolog közül nem mindegyik volt hibás illetve hiányos, akkor általában csak a hibásak vonatkozásában élhetett a vevő a kicserélés jogával. Azonban ha bármelyik fél érdeke megkívánta, akkor a dolgok összességére nézve is gyakorolhatta azt. Ezen kívül a kicserélési jognak valamely hiba miatti érvényesítése nem gátolta azt, hogy egy később kiütközö hiányosság miatt ugyanezzel az igénnyel éljen a vevő. A vevő e jog érvényesítése mellett követelhette a késedelmes teljesítésből eredő kárának megtérítését is (Mtj. 1400. §). ${ }^{608}$

\subsubsection{Kártérítés}

A jogtudomány meghatározása szerint a kártérítés egyik fajtája az ún. „másodlagos kártérítés”, ami az adós, azaz a szerződéses kötelezett vétkességén (felróható magatartásán) alapul. ${ }^{609}$ Másodlagos volt, mert a kötelem nem eredendően irányult a kártérítésre, hanem az adós kötelemszegéséből fakadt ez az igény. ${ }^{610} \mathrm{~A}$ kötelmi jogi részben úgy rendelkezett az Mtj., hogy a kötelezettsége nemteljesítésével illetve megszegésével okozott károkat a kötelezett a körülményekre és a felek vagyoni viszonyaira tekintettel a méltányosság követelményének megfelelően, arányosan köteles megtéríteni. ${ }^{611} \mathrm{Az}$ eladó hibás teljesítésben megnyilvánuló szerződésszegéséből is származhatott kára a vevőnek, az azonban az Mtj. megalkotásakor vita tárgyát képezte, hogy a kártérítés szerepeljen-e egyáltalán a szavatossági igények között. ${ }^{612}$ Végül így rendelkezett az adásvétel kellékhibás teljesítéséből fakadó kártérítésről az Mtj.:

„Ha az eladó a dolog hiánymentességéért jótállott vagy a hiányt a vevö elöl csalárdul elhallgatta, vagy ha a hiány az eladót terhelö teljesitési kötelezettség oly megsértéséböl ered, amely az eladó terhére róható: a vevö a dolog hiányosságára tekintettel nemteljesités miatt kártéritést követelhet. A vevö, akit ily kártérités megillet, vagy ezt a jogát, vagy az elöbbi §-ban megállapitott jogok valamelyikét gyakorolhatja. , 613

A kártérítési jogosultság ezek szerint vagylagosan, a többi szavatossági jog helyett, és nem azok mellett illette meg a vevőt. A hiánymentességért fennálló eladói helytállásnak a

\footnotetext{
${ }^{608}$ Lásd: SZLADITS (1942), 306. p.

${ }^{609}$ SZLADITS (1933), 67. p.; TÓTH (1938), 124. p.

${ }^{610}$ SZLADITS (1933), 67. p.

${ }^{611}$ Mtj. 1149. §. Az Mtj. a modern magánjogi dogmatika szerinti szerződésszegéssel okozott károkról rendelkezett.

${ }^{612}$ Lásd: TÓTH (1938), 317. p.

${ }^{613}$ Mtj. 1386. §.
} 
fentiek értelmében ez lett a szubjektív, azaz az eladó felróható magatartásán alapuló jogkövetkezménye. A vétlenség bizonyítása az eladó feladata volt, azaz az ún. exkulpációs rendszer érvényesült a gyakorlatban (fordított bizonyítási teher). ${ }^{614}$ A bírói gyakorlat azon az állásponton volt, hogy a magánjogban a károsító fél vétkességének foka - azaz szándékossága illetve gondatlansága - közömbös a kártérítés mértékét illetően, annak megállapításánál egyedül a károsult vagyoni érdeke lehet mérvadó. ${ }^{615} \mathrm{Az}$ is általános elv volt a joggyakorlatban, hogy a károsító félnek olyan helyzetbe kellett hoznia a károsultat, mint amilyenben a károkozás előtt volt. ${ }^{616} \mathrm{Az}$ Mtj. általános kártérítési szabályainak értelmében a vevő mindazon vagyoni kárnak a megtérítését követelhette, amely a hibás teljesítésből közvetlenül vagy közvetve keletkezett (1111. §). Az „elmaradt nyereség” annyiban volt megtérítendő, amennyiben az a „dolgok természetes rendjére”, az adott körülményekre és a megtett intézkedésekre figyelemmel várható, előre látható volt (1111. §). ${ }^{617} \mathrm{Az}$ elmaradt haszon vonatkozásában sem volt mérvadó a felróhatóság foka: a gondatlanul kárt okozót is kötelezhették annak megtérítésére. ${ }^{618}$ Nem ítélte viszont méltányosnak a bírói gyakorlat az elmaradt haszon követelését, ha a jogosult irreálisan hosszú ideig késlekedett a kártérítési igénye érvényesítésével. ${ }^{619}$

A gyakorlat szerint a kártérítés elsődleges módja a pénzbeli reparáció volt, és ezt építette be szabályozásába az Mtj. is (1113. §). ${ }^{620}$ Ha azonban helyettesíthető dolog pusztult el a hibából fakadóan, akkor a kártérítés keretében követelhető volt az ugyanolyan dolog természetben való szolgáltatása is, ${ }^{621}$ ami eredményét tekintve tulajdonképpen megegyezett a kicserélés szavatossági igényével. Ezzel összefüggésben már egy 1919-es bírói ítéletben kimondták, hogy a kétoldalú szerződések esetén a feleknek elsősorban a szerződés teljesítésére van igényük, és ha szerződést szeg valamelyik fél, akkor a másik fél kártérítést csak másodsorban követelhet, akkor, ha a szerződésszerü teljesítés lehetetlenült. ${ }^{622}$ Az Mtj. általános kártérítési szabálya alapján a vis maior következtében

\footnotetext{
${ }^{614}$ SZLADITS (1933), 67. és 106. p.

${ }^{615}$ SZLADITS - FÜRST (1935), 141. p. hivatkozása a 3849/1916. (MD. XI. 11.) döntésre. Ez ellenkezett a korábbi ABGB-n alapuló megközelítéssel.

${ }^{616}$ SZLADITS - FÜRST (1935), 141. p. hivatkozása a 7091/1917. (MD. XII. 115.) döntésre.

${ }^{617}$ Ezt a bírói gyakorlat is igazolta, lásd: SzLADITS - FürST (1935), 150. p. hivatkozása a P. II. 7999/1929. (Grill XXIV. 582.) döntésre.

${ }^{618}$ Lásd: SZLADITS - FÜRST (1935), 148. p. hivatkozása az 193/1897. döntésre.

${ }^{619}$ Lásd: SZLADITS - FÜRST (1935), 162. p. hivatkozása az 2456/1913. (Gr. XV. 497.) döntésre.

${ }^{620}$ Lásd többek között: SzLADITS - FÜRST (1935), 154. és 155. p. hivatkozása a P. IV. 6063/1922. (MD. XVI.

98.) és az 5840/1924. (Gr. XIX. 579.) döntésekre.

${ }^{621}$ SZLADITS - FÜRST (1935), 154. p. hivatkozása a P. II. 2103/1922. (MD. XVI. 87.) döntésre.

${ }^{622}$ Lásd: 469/1919. döntés, SZLADITS - FÜRST (1935), 177. p.
} 
beálló kár megtérítésére csak az az eladó volt köteles, akit szándékosság vagy súlyos gondatlanság terhelt (1111. §).

\subsection{Jótállás}

A joggyakorlatban az az elv érvényesült, hogy ha az eladó az adásvétel tárgyának valamely tulajdonságáért ún. „garanciaszerződésben” külön jótállást vállalt, azért akkor is helyt kellett állnia, ha annak teljesítése lehetetlenült. ${ }^{623}$ Ilyenkor az adásvételi szerződés maga nem lett érvénytelen, azonban - mivel szerződésszerü teljesítés értelemszerüen már nem volt követelhető - kártérítéssel, pozitív interesse megfizetésével tartozott az eladó a vevőnek. ${ }^{624}$ A pozitív interesse római jogból ismert fogalma a teljesítési érdeket jelentette, és a mértékét elsősorban az szabta meg, hogy mekkora lett volna a szolgáltatás értéke, ha lehetséges lett volna azt teljesíteni. ${ }^{625}$ A bírói gyakorlat szerint a jótállás esetén az eladó csak akkor nem tartozott helytállással, ha a vevő ismerte a hibát. Ha azonban azt a vevő a saját súlyos gondatlansága miatt nem ismerte, akkor is helyt kellett állnia az eladónak. ${ }^{626}$

Mivel az Mtj. a kifejezetten kikötött tulajdonságok hiányára, hibájára nézve is a kellékszavatossági szabályokat rendelte alkalmazni, nem szólt külön a jótállás intézményéröl. $^{627}$

\subsection{A vevö felróható közrehatása}

A vevőnek a szerződés teljesítésével és szavatossági igényérvényesítésével kapcsolatos magatartásáról az Mtj. nem tett említést, de a korabeli bírói gyakorlatban fellelhetőek ehhez kapcsolódó megállapítások is. Egy 1904-es jogeset szerint „az alperesek annak ellenére, hogy a felperes szerelője által véghezvitt javítási munkák befejezése után meggyőződtek arról, hogy a javítási kísérletek eredményre nem vezettek, mindamellett a géppel tovább is kísérleteztek és arra sikertelen költséget fordítottak, ahelyett, hogy felperest a gép rosszaságáról ismételve értesítették volna" ${ }^{628}$ A bíróság szerint a

\footnotetext{
${ }^{623}$ SZLADITS (1933), 23. p.

${ }^{624}$ Lásd: SZLADITS (1933), 23. p.

${ }^{625}$ SZLADITS (1933), 23. p.

${ }^{626}$ A BGB kikötött tulajdonságaira vonatkozó szabályával egyezően (vö. BGB § 460), lásd: 1891/1917. (MD. XI. 159.) és P. IV. 698/1928. (PHT. 848.) döntések, SZLADITS - FÜRST (1935), 372-373. p.

${ }^{627}$ Ebben a korszakban a dolog valamely tulajdonságára, minőségére vonatkozó kifejezett eladói ígéret minősült a mai értelemben vett jótállásnak, ami tehát dogmatikailag még nem különült el a kellékszavatosságtól.

${ }^{628}$ G. 87/1904. (Dt. 3. f. XXVII. 128.) döntés.
} 
tevékenységük során felmerült káraikat és költségeik megtérítését a felperestől nem követelhették jogszerüen. Ez azt mutatja, hogy a vevőtől is elvárták a tisztességes és ésszerű eljárást az igényei érvényesítése során, ${ }^{629}$ ami a caveat emptor ókori elvének továbbélését tükrözi.

A vevő körültekintő eljárásának követelményét mutatja az a jogeset is, amelyben az adásvétel tárgya „síma amerikai szőlővessző” volt, és amelynek oltásra alkalmatlan volta a bíróság álláspontja szerint - az adásvétel megkötésekor puszta megtekintéssel is megállapítható lett volna. ${ }^{630}$ Ennek fényében az ítéletben elutasították a vevő szavatossági jogainak érvényesítését, illetve a kártérítésre vonatkozó követelését is.

\subsection{Igényérvényesitési határidők}

„A szavatossági hiány miatt támasztható követelések ingó dolog tekintetében hat hónap, ingatlan tekintetében egy év alatt évülnek el.

E határidöt ingókra nézve a kiszolgáltatás [...] idöpontjától kell számítani és szerzödéssel a rendes elévülési idö tartamáig meg lehet hosszabbitani... "631

Az Mtj. szavatossági határideje tehát ingó esetén 6 hónap volt, de mivel ez diszpozitív rendelkezés volt, lehetőség volt a szerződéses meghosszabbításra, amely legfeljebb az általános elévülési idő tartamára, azaz 32 évre szólhatott. ${ }^{632}$ A határidő szerződéses megváltoztatása esetén az Mtj. úgy rendelkezett, hogy a szavatossági hiánynak a kikötött határidőn belüli kiütközése esetén helytállással tartozik az eladó (1402. §). A határidő elvülési jellegét mutatja, hogy az Mtj. rendelkezett annak félbeszakadásáról is: az nem csak az igényérvényesítés, hanem már a hiány megállapítása végett kezdeményezett bizonyítási eljárás kérelmezése esetén is félbeszakadt, és az eljárás befejeztével vette újra kezdetét (1403. §). A határidő keresetindítás miatti félbeszakadása után a per jogerős befejezése, illetve ha az eljárás szünetelt, akkor a felek vagy a bíróság utolsó perbeli cselekménye után, vagy az esetlegesen elmulasztott perfelvételi vagy tárgyalási határnappal kezdődött újra az elévülés. ${ }^{633}$

Amennyiben a vevő az elévülési időn belül értesítette az eladót a kellékhibáról, akkor a hibás teljesítésből fakadó jogainak az elévülése esetén is érvényesíthette a hiányra vonatkozó panaszát kifogásként (1404. §).

\footnotetext{
${ }^{629}$ Lásd: SZLADITS - FÜRST (1935), 174. p.

${ }^{630}$ Lásd: 5949/1901. (Dt. 3. f. XXII. 40.), SZlaDITS - FÜRST (1935), 372-373. p.

${ }^{631} \mathrm{Mtj} .1401 . \S$

${ }^{632}$ Vö. Mtj. 1283. §. A rövid határidők harmonizáltak az ABGB és a BGB szabályaival.

${ }^{633}$ Lásd: Mtj. 1403. § utalása az 1301., 1302. és 1309. §§-ra.
} 
A szavatossági hiba miatt érvényesített kártérítési követelésröl a nemteljesítés miatti kártérítésként rendelkezett az Mtj. (1386. §), ${ }^{634}$ ebből következően az ilyen kártérítés érvényesítésére a szerződésszegésekre általában irányadó általános 32 éves elévülési idő állt nyitva. ${ }^{635} \mathrm{Ha}$ az eladó csalárdul elhallgatta a kellékhibát, akkor az abból eredő kártérítési igény értelemszerűen ugyancsak a rendes elévülési idő alatt évült el.

A határidőhöz kapcsolódóan meg kell jegyezni, hogy sem az Mtj.-t megelőző gyakorlat nem igazolta, és az azt követö joggyakorlat sem követte az elévülés tekintetében az Mtj. rövid kellékszavatossági igényérvényesítési határidőit, hanem az általános elévülési időt vették figyelembe. ${ }^{636}$ A jogtudományban azonban elfogadott volt az az álláspont, hogy a vevő a jogai gyakorlásakor nem hagyhatta sokáig bizonytalanságban az eladót; ha mégis így tett, akkor az eladó joggal feltételezhette, hogy a vevőnek többé már nincs (és nem is lesz) szavatossági követelése: ezért ilyenkor a szavatossági igények elenyésztek. ${ }^{637} \mathrm{Az}$ igényérvényesítéssel való késlekedés elfogadható okának tekintették azonban, ha a hiba nem azonnal ütközött ki, illetve nem volt azonnal felismerhetö, vagy ha a felismerés különleges, hosszabb vizsgálatot kívánt. ${ }^{638}$

Az igényérvényesítés során a vevőnek kellett bizonyítania a hibát, és azt, hogy az fennállt már az átadáskor is, ${ }^{639}$ valamint valószínűsítenie kellett azt is, hogy jogai érvényesítésével nem késlekedett indokolatlanul. ${ }^{640} \mathrm{Ez}$ csak az objektív jogalapú kellékszavatossági és a hiánymentességért vállalt jótállásból fakadó kártérítési igénynél volt így, ugyanis ha az eladó csalárdul járt el, akkor megfordult a bizonyítási teher. ${ }^{641}$ Kártérítési igény bírósági érvényesítése esetén az alperes eladó tagadásával szemben a felperes vevőnek kellett bizonyítania, hogy a keresetben foglalt mulasztások és tények valóban fennállnak, és hogy az ő károsodása ezeknek az okszerü következménye volt. ${ }^{642}$

\footnotetext{
${ }^{634}$ Mtj. 1386. §.

${ }^{635}$ Lásd: 1401. és 1283 . $§$.

636 TÓTH (1938), 322. p.; SZLADITS (1933), 200. p.

${ }^{637}$ ViLLÁNYi (1941), 333. p.; SZLADiTS (1933), 200-201. p.; TÓTH (1938), 322. p.

${ }^{638}$ VILLÁNYI (1941), 334. p.

${ }^{639}$ Lásd: I. G. 651/1901. (Dt. 3. f. XXII. 178.) döntés, SZLADITS - FÜRST (1935), 372. p.

${ }^{640}$ ViLLÁNYi (1941), 334. p.

${ }^{641}$ Lásd fent.

${ }^{642}$ 4502/1905. (MD. I. 16.) döntés, lásd: SZLADITS - FÜRST (1935), 140. p.
} 


\subsection{Elhatárolási kérdések}

Amennyiben a kellékszavatosságot megalapozó tények bizonyos más kötelmi igények tényállását is megvalósították, akkor a vevő e jogaival is élhetett. ${ }^{643}$ Így ha a hiba/hiány az eladó vétkes késedelme folytán keletkezett, a vevő követelhette a késedelemből eredő kárának megtérítését is; ezt a szabályt az Mtj.-be is beépítette a jogalkotó. ${ }^{644}$

A szerződéskötéskor már meglévő hiba csalárd elhallgatásakor a magánjog szabályai szerint a vevő megtévesztés áldozata lett, így a szerződést ez alapján megtámadhatta. ${ }^{645}$ A kötelmi általános szabályok szerint akkor volt tévedésben a dolog lényeges tulajdonsága tekintetében, ha nem ismerte és nem is ismerhette a hibát a szerződéskötéskor. ${ }^{646} \mathrm{Ha}$ azonban a tévedést nem az eladó okozta, akkor a lex specialis derogat legi generali elve érvényesült, és tévedésből eredő jogait a vevő nem érvényesíthette. ${ }^{647}$ A szerződést csak akkor támadhatta meg tévedés címén, ha a hiány/hiba miatt a dolog egészen más volt, mint aminek a vevő hitte, azaz ha aliud volt a szolgáltatás. ${ }^{648}$ Ilyenkor is kizárta azonban ezen igény érvényesítése a szavatossági jogok egyidejü követelését. ${ }^{649}$

\subsection{Allatszavatossági szabályok}

$\mathrm{Az}$ állatszavatossággal kapcsolatban a speciális hibák és a rendelkezések részben igazgatási jellege miatt már az 1900-as polgári törvénykönyv tervezet megalkotása során felmerült az igény a külön törvényi szabályozásra. ${ }^{650}$ Az ABGB szabályozása hatott leginkább az állatszavatossági jogesetek megítélésére, de a Kúria már a XX. század elején helytelenítette az ABGB elavult rendelkezéseire való hivatkozást állatszavatossági kérdésekben. ${ }^{651}$ A XX. század eleji bírói gyakorlat szerint - ehhez igazodva - az eladó

\footnotetext{
${ }^{643}$ VILLÁNYi (1941), 333. p.

${ }^{644}$ Lásd: Mtj. 1400. § és 1151-1164. §§.

${ }^{645}$ VILLÁNYI (1941), 333. p.

${ }^{646}$ VILLÁNYI (1941), 333. p.

${ }^{647}$ VILLÁNYI (1941), 333. p.; SZLADITS (1942), 284. p.

${ }^{648}$ VILLÁNYI (1941), 333. p.

${ }^{649}$ VilLÁNYi (1941), 333. p.

${ }^{650}$ Lásd: A Polgári Törvénykönyv törvényjavaslatának tárgyalása a képviselöház külön bizottságában (1915), 38. és 92. p.

${ }^{651}$ Lásd: A Polgári Törvénykönyv törvényjavaslatának tárgyalása a képviselöház külön bizottságában (1915), 38. p.
} 
szavatolt az eladás idején már fennálló minden rejtett és külsőleg fel nem ismerhető hibáért, arra való tekintet nélkül, hogy az föhibának minősült-e vagy sem. ${ }^{652}$

A kodifikáció hiánya nagy jogbizonytalanságot szült, mert bár a Kt. szabályai elvben vonatkoztak az állatszavatosságra is, gyakoriak voltak a kereskedelminek nem minősülő állat-adásvételek is. Az 1913-as polgári törvénykönyv tervezetének képviselőházi vitájakor Issekutz Győző úgy vélekedett, hogy a vásárokon lebonyolódó ügyleteket nem szabad általánosan kereskedelminek titulálni:

„Például vesz [ti. egy földműves] a családja részére igásmarhát. Ez nem kereskedelmi ügylet. Az ilyen ügyleteknek kereskedelmivé minősítése a kevésbbé jártas embert a furfangos kereskedő kapzsiságának, haszonlesésének, esetleg kizsákmányolásának tenné ki, ami nem lehet a törvényhozás feladata." ${ }^{653}$

A jogalkotó a megelőző jogértelmezési vitáknak és a joggyakorlatban felmerülő bizonytalanságoknak véget vetve az 1923. évi X. törvénycikkben rendezte az állatszavatosság kérdését. ${ }^{654} \mathrm{Az}$ állatok adásvétele hazánk mezőgazdasági berendezkedése miatt is fontos jogügylet volt. A törvénycikk hatálya alá a ló, szamár, öszvér, szarvasmarha, bivaly, juh, kecske és sertés adásvétele és cseréje tartozott, ${ }^{655}$ valószínűleg azért, mert ezek voltak a leggyakoribb adásvételi tárgyak, és a legjelentősebbek a mezőgazdasági termelésben.

\subsubsection{Hibafogalom}

Az eladott állatok kellékhibáit két kategóriára bontotta a törvény (az ABGB-ből átvett hagyományoknak és a BGB-nek megfelelően). Az ún. főhibákat minisztériumi rendelet határozta meg, ${ }^{656}$ és ezen kívül a törvénycikk hatálya alá tartoztak azon hibák is, amelyek „következtében az állat a szavatossági idő alatt elhullott vagy leöletvén, hatósági intézkedés miatt a vételárban kifejezett értékét legalább egynegyed résznél nagyobb mértékben elvesztette vagy pedig a hiba oly természetü, hogy az állat értékét vagy

\footnotetext{
${ }^{652}$ Lásd többek között: 308/1909. (MD. III. 163.) és Budapesti Tábla 1071/1918. (MD. XII. 177.) számú döntések, SZLADITS - FÜRST (1935), 375-376.

${ }^{653}$ A Polgári Törvénykönyv törvényjavaslatának tárgyalása a képviselőház külön bizottságában (1915), 26-27.

${ }^{654}$ 1923. évi X. törvénycikk az állatforgalmi szavatosságról, a továbbiakban: 1923. évi X. tc. Elérhető: http://1000ev.hu/index.php?a=3\&param=7550 (2013. november 25.). A kérdéskörhöz részletesen lásd: SZLADITS (1942), 309-327. p.

${ }_{655}$ 1923. X. tc. 1. §.

${ }^{656}$ Az 1934/1923. M. E. sz. rendelet.
} 
rendeltetésszerü használhatóságát egyébként tetemesen csökkenti vagy kizárja”. ${ }^{657}$ Mindkét kategória esetében az állat átadásakor már meglévő jelentős betegségre, illetve hibára nézve szavatolt az eladó. ${ }^{658}$ Az állat rendeltetésszerű használhatóságát érintő hibával kapcsolatos jogesetben a bíróság megállapította, hogy ha a vevő az eladó által tudottan mezőgazdaságban használható és „tenyészképes” lovakat kívánt venni, az eladó azonban a lovak életkorát ismerve tudta, hogy erre a célra nem alkalmasak, és ezt mégis elhallgatta, a vevő élhetett a vétel felbontásának jogával. ${ }^{659}$

\subsubsection{Föbb eltérések az általános szavatossági szabályokhoz képest}

Állatszavatosság esetén nem volt helye árleszállításnak, hanem csak a vétel felbontásának, de fajlagos vétel esetén itt is követelhetett másik, hibátlan állatot a vevő. ${ }^{660}$ Mindkét igény helyett, vagylagosan a kártérítésnek is helye volt, ha az eladó csalárdul elhallgatta a hibát, vagy a hibátlanságért jótállott, valamint ha az állat konkrétan kikötött tulajdonsága hiányzott. $^{661}$

A törvény kettős határidőről rendelkezett. A törvényes szavatossági határidő a kellékhiba jelentkezésének határideje volt: az átadástól számított 6 héten belül kellett a kellékhibának kiütköznie az állatban. ${ }^{662}$ Ha azonban az eladó csalárdul elhallgatta a hibát, akkor ez a rövid határidő nem érvényesült. ${ }^{663}$ Az igényérvényesítésre a szavatossági idő leteltétől számított 15 napos elévülési határidő állt a vevő rendelkezésére, a rövid határidő lejárta után is lehetőség volt azonban kifogásként hivatkozni a hibára. ${ }^{664}$ „Csalás”, azaz az eladó csalárdsága e határidő-szabályozásánál is megtorlást nyert: ilyen esetben a rendes elévülési idő alatt érvényesíthette jogait a vevő. ${ }^{665}$

A vonatkozó miniszteri rendelet által konkretizált ún. (megdönthetö) vélelmi időszak az állat adott betegségének természete szerint 3-30 napig tartott: az e határidőkön belül jelentkező főhibát - ellenkező bizonyításig - az átadáskor már meglévőnek

\footnotetext{
${ }^{657}$ 1923. X. tc. 2. §.

658 1923. X. tc. 2. §; SZLADITS (1942), 309-310. és 312. p.

${ }^{659}$ Lásd: P. II. 513/1927. (Grill XXI. 746.) döntés, SZLADITS - FÜRST (1935), 377. p.

${ }^{660}$ 1923. X. tc. 6. §. Ez a BGB szabályozásának felelt meg, vö. BGB $§ \S ~ 485,487$.

661 1923. X. tc. 14. §.

662 Azonban a határidő lejárta után is lehetődés volt kifogásként hivatkozni a hibásságra, vagy beszámítani azt, lásd: 1923. X. tc. 17. §.

663 1923. X. tc. 2 . .

${ }^{664} 1923$. X. tc. 16-17. §§. Ez általában akkor volt releváns, ha a vevő a vételárat még nem vagy nem teljesen egyenlítette ki.

${ }^{665} 1923$. X. tc. 16. § utolsó mondat.
} 
vélelmezték. ${ }^{666}$ Erre a vélelemre azonban csak akkor lehetett hivatkozni, ha a vevő a határidő lejártát követő 3 napon belül értesítette az eladót, vagy a hibát a községi elöljáróságnak bejelentette, vagy állatorvosi vizsgálat történt; mindezekre ellenére is fennállt a vélelem, ha az eladó a hibát csalárdul elhallgatta. ${ }^{667}$

A törvény csak írásbeli szerződésben tette lehetővé a szavatosságnak a fö- és mellékhibákon kívüli hibára való kiterjesztését, a szavatossági idő rövidítését vagy meghosszabbítását, valamint a szavatossági helytállás korlátozását és kizárását. ${ }^{668} \mathrm{Az}$ utóbbi esetben azonban hatálytalan volt a kikötés, ha az eladó a hibát a vevő elöl csalárdul elhallgatta. ${ }^{669}$ A törvény többi rendelkezése lényegében azokat az általános szavatossági szabályokat tükrözte, amelyek később az Mtj.-ben szerepeltek.

\subsection{Exkurzus: „szédelgő feldícsérés (reklámszédelgés) „670}

Érdekességképp érdemes szólni a tisztességtelen versenyről szóló 1923. évi V. törvénycikkről, illetve annak vonatkozó fejezetéről. Ez a jogszabály jóval a modern piacgazdaság kialakulása előtt már olyan tényállásokat tartalmazott, amelyek megvalósulása részben a tisztességes gazdasági verseny sérelmét, részben pedig a vevők érdekeinek sérelmét okozhatta.

Rendelkezett többek között az ún. „szédelgő feldícsérésről”, más néven „reklámszédelgésröl” is. ${ }^{671}$ A törvény meghatározása szerint ennek minősült, „, ha áru forgalomba hozatalánál a kelendöség fokozására alkalmas olyan adatokat közölnek, illetve terjesztenek, amelyek a valóságnak nem felelnek meg, és megtévesztésre alkalmasak”. ${ }^{672}$ Ezen kívül reklámszédelgés volt a valóságnak megfelelö adat olyan híresztelése, amelynek a szokásos figyelem mellett a valóságnak meg nem felelő értelmet lehet tulajdonítani. ${ }^{673}$ „Szédelgő feldícsérés” volt az is, ha az árut a valóságnak meg nem felelő olyan jelzéssel vagy csomagolással hoztak belföldön forgalomba, amely alkalmas

\footnotetext{
${ }^{666}$ Lásd: 1923. X. tc. 3. §; VILLÁNYI (1941), 334. p. A korábbi bírói gyakorlat általában 8 napos vélelmi időszakot alkalmazott, lásd: 5437/1908. (PHT. 116., MD. III. 178.), SZLADITS - FÜRST (1935), 375. p.

${ }^{667}$ Lásd: 1923 . X. tc. 3. §.

668 1923. X. tc. 2. § utolsó mondat; 16. § 2. mondat.

669 1923. X. tc. $15 . \S$

${ }^{670}$ A tisztességtelen versenyről szóló 1923. évi V. törvénycikk (a továbbiakban: 1923. évi V. tc.), II. fejezet: „Az üzleti tisztesség szabta korlátoknak egyes fontosabb áthágásai”, 2-6. $\S$. Elérhető: http://1000ev.hu/index.php?a=3\&param=7545 (2013. 11. 25.).

${ }^{671}$ A törvény és a „,szédelgő feldicsérés” tényállásának magyarázatához lásd: KUNCZ - BALÁs (1924), 32-41.

p. 672 1923. évi V. tc. 2. §.

${ }^{673}$ 1923. évi V. tc. 2. §.
} 
arra, hogy külföldön készült áru belföldi árunak, vagy belföldön készült áru külföldi árunak a látszatát keltse. ${ }^{674}$ Ezek a fenti magatartások az „üzleti forgalom szabta korlátok fontosabb áthágásának" minősültek.

A törvénycikk a „szédelgő feldícsérésről” a szabályozott büntetőjogi tényállások körében is rendelkezett. E szerint vétséget követett el az:

„,aki abból a célból, hogy valamely árú (szolgáltatás) kelendöségét fokozza, vagy másnak üzleti közönségét elvonja, nyilvános hirdetésben, nyilvános ajánlatban vagy a személyek nagyobb körének szánt egyéb közleményben (irrásban, élöszóval vagy bármely más módon) vagy az árúkon vagy azok burkolatán jobb tudomása ellenére valótlan és megtévesztésre alkalmas olyan ténybeli adatot vagy kifejezést használ, amely az árúnak (szolgáltatásnak) minöségére, az érték tekintetében mértékadó tulajdonságára, szerkezetére vagy szabadalmazott voltára, elöállitási módjára, az üzem, az üzlet vagy az árúkészlet nagyságára, az árú eredetére (származási helyére), a beszerzés forrására vagy módjára, az eladás módjára, alkalmi okára vagy céljára, a közzétett ár megszabására, az üzleti vagy fizetési feltételekre, vagy a vállalat vagy tulajdonosa által elnyert kitüntetésre, vagy más személyi, üzemi vagy üzleti ténykörülményre vonatkozik."675

Az elkövetési magatartásokat magában foglaló taxatív felsorolásban főként az árura, azon belül is az annak minőségi tulajdonságaira vonatkozó megtévesztésre alkalmas tájékoztatás kapott nagy hangsúlyt. Úgy vélem, hogy ezek a „tájékoztatási hiányosságok” egytől egyig megalapozhatták az ingó áru eladójának magánjogi értelemben vett hibás teljesítését, és az azért fennálló kellékszavatossági helytállását is.

\section{Összefoglalás}

A fejezetben vizsgált időszak kezdetén az adásvétel kellékhibás teljesítésének kérdésében a hazai jogfejlődésre és a jogtudományi megfontolásokra hatottak az osztrák magánjog vonatkozó szabályai, de nagy zavart okozott a kodifikáció hiánya a hibás teljesítés illetve annak centrális jogintézménye, a kellékszavatosság megítélésében. A helyzetet segítette az 1875. évi Kt. megalkotása, amelynek a kellékhibás teljesítésre vonatkozó rendelkezéseit azonban csak analógia útján lehetett a kereskedelmi vételnek nem minősülő ingó adásvételi ügyletekben alkalmazni.

A XX. század elején két elvetett magyar polgári törvénykönyv-tervezet után 1928ra készítették el a Magánjogi Törvényjavaslatot a magyar jogalkotók. Az Mtj. nagyban tükrözte a kellékhibás teljesítésre vonatkozó korábbi magyar bírói gyakorlatot, és annak

\footnotetext{
${ }^{674}$ 1923. évi V. tc. 4. §.

675 1923. évi V. tc. 16 . $\$$.
} 
ellenére, hogy nem lépett hatályba, szabályai a megalkotása utáni időszakban nagy hatást gyakoroltak a bírói jogalkalmazásra. A kellékhibás teljesítésre vonatkozó rendelkezések (a visszterhes szerződésekre is kiterjedő hatállyal) az adásvétel jogában kaptak helyet az Mtj.ben, és e rendszerbeli elhelyezés mellett a kérdéskör szabályozási koncepciója és részletes rendezése is a pandekta-jog és a BGB hatását mutatja.

A következő fejezetben tárgyalt korszak üdvözlendő eredménye a magyar jogalkotásban, hogy a kellékhibás teljesítés szabályai a bemutatott több mint száz éves jogfejlödést követően a magyar polgári jogi kódexben váltak minden visszterhes szerződésre kiterjedő, hatályos törvényi rendelkezésekké. 


\section{AZ INGÓ ADÁSVÉTEL HIBÁS TELJESÍTÉSÉNEK SZABÁLYOZÁSI TÖRTÉNETE A POLGÁRI TÖRVÉNYKÖNYV HATÁLYBA LÉPÉSÉTŐL AZ EZREDFORDULÓIG}

\section{Bevezetés}

A második világháborút megelőző hosszú magánjogi kodifikálási folyamat eredményeként született tervezetek közül egyik sem lépett hatályba, így a hibás teljesítés és annak központi jogintézménye, a kellékszavatosság a Polgári Törvénykönyvről szóló 1959. évi IV. törvényben ${ }^{676}$ materializálódott elöször hatályos magánjogi szabályként. Ez a fejezet a hibás teljesítés szerződésszegési esetkörét, és az ahhoz kapcsolódó jogintézmények - a kellékszavatosság, a jótállás és a kártérítés - történetét mutatja be a Ptk. hatályba lépésétől a hatályos szabályozásig. A fejezet célja, hogy rávilágítson olyan dogmatikai és gyakorlati kérdésekre, amelyek a szabályozásban és a jogalkalmazás területén minduntalan felkeltették a jogtudomány képviselőinek érdeklődését és vitakedvét. A dolgozat szűkebb témájához igazodóan az ingó adásvételi szerződés kerül a középpontba a jogintézmények bemutatásakor, ezen belül is az ún. kiskereskedelmi vételek, amelyekben a vásárló a saját használatára szerződést kötő átlagember, az eladó pedig valamilyen kereskedelmi vállalat, vagy üzletszerűen tevékenykedő személy volt. ${ }^{677}$

\section{Az 1959. évi IV. törvény megalkotásának előzményei}

A második világháborút követően hazánkban - szovjet nyomásra - megindult a szocialista állam, a „népi demokrácia” rendszerének kiépítése. Többek között ezt a célt szolgálta az a jogalkotási folyamat is, ami a Magyar Népköztársaság Polgári Törvénykönyvének, az 1959. évi IV. törvénynek a megalkotásához vezetett. $\mathrm{Az}$ 1956. július 18-21-ei párthatározatok szerint az állami, társadalmi és gazdasági élet minden jogi szabályozást kívánó területén átfogó törvénykönyvek a legalkalmasabbak a jogbiztonság megteremtésére. ${ }^{678}$ A Polgári Törvénykönyv megalkotása a társadalmi-gazdasági viszonyok nagyon széles körének szabályozása mellett azért is volt rendkívül jelentős, mert

\footnotetext{
${ }^{676}$ A továbbiakban: Ptk. Az 1959-es eredeti szövege elérhetö: http://1000ev.hu/index.php?a=3\&param=8428 (2013. november 27.).

${ }^{677}$ A Ptk. megalkotása után csaknem húsz évvel született belkereskedelemről szóló 1978. évi I. törvény 7. § rendelkezése a célkitüzés és a fogalom-meghatározás miatt ehelyütt is idézhető: „Kiskereskedelem a beszerzett fogyasztási cikkek és a lakosság által használt egyéb termékek üzletszerü értékesitése a fogyasztóknak és felhasználóknak.”.

${ }^{678}$ Lásd: A Magyar Népköztársaság Polgári Törvénykönyve. Tervezet (1957), 107. p. A továbbiakban: Tervezet (1957).
} 
a megelőző, hatályba sosem lépett magánjogi kódextervezetek után egy „több mint 100 éves program valóra váltását" jelentette. ${ }^{679}$

A Minisztertanács 1953 decemberében kormánybizottságot állított fel a Ptk. tervezetének elkészítésére, amely a munkájába bevonta - többek között - a Magyar Tudományos Akadémia Állam- és Jogtudományi Bizottságát és Állam- és Jogtudományi Intézetét, az Eötvös Loránd Tudományegyetem, a Szegedi Tudományegyetem és a Pécsi Tudományegyetem Állam- és Jogtudományi Karát, a Legfelsőbb Bíróság, a Legfőbb Ügyészség és az egyes minisztériumok jogi osztályait. ${ }^{680}$ Bár a Tervezet általános indokolása több szocialista ország magánjogi kódexére is, mint a kodifikációs munkálatok előtt álló példákra, és a kormánybizottságnak a francia és a német törvénykönyvekre kiterjedő hasznos összehasonlító tanulmányaira hivatkozott, de elismerte azt is, hogy a szövegtervezet nagyban támaszkodik az 1928-as Mtj.-re is. ${ }^{681}$

A kormánybizottság koncepciójának legfontosabb elve az volt, hogy lehetőleg a polgári jog egészének anyagát átfogja a kodifikáció, és legalább elvi kereteket adva szabályozásra kerüljön minden jogintézmény. ${ }^{682}$ A Ptk. 1960. május 1-jén lépett hatályba. Rendszerét tekintve a pandekta-hagyományt tükrözi, öt fő részből épül fel: „Bevezető rendelkezések”, személyek joga, dologi jog („A tulajdonjogról”), kötelmi jog és öröklési jog. A kötelmi jogi rész elsőként a szerződések közös szabályairól, majd a jogellenes károkozásért és jogalap nélküli gazdagodásért való felelősségről, végül az egyes szerződésekről szóló rendelkezések szerepeltek. ${ }^{683}$

\section{Gazdaság, szerződések és adásvétel a Ptk. megalkotásának idején}

Az 1959. évi IV. törvény a magyarországi szocialista jogalkotás terméke volt. A korabeli gazdaság az állami tulajdon elsődlegességén és a tervgazdálkodáson alapult. A szerződések azonban továbbra sem csak a szocialista szervezetek és az állam gazdasági tevékenységének, hanem az állampolgári szükségletek kielégítésének eszközeiként is

\footnotetext{
${ }^{679}$ Tervezet (1957), 107. p.

${ }^{680}$ Tervezet (1957), 109. p.

${ }^{681}$ Tervezet (1957), 109. p.

${ }^{682}$ Tervezet (1957), 110. p. Nem tartalmazta azonban a koncepció a családi jog és munkajog szabályanyagát, mert - az indokolás szerint - ezek ,,a szocialista jogtól különváltak és önállóvá lettek”. Ezeken kívül nem a Ptk.-ban kaptak helyet a szellemi alkotásokkal, valamint a szocialista társadalomban, gazdaságban és jogrendszerben jelentőséggel nem bíró intézményekkel (mint például a részvénytársasággal, a váltóval vagy a csekkel) kapcsolatos szabályok sem, lásd: Tervezet (1957), 110-111. p.

${ }^{683}$ Ez a koncepció Világhy Miklóstól ered, lásd: FöLDI (2012), 344-345. p.
} 
szolgáltak, így az árukapcsolatok szabályozásánál is fontos szerepet kaptak. ${ }^{684}$ Zoltán Ödön úgy fogalmaz, hogy bár a szocialista társadalmakban a termelési eszközök magántulajdonát azok szocialista tulajdona váltotta fel, azonban „az árucsere kikapcsolását a termelőerők fejlettségi állapota még a szocializmusban sem teszi lehetővé". ${ }^{655}$ A szerződésekre vonatkozó jogszabályok elsődleges jogpolitikai célja azonban az állam gazdaságszervező tevékenységének, a gazdasági viszonyok kezdeményező alakításának a biztosítása volt. ${ }^{686}$

$\mathrm{Az}$ árucsereviszonyok rendeltetése - a jogtudomány álláspontja szerint - a szocializmusban is részben „,a szükségletek egyre fokozódó mértékủ kielégítése”, ${ }^{67}$ és az adásvétel e korszakban is „az áruviszonyok alapvető sajátosságait mutató, s a legáltalánosabban előforduló szerződésfajta” ${ }^{688}$ volt. Ez volt a „fogyasztási-használati javak” megszerzésének a leggyakoribb jogi eszköze, ${ }^{689}$ a polgárok „legszélesebb köreit legközvetlenebbül érintő szerződési típus". ${ }^{60}$ Ezt a szerepet erősítette az is, hogy a magánjogunkban korábban kialakított különbség a kereskedelmi és az egyéb (köztörvényi) adásvételek között a Ptk. hatályba lépésével megszünt, és egységes szabályozás vonatkozott az összes adásvételi szerződésre függetlenül attól, hogy mely jogalanyok között jött létre. ${ }^{691}$

\section{Az adásvételi szerződés megkötése és tartalma}

Az adásvétel megkötésére és tartalmára speciális rendelkezések hiányában a szerződések általános szabályai vonatkoztak. A szerződés tartalmát a felek szabadon állapíthatták meg, és a Ptk. szerződésekre vonatkozó szabályaitól eltérhettek, kivéve, ha azt jogszabály tiltotta [200. § (1) bekezdés]. A lehetetlen szolgáltatásra irányuló szerződés semmisnek minősült ]226. § (1) bekezdés]. Általános elvként jelent meg a szabályozásban, hogy a szerződő felek egymással együttmüködve kötelesek eljárni. ${ }^{692}$ Ezen kívül előírta a kódex, hogy „a kötelezettnek a szerzödés teljesitése érdekében úgy kell eljárnia, ahogy az az adott

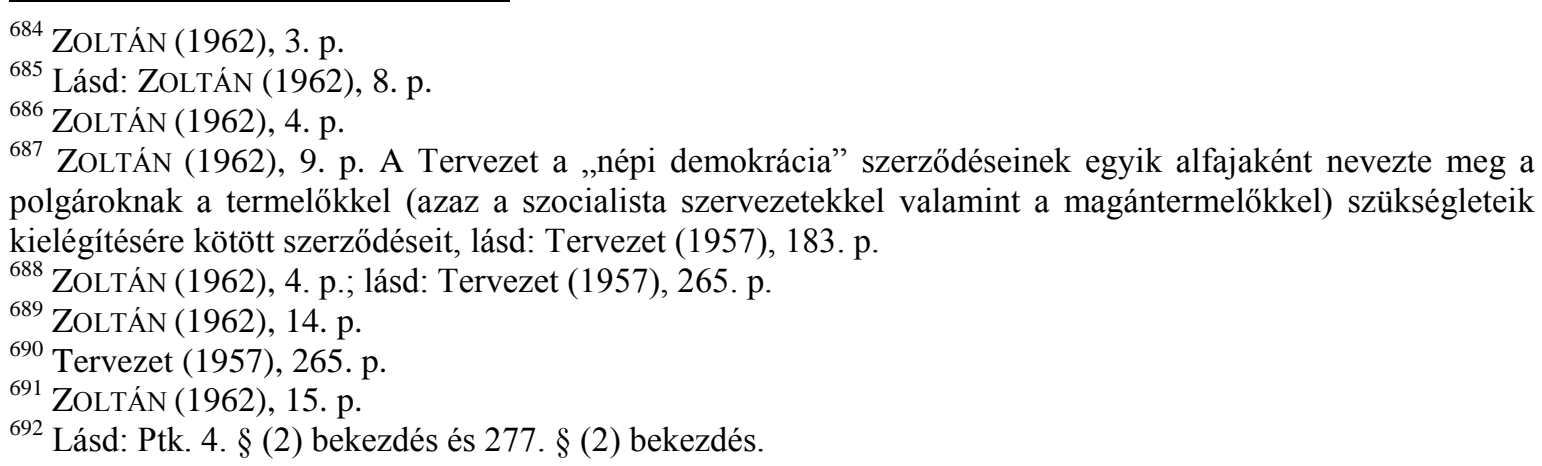


helyzetben általában elvárható, a jogosultnak pedig ugyanilyen módon elö kell segítenie a teljesitést. ",693

$\mathrm{Az}$ adásvételi szerződés tárgya lehetett minden olyan dolog, amely nem volt kivonva a forgalomból [Ptk. 365. § (2) bekezdés], emellett azonban a jogalkotó külön jogszabályokban a főszabály alóli számos kivételt tett, amelyek korlátozták a felek szerződési szabadságát. Hatósági jóváhagyással adhatták csak el például az olyan hajót, amely nem sportcélra épült vagy nem halászhajó volt, valamint ahhoz is hatósági engedély kellett például, hogy külföldi személy belföldön található vagyontárgyát bárkinek, valamint belföldi személy külföldön található vagyontárgyát külföldi személynek eladja; ${ }^{694}$ az erről rendelkező törvényerejű rendelet az ingóságokra vonatkozó vételár összeghatárát 500 forintnál húzta meg. ${ }^{695}$

További korlátozás állt fenn egyes vagyontárgyak adásvétele esetén, amennyiben csak meghatározott személyek szerepelhettek felekként a szerződésben. Ilyen korlátozás érvényesült például az arany- vagy platinatárgyak esetén; ${ }^{696}$ magánszemély az általa külföldröl behozott személygépkocsit az üzembe helyezéstöl számított két éven belül csak az Autókernek adhatta el; ${ }^{697}$ szőlőt az abból nyert must és bor továbbeladás útján történő értékesítése céljából kizárólag az Élelmezésügyi Minisztérium irányítása alá tartozó állami piacgazdaságok vásárolhattak. ${ }^{698}$ Mindezeken kívül jogszabály korlátozhatta a mennyiséget és a mértéket is egyes vagyontárgyak magánszemélynek történő eladása esetén. ${ }^{699}$ A Ptk. alapján jogszabály meghatározhatta az egyes adásvételi tárgyak legalacsonyabb illetve legmagasabb vételárát, és a felek ellentétes kikötése hiányában ez volt az irányadó, illetve ha nem kötöttek ki mást, és az adott adásvételi tárgynak mindkét árkorlátjáról rendelkezett jogszabály, akkor a középárat kellett vételárnak tekinteni. ${ }^{700} \mathrm{Ez}$ a rendelkezés a Ptk. Tervezete szerint - többek között - „a fogyasztók vásárlóereje védelmének az egyik eszköze” és „az áruviszonyok viszonylagos egyenértékűsége

\footnotetext{
${ }^{693}$ Lásd: Ptk. 277. $§(2)$ bekezdés.

${ }^{694}$ A felsorolást lásd: ZolTÁN (1962), 39-40. p.

695 Lásd: 1950. évi 30. számú törvényerejü rendelet a tervszerü devizagazdálkodással kapcsolatos szabályokról, 50. §. A továbbiakban: 1950. évi 30. tvr.

${ }^{696}$ Lásd:1950. évi 30. tvr. 44. §.

${ }^{697}$ Lásd: 29/1958. (IV. 15.) Korm. rendelet 7. §-ának a 21/1959. (IV. 23.) Korm. rendelet 4. §-ával módosított (1) bekezdése.

${ }^{698}$ Lásd: a 3/1961. (XII. 14.) Élm. M.-Bk. M. sz. együttes rendelettel módosított 2/1961. (VI. 15.) Élm. M.Bk. M. sz. együttes rendelet 1. és 4. §. A felsorolást lásd: ZOLTÁN (1962), 40-42. p.

${ }^{699}$ ZOLTÁN (1962), 42. p.

${ }^{700}$ Lásd: Ptk. 366. § (1) és (3) bekezdés. Az árhatósági hatáskörökről az 1/1968. (VI. 8.) ÁH sz. rendelkezés, az árszabályozásról pedig az 56/1967. (XII. 19.) Kormányrendelet szólt.
} 
érvényrejuttatásának jogi biztosítéka” volt. ${ }^{701}$ Figyelemre méltó, hogy a „fogyasztó” kifejezés - bár még nyilvánvalóan nem a mai piacgazdasági értelemben, de - már a Ptk. Tervezetében szerepelt, és az átlagember vásárlót jelölte, aki a termék végső felhasználása céljából kötött adásvételi szerződést. Látható azonban, hogy a szerződési szabadságot korlátozó jogszabályi rendelkezések többnyire még nem az átlagember, hanem a szocialista gazdasági és társadalmi rend érdekében születtek.

Az adásvétel tárgyát a felek meghatározhatták egyedileg és fajlagosan is. Szükséges azonban fogalmilag tisztázni, hogy egyedi szolgáltatásként helyettesíthető dolog is lehet adásvételi tárgy, azaz ha az áru szám, súly illetve mérték alapján szerepel a forgalomban, de a felek a konkrét egyedet kijelölik, akkor az egyedi szolgáltatásként szerepel az adásvételi szerződésben. ${ }^{702} \mathrm{~A}$ fajta és mennyiség szerint meghatározott szolgáltatás esetén általában helyettesíthető dolog szerepel az adásvételben, de a kettőt nagyon fontos elkülöníteni: „helyettesíthetők a dolgok és fajlagosak a kötelmek” - írta már Grosschmid Béni is. ${ }^{703}$ A helyettesíthetőség ,a dolog forgalmi tulajdonságát fejezi ki”, a fajlagosság pedig „a szerződési szolgáltatás meghatározásának egyik módja”, ${ }^{704}$ az előbbi „dologsajátosság”, az utóbbi „kötelemsajátosság”. ${ }^{705}$ Fajlagos szolgáltatás tárgya is lehet helyettesíthetetlen dolog: erre példa Zoltán Ödön szerint, ha valaki egy szobrász két eredeti szobrát vásárolja meg az egyedek megjelölése nélkül. ${ }^{706}$ Véleményem szerint ez már inkább zártfajú szolgáltatás.

Az eladó köteles volt a vevőt - többek között - a dolog lényeges tulajdonságairól tájékoztatni (Ptk. 368. §). A jogtudomány szerint ez magában foglalt minden olyan, az árura vonatkozó ismérvet, ami a dolog rendeltetésszerü használhatóságát érintette, és ami a vevő áruval kapcsolatos és az eladó által is ismeretes céljára befolyással volt. ${ }^{707}$ Ezen a szabályon kívül az eladónak az áru minőségéért és a kellékhibákért való helytállásáról külön nem rendelkezett a Ptk., így e kérdésben a szavatosságra vonatkozó általános szabályok voltak alkalmazandóak.

\footnotetext{
${ }^{701}$ Lásd: Tervezet (1957), 266. p.

702 ZOLTÁN (1962), 48. p. Lásd még: VILÁGHY - EÖRSI (1962), 360-363. p.

${ }^{703}$ Lásd: ZolTÁn (1962), 48. p. hivatkozása Grosschmid Bénire.

${ }^{704}$ BENEDEK - VILÁGHY (1965), 278. p.

705 TÓTH (1938), 140. p.

706 ZOLTÁN (1962), 48-49. p.

${ }^{707}$ Lásd: ZOLTÁN (1962), 142. p.; VILÁGHY -EÖRSI (1962), 13. p.
} 


\section{Hibás teljesítés, kellékszavatosság és hibafogalom}

A Ptk. a fentiek szerint nem követte mindenben az Mtj. tradicionális, a német jogtudomány hatását tükröző koncepcióját, és rendszertanilag nem az adásvétel szabályai között, hanem a kötelmi általános részben, a szerződésszegés nevesített eseteként rendelkezett a hibás teljesítésről és annak jogkövetkezményeiről, így azok minden olyan szerződés esetén alkalmazandóak voltak, amelyben a felek egymásnak kölcsönös szolgáltatásokkal tartoztak [305. § (1) bekezdés]. ${ }^{708}$ A Tervezet szerint a minőségvédelem prioritását szem előtt tartva szakított a Ptk. a hibás teljesítésnek és a kellékszavatosságnak az egyes szerződések szabályaiban való rendezésével. ${ }^{709}$ A jogalkotó úgy vélte, hogy „a megfelelő minőségben való szolgáltatás a szerződő fél legfontosabb kötelezettségei közé tartozik; ez nem csak a jogosult, de valamennyi fogyasztó közvetlen érdeke". ${ }^{710}$ Megjegyzendő azonban, hogy ez a rendszerbeli elhelyezés nem állt olyan távol a magyar magánjogtól, hiszen a XIX. század közepén a hazánkban majdnem 10 évig hatályban volt ABGB mind a mai napig szintén ezt a rendszertani elhelyezést követi.

A teljesítés általános szabálya alapján az eladó a szerződés tartalmának megfelelően, ${ }^{711}$ a kikötött helyen, időben, és a megállapított mennyiség, minőség és választék szerint volt köteles az árut a vevő részére szolgáltatni, és teljesítése érdekében úgy kellett eljárnia, ahogy az az adott helyzetben általában elvárható [Ptk. 277. § (1)-(2) bekezdések].

A Ptk. a szerződésszegés fogalmát tágan értelmezte, így abba beletartozott minden olyan magatartás, amely a szerződésre vonatkozó jogszabályt vagy szerződéses kikötést sértett. ${ }^{712}$ A hibás teljesítés a szerződésszerü teljesítést sértő magatartások összefoglaló kategóriája volt, amelynek a centrális jogkövetkezménye a kellékszavatosság volt. ${ }^{713} \mathrm{~A}$ kellékszavatosság ex lege attól függetlenül fennállt, hogy a kellékhiba jogszabály rendelkezése vagy szerződési kikötés alapján merült-e fel. ${ }^{714}$

\footnotetext{
${ }^{708}$ A Ptk. 1959-es eredeti szabályaihoz részletesen lásd: CSÉCSY (2008), 68-81. p.

${ }^{709}$ Tervezet (1957), 223. p.

${ }^{710}$ Tervezet (1957), 223. p.

711 A szerződésszerü teljesítés fontosságát a bíróis gyakorlat is hangsúlyozta, lásd például: PJD. IV. 116. számú döntés, NÉMETH (1982), 151. p.

${ }^{712}$ VÉKÁs (1967), 197. p. Az ingó adásvételi szerződések kikötéseivel kapcsolatos esetleges jogvita esetén nehézséget jelentett a kellékhiba/hiány bizonyítása, mert a Ptk. e szerződések esetén nem követelt írásbeli alakot, vö. Ptk. 365. § (3) bekezdés.

${ }^{713}$ VÉKÁS (1967), 197-198. p.; A Magyar Népköztársaság Polgári Törvénykönyve (1963), 328. p.

${ }^{714}$ Lásd: Ptk. 305. § (1) bekezdés; Tervezet (1957), 228. p.; VÉKÁs (1967), 200. p.
} 
A hibafogalom magában foglalta tehát a törvényes kellékek hiányát, amely mindenekelőtt a rendeltetésszerü használatra való alkalmasságot jelentette. ${ }^{715}$ Ennek megítélésénél nem az objektív alkalmatlanságból, hanem abból kellett kiindulni, hogy a dolog annak a rendeltetésnek megfelel-e, amelynek érdekében a konkrét szerződés megköttetett, ${ }^{716}$ azaz egy ún. szubjektív hibafogalom érvényesült.

A törvényi kellékekhez tartozott, hogy a kötelmi általános szabályok alapján fajlagos szolgáltatás esetén az eladó „, a forgalomban szokásos jóminőségü dolgokkal” volt köteles teljesíteni (Ptk. 288. §); e rendelkezés a „fokozott minőségvédelem” követelményéből fakadt. ${ }^{717}$ Meghatározásánál vitás esetben figyelembe kellett vennie a bíróságnak a vételár összegét, illetve azt, hogy milyenek a dologra vonatkozó általános minőségi jellemzők a gazdaság adott szintjén és a közfelfogás szerint, és hogy a vevő milyen célra kívánta felhasználni a dolgot. ${ }^{718}$ A fajlagos szolgáltatás minőségével kapcsolatos jogvitákban a jogtudósok szerint a bíróság feladata az ítélet meghozatalával arra is irányult, hogy a termékek minőségének javítására, és ezzel a szükségletek minél jobb kielégítésére sarkalljon. ${ }^{719}$

A szerződési kikötéseket mindig egyedileg kellett a bíróságnak megítélnie a kellékszavatosság szempontjából. Egy bírósági döntés például kimondta, hogy ha az áru csomagoltan vesz részt a kereskedelmi forgalomban, akkor amennyiben az azon feltüntetett felirat vagy használati utasítás nem felel meg az árunak és tulajdonságainak, ezért megtévesztésre alkalmas, az minőségi hibának minősül, azaz megalapozza a kellékszavatossági helytállást. ${ }^{720}$ A Legfelsőbb Bíróság egyik ítéletében arról rendelkezett, hogy ha valamely termék megfelel ugyan a vonatkozó szabvány elöírásainak, de a szabványban meg nem határozott egyes tulajdonságai a rendeltetési célból eredő követelményeket nem elégítik ki, akkor a szerződésszegés jogkövetkezményeinek - így a kellékszavatosságnak is - helye van. ${ }^{721}$

\footnotetext{
${ }^{715}$ Lásd: Ptk. 305. (1) bekezdés b) és d) pontok.

${ }^{716}$ Lásd: Tervezet (1957), 229. p.

${ }^{717}$ Lásd: ZoLTÁN (1962), 151. p.; Tervezet (1957), 219. p.

718 Lásd: Tervezet (1957), 219. p.; A Magyar Népköztársaság Polgári Törvénykönyve (1963), 308. p.; ZOLTÁN (1962), 152. p.

${ }^{719}$ ZOLTÁN (1962), 152. p.

${ }^{720}$ Lásd: GKT 75/1973. számú döntés.

${ }^{721}$ Lásd: BH 1980/1/26., NÉMETH (1982), 154-155. p.
} 


\subsection{A védett vagyoni érdek, a szabályozás jogalapja és diszpozitivitása}

A hibás teljesítésből fakadó kellékszavatosság Vékás Lajos szerint a minőségvédelem kiemelkedő jelentőségü eszköze, amely a „reális teljesítés” magánjogi elvéből fakad. ${ }^{722}$ A Ptk. rendelkezése szerint csak akkor mentesült a kötelezett a hibás teljesítés következményei alól, ha a jogosult a hibát ismerte [305. § (4) bekezdés]. ${ }^{723}$ Ez a kötelezett tudati állapotától független körülmény a jogtörténeti hagyományoknak megfelelöen a kellékszavatosság objektív jogalapját jelezte. Nem tartotta fenn a szabályozás a csalárd eladói magatartásra vonatkozó, a korábbi magánjogunkban szereplő szigorúbb szabályokat, ${ }^{724}$ mert a Ptk. miniszteri indokolása szerint így is majdnem feltétlen helytállást eredményezett a szabályozás. ${ }^{725}$ A csalárdságot a hibás teljesítés miatti kártérítés esetén értékelték szigorúbban. ${ }^{726}$

Vékás elemzi, hogy a magánjogi dogmatikában vitatott volt, hogy a kellékszavatosság felelősségi tényállásnak tekinthető-e vagy sem. ${ }^{727}$ Az egyik nézet szerint a felelősség jogilag kötelezettségszegésért való helytállást jelent, így a szavatosság is felelősségi tényállásnak tekintendő. A jogtudomány másik tábora viszont úgy vélte, hogy a felelősség szubjektív kategória, amelyről csak felróhatóság esetén lehet szó, így szerintük az objektív jogalapú kellékszavatossági igények magánjogi értelemben nem tartoznak a felelösség körébe. ${ }^{728}$

A felelősségi vita problematikája abban gyökerezik, hogy a materiálisan hibás teljesítés is kötelemszegés. A kötelemszegések jogkövetkezményei a magánjogban azonban általában szubjektív, felelösségi alapúak, azaz a kötelezett általában akkor felel, ha az elvárható gondosságot elmulasztotta. A kellékszavatosság esetén azonban nincsenek a kötelezetthez kapcsolódó szubjektív körülmények a szabályozásban, így az nem

${ }^{722}$ VÉKÁS (1967), 328. p.

${ }^{723}$ Lásd: ZOLTÁN (1962), 223. p. Zoltán egyenesen úgy fogalmaz, hogy „a kötelezettnek [...] az eredményért kell helytállnia".

${ }^{724}$ A csalárdul eljáró eladónak a Ptk. előtti magánjogunkban feltétlen, kimentési lehetőség nélküli helytállási kötelezettsége volt, lásd többek között: Mtj. 1383., 1386., 1390. és 1405. §§.

${ }^{725}$ Lásd: A Magyar Népköztársaság Polgári Törvénykönyve (1963), 330. p.

${ }^{726}$ Ptk. 307. § (2), lásd később.

${ }^{727}$ Ez volt az ún. felelösségi vita, lásd: VéKÁs (1967), 201. p. E kérdésröl egy külön tanulmány is született Józsa Mihály tollából, lásd: JózSA (1968), 603-610. p.

${ }^{728}$ Világhy Miklós - Eörsi Gyula: Magyar polgári jog (Tankönyvkiadó, Budapest, 1962.), Eörsi Gyula: A jogi felelősség alapproblémái. A polgári jogi felelősség (Budapest, 1961.) és Eörsi Gyula: A jótállásról, I. (Döntőbíráskodás, 1961. évi 5. szám 130. p.) címü müveire hivatkozik VÉKÁs (1967), 201. p.

Józsa Mihály a fenti szerzők mellett Eörsi Gyula: A gazdaságirányítás reformjával kapcsolatos kérdések, 1. Jogi kérdések a gazdaságirányítás köréböl (Közgazdasági Kiadó, Budapest, 1967., 58. p.) és Asztalos László: A polgári jogi szankció (Akadémiai Kiadó, Budapest, 1966. 317-318. p.), valamint a felelősségi álláspontot képviselő Görgey Mihály: Kellékszavatosság a szállítási szerződések körében (Közgazdasági Kiadó, Budapest, 1965., 140-142. p.) címü műveire hivatkozik, lásd: JózSA (1968), 603. p. 
illeszkedik a kötelemszegés rendszerébe maradéktalanul. Én a második felfogást pártolom: a fent említetteknek megfelelően a Ptk. „kimentési oka” független az eladótól és az ő tudattartalmától, a felróhatóságtól, így a kellékszavatosság nem felelősségi, hanem objektív jogalapú magánjogi helytállást jelent. A dolgozatban ennek megfelelően a „felelősség” helyett a továbbiakban (is) a „helytállás” kifejezést alkalmazom a hibás teljesítésért fennálló kellékszavatossággal kapcsolatban.

A kódex szövege ugyan kifejezetten nem foglal állást, de a kellékszavatossági jogokra vonatkozó Ptk.-beli rendelkezések diszpozitív jellegére lehet következtetni, amit a Legfelsőbb Bíróság Polgári Kollégiuma 35. számú állásfoglalásában kifejezetten ki is mondott. ${ }^{729}$ Két korlátozást tett azonban: ha a kötelezett felróható magatartása teremtett olyan helyzetet, hogy a jogosult nem tudta a szavatossági jogát a szerződés szerint érvényesíteni, akkor a szavatosság kizárása és korlátozása nem volt hatályos. ${ }^{730}$ Ezen kívül nem lehetett érvényesen kizárni a szavatossági jogokat a szándékosan, súlyos gondatlansággal vagy büncselekménnyel okozott, valamint a társadalmi tulajdont megkárosító szerződésszegés esetére vonatkozóan. ${ }^{731}$ A magánfelek minőséghez füződő érdekvédelme tehát még egyáltalán nem jelent meg kógens szabály szintjén.

\subsection{A vevö tudomása a hibáról}

A Ptk. úgy rendelkezett, hogy „, a kötelezett a szavatossági felelösség alól mentesül, ha a jogosult a hibát a szerzödéskötéskor ismerte.”.732 A törvény megfogalmazása a fenti megfontolások fényében véleményem szerint dogmatikailag nem volt megfelelő, mert felelősségi tényállásra utalt. A „felelösség alóli mentesülés” megfogalmazás azért nem helyes, mert amennyiben a jogosult tudatában van a hibának, akkor nem is lehet szó hibás teljesítésről, hiszen ha a vevő a hiba tudatában veszi át a dolgot, méltánytalan az eladót helytállási kötelezettséggel sújtani. Erre egyébként a Ptk. miniszteri indokolása is utalt: ,a szavatossági jog [...] voltaképpen nem felelősségre vonásra, hanem az eredetileg kikötött szolgáltatás kikényszerítésére irányul..." ${ }^{733} \mathrm{Ha}$ a vevő ismeri a hibát, akkor a tisztességes joggyakorlás követelményének megfelelően (a későbbi jogvita elkerülése érdekében)

\footnotetext{
${ }^{729}$ A továbbiakban: PK. 35. a) pont.

${ }^{730}$ PK. 35. a) pont. Ez hasonló volt az ABGB szabályozásához, vö. ABGB § 930.

${ }^{731}$ PK. 35. b) pont, vö. Ptk. 314. § (a szerződésszegés közös szabálya).

732 Lásd: Ptk. 305. § (4) bekezdés. Ez a szabály a történeti hagyományokat, az ABGB és a BGB rendelkezéseit idézi.

${ }^{733}$ Lásd: A Magyar Népköztársaság Polgári Törvénykönyve (1963), 328. p.
} 
egyébként is vissza kell utasítania a teljesítést, vagy nyomban kifogással kell élnie. ${ }^{734}$ Mindezzel összefüggött a szerződések általános szabálya, miszerint a jogosult köteles a körülmények által lehetővé tett legrövidebb időn belül meggyőződni a teljesítés megfelelőségéről [Ptk. 283. § (1) bekezdés]. Ezt a Ptk. Tervezete szerint mindkét fél érdeke megkívánja, mert a jogosult esetleges kifogásainak azonnali közlésével gyorsabban és biztosabban remélheti a nem szerződésszerü teljesítés korrigálását, és a hiba bizonyítását is megkönnyíti. ${ }^{735} \mathrm{~A}$, körülmények által lehetővé tett legrövidebb idö” természetesen a szolgáltatás jellegének és az eset összes körülményének a függvénye. ${ }^{736}$

\subsection{A hibás teljesítés jogkövetkezményei}

A ,reális teljesítés” elve szerint a szerződések tartalmuknak és céljuknak megfelelő teljesítése a kötelmi jogviszony elsődleges célja, ezért a jogviszony megszüntetésére irányuló jogkövetkezményeknek szubszidiáriusnak kell lenniük, azaz csak akkor szabad őket alkalmazni, ha a szerződéses igény illetve cél már nem elégíthető ki. ${ }^{737}$ Ezt a Ptk. a hibás teljesítés jogkövetkezményei, a kellékszavatossági jogok szabályozásánál is messzemenően szem előtt tartotta.

A szavatossági jogokat illetően a Ptk. eredeti szövege a szolgáltatás és a hiba jellege alapján differenciált: a jogkövetkezmények tekintetében különbséget tett az egyedi és a fajlagos szolgáltatás között, ${ }^{738}$ és különböző jogkövetkezmények érvényesültek aszerint is, hogy a hiba/hiány a dolgot a rendeltetésszerü használatra teljesen alkalmatlanná tette-e vagy megfelelő javítással az még alkalmassá tehető volt-e a használatra. ${ }^{739} \mathrm{Az}$ igényérvényesítési határidő meghatározásakor a Ptk. a korábbi magánjogunkban ismeretlen módon különbséget tett aszerint is, hogy a hiba felismerhető volt-e (ún. nyílt hiba), vagy csak a használat közben illetve egyébként hosszabb idő után ütközött-e ki (ún. rejtett hiba). ${ }^{740}$

\footnotetext{
${ }^{734}$ Erre ugyancsak a Ptk. Tervezetének indokolása utal, lásd: Tervezet (1957), 229. p. A római jogi caveat emptor elvének tükröződése.

${ }^{735}$ Lásd: Tervezet (1957), 217. p. A Tervezet indokolása egyébként nem is a szerződésszerü teljesítést, hanem ezt a jogosulti kötelezettséget emelte ki.

${ }^{736}$ GELLÉRT - ZOLTÁN (1975), 323. p.

${ }^{737}$ VÉKÁs (1967), 202. p.; Tervezet (1957), 228. p.

${ }^{738}$ Ennek elöképe a BGB és az Mtj. szabályozása.

${ }^{739}$ Ez az ABGB szabályozási koncepcióját tükrözi.

${ }^{740}$ Lásd: Ptk. 306. § (1)-(2) bekezdések.
} 


\subsubsection{Egyedileg meghatározott dolog szolgáltatása}

„Olyan szerződés hibás teljesitése esetében, amelyben a felek egymásnak kölcsönös szolgáltatásokkal tartoznak, a jogosultat - ha a jogszabály eltéröen nem rendelkezik - a következö szavatossági jogok illetik meg:

a) Ha a szerzödés egyedileg meghatározott dolog szolgáltatására irányul, és a dologban az átadáskor nincsenek meg a törvényes vagy a szerzödésben meghatározott tulajdonságok, a jogosult választhat a dolog kijavitása és a megfelelö árleszállítás között.

b) Ha az egyedileg meghatározott dolog az átadáskor a rendeltetésszerü használatra alkalmatlan és megfelelöen ki sem javitható, vagy az túlságosan hosszú idöt venne igénybe, illetöleg a kötelezett a kijavitást nem vállalja, a jogosult a szerzödéstöl elállhat.,"741

Az elsődleges szavatossági igények közé egyedi dolog szolgáltatása esetén megelőző magánjogunkhoz képest újonnan került be a kijavítás igénye. ${ }^{742}$ Amennyiben a dologban az átadáskor nem voltak meg a törvényes vagy a szerződésben meghatározott tulajdonságok, a jogosult szabadon választhatott a kijavítás és a megfelelő árleszállítás igénye között. Zoltán Ödön a helyettesíthető dolog és fajlagos szolgáltatás dogmatikailag tiszta elhatárolása ellenére a szavatossági jogkövetkezmények tárgyalásánál azt írta, hogy a kicserélés igénye itt nem jöhet szóba, mert az adásvétel tárgya egyedileg meghatározott dolog. ${ }^{743}$ Véleményem szerint e szabály kialakításánál a jogalkotó sem tisztázta egyértelmüen az ,egyedileg meghatározott dolog szolgáltatásának” a fogalmát. A helyettesíthetetlen és helyettesíthető dolgok alapján történő különbségtétel helyesebb lett volna.

Ha az egyedileg meghatározott dolog alkalmatlan volt a rendeltetésszerü használatra, és (1) megfelelően ki sem volt javítható, illetve (2) az túlságosan hosszú időt vett volna igénybe, vagy (3) ha a kötelezett azt nem vállalta, akkor a jogosult elállhatott a szerződéstől.

Ezek a szabályok több olyan absztrakt, közelebbről meg nem határozott fordulatot és kritériumot tartalmaznak, amelyekkel a jogalkotó a jogalkalmazó, a bíróság eseti mérlegelésére hagyatkozott: a „megfelelő árleszállítás”, „a rendeltetésszerü használatra való alkalmatlanság”, a „túlságosan hosszú ideig” tartó kijavítás mindig csak a konkrét

\footnotetext{
${ }^{741}$ Ptk. 305. § (1) bekezdés.

${ }^{742}$ Valószínüsíthető az osztrák minta, vö. ABGB § 932.

743 Lásd: ZolTÁN (1962), 232. p. Ez a felfogás a római jogi hagyományokat idézi, ahol ugyancsak a kiválasztás után az egyedre koncentráltak.
} 
eset körülményeinek fényében értelmezhető és határozható meg, ami gyakran megnehezíthette a jogalkalmazó dolgát. ${ }^{744}$

„Ha a kötelezett a dolog kijavitását megfelelö határidőre nem vállalja, vagy nem végzi el, a jogosult a hibát a kötelezett költségére maga kijavithatja vagy mással kijavittathatja." 745

E szabály alapján nem kellett indokolatlanul sokáig várnia a jogosultnak a kellékszavatossági igénye érvényesítésére, a szükséges kijavítást maga is elvégezhette vagy mással elvégeztethette, és ennek a költségét követelhette a kötelezettöl. A szabály specialitása abban mutatkozik meg, hogy a szerződés, mint kétoldalú megállapodás ellentettjeként itt az egyik szerződő fél, a vevő egyoldalú cselekménnyel változást idézhet elő a jogviszonyban az eladó beleegyezése nélkül.

Vékás Lajos - Benedek Károly és Világhy Miklós álláspontjától eltérően - úgy vélekedik, hogy ilyen esetben a kötelezettől követelhető kijavítási költség nem egyezik az árleszállítás mértékével, mert egyrészt a kettő a gyakorlatban az összegszerüséget tekintve is gyakran eltér, ${ }^{746}$ másrészt, míg dogmatikailag a kijavítás a szerződéses érdek védelmét és helyreállítását szolgálja, addig az árleszállítás elsősorban a szolgáltatás-ellenszolgáltatás megbomlott értékegyensúlyát hivatott visszaállítani. ${ }^{747}$

Kérdésként merült fel a jogtudományban és a gyakorlatban, hogy hogyan ítélendő meg az, ha az eladó vállalja ugyan a kijavítást, de csak térítés ellenében. Ilyen esetben a bírói gyakorlat szerint az eladó magát a szavatossági kötelezettséget vitatta, a térítés ellenében vállalt kijavítás pedig a jogintézmény rendeltetésének nem felel meg: a kijavítást - a reális teljesítés elvének megfelelően - mindig ingyen kell elvégezni. ${ }^{748}$ Ha így nem vállalta az eladó, és a dolog a rendeltetésszerü használatra alkalmatlan is volt, akkor a vevő elállhatott a szerződéstől. ${ }^{749}$

A Ptk. 1957-es Tervezetéhez képest végrehajtottak néhány módosítást a kódex végleges szövegében. A Tervezet úgy szólt, hogy az árleszállítás utáni összegnek a dolog hiba miatti - alacsonyabb értékének kell megfelelnie. ${ }^{750} \mathrm{Ez}$ a jogalkalmazást segítő rendelkezés kikerült a végleges szövegböl. Szerepelt a Tervezet elállási szabályainál egyedi és fajlagos szolgáltatás esetén egyaránt a kijavítás aránytalan költségvonzatú

\footnotetext{
${ }^{744}$ Lásd: VÉKÁS (1967), 206. p.

745 Ptk. 305. § (2) bekezdés.

${ }^{746}$ Vékás itt Zoltán Ödön müvére hivatkozik (ZOLTÁN (1962), 262. p.).

${ }^{747}$ Lásd: VÉKÁs (1967), 208-209. p. Vö. az ókorban és a német kódexben alkalmazott relatív számítási módszer.

748 VÉKÁS (1967), 207.p

${ }^{749}$ VÉKÁS (1967), 207. p.

750 Tervezet (1957), 45. p. (279. § (1) bekezdés a) pont).
} 
előfeltétele is. ${ }^{751}$ Ennek kihagyása a végleges szövegből a vevő érdekeit szolgálta. A kódex végleges szövegével ellentétben az is szerepelt a Tervezetben, hogy a hibának a kötelezett költségén való kijavítása illetve kijavíttatása akkor is lehetséges, ha a hiba kisebb jelentőségü. ${ }^{752} \mathrm{Ez}$ a szabály valószínüleg a méltányosság követelményét szem előtt tartandó került ki utóbb a szövegből. Nem szerepelt a Tervezetben az a kitétel, hogy amennyiben ,a kötelezett a kijavítást nem vállalta”, a jogosult akkor is elállhatott a szerződéstől, amelyet a jogalkotó végül beépített a szabályozásba. ${ }^{753}$

A gyakorlatban problémát okozott a szavatossági helytállás tartalmának megállapítása a használt tárgyak esetén. ${ }^{754}$ Zoltán Ödön úgy véli, hogy a gyakorlatban megszokott szerződési kikötések, mint a „vevő a dolgot megtekintett állapotban”, vagy „megtekintett és üzemképes állapotban” veszi meg, önmagában nem zárhatják ki a szavatossági jogokat. ${ }^{755}$ Szerinte ilyen esetekben a szerződéskötés körülményeiből, a felek kijelentéseiből, és főként abból kell következtetni a szerződés (és a dolog használatának) céljára, hogy az eladó milyenként kínálta, milyennek állította a dolgot: például javításra szorulónak, üzemképesnek, használhatónak, jó állapotban lévőnek, kifogástalannak vagy éppen roncsnak. ${ }^{756}$ Használt dolgoknál a hibának, a hiba forrásának illetve keletkezésének megállapítása még gondosabb vizsgálatot igényel, mint általában, így különösen nagy körültekintéssel kell vizsgálni a vevő esetleges javító munkáit, a dolog tárolásának körülményeit. ${ }^{757}$ A használt áru vételénél igazán szemléletes az, hogy mindig a konkrét szerződéshez és az eset körülményeihez viszonyítva kell értékelni a hibás teljesítést: itt mutatkozik meg leginkább a szubjektív hibafogalom mibenléte. ${ }^{758}$

\subsubsection{Fajta és mennyiség szerint meghatározott dolog szolgáltatása}

„Ha a fajta és mennyiség szerint meghatározott dologban az átadáskor a törvényes vagy a szerzödésben meghatározott tulajdonságok nincsenek meg, a jogosult választhat a dolog kicserélése, kijavitása és a megfelelö árleszállítás között; a kötelezett kijavítás vagy árleszállitás helyett a dolgot kicserélheti, ha ez olyan

\footnotetext{
${ }^{751}$ Tervezet (1957), 45. p. (279. § (1) bekezdés b) és d) pontok).

${ }^{752}$ Tervezet (1957), 45. p. (279. $\$$ (2) bekezdés).

753 Tervezet (1957), 45. p. (279. § (3) bekezdés).

${ }^{754}$ ZOLTÁN (1962), 232. p.

755 ZOLTÁN (1962), 232. p.

${ }^{756}$ Lásd: ZoLTÁN (1962), 232-233. p.

${ }^{757}$ ZOLTÁN (1962), 233. p.

758 A német jogban nagy hagyománya van a szubjektív hibafogalom megközelítésének, lásd: ERNST (2013), 93. p.
} 
késedelem nélkül lehetséges, amelynek esetében a jogosultat már az elállás joga illeti meg (300. §)., 759

A fajlagos szolgáltatásként meghatározott ingó dolog hibás teljesítése esetén a jogosult elsősorban a kijavítás, kicserélés és a megfelelő árleszállítás igényei közül választhatott. A kötelezettnek kedvezett, de mindkét fél érdekét szolgálta az a szabály, miszerint a kötelezett a jogosult választásától függetlenül kicserélhette a hibás dolgot, ha ez olyan késedelem nélkül lehetséges volt, amely esetén az érdekmúlás miatt a vevőt már megillette volna az elállás joga (a késedelem szabályainak értelmében). ${ }^{760}$ A gyakorlatban a kicserélés küszöböli ki a legteljesebben a fajlagos vétel tárgyának hibáját, ezért adhatta meg a jogalkotó a kötelezettnek is a jogot arra, hogy ezen igény teljesítését válassza. ${ }^{761}$

Ha a dolog az átadáskor a rendeltetésszerü használatra alkalmatlan volt, és (1) megfelelően ki sem lehetett javítani, illetve (2) az túl hosszú időt vett volna igénybe, vagy (3) az eladó a kijavítást nem vállalta, akkor a jogosult először is a kicserélést követelhette, és csak akkor élhetett az elállási jogával, ha bizonyította, hogy a teljesítés többé már nem áll érdekében. ${ }^{762}$

A fenti négy „klasszikus”, a hatályos jogban is szereplő kellékszavatossági igény között a bemutatott kereteken belül biztosította csak a jogosult választási jogát a kódex. Ezt tovább szigorította az a szabály, hogy a jogosult csak akkor térhetett át a már kiválasztott szavatossági jogról másikra, ha azt törvény kifejezetten engedte [305. § (3) bekezdés]. Zoltán úgy értékeli, hogy ez a kifejezett törvényi engedély csak akkor volt adott, amikor a jogosult a kötelezett el nem végzett, vagy megfelelő határidőre nem vállalt kijavítását a kötelezett költségére maga kijavította vagy mással kijavíttatta. ${ }^{763}$

\subsubsection{Kártérítés}

Eörsi Gyula szerint elvi különbségtétel nincs a szerződésszegéssel és az azon kívül okozott károkért való felelösség között, csak részleteltérések, amelyek abból fakadnak, hogy a

\footnotetext{
${ }^{759}$ Ptk. 305. § (1) bekezdés c) pont.

${ }^{760}$ Vö. 300. §: ,,(1) A jogosult - függetlenül attól, hogy a kötelezett késedelmét kimentette-e - követelheti a teljesitést, vagy ha ez többé nem áll érdekében, elállhat a szerzödéstöl.

(2) Nincs szükség a teljesitéshez füzödö érdek megszünésének bizonyitására, ha a szerzödést a felek megállapodásánál vagy a szolgáltatás felismerhetö rendeltetésénél fogva meghatározott idöpontban - és nem máskor - kellett volna teljesiteni, vagy ha a jogosult az utólagos teljesitésre megfelelö határidöt szabott, és az is eredménytelenül telt el.".

${ }^{761}$ ZOLTÁN (1962), 234. p.

${ }^{762}$ Lásd: Ptk. 305. § (1) bekezdés d) pont.

763 Ezt a fajlagos szolgáltatás esetén tovább korlátozta az, hogy csak akkor élhetett vele, ha az eladó a kicserélést nem ajánlotta fel, lásd: ZOLTÁN (1962), 235. p.
} 
konkrét intézményesült jogviszony, a szerződés a felek között „megnöveli az előreláthatóságot és az elővigyázati követelményeket”. ${ }^{764}$ A károkozást megelőző kötelmi jogviszony fennállása a jogkövetkezmények terén összetett képet mutat, mert felróhatóságtól független jogintézmények mellé is társulhat a szubjektív jogalapú polgári jogi szankció. ${ }^{765}$ A Ptk. a hibás teljesítés szubjektív jogalapú szankciójáról ekként rendelkezett:

„Hibás teljesités esetén a jogosult kárának megtéritését is követelheti, kivéve ha a kötelezett bizonyitja, hogy a hibátlan teljesités érdekében úgy járt el, ahogy az az adott helyzetben általában elvárható. "766

A kötelezett a hibás teljesítésböl eredő kártérítési kötelezettség alól tehát csak akkor mentesülhetett, ha bizonyította, hogy a hibátlan teljesítés érdekében úgy járt el, ahogy az az adott helyzetben általában elvárható (azaz, hogy a károkozás nem az ő felróható magatartásának a következménye). ${ }^{767} \mathrm{~A}$ Ptk. szerződésszegéssel okozott károk esetén a szerződésen kívül okozott károkért való felelősségre vonatkozó szabályokat rendelte alkalmazni (318. §), a szerződésszegéssel okozott kár esetén azonban még kivételes esetben sem volt helye a kártérítés enyhítésének. ${ }^{768}$

A Ptk. kötelmi általános szabályai szerint kárnak minősült a felmerült tényleges kár, azaz a károsult vagyonában beállott értékcsökkenés, az elmaradt jövedelem vagy haszon, valamint a költségek és kiadások, amelyek a bekövetkezett hátrány csökkentéséhez vagy kiküszöböléséhez szükségesek [Ptk. 358. § (1) bekezdés].

Az adásvétel hibás teljesítése folytán felmerült kár azzal az értékkel volt egyenlő, amitől a károsult az adásvétel tárgyának elpusztulása, megrongálódása folytán elesett, illetve azzal az értékcsökkenéssel, ami a megrongálódott dolog kijavítása ellenére is fennmaradt. ${ }^{769}$ Eörsi Gyula szerint azonban a kijavítás költségeit a vevőnek a szavatossági igényérvényesítés keretében kellett behajtania. ${ }^{770} \mathrm{Az}$ általános szabályok szerint a kár mértékének megállapításánál a dolog károsodáskori állapota és értéke volt irányadó.

\footnotetext{
${ }^{764}$ EÖRSI (1966), 66. p.

${ }^{765}$ EÖRSI (1966), 66. p.

${ }^{766}$ Ptk. 307. § (1) bekezdés.

${ }^{767}$ Megjegyzendő, hogy a Tervezet szövegében még az alábbi szerepelt: „... kivéve, ha [...] bizonyítja, hogy a hibátlan teljesítés érdekében mindent megtett, ami elvárható volt”, lásd: Tervezet (1957), 46. p. (281. §). Mindez a kártérítés általános szabályaiból eredt, ahol szintén az szerepelt, hogy akkor mentesülhet a kötelezett, „ha bizonyítja, hogy a kár elhárítására mindazt megtette, ami elvárható volt”, lásd: Tervezet (1957), 50. p. (309. § (1) bekezdés).

${ }^{768}$ Vö.: Ptk. 318. § és 339. § (2) bekezdés.

${ }^{769}$ Lásd: BH. 1964. 4. 3948.

${ }^{770}$ EÖRSI (1966), 75. p.
} 
Különösen releváns volt ez használt állapotú ingók vétele esetén. ${ }^{771}$ A Fővárosi Bíróság ezzel kapcsolatos egyik döntésében kimondta, hogy pusztán az adásvétel tényével még nem csökken a dolog értéke és használhatósága, ${ }^{772}$ de az adásvételt követően már több ezer km-t megtett gépkocsi esetén jogos a kártérítés összegét ennek megfelelően csökkenteni. ${ }^{773}$

A Ptk. szerint a kártérítés a szavatossági jogok melletti párhuzamos jogosultság volt, de ez nem jelentette azt, hogy a vevő adott esetben duplán érvényesíthette követelését kártérítés és a többi szavatossági jog keretei között. Ezt példázza a következő jogeset. ${ }^{774} \mathrm{~A}$ termelőszövetkezettől a vevő 100 naposcsibét vett, amelyek közül 10 baromfipestisben elhullott az átvételtől számított 8 nap alatt, majd a betegség később átterjedt a többi csibére is, és valamennyi elpusztult. ${ }^{775}$ A szakértői vélemény szerint az elsőként elhullott 10 csibe volt csak feltőzött az átadáskor, ez alapján a Ptk. hibafogalmából kiindulva szavatossági igényt csak e 10 csibe esetében lehet érvényesíteni, a kártérítési igény pedig a többi 90 csibe kapcsán merülhet fel. ${ }^{776}$ A kártérítési kötelezettség alól azonban az eladó kimenthette magát azzal, ha bizonyította, hogy a hibátlan teljesítés érdekében úgy járt el, ahogy az az adott helyzetben általában elvárható volt. ${ }^{777} \mathrm{Ha}$ ez sikerült neki a perben, akkor a vevő érdeksérelme (a 90 csibe értéke) nem nyert orvoslást.

A következő jogeset is kapcsolódik a hibás teljesítés miatti kártérítés kérdéséhez. ${ }^{778}$ A felperes egy női cipőt vásárolt a Cipőkereskedelmi Vállalat alperes egyik boltjában, majd amikor annak sarka két hónap használat után eltörött, visszavitte azt a boltba, és kijavítást kért. Az alperes a cipőt továbbította a Vállalat központjába, ahol selejtnek titulálták, és a Bizományi Áruház Vállalathoz küldték el. Az alperes az így „eltűnt” cipő vételárának a visszafizetését ajánlotta fel, amit a felperes nem fogadott el, hanem a kijavított cipő visszaadása, vagy ugyanolyan fajtájú cipő szolgáltatása iránt keresetet indított. Az alperes azonban ezek egyikét sem tudta teljesíteni, mert védekezése szerint a megvásárolt majd visszavitt cipő eltünt, és olyan típusú cipőt már nem gyártottak, illetve abból raktáron sem volt már példány, a vevő mégis ragaszkodott az eredeti kereseti kérelméhez, amelyet a bíróság végül elutasított.

\footnotetext{
${ }^{771}$ Lásd: LB. P. törv. I. 22.044/1960. sz. ítélet.

${ }^{772}$ Lásd: Fővárosi Bíróság Táj. 29/848. 1963. sz. ítélete.

${ }^{773}$ Lásd: Kecskeméti Járásbíróság P. 22.919/1963. sz. ítélete.

774 ZOLTÁN (1962), 244. p. példája.

${ }^{775}$ Lásd: ZOLTÁN (1962), 244. p. Később kerül bemutatásra a szavatosság az állatok adásvétele esetén. A Ptk. e speciális rendelkezéseit csak meghatározott (nagytestü) állatokra lehetett alkalmazni, így a fenti jogesetben a szavatosság általános szabályai érvényesültek.

${ }^{776}$ ZOLTÁN (1962), 245. p.

777 Vö. Ptk. 307. § (1) bekezdés.

${ }^{778}$ Lásd: BENEDEK - VILÁGHY (1965), 275. p. példája.
} 
Az esetben a jogi probléma a Ptk. 306. §-hoz, és az egyedileg meghatározott, de helyettesíthető dolog szolgáltatásához kapcsolódik. A cipő ugyanis helyettesíthető dolog (sorozatban gyártott és kereskedelemben forgalomba hozott, szám és mérték szerint meghatározható), a vevő azonban egy konkrétan kiválasztott, egyedileg meghatározott párt vett meg belőle. A Ptk. nem rendezte azt a fogalmi kérdést, hogy mi tekintendő egyedileg, és mi fajta szerint meghatározott dolognak, e kategóriákat csak a jogtudósok különítették el megfelelően. ${ }^{779}$

A jogi problémához tartozott az is, hogy a vásárlók minőségi kifogásairól külön jogszabály rendelkezett. Ez az 1/1964 (I. 11.) BkM rendelet a kereskedelmi forgalomban vásárolt ingókkal kapcsolatban tett minőségi kifogás esetén a Ptk. 305. § (1) bekezdés c)-d) pontjaiban foglaltakat, azaz a fajta és mennyiség szerint meghatározott szolgáltatások kellékhibája esetén támasztható szavatossági igényeket rendelte alkalmazni, ${ }^{780}$ így a gyakorlatban az érvényesíthető igények körét egyedi vétel esetén is megtoldotta a kicserélési joggal. Mindez arra enged következtetni, hogy a rendelet a kereskedelmi forgalomban lebonyolított ingó adásvételeket általában fajta és mennyiség szerinti vételnek titulálta. Erre utal az is, hogy az egyedi árucikkeket taglaló rendelkezése példálózó jelleggel a mütárgyat, használt cikket, stb. említette. ${ }^{781}$ A helyes jogszabály-értelmezés szerint viszont a jogesetben egyedi vételről van szó, ahol a rendelet szerinti kicserélési jog csak a vevő kívánsága esetén érvényesülhet, az eladónak nincs lehetősége arra. Ezt az igényt a kijavításhoz hasonlóan (az áru „eltünése” miatt) azonban nem tudta teljesíteni az alperes.

Benedek Károly és Világhy Miklós álláspontja szerint a jogesetben a teljesítés lehetetlenné vált, ezért az erre vonatkozó Ptk. 309-312. §§-ok alkalmazandóak. E szabályok szerint, ha egyik félnek sem felróható okból vált lehetetlenné a teljesítés, akkor a szerződés megszünik. ${ }^{782} \mathrm{Az}$ álláspontjukkal egyetértek, de az érveléssel nem. Benedek és Világhy szerint a teljesítés lehetetlenné vált, és így a szerződés megszünt, de ezt és a jogkövetkezményeket a teljesítés általános szabályára vezetik vissza. Úgy vélik, hogy a hibás teljesítés - ez esetben - jogi értelemben egyenlő a nem teljesítéssel, ezáltal a

\footnotetext{
${ }^{779}$ Lásd például fentebb: ZOLTÁN (1962), 48. p. A jogi probléma mind a mai napig aktuális, és sok esetben még a jogászok körében is bizonytalanságot okoz.

780 1/1964 (I. 11.) BkM rendelet 7. §.

781 1/1964 (I. 11.) BkM rendelet 9. §. BENEDEK - VILÁGHY (1965), 277. p.

${ }^{782}$ Ptk. 309. § : „Ha a teljesités olyan okból vált lehetetlenné, amelyért egyik fél sem felelös, a szerzödés megszünik.".
} 
kárveszély nem száll át a másik szerződő félre, ${ }^{783}$ ezért a kárt az eladónak kell viselnie. Én is úgy vélem, hogy az eladó köteles viselni a kárt a lehetetlenülés miatt. Mivel azonban a cipő a Vállalat központjában tünt el, és a boltban a vevő a Vállalattal (annak képviselőjével) szerződött, én a Ptk. 310. § (2) bekezdés szabályát hívtam volna fel, amely a kötelezettnek felróható lehetetlenülést szabályozta: ilyen esetben a vevő a teljesítés elmaradása miatt kártérítést követelhetett. ${ }^{784} \mathrm{Ez}$ a kár ebben az esetben megfelel a cipő eredeti vételárának, és ide tartozhat az az összeg is, amelyért a vevő új cipőt kényszerült venni azért, mert a törött sarkút használni képtelen volt.

\subsection{Jótállás}

A Ptk. eredeti szövege a kötelmi általános részben a szerződést biztosító mellékkikötések között egy rövid, absztrakt szabályban rendelkezett a jótállásról:

„Aki valamely szolgáltatásért jótállást vállal, a jótállás időtartama alatt a felelösség alól csak akkor mentesül, ha bizonyítja, hogy a hiba oka az átadás után keletkezett."

A jótállás egy egyoldalúan vállalt helytállás a szolgáltatásért, de a gyakorlatban nyilvánvalóan a felek alkujának és megállapodásának eredményeképp is létrejöhetett. Felelősségi tényállásra utal a Ptk. megfogalmazása, akárcsak a hibás teljesítésért való helytállásnál, ez azonban ehelyütt sem állja meg a helyét véleményem szerint. Itt is majdnem feltétlen helytállási kötelezettségről van szó: a „mentesülés” lehetősége nem egy szubjektív körülménytöl, hanem a hiba okának keletkezési idejétől függött. Elvileg bármilyen szerződésszegésért lehetett jótállást vállalni, de a legtipikusabb az üzleti fogalomban a hibás teljesítésért vállalt helytállás volt. ${ }^{786}$

A jótállás és a hibás teljesítés központi jogintézménye, a kellékszavatosság viszonya kezdettől fogva neuralgikus pontja volt a Ptk. szabályzásának. ${ }^{787}$ A kérdés

\footnotetext{
${ }^{783}$ Lásd: Ptk. 279. §: „A teljesitéssel a kárveszély - ha a törvény kivételt nem tesz - a másik szerzödö félre száll át.".

${ }^{784}$ „Ha a teljesités olyan okból vált lehetetlenné, amelyért a jogosult felelös, a kötelezett szabadul tartozása alól, és követelheti kárának megtéritését.".

${ }_{785}$ Ptk. 248. §.

786 Zoltán (1962), 183. p.; BENEDEK - VILÁGHY (1965), 247. p. Ezt a Ptk. miniszteri indokolása is hangsúlyozta, és „fokozott felelösségként” jellemezte, lásd: A Magyar Népköztársaság Polgári Törvénykönyve (1963), 274. p.

${ }^{787}$ Kezdettől fogva vitatták a jótálás rendszerbeli elhelyezését, és több szerző hivatkozik a jogintézmény döntően hibás teljesítés esetén elnyert relevanciájára.
} 
tárgyalásánál elöljáróban érdemes Benedek és Világhy művének egy idevágó, és a mai viszonyokra is tökéletesen ráillö gondolatát idézni:

„... a szavatosság (kellékszavatosság) és a jótállás (garancia) egymáshoz való viszonyát illetően a hétköznapi (laikus) nyelv- és fogalomhasználatban is jelentős homály uralkodik. Mindennapi nyelvhasználatunkban a szavatosság, de különösen a kellékszavatosság elnevezés alig ismeretes, az emberek - ideértve a gazdasági és müszaki szakembereket is - e fogalmakat ,jogi dolgok"-nak tartják. Ezzel szemben a jótállás, de még inkább a „garancia” kifejezések a laikus nyelvhasználatban is használatosak, s mindenki a termék minőségéért való felelősségvállalást érti rajtuk. Müszaki és gazdasági szakembereink előtt is legtöbbször csak az utóbbi kifejezések ismeretesek, rendszerint nem is tudnak arról, hogy az elöállító a termék minőségéért külön elvállalás nélkül is, törvény alapján, szavatosság címén felelös. Ezért nem is lehet csodálkozni azon, hogy a minőségért való felelősség gazdaságimüszaki részletkérdéseit rendező és sokszor megfelelő jogászi közreműködés nélkül készülő szabályok a kellékszavatosság és a jótállás kérdéseit szinte reménytelenül összekavarják; ami azután e szabályok alkalmazása során nem kevés nehézséget okozhat. A kellékszavatosság és a jótállás egymáshoz való viszonya azonban nemcsak a mindennapi életben és a nem-jogászok tudatában mosódik el, hanem sokszor a jogban, a jogászok tudatában is."

Amíg e dogmatikai bizonytalanságra nem érkezett válasz és konkretizálás a joggyakorlat részéről, addig a jogtudomány igyekezett állást foglalni a kérdésben. A jótállás a Ptk. miniszteri indokolása szerint sok vonatkozásban a kellékszavatossághoz áll közel. ${ }^{789} \mathrm{~A}$ két jogintézmény közötti különbség Benedek és Világhy szerint abban ragadható meg, hogy a jótállás nem a törvényből folyó, hanem megállapodással elvállalt „felelősségi” forma, amely szigorúbb a szavatosságnál, hiszen a hiba ismerete a jogosult részéről nem mentesíti a kötelezettet. ${ }^{790}$ Meglátásuk szerint bár a kellékszavatosság törvényi szabályai diszpozitívek, azok nem enyhíthetők, hanem csakis szigoríthatók a jótállás vállalásával. Benedek és Világhy szerint közös a két jogintézményben, hogy a kötelezett - a kötelmi általános szabályok alapján - jótállás esetén sem köteles a hibás teljesítéssel okozott károk megtérítésére, ha kimenti magát annak bizonyításával, hogy a hibátlan teljesítés érdekében úgy járt el, ahogy az az adott helyzetben általában elvárható volt. ${ }^{791}$ Eltért azonban a két jogintézmény abban, hogy jótállás esetén nem volt különbség a nyílt és a rejtett hiba között. ${ }^{792}$

A jótállási jogviszony tartalmát, valamint a jótállás és a szavatosság viszonyát övező dogmatikai homály eloszlatása érdekében a Ptk. rövid szabályát később a

\footnotetext{
${ }^{788}$ BENEDEK - VILÁGHY (1965), 245-246. p.

789 A Magyar Népköztársaság Polgári Törvénykönyve (1963), 274. p.

790 BENEDEK - VILÁGHY (1965), 254. p.; A Magyar Népköztársaság Polgári Törvénykönyve (1963), 274. p.

${ }^{791}$ BENEDEK - VILÁGHY (1965), 255. p.

792 BENEDEK - VILÁGHY (1965), 255. p.
} 
Legfelsőbb Bíróság elvi döntésével igyekezett konkretizálni. ${ }^{793}$ A XXX. PED indokolásának bevezetője utalt rá, hogy a jótállással kapcsolatos jogviták esetén a bíróságok bizonytalanok abban, hogy a jogosult milyen jogokat és mely időpontig érvényesíthet.

Az LB leszögezte, hogy a jótállás a minőségvédelem, és ezáltal a gazdasági fejlődés fontos eszköze, amely a törvényen alapuló szavatosságnál szigorúbb helytállási kötelezettség azért, hogy a szolgáltatott dolognak megvannak a törvényes és a szerződésben meghatározott kellékei. ${ }^{794}$ Azért volt szigorúbb a szavatossági helytállásnál, mert csak akkor mentesülhetett alóla az eladó, ha bizonyította, hogy a hiba oka az átadás után keletkezett, azaz, hogyha a hiba ugyan az átadás után ütközött ki, de annak oka már annak idején is fennállt, akkor is helyt kellett állnia.

A PED szerint, amennyiben a jótállási nyilatkozatban/megállapodásban nem kötöttek ki mást, akkor a jogosult a Ptk. 305. §-ába foglalt szavatossági jogokat érvényesítheti jótállási igények címén, és ebben az esetben is követelheti a hibás teljesítésből eredő kárának a megtérítését is. ${ }^{795}$ A PED indokolása a jótállás alapján hibás teljesítés miatt érvényesített kártérítés vonatkozásában a korábbi jogtudományi álláspontokkal ellentétben azt tartalmazta, hogy a kötelezett kimentésére nem a kártérítés általános szabálya [Ptk. 339. § (1) bekezdés], hanem a 248. § alkalmazandó. ${ }^{796}$ Azaz kártérítési követelés esetén is csak akkor mentesült a jótálló a helytállás alól, ha bizonyította, hogy a hiba oka az átadás után keletkezett.

A nem jogászi irodalomban a XXX. PED megalkotása után sem kristályosodott ki a különbség a szavatosság és a jótállás között. Pálfalvi József a szavatosság és a jótállás köznapi és jogi értelme közötti eltéréseket taglaló 1975-ös tanulmányában sorra veszi a Magyar Értelmező Kéziszótár és a Magyar Nyelv Értelmező Szótárának vonatkozó fogalom-meghatározásait, és javaslatot tesz arra, hogy a törvényben használt elnevezéseket közérthetőbbé kellene tenni. ${ }^{797}$ Az előbbi szótárban a szavatosságot az eladott tárgy természeti, jogi szempontból hibátlan voltáért fennálló szerződésbeli vagy törvényes eladói

\footnotetext{
${ }^{793}$ A XXX. számú PED. A Ptk. miniszteri indokolása egyébként az egy mondatos rendelkezés igazolásaként a jótállásra vonatkozóan megalkotandó speciális jogszabályokat hozta fel, amelyek mellett - a jogalkotó véleménye szerint - elegendő, hogy a kódex csupán egy általános rendelkezést rögzítsen a jótállásról, lásd: A Magyar Népköztársaság Polgári Törvénykönyve (1963), 274. p.

794 XXX. PED a) pont. A PED szövegét lásd: GELLÉRT - ZOLTÁN (1975), 263-272. p.

${ }^{795}$ XXX. PED a) pont. Erre egyébként már a miniszteri indokolás is utalt, lásd: A Magyar Népköztársaság Polgári Törvénykönyve (1963), 274. p. Benedek és Világhy szerint kivétel ez alól a hibás teljesítésből eredő károk megtérítésének igénye, lásd: BENEDEK - VILÁGHY (1965), 254. p.

${ }^{796}$ XXX. PED a) pont indokolás.

${ }^{797}$ PÁLFALVI (1975), 661-663. p.
} 
felelősségként határozták meg, majd szinonimaként megtoldották a meghatározást a jótállás szóval. ${ }^{798}$ A jótállás meghatározásánál pedig a szótár szinonimaként a szavatosság szót használta. Pálfalvi azt javasolta, hogy a jogalkotó adjon a két jogintézménynek azok mibenlétét jelző közérthetőbb elnevezéseket. ${ }^{799}$

Már a Ptk. megalkotása előtt elfogadták azt a jogszabályt, ami az ipari termékek minőségének védelméről szólt, és előírta, hogy egyes tartós használatra rendelt árucikkeket kötelezően jótállás vállalásával kell árusítani, ${ }^{800}$ majd a Ptk. hatályba lépését követő években több olyan jogszabály született, amely a jótállásra vonatkozó specifikus szabályokat tárgyalta. ${ }^{801} \mathrm{~A}$ tartós fogyasztási cikkek jótállási kötelezettségéről szóló 7/1968. (I. 30.) Kormányrendelet szóhasználata figyelemre méltó, hiszen fogyasztói társadalomról még korántsem beszélhetünk a '60-as évek végi Magyarországon. Megállapítható ugyanakkor, hogy a jogszabály alapján kötelező jótállás Európában máig is különlegességnek számító rendszerének megjelenése a magánjogunkban a szocializmus időszakára datálható. ${ }^{802} \mathrm{~A}$ jogpolitikai cél és eszköz az aediliszi edictumra is emlékeztet, mert kiemelt árukra vonatkozóan szigorúbb, objektív helytállást ír elő rendeletileg. Belenyúl a magánautonómiába, és ezáltal a gazdasági versenybe is.

\subsection{Igényérvényesitési határidők és bizonyítási teher}

\subsubsection{Szavatossági határidők}

A Ptk. miniszteri indokolása szerint a kellékszavatossági igényérvényesítésre szabott határidők szabályozásakor az együttmüködés általános polgári jogi elvéböl indult ki a jogalkotó. ${ }^{803}$ A kellékhibának a dolog átadásakor kellett fennállnia a szavatossági helytállás megállapításához, és ez az időpont volt az irányadó az igényérvényesítésnél is.

„Ha a hiba felismerhetö, a jogosult szavatossági jogait a szolgáltatás megvizsgálásának befejezésétöl számított nyolc napon belül köteles a másik félhez intézett nyilatkozattal érvényesiteni.

\footnotetext{
798 Lásd: PÁlfalvi (1975), 661. p. hivatkozása a Magyar Értelmező Kéziszótárra (Akadémiai Kiadó, Budapest, 1972.).

799 PÁlfalvi (1975), 663. p.

800 1953. évi 12. sz. tvr. 17. §.

${ }^{801}$ Lásd: a fent már hivatkozott 1/1964. (I. 11.) BkM sz. rendelet; a jótállási alap képzéséről és a jótállási költségek elszámolásáról szóló 5/1968. (I. 27.) PM sz. rendelet; a tartós fogyasztási cikkek jótállási kötelezettségéről szóló 7/1968. (I. 30.) Korm. sz. rendelet; egyes tartós fogyasztási cikkek jótállásának legkisebb kötelező mértékéről szóló 4/1969. (III. 30.) BkM - KGM - KipM - KkM - NIM sz. együttes rendelet.

${ }^{802}$ Európában hazánkon kívül máig Szlovénia magánjogában van tradíciója a kötelező jótállásnak, lásd: SCHÜLTE-NÖLKE - TWIGG-FLESNER - EBERS (2008), 436. p.

${ }^{803}$ Lásd: A Magyar Népköztársaság Polgári Törvénykönyve (1963), 328. p.
} 
Ha a hiba csak a használat közben vagy egyébként hosszabb idö után ütközik ki (rejtett hiba), a hiba felfedezésétöl számitott nyolc napon belül, de legkésöbb a szolgáltatás megvizsgálásától számított hat hónapon belül kell a jogosultnak a nyilatkozatot megtennie.

A szavatossági jogokat a nyilatkozat megtételétöl számitott hat hónapon belül kell keresettel érvényesiteni, kivéve, ha a felek hosszabb tartamú jótállásban állapodtak meg.

A nyolc napi, illetöleg hat havi határidök elmulasztása jogvesztéssel jár. A szavatossági jogokat azonban ugyanabból a jogalapból eredö követeléssel szemben kifogásként érvényesiteni lehet, ha a jogosult a nyilatkozatot kellö idöben megtette. "804

A Ptk. a szavatossági határidők meghatározásakor különbséget tett az ún. nyílt és a rejtett hibák között. A nyílt hiba olyan kellékhibát takart, ami felismerhető lett volna a megvizsgálás során, a rejtett hiba azonban csak a használat közben vagy egyébként hosszabb idő után kiütköző hiányosságot, kellékhibát jelentette. A Ptk. ezen kívül kétféle határidőről rendelkezett: az egyik határidő a hibára vonatkozó kifogásolási, nyilatkozattételi határidő, a másik pedig a kellékszavatossági kereset megindításának a határideje volt.

Nyílt hiba esetén a jogosult a dolog megvizsgálásának befejezésétől számított nyolc napon belül volt köteles megtenni a kötelezett felé a nyilatkozatát arra nézve, hogy a teljesítést hibásnak tartja, és szavatossági jogait érvényesíteni kívánja. Rejtett hiba esetén a hiba felfedezésétől kellett számítani ezt a nyolc napos nyilatkozattételi határidőt, amely kiegészült egy objektív, a dolog megvizsgálásától számított hat hónapos időszakkal, amelyen túl a szavatossági igények érvényesítésére vonatkozó jogosulti nyilatkozatot már nem lehetett megtenni. A nyolc napos szubjektív határidő a miniszteri indokolás szerint arra ösztönzi a jogosultat, hogy nyilatkozatát nyomban tegye meg, mert a késlekedés egyik fél érdekeit sem szolgálja, így az az igényérvényesítési jog megvonásával is szankcionálható. ${ }^{805} \mathrm{~A}$ nyolc napos határidő a hiba felfedezését követő naptól indult a határidőszámítás szabályai alapján. ${ }^{806}$

Az objektív hat hónapos határidőt azért tarthatta fontosnak a jogalkotó, mert a hiba felfedezése a vevő magatartásán múlott, és a felfedezés időpontjának bizonyítása nehézségekbe ütközhetett. Előfordulhatott azonban, hogy a hiba nem a vevő hanyagsága

\footnotetext{
${ }^{804}$ Lásd: Ptk. 306. § (1)-(4) bekezdések.

805 A Magyar Népköztársaság Polgári Törvénykönyve (1963), 331-332. p. A cél a szerződések gyors lebonyolításának biztosítása volt, lásd: XXXI. PED indokolása. A XXXI. PED szövegét lásd: GELLÉRT ZOLTÁN (1975), 320-334. p.

806 Lásd: 1960. évi 11. számú törvényerejü rendelet a Polgári Törvénykönyv hatálybalépéséröl és végrehajtásáról. A továbbiakban: Ptké., 3. § (1) bekezdés.
} 
vagy késlekedése miatt ütközött ki csak később, annak ellenére, hogy már a szerződéskötéskor „lappangott” vagy fennállt az oka. Az ezzel kapcsolatos kérdésekre is kitért a Legfelsőbb Bíróság XXXI. Polgári Elvi Döntése. ${ }^{807}$ Az LB ebben úgy rendelkezett, hogy „ha a szolgáltatott dolog hibája - jellegénél vagy a szolgáltatás természeténél fogva csak huzamosabb vizsgálat alapján ismerhető fel”, akkor az objektív hat hónapos nyilatkozattételi határidőt ,attól az időponttól kell számítani, amikor a hiba gondos vizsgálat mellett egyáltalán felfedezhetővé vált”. 808

Gyakori volt a rejtett hiba például a vetőmagoknál, ahol bizonyos hibák a növény meghatározott fejlettségi fázisában, illetve a kikelés után mutatkoztak csak. ${ }^{809}$ Ugyanígy a szőlő- és bortermelésnél is nehézségeket jelentett a kellékszavatossági határidők számítása. A szőlö-, gyümölcs- és borgazdálkodásról szóló 1959. évi 23. törvényerejü rendelet 8 . § úgy rendelkezett, hogy az eladó szavatol a szaporítóanyag fajtaazonosságáért és szabványszerinti minőségéért. A jogszabály elrendelte, hogy a szavatossági hiány miatti hat hónapos jogvesztő igényérvényesítési határidőt attól kezdve kellett számítani, amikor „a vevö a hiányosságról a dolog természete szerint” tudomást szerezhetett”, ${ }^{810}$

A bírósági igényérvényesítésre vonatkozó határidőt a Ptk. rejtett és nyílt hiba esetén egyaránt a kellékhibára vonatkozó jogosulti nyilatkozat megtételétől számított hat hónapban állapította meg [Ptk. 306. § (3) bekezdés]. A miniszteri indokolás hangsúlyozta, hogy a határidőre vonatkozó elöírások is diszpozitívek, azaz azokat a felek meg is hosszabbíthatták megállapodásukban. ${ }^{811}$

A két határidő egymásra épült, és a hibás teljesítés jogi tényének gyors, mielőbbi megállapítását, valamint a minél hamarabbi igényérvényesítést elősegítendő alakították ki e szabályokat. Mind a két szavatossági határidő jogvesztő volt. A keresetindítási határidő letelte után azonban a jogosult a szavatossági jogait az ugyanabból a jogalapból eredő követeléssel szembeni kifogásként érvényesíthette, ha a hibára vonatkozó nyilatkozatát az eladó felé annak idején kellő időpontban megtette [Ptk. 306. § (4) bekezdés]. Ez tulajdonképpen a jogvesztő jelleg alóli kivétel volt a kódexben, amelyet a miniszteri indokolás szerint a méltányosság szempontja indokolt: a jogosult késlekedése nem járhat azzal a súlyosabb szankcióval, hogy a vevővel szemben érvényesített eladói igény esetén ő

\footnotetext{
${ }^{807}$ A továbbiakban: XXXI. PED.

${ }^{808}$ XXXI. sz. PED a) pont.

${ }^{809}$ ZOLTÁN (1962), 239. p.

${ }^{810}$ Az idézetet lásd: ZOLTÁN (1962), 239. p.

811 A Magyar Népköztársaság Polgári Törvénykönyve (1963), 333. p.
} 
ne érvényesíthesse szavatossági jogait, azaz kedvezötlenebb helyzetbe kerüljön az eladónál. $^{812}$

A határidők részletszabályaira vonatkozó fent említett XXXI. PED-nek a Ptk.-t pontosító rendelkezéseit szemléltetik a következő konstruált, ingó adásvételével kapcsolatos példák. Amennyiben egy kerékpár adásvétele után annak egyik kereke az első használat után leeresztett, mert a kerékbelső foltozott volt, a hibás kerék kijavításától függetlenül a kerékpár másik kerekére illetve egyéb részeire vonatkozóan a szavatossági jog nem volt érvényesítettnek tekinthető. ${ }^{813}$ A kicserélt kerék esetében azonban a szavatossági határidő újra kezdődött, mert a kicserélés - tartalmát tekintve - új dolog(rész) szolgáltatását jelentette, és a jogintézmény akkor éri el gazdasági célját, ha az új, kicserélt dolgot szerződésszerünek tekintve az arra irányadó szavatossági határidő nem rövidül indokolatlanul. $^{814}$

Amennyiben egy gépkocsi adásvételének hibás teljesítése miatt a vevő az általa választott kijavítási jogáról az eladóval tárgyalást folytatott, de utóbb mégsem jutottak kielégítő megegyezésre, mert az eladó a kijavítást csak túl hosszú időn belül tudta volna foganatosítani, akkor a hat hónapos jogvesztő keresetindítási határidő akkor kezdődött, amikor nyilvánvalóvá vált, hogy nem tudnak megegyezni. ${ }^{815}$ Ha mégis kijavította a gépkocsit az eladó, ami X napot vett igénybe, akkor a PED szerint ellenkező megállapodás hiányában a szavatossági határidő meghosszabbodott ugyanezzel az X nappal, amely alatt a vevő az autót a hiba miatt nem használhatta. Ha tehát később ismét szavatossági jogot szeretett volna érvényesíteni, akkor ezt figyelembe kellett venni a határidő számításánál. ${ }^{816}$ Ha a felek megállapodással mégis rendezni tudták az igényérvényesítés módját, de utóbb annak az eladó valamilyen okból mégsem tett eleget, akkor a megállapodáson alapuló jogát a vevő a hat hónapos keresetindítási határidő helyett a rendes öt éves elévülési határidőn belül érvényesíthette a bíróság előtt. ${ }^{817}$

A minőségi hibákkal kapcsolatos igényérvényesítésre ezeken kívül a fent hivatkozott 1/1964. (I. 11.) BkM rendelet is megfelelően alkalmazandó volt.

\footnotetext{
${ }^{812}$ A Magyar Népköztársaság Polgári Törvénykönyve (1963), 332. p.

${ }^{813}$ XXXI. PED b) pont.

${ }^{814}$ XXXI. PED d) pont és indokolása, lásd: GELLÉRT - ZOLTÁN (1975), 331. p.

${ }^{815}$ XXXI. PED c) pont.

${ }^{816}$ XXXI. PED c) pont.

${ }^{817}$ XXXI. PED c). pont.
} 


\subsubsection{A kártérítési igény érvényesítésének határideje}

A Ptk. szerint a hibás teljesítésből eredő kártérítési igényt is a fenti szavatossági határidőkön belül érvényesíthette a vevő [Ptk. 307. § (2) bekezdés]. A többi szavatossági igény érvényesítésére nyitva álló határidő alkalmazását a hibás teljesítésből eredő károk esetén azzal indokolta a jogalkotó, hogy a szabályozás célja az, hogy a jogosult csak azt a kárt követelhesse, amely a szavatossági joga érvényesítésével nem térül meg, és azt nem, amit szavatossági igényként sikertelenül érvényesített, ebből következően a határidők sem lehetnek hosszabbak a kártérítési igényérvényesítés esetén. ${ }^{818} \mathrm{~A}$ jogosult perbeli pozícióját egyedül a bizonyítás szabálya segítette: az kötelezettnek kellett kimentenie magát az adott esetben általában elvárható magatartása bizonyításával [Ptk. 307. § (1) bekezdés].

Korábbi magánjogunkban az eladó csalárdsága a kellékszavatossági igény érvényesítésénél relevanciát nyert, és szigorúbb elbírálás alá esett. A hibás teljesítéssel kapcsolatos csalárdságot a Ptk.-ban a kártérítés szubjektív jogalapú jogkövetkezménye körében értékelte a jogalkotó, amikor kivételt teremtett: ha a vevő bizonyítani tudta, hogy az eladó a hibás teljesítés tekintetében csalárd módon járt el, akkor a rendes polgári jogi elévülési határidő, azaz öt év állt a rendelkezésére kártérítési joga érvényesítésére. ${ }^{819} \mathrm{~A}$ jogtudományi meghatározások szerint a csalárdság „feltétlenül rosszhiszemű magatartást” jelentett, mindig célzatos szándékosságot, amelynek célja a jogosult megtévesztése, tévedésben tartása, például a hiba leplezése, a vevő félrevezetése, becsapása, a hiba megtévesztési szándékkal való elhallgatása volt. ${ }^{820}$ Benedek és Világhy szerint „a csalárdság a vétkesség és a rosszhiszemüség egysége", azonban úgy vélik, hogy önmagában az, hogy valaki tudottan hibás árut szállít, nem jelent csalárdságot, mert ahhoz az is kell, hogy a jogsértés célzatával járjon el a vevő tévedésbe ejtése és tévedésben tartása tekintetében. ${ }^{821}$

A határidők szabályozásánál nyert tehát relevanciát az eladó csalárd magatartása. A csalárdság bizonyítása azonban nehézségekbe ütközhetett a gyakorlatban, így a rövid határidők letelte után érvényesítendő károkat szerződésszegés címén csak ritka esetben térítették volna meg, ami joghátrányt jelentett volna a jogosultnak. A bírói gyakorlat e problémát érzékelve következetesen figyelmen kívül hagyta az adott esetben fennálló

\footnotetext{
${ }^{818}$ Lásd: A Magyar Népköztársaság Polgári Törvénykönyve (1963), 333.p.

${ }^{819}$ Lásd: Ptk. 307. § (2) bekezdés és 324. § (1) bekezdés. Így rendelkezett a BGB is, lásd: II. fejezet 2.8. pont.

${ }^{820}$ Lásd: ZOLTÁN (1962), 246. p.; BENEDEK - VILÁGHY (1962), 107-108. p.

${ }^{821}$ Lásd: BENEDEK - VILÁGHY (1962), 107-108. és 292. p. Ugyanígy: ZOLTÁN (1962), 239-240. p. Messzire rugaszkodik a csalárdság római jogban gyökerező felfogásától ez a megközelítés. Véleményem szerint a tudva hibás áru szolgáltatásában mindig benne foglaltatik a károsítás tudata is.
} 
szerződéses jogviszonyt, és közvetlenül inkább a Ptk. 339. §-ra, azaz a szerződésen kívüli károkozás általános szabályára alapították az ítéletet. ${ }^{822}$ Eörsi Gyula ezt dogmatikailag helytelennek véli, valódi kollíziónak tartja azonban azt, ha egymás mellett valósul meg a szerződésszegésből eredő és a szerződésen kívüli károkozás, így például alkalmazotti károkozás esetén, amikor szerinte a szerződéses felelősségnek kell általában felülkerekednie a jogvita elbírálásakor. ${ }^{823}$ Ellenpélda erre a Legfelsőbb Bíróság döntése abban a jogesetben, amelyben az alperes szerelővállalat alkalmazottai büncselekménynek minősülő gondatlan eljárása a gázbojler bekötése során súlyos károkat előidéző robbanást okozott. ${ }^{824}$ Itt nem csak szerződésszegés, méghozzá hibás teljesítés esete forgott fenn, hanem megvalósult az alkalmazott károkozásának szerződésen kívüli felelősséget teremtő tényállása is (Ptk. 348. §), és mindez egy büntetőjogi törvényi tényállásba is beleillett. Ez utóbbi erősítette meg a szerződésen kívüli polgári jogi igényt, amelyre alapítva hozta meg végül a bíróság a marasztaló ítéletét. ${ }^{825}$

A XXXI. PED a kártérítésről úgy rendelkezett, hogy ha a jogosult bármely szavatossági jogát a nyilatkozattételre meghatározott határidőn belül közölte, akkor ezzel a nyilatkozatban megjelölt hibából eredő kár megtérítésének igénye is implicite érvényesítettnek tekintendő. ${ }^{826} \mathrm{~A}$ fenti jogalkalmazási nehézségeket megkönnyítendő azt is megállapította a PED, hogy a nyilatkozat megtétele után bekövetkezett kár esetén a hat hónapos jogvesztő határidő a kár bekövetkezésétől számítandó. ${ }^{827}$

\subsubsection{Jótállási határidő}

A jótállásról szóló XXX. PED a határidőkkel kapcsolatban is releváns megállapításokat tett. A jótállási igények érvényesítésére a jótállási nyilatkozatban foglalt határidők voltak irányadóak. Nem érvényesült kötelező külön nyilatkozattételi határidő, és az LB a nyílt és rejtett hibák között sem tett különbséget az igényérvényesítés vonatkozásában. ${ }^{828}$ Amennyiben a jótállási nyilatkozatban meghatározott határidőn belül egyoldalú nyilatkozatban a jogosult értesítette a hibáról a kötelezettet, az értesítéstől számított hat hónapos határidőn belül akkor is érvényesíthette a jótállási igényeit, ha a jótállási határidő

\footnotetext{
${ }^{822}$ Lásd például: P. II. 25.817/1961., 16. P. 86.721/1961., 16. P. 29.855/1961., 43. Pf. 27.657/1961., 55. Pf. 30.857/1960. számú ítéletek; EÖRSI (1966), 68. p.

${ }^{823}$ EÖRSI (1966), 69. p.

${ }^{824}$ Lásd: Pf. IV. 22.202/1961. számú ítélet.

${ }^{825}$ Lásd: EÖRSI (1966), 70. p.

${ }^{826}$ XXXI. PED e) pont 1 . mondat.

${ }^{827}$ XXXI. PED e) pont 2. mondat.

${ }^{828}$ XXX. PED b) pont indokolása.
} 
közben már letelt. ${ }^{829}$ A Legfelsőbb Bíróságnak ez utóbbi megállapítása védelmet nyújtott a vevő számára, hogy ha nem késlekedett a hiba közlésével, akkor ne érje őt hátrány a túl rövid jótállási határidő miatt. Ezt a kiegészítő határidőt az LB a jótállás alapján követelt kártérítés esetén is alkalmazandónak ítélte, és ekkor a jogosult eljárási helyzetét is megkönnyítette azzal, hogy a kötelezett csalárdságának bizonyítását „elengedte”. 830

A XXX. PED külön kitért a kijavítási és a kicserélési igény jótállás alapján történő érvényesítési határidejére is. Kijavítás esetén azt a diszpozitív szabályt konstruálta az LB, hogy a hiba közlésétől számítva meghosszabbodik a jótállási idő azzal az időtartammal, amely alatt a jogosult a dolgot a hiba miatt képtelen volt rendeltetésszerüen használni. ${ }^{831} \mathrm{~A}$ dolog vagy annak jelentős része kicserélésének esetén - a szavatossági határidőkhöz hasonlóan - a jótállási idő a kicserélt dolog(rész) tekintetében újraindult. ${ }^{832}$

\subsection{Szavatosság állatok adásvétele esetén}

Az állatok adásvétele magánjogunkban mindig is kiemelt fontosságú kérdés volt az állatok gazdaságban betöltött szerepe és speciális tulajdonságai miatt. A jogalkotó az addig külön jogszabályban szabályozott állatszavatosság kérdését beemelte a Ptk. hatálya alá, azonban a vonatkozó rendelkezések nem a kellékszavatosság, hanem az adásvétel szabályai között kaptak helyet. ${ }^{833}$ A speciális szabályok hatálya alá tartozó állatokat a Ptké. adta meg: a ló, a szamár, az öszvér, a szarvasmarha, a bivaly, a juh, a kecske és a sertés adásvételére vonatkoztak e speciális szabályok. ${ }^{834}$

„Ha az eladó hibás állatot szolgáltat, a vevö követelheti a szerzödés felbontását, fajta (nem) szerint meghatározott állat adásvétele esetén pedig az állat kicserélését is., 835

Ha az eladó hibás állatot szolgáltatott, a vevő egyedvétel esetén tehát csupán a szerződés felbontását követelhette, a fajta (nem) szerint meghatározott állat adásvétele esetén azonban megillette a választás joga a szerződés felbontása és az állat kicserélése között. ${ }^{836}$

\footnotetext{
${ }^{829}$ XXX. PED b) pont indokolása.

${ }^{830}$ XXX. PED b) pont 2. mondat.

${ }^{831}$ XXX. PED c) pont 1 . mondat.

${ }^{832}$ XXX. sz. PED c) pont 2. mondat.

${ }^{833}$ Lásd a miniszteri indokolást: A Magyar Népköztársaság Polgári Törvénykönyve (1963), 334. p. A Ptk. Tervezete még a külön jogszabályban történő szabályozásban gondolkodott, lásd: Tervezet (1957), 46. p.

${ }^{834}$ Lásd: Ptké. 61 . $§(1)$ bekezdés.

${ }^{835}$ Ptk. 383. § (1) bekezdés.

${ }^{836}$ Ez a BGB megoldását tükrözi, vö. BGB $§ 485$.
} 
A felbontás követelése esetén a bíróság, ha a helyzetet és a hiba jelentőségét mérlegelve úgy látta, akkor kivételesen fenntarthatta a szerződés hatályát a vételár egyidejü leszállításával. ${ }^{837} \mathrm{Az}$ eladónak fajta szerinti vétel esetén megadta a kódex azt a facultas alternativát, hogy a hibás állatot egy ugyanolyan hibátlanra kicserélje, ha ezt a vevő érdekeit nem sértő késedelem nélkül végre tudta hajtani. ${ }^{838} \mathrm{Ha}$ több állatot mint együvé tartozót vagy egész nyájat adtak el, akkor a vevő illetve az eladó érdekeire figyelemmel nem csak a hibás egyed(ek), hanem az összes állat tekintetében is helye lehetett a vétel felbontásnak [Ptk. 383. § (3) bekezdés]. ${ }^{839}$

Az igényérvényesítési határidőknél a Ptk. nem tett különbséget rejtett és nyílt hiba között, de itt is elkülönítette a nyilatkozattételi és keresetindítási határidőket:

„A vevö szavatossági jogait a hiba felismerésétöl számított nyolc napon belül jogvesztés terhével az eladóhoz intézett nyilatkozattal érvényesitheti; ennek eredménytelensége esetén pedig az átvételtöl számitott hatvan napon belül indithat keresetet. $" 840$

A nyilatkozattételre tehát a hiba felismerésétől számított nyolc napos jogvesztő határidő állt rendelkezésre, és ha ez eredménytelennek bizonyult, akkor a vevő az állat átvételétől számított 60 napon belül indíthatott a hiba miatt keresetet. Az utóbbi elévülési határidő volt, azaz nyugodhatott és félbe is szakadhatott, és az azonos jogalapból eredő eladói követeléssel szemben is felhozhatta a vevő a szavatossági kifogását, ha korábban a hibára vonatkozó nyilatkozatát a 8 napos határidő alatt megtette [Ptk. 384. § (2) bekezdés].

A szabályozásra vonatkozóan született egy polgári kollégiumi állásfoglalás is. ${ }^{841}$ Ennek rendelkezése szerint az általános szavatossági szabályok közül az állatok adásvételénél is alkalmazandó volt az a szabály, miszerint a hibás teljesítés tekintetében csalárdul eljáró eladóval szemben a hibás teljesítésből eredő károkra vonatkozó igény az általános elévülési idő alatt érvényesíthető a bíróságon. ${ }^{842}$

\footnotetext{
${ }^{837}$ Ptk. 383. § (2) bekezdés a) pont.

${ }^{838}$ Túl nagy késedelemmel végrehajtott kicserélés esetén a vevőt a késedelem szabályára utaló rendelkezés alapján már az elállás joga illette meg, így olyankor az eladó nem térhetett át a kicserélés jogára, vö. Ptk. 383. $\S(2)$ bekezdés b) pont, 305 . $\S$ (1) bekezdés c) pont és 300 . $\S$.

${ }_{839}$ Megmutatkoznak e szabályban a római jogi hagyományok, és az ABGB és BGB rendelkezéseinek mintája is.

${ }^{840}$ Ptk. 384. $§(1)$ bekezdés.

841 PK 56. számú állásfoglalás.

${ }^{842}$ Lásd: a PK 56. sz. állásfoglalás c) pontjának utalása a Ptk. 307. § (2) bekezdésének rendelkezésére.
} 


\subsection{Elhatárolási kérdések}

\subsubsection{Jogszavatosság}

A bíróság előtt egy jogeset kapcsán felmerült az a kérdés, hogy a kellékszavatosság szabályai, közelebbről a Ptk. 305. § (4) bekezdése, amely kimentést tesz lehetővé a helytállás alól, ha a hibát a jogosult ismerte, alkalmazható-e a jogszavatossági igényekre is. ${ }^{843} \mathrm{~A}$ jogesetben a felperes motort vett az alperestől, amely korábban egy jogellenesen külföldre távozott személy tulajdonában állt, akiröl a bejelentési kötelezettség elmulasztása miatt az államra szállt a tulajdonjog. A felperes minderre figyelemmel keresetet indított a vételár visszafizetése, azaz a szerződéstől elállás/szerződés egyoldalú felbontása iránt. Az elsőfokú bíróság marasztaló ítéletet hozott, de másodfokon a bíróság az ítéletet hatályon kívül helyezte, és egyéb bizonyítási kérdések mellett azt is szükségesnek látta tisztázni, hogy a vevő felperes vajon tudott-e az állam tulajdoni igényéről. Úgy vélte, hogy ha igen, akkor a Ptk. fenti 305. § (4) bekezdése értelmében nem érvényesíthet (jog)szavatossági igényt. A bíróság tehát úgy ítélte meg, hogy a kellékszavatosságról szóló kötelmi általános részben szereplö, illetve a jogszavatosságról az adásvétel szabályai között található rendelkezések az általános-különös viszonyában állnak, és a jogszavatosság körében nem rendezett kérdésekre a kellékszavatosság szabályai alkalmazhatóak.

A Ptk. miniszteri indokolása szerint a kellékszavatosságra vonatkozó számos megállapítás igaz a jogszavatosságra is, hiszen mindkettő a szerződés tartalmának megfelelő teljesítésre sarkall. A kettőt azonban nem csak rendszerbeli elhelyezésük különbözteti meg egymástól: a kellékszavatosság a szolgáltatás fizikai, a jogszavatosság pedig a jogi hibamentességéért, a tehermentességért való helytállás - amint azt az elnevezésük is mutatja. Erre a szabályozási különbségre figyelemmel a Ptk. 305-308. §beli és a 372-373. §§-beli szabályok sem állhatnak az általános-különös viszonyában. Ezt a vitatott törvényhely vonatkozásában egy további praktikus szempont is igazolja: a kellékszavatossági rendelkezés esetén a jogalkotó a kivétel megadásával azt feltételezte, hogy a tudottan hibás áru átvétele, elfogadása teljesítésként a jogosult elégedettségét jelzi, ${ }^{844}$ a jogi hibánál illetve jogszavatosság esetén azonban aligha feltételezhető az, hogy bárki úgy szeretne megvásárolni valamit, hogy tudja, hogy nem szerez(het) rajta tulajdont. $^{845}$ A jogszavatosság szabályainak jogpolitikai indoka a jóhiszemű vevő védelme.

\footnotetext{
${ }^{843}$ Lásd: BENEDEK - VILÁGHY (1965), 281. p.

${ }^{844}$ A Magyar Népköztársaság Polgári Törvénykönyve (1963), 329. p.

${ }^{845}$ A jogesetben $6000 \mathrm{Ft}$ volt a vételár, ami a '60-as évek viszonyai között sok pénznek számított.
} 
A rosszhiszemü vevő védelme azonban nem indokolt, mert ő összejátszik az eladóval, és így olcsóbban jut a dologhoz. Benedek és Világhy további indokolása szerint a tudottan más tulajdonát képező dolog vétele esetén az adásvétel lehetetlenre irányul, így semmis. ${ }^{846}$

\subsubsection{Nemteljesítés}

Az egyedi vétel esetén érvényesíthető szavatossági jogokkal kapcsolatos női cipővásárlás jogesetének értékelésénél Benedek és Világhy úgy vélik, hogy a hibás teljesítés jogi értelemben nemteljesítésnek minősül, amely esetben a Ptk. szabálya, miszerint a teljesítéssel a kárveszély átszáll a másik szerződő félre (Ptk. 279. §), nem alkalmazható. ${ }^{847}$ Ez a problémakör a kellékszavatosságot érintő ún. létszaki vitához kapcsolódik, amely a jogintézmény szerződési életciklusban betöltött helyéhez kapcsolódott. Az egyik jogtudományi álláspont szerint a kellékszavatosság a szerződés teljesítése utáni új szakasz a felek jogviszonyában, a másik szerint a szerződés megszünésének rendes módja a hibamentes teljesítés, ennek megfelelően a hibás teljesítés nemteljesítésként értékelendő. ${ }^{848}$

Benedek és Világhy az utóbbi álláspontot képviselték az említett jogesetben. ${ }^{849}$ Úgy vélem, hogy az, hogy az eladó kellékhibásan, nem a szerződésnek megfelelően teljesít, nem értékelhető nemteljesítésként, mert az már a késedelem szerződésszegési esete. A jogtudósok azonban úgy vélték, hogy a nemteljesítés miatt a kárveszély átszállása nem következik be addig, amíg az eladó a szavatossági igényeket nem teljesíti. ${ }^{850} \mathrm{Ez}$ az álláspont különösen a rejtett hibák esetén problematikus. Ha a hiba csak később ütközött ki, az addig, illetve a hibás teljesítésröl szóló nyilatkozat megtételéig terjedő időben a kárt nem viselheti az eladó, hiszen a dolog a vevőnél van, jobb esetben már használja is. A szerződések életciklusában a hibás teljesítés - ahogy a neve is mutatja - a teljesítés fogyatékosságát jelöli, ami csak a teljesítés aktusa, és a dolog vevőhöz (jogosulthoz) kerülése után következhet be. Nemteljesítésről véleményem szerint csak a teljesen más áru szolgáltatása, azaz az aliud szolgáltatás esetén lehet szó, hiszen akkor egyáltalán nem a kialkudott adásvételi tárgy kerül átadásra, nem az, amiben a felek megállapodtak. Benedek

\footnotetext{
${ }^{846}$ BENEDEK - VilÁGHY (1965), 283. p. Vö. Ptk. 226. § (2) bekezdés.

${ }^{847}$ BENEDEK - VILÁGHY (1965), 280. p.

${ }^{848}$ Lásd részletesen: JÓZSA (1968), 604. és 608-610. p.

${ }^{849}$ Lásd: 4.3.3. pont.

${ }^{850}$ BENEDEK - VILÁGHY (1965), 280. p.
} 
és Világhy is úgy vélik, hogy ez esetben nemteljesítésről van szó, ezért ekkor a jogosult a szerződésszerü teljesítést követelheti elsődlegesen. ${ }^{851}$

\subsubsection{A szerződés teljesítése alkalmával a jogosult egyéb - nem szerzödési - érdekeinek sérelme}

A Ptk. eredeti szövege alapján nem lehet szó hibás teljesítésről abban az esetben, ha a teljesítés során a jogosultnak nem az ún. szerződési érdeke szenvedett sérelmet. Zoltán Ödön azt a példát hozza, hogy az eladó kiszállította a megvásárolt dolgot a vevő lakására, és a lakásba való bevitel, behelyezés során egyéb tárgyban kárt okozott, például összetörte a televíziót. ${ }^{852}$ Bár a teljesítés során következett be a károkozás, az mégsem a szerződéses kötelezettség megszegéséből fakadt, így a szerződésen kívüli károkozás szabályai vonatkoznak a cselekmény jogi értékelésére Zoltán szerint. ${ }^{853}$ Úgy véli azonban a jogtudós, hogy ez esetben is érvényesül az a megszorítás, hogy a kár összegét még méltányosságból sem lehet mérsékelni (Ptk. 318. §), és ha a kötelezett megbízottja, alkalmazottja okozta a kárt, a kötelezett nem mentheti ki magát. ${ }^{854}$

\section{Az 1959-es szabályozás jogtudományi kritikája}

Az 1959-es hibás teljesítésre vonatkozó szabályozás a '70-es évekre már több ponton nem tett eleget a gazdasági, társadalmi, jogpolitikai elvárásoknak, ezért a jogtudósok szerint megérett az igény a módosításra. Zoltán Ödön a módosítás indokaként „a szükségletek egyre magasabb szinten történő kielégítéséhez, a jó minőséghez, a szerződésekbe vetett bizalom erősítéséhez és a forgalom biztonságához füződő érdekre" hivatkozott. ${ }^{855} \mathrm{Az}$ új szabályozást szerinte a jogosulti (fogyasztói) érdek elsődleges védelmének kell vezérelnie, és ezzel is összefüggésben világosnak, egyszerünek és könnyen áttekinthetőnek kell lennie. $^{856}$

\footnotetext{
${ }^{851}$ Lásd: BENEDEK - VILÁGHY (1965), 304. p. Vö. Ptk. 300. § (1) bekezdés.

${ }^{852}$ ZOLTÁN (1962), 247. p.

${ }^{853}$ ZOLTÁN (1962), 247. p. Vö. Ptk. 339-344. §§.

${ }^{854}$ Vö.: Ptk. 315. § és 350. § (1) bekezdés. Az okfejtést lásd: ZoLTÁN (1962), 247. p.

${ }^{855}$ ZOLTÁN (1970a), 70. p.

${ }^{856}$ ZOLTÁN (1970a), 70. p.
} 
Zoltán Ödön és Kemenes Béla tanulmánysorozataikban részletes megoldási javaslatokat vázolva éltek kritikai megfontolásokkal. ${ }^{857}$ Ami a specifikus szavatossági jogokat illeti, igény mutatkozott arra, hogy a kicserélés igényét általánossá tegyék, hiszen az adásvételi szerződések esetében a gyakorlatban ez mutatkozott a vevői érdeksérelem legmegfelelőbb és egyben leggyorsabb módjának, ezen kívül a fogyasztó érdekét is jobban szolgálná. ${ }^{858}$ Az elállási jog, és annak gyakorlati érvényesítése is a reformálandó kérdések közé tartozott. ${ }^{859}$ Vitatott volt az is, hogy a speciális állatszavatossági szabályok csak a Ptké.-ben meghatározott állatokra korlátozása helytálló-e, sőt, az is, hogy van-e egyáltalán helye az állatszavatosság speciális, rendszertanilag is elkülönített szabályozásának. ${ }^{860} \mathrm{~A}$ jogtudomány képviselői előirányozták továbbá azt is, hogy a jogosult a hibás teljesítéshez füződő jogai közötti választás jogának rugalmasabban gyakorlása indokolt, ha ahhoz „lényeges érdeke füződik”. 861

Kemenes taglalta azt az igényt, amely a szavatossági jogok és azok érvényesíthetősége közötti valamilyen sorrendiség felállításához füződik, és a hiba foka, jelentősége és bizonyos értékhatár általi sorrendiséget tartotta ésszerünek. ${ }^{862}$

Kritika érte az igényérvényesítési határidők szabályozását, a kifogásközlési és keresetindítási fázisokra bontását, és a határidők jogvesztő jellegét is. ${ }^{863}$ Zoltán úgy vélte, hogy a határidő tartama szerinti differenciálás csak a szolgáltatás tárgya alapján lenne indokolható. ${ }^{864}$ Kemenes tárgyalta a határidő-számítás kezdő időpontjának problematikáját is, és javaslata az átvétel időpontja volt, de az üzembe helyezés és használatbavétel kiegészítő szempontjainak figyelembe vételét is indokoltnak tartotta. ${ }^{865} \mathrm{Az}$

857 Lásd: Zoltán (1970a), (1970b), 1970c); KeMEnes (1973a), Kemenes (1973a), KemenEs (1973b), KEMENES (1973c), KEMENES (1974). Kemenes Béla a kandidátusi értekezését is a fogyasztói érdekvédelem polgári jogi kérdéskörében írta meg 1973-ban.

${ }^{858}$ ZOLTÁN (1970a), 71. p. Zoltán azt a szövegmódosítást javasolta, hogy a kicserélési jog ne csak a fajlagos, hanem az egyébként helyettesíthető dologra irányuló szolgáltatás esetén is adott legyen. Ez megfelelő kiküszöbölése a kérdést övező dogmatikai félreértéseknek. Ugyanígy vélekedett Kemenes is, lásd: KEMENES (1973), 208. és 212. p.

${ }^{859}$ Lásd: KEMENES (1973a), 214-215. p. A vita az elállási jog korlátozott illetve korlátozásmentes elismerése mentén volt a legerőteljesebb. Kemenes szerint az utóbbit a fogyasztói érdekvédelem sem indokolta, és a hiba foka és jelentősége valamint bizonyos értékhatár mentén javasolta a korlátozást meghatározni. Uo. 215. p.

${ }^{860}$ Lásd: ZOLTÁN (1970a), 72-73. p.; ZOLTÁN (1970b), 345. p.

${ }^{861}$ Lásd: Zoltán (1970a), 74. p.; Kemenes (1973a), 216. p.

${ }^{862}$ KEMENES (1973), 211-212. p.

${ }^{863}$ ZOLTÁN (1970b), 342. p. Józsa a fázisoknál a külön nyilatkozattételi határidő ellen érvelt, és példaként hozta a szovjet, a csehszlovák, a bolgár, a nyugatnémet, a svájci, a francia, a belga, az angol és az osztrák szabályozást, amelyek nem ismertek külön nyilatkozattételi határidőket. A határidők jellegével kapcsolatban pedig úgy vélte, hogy az elévülési határidő rugalmasabb lehetőségeket kínál (ezt bizonyította a szovjet és a bolgár, az adásvétel vonatkozásában pedig a német, az angol és a svájci szabályozás), uo. 343. p.

${ }^{864}$ Az építményeket hozta példaként, ZOLTÁN (1970b), 344. p.

${ }^{865}$ Lásd: KEMENES (1973a), 218. p. 
igényérvényesítési határidő tartamát illetően úgy vélte, hogy a fogyasztók érdekvédelme nem feltétlenül igényli annak általános meghosszabbítását, sokkal fontosabbnak tartotta, hogy a törvényi hat hónap után is lehetőség nyíljon igényei érvényesítésére, ha az kétségkívül szükséges és indokolt. ${ }^{866}$ Mindkét szerző a jogvesztő jellegű határidők ellen érvelt. ${ }^{867}$

Különös figyelmet érdemel Zoltán azon felvetése, hogy a jogalkotó felhatalmazást adjon arra, hogy ,jogszabály a kellékszavatossággal kapcsolatos kérdéseket meghatározott körben (pl. a tömegfogyasztási cikkek vagy romló áruk tekintetében) az általános szabályoktól eltérően szabályozhassa, illetőleg hogy meghatározott rendelkezések vonatkozásában az eltérő megállapodás lehetőségét megtilthassa" ${ }^{868}$ Felmerült tehát a kógens szabályozás igénye.

A módosítás kapcsán komoly problémaként merült fel a hibás teljesítésből eredő kártérítés jogalapjának kérdése is, ami látszólagos vitának tűnik, hiszen a kártérítés, mint polgári jogi szankció a Ptk.-ban már felróhatóságon alapuló szubjektív jogintézményként jelent meg. Az objektívvá tétel melletti érvek a hibátlan teljesítésre való erőteljesebb ösztönzés, a vevőre (fogyasztóra) nézve méltányosabb jogorvoslat, és a szavatossági és kártérítési helytállás közelítése volt. ${ }^{869}$ Zoltán Ödön a felróhatósági alapú kártérítés mellett érvelt a hibás teljesítésből fakadó károkért való felelősséggel kapcsolatban, mert a kártérítés általános szabálya is a felróhatósági alapú volt, a szubjektív kártérítést rugalmasabbnak tartotta, és úgy vélte, hogy a kis értékủ dolgokkal kapcsolatos kártérítési igények objektív alapú kártérítés esetén a valóságtól elrugaszkodott eredményre vezethetnek. ${ }^{870}$ Indokoltnak tartotta a szavatossági kötelezettség teljesítésével összefüggő költségeknek a kötelezettre hárítását. ${ }^{871}$ Úgy vélekedett, hogy egységesen ki kellene kötni a hibás teljesítéssel okozott kártérítési igény általános elévülési időn belüli érvényesíthetőségét. ${ }^{872}$

Zoltán meglátása szerint a kellékszavatossággal rokon mivolta és gyakorlati alkalmazása miatt rendszertanilag a hibás teljesítés szabályai között indokolt szabályozni a

\footnotetext{
${ }^{866}$ KEMENES (1973a), 221. p.

${ }^{867}$ ZOLTÁN (1970b), 342. p. Kemenes szerint a minőségvédelem és a fogyasztói érdekvédelem szempontjai is ez ellen érvelnek, lásd: KEMENES (1973a), 222. p. Nyugvás esetén három hónapos meghosszabbodást javasolt, uo. 225. p.

${ }^{868}$ Lásd: ZOLTÁN (1970b), 345. p.

${ }^{869}$ A teljes kérdéskörhöz lásd: ZOLTÁN (1970c), 480. p.

${ }^{870}$ ZOLTÁN (1970c), 480. p.

${ }^{871}$ ZOLTÁN (1970c), 481. p.

${ }^{872}$ ZOLTÁN (1970c), 481. p.
} 
jótállás jogintézményét. ${ }^{873}$ Szükségesnek tartotta továbbá annak kimondását, amiről csupán a XXX. PED rendelkezett, hogy a jótállás alapján a szavatossági igényeket és a hibás teljesítésből eredő kártérítési igényt is érvényesítheti a jogosult. ${ }^{874}$

Kemenes vázlatpontokba szedve ismertette az egyes kérdésekre vonatkozó módosító javaslatait. Eszerint az igényérvényesítés kezdő időpontja az átvétel; az általános - elévülési jellegü - igényérvényesítési határidő hat hónap, amelynek nyugvása lehetséges, és a menthető ok megszünte után az három hónappal meghosszabbodik; a jogosulti hibaközlés félbeszakító körülmény; a jogosulti kifogásközlés nem elöfeltétele a bírósági igényérvényesítésnek, és az a határidőn belül bármikor megtehető; valamint szükséges egy objektív igényérvényesítési határidő megállapítása (18 hónap vagy 2 év). ${ }^{875}$

\section{Az 1977. évi IV. törvény módosításai}

A jogtudományi értekezések eredményeit részben magába foglalva a „Magyar Népköztársaság Polgári Törvénykönyvéről szóló 1959. évi IV. törvény módosításáról és egységes szövegéröl”" szóló 1977. évi IV. törvény ${ }^{876}$ több kardinális módosítást foganatosított a hibás teljesítés szabályozásában. Az 1978. március 1-jén hatályba lépett rendelkezések megállapították a hibás teljesítés fogalmát, nem tartalmazták többé a nyílt és rejtett hiba közötti különbségtételt, a kicserélés jogát részletesebben szabályozták, a jogosultnak a ius variandi gyakorlását rugalmasabbá tették, a határidő-számítás kezdeteként a teljesítést jelölték meg, és az igényérvényesítésre egy rövidebb elévülési és egy hosszabb jogvesztő határidőt határoztak meg. Az alábbiakban csak a módosított rendelkezések kerülnek bemutatásra.

\subsection{Hibás teljesítés, kellékszavatosság}

A teljesítésre vonatkozó általános szabály az 1977. évi IV. törvény által kiegészült azzal, hogy „, a szolgáltatásnak alkalmasnak kell lennie arra, hogy azt rendeltetésének, illetőleg a szerzödésben kikötött vagy egyébként a szerzödéskötéskor a kötelezett által ismert célnak

\footnotetext{
${ }^{873}$ ZOLTÁN (1970c), 482. p.

${ }^{874}$ ZOLTÁN (1970c), 483. p.

${ }^{875}$ Lásd: KEMENES (1973a), 232. p.

${ }^{876}$ Az 1977. évi IV. törvény szövege elérhető: http://1000ev.hu/index.php?a=3\&param=8519 (2013. 12. 03.). A továbbiakban a Ptk. rövidítés az 1978. március 1-jétől hatályos rendelkezéseket jelöli.
} 
megfelelően lehessen felhasználni" ${ }^{877}$ A módosítás konkrétan definiálta a hibás teljesítést és jogkövetkezményeként jelölte meg a kellékszavatosságot:

„Olyan szerzödés alapján, amelyben a felek kölcsönös szolgáltatásokkal tartoznak, a kötelezett hibásan teljesit, ha a szolgáltatott dolog nem felel meg a teljesitéskor a törvényes vagy a szerzödésben meghatározott tulajdonságoknak.

A kötelezett felel (szavatol) azért, hogy a szolgáltatott dologban a teljesitéskor megvannak a törvényben és a szerzödésben meghatározott tulajdonságok (kellékszavatosság)., "878

Anyagi jogi értelemben azonban ez a rendelkezés a hibásság időpontján kívül nem hozott jelentősebb változást. ${ }^{879}$

\subsection{Szavatossági igények}

\subsubsection{Kijavítás és árleszállítás}

A módosítás általános szavatossági jogként a kijavítás és az árleszállítás igényét határozta meg [Ptk. 306. $§(1)$ bekezdés]. ${ }^{880}$ E két igény teljesítésével kapcsolatban a kódex egyéb rendelkezést nem tartalmazott, így nyitott maradt az a kérdés is, hogy mekkora lehet az árleszállítás mértéke. Egy ítéletében a Legfelsőbb Bíróság úgy rendelkezett, hogy ha a dolog tökéletesen nem javítható, és a fennmaradó hibák a rendeltetésszerü használatra, a forgalmi értékre, vagy a dolog élettartamára kedvezőtlen kihatással vannak, akkor a jogosult árleszállításra is igényt tarthat, és ilyenkor az árleszállításnak a kijavított dolog értékéhez kell igazodnia. ${ }^{881}$ Az LB később kidolgozta azon elveket, amelyek az árleszállítás mértékére vonatkoztak: mérvadó volt az, hogy a szolgáltatás hibái milyen mértékben sértik a jogosult hibátlan teljesítéshez füződő érdekét, és a bíróságnak a szolgáltatás-ellenszolgáltatás közötti egyenértéküség helyreállítására kellett törekednie. ${ }^{882}$ A forgalmi értéket és a javításhoz szükséges költség mértékét csak mérlegelési tényezőként lehetett figyelembe venni az LB szerint. ${ }^{883}$

A vételárcsökkentésre irányadó szempontokkal foglalkozott egy személygépjármü adásvételének hibás teljesítésével kapcsolatos jogeset is. ${ }^{884} \mathrm{Az}$ ügyben a 405000 Ft-ért megvásárolt gépkocsi hibája miatt a vevő 82500 Ft árleszállítást követelt a bíróságon az

\footnotetext{
${ }^{877}$ Ptk. 277. § (1) bekezdés.

${ }^{878}$ Ptk. 305. § (1)-(2) bekezdés.

${ }^{879}$ A hibásság időpontjának kérdését lásd a határidőknél.

${ }^{880}$ PETRIK (1995), 38. p.

${ }^{881}$ Lásd: BH 1985. 320.

${ }^{882}$ Lásd: BH 1985. 394., BH 1995. 92.

${ }^{883}$ Lásd: BH 1995. 212.

${ }^{884}$ Lásd: BH 1988. 182.
} 
eladótól. A felperes egy olajcsere alkalmával fedezte fel, hogy az elülső váznyúlványon javítás nyomai, a fenéklemezen pedig hegesztés nyomai láthatóak. A gépkocsit szakértővel megvizsgáltatta, aki megállapította, hogy annak egyes szerkezeti részeit a szakszerütlenül végrehajtott javítás miatt korrózió kezdte ki, de egyébként a gépkocsi a korának és használtságának megfelelő állapotban van. A hiba miatt a gépkocsi adásvétel időpontjában fennálló fogalmi értékét 322500 Ft-ban jelölte meg. Elsőfokon a keresetet elutasították, a másodfokú bíróság azonban azt megváltoztatva helyt adott a kereseti követelésnek, és az alperest 82500 Ft-ban marasztalta. Az ítélet ellen benyújtott törvényességi óvást azért találta alaposnak a Legfelsőbb Bíróság, mert véleménye szerint a másodfokú bíróság nem megfelelően állapította meg az egyébként jogos árleszállítási igény mértékét. Indokolásában az LB kifejtette, hogy az árleszállítás mértéke nem azonos a kijavítás költségével, de egyik tényezője lehet a mérték megállapításának, és különösen akkor meghatározó, ha a hiba a dolog rendeltetésszerü használatát meghatározó módon befolyásolja. Az LB szerint azonban ebben a jogesetben a hiba a rendeltetésszerü használatot nem befolyásolta, hanem a gépkocsi elhasználódásának idejét gyorsította, azaz a természetes elhasználódás folytán is felmerülő javításra korábban lesz szükség a hiba miatt. A vevő által a szakértői vélemény alapján megjelölt költség azonban nem csak a hiba javítását, hanem az esetleges későbbi, az elhasználódás miatti javítás költségét is magába foglalta. Ennek fényében az LB szerint az árleszállítás mértékének megállapításánál a jogesetben azt kell vizsgálni, hogy „a természetes elhasználódásból eredő állapothoz képest az alváznyúlvány szakszerütlen javításából eredő hiba milyen értékcsökkenést okoz", és az így megállapított \%-os értékkel kell a gépkocsi vételárát leszállítani.

\subsubsection{Kicserélés és elállás}

A módosító rendelkezések értelmében bizonyos feltételekkel élhetett csak a jogosult a kicserélés és az elállás jogával. A kicserélési jog fajta és mennyiség szerint meghatározott dolog vétele, illetve a termelöi és kiskereskedelmi forgalomban eladott, elkülönítéssel vagy kiválasztással meghatározott helyettesíthető dolog esetén, és csak akkor illette meg a vevőt, ha a kijavítás értékcsökkenés és/vagy a jogosult érdeksérelme nélkül nem volt rövid időn belül kivitelezhető [Ptk. 306. § (2) bekezdés]. Ez a módosítás lehetővé tette, hogy a kiskereskedelmi forgalomban értékesített árukat a megelőző egyes jogirodalmi álláspontokkal ellentétesen - helyesen - helyettesíthető dolgokként, de azok adásvételét 
nem fajlagos, hanem egyedi vételként kezeljék. Értelemszerüen azonban használt dolog kiskereskedelmi adásvétele esetén általában nem volt lehetőség a kicserélés igényének érvényesítésére a dolog jellege miatt. ${ }^{885}$

Az elállásról így rendelkezett a módosító törvény:

„Ha a hibás teljesités miatt a jogosultnak a teljesitéshez füzödö érdeke megszünt igy különösen, ha a hiba nem javitható ki, a kötelezett a hiba kijavitását nem vállalja, vagy a hiba kijavitása rövid idő alatt értékcsökkenés és a jogosult érdekeinek sérelme nélkül nem lehetséges -, a jogosult elállhat a szerzödéstöl.,

A kicserélés és az elállás feltételei tehát részben megegyeztek. A Ptk. szerint ezen igények érvényesítése esetén a jogosultnak nem kellett megtérítenie a dolognak azt az értékcsökkenését, ami a rendeltetésszerü használat következménye volt [309. § (2) bekezdés]. ${ }^{887}$ Nagyban segítette a jogalkalmazást, hogy a Ptké. II. meghatározta, hogy kiskereskedelemben eladott árucikknél a hiba akkor tekintendő rövid idő alatt értékcsökkenés nélkül kijavíthatónak:

„... ha a javitás folytán az áru értéke és használhatósága az azonos ideig rendeltetésszerüen használt hibátlan áruhoz képest nem csökken és a hiba bejelentésétöl számított nyolc nap alatt az árut megjavítják, illetöleg a kötelezö jótállással értékesitett terméket a jótállásra vonatkozó jogszabályban megállapitott határidőn belül megjavitják. Ez a határidő akkor is irányadó, ha a jótállás kötelezö idötartama már eltelt. ",88

Az elállási jogot megalapozó érdekmúlás nyilvánvaló volt, ha a dolog nem javítható és nem is cserélhető $\mathrm{ki}^{8}{ }^{889}$ de érdekmúlásnak minősült az is, ha a kijavítást az eladó nem vállalta, vagy a kijavítás után is értékcsökkent volt a dolog, ${ }^{890}$ illetve ha a javítást már több ízben sikertelenül megkísérelték, ${ }^{891}$ vagy ha a kötelezett a dolog kijavítását a jogosulttal kötött megállapodás ellenére hosszú időn át nem végezte el. ${ }^{892} \mathrm{Az}$ érdekmúlás és így az elállás alapos indokául szolgált az is egy bírósági döntés alapján, hogy egy technikai berendezés üzemeltetése során rendkívül nagyszámú meghibásodás következett be, és a jövőben is számolni kellett a hibák sorozatos - bár javítható - jelentkezésével. ${ }^{893}$

\footnotetext{
${ }^{885}$ PETRIK (1990), 101. p.

${ }^{886}$ Ptk. 306. § (3) bekezdés.

${ }^{887}$ Ezt a kicseréléssel kapcsolatban egy bírósági határozat is kimondta, lásd: BH 1988. 41.

${ }^{888}$ Az 1977. évi IV. törvény hatálybalépéséről és végrehajtásáról szóló 1978. évi 2. törvényerejü rendelet, 6.

$\S$ (1) bekezdés. A továbbiakban: Ptké. II. Eredeti szövege elérhető: http://www.jogiforum.hu/forum/23/18090 (2013. december 3.).

${ }^{889}$ Lásd: GKT 63/1973. számú állásfoglalás.

${ }^{890}$ PETRIK (1995), 49. p.

${ }^{891}$ Lásd: BH 1992. 263.

${ }^{892}$ Lásd: BH 1986. 430. II.

${ }^{893}$ Lásd: BH 1982. 522.
} 
Az elállás jogkövetkezménye minden esetben az eredeti állapot helyreállítása volt. Az LB egy, a mortuus redhibetur ókorból ismert problematikájával kapcsolatos döntésében úgy ítélte meg, hogy ha a hibás teljesítés az eladott állat elpusztulásában áll, és a vevő elállása esetén így az eredeti állapot visszaállítása nem lehetséges, akkor a vevő az igényét csak kártérítésként érvényesítheti az eladóval szemben a Ptk. 310. § alapján. ${ }^{894}$ Ennek keretében visszajárt neki az állat vételára és a tartásával, kezeltetésével felmerült költségek, valamint az elmaradt jövedelem is. Ez a döntés a kártérítés szubjektív jogalapja, és az ebből fakadó bizonyítási nehézségek miatt problematikus, hiszen a vevőnek a hibás teljesítés tényét és az ezzel okozati összefüggésben keletkezett kárát magának kellett bizonyítania. $^{895}$

Az LB több ítéletben úgy foglalt állást, hogy a vevő elállása jogkövetkezményeként az eredeti állapot helyreállításán túl a Ptk. 310. § alapján az áremelkedésből fakadó kárának a megtérítésére is igényt tarthat. ${ }^{896}$ Ezzel a döntéssel az eredeti állapot elérését célzó jogkövetkezmény lényegi eleme kérdőjeleződött meg, ami a vevőre nézve természetesen előnyt jelentett, de az eladónak hátrányos volt, mivel a vételár visszafizetése mellett ő viselte a dolog hibás, illetve amortizálódott állapotából eredő értékcsökkenést is.

A kártérítés igényéről hibás teljesítés esetén a jogalkotó egyébként változatlan formában rendelkezett. Míg a szavatossági igények elsődleges jogpolitikai célja a szerződésnek megfelelő teljesítés kikényszerítése volt, addig a kártérítés a hibás teljesítés következményeinek reparációjára hivatott jogkövetkezmény volt. ${ }^{897}$ A jogtudományban ennek megfelelően a hibás teljesítéssel okozott kár két fajtáját különítették el: az egyik a dolog hibájában álló jogosulti kár. ${ }^{898}$ Ilyen esetben a kártérítés és a többi szavatossági jog ugyanazon a tényen alapul, csak más a helytállás jogalapja. ${ }^{899}$ A jogosult kártérítésként ilyenkor az eredeti állapot természetbeni helyreállítását vagy a vagyonában bekövetkezett értékcsökkenés pénzbeli megtérítését követelhette a bírói gyakorlat alapján. ${ }^{900} \mathrm{Az}$ előbbinek Kovács László szerint a kijavítás és a csere, az utóbbinak az árleszállítás és a dolog kijavítására/kijavíttatására fordított összeg feleltethető meg. ${ }^{901}$ A hibás teljesítéssel okozott károk másik csoportját az (akkor még) tapadó károknak nevezett károk alkották, amelyek esetén a hibás teljesítés csupán az oka a kár bekövetkezésének, amely beállhatott

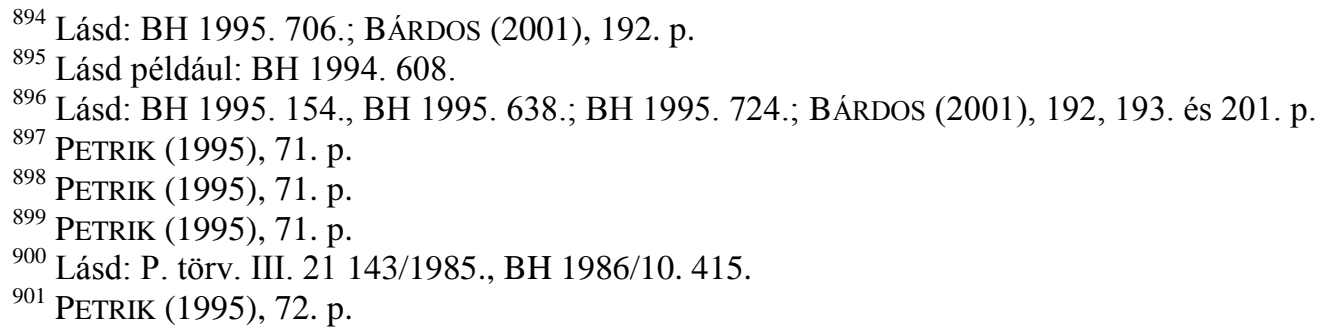


a jogosult vagyontárgyaiban, többletköltségek felmerülésében, vagy az elmaradt haszonban is. ${ }^{902}$

Az LB e kérdéskörrel kapcsolatos egyik döntése szerint a jogosult - a Ptk. 355. § (4) bekezdése alapján - kártérítés címén arra az összegre tarthatott igényt, amellyel a termék értéke a hiba miatt csökkent. ${ }^{903}$ Amennyiben azonban a szavatossági igényeit azok elévülése miatt nem érvényesítette, az LB álláspontja szerint kártérítés címén nem csak az elévült szavatossági igényen felüli többletkár megtérítését követelhette a jogosult, hanem annak a kárnak a megtérítését is, amely őt a hibás teljesítés folytán amiatt érte, hogy maga a dolog hibás volt. ${ }^{904}$ Azaz ilyen esetben nem csak a dologban beállott kár, hanem a tényleges kár megtérítésére is igényt tarthatott. ${ }^{905}$

\subsection{Igényérvényesités}

A kellékhibának a szavatossági jogok érvényesítéséhez a teljesítés időpontjában kellett fennállnia [Ptk. 305. § (2) bekezdés]. A jogosult bármikor áttérhetett a választott szavatossági jogról a másik szavatossági jogra [Ptk. 307. (2) bekezdés], de e választási joga csak a kijavítás és az árleszállítás esetén volt korlátlan. A jogválasztás nem jelentett azonban kereseti kötöttséget a bírósági eljárásban a bírói gyakorlat alapján. ${ }^{906}$

Az új szabályok a hibára vonatkozó nyilatkozattétellel kapcsolatban már nem tartalmaztak külön határidőt, hanem úgy rendelkeztek, hogy a kifogásközlésnek a hiba felfedezését követően haladéktalanul meg kell történnie [Ptk. 306. § (4) bekezdés]. Az igényérvényesítés határideje azonban a módosítások következtében is kettős volt:

„A jogosult a teljesitéstől számított hat hónapos elévülési határidő alatt érvényesitheti szavatossági jogait. $\mathrm{Ha}$ a dolog használhatóságának legkisebb időtartamát hatósági elöírás, szabvány vagy kötelezö müszaki elöírás határozza meg (kötelezö alkalmassági idö), és ez hat hónapnál rövidebb, az igény érvényesitésére ez a határidő az irányadó.

Ha a jogosult igényét menthetö okból nem tudja érvényesiteni - igy különösen, ha a hiba jellegénél vagy a dolog természeténél fogva az (1) bekezdésben meghatározott határidön belül nem volt felismerhetö -, szavatossági jogait a teljesitéstöl számitott egy évig, tartós használatra rendelt dolog esetében három évig érvényesitheti. Ha a kötelezö alkalmassági idö három évnél hosszabb, az

\footnotetext{
902 PETRIK (1995), 72. p. Ezt a jelenlegi joggyakorlat és jogirodalom már következménykárnak nevezi, lásd többek között: II. rész 3. fejezet.

${ }^{903}$ BH 1990. 387., BÁRDOS (2001), 241.p.

${ }^{904}$ Lásd: P. törv. III. 20 112/1985., BH 1986/2. 60., PJD XI. 130.

905 A mai magyar magánjogi dogmatika az előbbit nevezi tapadó kárnak, az utóbbit pedig következménykárnak, lásd később.

${ }^{906}$ Lásd: PETRIK (1995), 38-39. p.
} 
igény érvényesitésére ez a határidö az irányadó. Ezeknek a határidőknek az elmulasztása jogvesztéssel jár. "907

A szabályozás tehát egy általános hat hónapos elévülési és egy (objektív) egy éves illetve három éves jogvesztő határidő között tett különbséget. Mindkét határidő számításának kezdetét a teljesítés időpontjában jelölte meg a Ptk. [308. § (1) bekezdés]. A Ptké. II. 13. § rendelkezése szerint a hibás teljesítésre vonatkozó új rendelkezések csak azon szerződések esetén voltak alkalmazhatóak, amelyek teljesítése 1978. március 1. után ment végbe.

A hat hónapos elévülési határidőnél rövidebbet csak kötelező alkalmassági határidőként határozhattak meg hatósági vagy müszaki elöírások, illetve szabványok, de a Ptké. II. értelmében az ilyen határidőre az eladó a kiskereskedelmi fogalomban eladott dolgok esetén csak akkor hivatkozhatott, ha annak időtartamát ,, a jogosulttal a szerződés megkötésekor megfelelő módon (a terméken való feltüntetéssel, minöségi tanúsítvánnyal, fizetési jegyzéken stb.) közölte”. ${ }^{908}$ A kötelező alkalmassági idő a tartós használatra rendelt dolgok esetén - például gépjárműveknél - akár három évnél is hosszabb lehetett, ilyenkor az igényérvényesítésre ez volt irányadó.

A jogvesztő határidő érvényesülésének fontos feltétele a menthető ok fennállása volt. Ha nem állt fenn ilyen ok, és az elévülési idő már letelt, akkor a jogosult már csak az ugyanabból a jogalapból eredő követeléssel szembeni kifogásként érvényesíthette a szavatossági igényét. ${ }^{909}$

A határidőszámításra a Legfelsőbb Bíróság új elvi döntésben reagált. ${ }^{910}$ Az I. PEDGED többek között úgy foglalt állást, hogy ha a szavatossági igényét a jogosult menthető okból nem tudta érvényesíteni, akkor az akadály megszünésétől számított három hónapon belül az igényérvényesítésre akkor is jogosult, ha az elévülési idő már eltelt, vagy abból három hónapnál kevesebb van hátra; ${ }^{911}$ ez a szabály a Ptk. 326. § (2) bekezdéséből fakadt. ${ }^{912}$ Érdekes az I. PED-GED azon megállapítása, hogy „az elévülés nyugvása vagy megszakadása folytán még rendelkezésre álló határidő elteltéig a szavatossági igény akkor is érvényesíthető bírósági úton, ha különben a jogvesztő határidő már eltelt volna", ${ }^{913}$ a

\footnotetext{
${ }^{907}$ Ptk. 308. § (1)-(2) bekezdés.

908 Ptké. II. 6. $\S(2)$ bekezdés.

${ }^{909}$ Vö. Ptk. 308. § (3) bekezdés; PETRIK (1995), 66. p.

${ }^{910}$ I. számú PED-GED, szövegét lásd: BARANYAI - FLUCKNÉ DR. PAPÁCSY - ZOLTÁN (1985), 209-211. p.

911 I. PED-GED II. pont.

912 „Ha a követelést a jogosult menthető okból nem tudja érvényesíteni, az akadály megszünésétől számitott egy éven belül - egyéves vagy ennél rövidebb elévülési idö esetében pedig három hónapon belül - a követelés akkor is érvényesithetö, ha az elévülési idö már eltelt, vagy abból egy évnél, illetöleg három hónapnál kevesebb van hátra...".

913 I. PED-GED II. pont.
} 
jogvesztő határidő feltételeként meghatározott menthető ok ugyanis általában az elévülés nyugvását is eredményezi, ezen kívül a jogvesztő jelleg épp az elévülés végső gátja a mindenkori polgári jogi szabályozásban.

Beépítette a jogalkotó a módosító rendelkezések közé a XXXI. PED kijavításra vonatkozó szabályát:

„A dolog kijavitása esetében a határido" meghosszabbodik a hiba közlésétöl kezdödö azzal az idővel, amely alatt a jogosult a dolgot a hiba miatt rendeltetésszerüen nem használhatta. A dolognak vagy jelentösebb részének kicserélése esetén a szavatossági jog érvényesitésére biztositott határidö a kicserélt dologra (dologrészre) újból kezdödik."914

A Ptk. módosított szabályai továbbra sem rendelkeztek a hibás teljesítéssel okozott kártérítés érvényesítési határidejéről. Az I. PED-GED e hiányosságot pótolva úgy rendelkezett, hogy „a hibás teljesítéssel okozott kár megtérítése iránti igény érvényesítésére nem vonatkoznak a szavatossági jogok érvényesítésére megszabott határidők. Az ilyen igényt az általános (öt éves) határidőn belül lehet érvényesíteni." ${ }^{915} \mathrm{Az}$ LB tehát a hibás teljesítés miatti kártérítés szubjektív jogalapja mellett foglalt állást a határidőket illetően is. Ez megkönnyítette az igényérvényesítést olyan károk esetén, amelyek a többi szavatossági igény keretei között nem voltak érvényesíthetőek. Ha mentesülni akart e felelősség alól, akkor a kötelezettnek kellett kimentenie magát annak bizonyításával, hogy „a hibátlan teljesités érdekében úgy járt el, ahogy az az adott helyzetben általában elvárható". 916 Ez az exkulpációs rendszer tehát továbbra is érvényesült a szabályozásban. ${ }^{917}$

A speciális állatszavatossági rendelkezések a Ptk. 1977-es módosításával hatályukat vesztették. A helyükre lépő egyetlen új rendelkezés az általános kellékszavatossági szabályokat rendelte alkalmazni állatok szolgáltatására irányuló visszterhes szerződések esetén is azzal az eltéréssel, hogy - az állatok dolog-specifikus hibái miatt - az ilyen jogügyletek hibás teljesítésével összefüggő szavatossági igények érvényesítési idejét a teljesítéstől számított hatvan napban állapította meg [Ptk. 311. § (2) bekezdés]. Az I. PEDGED kiegészítette e szabályt azzal, hogy a rendelkezésre álló hatvan nap elévülési határidő, és ha a jogosult a szavatossági igényét ez alatt menthető okból nem tudja

\footnotetext{
${ }^{914}$ Ptk. 308. § (4) bekezdés. Vö. XXXI. PED d) pont.

${ }^{915}$ I. PED-GED III. pont.

${ }^{916}$ Ptk. 310. §.

917 A Ptk. 1959-es eredeti szövege is így fogalmazott. A felróhatóságot már a kódex megalkotásakor egy „társadalmi-pszichológiai ítéletként” fogalmazta meg a jogalkotó e definíció által, lásd: EÖRSI (1966), 126. p.
} 
érvényesíteni, akkor a teljesítéstől számított legfeljebb egy éven belül erre akkor is lehetősége van. ${ }^{918}$

Az 1/1964. (I. 11.) BkM rendelet helyébe az 1977-es módosítások révén egy új jogszabály, a vásárlók minőségi kifogásainak intézéséről szóló 4/1978. (III. 1.) BkM rendelet lépett. ${ }^{919}$ Amennyiben a vevő nem fordult azonnal a bírósághoz szavatossági igényei érvényesítése végett, akkor a szavatossági jogainak teljesítését illetően ez a jogszabály határozta meg az eladóra (,, a vásárlók részére árusitó gazdálkodó szervezetekre és egyéni vállalkozókra”) ${ }^{920}$ vonatkozó kötelezettségeket. A vásárló a szavatossági igényét az áru eladásakor adott fizetési bizonylat bemutatásával tudta érvényesíteni az eladónál (4/1978. BkM rend. 3. §).

A rendelet kógens szabálya szerint a vásárlók minőségi kifogásainak intézésére vonatkozó jogszabályoktól nem lehetett eltérni [1. § (3) bekezdés]. A kijavítási igény teljesítésével kapcsolatban így rendelkezett:

„A hibás áru kijavitását legkésőbb a hiba bejelentésétöl számitott 8 napon belül el kell végezni. Ha a javítás 8 napon belül nem készült el, a vásárló kívánsága szerint az áru árát le kell szállitani, az árut ki kell cserélni vagy a vételárat vissza kell téríteni, illetve ha a vásárló a hibát kijavitja, vagy mással kijavittatja, a javitás költségeit kell részére megtéríteni. "921

Nyolc nap volt tehát a kijavítás teljesítésének határideje. Az árleszállítási, kicserélési igényt és a „vételár visszatérítését” (azaz az elállás jogát) azonnal teljesíteni rendelte a 4/1978. BkM rendelet [5. § (2) bekezdés].

Amennyiben az áru „köztudomásúan csökkent értéku”” volt, vagy „,a vásárló az elözetesen igazolhatóan közölt minöségi hiba ismeretében az árut tényleges értékének megfelelöen csökkentett áron vásárolta meg, a csökkent értéket eredményezö, illetve az ismert minőségi hiba miatt” az eladó szavatossági helytállását a rendelet kizárta. Ezzel kapcsolatos egy bírósági határozat, amelyben az LB a leértékelt árú és minőségű ruhákkal kapcsolatos jogvita kapcsán úgy döntött, hogy kellékhibásnak minősül az a csökkent értékü és csökkent áron forgalomba hozott termék is, amely a szerződéssel elérni kívánt célnak nem felel meg. ${ }^{922}$ A csökkentértéküség az LB interpretációjában azt jelentette, hogy a dolog „nem felel meg az egyébként vele szemben támasztható magasabb minőségi

\footnotetext{
${ }^{918}$ Lásd: I. PED-GED V. pont.

${ }^{919}$ A továbbiakban: 4/1978. BkM rend. Elérhető: http://csutak.x3.hu/jog/04.htm (2013. december 3.).

${ }_{920}^{9}$ 4/1978. BkM rend. 1. § (1) bekezdés. A rendelet a vásárló fogalmát nem határozta meg külön, így arra lehet következtetni, hogy bármely jogalany minősülhetett vásárlónak, aki a kiskereskedelmi forgalomban a fenti jogalanyoktól árut vett meg. A rendelet az áru fogalmáról sem rendelkezett.

${ }_{921}^{4}$ 4/1978. BkM rend. 5. § (1) bekezdés.

${ }^{922}$ Lásd: BH 1987. 1., LB Gf. I. 30 274/1986.,; PETRIK (1995), 95. p.
} 
követelményeknek". ${ }^{923}$ Ennek fényében és figyelembe véve, hogy a csökkentértéküség a vételár csökkentésében materializálódik adásvétel esetén, a bíróság úgy vélte, hogy a csökkentértékü dolog sem lehet használhatatlan, és a szerződéses rendeltetési célra alkalmasnak kell lennie.

Amennyiben a minőséget érintő kifogás bejelentésekor lehetséges volt, akkor más szavatossági igény kérelme esetén is választhatta az eladó a dolog kicserélését [4/1978. BkM rend. 9. § (2) bekezdés]. Ha a kért csereigény érvényesítésére nem volt lehetőség, akkor az eladónak - a vásárló kívánságára - a vételár-különbözet elszámolása mellett más dolgot kellett eladnia neki [9. § (3) bekezdés].

Speciális szabály vonatkozott a minőséghibás élelmiszerre, háztartási vegyi árura és a kozmetikai készítményre: ezek esetén a vásárló az azonnali csere és a vételár visszatérítésének igénye közül választhatott csupán [10. § (1) bekezdés]. Az élelmiszerszavatosságról külön jogszabályban is rendelkezett a jogalkotó. ${ }^{924}$

\subsection{Jótállás}

Módosította és kiegészítette az 1977. évi IV. törvény a jótállásra vonatkozó rendelkezéseket is, de azok rendszertanilag továbbra is a szerződést biztosító mellékkötelezettségek között szerepeltek:

„Jogszabály jótállási kötelezettséget irhat elö, és meghatározhatja annak legkisebb kötelezö mértékét is. A felek jótállási kötelezettséget szerzödésben is vállalhatnak.

Jótállás alapján a kötelezett a szerzödésszerü teljesitésért ebben a törvényben foglaltaknál szigorúbb felelösséggel tartozik.

Aki a szerzödés hibátlan teljesitéséért jótállásra köteles, ennek időtartama alatt a felelösség alól csak akkor mentesül, ha bizonyitja, hogy a hiba oka a teljesités után keletkezett. Kötelezö jótállás esetén a jótállási idö alatt felmerülö szavatossági jogokat a jótállásra vonatkozó jogszabály szerint kell elbírálni. ",925

A módosítás egyértelműen jelezte, hogy a jótállás nem csak szerződésen alapuló helytállást jelenthet, hanem jogszabály is elöírhat kötelező jótállást. A szerződésen alapuló jótállást a joggyakorlat tágan értelmezte, így azt nem csak maga az adásvételi szerződés keletkeztethette, hanem a joggyakorlat alapján az átadás-átvételi jegyzőkönyvre vezetett

\footnotetext{
${ }^{923}$ Lásd: BH 1987. 1. indokolás (19. p.).

${ }^{224}$ Lásd: az élelmiszerekről szóló 1988. évi IV. törvénnyel módosított 1976. évi IV. törvény, és a végrehajtásáról szóló 10/1988. (VI. 30.) MÉM-SZEM egyesített rendelet.

${ }^{925}$ Ptk. 248. § (1)-(3) bekezdések.
} 
kötelezettségvállalás ${ }^{926}$ és a „garancia” vállalásáról szóló megállapodás is. ${ }^{927} \mathrm{Az}$ LB kifejtette, hogy „a gazdasági életben széleskörủen elterjedt „garancia” szóhasználatot szakszerűen jótállásnak nevezendő kikötésként" kell értelmezni. ${ }^{928}$ A szerződéssel, megállapodással vállalt jótállás lényeges tartalma a joggyakorlat tapasztalatai és a jogtudomány álláspontja szerint a konkrét jótállási kötelezettségvállalás és a jótállás időtartamának a megjelölése volt; a szavatossági határidőt meghosszabbító megállapodás önmagában nem hozott létre jótállási kötelezettséget. ${ }^{929}$

A Ptk. megfogalmazásában a „legkisebb kötelezö mérték” nyilvánvalóan a jótállás időtartamára utal, de a joggyakorlat már korábban sem tekintette jótállásnak például a szabvány által meghatározott tartóssági időtartamot, ${ }^{930}$ és a kötelező alkalmassági idő sem jelentett önmagában jótállási kötelezettséget. ${ }^{931}$ A jótállási időt nem igényérvényesítési határidőnek tekintették, hanem azt határozta meg a határidő, hogy a kötelezettségvállalás mennyi időre áll fenn, így az elévülés kérdése e körben tárgytalan volt az LB szerint. ${ }^{932}$ A jótállási határidőt pontos dátummal, vagy hónapokban, de például gépjármüveknél a megtett kilométerek számának megjelölésével is meg lehetett határozni. ${ }^{933}$

A fenti törvényhely második és harmadik bekezdése a szerződésszerü, hibátlan teljesítésért fennálló jótállásról rendelkezik, ezért továbbra is vitatható volt a jótállás rendszerbeli elhelyezése. A gyakorlatban továbbra is a hibátlan teljesítésért vállalt jótállás volt a legtipikusabb. ${ }^{934}$ Belefoglalta a jogalkotó a Ptk.-ba azt a jogirodalomban uralkodó álláspontot, miszerint a kellékszavatosság törvényi szabályainál csak szigorúbb „felelősséget” alapíthat a jótállás. ${ }^{935}$ Erröl a 4/1978. BkM rendelet is rendelkezett, miszerint jótállást csak az eladót „szavatosság, illetve kötelezö jótállás alapján terhelö kötelezettségeknél a vásárlóra kedvezőbb feltételekkel szabad vállalni ". 936

A jótállási igények a jótállás tartama alatt bármikor, de csak a jótállási kötelezettség fennállásának jogosulti bizonyításával voltak érvényesíthetőek. ${ }^{937}$ A 4/1978. BkM rendelet szerint a jótállás feltételeiről a vásárlót írásban tájékoztatni kellett: e dokumentum, azaz a

\footnotetext{
${ }^{926}$ Lásd: BH 1990. 9. 346., LB Gf. V. 31 815/1989.

${ }^{927}$ Lásd: BH 1992. 10. 654., LB Gf. V. 32 327/1991.

${ }^{928}$ Lásd: PETRIK (1995), 148. p.

${ }^{929}$ Lásd: LB GK 72. számú állásfoglalás; PETRIK (1995), 149. p.

${ }^{930}$ Lásd: GKT 31/1973. számú állásfoglalás.

931 PETRIK (1995), 148. p.

${ }^{932}$ Lásd: LB Gf. III. 31 401/1992.; PETRIK (1995), 149. p.

${ }^{933}$ PETRIK (1995), 154. p.

${ }^{934}$ PETRIK (1995), 147. p.

935 A ,felelősség” szóhasználatának helytelenségéről fent már esett szó.

936 4/1978. BkM rend. 13. § (2) bekezdés.

${ }^{937}$ Lásd: BH 1991. 10. 404., LB Gf. I. 31 970/1990.; PETRIK (1995), 154. p.
} 
„jótállási jegy” felmutatása így a kiskereskedelmi vétel hibás teljesítése esetén bizonyítékul is szolgált. ${ }^{938}$ Kérdéses volt a gyakorlatban, hogy miként kell kezelni azt a helyzetet, amikor a jogosult a jótállási határidőn belül közölte a hibára vonatkozó kifogását a jótállás vállalójával, de a határidőn belül a pert nem tudta megindítani, mert a hiba olyan időben ütközött ki. A Legfelsőbb Bíróság úgy foglalt állást, hogy ilyenkor a jogosultnak nem szabad késlekednie, és a jótállási határidő leteltétől számított legfeljebb három hónapon belül meg kell indítania a bírósági eljárást. ${ }^{939}$ Azt is kimondta döntésében az LB, hogy a jótállási igény akkor is érvényesíthető, ha a dolgot a jótállás jogosultja értékesítette, és vele szemben az új tulajdonos szavatossági igénnyel lép fel, illetve ha a hibás teljesítésből egyébként hátrányt szenved. ${ }^{940}$

A tartós használatra rendelt termékekre 1969-től kötelező jótállást írt elő a jogalkotó. ${ }^{941}$ A vonatkozó jogszabályok 1991 szeptemberéig hatályban voltak, de akkor az Alkotmánybíróság a 4/1969. együttes rendeletet megsemmisítette, mert megállapította, hogy az a Ptk. szavatossággal kapcsolatos szabályaitól a vevő hátrányára eltér azáltal, hogy a kijavítás igényét preferálja. ${ }^{942}$ Ennek megfelelően a jogalkotó új rendeletet alkotott: a 117/1991. (IX. 10.) Kormányrendelet ${ }^{943}$ az egyes tartós használatra rendelt termékek jótállási kötelezettségéről klaudikálóan kógens normákkal rendelkezett, azaz a vásárlóra nézve kedvezőbb jótállási feltételeket szabadon lehetett vállalnia a kereskedőnek. ${ }^{944}$

A jogszabály a mellékletében meghatározott, belföldön elöállított illetve forgalomba hozott új termékekre vonatkozott, amelyekre nézve 12 hónapos, illetve egyesekre 24 hónapos kötelező jótállást rendelt el. A hatálya alá tartozott például a háztartási varrógép, a hütő, az automata írógép, a számítógép, a rádió, a televízió, a személygépkocsi, a kerékpár, ezen kívül a $3000 \mathrm{Ft}$ feletti vételárú óra, bútor és hangszer is.

A rendelet a kötelező jótállás esetén kifejezetten a Ptk. kellékszavatossági jogait határozta meg érvényesíthető vásárlói igényekként (2. §). ${ }^{945}$ Úgy rendelkezett, hogy a kijavítási igény teljesítésére maximum 15 nap áll a kereskedő rendelkezésére, de ha ő a

\footnotetext{
${ }^{938}$ Lásd: 4/1978. BkM rendelet 13. § (1) bekezdés.

${ }^{939}$ Lásd: BH 1990. 4. 138., P. törv. III. 20 277/1989.

${ }^{940}$ Lásd: BH 1989. 6. 228., LB P. törv. III. 20 622/1988.; PETRIK (1995), 156. p.

${ }^{941}$ Lásd: 7/1968. (I. 30.) Kormányrendelet a tartós fogyasztási cikkek jótállási kötelezettségéröl és 4/1969. (III. 30.) BkM-KGM-KipM-KkM-NIM együttes rendelet az egyes tartós fogyasztási cikkek kötelezö jótállásának legkisebb kötelező mértékéröl.

${ }^{942}$ Lásd: 14/1991. (IV. 13. AB határozat.

943 A továbbiakban: 117/1991. Korm. rend. Szövege elérhető: http://csutak.x3.hu/jog/117.htm (2013. december 14.).

${ }^{944}$ 117/1991. Korm. rend. 1. § (2) bekezdés. A vásárló hátrányára eltérő jótállási feltételek semmisek voltak (1. § (6) bekezdés).

945 117/1991. Korm. rend. 2. §
} 
javítás idejére „kölcsönkészüléket (kölcsönjármüvet)” ad a jogosultnak, akkor is legfeljebb 30 nap alatt teljesítenie kell az igényt (3. §). Speciális kicserélési jogról rendelkezett is a jogszabály: a vásárlástól (üzembe helyezéstől) számított 3 napon belül meghibásodott terméket a vásárló kérésére azonos típusú új termékre kellett cserélni, vagy ha ez nem lehetséges, akkor vagy vissza kellett téríteni a vételárat, vagy a különbözet elszámolása mellett más terméket kellett a vevőnek adni. ${ }^{946}$ A vásárló érdekeinek kedvezett a rendelet azon szabálya, hogy a javítást az üzemeltetés helyén kellett foganatosítani a rögzített bekötésü és „a 10 kg-nál súlyosabb, vagy a helyi közúti közlekedési eszközön kézi csomagként nem szállitható termék” esetén [7. § (1) bekezdés].

A kötelező jótállás alapján érvényesíthető igényekkel kapcsolatos rendeleti szabály a Ptk. 248. § (3) bekezdésével együtt volt értelmezendő. Eszerint „kötelező jótállás esetén a jótállási idő alatt felmerülő szavatossági jogokat a jótállásra vonatkozó jogszabály szerint kell elbírálni”. Azaz kötelező jótállás esetén csak látszólagosan illette meg a jogosultat a szavatossági és jótállási igények közötti választás joga, valójában a jótállási határidő alatt csak a jótállás jogalapján érvényesíthette a jogait, ami kedvező volt, mert az igények ugyanazok voltak, mint szavatosság esetén, nem kellett azonban bizonyítania, hogy a hiba már az átadáskor megvolt a dologban. ${ }^{947}$

A vásárló a jótállási igényeivel kapcsolatos nyilatkozatát intézhette a kereskedőhöz és a jótállás keretébe tartozó javításokat rendeltetésszerủen végző javítószolgálathoz (szervizhez) is, de az igényérvényesítés feltétele volt a nyilatkozat mellett a jótállási jegy és a fizetési bizonylat felmutatása is. ${ }^{948}$ A 117/1991. Kormányrendelet meghatározta a jótállási jegy kötelező tartalmi elemeit is, de e szabály megsértése esetén is fennállt a jótállási kötelezettség. ${ }^{949}$

\section{Fogyasztói érdekvédelem}

A belkereskedelemről szóló 1978. évi IV. törvény ${ }^{950}$ az áruforgalommal és az áruk minőségével, valamint az ezekkel összefüggő fogyasztói érdekvédelemmel kapcsolatban a fennálló gazdasági rendszerhez képest korai időpontban már figyelemreméltó

\footnotetext{
${ }^{946}$ Lásd: 117/1991. Korm. rend. 5. § (1) bekezdés; e rendelkezés azonban személygépkocsi esetén nem volt alkalmazható.

947 TEMESVÁRI (1996), 17. p.

${ }^{948}$ Lásd: 117/1991. Korm. rend. 8. § (3) bekezdés és 9. § (1) bekezdés.

${ }^{949}$ Lásd: 117/1991. Korm. rend. 9. § (2) és (5) bekezdések.

950 A belkereskedelemröl szóló 1978. évi I. törvény, a továbbiakban: Bkt. Szövege elérhető: http://1000ev.hu/index.php?a=3\&param=8522 (2013. december 3.).
} 
rendelkezéseket tartalmazott. Annak ellenére, hogy a fogyasztók fogalmát nem határozta meg, az érdekeik védelméről egy teljes fejezetben rendelkezett.

A törvény alapján nem volt forgalomba hozható „az olyan áru, amely rendeltetésszerü használatra alkalmatlan, illetve forgalombahozatala a vásárlók életét, egészségét, vagy a közérdeket más módon veszélyezteti” [Bkt. 30. § (2) bekezdés]. A gazdálkodó szervezetek, akikkel a fogyasztó-vásárló árura vonatkozó adásvételi szerződést kötött, a törvény alapján felelösek voltak az áru minőségéért, és az azt érintő kifogás intézésével kapcsolatos költségek öket terhelték [Bkt. 32. § (1) bekezdés]. A törvény kötelezővé tette a vásárlók minőségi kifogásainak intézésére vonatkozó rendelkezéseknek az üzletben jól látható helyen történő kifüggesztését is, és úgy rendelkezett, hogy a gazdálkodó szervezet a vásárlót megillető jogoktól a vásárló terhére sem egyoldalúan, sem szerződésben nem térhet el. ${ }^{951}$

E törvény mutatta tehát az első kifejezett jogszabályi megnyilvánulását a mai értelemben vett fogyasztói érdekü minőségvédelemnek hazánkban. A rendszerváltozásig azonban a szabályozás megmaradt ezen a szinten, és különösen az európai integrációba kapcsolódás magyarországi megindulásáig magánjogi fogyasztóvédelmi jogalkotásunk jelentősebb változást nem mutatott.

\section{Összefoglalás}

A fejezet a hibás teljesítés magyar történetének feldolgozását folytatta az 1959. és 2002. közötti időszakban. Az 1960-ban hatályba lépett Ptk. az Mtj. koncepciójától eltérően - az ABGB mintáját követve - a visszterhes szerződések hibás teljesítéséről rendelkezett a szerződésszegés egyes esetei körében. Bár annak centrális jogkövetkezményeként a kellékszavatosságot jelölte meg, a szerződésen kívüli károkozás szabályainak alkalmazásával lehetővé tette a hibás teljesítés miatti kártérítés követelését is a jogosult számára. Ezen igény jogalapja azonban - a szükszavú rendelkezésnek is köszönhetően vita tárgyát képezte a jogtudományban. A jótállásról rendszertanilag a szerződést biztosító mellékkikötések körében rendelkezett a kódex. A jogintézmény elhelyezését azonban kezdettól fogva vitatta a jogtudomány, mert annak a legnagyobb relevanciája a hibás teljesítés (és az adásvétel) körében volt a gyakorlatban. Ezen kívül a Ptk. nyomán alkotott speciális jogszabályok meghonosították jogrendszerünkben a kötelező, jogszabályon

${ }^{951}$ Lásd: Bkt. 32. § (2)-(3) bekezdés. 
alapuló jótállást, amely a minőségvédelem fontos eszközeként funkcionált a kereskedelmi forgalomban eladott ingó dolgok esetén. A fenti körülmények azonban dogmatikai zavart okoztak a kellékszavatosság és a jótállás elhatárolásánál.

A XX. század második felében megfogalmazódott gazdasági, társadalmi és jogpolitikai elvárásoknak az 1959-es szabályok már több ponton nem tettek eleget, ezért került sor a hibás teljesítés és a jótállás szabályainak megreformálására is az 1977-es Ptk.novella keretei között. A belkereskedelemről szóló 1978-as törvény már külön fejezetben foglalkozott a fogyasztói érdekvédelem és a kereskedelmi forgalomban árusított (ingó) dolgok minőségvédelmének kérdésével. A magánjogi (diszpozitív) szabályozási koncepciót érintő legjelentősebb újítást a Ptk. felhatalmazása alapján megalkotott egyes speciális jogszabályok hozták, amelyek a vásárló („,fogyasztó”) javára klaudikálóan kógens rendelkezéseket tartalmaztak.

Ez a szabályozási megoldás mintegy átvezet a dolgozat következő, az ingó adásvétel hibás teljesítésének hatályos szabályait tárgyaló második részébe. A következőkben az ingó adásvétel európai fogyasztóvédelmi szabályozásának fényében kerül bemutatásra a jelen részben tárgyalt államok hatályos rendelkezésein kívül Svájc szabályozása is. 


\section{RÉSZ: AZ INGÓ ADÁSVÉTEL HIBÁS TELJESÍTÉSE A HATÁLYOS JOGBAN}

\section{FOGYASZTÓVÉDELEM ÉS AZ INGÓ ADÁSVÉTEL HIBÁS TELJESÍTÉSE AZ EURÓPAI UNIÓ JOGÁBAN}

\section{Bevezetés: a fogyasztóvédelem Európai Uniós történeti háttere}

Az Európai Közösség ${ }^{952}$ megalkotásának célja az európai gazdasági integráció megvalósítása volt. Korunk Európájában a gazdasági struktúra alapja a szabad piac, amelyben a gazdasági és magánjogi értelemben vett autonómia révén a jogalanyok szabadon köthetnek jogügyleteket egymással. ${ }^{953}$ Ezt feltételezte az Európai Közösség megalkotásának egyik célkitűzése, az európai közös, majd egységes belső piac kialakítása is. Az EK-t megalapító Római Szerződés eredeti 1957-es szövege azonban még nem tartalmazott utalást a fogyasztóvédelemre.

A piacgazdaság és a gazdasági unió folyamatos kiépülésével fokozatosan megjelent a gazdasági egyensúlyhiány a piac egyes szereplői, a gazdálkodók és a személyes szükséglet kielégítése érdekében szerződő személyek pozíciója között. ${ }^{954}$ Ennek következményeként kezdett megjelenni az igény a kereskedelmi láncolat végén álló magánszemélyek védelme iránt, és ez tette egyre szükségesebbé az állam, majd a szupranacionális szerv, az EGK beavatkozását is a piaci kereskedelem szabályozásába. ${ }^{955}$ Ennek első megjelenése az 1972-es párizsi csúcstalálkozón az életszínvonal és az életminőség javításának a kiterjesztő értelmezése volt. ${ }^{956}$ Megállapították, hogy ehhez a környezet és a fogyasztók védelmét is szabályozni kell az EU-s politika kialakításánál. ${ }^{957}$ A közösségi fogyasztóvédelmi szabályozás azoknak a tagállamoknak a kezdeményezésére nyert egyre nagyobb teret, amelyekben már megjelent a fogyasztóvédelem mint jogpolitikai célkitűzés. ${ }^{958}$

Az EK első olyan normáját, amely konkrétan a fogyasztóvédelem célkitűzéseiről szólt, 1975. április 14-én fogadták el. Ez volt az Európai Gazdasági Közösség előzetes

\footnotetext{
952 A továbbiakban: EK.

${ }_{953}^{95}$ MICKLITZ - STUYCK - TERRYN (2010), 1-2. p.

${ }^{954}$ Lásd: HAJNAL (2010), 15. p.

955 MICKLITZ - STUYCK - TERRYN (2010), 2. p.

956 SZIKORA (2010), 19. p.

957 SZIKORA (2010), 19. p.

${ }^{958}$ BENACCHIO (2003), 201. p.
} 
programja a fogyasztóvédelmi és tájékoztatási politikáról, ${ }^{959}$ amely a fogyasztóvédelmi politika jelentőségét elsődlegesen az EK-n belüli életminőség javításában határozta meg. ${ }^{960}$ Kijelölte azt az öt kategóriát, amit máig a fogyasztók öt legfontosabb jogaként tartanak számon az EU-ban és annak tagállamaiban, a joggyakorlatban és a jogtudományban egyaránt:

1. az egészség és biztonság védelméhez való jog,

2. a gazdasági érdekek védelméhez való jog,

3. a jogorvoslathoz való jog,

4. a tájékoztatáshoz és oktatáshoz való jog, és

5. a képviselet joga. ${ }^{961}$

Ebben az időszakban az EK még konkrét, alkotmányos értelemben vett felhatalmazással nem rendelkezett a fogyasztóvédelmi jogalkotásra nézve, így normái inkább soft law jellegüek, azaz kikényszeríthetetlen dokumentumok voltak, iránymutatásul szolgáltak. ${ }^{962}$ Ez annak is köszönhető, hogy kezdetben a gazdasági jogpolitikai cél nagyobb szerepet kapott a közösségi szabályozásban a társadalmi célnál, és a fogyasztóvédelem szükségességét elsősorban a torzulásmentes verseny fenntartásával és a közös piac zavartalanságával indokolták. ${ }^{963}$

Bár főként magánjogi jellegü jogok szerepelnek a fenti felsorolásban, az Európai Közösségek fogyasztóvédelmi jogalkotása kifejezetten a magánjog területén csak az 1980as évek derekán indult meg. Az első normák a társasági jog, a kereskedelmi képviseleti szerződés, a szerzői jog, az iparjogvédelem és a munkajog területén jelentek meg. ${ }^{964} \mathrm{~A}$ későbbi, a „magánjog centrális intézményeit” érintő jogalkotás is föként az EK fogyasztóvédelmi politikája nyomán kezdett kibontakozni. ${ }^{965} \mathrm{Az}$ első, határozottan fogyasztóvédelmi magánjogi jogközelítést célzó norma a termékfelelősségről szóló 1985/374/EGK Irányelv volt.

\footnotetext{
${ }^{959}$ Council Resolution of 14 April 1975 on a preliminary programme of the European Economic Community for a consumer protection and information policy. Angol nyelven lérhetö: http://eur-lex.europa.eu/LexUriServ/LexUriServ.do?uri=CELEX:31975Y0425(01):EN:NOT

(2012. november 13.), a továbbiakban: Első fogyasztóvédelmi program. Megemlítendő, hogy európai szinten az első nemzetközi fogyasztóvédelmi dokumentumot az Európa Tanács bocsátotta ki, ez volt a „Fogyasztóvédelmi karta”, lásd: Resolution 543 (1973) on a Consumer Protection Charter (17.05.1973), elérhető: http://www.assembly.coe.int/Mainf.asp?link=/Documents/AdoptedText/ta73/ERES543.htm

(2012. december 6.).

${ }^{960}$ FAZEKAS (2007), 22. p.

961 FAZEKAS (2007), 22. p.

962 BENACCHIO (2003), 202. p.

963 BENACCHIO (2003), 202. p.

964 Lásd: VÉKÁS (2001a), 327. p.

965 VÉKÁS (2001a), 327. p.
} 
Az alkotmányos értelemben vett legitimációt az 1986-os Egységes Európai Okmány adta meg az EK-nak a fogyasztóvédelmi jogalkotásra, ${ }^{966}$ amelynek értelmében a Bizottság a belső piac kiépítése és müködése céljából hozott intézkedések és javaslatok megalkotása során köteles mindig a fogyasztóvédelem magas szintjét alapul venni. ${ }^{967}$

Az 1993. november 1-jén hatályba lépett Maastrichti Szerződés már kifejezetten a Közösség legfontosabb tevékenységei között említette a fogyasztóvédelem erősítését, ${ }^{968}$ és e szerződés által az Unió alapnormájának a szintjén is szabályozást nyert a fogyasztóvédelem egy önálló fejezetben. A Szerződés eredeti szerkezetében a 129.a cikk határozta meg az EU-s fogyasztóvédelmi politikára vonatkozó rendelkezéseket. ${ }^{969}$ Eszerint a Közösségnek a fogyasztóvédelem magas szintjének kialakításához egyrészt a belső piac kiteljesítését célzó normák, másrészt olyan speciális intézkedések meghozatala révén kell hozzájárulnia, amelyek - a fogyasztói ,,alapjogokként” is felfogható - fogyasztói egészség, biztonság és gazdasági érdekek védelmét biztosítják, és a fogyasztók megfelelő tájékoztatását segítik elő. A Maastrichti Szerződés hatálybalépése után az addiginál még gyorsabb ütemben születtek a magánjog egy-egy szükebb területét érintő, fogyasztóvédelemi célú jogi normák a tagállami magánjogok jogközelítése jegyében.

Az 1999/283/EK tanácsi határozat volt az első olyan uniós norma, amely programjelleggel a fogyasztók érdekeit támogató és a védelmük magas szintjét ösztönző tevékenységek általános keretét határozta meg az 1999-2003 közötti időszakra vonatkozóan. ${ }^{970} \mathrm{Az}$ EU azóta minden soron következő négyéves időszakra kibocsát egy, az EU fogyasztóvédelmi prioritásait tartalmazó fogyasztóvédelmi programot. ${ }^{971}$

\footnotetext{
966 OsZTOVITS (2011), 2421. p.

${ }^{967}$ Lásd: Egységes Európai Okmány 18. cikk, amely az EGK-Szerződésbe a 100a. cikket építette be, a fenti rendelkezés annak (3) bekezdésében található. Elérhető: http://eur-lex.europa.eu/hu/treaties/dat/11986U/word/11986U.doc\%E2\%80\%8E (2013. november 14.).

968 Szerződés az Európai Unióról (Treaty on European Union), 3. cikk s. pont. Angol nyelven elérhető: http://eur-lex.europa.eu/hu/treaties/dat/11992M/htm/11992M.html (2013. november 13.).

969 „1. The Community shall contribute to the attainment of a high level of consumer protection through:

(a) measures adopted pursuant to Article 100a in the context of the completion of the internal market;

(b) specific action which supports and supplements the policy pursued by the Member States to protect the health, safety and economic interests of consumers and to provide adequate information to consumers.

2. The Council, acting in accordance with the procedure referred to in Article $189 \mathrm{~b}$ and after consulting the Economic and Social Committee, shall adopt the specific action referred to in paragraph 1(b).

3. Action adopted pursuant to paragraph 2 shall not prevent any Member State from maintaining or introducing more stringent protective measures. Such measures must be compatible with this Treaty. The Commission shall be notified of them.".

${ }^{970}$ Lásd: Decision 283/1999/EC establishing a general framework for Community activities in favour of consumers, angol nyelven elérhetö: http://eur-lex.europa.eu/LexUriServ/LexUriServ.do?uri=CELEX:31999D0283:EN:HTML (2012. november 20.).

971 A 2007-2013. közötti időszakra vonatkozó „Közösségi fogyasztóügyi politikai stratégia 2007-2013” (COM(2007) 99) elérhető: http://ec.europa.eu/consumers/overview/cons_policy/doc/cps_0713_hu.pdf (2013.
} 


\section{Az EU-s fogyasztóvédelem jelenlegi állapota és jellemzői}

A fogyasztóvédelem Európai Uniós jogi szabályozásának a legitimációját a Lisszaboni Szerződés nyomán 2009-től az Európai Unió Működéséről szóló Szerződés ${ }^{972}$ szolgáltatja:

„A fogyasztóvédelmi követelményeket figyelembe kell venni az egyéb uniós politikák és tevékenységek meghatározásakor és végrehajtásakor.

„,A Bizottság [...] a fogyasztóvédelemre vonatkozó javaslataiban a védelem magas szintjét veszi alapul...,

Az EUMSz külön címben rendezi az EU fogyasztóvédelmi politikájának legfontosabb célkitüzéseit:

„A fogyasztói érdekek érvényesülésének elömozditása és a fogyasztóvédelem magas szintjének biztositása érdekében az Unió hozzájárul a fogyasztók egészségének, biztonságának és gazdasági érdekeinek védelméhez, valamint a tájékoztatáshoz, oktatáshoz és az érdekeik védelmét célzó önszervezödéshez való jogaik megerösitéséhez. "975

A „fogyasztói érdekek érvényesülésének elömozditása” és a „fogyasztóvédelem magas szintje” is absztrakt fogalmak, amelyek az Unió széles mérlegelési jogkörét indikálják. ${ }^{976}$ A fogyasztók legfontosabb jogait is meghatározza az EUMsz (immár alapító szerződési szinten). Az Unió célja e jogok és érdekek védelmének előmozdítása és megerősítése a fogyasztóvédelem magas szintjének biztosítása érdekében [EUMSz 169. cikk (2) bekezdés]. Az EUMSz lefekteti az alapvető eljárási szabályokat az EU-s szintü fogyasztóvédelmi intézkedések megalkotására vonatkozóan is, ezen kívül felhatalmazza a tagállami jogalkotást az uniósnál szigorúbb szabályok megalkotására a fogyasztóvédelem területén [169. cikk (3)-(4) bekezdések]. Egyes szerzők szerint a fogyasztóvédelem nem

április 3.). A következő programra irányuló Európai Bizottsági javaslat (COM(2011) 707) elérhető: http://ec.europa.eu/consumers/strategy/docs/proposal_consumer_programme_2014-2020_hu.pdf

(2013. április 3.). Az Európai Parlament vonatkozó állásfoglalása elérhető:

http://www.europarl.europa.eu/sides/getDoc.do?pubRef=-//EP//TEXT+TA+P7-TA-2014$0005+0+\mathrm{DOC}+\mathrm{XML}+\mathrm{V0} / / \mathrm{HU}$ (2014. április 23.).

972 A továbbiakban: EUMSz. Elérhetö:

http://eur-lex.europa.eu/LexUriServ/LexUriServ.do?uri=OJ:C:2010:083:0047:0200:hu:PDF (2013. november 13.).

${ }_{973}$ EUMSz 12. cikk.

${ }^{974}$ EUMSz VII. cím 3. fejezet: „Jogszabályok közelítése”, 114. cikk (3) bekezdés.

${ }^{975}$ EUMSz 169. cikk (1) bekezdés. A 169. cikk rendelkezéseit az Amszterdami Szerződés léptette életbe (korábbi 153. cikk).

${ }^{976}$ HAJNAL (2011), 2427. p. 
csak valamilyen mérce, hanem maga az eszköz az integráció megvalósításához. ${ }^{977}$ Az EU és a tagállamok azonban megosztott hatáskörben szabályozzák a fogyasztóvédelmet. ${ }^{978}$

Az Európai Unió Alapjogi Chartájának ${ }^{979}$ első, 2000-es javaslata már tartalmazta a fogyasztók egészségének, biztonságának és érdekeinek védelmét. ${ }^{980}$ A Lisszaboni Szerződés 2009. december 1-jei hatályba lépésével az alapszerződésekkel azonos jogi kötőerőt nyert a Charta, ${ }^{981}$ amelynek a „Szolidaritásról” szóló IV. címe határozza meg a fogyasztók védelmére vonatkozó alapjogot illetve célkitűzést: „Az Unió politikáiban biztositani kell a fogyasztók védelmének magas szintjét. "982 A rendelkezést az EUMSz 169. cikkével együtt kell értelmezni. ${ }^{983} \mathrm{Az}$ EU egyik intézményi célkitűzéseként fogalmazták meg tehát a fogyasztók védelmét, mint objektív jogi normát, ${ }^{984}$ és a szövegezéséből is arra lehet következtetni, hogy az az EUMSz rendelkezésének egy absztrahált verziója. ${ }^{985}$

Az Európai Bizottság Egészségügyi és Fogyasztóvédelmi Főigazgatósága a 2005-ös „Fogyasztóvédelem az Európai Unióban: Tíz alapelv” címü, az EU húsz hivatalos nyelvén online elérhető kiadványában a következő tíz fogyasztóvédelmi alapelvet határozza meg:

1. „Vásároljon, amit akar, és ahol csak akarja!”

2. „Ha nem müködik, küldje vissza!”

3. Az élelmiszerekre és más fogyasztási cikkekre szigorú biztonsági elöírások vonatkoznak.

4. A fogyasztónak joga van tudni, hogy mit eszik.

5. „A szerződéseknek tisztességes feltételeket kell biztosítaniuk a fogyasztó számára.”

\footnotetext{
977 GRUNDMANN - BIANCA (2002), 29. p.

${ }^{978}$ Lásd: EUMSz 4. cikk (2) bekezdés f. pont. A fenti rendelkezések lényegében megegyeznek az 1999. május 1-jén hatályba lépett Amszterdami Szerződés által életbe léptetett szabályokkal, lásd: SzIKORA (2010), 21-22. p.

${ }_{979}$ A továbbiakban: Charta.

980 Draft Charter of Fundamental Rights of the European Union (Convent 34), Article 45. Angol nyelven elérhető: http://www.europarl.europa.eu/charter/activities/docs/pdf/convent34_en.pdf (2012. november 20.), "Consumer protection”: , Union policies shall ensure a high level of protection as regards the health, safety and interests of consumers." A Chartára vonatkozó elsö összjavaslat is ilyen formában tartalmazta a fogyasztóvédelmet, lásd: Draft Charter of Fundamental Rights of the European Union (Convent 45). Német nyelven elérhető: http://www.kirchenrecht.net/eu/localmirror/convent45-de.pdf (2012. november 20.).

${ }^{981}$ A 2007. évi végleges javaslatnak megfelelő szöveggel, lásd: Európai Unióról Szóló Szerződés, a továbbiakban: EUSz. Elérhető:

http://eur-lex.europa.eu/LexUriServ/LexUriServ.do?uri=OJ:C:2010:083:0047:020:hu:PDF (2012. november 20.), 6. cikk (1) bekezdés.

${ }^{982}$ Az Európai Unió Alapjogi Chartája, 38. cikk. Elérhető: http://eur-lex.europa.eu/hu/treaties/dat/32007X1214/htm/C2007303HU.01000101.htm (2012. november 20.). 983 Lásd többek között: Magyarázatok az Alapjogi Chartához (2007/C 303/02), 28. p. Elérhető: http://eurlex.europa.eu/LexUriServ/LexUriServ.do?uri=OJ:C:2007:303:0017:0035:HU:PDF (2012. november 20.).

A magyarázat mindössze ezt az EUMSz 169. cikkével való összefüggésre utal csupán a 38. cikkel kapcsolatban, egy mondatban.

${ }_{984}$ MEYER (2006), 413. és 415. p.

${ }^{985}$ MeYer (2006), 415. p.
} 
6. A fogyasztóknak lehetőségük van arra, hogy meggondolják magukat.

7. Meg kell könnyíteni az árak összehasonlítását.

8. „A fogyasztót nem szabad félrevezetni.”

9. Üdülés idején is biztosítani kell a fogyasztók védelmét.

10. Hatékony eszközöket kell biztosítani a határon átnyúló viták rendezésére. ${ }^{986}$

Ezen elvek között - közvetlenül illetve közvetve - hangsúlyos szerephez jut a fogyasztói szerződések, a fogyasztóvédelmi szerződési jog kérdésköre.

\section{Európai Uniós „fogyasztóvédelmi szerződési jog”}

Napjainkban a végső fogyasztó szerződési pozícióját számos, a piacgazdásági mechanizmusokból és a globalizációból fakadó korlát gyengíti. Ilyen tényezők felmerülnek a szerződés megkötéséhez vezető döntési folyamat során és a szerződéskötéskor egyaránt. $^{987}$

Korunk országhatárokon is átnyúló piacain különösen a fogyasztók helyzetét nehezítő alábbi tényezők kiküszöbölésére irányul a fogyasztóvédelmi szerződési jog EU-s szabályozásának koncepciója: 1) információs deficit, 2) tárgyalási deficit, 3) tisztességesség hiánya, 4) a biztonság hiánya, 5) jogérvényesítés, 6) képviselet hiánya, 7) a megbízhatóság/bizalom hiánya, és 8) a versennyel összefüggő deficit a piacon és a jogi szabályozásban. ${ }^{988}$ Ezekkel a fogyasztók gazdasági helyzetét és szerződési pozícióját gyengítő körülményekkel kapcsolatban alakultak ki a szerződésszerüség uniós jogi alapelvei. $^{989}$

A fentiekre figyelemmel alakul az Európai Unió szerződési jogot harmonizáló illetve egységesítő jogalkotása, amely az EUMSz belső piacot érintő rendelkezésén alapul:

„Az Unió a Szerzödések vonatkozó rendelkezéseinek megfelelöen meghozza a belső piac létrehozásához, illetve müködésének biztositásához szükséges intézkedéseket. A belsö piac egy olyan, belsö határok nélküli térség, amelyben a Szerzödések rendelkezéseivel összhangban biztositott az áruk, a személyek, a szolgáltatások és a töke szabad mozgása. "990

\footnotetext{
986 Lásd: „Fogyasztóvédelem az Európai Unióban: Tíz alapelv”; a magyar nyelvű dokumentum elérhető: http://ec.europa.eu/consumers/cons info/10principles/hu.pdf (2013. április 3.).

${ }_{987}$ RÖSLER (2004), 17-23. p.

${ }^{988}$ RÖSLER (2004), 46-48. p.

${ }^{989}$ Lásd: RÖSLER (2004), 133. p.

${ }^{990}$ EUMSz 26. cikk (1)-(2) bekezdések, vö. 1999/44/EK Irányelv, Preambulum (2) bekezdés.
} 
A belső piac elérése érdekében meghatározott négy szabadság közül a szerződési jog vonatkozásában különösen az áruk, a szolgáltatások és a tőke szabad áramlása bírnak relevanciával. $^{991}$

A fogyasztóvédelmi szerződési jogba tartozik a közösségi jog minden olyan normája, amely a fogyasztót a másik szerződési partnerrel szemben jogilag privilegizálja, és az aszimmetrikus pozíciókat igyekszik kiegyenlíteni, ezáltal a piaci folyamatok optimális müködőképességét támogatni. ${ }^{992}$ A szakirodalom az európai fogyasztóvédelmi jog koncepcióját „dualistának” nevezi, mert egyszerre kell megtartania az egymással ellentétes kategóriák és érdekek (mint a szerződési szabadság és annak korlátozása, a piac megfelelő müköd(tet)ése és védelme, a liberalizmus fejlesztési irányvonalai és a szerződéses kockázat szabályozása, a fogyasztó és a vállalkozó jogi helyzete) optimális egyensúlyát a szabályozásban. ${ }^{993}$

A fogyasztóvédelem megosztott hatáskörben való szabályozása az indoka annak, hogy bár a rendelet az EU általános hatállyal bíró, minden elemében kötelező és közvetlenül alkalmazandó jogi aktusa, ${ }^{994}$ mégis ritkán alkalmazott norma ezen a területen. A fogyasztóvédelmi szerződési jogot egységesítő uniós jogalkotás jellemző jogszabálya az elmúlt évtizedekben az irányelv volt, ${ }^{995}$ mert ez az Unió olyan jogi normája, amely céljaiban kötelező a címzettekre nézve, ${ }^{996}$ ugyanakkor viszonylag nagy szabadságot ad a tagállamoknak az implementálásra, így azok kellő figyelmet fordíthatnak az EU-s elvárások és a nemzeti magánjogi hagyományok összhangjának megteremtésére. ${ }^{997}$

A szerződési jogot érintő irányelvek a közelmúltig az ún. minimum-harmonizáció jegyében születtek. ${ }^{998}$ A minimum-harmonizáció elve azt jelenti, hogy a tagállamok jogalkotó szervei az uniós szinten meghatározott legalapvetőbb jogvédelmet tartalmazó rendelkezéseket kötelesek átültetni, annál szigorúbbakat pedig saját belátásuk szerint

\footnotetext{
${ }^{991}$ RIESENHUBER (2003), 29. p.

992 RÖSLER (2004), 1. p. Az utóbbi az ún. „piackompenzáló funkció”, uo. 15. p.

993 RÖSLER (2004), 1. p.

994 Lásd: http://ec.europa.eu/eu_law/introduction/what_regulation_hu.htm (2013. november 13.); BLUTMAN (2010), 228. p.

${ }^{995}$ Az irányelvek elfogadására a belső piac megvalósítása céljából az EUMSz 114. és 115. cikke hatalmazza fel az EU-s jogalkotó szerveket. „A 114. cikk sérelme nélkül a Tanács az Európai Parlamenttel, valamint a Gazdasági és Szociális Bizottsággal folytatott konzultációt követöen, különleges jogalkotási eljárás keretében, egyhangúlag irányelveket fogad el a tagállamok olyan törvényi, rendeleti vagy közigazgatási rendelkezéseinek közelitésére, amelyek közvetlenül érintik a belső piac megteremtését vagy müködését.", lásd: EUMSz 115. cikk.

${ }^{996}$ EUMSz 288. cikk 3. mondat: „Az irányelv az elérendö célokat illetöen minden címzett tagállamra kötelezö, azonban a forma és az eszközök megválasztását a nemzeti hatóságokra hagyja.”; lásd többek között: BLUTMAN (2010), 229-235. p.

${ }_{997}^{90}$ Lásd többek között: 1999/44/EK Irányelv, Preambulum (6)-(7) bekezdések.

998 „, Optimierung statt Maximierung”, lásd: DREXL (1998), 438. p.
} 
alkalmazhatnak. ${ }^{999}$ A jelenlegi helyzet jellemzője az egyes speciális szerződésekre vonatkozó szektorális irányelvekből álló jelentős joganyag, és mellette két, a fogyasztói szerződési jogon átívelö, horizontálisan szabályozó irányelv a fogyasztókkal kötött szerződésekben alkalmazott tisztességtelen feltételekről ${ }^{1000}$ és a fogyasztók jogairól. A legjelentősebb irányelvek elfogadásuk időrendjében az alábbiak:

1. 1987/102/EGK Irányelv a fogyasztói hitelre vonatkozó tagállami törvényi, rendeleti és közigazgatási rendelkezések közelítéséről;

2. 1990/314/EGK Irányelv a szervezett utazási formákról;

3. 1993/13/EGK Irányelv a fogyasztókkal kötött szerződésekben alkalmazott tisztességtelen feltételekröl;

4. 1994/47/EK Irányelv az ingatlanok időben megosztott használati jogának megszerzésére irányuló szerződések egyes szempontjai vonatkozásában a fogyasztók védelméről;

5. 1998/6/EK Irányelv a fogyasztók számára kínált termékek árának feltüntetésével kapcsolatos fogyasztóvédelemröl;

6. 1999/44/EK Irányelv a fogyasztási cikkek adásvételének és a kapcsolódó jótállásnak egyes vonatkozásairól;

7. 2000/31/EK Irányelv a belső piacon az információs társadalommal összefüggő szolgáltatások, különösen az elektronikus kereskedelem, egyes jogi vonatkozásairól;

8. 2002/65/EK Irányelv a fogyasztói pénzügyi szolgáltatások távértékesítéssel történő forgalmazásáról, valamint a 90/619/EGK tanácsi irányelv, a 97/7/EK irányelv és a 98/27/EK irányelv módosításáról;

9. 2005/29/EK Irányelv a belső piacon az üzleti vállalkozások fogyasztókkal szemben folytatott tisztességtelen kereskedelmi gyakorlatairól, valamint a 84/450/EGK tanácsi irányelv, a 97/7/EK, a 98/27/EK és a 2002/65/EK európai parlamenti és tanácsi irányelvek, valamint a 2006/2004/EK európai parlamenti és tanácsi rendelet módosításáról;

10. 2011/83/EU irányelv a fogyasztók jogairól, a 93/13/EGK tanácsi irányelv és az 1999/44/EK európai parlamenti és tanácsi irányelv módosításáról, valamint a 85/577/EGK tanácsi irányelv és a 97/7/EK európai parlamenti és tanácsi irányelv hatályon kívül helyezéséről. ${ }^{1001}$

A fenti jogszabályok többsége szektorális, de a fogyasztók jogairól szóló 2011/83/EU irányelv megalkotása és annak szabályozási elve jelzi, hogy az utóbbi években egy egységesedő fogyasztóvédelmi szerződési jog van kibontakozóban az Unióban. ${ }^{1002}$

\footnotetext{
${ }^{999}$ Lásd többek között: RÖSLER (2004), 201. p.; REMIEN (2003), 136. p.

${ }^{1000}$ Lásd: REMIEN (2003), 137. p.

$1001 \mathrm{Az}$ egyes, a fogyasztóvédelmi jogot érintő uniós jogi normáknak a speciális fogyasztói érdekek szempontjából való csoportosítását lásd: HAJNAL (2013), 1. számú függelék, 214-218. p.

1002 Lásd: REMIEN (2003), 138. p.
} 


\section{A fogyasztó EU-s fogalma és a vele szerződő fél kategóriája}

A fogyasztó Európai Unió által biztosított magánjogi többletvédelmét a vele szerződő féllel szembeni alárendelt gazdasági pozíciója indokolja a fent említettek fényében. ${ }^{1003} \mathrm{~A}$ fogyasztó fogalmába tartozó alanyok körét az EUMSz nem határozza meg konkrétan. ${ }^{1004}$ Az egyes uniós fogyasztóvédelmi irányelvek, illetve az egyéb jogi normák az adott speciális tárgyi hatálynak megfelelően határozzák meg a fogyasztó fogalmát, így nincs egységes meghatározás, ${ }^{1005}$ és gyakran olyan normák is fogyasztóvédelmiként aposztrofáltak, amelyek nem csupán a fogyasztókat részesítik védelemben. ${ }^{1006}$

Az egységes fogalmi meghatározás hiánya az irányelvek minimum-harmonizációs szabályozási elvéből is következik: a tagállamoknak hagyta meg az EU-s jogalkotó például azt a döntési lehetőséget is, hogy kizárják-e a fogyasztók közül a nem természetes személyeket. ${ }^{1007} \mathrm{Az}$ irányelvben található fogalmi meghatározások egyébként - egy kivételével (1990/314/EGK irányelv) - a természetes személyeket említik. ${ }^{1008}$ Ennél fontosabb kritérium, hogy mindegyik fogalmi meghatározás kiemeli, hogy a szerződéskötésnek kívül kell esnie a fogyasztó üzleti vagy szakmai tevékenységi körén. ${ }^{1009}$ Mivel a fogyasztóvédelmi szabályozás „,szituatív jellegű”, ${ }^{1010}$ az Európai Bíróság is csak esetileg tud dönteni a fogyasztói minőségröl, következetes gyakorlata szerint azonban a fogyasztó-fogalmát általában a természetes személyekre korlátozza. ${ }^{1011}$

A fogyasztó fogalmától megkülönböztetendő a fogyasztói magatartás, az ún. mintafogyasztó kategóriája, amely tulajdonképpen a fogyasztótól elvárható gondosság

\footnotetext{
1003 Lásd: VÉKÁS (2002), 3. p.

${ }^{1004}$ REMIEN (2003), 240. p.

${ }^{1005}$ Az európai jog szintjén található eltérő fogyasztó-fogalmi koncepciók kritikájához lásd: CHRISTIAN VON BAR (2002), elérhetö: http://www.cisg.law.pace.edu/cisg/biblio/vonbar1.html (2012. december 10.).

${ }^{1006}$ REMIEN (2003), 239. p.

1007 Lásd: VÉKÁs (2002), 5. p. Megjegyzendő, hogy a horizontális hatályú 2011/83/EU irányelvnek a fogyasztói adásvételre is alkalmazandó fogalma a maximum-harmonizáció jegyében kötelezően szó szerint implementálandó a tagállamokban, de e jogszabály is lehetővé teszi az alanyi hatálynak a nem természetes személyekre való tagállami kiterjesztését, vö.: 2011/83/EU irányelv, 2. cikk 1. pont és Preambulum (13) bekezdés.

1008 Lásd: REICH - MiCKLITZ (2003. 64. p. Az egyes fogyasztó-fogalmak összevetéséhez lásd: SCHULTENÖLKE - TWIGG-FLESNER - EBERS (2008), 453-454. p. Megjegyzendő, hogy a fent említett 1973-as Európa Tanácsi „Consumer Protection Charter” még egy tágabb fogalmi meghatározással élt: „A consumer is a physical or legal person to whom goods are supplied and services provided for private use.” [A. (i)]. 1009 „,... outside his trade, business or profession...”, lásd: SCHULTE-NÖLKE - TWIGG-FLESNER - EBERS (2008), 453-454. p.

${ }^{1010}$ Lásd: OSZTOVITS (2011), 2424. p.

1011 VÉKÁs (2002), 4. p. Lásd például: az Európai Bíróság C-541/99 és C-542/99. számú egyesített ügyben az 1993/13/EGK Irányelvvel kapcsolatosan hozott döntése: „The term consumer, as defined in Article 2(b) of Directive 93/13 on unfair terms in consumer contracts, must be interpreted as referring solely to natural persons.”. Lásd még: RIESENHUBER (2003), 83. p.
} 
mércéje. Az Európai Bíróság az egységes fogyasztófogalom körülírása helyett inkább ennek meghatározását tekintette feladatának. Precedens-értékü döntése nyomán az ésszerủen eljáró fogyasztó tekintendő mércének az Európai Bíróság joggyakorlatában:

„... the national court must take into account the presumed expectations which it evokes in an average consumer who is reasonably well-informed and reasonably observant and circumspect."

Ez alapján a nemzeti bíróságnak a konkrét jogvitákban ,azokat a feltételezhető elvárásokat kell számításba vennie, amiket [egy kijelentés vagy leírás] kivált egy átlagfogyasztóból, aki ésszerüen tájékozott, figyelmes és körültekintő." ${ }^{1013}$ Ugyanezt a mércét több későbbi ítéletében következetesen alkalmazta az EuB, így ez alapján most már egy ún. európai fogyasztói modellröl beszélhetünk. ${ }^{1014}$

A fogyasztókat a jogi védelem a velük szerződő, foglalkozásukhoz vagy ipari, kereskedelmi tevékenységükhöz kapcsolódó célból eljáró másik féllel szemben illeti meg. ${ }^{1015}$ Ez a fél a legtöbb Uniós jogszabály szerint lehet természetes és jogi személy egyaránt. A fogyasztóval szerződő fél „ipart üzö”, „foglalkozást űző”, illetve „vállalkozó/vállalkozás” néven is szerepelhet a jogszabályokban, de minősítésére az a gazdasági érdek és cél a meghatározó, amiért a szerződést a fogyasztónak minősülő személlyel megköti. ${ }^{1016}$

\section{Az 1999/44/EK Irányelv a fogyasztási cikkek adásvételének és a kapcsolódó jótállásnak egyes vonatkozásairól ${ }^{1017}$}

A magánjogi kérdéseket és jogintézményeket érintő irányelvek között az 1990-es években kezdődött meg a fogyasztói adásvételre, és elsősorban az ahhoz kapcsolódó kiegészítő

1012 A tojások adásvételével, és az azokra vonatkozó „értékesítési standardokkal” kapcsolatos C-210/96. számú ügyben, előzetes döntéshozatali eljárás keretében hozott döntés (1998.07.16.), EBHT 1998. I-04657. Angol nyelven elérhető:

http://eur-

lex.europa.eu/smartapi/cgi/sga_doc?smartapi!celexplus!prod!CELEXnumdoc\&lg=en\&numdoc=61996J0210 (2012. december 3.).

1013 Saját fordítás.

${ }^{1014}$ Lásd: C-470/93. számú ítélet (EBHT 1995. I-01923) és a C-220/98. számú ítélet (EBDT 2000. I-00117); OSZTOVITS (2011), 2424. p.

1015 RIESENHUBER (2003), 82. p.

1016 ,Gewerbetreibend”, ,, Berufausübend”, ,,Unternehmer”, lásd: RIESENHUBER (2003), 82. p.

${ }^{1017}$ Magyar nyelven elérhetö:

http://eur-lex.europa.eu/LexUriServ/LexUriServ.do?uri=CELEX:31999L0044:HU:HTML (2012. november 19.), a továbbiakban: Irányelv.

Az összehasonlító vizsgálathoz hasznos kétnyelvü változatok elérhetőek:

http://eur-lex.europa.eu/LexUriServ/LexUriServ.do?uri=CELEX:31999L0044:EN:NOT （2013. november 14.). 
szolgáltatásokra vonatkozó szabályozás előkészítése és megalkotása. Az Irányelv létrehozásának közvetett jogpolitikai célja a nemzeti kötelmi jogok, ezen belül pedig a szerződési jogok modernizálása és „,nemzetközisítése” volt. ${ }^{1018}$

A fogyasztói szerződések keretében nyújtott kereskedelmi garanciák (jótállási nyilatkozatok) szabályozásának igénye már korábban prioritást nyert a közösségi jogalkotásban, amit a fogyasztói szerződésekben szereplő tisztességtelen kikötésekre vonatkozó 1990-es irányelvtervezet szövege is mutatott. ${ }^{1019}$

Az Irányelvet előkészítendő az Európai Bizottság 1993-ban elöterjesztette a fogyasztási cikkekkel kapcsolatos jótállásról és a vétel utáni szolgáltatásokról szóló zöld könyvet. ${ }^{1020}$ A dokumentum többek között a következő kérdések tekintetében buzdította nyilvános véleménynyilvánításra az érdekelt szervezeteket, érdekvédelmi csoportokat: kívánatos-e a „törvényes szavatosságra” vonatkozó nemzeti jogszabályok harmonizációja; a „kereskedelmi jótállás” belső piacon belüli jobbítása kötelező szabályozás vagy önkéntes megközelítés által érendő-e el; a pótalkatrészek és a vevőszolgálat problematikája milyen szabályozási metódus által oldható meg? ${ }^{1021}$ Az Irányelv első javaslata 1996-ban született meg. ${ }^{1022}$ A javaslatban kifejezetten is megjelent, hogy az Irányelv „szabályozási mintaképe" az ENSZ berkeiben megalkotott 1980-as Bécsi Vételi Egyezmény, amit a szakirodalom is mindig hangoztat. ${ }^{1023}$

Az 1996-os javaslatot 1998-ban az intézményi és érdekvédelmi csoportokkal folytatott konzultáció eredményeképp több ponton jelentősen módosították. ${ }^{1024}$ A módosítások három kardinális kérdést érintettek: tisztázták a jogorvoslatok egymáshoz való viszonyát, a vevő közlési kötelezettsége opcionális rendelkezés lett, és a (törvényes)

\footnotetext{
${ }^{1018}$ GRUNDMANN - BiANCA (2002), 30. és 32. p.

${ }^{1019}$ Lásd: Proposal for a Council Directive on unfair terms in consumer contracts (COM(90) 322). Angol nyelven elérhetö: http://aei.pitt.edu/5704/1/5704.pdf (2012. november 21.), Article 19, 22 és annex c) (1).

${ }^{1020}$ Green Paper on Guarantees for consumer goods and after-sales services (COM(93) 509). Angol nyelven elérhető: http://eur-lex.europa.eu/LexUriServ/LexUriServ.do?uri=COM:1993:0509:FIN:EN:PDF

(2012. december 4.), a továbbiakban: Zöld könyv.

${ }^{1021}$ Zöld könyv, 101-102. oldal. A Zöld könyv angol nyelvü szövege a magyar nyelven kellékszavatosságnak nevezett jogintézményt „legal guarantee”, a (szerződő fél által önkéntesen felvállalt) jótállást pedig „commercial guarantee” névvel illeti.

${ }^{1022}$ 1996. évi javaslat [Proposal for a European Parliament and Council Directive on the sale of consumer goods and associated guarantees $\operatorname{COM}(95)$ 520], 5. p. Elérhető: http://eur-lex.europa.eu/LexUriServ/LexUriServ.do?uri=COM:1995:0520:FIN:EN:PDF (2012. december 4.), ${ }^{1023}$ 1996. évi javaslat, 11-14. p. Lásd többek között: RIESENHUBER (2003), 278. p.; GRUNDMANN - BIANCA (2002), 19. p. Az utóbbi mű szerzői rövid kritikai összehasonlítást is tesznek a két nemzetközi jogi norma között, hangsúlyozva, hogy mekkora szükség volt a Bécsi Egyezmény megalkotása óta eltelt jogi és gazdasági fejlemények figyelembevétele miatt egy modern irányelv megalkotására (lásd: 19-23. p.).

${ }^{1024} \mathrm{Az}$ 1998. évi módosított javaslat [Amended proposal for a European Parliament and Council Directive on the sale of consumer goods and associated guarantees (COM(1998) 217). Angol nyelven elérhetö:

http://eur-lex.europa.eu/LexUriServ/LexUriServ.do?uri=COM:1998:0217:FIN:EN:PDF （2012. november 19.).
} 
kellékszavatosság és a (kereskedelmi, önkéntes) jótállás közötti viszony szabályozása is világosabb formát öltött. ${ }^{1025}$ Végül a jogszabályt az Európai Parlament 1999. május 25-én fogadta el, és 2002. január 1-jét tủzte ki a tagállami implementáló jogszabályok megalkotásának határidejéül.

Az Irányelv legfontosabb célkitüzései a Preambulumában találhatóak. Mivel a belső piac megvalósulásával lehetővé vált a nemzeti határokon átnyúló kereskedelem, így az EUs jogalkotó szerint a fogyasztók számára is lehetővé kell tenni, hogy a fogyasztási cikkek adásvételét szabályozó egységesített minimális szabályok alapján szabadon vásárolhassanak fogyasztási cikkeket egy másik tagállam területén is [Preambulum (2) bekezdés]. Az Irányelv megalkotásával az uniós jogalkotó szerint a fogyasztói jogok minimális közös szabályainak létrehozása a fogyasztók bizalmát erősíteni hivatott, és lehetővé teszi, hogy a fogyasztók a belső piac előnyeit minél nagyobb mértékben élvezzék [Preambulum (5) bekezdés]. Az Irányelv fő célja „, a fogyasztási cikkek adásvételének egyes vonatkozásait szabályozó tagállami törvényi, rendeleti és közigazgatási rendelkezések közelitése a fogyasztóvédelem egységes minimális szintjének biztositása érdekében a belsö piac keretében”. ${ }^{1026}$ Az Irányelvben materializálódott az a célkitűzés is, amit már a Tanács 1992-es, a fogyasztóvédelem fejlesztésének jövőbeli prioritásairól szóló határozata is megfogalmazott: a jótállási szabályok és a belső piacon belüli, árukra és szolgáltatásokra vonatkozó adásvételt követő (járulékos) szolgáltatások szabályainak közelítése. ${ }^{1027}$

\subsection{Az Irányelv hatálya}

Az Irányelv rendelkezéseinek bemutatásánál a tárgyilagos, rövid ismertetésre szorítkozom, mert azt a dolgozat következő, az implementáció egyes lehetséges variánsait bemutató fejezetei hivatottak kitölteni és kiegészíteni az egyes értelmezési kérdések kapcsán. Az Irányelv hatálya a fogyasztó és az eladó között fogyasztási cikkre kötött adásvételi szerződésekre terjed ki. Az Irányelv az alanyi hatály tekintetében az alábbi fogyasztófogalommal operál:

\footnotetext{
${ }^{1025}$ Lásd: GRUNDMANN - BIANCA (2002), 27-28. p. Az összehasonlításhoz lásd még: LuSZCZ (1999), 15-18. ${ }^{1026}$ Lásd: Irányelv, 1. cikk (1) bekezdés.

${ }^{1027}$ Vö.: COM(95) 520, 2. p., és Council Resolution of 13 July 1992 on future priorities for the development of consumer protection policy (92/C 186/01). Az utóbbi angol nyelven elérhető: http://eur-lex.europa.eu/LexUriServ/LexUriServ.do?uri=CELEX:31992Y0723(01):EN:HTML (2012. november 19.), Annex, 6 (Economic Interests).
} 
„fogyasztó: minden olyan természetes személy, aki az ezen irányelv hatálya alá tartozó szerzödések tekintetében gazdasági vagy szakmai tevékenysége körén kívül esö célból jár el". ${ }^{1028}$

A tisztább fogalomhasználat érdekében Vékás Lajos az angol szövegezésre figyelemmel a következő szövegmódosítási javaslatokkal él: „gazdasági” helyett „üzleti” az angol „,trade, business” fordulatnak megfelelően, valamint „önálló foglalkozás” a „szakmai tevékenység” helyett az angol ,"profession”-re tekintettel. ${ }^{1029}$

Az Irányelv alkalmazásában eladó „,minden olyan természetes vagy jogi személy, aki, illetve amely, szerződés alapján gazdasági vagy szakmai tevékenysége keretében fogyasztási cikkeket értékesít”. ${ }^{1030}$ Az elöbbi szövegmódosítási javaslatok természetesen erre a definícióra is vonatkoznak.

Az Irányelv megadja, hogy mit ölel fel a fogyasztási cikk kategóriája. A meghatározás szerint az mindig ingó dolog, kizárja azonban a jogszabály a fogalomból „, $a$ végrehajtás vagy más bírósági intézkedés alapján értékesitett árukat”, a vizet és a gázt (feltéve, hogy „nem korlátozott térfogatban vagy meghatározott mennyiségben ajánlják fel adásvételre") és a villamos energiát [Irányelv, 1. cikk (2) bekezdés b. pont]. Ezen kívül a tagállamok implementáló szabályaikban opcionálisan kizárhatják a hatálya alól „a fogyasztók személyes részvételét lehetővé tevő nyilvános árverésen értékesitett használt árut" is [Irányelv, 1. cikk (3) bekezdés].

Áru és vételár cseréje, azaz a klasszikus adásvétel mellett az irányelv tárgyi hatálya alá tartozik a fogyasztási cikkre vonatkozó szállítási szerződés, ${ }^{1031}$ valamint az olyan szerződés is, amely „legyártandó vagy elöállitandó fogyasztási cikk átadására vonatkozik", ${ }^{1032}$ azaz a vállalkozási szerződés. A továbbiakban a szükebb témához igazodva csak a fogyasztói adásvételre koncentrálok, annak ellenére, hogy az Irányelv a fenti fogalmak mellett nem ad kifejezett definíciót a fogyasztói adásvételre. ${ }^{1033}$

\footnotetext{
1028 Lásd: Irányelv, 1. cikk (2) bekezdés a) pont. A 2011/83/EU irányelvnek a fogyasztói adásvételre is irányadó, 2013. december 13-ig implementálandó fogalma szerint: „fogyasztó bármely természetes személy, aki az ezen irányelv hatálya alá tartozó szerzödések keretében olyan célból jár el, amely kívül esik kereskedelmi, ipari, kézmüipari vagy szakmai tevékenysége körén” (2. cikk 1. pont).

${ }^{1029}$ Lásd: VÉKÁS (2001a), 328. p. 28. 1j.

${ }^{1030}$ Irányelv, 1. cikk (2) bekezdés c. pont.

${ }^{1031}$ Lásd: VÉKÁS (2001a), 339. p.

1032 Lásd: Irányelv, 1. cikk (4) bekezdés.

1033 MICKLITZ - STUYCK - TERRYN (2010), 305. p. Ezt megteszi azonban a 2011/83/EU irányelv, amelynek fogalmi meghatározása szerint: „fogyasztói adásvételi szerződés bármely olyan szerződés, amelynek értelmében a kereskedö átruházza vagy vállalja, hogy átruházza a fogyasztóra valamely áru tulajdonjogát, a fogyasztó pedig megfizeti vagy vállalja, hogy megfizeti annak vételárát; az adásvételi szerződések vonatkozhatnak árukra és szolgáltatásokra egyaránt.” (2. cikk 5. pont).
} 
Az Irányelv a fogyasztói adásvételi jognak csak egy kiemelt jelentőségü részterületére fókuszál: a fogyasztási cikkek ésszerüen elvárható minőségi standardjára, az e minőségi szintet el nem érő áruk esetén érvényesíthető fogyasztói jogorvoslati módokra és az önkéntesen vállalható jótállásra. ${ }^{1034}$ Nem illesztették be azonban a hatálya alá a szerződés megkötésére, annak értelmezésére, a veszély átszállására, az átadásra és átruházásra, valamint a hibás teljesítés miatti kártérítési igényre vonatkozó rendelkezéseket, ${ }^{1035}$ így e kérdések szabályozása tagállami hatáskörben maradt.

\subsection{A védett vagyoni érdek és a jogintézmény jogalapja}

A védett érdek vonatkozásában az első fogyasztóvédelmi programban foglalt és az EUMSz által megfogalmazott fogyasztói jogok jelentik a kiindulópontot. Már a fent említett 1992es, a fogyasztóvédelem fejlesztésének jövőbeli prioritásairól szóló tanácsi határozat is a fogyasztók gazdasági érdekei címszó alatt helyezte el a jótállást és az adásvételt követő kiegészítő szolgáltatások szabályozásának közelítésére vonatkozó törekvést. ${ }^{1036} \mathrm{Az}$ Irányelv is elsődlegesen a fogyasztó gazdasági érdekeit hivatott védeni, és a minőséghez füződő érdekének a védelme és a jogorvoslat iránti joga testesül meg benne. Szabályozási elve a már említett ún. minimum-harmonizáció, azaz a tagállamok belső jogába implementálandó Irányelvbeli szabályok csupán a „keretet” (a tagállamoktól elvárt minimum követelményeket) adják meg, de ezeknél a fogyasztóra nézve kedvezőbb rendelkezések is megállapíthatóak a nemzeti jogszabályokban. ${ }^{1037}$

Bár az eladói félrevezetéssel szembeni átlagfogyasztókat védő törekvés megjelenik az Irányelv Preambulumában is ( 21 bekezdés), mégis az általa meghatározott szerződésszerü teljesítés kötelezettségénél a felróhatóságtól független, azaz objektív helytállást rendel el. ${ }^{1038}$

A közgazdaságtanban szavatosság alatt a jogszabályilag vagy szerződésben meghatározott, a hibás vagy egyébként nem megfelelő áru miatt fennálló jogi igényeket értik, amelyeket a vevő az eladóval szemben érvényesíthet. ${ }^{1039}$ Ennek fényében a

\footnotetext{
${ }^{1034}$ Lásd: MICKLITZ - STUYCK - TERRYN (2010), 303-304. p.

1035 GRUNDMANN - BIANCA (2002), 40-41. p.

${ }^{1036}$ Lásd: Council Resolution 92/C 186/01, Annex 6. (Economic Interests).

${ }^{1037}$ Vö.: Irányelv, Preambulum (2) és (24) bekezdés; 1. cikk (1) bekezdés; 8. cikk (2) bekezdés. GRUNDMANN - BIANCA (2002), 46. p.; VÉKÁS (2002), 5. p.

${ }^{1038}$ GRUNDMANN - BIANCA (2002), 37. p.

1039 GRUNDMANN - BIANCA (2002), 63. p. Vö. ,,legal” és ,,commercial guarantee”, lásd: Zöld Könyv (6465. $1 \mathrm{j}$.
} 
szavatosság három funkcióját különböztetik meg: a biztosítási, a minőségmutató és az ún. rizikóminimalizáló funkciót. ${ }^{1040}$

A biztosítási funkció célja a hiba vagy hiányosság rizikójától tartó vevő védelme, és annak garantálása, hogy az esetlegesen felmerülő hibát minden esetben orvosolni fogják. ${ }^{1041}$ Mivel azonban ez a reparáció az eladó oldalán költségekkel jár, a vevők sokaságára vetített, valószínüleg várható költségek arányos részét már eleve beépítik a vételárba. A vevők ezáltal (a biztosítási jogviszonyhoz hasonlóan) kockázatközösséget vállalnak. Azaz a hiba rizikójától tartó vevő hajlandó lesz ezeket a végső soron a vételárba belekalkulált költségeket minden vétel alkalmával előre megfizetni. ${ }^{1042}$

Amennyiben a minőség foka az adott áru hibaarányával negatív korrelációban áll, a szavatosság a jó minőséget jelzi. ${ }^{1043}$ Az átlagfogyasztó vevő azonban gyakran nincs abban a helyzetben, hogy eldöntse, hogy az adott eladó milyen minőségű terméket kínál, nem rendelkezik elegendő információval az egyes termékek minőségének effektív összevetéséhez. A szavatosság ezzel a „minőségindikáló” funkciójával ezt az információs aszimmetriát hivatott orvosolni. ${ }^{1044}$ A vevő számára komoly kockázatot jelent a piacon, hogy a vételhez kapcsolódó eladói szavatossági helytállás sokszor nagyon határozatlan. Az átlagfogyasztó számára annak eldöntése, hogy adott termék a piacon jó vagy silány minőségü, nagyon nehéz feladat. ${ }^{1045}$ Ugyanakkor az alacsonyabb minőségü árukat kínáló eladó számára a szavatosság mindig nagyobb költségvonzatú, hiszen az ő árui hamarabb és gyakrabban tönkremennek. ${ }^{1046}$ A rizikótól tartó vevők esetében így nagy átlagban érvényesül a szavatosság biztosítási és minőségjelző funkciója is, ezáltal az optimális szavatossági védelem effektívebb, mint a „rizikó-semleges” vevőknél. A „rizikó-semleges” vevők (közgazdasági) csoportjánál a magas minőségű termékek eladója tulajdonképpen annak érdekében kínálja a szavatossági helytállást, hogy az alacsonyabb minőséget nyújtó konkurenseitől elhatárolja magát. ${ }^{1047}$

Az eladó (gyártó) azonban elméletileg - a gyártási folyamat fokozott ellenőrzése révén - a meghibásodás valószínűségét és mértékét is képes befolyásolni, így a költségvonzat a szavatosság harmadik funkciójánál még nagyobb szerepet kap: bár a minőség csökkentésével az eladó költségtakarékos lehet, a szavatosságból fakadó vevői

\footnotetext{
${ }^{1040}$ GRUNDMANN - BIANCA (2002), 63-64. p.

${ }^{1041}$ A német terminológiában ,,risikoscheu”, az angolban ,,risk-avers”.

1042 PARISI (2004), 11. p.; CHAPMAN - MEURER (1989), 114. p.

1043 GRUNDMANN - BIANCA (2002), 65. p.

1044 GRUNDMANN - BIANCA (2002), 65-66. p.

1045 A kérdés problematikájához lásd: AKERLOF (1970), 488-500. p.

${ }^{1046}$ GRUNDMANN - BIANCA (2002), 66. p.

1047 GRUNDMANN - BIANCA (2002), 66. p.
} 
igények mégis arra ösztönözhetik, hogy a „rizikó-minimalizálásba” invesztáljon. ${ }^{1048} \mathrm{E}$ rizikócsökkentő funkcióban testesül meg ,,a termék előállításának optimalizálása”. ${ }^{1049}$

\subsection{Hibafogalom - szerződésszerüség}

Az Irányelv az eladó kötelességévé teszi a szerződésszerű teljesítést, majd részletesen megadja, hogy mikor áll fenn a szerződésszerüség megdönthető vélelme. Eszerint a szolgáltatás szerződésszerü, ha a fogyasztási cikk:

„a) megfelel az eladó által adott leirásnak, és rendelkezik az eladó által a fogyasztónak bemutatott próba vagy minta tulajdonságaival;

b) alkalmas a fogyasztó által meghatározott sajátos célra, amelyet a fogyasztó a szerzödéskötéskor az eladó tudomására hozott, és az eladó elfogadott;

c) alkalmas minden olyan célra, amelyre az azonos fajtájú árukat szokásosan használják;

d) felmutatja az azonos fajtájú áruk tekintetében szokásos minöséget és teljesitményt, amelyet a fogyasztó ésszerüen elvárhat, figyelembe véve a fogyasztási cikk természetét, és ha van ilyen, az eladó, a gyártó vagy annak képviselöje által a fogyasztási cikk konkrét tulajdonságai tekintetében különösen a reklámozás során tett vagy a címkén megjelenő nyilvános kijelentéseket."1050

A dolog szerződés-konformitásának a teljesítés időpontjában kell fennállnia [Irányelv, 3. cikk (1) bekezdés], és a fent felsorolt alkalmassági/megfelelőségi paraméterek mindegyikének teljesülnie kell, amennyiben azok az adott szerződésnél relevánsak (például az eladó leírást mellékelt az áruhoz). ${ }^{1051} \mathrm{Ha}$ valamelyik kívánalom nem teljesül, az áru jogilag hibás. Mindezen megfelelőségi körülményekért - a leírásért, a nyilvános kijelentésekért - való helytállás szabályozása azon a jogpolitikai megfontoláson alapul, hogy azok bizonyos, az áru minőségét illető elvárásokat generálnak a fogyasztóban. ${ }^{1052}$

Az eladó által adott leírásnak nem csak a szerződésben konkrétan szereplő, hanem a nyilvános kijelentésekben elhangzott vagy leírt tulajdonságoknak is meg kell felelniük. ${ }^{1053}$ Ide tartoznak különösen a reklámok; így ha egy átlagos fogyasztó a reklám alapján egy meghatározott tulajdonságot elvárhat, az is ebbe az esetkörbe tartozik. ${ }^{1054}$

\footnotetext{
1048 GRUNDMANN - BIANCA (2002), 68. p.

1049 ,... to optimize the performance of the product...”; , The warranty in this regard operates as a performance bond...", lásd: PRIEST (1981), 1309. p. Elérhetö:

http://digitalcommons.law.yale.edu/cgi/viewcontent.cgi?article=1570\&context=fss_papers (2012. december 10.).

${ }^{1050}$ Irányelv, 2. cikk (2) bekezdés.

${ }^{1051}$ VÉKÁS (2001a), 340. p.; GRUNDMANN - BIANCA (2002), 77. p.

${ }^{1052}$ MICKLITZ - STUYCK - TERRYN (2010), 333. p.

${ }^{1053}$ Mint egykor az eladói dictum et promissumnak a római jogban.

${ }^{1054}$ Lásd: GRUNDMANN - BIANCA (2002), 77-78. p.
} 
Amennyiben a harmadik feltétel, az azonos fajtájú áruk szokásos használatával való konformitás nem lenne elöírva, az a tranzakciós költségek jelentős növekedését eredményezné. ${ }^{1055}$

Hibának minősül a fentieken kívül a szakszerütlen összeszerelés is, bizonyos korlátokkal: az összeszerelésnek az adásvételi szerződés tárgyát kell képeznie, és azt az eladónak vagy segédjének kell elvégeznie, vagy amennyiben maga a fogyasztó végzi el a szerződés alapján, akkor a szakszerütlenségnek a hibás szerelési útmutatóból kell fakadnia [Irányelv, 2. cikk (5) bekezdés].

Ha a gyártó (vagy kéviselője) vagy az eladó bizonyos fajtájú árura, annak minőségére vagy teljesítményére vonatkozóan, nyilvánosan kijelentéseket tesz (például reklám kampány keretében), akkor ezek a kijelentések is relevánsak, azaz megalapozzák a fogyasztói panaszt és igényérvényesítést. Ezeknek a kijelentéseknek azonban konkrétnak kell lenniük, nem elég az áru puszta dicsérete, felmagasztalása. ${ }^{1056} \mathrm{Nem}$ felel azonban a gyártói nyilvános kijelentésekért az eladó, ha bizonyítja, hogy

„a kijelentésröl nem tudott és arról ésszerüen eljárva nem is kellett tudnia; a szerzödéskötés idöpontjáig a kijelentést helyesbitették; vagy a fogyasztási cikk megvételére vonatkozó elhatározást a kijelentés nem befolyásolhatta. "1057

A szerződéses viszonyon kívül álló fél, a gyártó cselekedeteiért való helytállás (még a fenti kivételekkel is) nagyon szigorú fogyasztóvédelmi rendelkezés, és az eladóra súlyos terhet ró, hiszen a kimentő körülmények bizonyítása adott esetben nagyon nehéz lehet. Az eladó visszkereseti igénye hivatott orvosolni ezt a problémát; ${ }^{1058}$ a közte és a kereskedelmi láncolat többi szereplője közötti jogviszonyok azonban nem hathatnak ki a fogyasztói szerződésre és az abból fakadó fogyasztói jogosultságokra.

\subsection{A szabályozás kógens jellege}

Az Irányelv klaudikálóan, azaz egyoldalúan kógens rendelkezéseket határoz meg a fogyasztóra nézve hátrányos kikötésekkel kapcsolatban:

\footnotetext{
1055 GRUNDMANN - BIANCA (2002), 78. p.

${ }^{1056}$ VÉKÁs (2001a), 341. p. Mint a római jogban, vö. I. rész 1. fejezet 3.4. pont.

${ }^{1057}$ Lásd: Irányelv, 2. cikk (4) bekezdés.

${ }^{1058}$ Vö. Irányelv, 4. cikk: „Ha az utolsó eladó a gyártó, a szerződésláncban öt megelöző korábbi eladó vagy más közvetitö cselekménye vagy mulasztása miatt felel a fogyasztóval szemben, jogosult visszkereseti igényt érvényesiteni a szerzödésláncban a felelös személlyel (személyekkel) szemben. A felelös személyt (személyeket), akivel (akikkel) szemben az utolsó eladó visszkereseti igényt érvényesithet, valamint a vonatkozó eljárást és annak feltételeit a nemzeti jogban kell meghatározni.".
} 
„Az eladóval a megfelelés hibájáról való értesitését megelözöen kötött olyan szerzödési kikötés vagy megállapodás, amely az ezen irányelvben biztositott jogokat közvetve vagy közvetlenül elvonja vagy korlátozza, a fogyasztót a nemzeti jogban szabályozottak szerint nem köti. "1059

A fogyasztóra nézve hátrányos kikötések tehát érvénytelenek az Irányelv értelmében, de megengedi a hátrányos kikötést az után, hogy az eladót a fogyasztó már értesítette a kellékhibáról. Ezen kívül úgy rendelkezik, hogy a nemzeti szabályozásnak törekedni kell arra, hogy ha egy szerződés szoros kapcsolatban áll valamelyik tagállammal, akkor ne lehessen a fogyasztók Irányelv biztosította jogait elvonni más állam jogának kikötésével [Irányelv, 7. cikk (2) bekezdés].

\subsection{A hiba vevö általi ismerete}

A caveat emptor elvét idézi, és az Európai Bíróság által meghatározott fogyasztói mintának $^{1060}$ felel meg az a rendelkezés, amely szerint „,nem minősül a megfelelés hibájának, ha a szerzödés megkötésének időpontjában a fogyasztó a hibáról tudott vagy arról ésszerüen eljárva tudnia kellett...”. ${ }^{1061} \mathrm{Az}$ implementálás és a tagállami jogalkalmazás során a körültekintően eljáró fogyasztóval szemben támasztott követelményt jelző, ,, arról ésszerüen tudnia kellett” fordulat vetett fel értelmezési kérdéseket. ${ }^{1062}$

Az Irányelv értelmében nincs szó hibás teljesítésről akkor sem, ha a hiba a fogyasztó által az árucikk elkészítéséhez szolgáltatott anyag hibájára vezethető vissza [Irányelv, 2. cikk (3) bekezdés]: ez a vállalkozási jellegü szerződések esetén releváns.

\subsection{A hibás teljesítésböl fakadó jogkövetkezmények}

Az Irányelv szerint az eladó minden hibáért felel, ami az átadáskor a fogyasztási cikkben megvolt [Irányelv, 3. cikk (1) bekezdés]. A norma azon jogorvoslatokra fókuszál, amelyek a szolgáltatás-ellenszolgáltatás egyenértéküségét érintik. ${ }^{1063} \mathrm{Az}$ Irányelv fogyasztói igényérvényesítés ún. lépcsős rendszerét alakítja ki, azaz a jogok igényérvényesítési sorrendjét, hierarchiáját határozza meg. A szerződésszerü teljesítés elvének előtérbe helyezésével az első lépcső, azaz a fogyasztó által elsődlegesen választható igények a

\footnotetext{
${ }^{1059}$ Irányelv, 7. cikk (1) bekezdés.

${ }^{1060}$ Lásd fent: az Európai Bíróság C-210/96. számú döntése.

${ }^{1061}$ Lásd: Irányelv, 2. cikk (3) bekezdés. A caveat emptor elvének tükröződése.

1062 Lásd többek között a később elemzett C-65/09. számú EuB ítéletet.

1063 GRUNDMANN - BIANCA (2002), 37. p.
} 
kijavítás és a kicserélés; a második lépcsőhöz pedig az elállás és az árleszállítás igényei tartoznak. $^{1064}$

\subsubsection{Elsö lépcső - kijavitás vagy kicserélés iránti igény}

A fogyasztó minden esetben elsődlegesen a hibás dolog kijavítását vagy kicserélését kérheti, amely igények a szerződésszerű teljesítés elvének előtérbe helyezését tükrözik. ${ }^{1065}$

„A fogyasztó az eladótól elöször a fogyasztási cikk téritésmentes kijavitását vagy kicserélését követelheti, kivéve, ha ez lehetetlen vagy aránytalan.

Az orvoslást aránytalannak kell tekinteni, ha az az eladónak más orvoslási módszerrel összehasonlitva ésszerütlen költséget okoz, figyelembe véve

- a fogyasztási cikk hibátlan állapotbani értékét,

- a hiba jelentöségét, és

- azt, hogy az alternatív orvoslási módszer a fogyasztónak okozott jelentös kényelmetlenség nélkül végrehajtható-e."1066

Elvben megilleti a vevőt a két igény közötti szabad választás joga, a gyakorlatban azonban e két igény érvényesítésének a lehetetlenség illetve az aránytalanság körülménye szab gátat. Az aránytalanság megállapításánál a fogyasztási cikk hibátlan állapotbani értékét, a hiba jelentőségét és azt kell mérlegelni, hogy az adott igény érvényesítése mekkora kényelmetlenséget okoz a fogyasztónak. Az arányosság a fenti orientációs pontok meghatározása ellenére is absztrakt kategória, amelynek implementálása és a jogalkalmazásban való megítélése is nehézségeket okoz. ${ }^{1067}$

A kicserélési és kijavítási igény érvényesítése, azok alternatívája Vékás Lajos szerint a felek közötti érdekegyensúly fenntartását célozza. A kicserélést és kijavítást szerinte úgy kellene alkalmazni, hogy a nagyobb értékű áruknál a kijavítást, a kisebb értéküeknél pedig inkább a kicserélést vállalja az eladó. ${ }^{1068}$

Kiemelendő az első lépcsős jogorvoslati igények teljesítésének térítésmentes jellege a fogyasztó oldalán. Ez azt jelenti, hogy a szerződésszerü állapot helyreállításának minden költsége - így különösen a postaköltség, az anyagdíj és a munkadíj - az eladót terheli [Irányelv, 3. cikk (4) bekezdés]. Az igények teljesítési módjához tartozik továbbá az a követelmény, hogy az ésszerű határidőn belül, a fogyasztót érő jelentős kényelmetlenség

\footnotetext{
${ }^{1064}$ Lásd: VÉKÁS (2001a), 342. p.

1065 Lásd: MICKLITZ - STUYCK - TERRYN (2010), 345. p.

${ }^{1066}$ Lásd: Irányelv, 3. cikk (3) bekezdés.

${ }^{1067}$ C-65/09. számú EuB ítélet, lásd: II. rész 2. fejezet 8. pont.

1068 VÉKÁs (2001a), 343. p.
} 
nélkül történjen meg. E két kitételnek azonban mindig az adott fogyasztási cikk természetéhez és használati céljához kell igazodnia [Irányelv, 3. cikk (3) bekezdés].

\subsubsection{Második lépcső - vételárcsökkentés vagy elállás iránti igény}

Az elsőről a második lépcsős jogok érvényesítésére az alábbi esetekben, az alábbi korlátok között térhet át a fogyasztó:

„A fogyasztó a vételár megfelelö csökkentését kérheti vagy elállhat a szerzödéstől, ha nem jogosult sem a fogyasztási cikk kijavitására, sem a kicserélésére, vagy az eladó a hibát ésszerü határidön belül nem orvosolta, vagy az eladó a hibát nem a fogyasztót érö jelentős kényelmetlenség nélkül orvosolta. "1069

A szabály tagállami implementációja során az a fordulat okozott értelmezési problémát, amely szerint a fogyasztó „,nem jogosult” az első lépcsős igények követelésére. ${ }^{1070}$ További korlátot jelent, hogy csekély mértékü hiba esetén elállásnak nincs helye [Irányelv, 3. cikk (6) bekezdés], az elállás ugyanis a legradikálisabb jogorvoslati forma. Az Irányelv nem szól az elállás jogi természetéröl, azaz a tagállamokra bízza annak dogmatikai meghatározását. Vékás szerint ezt vélhetően azért tartotta megfelelőnek az EU-s jogalkotó, mert a nemzeti - különösen a pandekta hagyományokat magukon viselö - magánjogokban egyébként is az egyik hagyományos szavatossági jog az elállás. Az angol nyelvű szöveg a „have the contract rescinded”, a német pedig a ,Vertragsauflösung” terminust alkalmazza, amelyek fordítása és dogmatikai jellemzői szövegkörnyezettől függően eltérőek lehetnek. ${ }^{1071}$ Nyitva hagyja a tagállami törvényhozás részére az Irányelv azt a kérdést is, hogy hogyan számítandó a vételár csökkentése.

A második lépcsős jogok alkalmazásának három vagylagos feltételét tartalmazza a fenti meghatározás. Az első azokra az esetekre értendő, amelyek fentebb, az első lépcsős jogoknál ismertetésre kerültek: amennyiben a lehetetlenség vagy aránytalanság esete merül fel. A második és harmadik feltétel pedig a kicserélés illetve a kijavítás nem megfelelö elvégzése. ${ }^{1072}$ Itt is irányadó az, hogy az ésszerü határidő és a kényelmetlenség nélküli jogorvoslás mindig az adott áru jellegéhez és a konkrét szerződéshez igazodik.

\footnotetext{
${ }^{1069}$ Lásd: Irányelv, 3. cikk (5) bekezdés.

${ }^{1070} \mathrm{E}$ fordulathoz is kapcsolódik a II. rész 2. fejezet 8. pontjában elemzett C-65/09. számú EuB ítélet.

${ }^{1071}$ Lásd: VÉKÁS (2001a), 344. p.

1072 Lásd fent: Irányelv, 3. cikk (3) bekezdés.
} 


\subsection{Igényérvényesítési határidök - bizonyítási teher}

A tagállami szabályozásban opcionálisan előírható a fogyasztói igényérvényesítés feltételeként, hogy a vevő köteles az árucikk hibásságát a felismeréstől számított két hónapon belül az eladóval közölni [Irányelv, 5. cikk (2) bekezdés]. Az eladói helytállási kötelezettség megfogalmazása szerint a dolog átadásakor meglévő hiba esetén állhat fenn a jogi értelemben vett hibás (nem szerződésszerü) teljesítés:

„Az eladó köteles a fogyasztónak az adásvételi szerzödésnek megfelelö fogyasztási cikket átadni.

Az eladó felel a fogyasztóval szemben a fogyasztási cikk átadásának idöpontjában meglévö minden hibáért.

Az eladó a 3. cikk szerint akkor felel, ha a megfelelés hibája a fogyasztási cikk átadásától számított két éven belül megnyilvánul. "1073

A hiba ismeretére vagy lehetséges ismeretére vonatkozó szabállyal függ össze ez a rendelkezés, mert ha a fogyasztó már az átadáskor ismeri vagy körültekintő eljárásának következtében észreveszi a hibát, akkor nyomban kifogásolhatja azt. ${ }^{1074}$ A hiba azonban gyakran csak később, a használat során ütközik ki, noha sokszor már az átadáskor fennáll valamilyen körülmény, amely annak eredője. Erre figyelemmel rendelkezik úgy az Irányelv, hogy csak az átadást követő két éven belül jelentkező hiba alapozza meg az eladói helytállást. ${ }^{1075}$ Mindennek bizonyítása azonban gyakran - különösen bizonyos fogyasztási cikkek esetén - igen nehéz, ezért az Irányelv felállít egy vélelmet:

„Az ellenkezö bizonyitásáig vélelmezni kell, hogy a fogyasztási cikk átadásától számitott hat hónapon belül megnyilvánult hiba már az átadás időpontjában létezett, kivéve, ha ez a vélelem nem egyeztethetö össze a fogyasztási cikk természetével vagy a hiba jellegével. "1076

A hiba létezésére vonatkozó megdönthető vélelem tehát az átadástól számított hat hónapon belül áll fenn, és gyakorlati előnye, hogy megfordítja a bizonyítási terhet, ezzel a fogyasztó helyzetét lényegesen megkönnyíti: ez alatt az időtartam alatt az eladónak kell bizonyítania, hogy a hiba nem volt még meg a dolog átadásakor. ${ }^{1077}$

Az Irányelv a szavatossági igény érvényesítési határidejéröl a következőképp rendelkezik:

„Ha a nemzeti jog a 3. cikk (2) bekezdése szerinti jogok érvényesitésére elévülési határidőt ír elö, az nem járhat le az átadástól számított két éven belül."1078

\footnotetext{
1073 Lásd: Irányelv, 2. cikk (1) bekezdés, 3. cikk (1) bekezdés, és 5. cikk (1) bekezdés 1. mondat.

1074 A kifogásolás azonnalisága természetesen relatív, mindig a körülményektől függ.

1075 Vö. Irányelv, Preambulum (17) bekezdés.

${ }^{1076}$ Lásd: Irányelv, 5. cikk (3) bekezdés.

1077 GRUNDMANN - BIANCA (2002), 68. p

${ }^{1078}$ Lásd: Irányelv, 5. cikk (1) bekezdés.
} 
A határidő a bizonyítási teher szempontjából tehát két lépcsős: az átadástól számított hat hónapban a kötelezettnek kell bizonyítania a hibamentességet, az után pedig az összesen két éven belül a fogyasztót terheli a kötelezettség, hogy a kellékhibát bizonyítsa.

A Preambulum utal rá, hogy az egyes tagállamok magánjogi szabályozása lehetővé teheti, hogy az elévülési határidők számításának kezdete ne az átadás, hanem valamely más cselekmény legyen. ${ }^{1079}$ Ezért határozza meg a minimum két éves elévülési időt, amely az átadástól számítandó. Jogvesztő határidőkről egyáltalán nem ejt szót a szabály, ami azt jelzi, hogy a tagállamok szabályozásukban azt is elöírhatnak.

\subsection{Jótállás}

Az Irányelv Preambuluma kiemeli, hogy az Unióban elterjedt gyakorlat az, hogy egyes árufajták adásvételekor az eladók és/vagy a gyártók garanciát nyújtanak a fogyasztási cikkekre olyan hibák tekintetében, amelyek egy bizonyos határidőn belül merülnek fel [(21) bekezdés]. Ez a gyakorlat ösztönözheti a versenyt és így jogszerü marketingeszköz. Ügyelni kell azonban arra, hogy ez ne vezesse félre a fogyasztókat [(21) bekezdés]. Ennek megfelelően az Irányelv a hatálya alá tartozó jótállás részletes definícióját adja:

„jótállás: az eladó vagy a gyártó kötelezettségvállalása a fogyasztóval szemben külön dij felszámitása nélkül, amely alapján a jótállási nyilatkozatban vagy a vonatkozó reklámban feltüntetett tulajdonságoknak nem megfelelö fogyasztási cikk vételárát visszatériti, vagy az ilyen fogyasztási cikket kijavitja, kicseréli vagy az igényt más módon kezeli.,"1080

A jótállás tehát az Irányelv szerint egy opcionálisan felvállalható helytállás, amelynek nem az adásvételi szerződés, hanem a jótállási nyilatkozat vagy az árura vonatkozó reklám a jogalapja. ${ }^{1081} \mathrm{~A}$ jótállás mindig a fogyasztóvédelmi normákon túlnyúló, azokat kiegészítő helytállást jelent. Azaz a jótállás semmiképpen sem vezethet a fogyasztó (kellékszavatossági) jogainak szükítéséhez, korlátozásához. Akár az eladó, akár a gyártó is tehet jótállási nyilatkozatot, amely az áru minőségéért vagy valamely speciális

\footnotetext{
${ }^{1079}$ Vö. Irányelv, Preambulum (17) bekezdés.

${ }^{1080}$ Irányelv, 1. cikk (2) bekezdés e) pont. A 2011/83/EU irányelv is hasonló definíciót határoz meg: „jótállás: a kereskedönek vagy valamely gyártónak (,, a jótállásra kötelezett”) a megfelelöség szavatolására vonatkozó jogszabályi kötelezettsége teljesitésén túlmenö bármely olyan kötelezettségvállalása a fogyasztóval szemben, amely alapján a jótállási nyilatkozatban vagy a vonatkozó, a szerzödéskötés idöpontjában vagy azt megelözöen elérhetö reklámban feltüntetett tulajdonságoknak vagy a megfelelöséghez nem kapcsolódó bármely egyéb követelménynek nem megfelelö áru vételárát visszatéríti, vagy az ilyen árut kicseréli vagy kijavitja, illetve az áruhoz kapcsolódó szolgáltatást nyújt." (2. cikk 14. pont).

${ }^{1081}$ Irányelv, 6. cikk (1) bekezdés.
} 
tulajdonságáért való helytállásra irányul. A jótállásból fakadó igény az Irányelv szerint a szavatossági igények mellett bármely más jogorvoslati mód is lehet. A ,vételár visszatérítése" kifejezés valószínűleg az elállásra utal, de ezt nem rögzíti explicite az Irányelv.

Mivel az Irányelv nem rendelkezik szubjektív vagy egyéb kimentési körülményekről, így az Irányelv felfogásában a jótállás is objektív, azaz felróhatóságtól független helytállás: a jótállási nyilatkozatban és reklámban tett kijelentések elhangzásának puszta ténye megalapozza a helytállási kötelezettségét a gyártó vagy az eladó vétkességétől függetlenül.

Meghatározza az Irányelv, hogy a jótállási nyilatkozatnak milyen formai követelményeknek kell megfelelnie. Ezek szerint (1) utalnia kell arra, hogy a fogyasztót a nemzeti jog szerint törvényen alapuló jogok illetik meg, és (2) nyilvánvalóvá kell tennie, hogy ezeket a jogokat a jótállás nem érinti, ezen kívül (3) világosan és közérthetően kell meghatároznia a jótállás tartalmát, és (4) „igénybevételének lényegi feltételeit”. Így különösen (a) a jótállás időtartamát, (b) területi hatályát, és (c) a jótállásra kötelezett nevét és címét. ${ }^{1082}$ Ezen elő́rások be nem tartása esetén sem csorbulhatnak azonban a vevő jótállási jogai [Irányelv, 6. cikk (5) bekezdés].

A jótállási igények érvényesítési határideje értelemszerűen a kötelezettségvállaló nyilatkozat tartalmától függ.

\section{Összefoglalás}

Az Európai Közösségben a szabad piac kiépítésének igényei hívták életre azon gazdasági és társadalmi folyamatokat, amelyek az 1970-es évek közepére a szupranacionális jogalkotó fogyasztóvédelmi jogpolitikai törekvéseihez és normaalkotásához vezettek. Az 1990-es évekre kibontakozott az EU fogyasztóvédelmi szerződési jogot érintő jogalkotása is, amelynek keretei között megszületett a fogyasztási cikkek adásvételének és a kapcsolódó jótállásnak egyes vonatkozásairól szóló 1999/44/EK irányelv. Az Irányelv megalkotásának elsődleges célja az volt, hogy a tagállami törvényi, rendeleti és közigazgatási rendelkezések közeledjenek egymáshoz a fogyasztóvédelem egységes minimális szintjének biztosítása érdekében. Ennek fényében többek között meghatározta a termék (bizonyos kivételekkel a kereskedelmi forgalomban árusított ingó dolog)

${ }^{1082}$ Lásd: Irányelv, 6. cikk (2) bekezdés. 
szerződésszerűségének kritériumait, a nem szerződésszerű teljesítésből fakadó fogyasztói igényekre vonatkozó klaudikálóan kógens rendelkezéseket, az igényérvényesítés határidejét és az önkéntesen felvállalható jótállásra vonatkozó rendelkezéseket.

A következőkben a jelen fejezetben felvázolt szabályok bizonyos tagállami implementációi kerülnek bemutatásra az annak kapcsán felmerülő jogértelmezési kérdések megvilágításával. Ezen kívül az Irányelv hatálya alá nem tartozó, hibás teljesítés miatti kártérítési igény szabályozási megoldásainak összehasonlító vizsgálata is célkitüzés, hiszen az jól szemlélteti, hogy a tagállamok - egyéni magánjogi hagyományaira is - támaszkodó jogalkotása ezen „tradicionális vevői (fogyasztói) igény” esetén milyen eltérően valósulhat meg.

Az Irányelv által meghatározott, a fogyasztóvédelem gazdasági, társadalmi, jogi koncepciójának megfelelő klaudikáló kógencia előírása jelenti a legnagyobb változást a korábbi tagállami magánjogi szabályozáshoz képest. Németország, Ausztria és Magyarország implementáló megoldásain kívül a vizsgálat tárgyát képezik a nem EU-s tagállam Svájc vonatkozó rendelkezései is. Svájc magánjogi jogalkotása indirekt harmonizációs törekvést mutat az EU fogyasztóvédelmi magánjogi normáihoz, ezért az összehasonlítás érdekes következtetésekre ad alapot. A fentieken kívül bemutatásra kerül az Európai Bíróság vonatkozó gyakorlatának egyik, a német szabályozáshoz kapcsolódó szemelvénye is. 


\section{AZ INGÓ ADÁSVÉTEL HIBÁS TELJESÍTÉSÉNEK SZABÁLYAI A HATÁLYOS NÉMET, OSZTRÁK ÉS SVÁJCI JOGBAN}

\section{Bevezetés: fogyasztóvédelem és az adásvétel hibás teljesítése}

\subsection{Németország}

A piacgazdaság nem kívánt hatásai, a gyors gazdasági növekedés és a kereskedelem egyre szélesedő platformjának kihívásai, valamint az Európai Unió jogalkotása tette szükségessé a német magánjog területén (is) az új fogyasztóvédelmi jogalkotást. ${ }^{1083}$ A fogyasztókat védő szabályok létrehozása különösen azokon a területeken vált égetővé, amelyeken a versenyjogi védelem már nem bizonyult elégségesnek. Így különösen a fogyasztók nem objektív eszközökkel történő befolyásolása elleni védekezés terén, valamint a kereskedők nem megfelelő tájékoztatási gyakorlatának javítása érdekében. ${ }^{1084}$ A szövetségi kormány 1971-ben fogadta el az első jelentést a fogyasztóvédelem fokozása érdekében szükséges rövid és hosszú távú feladatokról, amelynek nyomán több fogyasztóvédelmi tárgyú jogszabály született. ${ }^{1085}$

A minőségi hibás termékekkel kapcsolatos fogyasztóvédelem kérdése ugyancsak korán elötérbe került a törvényhozásban, többek között azért, mert bebizonyosodott, hogy az arra vonatkozó állami biztonsági előírások, a német ipari szabványok és a versenyjogi nyomás csak korlátozott védelmet nyújt. ${ }^{1086}$ A BGB hatálybalépése (1900. január 1.) óta nem hajtottak végre jelentős reformot a német kötelmi jogban, így az adásvételi jog hibás teljesítésre vonatkozó rendelkezéseiben sem. ${ }^{1087}$

Az új szabályozás iránti igény és a BGB átfogó reformfolyamatának kezdete az 1970-es évek végére datálható. ${ }^{1088} \mathrm{Az}$ akkori igazságügyi miniszter számos jogász professzort bízott meg szakvélemények elkészítésével, amelyek háromkötetes gyüjteménye 1981-ben került publikálásra, 1984-ben pedig kijelölték a jelentés és a reformtervezet megalkotására hivatott bizottságot. ${ }^{1089}$ 1992-re készültek el a munkával, ${ }^{1090}$ amely - bár az

\footnotetext{
1083 Bürgerliches Gesetzbuch (2010), XXIV. p.

${ }^{1084}$ Bürgerliches Gesetzbuch (2010), XXVI. p.

1085 Így többek között az 1976-os AGB-Gesetz az általános üzleti feltételekről. Lásd: FAZEKAS (1995b), 52-

53. p. hivatkozása Lontai Endre: Korreferátum a fogyasztói érdekvédelemről (Előadásanyag a Magyar Jogász Szövetség konferenciáján, 1987.) című művére (181.p.).

${ }^{1086}$ Bürgerliches Gesetzbuch (2010), XXVI. p.

${ }^{1087}$ SIVESAND (2005), 23. p.

1088 ZIMMERMANN (2006a), 73. p.

1089 ZIMMERMANN (2006a), 73. p.
} 
ENSZ Bécsi Vételi Egyezmény vonásait tükrözte -, nem váltott ki túl nagy szakmai érdeklődést. A reformfolyamat egy időre megrekedt. ${ }^{1091}$

Az 1999-es Irányelv elfogadása után az akkori igazságügyi minisztérium célja az volt, hogy annak implementálásával egybekötve megvalósítsa a kötelmi jog teljes, korábban megtorpant reformját. ${ }^{1092}$ 2000-ben kibocsátották az új hivatalos BGB reformtervezetet, ${ }^{1093}$ amelyet - a teljes reformfolyamat hosszához viszonyítva - rövid szakmai konzultáció és módosítások után 2001. november 26-án ki is hirdettek, és 2002. január 1-jén lépett hatályba. ${ }^{1094}$ A reform egyik fő célja - az Irányelv átültetése mellett - a német kötelmi jog „európai jog-konformmá” tétele volt. ${ }^{1095}$

Az európai fogyasztói szerződési jognak a magánjog rendszerébe illesztésére alapvetően három megoldási variáció kínálkozik: szabályozás elkülönített jogszabályokban, külön fogyasztói magánjogi kódex alkotása, ${ }^{1096}$ vagy a fogyasztói szerződési jognak a polgári törvénykönyvbe történő integrálása. ${ }^{1097}$ A német törvényhozó koncepciója az volt, hogy nem egy különálló, speciális fogyasztóvédelmi polgári jogi szabályrendszert kell létrehozni, hanem a szabályozási mintákat általánosítani kell, és valamilyen módon a polgári jogba kell azokat integrálni. ${ }^{1098}$ Ennek megfelelően a reform végül a fent említettek közül az első és a harmadik megoldási variáció egyfajta kombinációját valósította meg, ${ }^{1099}$ így az Irányelvet implementáló szabályok is kifejezetten a BGB-be kerültek. ${ }^{1100}$ E koncepció mellett szól többek között az az érv, hogy az általános szerződési jognak és a fogyasztói szerződések jogának ugyanaz a célja. ${ }^{1101}$ A szerződési szabadság eszméjével összefüggésben hangsúlyozzák a jogtudósok, hogy csak az olyan szerződés lehet jogszerü, amelyben mindkét szerződő fél szabad szerződéses akarata és

1090 Lásd: Bundesminister der Justiz (Hrsg.): Abschlußbericht der Kommission zur Überbereitung des Schuldrechts (Bundesanzeiger Verlag, Cologne, 1992.).

${ }^{1091}$ SIVESAND (2005), 23. p.

1092 Az ún. „,große Lösung”, lásd: DAUNER-LIEB (2003), 6. p.

1093 A tervezet áttekintéséhez lásd: ZIMMER (2001), 191-204. p. A tervezet célmeghatározása az első helyen említette az Irányelv implementálásának követelményét, lásd: Deutscher Bundestag Drucksache 14/6040. A továbbiakban a német rövidítésnek megfelelöen: BT-Drucks. 14/6040. Szövege elérhetö: http://dipbt.bundestag.de/dip21/btd/14/060/1406040.pdf (2013. január 29.).

${ }^{1094}$ ZIMMERMANN (2006a), 73-74. p. A kérdés részletes tárgyalásához lásd többek között: CANARIS (2002)

1095 A magyarban használatos kifejezés erre az „európaisodás” illetve „európaizálódás”, a német zsargonban pedig az „Europäisierung”; lásd: ROTH (2003), 25-26. p.; ZIMMERMANN (2006b), 35-38. p.

1096 Ilyen például az osztrák megoldás, lásd később.

1097 ZIMMERMANN (2006a), 83. p.

1098 Bürgerliches Gesetzbuch (2010), XXVIII. p.

1099 ZIMMERMANN (2006a), 83. p.

1100 Lásd többek között: a házaló kereskedelemröl: BGB $\S \S 312,312 \mathrm{a}$; a távollévők között kötött szerződésekről - beleértve az elektronikus kereskedelem keretei között kötött szerződéseket is: $\S \S 312 \mathrm{~b}$, 312f; a time-sharingről: $\S \S ~ 481-487$; a fogyasztói kölcsönről: $§ 491$; az utazási szerződésröl: $\S \S ~ 651-6511$; a pénzforgalmi szolgáltatásokról: $\S \S 675 c-676 c$; DAUNER-LIEB (2003), 6. p.

${ }^{1101}$ Lásd: ZIMMERMANN (2006a), 84-85. p. 
független elhatározása tükröződik. ${ }^{1102}$ A német jogalkotó és a jogtudomány szerint az egyik legfontosabb magánjogi fogyasztói jogosultság ennek fényében a tájékoztatási kötelezettség. ${ }^{1103}$

A magánjogba integrált fogyasztóvédelmi rendelkezések vonatkoznak egyrészt a BGB-ben szereplő egyes speciális szerződésekre, ${ }^{1104}$ valamint a fogyasztási cikkek adásvételére. ${ }^{1105} \mathrm{~A}$ fogyasztóvédelem mindegyik szerződési formát érintő általános rendelkezései pedig általában a kötelmi általános részben találhatóak. ${ }^{1106}$

\subsection{Ausztria}

Az osztrák törvényhozó európai viszonylatban igen korán, 1979-ben fogadta el a fogyasztóvédelmi törvényt, ${ }^{1107}$ amely nem a már létező, fogyasztókat védő osztrák jogszabályok összefoglalásaként készült, hanem egy, a fogyasztóvédelem interdiszciplináris jellegét tükröző magánjogi és igazgatási jellegü szabályokat egyaránt tartalmazó jogszabály lett. ${ }^{1108}$ Így nem csak korai hatályba lépésével tűnik ki ma is az uniós tagállamok fogyasztóvédelmi törvényeinek sorából, hanem azért is, mert jelentős magánjogi rendelkezéseket is tartalmaz. Az EU-s fogyasztóvédelmi normák implementálásánál a jogalkotó nem az egységes koncepció elvét követte, hanem részben az osztrák polgári törvénykönyvben, részben a fogyasztóvédelmi törvényben és külön jogszabályokban találhatók a speciális szabályok. ${ }^{1109}$ A fogyasztó és a vállalkozó egységes magánjogi fogalmát a fogyasztóvédelmi törvény adja meg.

Az Irányelv átültetése az osztrák kellékszavatossági szabályokat érintette gyökeresen. Már a módosítások előtti jó pár évben napirenden szerepelt a szavatossági szabályok megújítása. ${ }^{1110}$ Bár javaslat szólt a kizárólag a KSchG-be integrálás mellett,

\footnotetext{
1102 Lásd: ZIMMERMANN (2006a), 84-85. p.

1103 Vö. Einführungsgesetz zum Bürgerlichen Gesetzbuch, §§ 246-248.: „Informationspflichten bei besonderen Vertriebsformen”, „Informationspflichten bei Verbraucherdarlehensverträgen, entgeltlichen Finanzierungshilfen Darhlehensvermittlungsverträgen” und „Informationspflichten bei der Erbringung von Zahlungsdienstleistungen"; Verordnung über Informations- und Nachweispflichten nach bürgerlichem Recht (BGB-InfoV), elérhető: http://www.gesetze-im-internet.de/bgb-infov/BJNR034200002.html (2013. január 31.).

${ }^{1104}$ Lásd fent: $1100.1 \mathrm{j}$.

1105 BGB $\S$ 474-479: Verbrauchsgüterkauf.

${ }^{1106}$ Lásd többek között: az általános szerződési feltételekre (,,allgemeine Geschäftsbedingungen” (AGB), a továbbiakban a magyar rövidítésnek megfelelően: ÁSZF) vonatkozó előírások (BGB $\S \S 305-310$ ); ZERRES (2010), 108. p.

${ }^{1107}$ Konsumentenschutzgesetz, BGB1 1979/140. A továbbiakban: KSchG.

${ }^{1108}$ LURGER - AUGENHOFER (2005), 8. p.

${ }^{1109}$ LURGER - AUGENHOFER (2005), 11. p.

${ }^{1110}$ FERCH-FISCHER (2011), 11. p.
} 
végül a törvényhozó mégis úgy döntött, hogy a reform ne csak a fogyasztó és vállalkozás közötti jogügyleteket célozza, hanem a kellékszavatosság általános szabályait is. ${ }^{111}$ Ennek fényében az implementációt az ABGB-ben, ${ }^{1112}$ a KSchG-ben ${ }^{1113}$ és a Versicherungsvertragsgesetzben (a biztosítási szerződésről szóló törvényben) ${ }^{1114}$ hajtotta végre a módosító törvény. ${ }^{1115}$

A szavatosság a kötelmi jog és a szerződésszegési jog központi jogintézménye volt korábban is. ${ }^{1116}$ A reform célja az EU-s követelmények „kényszerü” átvétele mellett ezért az volt, hogy a joggyakorlat és a gazdasági praxis által szépen kimunkált tradicionális, és a forgalmi életben jól bevált szavatossági szabályok ne menjenek át gyökeres, illetve rendszeridegen változtatáson. ${ }^{1117}$ Ezért az általános szavatossági szabályok korábbi rendszerbeli helyét megtartva, a jogalkotó e rendelkezések hatályát is minden visszterhes szerződésre kiterjesztette. ${ }^{1118}$ A módosító szabályok 2002. január 1-jén léptek hatályba, és az azt követően kötött szerződések esetén alkalmazandóak.

\subsection{Svájc}

A svájci magánjog hibás teljesítésre vonatkozó hatályos szabályai több szempontból is érdekesek a dolgozat témájának komplex, jogösszehasonlító tárgyalása tekintetében. A svájci magánjog fejlődésére, így a svájci kötelmi jogi kódex (OR) hibás teljesítésre vonatkozó szabályainak kialakítására is kezdettől fogva nagy hatással voltak az egyes, római jogi gyökerekből „táplálkozó” európai magánjogi kodifikációk és hagyományok.

Svájc nem Európai Uniós tagállam, 1992-ben azonban aláírta az Európai Gazdasági Térségről szóló megállapodást, ${ }^{119}$ amelynek célja az Európai Unió és tagállamai, valamint

\footnotetext{
${ }^{1111}$ Gewährleistungsreform (2001), 1.p.

1112 Lásd: ABGB $§ 922$ (1)-(2), 924, 932 (1)-(4), 933 (1)-(3), 933a (1)-(3), 933b (1)-(2), 1167; KoLMASCH (2001), 15-19. p.

${ }^{1113}$ Lásd: KSchG $\S \S 8$ (1)-(3), 9 (1)-(2), 9a, 9b (1)-(4), 13a (1) 4. és 28a (1); KolmASCH (2001), 20-22. p.

1114 Lásd: Versicherungsvertragsgesetz $§ \S 178 \mathrm{~g}(1)$ és 191c (4).

1115 Bundesgesetz, mit dem das Gewährleistung im Allgemeinen Bürgerlichen Gesetzbuch und im Konsumentenschutzgesetz sowie das Versicherungsvertragsgesetz geändert werden, BGB1 2001/48, amelyet az osztrák parlament 2001. május 5-én fogadott el.

${ }^{1116}$ PIRKER-HÖRMANN - HAMMERL (2004), 14. p.

${ }^{1117}$ PIRKER-HÖRMANN - HAMMERL (2004), 14-15. p.; FERCH-FISCHER (2011), 12. p

1118 Néhány szerződés különös szabályai azonban érintetlenül maradtak, mint például a Bestandvertrag (haszonbérleti szerződés $\S 1096$ ), Zession (engedményezés $§ 1397)$, Pauschalreisevertrag (szervezett utazási sz. KSchG) § 31e), lásd: PIRKER-HÖRMANN - HAMMERL (2004), 15. p.

${ }^{1119}$ European Economic Area Agreement (EEA). A Tanács és a Bizottság határozata (1993. december 13.) az Európai Közösségek, azok tagállamai, valamint az Osztrák Köztársaság, a Finn Köztársaság, az Izlandi Köztársaság, a Liechtensteini Hercegség, a Norvég Királyság, a Svéd Királyság és a Svájci Államszövetség között az Európai Gazdasági Térségröl létrejött megállapodás megkötéséről. Elérhető: http://eurlex.europa.eu/LexUriServ/LexUriServ.do?uri=DD:11:19:31994D0001:HU:PDF (2014. március 4.).
} 
az Európai Szabadkereskedelmi Társulás országai ${ }^{1120}$ közötti kereskedelmi és gazdasági kapcsolatok megerősítése volt. Ennek is köszönhetően az 1990-es évek elejétől kezdve megfigyelhető, hogy az EU magánjogi jogközelítési illetve jogegységesítési törekvései ezen belül a fogyasztóvédelmi politika érvényesítése - közvetlenül vagy közvetve megjelennek a svájci polgári jogi jogalkotásban is. ${ }^{1121}$ Ennek egyik bizonyítéka, hogy 2001-ben a svájci jogalkotó javaslatot dolgozott ki az elektronikus kereskedelemről szóló szövetségi törvényről, amelynek keretei között sor került volna az uniós Irányelv ún. „autonóm átültetésére” is. ${ }^{1122}$ A módosítás a hibás teljesítés centrális jogkövetkezményének, a kellékszavatosságnak a fogalmát, a kellékszavatosság kizárásának illetve korlátozásának lehetőségét, a vevő igényérvényesítési előkötelezettségeit, a kellékszavatossági igények sorrendjét, a kicserélési igényt, a hibás teljesítés miatti kártérítést és az igényérvényesítési határidőt is érintette volna. ${ }^{1123} \mathrm{~A}$ javaslat nem lépett ugyan hatályba, de említésre méltó törekvései a svájci magánjog EUkonformmá tétele jegyében fogalmazódtak meg.

A Svájci Államszövetség fogyasztóvédelmi jogalkotásával kapcsolatban mindenekelőtt meg kell említeni a Szövetségi Alkotmány ${ }^{1124}$ 2000. január 1-től hatályos rendelkezését a fogyasztók védelmére vonatkozóan, amely deklaratív jellegü, és az állam objektív intézményvédelmi kötelezettségét hangsúlyozza ki:

„Der Bund trifft Massnahmen zum Schutz der Konsumentinnen und Konsumenten. Er erlässt Vorschriften über die Rechtsmittel, welche die Konsumentenorganisationen ergreifen können. Diesen Organisationen stehen im Bereich der Bundesgesetzgebung über den unlauteren Wettbewerb die gleichen Rechte zu wie den Berufs- und Wirtschaftsverbänden. "1125

A rendelkezés szerint az állam intézkedéseket foganatosít a fogyasztók védelme érdekében, és szabályozza azokat a jogorvoslati eszközöket, amelyekhez a fogyasztóvédelmi szervek folyamodhatnak. Ezen kívül felhatalmazza a kantonbeli törvényhozókat, hogy a Szövetségi Tanács által meghatározott értékhatárig terjedő

\footnotetext{
${ }^{1120}$ European Free Trade Association (EFTA). Ma az EFTA tagállamai Izland, Liechtenstein, Norvégia és Svájc, lásd: http://www.efta.int (2014. február 26.).

1121 PiCHONNAZ (2003), 288. p.

1122 ,Autonome Umsetzung ”, lásd: PICHONNAZ (2003), 289. p.

${ }^{1123}$ A javaslat szövege német nyelven elérhetö:

http://www.ejpd.admin.ch/content/dam/data/wirtschaft/gesetzgebung/konsumentenschutz_geschaeftsverkehr/ vn-ve-d.pdf (2014. február 12.).

${ }^{1124}$ Bundesverfassung der Schweizerischen Eidgenossenschaft (a továbbiakban: Svájci Alkotmány). Német nyelven elérhetö: http://www.admin.ch/opc/de/classified-compilation/19995395/201303030000/101.pdf (2014. február 3.).

1125 Svájci Alkotmány, 97. cikk (1)-(2).
} 
jogvitákban egyeztető-eljárás vagy egyszerü és gyors bírósági eljárás lefolytatását írják elö. ${ }^{1126}$

A svájci jogtudomány is interdiszciplináris jogterületként tekint a fogyasztóvédelemre, amelyhez kapcsolódó jogalkotás számos fogyasztói érdeket megjelenít. ${ }^{1127}$ A fogyasztói szerződések témaköre a fogyasztók gazdasági érdekeinek kategóriájába sorolható be. ${ }^{128}$ A svájci jogalkotó, a joggyakorlat és a jogtudomány képviselöinek tevékenysége következtében egy „különös magánjog” fejlődött ki a svájci polgári jogon belül, amit részben az $\mathrm{OR}$, részben pedig a magánjog területére tartozó külön jogszabályok tartalmaznak. ${ }^{1129}$ A fogyasztó és a fogyasztói szerződés egységes fogalmát azonban nem adja meg sem a polgári jogi, sem a kötelmi jogi kódex. ${ }^{1130}$ A tudományos tipológia a tipikus fogyasztói szerződések közé sorolja a fogyasztói adásvételt, ami azonban csak jogtudományi, elméleti kategória. ${ }^{1131}$

\section{A fogyasztó és a vállalkozó fogalma}

\subsection{Németország}

A fogyasztó és a fogyasztóvédelmi magánjogi értelemben vett vállalkozó fogalma ${ }^{1132}$ a kötelmi jogi reform nyomán a BGB általános részében található. Fogyasztónak minősül minden természetes személy, aki ipari és önálló szakmai tevékenységi körén kívül eső célból köt jogügyletet:

\footnotetext{
${ }^{1126}$ Svájci Alkotmány, 97. cikk (3): „Die Kantone sehen für Streitigkeiten bis zu einem bestimmten Streitwert ein Schlichtungsverfahren oder ein einfaches und rasches Gerichtsverfahren vor. Der Bundesrat legt die Streitwertgrenze fest.".

${ }^{1127}$ Különösen a fogyasztó biztonsághoz és egészséghez, tájékoztatáshoz füződő érdekét, a politikai, jogi (jogérvényesítési) és gazdasági érdekeit, lásd: BRUNNER (2007), 10. p.

${ }^{1128}$ BRUNNER (2007), 9. p.

${ }^{1129}$ BRUNNER (2007), 9. p.

1130 A Bundesgesetz über den Gerichtsstand in Zivilsachen (1998-ban elfogadott törvény a bíróságok illetékességéről polgári ügyekben) ad meghatározást a fogyasztói szerződésre, lásd: § 22 (2): „Als Konsumentenverträge gelten Verträge über Leistungen des üblichen Verbrauchs, die für die persönlichen oder familiären Bedürfnisse des Konsumenten oder der Konsumentin bestimmt sind und von der anderen Partei im Rahmen ihrer beruflichen oder gewerblichen Tätigkeit angeboten werden.".

Az egyik konkrét fogyasztói szerződésről, a fogyasztói hitelről szóló törvény, a 2003. január 1-jétől hatályos Bundesgesetz über Konsumkredit $\S 3$ meghatározza a fogyasztó fogalmát, lásd: „Als Konsumentin oder Konsument gilt jede natürliche Person, die einen Konsumkreditvertrag zu einem Zweck abschliesst, der nicht ihrer beruflichen oder gewerblichen Tätigkeit zugerechnet werden kann.”. Eszerint fogyasztónak minősül minden természetes személy, aki a foglalkozási vagy ipari tevékenységi körén kívül eső célból köt fogyasztói hitelszerződést.

${ }^{1131}$ BRUNNER (2007), 36. és 38. p.

${ }^{1132}$ A BGB az elnevezésben nem tett különbséget a fogyasztóval kereskedelmi célból szerződést kötő fél, valamint a vállalkozási szerződés alanya között, vö. BGB § 14 (1) és $§ 631$.
} 
„,Verbraucher ist jede natürliche Person, die ein Rechtsgeschäft zu einem Zwecke abschließt, der weder ihrer gewerblichen noch ihrer selbständigen beruflichen Tätigkeit zugerechnet werden kann." 1133

A német legfelsőbb bíróság, a Bundesgerichtshof egyik ítéletében úgy döntött, hogy kétség esetén természetes személyeknél mindig vélelmezendő a fogyasztói minőség. ${ }^{1134}$ Ezzel szemben egy korlátolt felelősségü társaság nevében eljáró személy által vásárolt ingó adásvétele esetén az ipari, szakmai tevékenységi kör érdekében történő ügyletkötés vélelme áll fenn. ${ }^{1135} \mathrm{~A}$ vitatható esetekben, azaz ahol a vásárolt dolog mind a személyes, mind az ipari illetve szakmai célt kielégítheti, mindig azt kell vizsgálni, hogy melyik van túlsúlyban. ${ }^{136} \mathrm{Az}$ ipari és önálló szakmai tevékenyégi körön kívüli jelleget a többségi jogtudományi álláspont szerint objektív körülmények határozzák meg, és azt az eladó vállalkozó szempontjából kell vizsgálni. ${ }^{1137}$

A fentiek szerint a fogyasztói minőség mindig szituáció- illetve szerződésfüggő. ${ }^{1138}$ A fogyasztóval szemben álló fél a vállalkozó, aki olyan természetes illetve jogi személy, vagy a jogalanyisággal felruházott személyegyesülés, aki ipari vagy önálló szakmai tevékenységének gyakorlása során köt jogügyletet:

„,Unternehmer ist eine natürliche oder juristische Person oder eine rechtsfähige Personengesellschaft, die bei Abschluss eines Rechtsgeschäfts in Ausübung ihrer gewerblichen oder selbständigen beruflichen Tätigkeit handelt."1139

A joggyakorlat nem korlátozza a fogalmat azzal az előfeltétellel, hogy a vállalkozónak mindenképp haszonszerzési célból kell ügyletet kötnie, ${ }^{1140}$ hanem egy ún. európai-autonóm vállalkozó-fogalmat alkalmaz és ismer el. ${ }^{1141} \mathrm{Az}$ ipari tevékenységgel összefüggésben a kereskedelmi törvény szerinti tradicionális megközelítésből kell kiindulni a jogtudomány álláspontja szerint, azaz a piacon ellenszolgáltatás fejében folytatott tevékenység jelent ipari tevékenységet. ${ }^{1142}$

\footnotetext{
${ }^{1133}$ Lásd: BGB $§ 13$.

${ }^{1134}$ Lásd: BGH NJW 2009, 3780. számú ítélet.

${ }^{1135}$ Lásd: BGH, 13.07.2011, VIII ZR 215/10.

${ }^{1136}$ Lásd: OLG Celle, ZGS 2004, 474. számú ítélet.

${ }^{1137}$ Lásd: LOOSCHELDERS (2011), 82. p.; ARLT (2010), 223. p.

${ }^{1138}$ Lásd: ZERRES (2010), 108. p.

${ }^{1139}$ Lásd: BGB $§ 14$ (1).

${ }^{1140}$ LOOSCHELDERS (2011), 83. p.

${ }^{1141}$ Lásd: BGH NWJ 2006, 2251: „, Beim Verbrauchsgüterkauf setzt das Vorliegen eines Gewerbes und damit die Unternehmerstellung des Verkäufers nicht voraus, dass dieser mit seiner Geschäftstätigkeit die Absicht verfolgt, Gewinn zu erzielen... Statt dessen gilt ein europäisch-autonomer Unternehmerbegriff.”.

${ }^{1142}$ Lásd: LOOSCHELDERS (2011), 83. p.
} 


\subsection{Ausztria}

Az osztrák KSchG első förészének a hatálya a fogyasztó és vállalkozás között kötött jogügyletekre terjed ki. A 2001-es fogyasztóvédelmi módosítások során az Irányelv átültetésével került a jogszabályba a fogyasztó és a vele szerződő fél, a vállalkozó fogalma:

„,Dieses Hauptstück gilt für Rechtsgeschäfte, an denen

1. einerseits jemand, für den das Geschäft zum Betrieb seines Unternehmens gehört, (im folgenden kurz Unternehmer genannt) und

2. andererseits jemand, für den dies nicht zutrifft (im folgenden kurz Verbraucher genannt) beteiligt sind." 1143

A meghatározások szerint vállalkozó mindenki, akinek a jogügylet a vállalkozása területére tartozik, és fogyasztó az, ,akire ez nem áll”, azaz aki nem a vállalkozásához tartozó célból köti a jogügyletet. E két szerződő fél jogügylete minősül fogyasztói jogügyletnek.

A törvény - az Irányelvhez és a BGB-hez képest - mindkét fogalmat meglehetősen absztraktan határozza meg, a fogyasztóról egyenesen a vállalkozó ellentettjeként rendelkezik. A vállalkozó fogalmát annyiban pontosítja, hogy megadja, hogy vállalkozásnak tekintendő minden állandó, önálló gazdasági tevékenységre létrehozott szervezet akkor is, ha a müködése nem nyereségszerzésre irányul. ${ }^{1144}$ Ez a meghatározás megegyezik az Unternehmensgesetzbuch, azaz a kereskedelmi törvény vállalkozófogalmával. ${ }^{1145}$ A jogtudomány a fentiek fényében a következő kívánalmakat állítja fel a fogyasztóvédelmi értelemben vett vállalkozóval kapcsolatban: gazdasági tevékenységének állandónak kell lennie, szervezett és önálló (független) tevékenységet kell folytatnia, amely gazdasági értékkel bíró szolgáltatásokat foglal magában. ${ }^{1146}$ A jogügyletnek, amelyet a fogyasztónak minősülő személlyel köt, tárgyi összefüggésben kell lennie a vállalkozásával. ${ }^{1147} \mathrm{~A}$ KSchG egy megdönthetetlen vélelmet is felállít, amikor elrendeli, hogy a közjogi jogi személyek minden esetben vállalkozónak minősülnek a KSchG

\footnotetext{
${ }^{1143}$ Lásd: KSchG $\S 1$ (1) 1. és 2. mondat.

${ }^{1144}$ KSchG $\S 1$ (2): ,, ... jede auf Dauer angelegte Organisation selbständiger wirtschaftlicher Tätigkeit, mag sie auch nicht auf Gewinn gerichtet sein.".

1145 A korábbi kereskedelmi törvényt, a Handelsgesetzbuchot (HGB) a Handelsrechts-Änderungsgesetz (BGBl I 2005/120) 2005-ben módosította, amelynek rendelkezései 2007. január 1-jétől hatályosak, és a törvényt azóta nevezik Unternehmensgesetzbuchnak (a továbbiakban: UGB). A vállalkozó-fogalmat lásd: UGB § 1 (1)-(2): ,Unternehmer ist, wer ein Unternehmen betreibt. Ein Unterhenmen ist jede auf Dauer angelegte Organisation selbständiger wirtschaftlicher Tätigkeit, mag sie auch nicht auf Gewinn gerichtet sein.". Megjegyzendő, hogy a korábbi HGB vállalkozó-fogalmával még nem harmonizált a KSchG meghatározása, lásd: LURGER - AUGENHOFER (2005), 22. p.

1146 KOZIOL (2010), 1916. p.

${ }^{1147}$ KozIOL (2010), 1917. p.
} 
alkalmazásában. ${ }^{1148}$ Egy leendő természetes személy vállalkozó azonban a vállalkozás alapítását megelőző illetve előkészítő ügyletek tekintetében még fogyasztónak minősül, és csak akkor lesz a KSchG értelmében vett vállalkozó, ha már ténylegesen megkezdte a müködését. ${ }^{1149}$

Az osztrák jogtudomány álláspontja szerint fogyasztó - a nem túl kifejező és absztrakt fogalmi meghatározásnak köszönhetően - nem csak természetes személy lehet, hanem olyan jogi személy is, aki nem űz vállalkozói tevékenységet. ${ }^{1150}$ A joggyakorlat ilyennek tekinti például a csekély számú taggal rendelkező „eszmei (célú) egyesületet” (Idealverein), ${ }^{1151}$ de a társasházi közös tulajdonban a tulajdonostársak közösségét (Wohnungseigentümergemeinschaft) is. ${ }^{1152}$ A személyegyesülések megítélése fogyasztóvédelmi szempontból attól függ, hogy azokat valamely vállalkozás működéséhez hozzá lehet-e rendelni vagy sem. ${ }^{1153}$ Összefoglalóan az mondható, hogy fogyasztó mindenki, akire vonatkozóan a vállalkozófogalom egyik kritériuma sem állja meg a helyét: azaz nem rendelkezik vállalkozással, és a tevékenységének sincs gazdasági illetve vállalkozással összefüggő vonatkozása. ${ }^{1154}$ A KSchG $§ 1$ (4) alapján nem minősül fogyasztói ügyletnek a munkáltató munkavállalóval kötött ügylete.

A korábbi joggyakorlat alapján még annak kellett bizonyítania, hogy ő fogyasztónak, szerződési partnere pedig vállalkozónak minősül, aki fogyasztói jogügyletre hivatkozott a jogvitában. ${ }^{155} \mathrm{Az}$ újabb gyakorlat azonban könnyítéseket vezet be a fogyasztó oldalán, így például aki nem vállalkozóként lép fel a bíróság előtt, annak vélelmezik a fogyasztói státuszát, ugyanúgy, mint Németországban. ${ }^{1156}$

A fent említettek szerint a svájci jogban nem található egységes magánjogi fogyasztó- illetve vállalkozó-fogalom.

\footnotetext{
${ }^{1148}$ Lásd: KSchG $§ 1$ (2) 2. mondat.

${ }^{1149}$ LURGER - AUGENHOFER (2005), 23. p. A joggyakorlat alapján a következő személyek például minden esetben vállalkozónak minősülnek: az ügyvéd (SZ 54/74. számú döntés); az adó- vagy pénzügyi tanácsadó (OLG Wien KRES 1a/23. és EvBl 1989/116. számú döntések); a gazdasági vagyonkezelő (2 Ob 191/07p ecolex 2008, 1014.); a szabadúszó múvész, az orvos (OLG Wien KRES 1a/22. számú döntés). További döntéseket a vállalkozónak nem minősíthető jogalanyokról lásd: KOZIOL (2010), 1917-1918. p.

${ }^{1150}$ Lásd: KozIOL (2010), 1916. p.; DENKINGER (2007), 183. p.

${ }^{1151}$ Lásd: JAB 1223 BlgNR 14. GP 2. számú döntés; DENKINGER (2007), 183. p.

1152 Lásd: 7 Ob 155/03z JB1 2004, 183. számú döntés; KozIOL (2010), 1916. p.

${ }^{1153}$ KozIOL (2010), 1916. p.

${ }^{1154}$ DENKINGER (2007), 183. p.

1155 Lásd: 3 Ob 547/93 wobl 1994, 230. és SZ 63/134. számú döntések; KoZIOL (2010), 1918. p.

${ }^{1156}$ KozIOL (2010), 1918. p. Ugyanúgy, mint a német jogban.
} 


\section{Az adásvétel és a hibás teljesítés rendszere}

\subsection{Németország}

$\mathrm{Az}$ adásvételi jog Németországban két nagy normatömegre tagolódik. A kereskedők közötti adásvételekre a kereskedelmi törvény, a Handelsgesetzbuch szabályai alkalmazandóak. ${ }^{1157}$ A BGB kötelmi különös része tartalmazza az adásvételi szerződés szabályait, amelyek a kereskedelminek minősülő szerződéseken kívül minden más adásvételre alkalmazandóak. ${ }^{1158} \mathrm{Az}$ Irányelvből fakadó speciális fogyasztóvédelmi rendelkezések az adásvétel különös fajtája, a fogyasztási cikkek adásvételére vonatkozó szabályok között, ${ }^{1159}$ és a kötelmi általános részben szerepelnek. ${ }^{160}$

A korábbi szabályozás értelmezési és jogalkalmazási problémákat felvető különbségtételei egyszerüsödtek. ${ }^{1161}$ A reform karakterisztikája leginkább abban ragadható meg, hogy az Irányelv szabályozását igyekezett nem csak a fogyasztói, hanem az összes adásvételi szerződésre kiterjeszteni, valamint a rejtett hibák jogkövetkezményeit az általános szerződésszegési rendszerbe integrálni. ${ }^{1162} \mathrm{Az}$ Irányelv implementálásának legfontosabb vívmánya, hogy egységesítette a kellék- és jogszavatosság jogkövetkezményeit. Az eladó fökötelezettségei közé került a kellékhiba-mentes teljesítés, egységes lett a kellékhiány fogalma, nincs többé különbségtétel a jogkövetkezményeknél a fajlagos és a specifikus adásvétel között, 2 év lett az általános szavatossági elévülési határidő, és a klasszikus szavatossági jogok mellett kártérítést is követelhet a vevő a kötelmi általános szabályok alapján. ${ }^{1163} \mathrm{Az}$ általánosan elfogadott tudományos álláspont szerint minden fogyasztói adásvételre vonatkozó szabályt „,irányelv-konform módon” kell értelmezni, és ahol nem alkotott a német törvényhozó speciális szabályokat, ott az adásvételi szerződésre vonatkozó minden általános rendelkezés is ily módon értelmezendő. ${ }^{1164}$

\footnotetext{
${ }^{1157}$ Lásd: Handelsgesetzbuch (HGB), § 373-tól: , Handelskauf”.

1158 ZERRES (2010), 164. p.

${ }^{1159}$ Lásd: BGB $\S \S 474-479$.

${ }^{1160}$ A kötelmi jogi reform a különös részben egyébként az adásvételre vonatkozó szabályozásban hozott a legnagyobb változást, lásd: MEDICUS (2003), 65. p.

1161 ZIMMERMANN (2006a), 78-79. p.; ROTH (2003), 29. p.

1162 ZIMMERMANN (2006a), 78-79. p.; ROTH (2003), 29. p.

${ }^{1163}$ Lásd: CSIZMAZIA (2002), 431. p.; DAUNER-LIEB (2003), 16-18. p. A kötelmi jogi reform egységesítette a szerződésszegés fogalmát, a szerződésszegés új rendszere jogorvoslat-orientált lett, és az elállás nincs többé felróhatósághoz kötve, illetve összevonható a kártérítési igény érvényesítésével; lásd: ZIMMERMANN (2006a), 74-75. p.

1164 Lásd: CANARIS (2002), 47. és 49-50. p. Az utóbbi az ún. „túlterjeszkedő” implementáció (,überschießende Umsetzung”), lásd: GRUNEWALD (2006), 10. p. A kérdéskörhöz lásd még: ROTH (2003), 29-36. p.
} 
Az adásvétel Németországban is az egyik leggyakoribb jogügylet, ${ }^{1165}$ amelynek egyik gyakori formája a fogyasztási cikkek adásvétele. A BGB szerint ez a fogyasztó és a vállalkozó közötti ingó dologra kötött adásvételi szerződést jelenti:

„Kauft ein Verbraucher von einem Unternehmer eine bewegliche Sache (Verbrauchsgüterkauf)[...] Dies gilt nicht für gebrauchte Sachen, die in einer öffentlichen Versteigerung verkauft werden, an der der Verbraucher persönlich teilnehmen kann." 1166

Az Irányelvnél szélesebb körben határozza meg a fogyasztási cikkek kategóriáját a német kódex, mert nem zárja ki a fogalomból a nem korlátozott térfogatú illetve mennyiségü gázt és vizet, valamint a villamos energiát sem. Kizárja azonban a jogalkotó a fogalomból a használt ingó árukat, amelyeket olyan nyilvános árverésen értékesítenek, amelyen a fogyasztó személyesen részt tud venni. Nem esnek ez alá az internetes aukciók, hiszen azok esetén hiányzik a személyes részvétel követelménye. ${ }^{1167}$

A , Sache”, azaz a dolog a BGB értelmében csak testi dolog lehet (§ 90). ${ }^{1168}$ Bár az állatok nem minősülnek jogi értelemben vett dolgoknak, azokra megfelelően alkalmazni kell a dolgokra vonatkozó szabályokat (§ 90a). Egy nyilvános árverésen értékesített lóval kapcsolatos jogesetben a bíróság kimondta, hogy egy állat nem tekinthető jogi értelemben használtnak rögtön a születése után. ${ }^{1169}$ A jogesetben nyilvános árverésen értékesített fél éves lovat korábban még sem lovaglásra, sem fedeztetésre nem használták. Az állatok használt voltát mindig egyedileg, minden lényeges szubjektív körülmény figyelembe vételével kell megállapítani a bíróság döntése szerint. Megállapodhatnak azonban a felek abban, hogy valamely körülmény bekövetkezte után automatikusan használtnak számít az állat. ${ }^{1170}$ Egy másik ügyben nem minősítette a bíróság fogyatási cikknek, azaz használt dolognak azt a lovat sem, amelyet a nyilvános értékesítésen történt adásvételt megelőzően lovaglás céljára már használtak. ${ }^{1171}$

Kiegészítendő a fogyasztási cikkek adásvételének fenti fogalma annyiban, hogy a német szabályozás a bejegyzett hajók adásvételére az ingatlan adásvételére vonatkozó rendelkezéseket rendeli alkalmazni (BGB § 452), így azok is kívül esnek a fogyasztói adásvétel szabályainak alkalmazási körén.

\footnotetext{
1165 Lásd: ZERRES (2010), 163. p.

1166 Lásd: BGB $§ 474(1)$.

${ }^{1167}$ Lásd: LOOSCHELDERS (2011), 83. p. A különbség alapja nyilván a megvizsgálás lehetősége illetve annak hiánya.

${ }^{1168}$ Ez római jogi örökség, vö. KASER - KNÜTEL (2014), 112. p.

${ }^{1169}$ Lásd: OLG Braunschweig 20.02.2006, 3U 42/05. számú ítélet.

${ }_{1170}$ Lásd: MICKLITZ - STUYCK - TERRYN (2010), 315. p.

${ }^{1171}$ Lásd: OLG Oldenburg 9 O 2979/05, 2006. számú ítélet.
} 


\subsection{Ausztria}

Az ABGB kötelmi általános része négy szerződésszegési esetkört tartalmaz: a szolgáltatás lehetetlenülése (endgültige Nichterfüllung), a késedelem (vorläufige Nichterfüllung), a materiálisan hibás teljesítés (erfolgte Schlechterfüllung) és az egyéb különös, „pozitív” szerződésszegések (különösen a kötelemből fakadó mellékkötelezettségek megszegése). ${ }^{1172}$

Az osztrák magánjog az adásvételi jog területén a 2001-es módosítások elött is az ún. duális megoldást követte, aminek lényege az „egyszerü” és a kereskedelmi vétel elkülönítése, ugyanúgy, mint a német jogban. Az osztrák jogalkotó az Irányelv implementálásával - a német megoldással ellentétesen - az ún. „,Trennungstheorie”-t valósította meg a gyakorlatban: ${ }^{1173}$ a szerződő felek jogalanyiságához igazodva a fogyasztói adásvételre vonatkozó speciális szabályokat a KSchG tartalmazza, ${ }^{1174}$ az ún. „,Warenkauf” (kereskedelmi vétel) szabályai pedig az UGB-ben szerepelnek. ${ }^{1175} \mathrm{Az}$ e kategóriákba nem eső „egyszerü” adásvételi szerződésekre az ABGB általános kellékszavatossági szabályai irányadóak. E szabályok minden visszterhes szerződésre kiterjedő hatálya miatt a jogalkotó nem az Irányelvben használatos megnevezéseket, hanem az átvevő (Übernehmer), és az átadó illetve gyártó (Übergeber/Hersteller) elnevezéseket használja. ${ }^{1176}$

Az ABGB kötelmi jogának különös részében a jogtudomány hat szerződési kategóriát határol el; ${ }^{177}$ az adásvételi szerződés, mint valamely dolog elidegenítésére irányuló konszenzuális szerződés a „Veräußerungsvertäge” csoportba tartozik. Az adásvételre vonatkozó ABGB-beli elöírások számos ponton utalást tartalmaznak a kötelmi általános szabályokra. ${ }^{1178}$ Ennek megfelelően a szerződés hibás teljesítésére a kellékszavatosság ABGB-beli általános, és KSchG-beli különös szabályai alkalmazandóak a fogyasztói adásvétel esetén. A KSchG hatálya egyébként a kellékszavatossági szabályok

\footnotetext{
1172 KREJCI (2007), 110. és 110-126. p.

1173 Vagy „Trennungskonzept”, lásd: KOZIOL (2010), 946. p. A német kodifikátorok is ezt a megoldást választották.

${ }^{1174}$ Lásd: KSchG $\S 8-9 b$.

1175 KREJCI (2007), 141. p. Lásd: UGB $\S \S 373-381$.

${ }^{1176}$ Lásd: ABGB $\S 922(1)$.

1177 Ezek: a Veräußerungsverträge (elidegenítési szerződések), Gebrauchsüberlassungsv. (használati sz.), Dienstleistungsv. (szolgáltatási sz.), Gesellschaftsv. (társasági sz.), Sicherungsv. (biztosítási sz.), és Glückv. (szerencsesz.), lásd: KREJCI (2007), 139. p.

${ }^{1178}$ Lásd többek között: ABGB $§ \S 1061,1064,1066$.
} 
vonatkozásában is minden olyan jogügyletre kiterjed, amely fogyasztó és vállalkozás között jön létre: nem korlátozta a törvény az Irányelv tárgyi hatályára, a fogyasztási cikkek adásvételére az implementációt. ${ }^{1179}$

A tömegtermelés korában egyre több standardizált szerződést alkalmaznak a vállalkozók a gyakorlatban. Napjainkban az ÁSZF-fel és az azt magában foglaló blankettaszerződésekkel történő ügyletkötés különösen a vállalkozások és fogyasztók között jellemzö. Ezek megítélésénél ezért fokozott szerepet kap a tisztességtelen (általános) szerződési kikötések elleni jogi védelem. Bár a modernkori gazdaságban az ügyletforgalom racionalizálását és modernizálását segíti elő az ÁSZF alkalmazása, „kockázatáthárító funkciója” miatt veszélyt jelent az átlagfogyasztóra nézve, így kiemelt jelentősége van annak, hogy az ÁSZF milyen tartalommal bír. ${ }^{180}$ Az osztrák magánjogban az 1993/13/EGK rendelet implementálása során született fogyasztóvédelmi törvényi rendelkezések a KSchG-ben kaptak helyet. A törvény két listát tartalmaz a tisztességtelen szerződési kikötésekröl. ${ }^{1181}$ A hibás teljesítéssel összefüggésben tiltott minden olyan kikötés, amely kizárja a vállalkozó kártérítési kötelezettségét szándékos illetve súlyosan gondatlan magatartása esetére; amely a fogyasztó hátrányára megfordítja a bizonyítási terhet; kizárja a fogyasztó igényérvényesítését; vagy általában zavaros és érthetetlen. ${ }^{1182}$

\subsection{Svájc}

A svájci magánjogban az „eredmény-orientált szerződésszegési rendszer” érvényesül. ${ }^{1183}$ Ennek megfelelően a szerződésszegés következő esetei különböztethetök meg: nemteljesítés (Nichterfüllung vagy Falschlieferung, OR § 97-től), késedelmes teljesítés (Spätleistung, OR § 102-től), valamint a „nem megfelelő teljesítés” (Schlechterfüllung vagy nicht gehörige Erfüllung). ${ }^{1184}$ Az utóbbi, minőségileg hibás teljesítés szabályai az OR-ben „szétszórva” találhatóak meg. A kellékszavatosságra, mint a hibás teljesítés esetén

${ }^{1179}$ FERCH-FISCHER (2011), 12. p. Ide tartozik tehát az ingatlan, a software, stb. fogyasztó és vállalkozó közötti adásvétele, az általuk megkötött vállalkozási szerződés stb. is, lásd: FABER (2001), 33. p. Vö. Irányelv 1. cikk (2) bekezdés b) pont (fogyasztási cikk fogalma) és BGB § 474 (1) [a fogyasztói adásvétel fogalma].

${ }^{1180}$ KRAMER (2009), 13. p. A problémafelvetéshez lásd többek között: BRUNNER (2007), 22-24. p.

${ }^{1181}$ Az elsőben található kikötések az ABGB $§ 879$ értelmében minden esetben semmisnek minősülnek, a másikban pedig olyan szerződési feltételek találhatóak, amelyek akkor semmisek, ha a vállalkozó nem tudja bizonyítani, hogy azokat egyedileg tárgyalta meg a fogyasztóval, lásd: KSchG § 6 (1)-(2) [ún. szürke és fekete lista].

${ }^{1182}$ Lásd: KSchG $§ 6$ (1) 9., 11., 14. pontok és (3).

1183 „,Ursachenorientierten System”, lásd: GINTER (2005), 12. p.

${ }^{1184}$ Lásd: GINTER (2005), 12. p. 
fennálló tradicionális jogintézményre vonatkozó rendelkezések - a pandekta jogi hagyományoknak megfelelően - a kötelmi jog különös részében, az adásvétel jogában kaptak helyet. $^{1185}$

A svájci magánjog az adásvétel szabályozását illetően az egységes koncepció elvét vallotta a ZGB és az OR előkészítésétől kezdve. Ez egyrészről azt jelenti, hogy a törvényhozók - az osztrák és német megoldással ellentétben - nem alkottak külön kereskedelmi törvényt a kereskedők egymás között kötött ügyleteire, másrészről az adásvétel szabályain belül a kellékszavatosságra vonatkozó szabályok is egységesek. ${ }^{1186} \mathrm{~A}$ szabályozási hiányosságot kritizáló számos tanulmány hatására sem alkotott még a jogalkotó külön szabályokat ${ }^{1187}$ annak ellenére, hogy a „fogyasztói adásvétel” az egyik leggyakoribb ügylet a fogyasztói szerződések között. ${ }^{1188}$ Ennek a szabályozásbeli hiányosságnak köszönhetően a fogyasztók és a kereskedők között kötött adásvételi szerződésekre ugyanazok a szabályok vonatkoznak minden tekintetben, mint a bármely más jogalanyok közötti adásvételre. ${ }^{189}$ Így az adásvételi szerződés a fogyasztói szerződések szemszögéből a vegyes (ambivalent) szerződések közé tartozik. ${ }^{1190}$

Az adásvételi szerződés megkötésére vonatkozóan a svájci jogban az OR általános részében szereplő szabályok irányadóak. Az általános diszpozitív szabály szerint a szerződés tartalma a törvényi korlátokon belül tetszés szerint megállapítható [OR $§ 19$ (1)]. ${ }^{1191}$

A standardizált szerződésekkel történő ügyletkötéssel összefüggésben az ÁSZF dogmatikai fogalma nem található meg a svájci jogszabályokban; a jogtudomány a BGB meghatározását tekinti irányadónak. ${ }^{1192}$ A svájci tisztességtelen versenyről szóló

\footnotetext{
${ }^{1185}$ Akárcsak a német kódexben. Az OR adásvétel szabályai a $\S$ 184-236-ban találhatók. Az OR kifejezett utaló szabályainak értelmében az adásvételnél kifejtett kellékszavatossági szabályok egyébként megfelelően alkalmazandóak a csere (§ 237), a vállalkozási szerződés (§ 365) és a társasági betét szolgáltatása [§531 (3)] esetében.

A különös részben való szabályozás vitatott, mert a dolgok átadásával (elidegenítésével, használatának átengedésével, előállításával) járó visszterhes szerződések tekintetében a kellékszavatosság áthatja az egész kötelmi jogot, lásd: GIGER (1979), 304. p., illetve a kérdés problematikájához már a XX. század első felében lásd: LAUTNER (1937), 9-11. p.

1186 PiCHONNAZ (2003), 289. p.

${ }^{1187}$ Az igényérvényesítési határidőkre vonatkozó új, 2013. január 1-jétől hatályos rendelkezések kivételével, lásd később.

${ }^{1188}$ BRUNNER (2007), 36. p.

${ }^{1189}$ Lásd: BRUNNER (2007), 35. p.

${ }^{1190}$ Lásd: BRUNNER (2007), 35. p.

1191 A szerződési szabadság korlátai három nagy kategóriába sorolhatóak: a jóerkölcsbe ütközés, a jogellenesség, valamint a teljesítés eredendő lehetetlensége, lásd: KRAMER (2009), 95. p.

1192 Lásd: KRAMER (2009), 12. p. Vö. BGB § 305 (1).
} 
törvény ${ }^{193}$ azonban tartalmazza a tisztességtelen általános szerződési feltételek tartalmi korlátaival kapcsolatos legfontosabb szabályt. Ez a nem rég módosított rendelkezés 2012. július 1-jén lépett hatályba:

„,Unlauter handelt insbesondere, wer allgemeine Geschäftsbedingungen verwendet, die in Treu und Glauben verletzender Weise zum Nachteil der Konsumentinnen und Konsumenten ein erhebliches und ungerechtfertigtes Missverhältnis zwischen den vertraglichen Rechten und den vertraglichen Pflichten vorsehen."

Az új meghatározás szerint tisztességtelenül kereskedik különösen az, aki olyan általános szerződési feltételeket alkalmaz, amelyek a jóhiszemüséget és tisztességet (Treu und Glauben) sértő módon a fogyasztók hátrányára a szerződéses jogok és kötelezettségek között jelentős és indokolatlan aránytalanságot tartalmaznak. A megelőző szabályozás még bármilyen szerződési partnerrel szembeni védelmet jelentett, és két vagylagos esetet emelt ki. ${ }^{1195}$ Az új szabályozás az ÁSZF tartalmára vonatkozóan a fogyasztókat és azok jogait emeli ki. A rendelkezés megteremtette az összhangot az EU-s szabályozással, és kiküszöbölte a polgárokkal szembeni hátrányos megkülönböztetést. ${ }^{1196}$ Az UWG természetesen versenyjogi törvény, ${ }^{1197}$ így rendelkezéseit elsősorban nem a konkrét esetben sérelmet szenvedő fogyasztó védelmeként, hanem a tisztességtelen ÁSZF-et alkalmazó piaci fél magatartásának tilalmaként kell felfogni. ${ }^{1198}$ Mivel azonban egyértelmüen a felek szerződéses jogainak és kötelezettségének aránytalanságáról szól, megjelenik a védelem polgári jogi vetülete is a fogyasztók oldalán. Ennek azért van nagy jelentősége, mert a fent említettek alapján a svájci adásvételi jog nem tesz különbséget a „fogyasztói adásvételnek” minősülő szerződések esetén. ${ }^{1199}$

1193 Das Bundesgesetz gegen den unlauteren Wettbewerb (a továbbiakban: UWG), elérhető: http://www.admin.ch/opc/de/classified-compilation/19860391/201301010000/241.pdf (2014. február 3.).

${ }^{1194}$ Lásd: UWG $\S 8$.

1195 Akkor volt tisztességtelen egy ÁSZF, ha a szerződésre alkalmazandó törvényes rendtől jelentősen eltért, vagy ha a jogok és kötelezettségek megosztását a szerződés természetétől jelentősen eltérő módon határozta meg, lásd: BÜHLER - STÄUBER (2012), 87. p.

1196 Lásd: STÖCKLI (2011), 184. és 186. p. Lásd ezen kívül: Botschaft zur Änderung des Bundesgesetzes gegen den unlauteren Wettbewerb (UWG) [09.069, 2009], elérhető: http://www.admin.ch/opc/de/federalgazette/2009/6151.pdf (2014. február 9.), 6186. p.

1197 Elsősorban a Svájci Alkotmány 96. cikk (b) pontjának rendelkezésén alapuló állami kötelezettség materializálódása a törvényhozásban.

1198 BÜHLER - STÄUBER (2012), 88-89. p.

1199 Lásd: PICHONNAZ (2003), 289. p. Eltérő szabályok vonatkoznak viszont az ingó (OR §§ 187-215) és az ingatlan (OR $\S \S 216-221)$ adásvételére, valamint az OR nevesíti az adásvétel különös fajtáit (OR $\S \S 222$ 236). AZ ÁSZF tisztességtelen mivoltának különösen a kellékszavatossági szabályok diszpozitív jellege miatt van jelentösége. 


\section{A fogyasztói adásvétel hibás teljesítése}

\subsection{Kellékszavatosság és hibafogalom a német jogban}

A BGB-ben a hibás teljesítés jogkövetkezményének, a kellékszavatosságnak a szabályai a történeti gyökereknek köszönhetően már az eredeti szöveg szerint az adásvételre vonatkozó rendelkezések között kaptak helyet, és ez nem változott a 2002-es reform után sem. ${ }^{1200}$ Bár még a kötelmi jogi reformot közvetlenül megelőzően is jelentős volt a vita a jogtudományban a hibás teljesítés meghatározását illetően, a többségi álláspont és a gyakorlat a szubjektív hibafogalomból indult ki: ${ }^{1201}$ a kellékhiba akkor áll fenn, ha eltérés mutatkozik a dolog ténylegesen meglévő tulajdonságai és az adásvételi szerződésben kikötött tulajdonságok, a tényleges minőség (Ist-Beschaffenheit) és az „elvárt” minőség (Soll-Beschaffenheit) között. ${ }^{1202}$

Az új kellékszavatossági szabályok kiindulópontja és egyben egyik legjelentősebb újítása az adásvétel definíciójában jelenik meg. Az eladó elsődleges kötelezettsége közé emelték, ${ }^{1203}$ hogy jog- és kellékhibáktól mentes dolgot szolgáltasson:

„Durch den Kaufvertrag wird der Verkäufer einer Sache verpflichtet, dem Käufer die Sache zu übergeben und das Eigentum an der Sache zu verschaffen. Der Verkäufer hat dem Käufer die Sache frei von Sach- und Rechtsmängeln zu verschaffen.",1204

A hibás áru szolgáltatása tehát szerződésszegésnek minősül, és a szerződésszegés általános szabályainak hatálya alá tartozik. ${ }^{1205} \mathrm{Az}$ olyan áru, amely a veszély átszállásakor nem rendelkezik - elsősorban - a szerződésben kikötött tulajdonságokkal, kellékhibásnak minősül. ${ }^{1206}$ Az adásvételi jog szavatossági rendelkezései - amelyek számos utaló normát tartalmaznak a kötelmi általános részre -, a reform után is speciális szabályozást alkotnak a szerződésszegés általános szabályaihoz képest. ${ }^{1207}$

\footnotetext{
${ }^{1200}$ Lásd: BGB eredeti, 1900-as szövege, Rosenthal (1927), 147. p. A hibás teljesítés német szabályait részletesen tárgyalja doktori értekezésében Csécsy Andrea, lásd: CSÉCSY (2008), 173-182. p.

${ }^{1201}$ KÄMPF M. (2007), 60-61. p.

${ }^{1202}$ Lásd: LoOSCHELDERS (2011), 10. p. A korábbi joggyakorlathoz lásd: RG, 08.06.1920, Rep. II. 549/19. számú döntés.

${ }^{1203}$ Hauptleistungspflicht, lásd: FeZER (2009), 26. p.

${ }^{1204}$ Lásd: BGB $§ 433$ (1).

${ }^{1205}$ BGB § 320. Lásd: KÄMPF M. (2007), 131. p.; DAUNER-LIEB (2003), 16. p.; ZERRES (2010), 167. p.

${ }^{1206}$ Lásd: BGB $\S 434$ (1) 1. mondat: „Die Sache ist frei von Sachmängeln, wenn sie bei Gefahrübergang die vereinbarte Beschaffenheit hat. “. Jelenleg is a szubjektív hibafogalom érvényesül tehát a szabályozásban; lásd többek között: a használt autó adásvételéről szóló BGH NJW 2006, 434. számú bírósági döntést. EMMERICH (2012), 21. p.

1207 Lásd: FEZER (2009), 27. p.
} 
A reform után a kellékhiba (Sachmangel) definíciója nem magára a hibára, hanem a kellékhiányra, azaz a hibátlan árura fókuszál. Ha a felek a dolog minőségét külön nem kötötték ki a szerződésben, akkor a kellékhiba-mentességre a BGB részletes előírása irányadó:

„....Soweit die Beschaffenheit nicht vereinbart ist, ist die Sache frei von Sachmängeln,

1. wenn sie sich für die nach dem Vertrag vorausgesetzte Verwendung eignet, sonst

2. wenn sie sich für die gewöhnliche Verwendung eignet und eine Beschaffenheit aufweist, die bei Sachen der gleichen Art üblich ist und die der Käufer nach der Art der Sache erwarten kann.

$\mathrm{Zu}$ der Beschaffenheit nach Satz $2 \mathrm{Nr}$. 2 gehören auch Eigenschaften, die der Käufer nach den öffentlichen Äußerungen des Verkäufers, des Herstellers (\$ 4 Abs. 1 und 2 des Produkthaftungsgesetzes) oder seines Gehilfen insbesondere in der Werbung oder bei der Kennzeichnung über bestimmte Eigenschaften der Sache erwarten kann, es sei denn, dass der Verkäufer die Äußerung nicht kannte und auch nicht kennen musste, dass sie im Zeitpunkt des Vertragsschlusses in gleichwertiger Weise berichtigt war oder dass sie die Kaufentscheidung nicht beeinflussen konnte. "1208

A kimerítő meghatározás szerint az áru kellékhibáktól mentes, ha alkalmas a szerződés alapján előirányzott rendeltetésre vagy a szokásos használatra, és rendelkezik a hasonló áruknál szokásos, és a vevő által az áru fajtája, jellege alapján elvárható tulajdonságokkal. Ide tartoznak azon tulajdonságok is, amelyeket a vevő az eladó, a gyártó ${ }^{1209}$ vagy annak segédje által tett nyilvános kijelentések, különösen az árura vonatkozó reklám vagy ismertető jelzés által meghatározott tulajdonságok alapján elvárhat. E szabály alól akkor mentheti ki magát az eladó, ha a kijelentést nem ismerte és nem is kellett ismernie, vagy ha azt a szerződéskötés időpontjában megfelelően helyesbítették, vagy ha az a vételi döntést nem befolyásolhatta. ${ }^{1210}$

A kellékhiba akkor is fennáll, ha a megegyezés szerinti összeszerelést az eladó vagy teljesítési segédje szakszerütlenül hajtotta végre, illetve az összeszerelést igénylő

\footnotetext{
1208 Lásd: BGB § 434 (1)-(2). Az elsődleges tehát - a szubjektív fogalomból következően - a felek megállapodása, a szerződés maga, lásd: LoOSCHELDERS (2011), 11. p. A specifikus megállapodás hiánya a dolog minőségére nézve akkor merülhet fel leggyakrabban, ha az árut az eladó nem reklámozza, részletes leírást sem ad róla, és a szerződést szóban kötik meg.

1209 A gyártó fogalmára nézve a termékfelelősségről szóló törvény, a Produkthaftungsgesetz § 4 (1)-(2) bekezdései irányadóak a BGB utaló szabálya alapján. A fogalom teljes konformitásban van az Irányelv meghatározásával, sőt, azon túl is terjeszkedik, vö.: Irányelv, 1. cikk (2) bekezdés d. pont.

${ }^{1210}$ A kérdéskörhöz lásd: ARLT (2010), 82-86. p.
} 
árunál akkor is, ha a szerelési útmutató hibás, kivéve, ha a dolgot hibátlanul összeszerelték. ${ }^{1211}$

Egy bírósági döntés értelmében hatálytalan az a leírás, amely arra irányul, hogy csökkentse vagy kizárja a szerződésszerüség követelményét, és összeegyeztethetetlen az adásvétellel kapcsolatos minden releváns körülménnyel. ${ }^{1212} \mathrm{Az}$ ügyben egy használt személygépjármű adásvétele esetén az eladó „,Bastlerfahrzeug”-ként (barkácsolt jármű) ${ }^{1213}$ írta le a szerződésben az autót. Azonban a szerződésből és a vevő szándékából kitünt, hogy a gépjármüforgalomban való közlekedés céljából akarta megvenni az autót, és ezért kötötték meg az adásvételi szerződést. Az alperes kereskedő a perben elismerte, hogy azért nevezte az autót „Bastlerfahrzeug”-nak, mert úgy gondolta, hogy az autó általános müszaki állapota miatt nem tud helytállást vállalni annak esetleges kellékhibáiért. A bíróság azonban fogyasztói adásvételként értékelte a jogügyletet, és a tényállásból arra következtetett, hogy a vevő az eladótól, mint autókereskedőtől, nem pedig hulladékfémkereskedőtől vette meg a gépjármüvet. Az autóra vonatkozó leírás a bíróság szerint az eladó részéről a $\mathrm{BGB}$ fogyasztói adásvételre vonatkozó kógens szabályainak megkerülésére irányult. ${ }^{1214}$

A BGB részletes meghatározásából következik, hogy a kellékszavatossági helytállás nem csak a materiális hibák, hanem az eladó által megígért, de hiányzó tulajdonságok tekintetében is fennáll. ${ }^{1215}$ A rendelkezés tulajdonképpen a szerződésszerüség vélelmének tekintendő, és szinte szó szerint megfelel az Irányelvnek, bár csak másodsorban, a felek eltérő rendelkezése hiányában alkalmazandó. ${ }^{1216} \mathrm{~A}$ jogalkotó nyitva hagyta azt a kérdést, hogy csupán az olyan tulajdonságok tartoznak-e a szerződésszerüség fogalmába, amelyek fizikailag közvetlenül „hozzátapadnak” az áruhoz (,,Qualitätsmängel”, minőségi hibák), mint például az étel romlása, ${ }^{1217}$ vagy olyan állapotbeli hibák is, amelyek az adásvétel tárgyának a környezetéhez kapcsolódó tárgyi, gazdasági vagy jogi körülményeiből fakadnak, és amelyek a dolog használhatósága és értéke szempontjából meghatározóak (,, Umstandsmängel”), mint például egy használtautó

\footnotetext{
${ }^{1211}$ Lásd: BGB $\S 434$ (2): ,Ein Sachmangel ist auch dann gegeben, wenn die vereinbarte Montage durch den Verkäufer oder dessen Erfüllungsgehilfen unsachgemäß durchgeführt worden ist. Ein Sachmangel liegt bei einer zur Montage bestimmten Sache ferner vor, wenn die Montageanleitung mangelhaft ist, es sei denn, die Sache ist fehlerfrei montiert worden. “. Vö. Irányelv, 2. cikk (5) bekezdés.

${ }^{1212}$ Lásd: OLG Oldenburg 22.09.2003, 9 W 30/03. számú döntés.

${ }^{1213}$ Bastlerfahrzeug = barkácsolt, összebarkácsolt, ezerszer javított, átépített jármü.

${ }^{1214}$ Vö. BGB $§ 475$ (2), lásd: jelen fejezet 5.1. pont. MiCKLITZ - STUYCK - TERRYN (2010), 332. p.

${ }^{1215}$ Lásd: KÄMPF M. (2007), 131. p. (dictum et promissum).

${ }^{1216}$ Vö. Irányelv, 2. cikk. SCHULTE-NÖLKE - TwIGG-FLESNER - EbERS (2008), 421. p.; ZIMMERMANN (2005), 28. p.

${ }^{1217}$ Lásd: ZERRES (2010), 173. p.
} 
kora és balesetmentessége. ${ }^{1218}$ A többségi tudományos álláspont szerint természetesen mindkét kategória releváns a hibafogalom szempontjából. ${ }^{1219}$

\subsection{Kellékszavatosság és hibafogalom az osztrák jogban}

Az osztrák kódex a kellékszavatosságról, mint a visszterhes szerződés kötelezettjének a szolgáltatás materiális hibáiért és nem szerződésszerü állapotáért fennálló törvényen alapuló helytállásáról rendelkezik. ${ }^{1220}$ Ennek megfelelően a szerződésszerüség Irányelvbeli fogalmát is a szavatosságról szóló rendelkezések közé építette be a jogalkotó. ${ }^{1221}$ A rendelkezések egyaránt vonatkoznak a visszterhes szerződésekben szereplő egyedi és fajlagos szolgáltatásokra, valamint ingó és ingatlan dolgok teljesítésére is. ${ }^{1222}$

„,Wer einem anderen eine Sache gegen Entgelt überlässt, leistet Gewähr, dass sie dem Vertrag entspricht. Er haftet also dafür, dass die Sache die bedungenen oder gewöhnlich vorausgesetzten Eigenschaften hat, dass sie seiner Beschreibung, einer Probe oder einem Muster entspricht und dass sie der Natur des Geschäftes oder der getroffenen Verabredung gemäß verwendet werden kann. "1223

Eszerint aki másnak ellenszolgáltatás fejében átenged egy dolgot, szavatol azért, hogy a dolog megfelel a szerződésben foglaltaknak. Azért felel tehát, hogy (1) a dolog a kialkudott vagy szokásosan elvárható tulajdonságokkal rendelkezik, és hogy (2) a leírásának, és (3) a próbának vagy mintának megfelel, és hogy (4) az ügylet természetének vagy a kötött megállapodásnak megfelelően használható.

Az ABGB § 922 (2) bekezdése tartalmazza az Irányelvnek teljes mértékben megfelelő új szabályt, amely kimondja, hogy a szerződésszerüség megítélésénél azt is figyelembe kell venni, hogy mit várhatott el az átvevő az átadónak vagy a gyártónak a dologra vonatkozó nyilvános kijelentése, mindenekelőtt a dologra vonatkozó reklám és a dologhoz csatolt adatok (pl. termékleírás, használati- és kezelési útmutató, stb.) alapján. ${ }^{1224}$ Ezek a nyilvános kijelentések hallgatólagos megállapodásnak minősülnek a felek közötti

\footnotetext{
1218 Lásd: ZERRES (2010), 173. p. hivatkozása: Kropholler, Jan: Studienkommentar BGB (C. H. Beck, München, 2008.) címü müvére (§ 434 BGB Rn. 3.).

1219 Lásd: LoOsCHELDERS (2011), 11. p. 17. lj. hivatkozása többek között Brox, Hans - Walker, Wolf Dietrich: Besonderes Schuldrecht (C. H. Beck, München, 2007.) címü müvére.

${ }^{1220}$ KOZIOL (2010), 947. p.; PIRKER-HÖRMANN - HAMMERL (2004), 18. p.

${ }^{1221}$ Nem a teljesítés általános szabályai tartalmazzák, lásd: SÄÄF (2005), 52. p.

1222 Lásd: OGH 27.4.1976 EvBl 1976/238. számú döntés; PIRKER-HÖRMANN - HAMMERL (2004), 17. p.

1223 ABGB $§ 922(1)$.

${ }^{1224}$ E szabályok alkalmazásában gyártónak értendő az is, aki a dolgot az EU-s gazdasági térségbe bevezeti, illetve aki a dolgon a nevének (márkajelzésének vagy más jelölésének) feltüntetésével magát gyártónak nevezi $[\mathrm{ABGB} \S 922(2)]$.
} 
szerződésben, ${ }^{1225}$ de csak akkor, ha konkrét, a dolog minőségét is érintő tulajdonságokra vonatkoznak, ${ }^{1226}$ és a szerződéskötést befolyásolják. Az ilyen kijelentések közül is csak arra lehet kellékszavatossági igényt alapítani, amelyet a kötelezett ismert vagy ismerhetett, illetve ha azokat a szerződéskötés időpontjáig nem helyesbítették [§ 922 (2)]. Az utóbbi körülményekkel kapcsolatban az átadót terheli a bizonyítási teher esetleges jogvita esetén. $^{1227} \mathrm{Az}$ Irányelv elvárásai maradéktalanul megjelennek e rendelkezésekben. ${ }^{1228}$ Egyes jogtudományi álláspontok szerint a független médiumokban vagy fogyasztóvédelmi szervezet által kibocsátott tesztanyagokban szereplő adatok például nem alapozzák meg az átadó szavatossági helytállását. ${ }^{122}$ Mások azonban úgy vélik, hogy igen, mert az ilyen anyagok gyakoriságuk miatt a kereskedelmi forgalomban általánosan elfogadottnak tekinthetők. ${ }^{1230}$

A szerződésszerüség ilyen részletes törvényi meghatározása sem változtat azon a jogtudományi állásponton, hogy a kellékhiba elsősorban a konkrét szerződő felek jogviszonyában és az adott szerződéses kikötések fényében ítélhető meg, azaz a szubjektív hibafogalom érvényesül itt is, mint a német jogban. ${ }^{1231}$ Az átadó (eladó) szavatol nem csak a külön kikötött, hanem a szokásosan feltehető tulajdonságokért is, amely utóbbi a jóhiszeműség és tisztesség elvéből is levezethető. ${ }^{1232}$ A szokásosan feltehető tulajdonságok megítélése okozza a gyakorlatban a nagyobb problémát, hiszen amíg mindenkinek egyértelmü, hogy az eladott autónak például müködőképes üzemi fékkel kell rendelkeznie, addig az korántsem olyan evidens, hogy egy téli csizma vízálló, holott rendeltetéséből fakadóan (őszi-téli használat) elvárható lenne. ${ }^{1233}$

Meghagyta a jogalkotó a szavatosság eseteiről szóló, az ABGB 1812-es hatályba lépése óta létező szabályt, amely a kellékszavatosságról és a jogszavatosságról összevontan rendelkezik. Ez alapján az eladó szavatol a dolog olyan tulajdonságaiért, amelyeket a felek kifejezetten vagy az ügylet természetéből eredően hallgatólagosan kikötöttek, de amelyekkel az mégsem rendelkezik (§ 923). Szavatol akkor is, ha az eladó valamilyen

\footnotetext{
1225 SÄÄF (2005), 53. p.

${ }^{1226}$ SÄÄF (2005), 53. p.; PIRKER-HÖRMANN - HAMMERL (2004), 19. p.

1227 SÄ̈̈F (2005), 53. p.

${ }^{1228}$ Vö. Irányelv 2. cikk (2) bekezdés d) pont és (4) bekezdés. A korábbi szabályok értelmében is szavatolt azonban az eladó az ilyen nyilvánosan tett kijelentésekért, ha azok, mint „szokásosan feltehető tulajdonságok" mégsem voltak meg a dologban, lásd: PIRKER-HÖRMANN - HAMMERL (2004), 19. p. A rendelkezés a BGB szabályával teljesen egybevág.

${ }^{1229}$ Lásd: PIRKER-HÖRMANN - HAMMERL (2004), 20. p.

${ }^{1230}$ Lásd: PIRKER-HÖRMANN - HAMMERL (2004), 20. p.

${ }^{1231}$ Lásd: KLETECKA (2001), 20. p.; PERNER - SPITZER (2007), 166. p. Vö. EMMERICH (2012), 21. p. és a német OLG Oldenburg 22.09.2003, 9 W 30/03. számú döntés (lásd fent: 4.1. pont).

1232 PERNER - SPITZER (2007), 166. p.

${ }^{1233}$ Hasonló példák: PERNER - SPITZER (2007), 166. p.
} 
rendkívüli hibát hallgat el, vagy csalárdul azt állítja, hogy a dolog meghatározott használatra alkalmas, vagy, hogy az a szokásos hibáktól mentes. Az utolsó tagmondat e szigorúbb esetekben a hibásság vélelmére enged következtetni: „amennyiben az ellenkezője kiderül, mindezért felel" az átadó. Azaz elég az eladói kijelentésben megígért tulajdonság hiányának a bizonyítása az eladó helytállási kötelezettségének kiváltásához. ${ }^{1234}$ Még korunkban is jelentőséget tulajdonít tehát az eladó felróható magatartásának az osztrák jogalkotó. ${ }^{1235}$

A fogyasztói szerződésekre vonatkozóan a fogyasztóvédelmi törvény - a BGB-vel egyezően - elrendeli, hogy amennyiben a szerződés alapján az összeszerelés is a vállalkozó kötelezettsége, akkor a szakszerütlen összeszerelés következtében bekövetkező hiba, valamint ha a fogyasztó szereli össze a dolgot, akkor a nem megfelelő szerelési útmutató miatti szakszerütlen összeszerelés következtében beálló hiba is megalapozza a kellékszavatossági igényeket, azaz jogilag hibás teljesítésnek minősül (KSchG § 9a). ${ }^{1236}$

\subsection{Kellékszavatosság és hibafogalom a svájci jogban}

Az OR az adásvétel szabályai között nem tér ki erre külön, azonban a kommentárok utalnak rá, és az általános szabályokból is következik, hogy csakis a szerződésben kikötötteknek minőségben és mennyiségben is megfelelő teljesítés elégíti ki a jogszabály által támasztott követelményeket. ${ }^{1237}$ A törvényi definíció szerint:

„,Der Verkäufer haftet dem Käufer sowohl für die zugesicherten Eigenschaften als auch dafür, dass die Sache nicht körperliche oder rechtliche Mängel habe, die ihren Wert oder ihre Tauglichkeit zu dem vorausgesetzten Gebrauche aufheben oder erheblich mindern. "1238

Ezek szerint az eladó felel mind a megígért tulajdonságokért, mind azért, hogy a dolognak nincs olyan fizikai vagy ,jogi” hibája, amely az értékét vagy a feltételezett használatra való alkalmasságát kizárja vagy jelentősen csökkenti. ${ }^{1239}$

Mivel a törvény a joghibákért való helytállást is szavatosság névvel illeti, érdemes szót ejteni a jog- és kellékszavatosság közötti különbségtételről a svájci jogban. A

\footnotetext{
${ }^{1234}$ Ugyanúgy, mint a dicta et promissa esetén a római jogban, lásd: I. rész 1. fejezet 3.4. pont.

${ }^{1235} \mathrm{Az}$ elhallgatott szokatlan hiba, illetve negatív tulajdonság a jogtudomány álláspontja szerint minden észrevehetetlen, felismerhetetlen hibát magába foglal, lásd: KOZIOL (2010), 952. p.

${ }^{1236}$ Az Irányelv szó szerinti átültetése, vö.: Irányelv, 2. cikk (5) bekezdés, illetve BGB § 434 (2).

${ }^{1237}$ Lásd többek között: GIGER (1979), 22. p.

1238 OR $§ 197$ (1).

1239 A fogalmi meghatározás nagyon hasonló a BGB eredeti szabályához, lásd: I. rész 2. fejezet 2.2. pont.
} 
nehézséget itt a jogtudomány szerint az jelenti, hogy - amint az a fenti törvényi és a tankönyvi meghatározásból is kitünik - a kellékszavatosság körébe tartozó hiba jogi jellegü is lehet (például ha egy gép, berendezés, autó, stb. nem felel meg a jogszabályok biztonsági elöírásainak). ${ }^{1240} \mathrm{Az}$ elhatárolásnál azt kell szem előtt tartani, hogy a kellékszavatosság a dolog tényleges és (a szerződés alapján) elvárt minősége közötti, a vevőre nézve kedvezőtlen eltérés, ${ }^{1241}$ legyen szó akár fizikai, akár jogi jellegű hibáról.

A kommentárok és tankönyvek ennek megfelelően az „objektív - szubjektív hiba” fogalompárral operálnak, és hangsúlyozzák, hogy a kellékszavatosság körébe nem csak az objektíve hibás dolog, ${ }^{1242}$ hanem egy objektíve ép, de szubjektíve hibás, azaz a konkrét szerződés kívánalmait ki nem elégítő dolog is éppúgy beletartozik. ${ }^{1243}$ A szubjektív hibának azért van nagy jelentősége, mert nagy befolyással van a vételárra. ${ }^{1244}$ A szubjektív hibafogalom érvényesül tehát a svájci jogban is, a német és az osztrák megközelítéssel egyezően.

A kötelmi jogi tankönyvek meghatározásai szerint „a kellékszavatosság garanciát biztosít a vevőnek a minőségi hiányosságokból, vagy a fizikai, jogi vagy gazdasági jellegü hibákból eredő, a vétel tárgyában beálló károsodással és értékcsökkenéssel szemben”. ${ }^{1245}$ A gazdasági jellegü hibák (mint például az eladott motorral megtett kilométerek száma) implicite a kellékhibák közé tartozását a bírói gyakorlat is megerősíti. ${ }^{1246}$

A római jogi hagyományokkal egyezően az eladói ígéret is „beleolvad” a hibafogalomba, így a szerződéstől való eltérés kétféleképp valósulhat meg: a szolgáltatott áru nem felel meg az eladói ígéretnek, illetve nem elégíti ki a szerződéses elvárásokat. A törvényszöveg nem tartalmazza a „kifejezett” jelzőt az eladói ígéretre vonatkozóan, aminek az esetlegesen az árura vonatkozó reklámban tett, és egyéb, dicsérő jellegü kijelentések, valamint az „önálló garanciától” való elhatárolás szempontjából van jelentősége. A tankönyvek kiemelik, hogy nem elvárás a kifejezett „garanciavállalás”,

${ }^{1240}$ HONSELL (2010), 76. p.; konkrét jogesetben az elektromos készülék nem tett eleget a genfi ipari üzemeltetésre vonatkozó szabályoknak, lásd: BGE 95 II 123. számú ítélet. A német terminológia szerint a jogszavatosság: ,, Gewährleistung für Rechtsmängel”, míg a jogi (jellegü) hibák: ,,rechtliche Mängel”.

${ }^{1241}$ "Ist-Beschaffenheit” - ,Soll-Beschaffenheit”, HONSELL (2010), 80. p.; KelLER - SIEHR (1995), 76. p., MÜLLER-CHEN - HUGUENIN - GIRSBERGER (2012), 161. p.

${ }_{1242}$ Például egy software-hibás, és emiatt nem müködő telefon.

${ }^{1243}$ Lásd: HONSELL (2010), 80. p.

${ }^{1244}$ Ha például a megvásárolt telefon teljesen múködőképes, de nem tartalmazza a szerződésben szereplő valamely alkalmazást (wifi, stb.). Az ilyen alkalmazások kihatnak a vételárra.

${ }^{1245}$ HONSELL (2010), 77. p.

${ }^{1246}$ Lásd: BGE 87 II 245. számú itélet: „Das Bundesgericht lässt deshalb nicht nur körperliche und rechtliche Eigenschaften als im Sinne des Art. 197 OR zugesichert gelten, sondern auch rein wirtschaftliche, z.B. den Zinsertrag einer Liegenschaft (BGE 45 II 444 f.), den Umsatz einer in der Liegenschaft betriebenen Gastwirtschaft (BGE 63 II 78 f.), die Zahl der mit einem Motorwagen gefahrenen Kilometer (BGE 71 II 240 f.).". 
hanem az a fontos, hogy az eladói ígéret a szerződés alkotóeleme legyen. ${ }^{1247}$ A bírói gyakorlat is a törvényböl folyó helytállásként kezeli az eladói ígéretet, ${ }^{1248}$ és azt tekinti döntő tényezőnek, hogy az ígéret hatással van-e a vevő vételi döntésére. ${ }^{1249}$ Heinrich Honsell szerint akár egy prospektusban vagy apróhirdetésben is szerepelhet eladói ígéret, illetve üzletforgalmi vagy kereskedelmi szokásból is fakadhat. ${ }^{1250}$ A különösen a reklámban szereplő puszta dicséretek azonban nem alapozzák meg a kellékszavatosságot. $^{1251}$

A törvényi szóhasználatból egyértelmüen kitünik, hogy amennyiben nem megígért tulajdonságról van szó, akkor csak a ,jelentős hibák” relevánsak a kellékszavatosság tekintetében, a jelentéktelennek minősülő hiányosságok, hibák nem alapozzák meg a helytállást. ${ }^{1252}$ A mennyiségi hibák akkor alapozzák meg a kellékszavatossági helytállást, ha kifejezetten az adott szerződés tartalmát képezték a mennyiségi paraméterek is. ${ }^{1253}$

A fentieken kívül a hibás teljesítés miatti igényérvényesítés előfeltételeit rendező OR § 201 alapján megkülönböztetendőek az áru megvizsgálásakor már felismerhető ún. nyílt hibák az ún. rejtett hibáktól, amelyeket a vevő csak később fedez fel. ${ }^{1254}$

\section{A védett vagyoni érdek, a jogintézmény jogalapja és a szabályozás jellege}

\subsection{Német jog}

A német szabályozás korábban említett újítása, miszerint az eladó főkötelezettsége a dolog kellékhibáktól mentes szolgáltatása, valamint a kellékhiány definiálása egyértelmüen azt

\footnotetext{
${ }^{1247}$ Lásd: GIGER (1979), 340-341. és 353. p.

${ }^{1248}$ Lásd: BGE 88 II 416. számú ítélet és annak hivatkozása a Bundesgericht korábbi döntéseire: „Gewiss gilt die Gewährspflicht des Verkäufers für zugesicherte Eigenschaften als eine <auf die Grundsätze von Treu und Glauben zurückzuführende gesetzliche Haftung, die beim Vorhandensein eines bestimmten Tatbestandes, nämlich der bestimmt umschriebenen Vorstellungsäusserung oder Aussage des Verkäufers platzgreift.> (BGE 71 II 241, BGE 73 II 220). Honsell azonban ezt a különbségtételt felületesnek és feleslegesnek tartja, HONSELL (2010), 86. p.

1249 Lásd: BGE 87 II 245. számú ítélet és annak hivatkozása a Bundesgericht korábbi döntéseire: „Nötig ist nach der Rechtsprechung nur, dass die Zusicherung den Entschluss des Käufers, die Sache überhaupt oder zu den vereinbarten Bedingungen zu erwerben, beeinflusst habe (BGE 71 II 240, BGE 73 II 222, BGE 81 II 209).".

${ }^{1250}$ HONSELL (2010), 86-87. p.

${ }^{1251}$ Lásd: HoNSELL (2010), 86-87. p. Akárcsak a római jogban, illetve a hatályos német és osztrák jogban. Az eladói ígéretnek egyébként a helytállás terjedelmével összefüggő körülmények szempontjából is jelentősége van, lásd később.

${ }^{1252}$ Ez a caveat emptor és a minima non curat praetor ókori elveinek következetes alkalmazását tükrözi, vö. OR $\S 197$ (1).

${ }^{1253}$ HONSELL (2010), 84. p.

1254 Lásd: OR § 201 (1)-(3). Ezzel azonos megoldás érvényesült a magyar Ptk. eredeti, 1959-es szabályozásában is, lásd: I. rész 4. fejezet 4.5.1. pont. A rejtett és nyílt hibák közötti különbségtételnek az igényérvényesítést megelőző kifogásközlési határidő vonatkozásában van jelentősége, lásd: jelen fejezet 7. pont.
} 
mutatja, hogy az eladó kellékszavatossági helytállása a vevőnek a szerződésszerü teljesítéshez és egyben az áru minőségéhez füződő érdekét hivatott védeni Németországban is. Ez kapcsolódik a teljesítés általános szabályához is, miszerint a kötelem annak tartalma alapján a másik fél jogaira, jogilag védett érdekeire és (egyéb) érdekeire figyelemmel kötelez. ${ }^{1255}$ Emellett a „Treu und Glauben”, azaz a tisztesség és jóhiszemüség alapelvére ${ }^{1256}$ is visszavezethető az eladó objektív, azaz a felróhatóságtól független helytállási kötelezettsége. ${ }^{1257}$

A kellékszavatossági helytállás általános szabályai diszpozitívek. ${ }^{1258}$ A fogyasztási cikkek adásvételéről szóló BGB-beli rendelkezések azonban meghatározzák azokat a szakaszokat, amelyek esetében klaudikáló kógencia érvényesül, azaz amelyeknél csak a fogyasztó számára előnyösebb kikötést tartalmazhat a konkrét fogyasztói adásvételi szerződés. A kógencia csak az olyan kikötésekre nézve érvényesül (az Irányelv szövegének megfelelően), amelyek azelött köttettek, hogy a fogyasztó az eladó tudomására hozta a konkrét kellékhibát:

„Auf eine vor Mitteilung eines Mangels an den Unternehmer getroffene Vereinbarung, die zum Nachteil des Verbrauchers von den $\$ \S 433$ bis 435, 437, 439 bis 443 sowie von den Vorschriften dieses Untertitels abweicht, kann der Unternehmer sich nicht berufen." 1259

Az adásvételi szerződésből fakadó főkötelezettségekről, a kellékhibáról (annak fogalmáról), a vevő szavatossági jogairól, azok elévüléséről és a jótállásról szóló rendelkezésektől tehát azelőtt nem lehet eltérni, hogy a hibát a fogyasztó az eladó tudomására hozta. ${ }^{1260} \mathrm{~A}$ hiba közlésére az akaratnyilatkozatokra vonatkozó általános

\footnotetext{
${ }^{1255}$ BGB $\S 241$ (2): „,Das Schuldverhältnis kann nach seinem Inhalt jeden Teil zur Rücksicht auf die Rechte, Rechtsgüter und Interessen des anderen Teils verpflichten.".

${ }^{1256}$ A „,Treu und Glauben” elvének egy objektív és egy szubjektív jelentésváltozata is kialakult a jogfejlődés során. Míg azonban számos európai nemzeti magánjogi dogmatikában a monista megközelítés érvényesül, amely e jelentés-különbséget figyelmen kívül hagyja (illetve a terminológiában sem differenciál), addig a német és a svájci jogtudományban a dualista koncepciót támogatják. A német nyelvben a fenti, objektív értelemben vett jóhiszemű és tisztességes eljárás elvét illetik „,Treu und Glauben” névvel, a szubjektív, azaz az eljáró személy tudatán alapuló jóhiszemüség elnevezése pedig „guter Glaube”. A kérdéskörhöz lásd: FÖLDI (2001), 6. és 43-52. p.

${ }^{1257}$ BGB § 242: „Der Schuldner ist verpflichtet, die Leistung so zu bewirken, wie Treu und Glauben mit Rücksicht auf die Verkehrssitte es erfordern.".

${ }^{1258}$ Ez a BGB § 444-ből vezethető le. E rendelkezés szerint a vevő szavatossági jogait korlátozó illetve kizáró megállapodásra csak akkor nem hivatkozhat az eladó, ha ö csalárd módon elhallgatta a hibát, avagy ha jótállás keretében vállalt helytállást az áru minőségéért. (A korábbi szabályok is így rendelkeztek.)

${ }^{1259}$ Lásd: BGB $\S 475$ (1); vö. Irányelv, 7. cikk (1) bekezdés.

${ }^{1260}$ Lásd: a BGB $\S 475$ (1) utaló szabálya a $\S \S 433,434,435,437,439,440,441,442,443$-ra. A kártérítésröl, mint egyébként általános szerződésszegési jogkövetkezményröl szóló megállapodások esetén a törvény nem ilyen szigorú, vö. § 475 (3); lásd később.
} 
szabályok analógia útján alkalmazandóak, tehát az az időpont az irányadó, amikor a vevő hibára vonatkozó nyilatkozata hozzáférhetővé válik az eladó számára. ${ }^{1261}$

\subsection{Osztrák jog}

A szavatosság jogi szabályozásának általános célja az osztrák jogban elsősorban az, hogy a szolgáltatás-ellenszolgáltatás megbillent egyensúlyát helyreállítsa. ${ }^{1262}$ A jogtudomány elkülöníti a jogügyletben szereplö szolgáltatások szubjektív és objektív egyenértéküségét: az előbbi az adásvételnél a felek vételárra vonatkozó egyezségében testesül meg, az utóbbi pedig a szolgáltatások tényleges értékarányosságát jelenti. ${ }^{1263}$ Hibás teljesítés esetén a vevő hátrányára sérül a szubjektív egyenértékűség, hisz a vevő hibátlan áruért ajánlotta fel a kialkudott vételárat. ${ }^{1264}$ Így vezeti le a jogtudomány azt a tényt, hogy az osztrák magánjog is felróhatóságtól független, objektív jogalapú jogintézményként kezeli és szabályozza a kellékszavatosságot. $^{1265}$ A szubjektív egyenértéküség tana összefügg az ABGB szabályozási koncepciójával is, hiszen a kellékszavatossági szabályok minden visszterhes szerződés esetén alkalmazandóak.

A dolog hibás volta a szubjektív egyenértéküség tana alapján „árképző” tulajdonság, azaz befolyásolja a vételár (ellenérték) mértékére vonatkozó felek közötti megállapodást, kompromisszumot. ${ }^{1266} \mathrm{Ha}$ tehát a vevő nem jut szerződésszerü szolgáltatáshoz, akkor csorbulnak a vagyoni (és egyéb) érdekei, a szavatossági jogok szabályozása ezért az osztrák jogban is a fogyasztó (más jogosult) vagyoni érdekei védelmének és a minőségvédelemnek az egyik eszköze.

A szolgáltatások egyenértéküsége követelményének fokozottan érvényre kell jutnia a fogyasztói szerződések esetén. A KSchG ezért úgy rendelkezik, hogy az ABGB-ben szereplő szavatossági jogok a fogyasztó által kötött szerződés esetén nem korlátozhatóak és nem is zárhatóak ki a hibáról való tudomásszerzés előtt:

„,Gewährleistungsrechte des Verbrauchers ( $\$ \oint 922$ bis 933 ABGB) können vor Kenntnis des Mangels nicht ausgeschlossen oder eingeschränkt werden. ",267

\footnotetext{
${ }^{1261}$ Lásd: GRUNEWALD (2006), 259. p.

1262 KOZIOL (2010), 947. p.; PERNER - SPITZER (2007), 165. p.

1263 Subjektive und objektive Richtigkeit; Äquivalenz der Leistungen, lásd: KOZIOL (2010), 947-948. p.; PERNER - SPITZER (2007), 165. p.

${ }^{1264}$ Lásd: KOZIOL (2010), 947. p.

1265 Lásd: KoZIOL (2010), 947. p.; PERNER - SPITZER (2007), 166. p.

1266 PERNER - SPITZER (2007), 165. p.

${ }^{1267}$ Lásd: KSchG $§ 9$.
} 
Ez az előírás a gyakorlatban a szavatossági határidőket, a szavatossági igényeket és a bizonyítási teher megfordulását érinti. ${ }^{1268}$ A megszövegezésből fakad, hogy a fogyasztó számára kedvezőbb szavatossági szabályok alkalmazása megengedett, azaz az említett szabályok klaudikáló kógenciájáról van szó az Irányelvnek megfelelően, a BGB szabályával egyezően. ${ }^{1269}$ A hibáról való tudomásszerzés azonban a német szabállyal ellentétben a fogyasztó szempontjából releváns, azaz a fogyasztónak a hibáról való tudomásszerzése előtt nem lehetséges a hátrányos kikötés. ${ }^{1270}$ A fenti implementáló rendelkezés valóban ezt tükrözi, annak ellenére, hogy az Irányelv német szövegváltozata (is) egyértelműen az eladónak a hibáról való értesítése előtti kikötésekről szól. ${ }^{1271}$

\subsection{Svájci jog}

A svájci fogyasztóvédelmi törvény szerint a fogyasztói érdekvédelem megköveteli, hogy a vételre vagy használatra kínált áruk lényeges tulajdonságairól a fogyasztók összehasonlítható formában értesüljenek. ${ }^{1272}$ Bár a törvény elsősorban közigazgatási jellegü norma, ez a követelmény egyértelmüen a magánjogi jogalkotásra, illetve különösen a minőségvédelemre és az erre vonatkozó transzparenciára irányul.

Az OR nem konkrétan a szerződésszerüség, hanem a hibátlanság követelményét adja meg, és mind ebből, mind a tankönyvi definícióból egyértelműen kiderül, hogy az eladó kellékhibáktól mentes teljesítésének kötelezettsége a vevőnek az áru minőségéhez füződő érdekét hivatott védeni. ${ }^{1273}$ A minőségileg nem megfelelő teljesítés (Schlechterfüllung) következménye a kellékszavatosság, amely az eladó „megtérítési” kötelezettségeként (Ersatzverpflichtung) az ő elsődleges teljesítési kötelezettségeinek sorába lép, akárcsak a német kódex kifejezett rendelkezése szerint. ${ }^{1274}$ Ehhez a szigorú minőségvédelmi követelményhez - és a pandektajogi hagyományokhoz igazodva - a helytállás jogalapja a svájci jogban is objektív, azaz nem függ az eladó felróhatóságától. ${ }^{1275}$

\footnotetext{
${ }^{1268}$ KOZIOL (2010), 1969. p.

${ }^{1269}$ Lásd többek között: KREJCI (2004), 131. p.

${ }^{1270}$ Lásd: FERCH-FISCHER (2011), 20. p.

${ }^{1271}$ Vö. Irányelv, 7. cikk (1) bekezdés.

1272 Lásd: Bundesgesetz über die Information der Konsumentinnen und Konsumenten (1990), § 2 (1) a): „Liegt es im Interesse der Konsumenten, so sind in vergleichbarer Form zu deklarieren: die wesentlichen Eigenschaften der zum Kauf oder Gebrauch angebotenen Waren...”.

${ }^{1273}$ PICHONNAZ (2003), 290. p.

1274 Lásd: GIGER (1979), 308. p. Vö. BGB § 433 (1).

1275 GIGER (1979), 303. p. Egyes szerzők egyenesen eredményfelelősségként (Kausalhaftung) emlegetik, lásd: HONSELL (2010), 71. p. A kellékszavatosság esetén érvényesíthető kártérítési igény [OR § 208 (3)], azonban szubjektív igény, lásd később: 7.4.3. pont.
} 
Az OR így rendelkezik a szabályozás jellegéröl:

„Eine Vereinbarung über Aufhebung oder Beschränkung der Gewährspflicht ist ungültig, wenn der Verkäufer dem Käufer die Gewährsmängel arglistig verschwiegen hat.",1276

A rendelkezésböl a contrario következik, hogy a föszabály - a német és osztrák joggal ellentétben - az, hogy a felek a szavatossági helytállást korlátozhatják és akár ki is zárhatják. A kivétel tekintetében azonban szerepet kap a szubjektív motívum az eladó oldalán: ha a szavatossági hibát csalárdul elhallgatta a vevő elől, akkor érvénytelen a szavatosság korlátozására vagy kizárására vonatkozó kikötés a szerződésben. ${ }^{1277}$

A legújabb szakirodalom is erősen bírálja a szabályozás diszpozitív természetét, mert az ellenkezik a magánjogi fogyasztóvédelmi törekvésekkel és elvárásokkal. ${ }^{1278} \mathrm{~A}$ gyakorlatban számtalan korlátozó vagy kizáró klauzula értelmezésével kerül szembe a jogalkalmazás és a jogtudomány. Ezek értékelésénél az ún. „Unklarheitenregel”-t alkalmazzák. ${ }^{1279}$ Ez azt jelenti, hogy a nem kellően világosan, egyértelmüen, érthetően megfogalmazott kikötések az azokat megfogalmazó illetve alkalmazó fél, azaz fogyasztói adásvétel esetén az eladó terhére esnek. ${ }^{1280}$ Megengedett a kizárás, de annak és tartalmának egyértelműnek kell lennie. ${ }^{1281}$ A kikötés formája azonban nem csak kifejezett, hanem ráutaló, illetve akár hallgatólagos is lehet. ${ }^{1282} \mathrm{Az}$ utóbbit természetesen mindig a konkrét eset fényében, szigorúan kell értelmezni, de példa lehet rá, ha egy tömegterméket nagy tételben rendkívül és szokatlanul olcsó áron értékesítenek a kereskedelmi forgalomban. ${ }^{1283}$ Annak ellenére, hogy a jogirodalom régóta kritizálja a diszpozitív szabályozás fenntartását e vonatkozásban, a legújabb joggyakorlat is következetesen hangsúlyozza, hogy a diszpozitivitás a kizáró klauzulák tekintetében is irányadó. ${ }^{1284}$

\footnotetext{
${ }^{1276}$ OR $\S 199$.

1277 Ezt a legújabb joggyakorlat is megerősíti, lásd: BGer. 4A. 70/2011. számú ítélet. A szabály a BGB eredeti szabályához nagyon hasonló.

1278 Lásd többek között: KRAMER (1998), 209. p.; PICHONNAZ (2003), 294-295. p.

1279 A szabály tartalmához lásd többek között: BGE 135 III 7. számú ítélet.

${ }^{1280}$ Lásd: HONSELL (2010), 92. p.

${ }^{1281}$ Lásd: BGE 73 II 225. számú ítélet.

1282 Lásd: GIGER (1979), 402. p.

${ }^{1283}$ Lásd: GIGER (1979), 402. p.

1284 Nagyon érdekes ebből a szempontból a BGer. 4A. 272/2011. számú döntésének indokolása, amely a diszpozitív jelleg miatt azt is megengedhetőnek ítélte, hogy a kizáró klauzulát alapértelmezett szerződési elemként alkalmazzák („Die dispositive Bestimmung dient einzig dazu festzulegen „was gilt, wenn keinen andere Parteiabrede getroffen wird". Somit ist eine von der dispositiven Regelung abweichende Freizeichnungsklausel auch bei standardmässiger Verwendung zulässig.”), lásd: REETZ - ZIMMERLI (2012), 10. p. A kizáró/korlátozó kikötések tartalmának nem létező kontrollját régóta kritizálja a jogtudomány, lásd többek között: KRAMER (1998), 209-211. p.
} 
Nehezebb a megítélése az olyan eseteknek, amelyekben kizárják ugyan a szavatosságot, ugyanakkor az eladó ígéretet is tesz bizonyos tulajdonság(ok)ra. Ilyenkor a gyakorlat szerint a kizáró kikötés nem vonatkozik az utóbbira, hanem csak az egyéb hibákra érvényes. ${ }^{1285}$

Ebben a kérdéskörben kap igazán erőteljes szerepet az ÁSZF tisztességtelenségének vizsgálata az UWG $\S 8$ alapján, amely a fogyasztók védelmét célozza. ${ }^{1286}$ Kérdés azonban, hogy annak fogalma kiterjeszthető-e a szavatosságot kizáró illetve korlátozó szerződéses kikötésekre, és hogy ezek esetén fennforog-e a jóhiszeműséget és tisztességet sértő, a szerződéses jogok és kötelezettségek közötti jelentős és indokolatlan aránytalanság a fogyasztók hátrányára. ${ }^{1287}$ Amennyiben az egyedi jogesetben fennáll az aránytalanság, azaz tisztességtelennek minősül a kikötés, akkor jogellenességről, azaz az UWG $\S 8$ megsértéséről van szó az OR $\S 20$ alapján. ${ }^{1288}$ E két rendelkezés nyomán a blankettaszerződések versenyjogi és magánjogi jogellenességi vizsgálata így a joggyakorlatban összefonódhat, és a fogyasztó és vállalkozás közötti szerződésekre vonatkozó kereskedelmi szokások és gyakorlat tekintetében az EU-s Irányelvhez hasonló követelményeket szabhat majd meg.

\section{A vevő tudomása a hibáról}

\subsection{Németország}

A BGB szerint kizárt a vevő hibás teljesítés miatti igénye, ha a hibáról a szerződés megkötésekor tudomása volt:

„Die Rechte des Käufers wegen eines Mangels sind ausgeschlossen, wenn er bei Vertragsschluss den Mangel kennt. Ist dem Käufer ein Mangel infolge grober Fahrlässigkeit unbekannt geblieben, kann der Käufer Rechte wegen dieses Mangels nur geltend machen, wenn der Verkäufer den Mangel arglistig verschwiegen oder eine Garantie für die Beschaffenheit der Sache übernommen hat.",,1289

\footnotetext{
1285 Lásd: BGE 109 II 24. számú ítélet. Azt, hogy mi minősül ígéretnek, mindig az adott szerződés értelmezése útján kell eldönteni a Szövetségi Bíróság szerint.

${ }^{1286}$ Lásd fent: jelen fejezet 3.3. pontja.

${ }^{1287}$ Ezt a kérdést nyilvánvalóan a joggyakorlat és jogtudomány értékelése fogja eldönteni, de bizonyos, hogy itt is mindig az adott eset körülményeiböl kell majd kiindulni.

${ }^{1288}$ Lásd: „,Ein Vertrag, der einen unmöglichen oder widerrechtlichen Inhalt hat oder gegen die guten Sitten verstösst, ist nichtig. Betrifft aber der Mangel bloss einzelne Teile des Vertrages, so sind nur diese nichtig...". Semmis ezek szerint az a szerződés, vagy annak az a része, amely lehetetlen vagy jogellenes tartalmú. A kérdéshez lásd: BRUNNER (2007), 28-30. p.

${ }^{1289}$ Lásd: BGB $§ 442$ (1): Ez a szabály a caveat emptor ókori római jogi szabályait idézi, és ugyanígy szerepelt a BGB eredeti szövegében, lásd: RosENTHAL (1927), 146. p.
} 
A rendelkezés a történeti hagyományokat idézi. Dogmatikailag tiszta megfogalmazása értelmében a jogosult tudati állapota nem kimentési ok, hanem a jogellenes magatartás hiányát jelenti, ezért nem keletkezik kellékszavatossági helytállás. A vevő továbbra is érvényesítheti azonban szavatossági jogait, ha a hiba ugyan az ő súlyos gondatlanságból fakadóan nem volt ismert elötte, de azt az eladó csalárdul elhallgatta előle, vagy kifejezett jótállást vállalt a dolog minőségéért. ${ }^{1290} \mathrm{E}$ szubjektív körülmények a kellékszavatosság objektív jogalapja mellett szigorúbb értékeléshez vezetnek, akárcsak a korábbi szabályozásban. ${ }^{1291}$

Nyitott a kérdés, hogy mennyiben egyeztethető össze ez a rendelkezés az Irányelv azon követelményével, miszerint „arról [ti. a hibáról] ésszerüen eljárva tudnia kellett”. ${ }^{1292}$ Úgy vélem, hogy a contrario azt jelenti a fenti BGB-beli szabály, hogy ha az eladó nem tanúsított csalárd magatartást, és a kifejezett jótállás esete sem áll fenn, akkor a vevő bármilyen fokú gondatlan eljárása esetén ugyancsak kizárt a szavatossági helytállás. Ezt azonban nyilvánvalóan mindig egyedileg kell megítélni.

\subsection{Ausztria}

Az ABGB korábban sem tartalmazott semmilyen megvizsgálási kötelezettséget a vevő (jogosult) oldalán, és ezen a 2001-es reform sem változtatott. ${ }^{1293}$ Meghagyta azonban a jogalkotó azt az 1917 óta hatályos szabályt, amely szerint nincs helye szavatosságnak, azaz nem hibás a teljesítés, ha a kellékhibák szemmel láthatóak:

„Fallen die Mängel einer Sache in die Augen [...], so findet außer dem Falle arglistigen Verschweigens des Mangels oder einer ausdrücklichen Zusage, daß die Sache von allen Fehlern [...] frei sei, keine Gewährleistung statt."1294

A jogtudományi álláspont szerint akkor szemmel láthatóak a hibák, ha azokat még a szerződéskötés előtt az átvevő minden további nélkül felismerhette. ${ }^{1295}$ Ilyen esetben, ha

\footnotetext{
${ }^{1290}$ Lásd: BECKMANN (2010), 117-124. p.

${ }^{1291}$ E szabály gyökere is a római jogi megoldásban keresendő.

${ }^{1292}$ Vö.: BGB § 442 (1): „, ... dem Käufer ein Mangel infolge grober Fahrlässigkeit unbekannt geblieben ”, és „,vernünftigerweise nicht in Unkenntnis darüber [die Vertragswidrigkeit] sein konnte”, és Irányelv, 2. cikk (3) bekezdés. A problémafelvetést lásd: KÄMPF M. (2007), 132. p.

Az összehasonlításhoz hasznosak az Irányelv kétnyelvű szövegváltozatai. Elérhetőek:

http://eur-

lex.europa.eu/Notice.do?val=330258:cs\&lang=hu\&list=330258:cs,\&pos=1\&page=1\&nbl=1\&pgs=10\&hwor $\mathrm{ds}=$ fogyaszt $\% \mathrm{C} 3 \% \mathrm{~A} 1 \mathrm{si} \% 20$ cikkek $\&$ checktexte=checkbox \&visu=\#texte $(2013$. január 25.).

${ }^{1293} \mathrm{SÄÄF}(2005)$, 53. p.

${ }^{1294}$ Lásd: ABGB § 928.

${ }^{1295}$ KOZIOL (2010), 961. p.
} 
mégis megkötik a szerződést, az a tudottan „hibás” dolog elfogadásának minősül, és így hibátlannak tekintendő a szolgáltatás az ABGB szerződések értelmezésére vonatkozó szabálya szerint (§ 914). ${ }^{1296}$ Érdekes, hogy egyes ABGB-kommentárok szerint azt, hogy az átvevő a negatív tulajdonságokat ténylegesen tudomásul vette, nem kell bizonyítani, a szándékosan elhallgatott negatív tulajdonságok azonban vélelmezendően nem elfogadottak. ${ }^{1297}$ Ezért képez kivételt a főszabály alól a BGB-vel egyezően az, hogy ha az átadó a hibát csalárdul, azaz neki felróható módon elhallgatta, valamint, ha olyan kifejezett ígéretet tett, miszerint a dolog mentes mindenféle hibától. ${ }^{1298} \mathrm{~A}$ szavatosság kizárására a főszabállyal ellentétben nincs lehetőség fogyasztói ügyletek esetén a KSchG kógens rendelkezésének értelmében. ${ }^{1299}$

\subsection{Svájc}

A caveat emptor történeti elvének érvényesülése mutatkozik meg az OR § 200-ban: „,Der Verkäufer haftet nicht für Mängel, die der Käufer zur Zeit des Kaufes gekannt hat.". ${ }^{1300}$ A fogalmazásmód egyértelmüen mutatja, hogy dogmatikailag nem hibás a teljesítés, ha a vevő a hibát az adásvétel időpontjában ismerte. ${ }^{1301} \mathrm{Az}$, hogy a törvény az ésszerü, körültekintő eljárást várja el a vevőtől, nem csak a később tárgyalandó megvizsgálási és kifogásközlési kötelezettségek elöírásából derül ki, hanem abból is, hogy a kellő figyelem tanúsítása esetén felismerhető hibákért való helytállást csak akkor követeli meg az eladótól, ha ő az adott konkrét hiba hiányára a vevőnek ígéretet tett [OR § 200 (2)]. Ez a követelmény harmonizál az ésszerủen eljáró minta-fogyasztó kategóriájával és az EU-s szabályozással, ezen kívül szinte teljesen megegyezik az ABGB rendelkezésével. ${ }^{1302}$

\section{A hibás teljesítésből fakadó jogkövetkezmények}

Németországban a már említettek szerint a kellékhibás teljesítés az eladó elsődleges szerződéses kötelezettségének a megszegése, így a vevőnek az átvétel megtagadásához füződő jogát eredményezheti (BGB § 320). A kötelmi általános szabályok szerint azonban,

\footnotetext{
${ }^{1296}$ KOZIOL (2010), 961. p.

1297 SCHWIMANN (1997), 421. p.

${ }^{1298}$ A kifejezett (ausdrücklich) kétség kívüliként értelmezendő. lásd: KOZIOL (2010), 961. p.

${ }^{1299}$ Vö.: KSchG $\S 9$ és ABGB $§ 929$.

${ }^{1300}$ Lásd: OR § 200 (1).

1301 Akárcsak a BGB szabálya, vö. BGB § 442 (1).

1302 Vö.: EuB C-210/96. számú Európai Bírósági ítélet, valamint Irányelv, 2. cikk (3) bekezdés, és ABGB $\S$ 928.
} 
ha a jogosult a nem kötelemszerü teljesítést elfogadta teljesítésként, akkor annak ugyanolyan a joghatása, mint a teljesítésnek, azaz megszünteti a kötelmet. ${ }^{1303}$ Amennyiben a kellékhiba az áru átvétele után derül ki, akkor a szavatossági helytállásból eredő jogkövetkezményeknek van helye. ${ }^{1304}$

A szavatossági jogokat kellék- és joghibák esetén - a reform után már egységesen a BGB $\S 437$ határozza meg. A rendelkezés a korábbi szabályozással ellentétben, az Irányelv elvárásainak megfelelően kialakítja az ún. lépcsős igényérvényesítés rendszerét:

„Ist die Sache mangelhaft, kann der Käufer, wenn die Voraussetzungen der folgenden Vorschriften vorliegen und soweit nicht ein anderes bestimmt ist,

1. nach $\$ 439$ Nacherfüllung verlangen,

2. nach den $\S \S 440,323$ und 326 Abs. 5 von dem Vertrag zurücktreten oder nach $\S$ 441 den Kaufpreis mindern und

3. nach den $\$ \S 440,280,281,283$ und 311 a Schadensersatz oder nach $\S 284$ Ersatz vergeblicher Aufwendungen verlangen. "1305

A vevő ezek alapján követelheti a (1) ,pótteljesítést” (Nacherfüllung), ${ }^{1306}$ amely a kijavítás és az ugyanolyan hibátlan dologra történő kicserélés igényeit foglalja magában. Bizonyos feltételekhez kötötten (2) vételárcsökkentést (Kaufpreisminderung) követelhet, és emellett vagylagosan az elállás jogával (Rücktritt) élhet, amely utóbbi a reform után már általános szerződésszegési jogorvoslat is. Mindezek mellett akár kumulatívan is (3) kártérítést kérhet (Schadensersatz), vagy a feleslegesen ráfordított költségek megtérítését követelheti a kötelmi jog általános szabályai szerint. A BGB § 475 kógens rendelkezésének megfelelően ettől a sorrendtől fogyasztói adásvétel esetén nem lehet eltérni a fogyasztó hátrányára. $A$ contrario előnyére, a beleegyezésével természetesen el lehet térni tőle.

Ausztriában a már említettek szerint a szavatossági igényekről szóló rendelkezéseket az ABGB-ben és a fogyasztóvédelmi törvényben is érintette az Irányelv implementációja. Az ABGB így rendelkezik:

„Der Übernehmer kann wegen eines Mangels die Verbesserung (Nachbesserung oder Nachtrag des Fehlenden), den Austausch der Sache, eine angemessene Minderung des Entgelts (Preisminderung), oder die Aufhebung des Vertrags fordern. "1307

\footnotetext{
${ }^{1303}$ BGB $\S 364$ (1): „Das Schuldverhältnis erlischt, wenn der Gläubiger eine andere als die geschuldete Leistung an Erfüllung statt annimmt.".

1304 ZERRES (2010), 169. p. Ez a szavatossági jogok kezdeteként meghatározott veszélyátszállási szabályból is fakad, BGB $\S \S 446-447$, lásd lentebb.

1305 Lásd: BGB $§ 437$.

${ }^{1306}$ Az igény tartalmára tekintettel ezt az elnevezést tartottam a legmegfelelőbbnek a magyar fordításban.

1307 ABGB $§ 932$ (1).
} 
Az átvevő a hiba miatt tehát kijavítást (illetve a hiány pótlását), a dolog kicserélését, az ellenszolgáltatás megfelelő csökkentését (árleszállítást), vagy a szerződés megszüntetését (elállást) követelhet. E szavatossági igények korábban is léteztek az osztrák jogban, de alkalmazásuk és a közülük való választás általában a hiba jellegétől függött. ${ }^{1308}$ Újat az hozott a szabályozásban, hogy az Irányelv elvárásainak megfelelően a módosító rendelkezések felállítják a „szavatossági jogok hierarchiáját”: ${ }^{1309}$ itt is elsődleges tehát a kijavítás és a kicserélés, másodlagos pedig az árleszállítás és az elállás igénye. ${ }^{1310}$ Mindemellett az osztrák jog szerint is lehetősége van a jogosultnak a hibás teljesítés miatt kártérítést követelni.

Svájcban a caveat emptor elvének a történeti jelentésénél szigorúbb kivetülése található az OR-ben a hibás teljesítés miatti igényérvényesítés előfeltételei között. Ezek az előírások kettős követelményt rónak a vevőre, amelyek a fogyasztónak minősülő átlagember vásárlók oldalán a magánjogi fogyasztóvédelem deficitjeként jelentkeznek a szabályozásban. ${ }^{1311}$

A vevő először is köteles az üzletmenethez képest a lehető leghamarabb megvizsgálni a dolog minőségét. Amint ez megtörtént, és a vevő hibát fedez fel, azonnal értesítenie kell arról az eladót, illetve ha a hiba később jelentkezik, akkor annak felfedezése után kell haladéktalanul közölnie azt $(\mathrm{OR} \S 201){ }^{1312}$ A bírói gyakorlat szerint a kifogásközlés egy szándéknyilatkozat, amelynek kellően konkrétnak kell lennie, azaz minden lényeges körülményt és adatot tartalmaznia kell a hibáról, illetve kifejezetten bele kell foglalni, hogy a vevő a teljesítést nem ismeri el szerződésszerűnek, és ezért az eladó helytállással tartozik. ${ }^{1313}$

Ugyancsak a vevő igényérvényesítési előkötelezettségei közé sorolható az eljárás a más helyről küldött áru esetében (az ún. helyközi vétel esetén). Amennyiben az eladónak az átvétel helyén (a vevő lakhelyén) nincs képviselete, akkor a vevő kellékhiba esetén

\footnotetext{
${ }^{1308}$ Gewährleistungsreform (2001), 3. p.

${ }^{1309}$ Lásd: PIRKER-HÖRMANN - HAMMERL (2004), 23. p.

1310 Vö. ABGB § 932 (2)-(4).

${ }^{1311}$ Lásd: PichONNAZ (2003), 291. p. A kérdéskör részletes fejtegetéséhez lásd: BUCHER (1971), 1. p. Bucher különösen azon ügyletekkel kapcsolatban hívja fel a figyelmet a szabályozás átlagfogyasztóra nézve hátrányos mivoltára, amelyek számára jelentős költséget jelentenek, mint például autó vagy bútor adásvétele, uo. 2. p. Érdekesség, hogy Bucher a tanulmányát több mint 40 évvel ezelött írta, de ez a deficit és a fogyasztóvédelem követelménye már akkor jelentkeztek a mindennapi gyakorlati tapasztalatok alapján.

${ }^{1312}$ A korai Szövetségi Bírósági gyakorlat szerint ezek az előkötelességek a forgalom biztonsága érdekében voltak szükségesek az adásvételi ügyletek esetén, lásd: BGE 88 II 365. számú ítélet: „Diese Vorschriften sind im Interesse der Verkehrssicherheit beim Kaufgeschäft aufgestellt...”. E döntést idézi közel 40 évvel később a BGer 4C. 395/2001. számú ítélet indoklása is.

1313 Lásd: HonSELL (2010), 88-89. p. hivatkozása a Szövetségi Bíróság döntésére (BGer 4C.395/2001.); a kifogásközlés tartalmához lásd: ZEHNDER (2000), 546. p.
} 
köteles a dolog ideiglenes megőrzéséről gondoskodni, nem küldheti azt vissza minden további nélkül [OR § 204 (1)]. A tényállást késedelem nélkül rögzíttetnie kell, mert őt terheli a bizonyítási kötelezettség, hogy az általa állított hibák már az átvételkor megvoltak a dologban [OR § 204 (2)]. Gyorsan romlandó áru, például élelmiszer vagy ételféleség esetén a vevő jogosult, illetve - ha az eladó érdekei megkövetelik, akkor - köteles is a dolog helyén illetékes hatóság közremüködésével azt eladni illetve eladatni, és erröl haladéktalanul értesíteni az eladót, annak érdekében, hogy a későbbi esetleges kártérítési kötelezettség alól magát kimentse [OR § 204 (3)].

A közlési kötelezettség „azonnaliságának” követelménye a svájci bírói gyakorlatban szigorúan értelmezett, és annál rövidebb ez a meghatározatlan tartamú jogvesztő határidő, minél hamarabb jelentkeznek a hibából eredő károk. ${ }^{1314}$

A megvizsgálási és kifogásközlési kötelezettség elmulasztása a vevő igényérvényesítésére nézve jár hátrányos következménnyel: a jogvesztő jellegü határidőből a bírói gyakorlat szerint az következik, hogy nem csak a szavatosságból eredő jogosultságainak érvényesítési lehetőségét veszíti el, hanem a kötelmi általános szabályok szerint követelhető, a nemteljesítés miatti kártérítés iránti igényt, sőt, a deliktuális jogalapú kártérítési igényét is. ${ }^{1315}$ A szubjektív motívum az eladó oldalán szankciós jelleggel ugyanakkor itt is megjelenik: ha a vevőt szándékosan megtéveszti, akkor az esetlegesen elmulasztott közlési kötelezettség sem zárja ki a szavatossági helytállást (OR § 203).

A kellékhibás teljesítés tekintetében az OR különbséget tesz a fajlagos és az egyedi ingó-adásvétel között. A fajlagos vételnél az általában elfogadott álláspont, az ún. „teljesítési elmélet” (Erfüllungstheorie) ${ }^{1316}$ szerint a minőség és a megígért tulajdonságok is részét képezik a szerződés tartalmának, mivel a fajta szerint meghatározott szolgáltatás általános szabálya is kimondja, hogy az adós nem szolgáltathat középminőségü dolgot, hanem kizárólag a fajtának minőségileg megfelelő dolgot ajánlhat fel a vevőnek. ${ }^{1317} \mathrm{~A}$ másik, ún. „szavatossági elmélet” (Gewährleistungstheorie) képviselői szerint az egyedi vételnél elválnak a teljesítés és a szavatosság szabályai, és így a hibamentesség nem az általános szolgáltatási kötelezettség része, hanem a speciális jogintézmény, a szavatosság

\footnotetext{
1314 A rendelkezésből azonban kiderül, hogy itt jelentősége van a hiba nyílt vagy rejtett mivoltának. Lásd: PICHONNAZ (2003), 291. p. A borvételnél például egységesen 9 napban állapította meg a gyakorlat a határidőt, mert a bornak először ,pihennie” kell, lásd: BGE 26 II 194. számú ítélet. A már a teljesítés alkalmával megállapított hibák azonnal közlendőek, lásd: BGer. 4D. 4/2011. számú ítélet. A legújabb bírósági gyakorlathoz lásd: REETZ - ZIMMERLI (2012), 9-34. p.

1315 Vö. OR §§ 41 és 97. Lásd: BGE 90 II 86; 67 II 137; 104 II 357; 113 II 78. számú ítéletek.

${ }^{1316}$ Lásd: KELLER - SIEHR (1995), 71-72. p.

1317 OR § 71, lásd többek között: NEUENSCHWANDER (1971), 24. p.
} 
tárgya. ${ }^{1318}$ A két elmélet közötti tudományos ellentét tárgya tehát az, hogy a dolog minősége szerződési tartalomnak minősül-e, és ennek függvényében annak nem megfelelő állapota eredményez-e szavatossági helytállást. ${ }^{1319}$ A többségi álláspont alapján a megfelelő minőség az egyedi dolog adásvételének is természetes szerződéses velejárója, ami levezethető a jóhiszeműség és tisztesség polgári jogi alapelvéből. ${ }^{1320}$

Eugen Bucher hangsúlyozza, hogy a fajlagos vétel és a helyettesíthető dolog vétele nem szinonim kategóriák. ${ }^{1321}$ A kereskedelmi forgalomban nagyon gyakori a csak „látszólag” fajlagos vételi ügylet: amennyiben a helyettesíthető dolog, azaz a fajta egy adott „példányára” köttetik meg a szerződés, akkor az egyedi vétel szabályai alkalmazandóak, és Bucher szerint csak akkor fajlagos a vétel, ha a vevő az árut minta szerint vette meg, vagy azt katalógusból ${ }^{1322}$ vagy web-áruházból „,rendelte”.

A jogkövetkezményekre vonatkozó föszabály megadja a választás jogát a vevőnek a két fő kellékszavatossági jog, a vételárcsökkentés és az elállás igénye között. ${ }^{1323}$ Emellett a vevő fajlagos vétel esetén élhet a kicserélés jogával is. Minden esetben rendelkezik azonban a kártérítés alternatív követelésének a jogával is.

\subsection{A kijavítás és a kicserélés joga}

\subsubsection{Németország}

Az Irányelv lépcsős igényérvényesítési rendszerének megfelelően a BGB szerint a vevő elsősorban pótteljesítést követelhet kellékhiba esetén. A pótteljesítés a kijavítás és a kicserélés igényeit foglalja magában, amelyek ún. teljesítési igények (Erfüllungsansprüche), azaz a hiba természetbeni orvoslását teszik lehetővé: ${ }^{1324}$

„(1) Der Käufer kann als Nacherfüllung nach seiner Wahl die Beseitigung des Mangels oder die Lieferung einer mangelfreien Sache verlangen.

\footnotetext{
${ }^{1318}$ Lásd többek között: BUCHER (1988), 68. p.

1319 A vita két szembenálló oldalának érveihez lásd: GIGER (1979), 306-307. p.

${ }^{1320}$ A többségi állásponthoz lásd többek között: NEUENSCHWANDER (1971), 25. p. A „,Treu und Gluben” a polgári jog alapelve, lásd: ZGB § 2 (1): ,Jedermann hat in der Ausübung seiner Rechte und in der Erfüllung seiner Pflichten nach Treu und Glauben zu handeln.”. Az elv az OR számos rendelkezésében külön nevesítve is szerepel, például a tévedésnél ( $§ 24)$, a halasztó feltételnél ( $§ 156)$, a bérlet felmondásánál ( $\S$ 271), stb.

${ }^{1321}$ BUCHER (1971), 6. p. Az elhatárolási kérdések fejtegetését a magyar jog vonatkozásában lásd: I. rész 4. fejezet 3. pont.

1322 BUCHER (1971), 6. p.

${ }^{1323}$ Lásd: OR $§ 205$ (1). A pandekta hagyományokat tükrözi a vevői igényeinek elnevezése: „,Wandelung” és „Minderung”, ezen kívül a választási jog, azaz az alternatív keresetek biztosítása. A választás joga azonban erősen behatárolt, lásd később.

${ }^{1324}$ SÄÄF (2005), 57. p.
} 
(2) Der Verkäufer hat die zum Zwecke der Nacherfüllung erforderlichen Aufwendungen, insbesondere Transport-, Wege-, Arbeits- und Materialkosten zu tragen.

(3) Der Verkäufer kann die vom Käufer gewählte Art der Nacherfüllung unbeschadet des $\S 275$ Abs. 2 und 3 verweigern, wenn sie nur mit unverhältnismäßigen Kosten möglich ist. Dabei sind insbesondere der Wert der Sache in mangelfreiem Zustand, die Bedeutung des Mangels und die Frage zu berücksichtigen, ob auf die andere Art der Nacherfüllung ohne erhebliche Nachteile für den Käufer zurückgegriffen werden könnte. Der Anspruch des Käufers beschränkt sich in diesem Fall auf die andere Art der Nacherfüllung; das Recht des Verkäufers, auch diese unter den Voraussetzungen des Satzes 1 zu verweigern, bleibt unberührt. " 1325

A vevőt megilleti a kijavítás és a kicserélés közötti választás joga, bizonyos korlátok között. Mivel az eladó köteles viselni a pótteljesítés foganatosításából eredő minden költséget, így különösen a szállítási-, az úti-, és az anyagköltségeket, valamint a munkadíjat, ezért a választott igény teljesítését megtagadhatja, ha az aránytalan költségekkel járna számára. Az arányosság kérdése a hibátlan állapotban lévő dolog értéke, a hiba jellege, és az alapján ítélendő meg, hogy a pótteljesítés másik módja nem járna-e a vevő számára jelentős hátránnyal. Amennyiben fennáll az aránytalan költségvonzat esete, akkor az eladó erre hivatkozhat, és a pótteljesítés másik módjára korlátozódik a vevő igénye. ${ }^{1326}$ Problematikus az, hogy a megfogalmazás nem általában a jogorvoslatok viszonylatában, hanem csak e két első lépcsős jog vonatkozásában fennálló arányosságra enged következtetni. Az Irányelv angol és német szövege is az „alternatív jogorvoslat” (alternative remedy; die alternative Abhilfemöglichkeit) kifejezést használja, ami valóban ezt tükrözi. ${ }^{1327}$ A kérdéssel kapcsolatos a később részletesen tárgyalandó C-65/09. számú Európai Bírósági ítélet. ${ }^{1328}$

Kicserélés esetén a fajlagos szolgáltatás általános szabálya szerint a kialkudott fajtába tartozó másik árut kell az eladónak szolgáltatnia [BGB § 243 (1)]. Egyedi vétel esetén más a helyzet, mert a jogtudomány egyik táborának álláspontja szerint eleve kizárt a kicserélés igénye. ${ }^{1329}$ A kérdés azért problematikus, mert a kötelmi jogi reform egyik újítása, hogy nem tesz különbséget a jogkövetkezmények tekintetében a fajlagos és egyedi vétel között. ${ }^{1330}$ A másik jogtudományi álláspont szerint, bár a törvényhozó kiindulópontja

\footnotetext{
${ }^{1325}$ Lásd: BGB § 439 (1)-(3).

${ }^{1326}$ BGB § 439. (3) 3. mondat.

${ }^{1327}$ Vö. Irányelv, 3. cikk (3) bekezdés.

${ }^{1328}$ Lásd: jelen fejezet 8. pontja.

${ }^{1329}$ CSIZMAZIA (2002), 431. p.

${ }^{1330}$ CSIZMAZIA (2002), 431. p.
} 
az volt, hogy az egyedi vételnél a legtöbb esetben kizárt a kicserélés, ${ }^{1331}$ mégsem vethető el annak lehetősége elvi éllel. ${ }^{1332}$ Azt kell eldönteni, hogy a felek megállapodása alapján egy másik dolog az eredeti adásvételi tárgy helyébe léphet-e a kicserélési jog keretei között. ${ }^{1333}$ A kérdés megválaszolása különösen az új állapotú helyettesíthető áruk, illetve a nem helyettesíthető használt áruk esetén jelent nehézséget. ${ }^{1334} \mathrm{Ez}$ a fent tárgyalt fajlagos vétel és helyettesíthető dolog elhatárolásával kapcsolatos. A fajlagos szolgáltatásra vonatkozó törvényi rendelkezés alapján, ha a kötelezett egy, a fajtába tartozó középminőségü dologgal teljesít, akkor a kötelem attól kezdve arra az adott dologra korlátozódik. ${ }^{1335}$ Individualizálódik tehát a kötelem tárgya, a szolgáltatás egyedi lesz annak ellenére, hogy eredetileg fajta szerint meghatározott dologról volt szó. ${ }^{1336}$ Így tehát véleményem szerint fajta szerinti vétel esetén is lehetôség van a dolog kicserélésére.

Kicserélés esetén az eladónak általában joga van arra, hogy a hibás árut valamint az időközben keletkezett hasznokat visszakövetelje a vevőtől [BGB § 439 (4)]. Fogyasztói adásvétel esetén a vevő kötelezettsége - a főszabálytól eltérően - csak a hibás dolog visszaszolgáltatására korlátozódik, ahelyett az esetlegesen megsemmisült dolog értékét és a hasznokat az eladó nem követelheti vissza. ${ }^{1337}$

Kijavítási igény esetén az eladó maga köteles megjavítani az árut, vagy mással is elvégeztetheti: amennyiben több módja is lehetséges az igény kielégítésének, akkor a költségvonzatot is szem elött tartva maga döntheti el, hogy melyiket választja. ${ }^{1338}$ Üdvözlendő, hogy a kódex kifejezetten szabályozza azt a megdönthető vélelmet, miszerint a kijavítás a második sikertelen kísérlet után meghiúsultnak tekintendő, azaz ez után a vevő minden további nélkül áttérhet a második lépcsős igényekre. ${ }^{1339}$

\footnotetext{
${ }^{1331}$ Lásd: BT-Drucks. 14/6040, 232. p. és annak utalása az Irányelv Preambulumának 16. bekezdésére.

${ }^{1332}$ LOOSCHELDERS (2011), 29. p.

${ }^{1333}$ Lásd: CANARIS (2003), 833. p.

${ }^{1334}$ Lásd: LOOSCHELDERS (2011), 29. p.

${ }^{1335}$ Lásd: BGB § 243 (1)-(2): ,,Wer eine nur der Gattung nach bestimmte Sache schuldet, hat eine Sache von mittlerer Art und Güte zu leisten. Hat der Schuldner das zur Leistung einer solchen Sache seinerseits Erforderliche getan, so beschränkt sich das Schuldverhältnis auf diese Sache.".

${ }^{1336}$ Ezt már a római jogban is így ítélték meg, lásd: MOLNÁR - JAKAB (2012), 250. p.

${ }^{1337}$ Lásd: BGB $\S 474$ (2). Az általános szabályok alapján az eladó az áru helyett igényt tarthat a dolog értékének a megtérítésére is, lásd: a BGB § 439 (4) utaló szabálya a § 346-ra.

1338 Lásd: LoOsCHELDERS (2011), 28. p. 126. lj. hivatkozása Reinicke, Dietrich - Tiedtke, Klaus: Kaufrecht (Carl Heymanns, Köln, 2009.) címü müvére.

1339 Lásd: BGB § 440 2. mondat: „,Eine Nachbesserung gilt nach dem erfolglosen zweiten Versuch als fehlgeschlagen, wenn sich nicht insbesondere aus der Art der Sache oder des Mangels oder den sonstigen Umständen etwas anderes ergibt.".
} 


\subsubsection{Ausztria}

A jogosult elsődleges szavatossági jogai az Irányelvnek megfelelően az ABGB alapján szintén a kijavítás és a kicserélés. ${ }^{1340}$ A kijavítási igény a hibás dolog javításán kívül az esetleg hiányzó alkatrész pótlását is magában foglalja. A kicserélés igénye az eredeti dologgal azonos másik, hibátlan dolog szolgáltatását jelenti, ebből következik, hogy lényegében csak helyettesíthető dolog esetén van helye. ${ }^{1341}$

A kicserélés és kijavítás igényei között választás illeti meg a jogosultat, azonban ennek korlátai vannak, amelyek ugyancsak az Irányelv minimumkövetelményeit tükrözik, és a BGB szabályaival is harmonizálnak: nem gyakorolható sem a kijavítás, sem a kicserélés joga, ha lehetetlen, vagy az átadónak, a másik jogorvoslattal összehasonlítva, aránytalanul magas költségráfordítással járna. ${ }^{1342} \mathrm{~A}$ jogorvoslat lehetetlensége merül fel például az egyedi, helyettesíthetetlen dolog (festmény, szobor, antik bútordarab) kicserélése kapcsán. Az aránytalanság megállapításánál figyelembe kell venni a dolog hibátlan állapotbani értékét, a hiba súlyát, és a másik jogorvoslattal az átvevőnek (esetlegesen) okozott kellemetlenséget [ABGB § 932 (2)].

A személygépjármü adásvétele e kérdésnél szemléletes példa, hiszen általában jelentős értéket képvisel a fogyasztó számára. Amennyiben például az új autó navigációs rendszerében adódó hiba miatt akar élni a vevő az első lépcsős szavatossági jogai közül a kicserélés igényével, az aránytalan költséget keletkeztetne az eladó oldalán, mert egy autó használt volta máris jelentős értékcsökkenést jelent, amely az eladót terheli, ha a visszavett autót újra el akarja adni. ${ }^{1343}$ A kicserélés helyetti kijavítás ideje alatt viszont a vevő az autót nem tudja használni, ami kellemetlenséget és esetleges további költségeket okoz neki. Figyelembe kell azonban venni, hogy a navigációs rendszerben rejlő hiba jelentősége nem hat ki a rendeltetésszerü használatra, mert anélkül is müködőképes müszaki állapotú az autó. Ezen felül a kicserélés esetén is több időt vehet igénybe az új, hibátlan autó papírjainak rendezése, stb. Egy ilyen, a példában szereplő hiba esetén tehát a körülményeket mérlegelve a kicserélés a kijavításhoz képest véleményem szerint aránytalannak minősíthető, ezért a jogosult csak a kijavítás igényével élhet.

\footnotetext{
${ }^{1340}$ Lásd: ABGB $§ 932$ (2): „Zunächst kann der Übernehmer nur die Verbesserung oder den Austausch der Sache verlangen...".

${ }^{1341}$ KLETECKA (2001), 43. p.

1342 ABGB $\S 932$ (2): ,, Ob dies der Fall ist, richtet sich nach dem Wert der mangelfreien Sache, der Schwere des Mangels und den mit der anderen Abhilfe für den Übernehmer verbundenen Unannehmlichkeiten .".

${ }^{1343}$ Lásd: PERNER - SPITZER (2007), 169. p.
} 
Amint azt az előző pontban is kifejtettem, problematikus, hogy az Irányelv megfogalmazása nem általában a jogorvoslatok viszonylatában, hanem csak e két első lépcsős jog vonatkozásában fennálló arányosságra enged következtetni a választás jogát illetően. Az osztrák jogalkotó azonban a második lépcsős jogok alkalmazásának előfeltételei között az Irányelvnél konkrétabban fogalmaz, mert úgy rendelkezik, hogy ha a kijavítás és a kicserélés is lehetetlen, vagy az átadónak aránytalanul magas költséggel járna, akkor élhet a jogosult a második lépcsős igényekkel. Így tehát mindkét első lépcsős jog esetén vizsgálni kell a korlátozó körülményeket, és ha azok mindkettő esetén fennállnak, akkor a vevőnek át kell térnie a második lépcsőben szereplő igényekre, ${ }^{1344}$ lényegében nincs is más lehetősége. ${ }^{1345}$

A dolog jellegéhez és rendeltetéséhez igazodó megfelelő határidőn belül, és az átvevőnek okozott lehető legcsekélyebb kellemetlenséggel kell teljesíteni a kijavítást és a kicserélést [ABGB § 932 (3)]. Teljesítésük módjáról fogyasztói szerződés esetén az ABGB mellett a KSchG is rendelkezik. Eszerint a kicserélést és a kijavítást az átadás helyén kell foganatosítani, ha pedig a dolgot az eladó a szerződésnek megfelelően valamely belföldi helyre küldi vagy szállítja, akkor ezen a helyen, mert ilyenkor ez minősül az átadás helyének [KSchG $\S 8$ (1) 1. mondat]. Ha a fogyasztó azt kéri, akkor azon a helyen kell végrehajtania a vállalkozónak az igényt, ahol a dolog szokásosan található, amennyiben az belföldön van, az eladónak nem „meglepő”, és ha a dolognak az eladóhoz szállítása a fogyasztó által a dolog jellege miatt lehetetlen - különösen, ha a dolog hatalmas, nehéz, vagy beépítés folytán ingatlanná vált $[\mathrm{KSchG} \S 8$ (1) 2. mondat]. Amennyiben azonban a dolog elküldése a fogyasztó által megvalósítható, akkor az eladó kérheti ezt, az azzal járó veszélyt, kockázatot és költségeket azonban neki kell viselnie [KSchG § 8 (2)].

A kicseréléssel és kijavítással járó költségek - különösen a szállítási- és anyagköltségek valamint a munkadíj - egyébként is minden esetben az eladót terhelik a BGB rendelkezésével egyezően [KSchG $§ \quad 8$ (3)]. Ezeket a törvény csak példálózó jelleggel, mint a legfontosabb költségvonzati kategóriákat adja meg (az Irányelv szövegezésének megfelelően), de emellett a joggyakorlat más, az igények teljesítésével összefüggő szükséges költségek viselését is a kötelezett terhére rója. Ilyen például a hibás

\footnotetext{
${ }^{1344}$ Lásd többek között: PERNER - SPITZER (2007), 169. p.

${ }^{1345}$ Vö. Irányelv, 3. cikk (5) bekezdés: „A fogyasztó a vételár megfelelö csökkentését kérheti vagy elállhat a szerzödéstöl, ha nem jogosult sem a fogyasztási cikk kijavitására, sem a kicserélésére...”. Ezzel ellentétesen döntött azonban a később tárgyalandó C-65/09. számú ítéletében az EuB, lásd később: 8. pont. Az irányelvkonform jogértelmezés problematikájához az osztrák jogban lásd: KLAMERT (2008), 159-164. p.
} 
jármü elszállításának a költsége. ${ }^{1346}$ Az azonban még a szakirodalomban is vitatott, hogy ide sorolható-e az abból fakadó szállítási költség megtérítése, hogy a fogyasztó a hibás dolgot visszaviszi az eladóhoz, illetve onnan elhozza azt. ${ }^{1347}$

\subsubsection{Svájc}

A svájci jog szerint fajlagos vételnél az áru nem individualizált, hanem a fajta jellemzőinek megfelelő, középminőségü dolgo(ka)t kell az eladónak szolgáltatnia a svájci jog szerint [OR § 71 (1)-(2)]. A törvény ennek fényében fajlagos vétel esetén rendelkezik a kicserélési jogról:

„, Geht der Kauf auf die Lieferung einer bestimmten Menge vertretbarer Sachen, so hat der Käufer die Wahl, entweder die Wandelungs- oder die Minderungsklage anzustellen oder andere währhafte Ware derselben Gattung zu fordern.",1348

Amennyiben tehát a vétel meghatározott mennyiségü helyettesíthető dolog szolgáltatására irányul, akkor a vevő az elálláson és a vételárcsökkentésen kívül a fajtába tartozó ugyanolyan másik árut is követelhet kellékszavatossági igényként. ${ }^{1349}$ Emellett az eladónak kedvező szabály az, hogy ha helyi vételről van szó, ${ }^{1350}$ akkor az eladó maga is dönthet úgy, hogy a meghatározott fajtába tartozó másik ugyanolyan árut szolgáltat, kimentve magát minden további igény teljesítése alól [OR $§ 206$ (2)]. ${ }^{1351}$

A fajlagos vétel és a helyettesíthető dolog egyedi vétele közötti különbségtétellel kapcsolatos fontolgatások a „Nachlieferung” igénye vonatkozásában (is) relevánsak. Bucher már 1971-ben írt tanulmányában felveti azt a - véleményem szerint - megalapozott javaslatot, miszerint a standardizált tömegtermékek korában megfontolandó lenne a kizárólag a fajlagos vételre korlátozott kicserélést a helyettesíthető dolgok egyedi vételére is kiterjeszteni. ${ }^{1352}$

\footnotetext{
${ }^{1346}$ Lásd: Erl 422 BlgNR 21. GP 23. számú döntés; KoZIOL (2010), 1968. p.

${ }^{1347}$ Lásd: KozIOL (2010), 1968. p. Van olyan jogtudományi álláspont, amely szerint a fenti költségviselési kötelezettséget helyesebb lett volna az ABGB-ben szabályozni, mert minden szavatossági igényérvényesítés esetén a kötelezett oldalán fennálló reális követelmény ez, de ha már a jogalkotó a KSchG-be építette azt, akkor is ésszerü az analóg alkalmazása nem fogyasztói jogügyletek esetén is. A kijavítás és kicserélés költségmentességének követelménye pedig ugyan csak a KSchG-ben szerepel, de magától értetődően minden esetben térítésmentes ezen igények érvényesítése, lásd ehhez: KREJCI (2004), 132. p.

${ }^{1348} \mathrm{OR} \S 206$ (1). Ez a szabály is a BGB eredeti rendelkezését tükrözi, lásd: I. rész 2. fejezet 2.7. pont.

1349 GIGER (1979), 513. p. Az OR szóhasználata szerint „Ersatzleistung”, a szakirodalomban „Nachlieferung”-ként emlegetik, lásd például: HONSELL (2010), 128. p.

1350 „Platzkauf”, lásd: BUCHER (1971), 6. p.

${ }^{1351}$ A vevő összes kárát meg kell azonban térítenie, lásd később.

${ }^{1352}$ Lásd: BUCHER (1971), 6. p. 15. lj. Ez történt meg hazánkban a Ptk. 1977-es módosításakor, lásd: I. rész 4. fejezet 6.2. pont.
} 
A svájci adásvételi jogból hiányzik az Irányelv nyomán az Európai Uniós tagállamok magánjogában szereplő kijavítás iránti igény szabályozása. Ezt a hiányosságot is régóta a kellékszavatosság törvényi konstrukciójának egyik deficitjeként emlegeti a tudomány. ${ }^{1353}$ Ennek ellenére a gyakorlatban a szerződő felek nagyon gyakran kötik ki a szerződésben a vevő kijavítási jogát, ${ }^{1354}$ ami egyébként levezethető a „,Treu und Glauben” általános elvéből is. ${ }^{1355}$ A joggyakorlat és a jogtudomány egyik tábora ebből az elvből, valamint a vállalkozási szerződésnél szereplő azonos igényből analóg módon vezeti le az adásvétel esetén is fennálló törvényes kijavítási igényt. ${ }^{1356}$

A szabályozási hiány azért is problematikus, mert a jogtudomány hangsúlyozza a vevő kijavítási igényének és az eladó kijavításhoz való jogának az elhatárolását. ${ }^{1357} \mathrm{Az}$ utóbbi ugyanis a jogtudomány álláspontja szerint - ugyancsak a „Treu und Glauben” alapján - a könnyen javítható hibák esetén mindig fennáll az eladó oldalán, azaz a vevőnek ilyen esetekben mintegy kötelessége a dolog kijavítását elfogadnia az eladótól. ${ }^{1358}$

\subsection{Elállás és vételárcsökkentés}

\subsubsection{Németország}

Az elállási jog az ún. második igényérvényesítési lépcsőben áll a jogosult rendelkezésére, és a BGB utaló szabálya alapján a kötelmi általános részben foglaltak szerint élhet vele a fogyasztó (§ 437). Az elállás tehát a visszterhes szerződés nemteljesítése vagy nem szerződésszerü teljesítése esetén alkalmazandó szerződésszegési jogorvoslat [§ 323 (1)]. A jog érvényesítése előtt a kötelezett számára megfelelö határidőt kell tüzni a teljesítésre vagy a pótteljesítésre:

„Erbringt bei einem gegenseitigen Vertrag der Schuldner eine fällige Leistung nicht oder nicht vertragsgemäß, so kann der Gläubiger, wenn er dem Schuldner erfolglos eine angemessene Frist zur Leistung oder Nacherfüllung bestimmt hat, vom Vertrag zurücktreten." 1359

\footnotetext{
${ }^{1353}$ Lásd többek között: KRAMER (1998), 211-212. p. Honsell a római jogi hagyományokra vezeti vissza a kijavítási jog hiányát, lásd: HoNSELL (2010), 101. p.

${ }^{1354}$ KÄSER (2000), 49. p. A joggyakorlathoz lásd többek között: BGE 91 II 344. számú ítélet.

1355 Lásd: GIGER (1979), 513. p.

1356 Giger (1979), 513-514. p.; KÄSER (2000), 49. p. 152. lj.; HonSELL (2010), 101. p. A tudomány megosztottsága a kérdésben egyébként az „Erfüllungstheorie” és a „,Gewährleistungstheorie” képviselőinek különböző álláspontjára vezethető vissza, a kérdéshez lásd: GULDIMANN (1986), 13-14. p.

${ }^{1357}$ KÄSER (2000), 49. p.; HONSELL (2010), 102. p.

${ }^{1358}$ GIGER (1979), 518. p.

${ }^{1359}$ BGB $\S 323$ (1).
} 
Amennyiben a kitüzött határidőn belül sem történik meg a szerződésszerü teljesítés, akkor élhet a fogyasztó az elállás jogával, amelyet egyoldalú jognyilatkozattal gyakorolhat. ${ }^{1360}$

A szerződésszerű teljesítésre vonatkozó határidőtűzés számos esetben mellőzhető, és az elállási jog ilyenkor lényegében feltétel nélkül gyakorolható. ${ }^{1361}$ Ezek az alábbi esetek:

1. ha a kötelezett a teljesítést súlyosan és végérvényesen megtagadja [§ 323 (2)],

2. az ún. fixhatáridős ügyletek esetén [§323 (2)],

3. olyan különös körülmények felmerülése esetén, amelyek mindkét fél érdekeit szem előtt tartva az elállási jog minél előbbi gyakorlását indokolják [§ 323 (2)],

4. abban az esetben akár az esedékesség előtt is, ha nyilvánvaló, hogy az elállás feltételei fenn fognak állni [§ 323 (4)],

5. amennyiben a szolgáltatás teljesítése a kötelezett (vagy bárki) számára lehetetlen [§ $275(1)]$,

6. ha olyan ráfordítást követel meg a teljesítés az eladótól, ami a kötelemre és a „,Treu und Glauben” elvére figyelemmel nagymérvű aránytalanságban áll a jogosultnak a szolgáltatáshoz füződő érdekével [§ 275 (1)],

7. ha a kötelem alapján az eladónak személyesen kellene teljesítenie, de az ezzel szemben felmerülő akadályok és a vevő teljesítéshez füződő érdekének összemérése alapján nem várhatóak el tőle [§ 275 (3)],

8. amennyiben az eladó a pótteljesítés mindkét módját megtagadja arra hivatkozva, hogy azok teljesítése csak aránytalan költségvonzattal lehetséges, ${ }^{1362}$

9. ha a pótteljesítés vevőt megillető formája meghiúsul [§ 440,2. mondat], valamint 10. ha a pótteljesítés vevőt megillető formája nem várható el az eladótól [§ 440, 1 . mondat].

Az Irányelv nem követel meg határidőtüzést a fogyasztótól az elállási jog gyakorlásához, így felmerül a német rendelkezések konformitásának kérdése. ${ }^{1363}$ Egyes tudományos álláspontok szerint azonban ezt a konformitási problémát irányelv-harmonikus jogértelmezéssel egyszerüen fel lehet oldani a BGB $§ 323$ (2) 3. mondata alapján. ${ }^{1364}$ Eszerint, amennyiben különös körülmények forognak fenn, amelyek mindkét fél érdekeinek mérlegelésével a mielőbbi elállást indokolják, akkor nem kötelező a határidőtűzés. ${ }^{1365}$

Az elállási jog gyakorlásának azonban egyéb korlátai is vannak: nem lehet elállni jelentéktelen kötelezettségszegés, azaz csekély kellékhiba esetén [ 323 (5) 2. mondat]. ${ }^{1366}$ Akkor sem megengedett az elállás, ha egyedül vagy túlnyomórészt a jogosultnak felróható

\footnotetext{
${ }^{1360}$ ZERRES (2010), 187. p.

1361 Ebben a körben a szabályozás áttekintése meglehetősen nehéz, mivel a BGB számtalan utaló normát tartalmaz. A teljes kérdéskörhöz lásd: CETINER (2006), 184-186. p.

${ }^{1362}$ Vö.: BGB $\S 439$ (3) és $\S 440,1$. mondat.

${ }^{1363}$ Vö. Irányelv, 3. cikk (5) bekezdés.

1364 Lásd: BGB $§ 323$ (2) 3. mondat: „Die Fristsetzung ist entbehrlich, wenn [...] besondere Umstände vorliegen, die unter Abwägung der beiderseitigen Interessen den sofortigen Rücktritt rechtfertigen.". 1365 Így vélekedik többek között LOOSCHELDERS (2011), 34-35. p.

${ }^{1366}$ Ez teljesen megfelel az Irányelv, 3. cikk (6) bekezdésének, valamint a BGB korábbi szabályának is.
} 
az a körülmény, ami őt az elállásra feljogosítaná, valamint, ha a kötelezettnek fel nem róható körülmény olyan idöben lép fel, amikor a jogosult késedelemben van az átvétellel [§ 323 (6)]. Ezen kívül a többségi tudományos álláspont szerint kizárt az elállás akkor is, ha az eladó pusztán mennyiségileg szolgáltatott kevesebbet a szerződésben kikötöttnél. ${ }^{1367}$

Az elállás jogkövetkezménye az eredeti, szerződéskötés előtti állapot helyreállítása. ${ }^{1368}$ A feleknek a kötelmi általános szabályok értelmében vissza kell szolgáltatni a korábban nyújtott szolgáltatásokat és az időközben keletkezett hasznokat, valamint a használatból eredő károkat is meg kell téríteni [BGB § 346 (1)]. Ez utóbbi szabály a német legfelsőbb bíróság döntése értelmében azért nem áll ellentétben az Irányelvvel, mert elállás esetén a vevő úgyis visszakapja a vételárat a kamatokkal együtt, és a rendeltetésszerü használatból eredő károk kívül esnek a megtérítési kötelezettségen. ${ }^{1369}$ A korábbi szabályozással ellentétben sosem kizárt az elállási jog az áru megsemmisülése esetén, hanem ilyenkor az áru értékének megtérítésére kötelezik a vevőt [§ 346 (2)]. Ismét felmerül azonban a kérdés, hogy mennyiben felel meg az Irányelvnek ez a rendelkezés. A jogtudomány álláspontja szerint, amennyiben a dolog a hiba miatt, rendeltetésszerü használat során semmisül meg, csak akkor alkalmazható a § 346 (2), azaz olyankor a vevő nem tartozik kártérítési kötelezettséggel. ${ }^{1370}$

A vételárcsökkentés nem került át a szerződésszegés általános szabályai közé, hanem megmaradt különös adásvételi jogintézménynek. A BGB, mint második lépcsős kellékszavatossági jogot szabályozza az elállási jog mellett. ${ }^{1371}$ Gyakorlásának előfeltétele a határidőtűzés a teljesítésre vagy pótteljesítésre, csakúgy, mint az elállási jognak, és arra csak a határidőtűzés sikertelen letelte után jogosult a vevő. ${ }^{1372}$ A jog érvényesítése, csakúgy, mint az elállásé, egyoldalú nyilatkozat útján foganatosítható. ${ }^{1373} \mathrm{Az}$ elállási joggal ellentétben azonban a vételárcsökkentés csekély hiba esetén is gyakorolható [§ 441 (2) 2. mondat].

Az eredeti szöveget fenntartva a BGB pontosan meghatározza a vételárcsökkentés mértékének számítási módját [BGB $§ 441$ (3)]. Olyan arányban kell a vételárat csökkenteni, amilyen arányban az adásvétel megkötésekor a hibátlan állapotban lévő dolog

\footnotetext{
${ }^{1367}$ Lásd: LOOSCHELDERS (2011), 37. p.

${ }^{1368}$ Lásd: ZERRES (2010), 187. p.

${ }^{1369}$ Lásd: BGH, NJW 2010, 148. számú döntés. Vö. BGB § 346 (2) 3. mondat.

${ }^{1370}$ LOOSCHELDERS (2011), 39-40. p.

${ }^{1371}$ DAUNER-LIEB - KONZEN - SCHMIDT (2003), 16. p. Lásd: BGB § 441 (1): , Statt zurückzutreten, kann der Käufer den Kaufpreis durch Erklärung gegenüber dem Verkäufer mindern.”.

1372 KÄMPF M. (2007), 136. p.; lásd: BGB $\S \S 441$ (1), 323 és 440.

${ }^{1373}$ KÄMPF M. (2007), 136. p.
} 
értéke a hibás dolog tényleges értékéhez viszonyul. ${ }^{1374}$ Amennyiben lehetséges, becslés útján kell megállapítani ezeket az értékeket. E relatív számítási módszer alapján a fogyasztó szavatossági igényének a kielégítése úgy megy végbe, hogy az eladó köteles a fenti módszer alapján kiszámított, csökkentett vételár és a már kifizetett vételár különbözetét a vevő részére visszatéríteni. ${ }^{1375}$ A módszer előnye, hogy megőrzi az ár-érték arány tekintetében a felek eredeti alkuját: a vevő számára kedvező vétel esetén a vételár az áru hibátlan objektív értékénél kevesebb, kedvezőtlen vétel esetén pedig több. A módszer a következő példával is szemléltethető:

1) A vevő számára kedvező vétel esete: „A” vett egy mobiltelefont 80 euróért, amelynek objektív piaci értéke hibátlan állapotban 100 euró, hibás állapotban pedig 60 euró. A mobiltelefonon nem használható több olyan alkalmazás, amely a szerződésben kikötött tulajdonságok részét képezi, de a vevő ezt csak a telefon átvétele után, otthon fedezi fel. $X$ az csökkentett vételárat jelöli. A relatív módszer alapján: $X / 80=60 / 100 \rightarrow X$ $=48$. A ténylegesen kifizetett 80 euró vételárból tehát a vevő 48 eurót kap vissza sikeres vételárcsökkentési igény érvényesítése esetén.

2) A vevő számára kedvezőtlen vétel esete: A vevő ugyanazért a mobiltelefonért 120 eurót fizetett. A számítás képlete így: $X / 120=60 / 100 \rightarrow X=72$. Azaz a vevő a ténylegesen kifizetett 120 euróból 72 eurót kap vissza vételárcsökkentés címén. Ha a két esetet összehasonlítjuk: a 48/80 és a 72/120 aránya megegyezik, így a vevő igényérvényesítése esetén az ár-érték arány „kompenzálásának” igénye a relatív módszer törekvéséhez igazodva célt ér.

A már nyújtott szolgáltatást a vételárcsökkentési igény esetén is vissza kell adni az elállás szabályai szerint, valamint a hasznokat (vagy azok helyett az értéküket) megfelelően vissza kell téríteni fogyasztói adásvétel esetén is. ${ }^{1376}$ A vételárcsökkentés igénye az elállással ellentétben azonban akkor sem zárható ki, ha egyedül vagy túlnyomórészt a jogosultnak felróható az a körülmény, ami őt a vételárcsökkentésre feljogosítja. $^{1377}$

\footnotetext{
${ }^{1374}$ Vö. a korábbi rendelkezéssel, lásd: I. rész 2. fejezet 2.5. pont.

${ }^{1375}$ A kérdéskörhöz lásd: CETINER (2006), 184-186. p.; LOOSCHELDERS (2011), 40. p.; GRUNEWALD (2006), 208-209. p. A hatályos szabályokban a korábbiaknak megfelelően a történeti megoldás tükröződése figyelhető meg, lásd: I. rész 1. fejezet 3.4.2. pont és 2. fejezet 2.5. pont.

${ }^{1376}$ Ellentétben a kicserélés igényénél említettekkel, lásd: BGB $§ 474$ (2) és a § 441 (4) utaló szabálya a § 346 (1) és a § 347 (1) rendelkezéseire.

${ }^{1377}$ Vö. BGB § 323 (6). GRUNEWALD (2006), 209. p.
} 


\subsubsection{Ausztria}

A vevő második lépcsős jogai közé az áru-vételár értékarányának helyreállítását célzó árleszállítás, és a szerződés előtti eredeti állapot helyreállítását célzó elállás joga tartozik az osztrák jogban is. Előfeltétele e két jog gyakorlásának, hogy (1) az átadó az első lépcsős jogok teljesítését megtagadja, vagy (2) azokat nem megfelelő határidőn belül hajtja végre, vagy (3) az első lépcsős jogok az átvevőnek jelentős kellemetlenséget okoznának, illetve (4) hogy azok teljesítése az átadótól, az „ő személyéhez kapcsolódó nyomós okból nem vélelmezhető" [ABGB § 932 (4)]. Az első három feltétel az első lépcsős jogok teljesítésére vonatkozó szabályokból is következik, az utolsó feltétel azonban értelmezésre szorul. A jogirodalom álláspontja szerint nem lehet e vélelmet fenntartás nélkül elfogadni, mert könnyen kijátszható vele az első lépcsős jogok primátusa. Ezért csak akkor lehet rá hivatkozni, ha az átadó személyéhez kapcsolódó ok az ö gondatlanságából vagy képzetlenségéből fakad. ${ }^{1378}$

Az árleszállítás jogáról, annak érvényesítési módjáról nem rendelkezik explicite az ABGB. A gyakorlatban az igény érvényesítése attól függ, hogy az átvevő kifizette-e már a vételárat vagy sem. ${ }^{1379}$ Ha nem, akkor az átadó fizetés iránti követelésével szemben kifogásában követelheti az átvevő a vételár tényleges csökkentését. Ha már fizetett, akkor az osztrák joggyakorlat a német magánjogból átvett relatív számítási módszert alkalmazza, ami egyébként a már említett szubjektív egyenértékűség tanából is levezethető. ${ }^{1380}$

Az elállás az eredeti állapot helyreállítására irányul, mintha a szerződést meg sem kötötték volna, ezért a felek visszakövetelhetik a már nyújtott szolgáltatásokat: a vevő a vételárat, az eladó pedig az árut. ${ }^{1381} \mathrm{Az}$ elállásnak, mint a legradikálisabb szavatossági igénynek az Irányelvvel és a BGB szabályával egyezően tehát nincs helye jelentéktelen hiba esetén [ABGB § 932 (4)]. ${ }^{1382}$ Sokszor nehéz azonban megállapítani, hogy mely hiba tekinthető jelentéktelennek. Az objektív körülményeknek (például a hiba miatti értékcsökkenésnek és az arányosságnak) valamint a szubjektív jellemzőknek (például egy

\footnotetext{
1378 PERNER - SPITZER (2007), 169. p.

1379 PERNER - SPITZER (2007), 169. p.

1380 Lásd: SÄÄF (2005), 56. p.; PERNER - SPITZER (2007), 170. p.; FERCH-FISCHER (2011), 55. p.

${ }^{1381}$ Ez az ABGB $§ 1435$ szabályán alapul, amely szerint, ha megszünik az a jogalap, amely alapján dolgok kerültek átadásra, akkor azokat az átadó jogosult visszakövetelni, lásd: PERNER - SPITZER (2007), 170. p.

1382 Gépjármü vételével kapcsolatban jelentéktelen például a fenti navigációs rendszerbeli hiba, amely a müködőképességet egyébként nem befolyásolja, vagy a sebváltó funkcionális károsodás nélkül jelentkező vibráló zaja, lásd: PERNER - SPITZER (2007), 170. p.
} 
tulajdonságra vonatkozó kifejezett ígéretnek) egyaránt jelentőséget kell tulajdonítani a kérdés megítélésénél. ${ }^{1383}$

\subsubsection{Svájc}

Az OR-nek a vevő által gyakorolható jogokról szóló rendelkezése szerint az elállás a német és osztrák joggal egyezően a vétel előtti állapot helyreállítására irányul, ${ }^{1384}$ és emellett ennek a gyakorlati megvalósulását is rendezni igyekszik a törvény. Akkor is elállhat a vevő a vételtől, ha a dolog a hiba vagy véletlen esemény következtében elpusztul, és ebben az esetben csak azt kell visszaadnia, ami a dologból megmaradt [OR § 207 (1)(2)]. ${ }^{1385}$ Ha a dolog nem semmisült meg, akkor azt minden időközben beszedett hasznával együtt vissza kell adni az eladónak. Az eladó sem csupán a vételárat köteles visszafizetni a vevő részére, hanem annak kamatait, ezen felül pedig az esetleges eljárási költségeket és a vevőnek a dologra költött ráfordításait is [OR $§ 208$ (1)-(2)]. ${ }^{1386}$

A törvény rendezi azt a kérdéskört is, amikor több együttesen eladott dologból vagy egy dologösszességből csak egy dolog kellékhibás. Ebben az esetben a föszabály az, hogy az elállás csak a hibás dolog vonatkozásában gyakorolható [OR § 209 (1)]. Kivételt képez, ha a hibás dolog a vevőnek vagy az eladónak okozott jelentős hátrány nélkül nem választható el a többitől: ekkor az elállásnak az összes dologra ki kell terjednie [OR § 209 (2)]. Ha tartozék vagy alkatrész is része a vételnek, akkor az OR megköveteli, hogy a fődolog esetén gyakorolt elállás a mellékdologra is kiterjedjen, még akkor is, ha az utóbbira külön vételárat határoztak meg a szerződésben. Fordított esetben azonban a mellékdolog vonatkozásában gyakorolt elállás nem terjedhet ki a födologra [OR § 209 (3)]. ${ }^{1387}$

A vagylagosan válaszható vételárcsökkentés mértékével és módjával kapcsolatban nem tartalmaz részletszabályokat az OR, csupán arról rendelkezik, hogy ez az igény a dolog hiba miatti értékcsökkenésének a követelését jelenti [§ 205 (1)]. Az értékcsökkenés

\footnotetext{
${ }^{1383}$ Lásd: FERCH-FISCHER (2011), 51. p.; Gewährleistungsreform (2001), 4. p.

${ }^{1384}$ Lásd: OR § 205: ,„... mit der Wandelungsklage den Kauf rückgängig zu machen ...”.

${ }^{1385} \mathrm{Ez}$ a rendelkezés a mortuus redhibetur római jogi problémájának megoldása. Vö. ZIMMERMANN (1996), 331-334. p.; WAGNER (2006), 593-595. p.

${ }^{1386}$ Ezeken kívül kártérítési kötelezettség is terheli, lásd később: jelen fejezet 7.4.3. pont. Ez a rendelkezés is a BGB korábbi szabályát tükrözi, lásd: I. rész 2. fejezet 2.4. pont.

${ }^{1387}$ Ezek a fenti szabályok teljes mértékben megfelelnek az ABGB és a BGB eredeti rendelkezéseinek, vö.: I rész 2. fejezet 1.3. és 2.4. pontok.
} 
kiszámításánál a többségi tudományos álláspont és a judikatúra - az osztrákkal egyezően a német polgári jogból ismert relatív számítási módszert támogatja. ${ }^{1388}$

A vevő választási jogának korlátját jelenti az, hogy ha jogvitára kerül sor, akkor elállási igény érvényesítése esetén is dönthet úgy a bíró, hogy vételárcsökkentést ítél meg, ha az adott jogeset körülményei az elállást nem indokolják [OR § 215 (2)]. ${ }^{1389}$ Ezen kívül a szabad választás korlátját képezi az is, hogy ha a vevö által vételárcsökkentésként követelt, a dologban beállt értékcsökkenés összege elérné a vételárat, akkor is csupán az elállási jogot érvényesítheti a vételárcsökkentési igény helyett [OR § 205 (3)]. A harmadik megszorítás szerint, amennyiben a vétel tárgya a vevő felróhatósága miatt pusztult el, vagy ő azt átalakította vagy elidegenítette, akkor nem érvényesíthet elállást, csupán vételárcsökkentést [OR § 207 (3)]. E korlátozások fényében meglehetősen relatívvá válik a vevőnek látszólag nagy szabadságot biztosító választási jog, ami ugyancsak a szabályozás fogyasztóvédelmi deficitjeként fogható fel. ${ }^{1390}$

\subsection{Kártérítés}

\subsubsection{Német jog}

A hibás teljesítéssel összefüggésben keletkezett károk tekintetében a német jogtudomány megkülönbözteti az ún. tapadó károkat az ún. következménykároktól. ${ }^{1391} \mathrm{Az}$ előbbi (Mangelschäden) az adásvétel tárgyában a kellékhiba miatt beálló károkat jelenti, így például az értékcsökkenést, amelyet a hiba más ugyanolyan hibátlan dologgal összehasonlítva generált a dologban. ${ }^{1392}$ A következménykárok (Mangelfolgeschäden) olyan károkat jelentenek, amelyek a kellékhiba folytán a dolgon kívül jelentkeznek,

\footnotetext{
${ }^{1388}$ HONSELL (2010), 108. p.; KELLER - SIEHR (1995), 92. p. A relatív módszer a korábban említettek szerint a pandektajogban gyökerezik, lásd: GIGER (1979), 509. p. A joggyakorlathoz lásd többek között: BGE 111 II 162. számú ítélet: „Gemäss der relativen Methode entspricht das Verhältnis zwischen dem herabgesetzten Preis und dem vereinbarten Preis dem Verhältnis zwischen dem objektiven Wert des Kaufgegenstandes mit Mangel und seinem Wert ohne Mangel.”. Az abszolút módszert a joggyakorlat elveti, lásd például: BGE 81 II 210. számú döntés.

${ }^{1389}$ Ez a kereseti kérelemhez kötöttség áttörésének lehetősége. Erre az esetre azonban a joggyakorlatban nincs számottevő példa, így a jogtudomány szerint általánosságban csak az a megállapítás tehető, hogy jelentéktelen hiba, illetve megígért tulajdonság hiányában van lehetőség adott esetben elállásról a vételárcsökkentésre való bírói áttérésre, lásd: HONSELL (2010), 108. p.

${ }^{1390}$ Lásd többek között: PICHONNAZ (2003), 292. p. A kellékszavatossági igények szabályai összességében nagyon hasonlítanak a BGB eredeti szabályaira, vö. I. rész 2. fejezet 2. pont.

1391 Lásd: ZIMMERMANN (2005), 36. p. A magyar elnevezéseket a magyar jogtudományban és joggyakorlatban használatos kategóriáknak megfelelően alkalmazom, lásd: II. rész 3. fejezet 2.5.3. pont.

${ }^{1392}$ ZIMMERMANN (2005), 36. p.
} 
például más vagyontárgyakban. ${ }^{1393} \mathrm{E}$ kategóriák fényében a hibás teljesítés miatti kártérítést a teljesítés helyett vagy a teljesítés mellett követelheti a vevő. ${ }^{1394}$

A „teljesítés helyetti kártérítés” esetén a vevő olyan károkat követelhet, amelyeket elsősorban a kellékszavatossági jogok révén lehet orvosolni. ${ }^{1395}$ Amennyiben az eladónak módja volt a pótteljesítés foganatosítására, de az mégsem volt sikeres, a vevő igényére a $\S$ 281 (1) bekezdésének szabálya irányadó:

„, Soweit der Schuldner die fällige Leistung nicht oder nicht wie geschuldet erbringt, kann der Gläubiger unter den Voraussetzungen des $\S 280$ Abs. 1 Schadensersatz statt der Leistung verlangen, wenn er dem Schuldner erfolglos eine angemessene Frist zur Leistung oder Nacherfüllung bestimmt hat. Hat der Schuldner eine Teilleistung bewirkt, so kann der Gläubiger Schadensersatz statt der ganzen Leistung nur verlangen, wenn er an der Teilleistung kein Interesse hat. Hat der Schuldner die Leistung nicht wie geschuldet bewirkt, so kann der Gläubiger Schadensersatz statt der ganzen Leistung nicht verlangen, wenn die Pflichtverletzung unerheblich ist."

A legfontosabb előfeltétele az ilyen teljesítés helyetti kártérítési követelésnek, hogy azt megelőzően az eladó számára megfelelő határidőt kell tűzni a teljesítésre illetve pótteljesítésre. A határidőtűzéstől akkor lehet eltekinteni, ha az eladó súlyosan és véglegesen megtagadja a szolgáltatást, azaz a pótteljesítést, vagy ha olyan különös körülmények lépnek fel, amelyek mindkét fél érdekeit számításba véve a kártérítési igény mielőbbi érvényesítését indokolják. ${ }^{1396}$ Ha a teljesítés csak részben hibás, akkor csak olyan esetben van helye a teljesítés helyetti kártérítési követelésnek, ha a vevő bizonyítja a teljesítéssel kapcsolatos érdekmúlását. A rendelkezés utolsó mondata szerint akkor nem lehet a szolgáltatás helyetti kártérítést követelni, ha a szerződésszegés jelentéktelen.

E szabály hatálya alá a fenti két kategória közül a tapadó károk esnek, így a vevő ennek keretében követelheti például a kijavítási költségeket, a dolog hiba miatti értékcsökkenését, az ún. fedezeti vétel költségeit, stb. ${ }^{1397}$ A teljesítés helyetti kártérítésre a teljesítés melletti kártérítésre vonatkozó szabályok megfelelő alkalmazását rendeli a fenti szabály.

\footnotetext{
${ }^{1393}$ ZIMMERMANN (2005), 36. p.

${ }^{1394}$ Lásd: BGB $§ 437$ 3. tagmondatának utaló szabálya. GRUNEWALD (2006), 209-210. p.

1395 „, Schadensersatz statt der Leistung”; KäMPF M. (2007), 136. p.

1396 Lásd: BGB § 281 (2): ,,Die Fristsetzung ist entbehrlich, wenn der Schuldner die Leistung ernsthaft und endgültig verweigert oder wenn besondere Umstände vorliegen, die unter Abwägung der beiderseitigen Interessen die sofortige Geltendmachung des Schadensersatzanspruchs rechtfertigen.".

${ }^{1397}$ GRUNEWALD (2006), 210. p.
} 
A hibás teljesítésből eredő „teljesítés melletti” kártérítési igényre ugyancsak a szerződésszegés általános szabályainak alkalmazását rendeli a BGB: ${ }^{1398}$

„Verletzt der Schuldner eine Pflicht aus dem Schuldverhältnis, so kann der Gläubiger Ersatz des hierdurch entstehenden Schadens verlangen. Dies gilt nicht, wenn der Schuldner die Pflichtverletzung nicht zu vertreten hat." 1399

E szabály szerint, ha a kötelezett megsérti a kötelemböl fakadó valamely kötelezettségét, akkor a jogosult az ebből fakadó kárának a megtérítését követelheti. A BGB tehát kifejezetten szabályozza a szerződésszegésből eredő kártérítés kategóriáját. E kártérítési felelősségnek a kötelezett felróható magatartásán kell alapulnia, tehát ez az eladó hibás teljesítésének a szubjektív jogalapú jogkövetkezménye. A teljesítés melletti kártérítés keretei között olyan vagyoni érdeksérelem orvoslására kerülhet sor, amely a kellékszavatossági jogok keretei között nem lenne lehetséges. ${ }^{1400}$ Így a fogyasztó követelheti a következménykárokat, a hiba megállapításának költségeit, a szakértői vélemények költségeit, az esetlegesen elmaradt hasznot, stb. ${ }^{1401}$

A német jogalkotó - kihasználva azt, hogy az EU-s jogalkotó az Irányelv hatályát a hibás teljesítés miatti kártérítési kötelezettségre nem terjesztette ki - úgy rendelkezett, hogy a fogyasztói adásvételi szabályokra egyébként jellemző klaudikáló kógencia nem érvényesül e kötelezettségek esetén. ${ }^{1402}$ Azaz az eladó a hibás teljesítés miatti kártérítési kötelezettségét a fogyasztóval szemben korlátozhatja, vagy akár ki is zárhatja. ${ }^{1403} \mathrm{~A}$ felelősség kizárásának egyetlen korlátja a tisztességtelen ÁSZF-re vonatkozó szabályozás, különösen a BGB § 309 7. mondat b) pontja, amely mérlegelés nélkül semmisnek nyilvánítja az olyan szerződési feltételeket, amelyek súlyos gondatlanság esetére korlátozzák vagy kizárják az eladó szerződésszegéséből eredő kártérítési kötelezettségét. ${ }^{1404}$

\footnotetext{
${ }^{1398}$ Lásd: BGB $§ 437$ (3) utaló szabálya.

${ }^{1399}$ Lásd: BGB $§ 280(1)$.

1400 GRUNEWALD (2006), 210. p.

1401 GRUNEWALD (2006), 210. p.

${ }^{1402}$ Vö. BGB $§ 475$ (3).

${ }^{1403}$ LOOSCHELDERS (2011), 84. p.; SCHULZE - GRZIWOTZ - LAUDA (2011), 657. p.

1404 LOOSCHELDERS (2011), 84. p. Lásd: BGB § 309 7. b): „Auch soweit eine Abweichung von den gesetzlichen Vorschriften zulässig ist, ist in Allgemeinen Geschäftsbedingungen unwirksam [...] ein Ausschluss oder eine Begrenzung der Haftung für sonstige Schäden, die auf einer grob fahrlässigen Pflichtverletzung des Verwenders oder auf einer vorsätzlichen oder grob fahrlässigen Pflichtverletzung eines gesetzlichen Vertreters oder Erfüllungsgehilfen des Verwenders beruhen...".
} 


\subsubsection{Osztrák jog}

A hibás teljesítésből származó károk megtérítésének szabályát a 2001-es módosítások építették be a szavatossági rendelkezések közé, de az osztrák legfelsőbb bíróság - a többségi jogtudományi álláspontnak megfelelően - már jóval korábban kimondta a szavatossági és kártérítési szabályok konkurenciáját. ${ }^{1405}$ A jogalkotó és a jogtudomány is úgy emlegeti a szabályt, mint „szavatosság helyetti kártérítés”. ${ }^{1406}$ Amennyiben a dolog hibája az átadónak felróható, akkor az átvevő kártérítést is követelhet. Az ABGB szerinti „általános” kártérítés előfeltétele a kár, az okozatosság, a jogellenesség és a felróhatóság. ${ }^{1407} \mathrm{Az}$ utóbbit a fenti szabály is kimondja, amely a jogkövetkezmény szubjektív jogalapjára utal. ${ }^{1408}$ A kártérítés módját illetően azonban a hibás teljesítésből eredő kártérítési szabályok nem az általános kártérítési rendelkezésekre utalnak, hanem a szavatossági jogokhoz közelítik ezt az igényt: ${ }^{1409}$

„Wegen des Mangels selbst kann der Übernehmer auch also Schadenersatz zunächst nur die Verbesserung oder den Austausch verlangen. Er kann jedoch Geldersatz verlangen, wenn sowohl die Verbesserung als auch der Austausch unmöglich ist oder für den Übergeber mit einem unverhältnismäßig hohen Aufwand verbunden wäre. Dasselbe gilt wenn der Übergeber die Verbesserung oder den Austausch verweigert oder nicht in angemessener Frist vornimmt, wenn diese Abhilfen für den Übernehmer mit erheblichen Unannehmlichkeiten verbunden wären oder wenn sie ihm aus triftigen, in der Person des Übergebers liegenden Gründen unzumutbar sind." 1410

A rendelkezés a kártérítési követelést is mintegy lépcsőkre bontja. E szabály alapján a hiba miatti kártérítésként először csak kijavítást vagy kicserélést követelhet a vevő, azaz ennél az igénynél is a teljesítési érdeksérelem orvoslása az elsődleges cél. ${ }^{1411}$

A jogirodalomban „kártérítési árleszállításnak” (schadenersatzliche Preisminderung ${ }^{1412}$ ) is nevezett igény keretében a károk pénzben történő megtérítését az átvevő csak a másodlagos szavatossági jogok alkalmazási feltételeinek fennállása esetén

\footnotetext{
1405 Az OGH 7.3.1990 SZ 63/37. számú döntésének rendelkező része materializálódott a 2002-től hatályos rendelkezésben, lásd: SÄÄF (2005), 57. p.

${ }^{1406}$ Lásd: ABGB § 933a (1): „Hat der Übergeber den Mangel verschuldet, so kann der Übernehmer auch Schadenersatz fordern.". Lásd többek között: PERNER - SPITZER (2007), 174. p.; FERCH-FISCHER (2011), 58. p.; KLETECKA (2001), 63. p. Vö. BGB § 281 (1) [„,teljesítés helyetti kártérítés”].

1407 ABGB $\S \S 1293-1296$, lásd: PERNER - SPITZER (2007), 266. p.

${ }^{1408}$ Lásd: FERCH-FISCHER (2011), 59. p.

${ }^{1409}$ SÄÄF (2005), 57. p.

${ }^{1410}$ Lásd: ABGB § 933a. (2).

${ }^{1411}$ SÄÄF (2005), 57. p.

1412 PERNER - SPITZER (2007), 175. p.
} 
követelheti. ${ }^{1413}$ A „Geldersatz” emellett magában foglalja a „kártérítési elállást” (schadenersatzliche Wandlung ${ }^{1414}$ ) is.

A „kártérítési árleszállítás” abban különbözik az árleszállítás rendes szavatossági igényétől, hogy az utóbbi a szerződéses jogviszonyon belüli alakítójog. ${ }^{1415}$ Ezen kívül, míg a szavatossági árleszállítás számításának módja a joggyakorlatban a vételárat és az értékcsökkenést is figyelembe vevő relatív módszer, addig a kártérítés keretében csak a hibás és hibátlan dolog értékének a különbsége követelhető. ${ }^{1416}$ A szavatossági igények és a hibás teljesítésből eredő kártérítési jog konkurenciáját azért is hangsúlyozzák a jogtudományban, mert az igényérvényesítés nem vezethet az átvevő alaptalan gazdagodására. ${ }^{1417}$ A két igény együttes alkalmazása csak akkor képzelhető el, ha a hiba csak részben javítható ki. ${ }^{1418}$

„Kártérítési árleszállítás” illetve „kártérítési elállás” esetén is a teljesítési érdeksérelem térítendő meg, elsődlegesen tehát az ún. tapadó károk, azaz a dologban a hiba miatt bekövetkező károk megtérítését lehet követelni. ${ }^{1419}$

A következménykárok jogi megítélése azonban eltérő. A jogtudomány ezekre az általános kártérítési szabályokat tartja alkalmazandónak. ${ }^{1420} \mathrm{Ez}$ mindenekelött azt jelenti, hogy a joggyakorlat nem követeli meg a kijavítás és kicserélés elsődlegességét a kártérítés módja vonatkozásában. ${ }^{1421} \mathrm{Az}$ ABGB általános kártérítési szabálya az § 1298-ban található, amely többek között arról rendelkezik, hogy azt terheli a felróhatóság hiányának a bizonyítása, aki arra hivatkozik: az eladó (átadó) felróhatósága tehát vélelmezendő. Ennek megfelelően az eladónak kell kimentenie magát, azaz bizonyítania, hogy neki nem felróható a kár bekövetkezése.

Az osztrák jogtudomány elkülöníti a következménykároktól az ún. kísérő károkat (Begleitschäden), amelyek egyáltalán nem a hibás teljesítésből, hanem a teljesítés során tanúsított gondatlanságból és elővigyázatlanságból fakadnak. ${ }^{1422}$ Annyiban hasonlítanak a

\footnotetext{
${ }^{1413}$ Vö. ABGB $§ 932$ (2) és (4).

${ }^{1414}$ Lásd PERNER - SPITZER (2007), 175. p. szóhasználatát.

1415 SÄÄF (2005), 56. p.

${ }^{1416}$ Lásd: FERCH-FISCHER (2011), 59. p.

1417 Lásd: SÄÄF (2005), 58. p.

1418 Lásd: SÄÄF (2005), 58. p.

${ }^{1419}$ Lásd: PERNER - SPITZER (2007), 174. p.; SÄÄF (2005), 58. p.

${ }^{1420}$ Speciális rendelkezés hiányában, az ABGB § 933a. figyelembe vételével, lásd: PERNER - SPITZER (2007), 176. p.

${ }^{1421}$ Lásd: FERCH-FISCHER (2011), 60-61. p.

${ }^{1422}$ Például a bútor kiszállítása alkalmával kárt okoznak a fogyasztó parkettájában, lásd: FERCH-FISCHER (2011), 58. p.
} 
következménykárokhoz, hogy ezek esetén is a kártérítés általános szabályai alkalmazandóak. ${ }^{1423}$

Probléma a következménykároknál akkor merül fel a gyakorlatban, ha az átvevőnek jelentős a hiba következtében felmerült kára, de nem az eladó kereskedőnek róható fel a hibás teljesítés, hanem a gyártónak. Erre példa, ha gyártási hiba miatt (azaz a gyártónak lehetségesen felróható ok miatt) egy televíziókészülék kigyullad, és a tüz miatt jelentős anyagi kár keletkezik a lakásban. A másik, a hibás teljesítésből eredő kárral kapcsolatos speciális problémát az jelenti az osztrák jogtudomány szerint, ha a hiba már a szerződéskötés idején fennállt, és nem javítható ki. ${ }^{1424} \mathrm{Ez}$ az eset áll fenn például akkor, ha a használtautó km-óráját az előző tulajdonos visszatekerte. Ez a hiba nyilvánvalóan nem javítható, így ha kiderül a hiba, akkor a vevő nem a teljesítési érdeksérelmet, hanem a vételár visszafizetése („kártérítési elállás”) mellett az ún. biztatási károk (Vertrauensschäden) megtérítését jogosult követelni. ${ }^{1425}$ Az utóbbihoz tartoznak például a szerződéskötési vagy a szerződéskötés miatti utazási költségek. ${ }^{1426}$

\subsubsection{Svájci jog}

A svájci adásvételi jog általános kártérítési szabálya így rendelkezik:

„Kommt der Verkäufer seiner Vertragspflicht nicht nach, so hat er den Schaden, der dem Käufer hieraus entsteht, zu ersetzen." 1427

Amennyiben tehát az eladó nem teljesíti szerződéses kötelezettségét, meg kell térítenie a vevő ebből fakadó kárát. A hibás teljesítés miatti speciális kártérítés iránti igény nem elkülönítve, hanem az egyes kellékszavatossági igényekről szóló rendelkezések közé ékelve található meg. Az egyik ilyen rendelkezés szerint fajlagos vételnél az eladó jogosult a kicserélés igényét magától is teljesíteni, ebben az esetben azonban meg kell térítenie a vevő összes kárát is annak érdekében, hogy a továbbiakban a vevő egyéb igényeinek teljesítése alól mentesüljön [OR § 206 (2)].

A jogtudományban a viták általában abból fakadnak, hogy az OR a hibás teljesítés miatti másik, az elállási jog körében szabályozott kártérítési kötelezettség tekintetében

\footnotetext{
${ }^{1423}$ Ugyanúgy a $§ 1298$-ban szabályozott vélelem is, lásd: PERNER - SPITZER (2007), 176. p.

${ }^{1424}$ Lásd: PERNER - SPITZER (2007), 175. p.

${ }^{1425}$ Lásd: PERNER - SPITZER (2007), 175. p.

${ }^{1426}$ PERNER - SPITZER (2007), 175. p.

${ }^{1427}$ Lásd: OR § 91 (1).
} 
differenciál, és nem is ad kellően világos fogalmat. ${ }^{1428} \mathrm{Ez}$ a rendelkezés az OR § 208-ban szerepel:

„Der Verkäufer hat den gezahlten Verkaufspreis samt Zinsen zurückzuerstatten und überdies, entsprechend den Vorschriften über die vollständige Entwehrung, die Prozesskosten, die Verwendungen und den Schaden zu ersetzen, der dem Käufer durch die Lieferung fehlerhafter Ware unmittelbar verursacht worden ist.

Der Verkäufer ist verpflichtet, den weitern Schaden zu ersetzen, sofern er nicht beweist, dass ihm keinerlei Verschulden zur Last falle."

A rendelkezés alapján az eladónak meg kell térítenie az eljárási költségeket, a ráfordításokat és azokat a károkat, amelyeket a hibás áru szolgáltatása a vevőnek közvetlenül okozott. Ezen felül az eladó köteles a többi kárt is megtéríteni, amennyiben nem tudja kimenteni magát, azaz bizonyítani, hogy semmilyen felróhatóság sem esik a terhére.

Kettős kártérítési rendelkezésről van tehát szó: az OR először a hibás teljesítéssel közvetlenül okozott károkról szól, amelyekért az eladónak objektív jogalapon kell helytállnia; a hibás teljesítéssel „nem közvetlenül okozott” egyéb károkért azonban felróhatósági alapon felel. ${ }^{1430}$ A svájci jogtudományban és a joggyakorlatban e két bekezdés elhatárolása és értelmezése heves vita tárgyát képezi. A problémát a negatív és pozitív interesse, illetve a közvetlen és közvetett károk közötti különbségtétel, valamint ezekkel összefüggésben a következménykárok rendszerezése jelenti. ${ }^{1431}$

A joggyakorlat az objektív jogalapú kártérítést csupán az elállás esetén engedi meg. ${ }^{1432}$ Honsell szerint ezekhez a közvetlenül a hibás teljesítéssel okozott károkhoz tartoznak a tapadó károk és az ún. „továbbható károk” is. ${ }^{1433}$ A harmadik, ide tartozó kárkategória pedig az árfolyamveszteség, amennyiben a dolog vételára külföldi valutában volt meghatározva. ${ }^{1434}$

A következménykárok a svájci jogtudomány szerint eshetnek a negatív és a pozitív interesse kategóriájába is. ${ }^{1435}$ A probléma a gyakorlatban abból adódik, hogy sokan a negatív interessét automatikusan az objektív jogalapú, míg a pozitív interessét a szubjektív

\footnotetext{
${ }^{1428}$ HONSELL (2010), 110. p.

${ }^{1429}$ Lásd: OR § 208 (2)-(3).

${ }^{1430}$ Ez a kategorizálás megfelel a BGB hatályos szabályozásának, vö. BGB $§ \S 280$ (1) és 281 (1).

${ }^{1431}$ Lásd: HoNSELL (2010), 111-112. p.

1432 Lásd például: BGE 107 II 165. számú ítélet.

${ }^{1433}$ HoNSELL (2010), 111. p.: „Mangelschaden” és „,weiterfressende Mangel”. Az utóbbira Honsell azt a példát hozza, ha egy gép nem müködő hőszabályzója miatt károsodik maga a gép.

${ }^{1434}$ HONSELL (2010), 111. p.: BGE 45 II 82. számú ítélet.

1435 Lásd többek között: HoNSELL (2010), 112. p.
} 
jogalapú kártérítési rendelkezéssel kapcsolják össze. ${ }^{1436}$ Egységes azonban a tudományos álláspont az elmaradt haszon vonatkozásában, amelynek megtérítését csak szubjektív jogalapon engedi meg. ${ }^{1437}$ A többségi tudományos álláspont alapján a következménykárok megtérítésének sem lehet objektív a jogalapja, így azokat az OR § 208 (3) szabálya szerint kell kezelni. ${ }^{1438}$

\subsection{Jótállás}

\subsubsection{Német jog}

A jótállási nyilatkozatok a gazdasági verseny egyre jelentősebb eszközei, amelyeknek a fogyasztói érdekeket is szolgálniuk kell. ${ }^{1439}$ Ahhoz, hogy a versenyben a konkurenciával szemben a vásárlók minél szélesebb körét megnyerje egy vállalkozó, olyan jótállási nyilatkozatra van szüksége, amely nem csak kedvező, hanem a fogyasztó számára világos és egyértelmü is; az ezzel ellentétes jótállás nem csak a fogyasztói érdekeket sérti, hanem a versenyt is gátolja. ${ }^{1440}$

A német kódex az Irányelv implementációja nyomán a jótállás két fajtáját szabályozza az adásvétel általános rendelkezései között: a dolog minőségéért (Beschaffenheitsgarantie) és tartós használhatóságáért (Haltbarkeitsgarantie) vállalt jótállást [BGB $§ 443$ (1)]. A jótállás mindkét esetében önkéntes, szerződésen (megállapodáson) alapuló, vagy egyoldalúan felvállalt kötelezettségvállalásról van szó, azaz jogszabály nem ír elő jótállási kötelezettséget a német jogban. Az Irányelvnek megfelelően nem csak az eladó, hanem harmadik, azaz az adásvételi szerződésen kívüli személy is vállalhat jótállást [BGB $§ 443$ (1)]. Ez a harmadik személy a gyakorlatban általában a termék gyártója vagy forgalmazója. A jogtudomány ezért a jótállásra kötelezett alapján különbséget tesz az ún. „Verkäufergarantie” és a „Herstellergarantie” között. ${ }^{1441}$ Az uralkodó ítélkezési gyakorlat szerint, amennyiben a termék gyártója vagy importőre jótállási jegyet mellékel az áruhoz, akkor azzal az eladón, mint „képviselőn” keresztül olyan megállapodás keletkezik, amely megalapozza az eladó helytállását is a gyártói jótállás alapján. ${ }^{1442}$ A jótállásra vonatkozó rendelkezés a BGB-ben a következő:

\footnotetext{
${ }^{1436}$ KELLER - SIEHR (1995), 60. p.

${ }^{1437}$ Lásd: BUCHER (1988), 105. p.

1438 Lásd: GIGER (1979), 575-580. p.; KELLER - SIEHR (1995), 90. p.; HONSELL (2010), 113. p.

${ }^{1439}$ PIRKER-HÖRMANN - HAMMERL (2004), 45. p.

1440 Lásd: PIRKER-HÖRMANN - HAMMERL (2004), 45. p.

${ }^{1441}$ Lásd: PlATE (2011), 754. p.

${ }^{1442}$ Lásd: PlATE (2011), 754. p.
} 
„Übernimmt der Verkäufer oder ein Dritter eine Garantie für die Beschaffenheit der Sache oder dafür, dass die Sache für eine bestimmte Dauer eine bestimmte Beschaffenheit behält (Haltbarkeitsgarantie), so stehen dem Käufer im Garantiefall unbeschadet der gesetzlichen Ansprüche die Rechte aus der Garantie zu den in der Garantieerklärung und der einschlägigen Werbung angegebenen Bedingungen gegenüber demjenigen zu, der die Garantie eingeräumt hat.",1443

A jótállás egy objektív jogalapú, azaz a jótállást vállaló személy felróhatóságától független helytállást keletkeztető jogintézmény, amely a jótállási nyilatkozatban illetve az arra vonatkozó reklámban foglaltaknak megfelelöen köti az eladót. ${ }^{1444}$ Olyan kötelezettségvállalásként definiálja a törvény, ami garantálja az áru minőségét, illetve azt, hogy az eladott áru meghatározott ideig meghatározott minőséggel fog rendelkezni. A tartós használhatóságért vállalt jótállás esetén fennáll a vélelem, hogy az annak időtartama alatt jelentkező kellékhiba megalapozza a jótállásból fakadó igényt. Ez értelemszerűen a bizonyítási teher tekintetében jelent könnyebbséget a vevő számára. ${ }^{1445}$ Magát a jótállási időt vagy időintervallumban, vagy más mutatókban határozhatják meg, ${ }^{1446}$ de ezek kombinációja is előfordul. ${ }^{1447}$

A kódex fogyasztási cikk adásvétele esetén - az Irányelvnek megfelelően meghatározza a jótállási nyilatkozat formájára és tartalmára vonatkozó követelményeket, ami a fogyasztó transzparenciához füződő érdekét hivatott szolgálni. ${ }^{1448}$ A legfontosabb követelmény az, hogy a nyilatkozatnak egyszerű és érthető szövegezésűnek kell lennie, és azt a fogyasztó kérésére írásos formában át kell nyújtani [BGB § 477 (2)]. A tartalmi előírások szerint a nyilatkozatnak különösen a jótállás érvényesítéséhez szükséges adatokat kell magában foglalnia, azaz annak időtartamát, területi hatályát, valamint a jótállás vállalójának nevét és aláírását [§ 477 (1)]. Ezeken kívül arra is feltétlenül utalnia kell a nyilatkozatnak, hogy a fogyasztónak a jótállási igényeken kívül törvényből fakadó jogai is vannak, és azok tartalmát illetve érvényesíthetőségét a jótállás nem sérti. ${ }^{1449}$

A fent idézett szabály az Irányelvnek megfelelően úgy rendelkezik, hogy a jótállás független a vevő egyéb törvényes jogaitól. Ez azt jelenti, hogy hibás teljesítés esetén a szavatossági jogok sértetlenül maradnak, a vevő bármikor élhet velük a jótállás tartama

\footnotetext{
${ }^{1443}$ Lásd: BGB $\S 443$ (1).

${ }^{1444}$ Lásd: STÖBER (2005), 69. p.

1445 BGB § 443. (2): „Soweit eine Haltbarkeitsgarantie übernommen worden ist, wird vermutet, dass ein während ihrer Geltungsdauer auftretender Sachmangel die Rechte aus der Garantie begründet.".

${ }^{1446}$ Erre példa gépjármü esetén a kilométer-teljesítmény.

1447 PLATE (2011), 754. p.

${ }^{1448}$ Vö. Irányelv, Preambulum (21) bekezdés.

${ }^{1449}$ Lásd: BGB $§ 477$ (3): ,Die Wirksamkeit der Garantieverpflichtung wird nicht dadurch berührt, dass eine der vorstehenden Anforderungen nicht erfüllt wird.".
} 
alatt is. A „,... den Hinweis auf die gesetzlichen Rechte des Verbrauchers sowie darauf, dass sie durch die Garantie nicht eingeschränkt werden..." fordulat megfogalmazása véleményem szerint azonban nem kielégítő, mert nem takarja a rendelkezés valódi célját. A fogyasztó számára nem teszi egyértelművé, hogy jótállás fennállásakor nem csak az abból fakadó jogaival élhet hibás teljesítés esetén, hanem törvényből fakadó kellékszavatossági jogai is vannak, és azokat is érvényesítheti. Ezen kívül úgy gondolom, hogy bár a törvényes jogokról való konkrét tájékoztatás nem a jótállás vállalójának a kötelezettsége, de mivel az Irányelv azt is elöírja, hogy a jótállási nyilatkozatnak utalnia kell e jogokra, az utalás konkrétságát is a kötelező közlendők közé vehette volna. ${ }^{1450}$

A jótállási nyilatkozatnak és a vonatkozó reklámnak (amelyeken a jótállási kötelezettség alapul) tartalmilag rögzítenie kell az érvényesíthető fogyasztói igényeket. A német kereskedelmi gyakorlatban a legjellemzőbb az, hogy csak a kijavításról és/vagy a kicserélésről szól a jótállási jegy, ritkábban az elállásról és a vételárcsökkentésről. ${ }^{1451}$ Általánosságban azonban elmondható, hogy a jótállási igények a szavatossági jogokra „támaszkodnak”. ${ }^{1452}$ A jótállásból fakadó kártérítési igényt általában akkor támaszthat a fogyasztó, ha a jótállási nyilatkozatban egy különös tulajdonságra vonatkozó ígéret is szerepel. ${ }^{1453}$ Amennyiben a nyilatkozat egyáltalán nem ejt szót a vevő jogairól, akkor a jogtudomány szerint az összes, a törvényben szabályozott szavatossági jog a fogyasztó rendelkezésére áll. ${ }^{1454}$

A fentiekkel összefüggő érdekes elhatárolási kérdés a jogkövetkezmények szempontjából, hogy van-e különbség az olyan jótállási nyilatkozatok között, amelyek a kellékhiba fogalmi meghatározásánál releváns tulajdonságra vonatkoznak, illetve amelyek ezen kívüli körülményeket, tulajdonságokat garantálnak. A jogtudomány úgy kezeli az előbbit, mint a szerződésszerüség követelményébe, azaz a kellékszavatossági szabályok alá eső eladói nyilatkozatot, ${ }^{1455}$ az utóbbit pedig önálló, a BGB $\S 443$ hatálya alá tartozó jótállási nyilatkozatnak tekinti. ${ }^{1456}$

\footnotetext{
${ }^{1450}$ A német szabályozás egyébként teljesen tükrözi az Irányelv elvárásait, vö. Irányelv, 6. cikk.

${ }^{1451}$ Lásd: PlATE (2011), 754. p.

1452 Plate (2011), 754. p.

${ }^{1453}$ Ez a minőségi jótállásnál a gyakoribb, lásd: PLATE (2011), 754. p.

${ }^{1454}$ PLATE (2011), 754. p. Ilyen esetben a jótállás egyetlen rációja a határidő, amely alatt az eladó a hibátlan minőségért - a fordított bizonyítás terhével - helytállni köteles, lásd később.

${ }^{1455}$ Vö. BGB § 434 (1): „,Die Sache ist frei von Sachmängeln, wenn sie bei Gefahrübergang die vereinbarte Beschaffenheit hat...".

${ }^{1456}$ Lásd: STÖBER (2005), 97. p.
} 


\subsubsection{Osztrák jog}

A jótállás a szolgáltatás, a dolog hibátlanságáért felvállalt helyállást jelenti az osztrák jogban is. ${ }^{1457}$ Ausztriában sem létezik a törvény alapján kötelező jótállás, hanem az minden esetben megállapodással önkéntesen felvállalt kötelmet jelent. A jogintézményt a KSchG szabályozza az Irányelvnek megfelelően, így a rendelkezés csak fogyasztói jogügyletek esetén alkalmazandó:

„, Verpflichtet sich ein Unternehmer gegenüber einem Verbraucher für den Fall der Mangelhaftigkeit der Sache diese zu verbessern, auszutauschen, den Kaufpreis zu erstatten oder sonst Abhilfe zu schaffen (Garantie), so hat er auch auf die gesetzliche Gewährleistungspflicht des Übergebers und darauf hinzuweisen, dass sie durch die Garantie nicht eingeschränkt wird. Der Unternehmer ist an die Zusagen in der Garantieerklärung und an den in der Werbung bekannt gemachten Inhalt der Garantie gebunden. "1458

A rendelkezés szerint a vállalkozó a fogyasztóval szemben a dolog hibátlanságáért jótállást vállalhat, és e kötelem keretében a mégis hibás dolog kijavítását, kicserélését, a vételár visszatérítését vagy egyéb igény teljesítését garantálja. Ha a vállalkozó ily módon jótállást vállal, akkor jótállási nyilatkozatában utalnia kell a saját, törvényes kellékszavatossági kötelezettségére, és arra, hogy a jótállási nyilatkozata a kellékszavatosságra vonatkozó törvényi rendelkezéseket nem korlátozza. Ez azt jelenti, hogy a jótállás csak előnyösebb lehet a fogyasztóra nézve. ${ }^{1459} \mathrm{Ha}$ nem derülnek ki belőle különös minőségi kritériumok, akkor a jótállónak a dolog szokásosan feltehető tulajdonságaiért kell helytállnia [KSchG $\S$ $9 \mathrm{~b}(2)] .{ }^{1460}$ Az osztrák jogalkotó szövegezése a némethez képest üdvözlendő, mert világos, és konkrétan utal a kellékszavatossági helytállásra.

A vállalkozó által vállalt jótállás a fenti definíció alapján a jótállási nyilatkozaton illetve a jótállás tartalmára vonatkozó reklámban foglaltakon alapul csakúgy, mint az Irányelv és a BGB szerint. A szerződésszerüség kritériumai a hibás teljesítés körében kerültek szabályozásra, és a KSchG megfogalmazásából arra lehet következtetni, hogy a vállalkozó jótállása nem terjed ki a gyártói/forgalmazói jótállással kapcsolatos nyilvános

\footnotetext{
${ }^{1457}$ Helyesnek tünik a magyar terminológia szerinti jótállás szó alkalmazása, annak ellenére, hogy németül „Garantie” a jogintézmény elnevezése, ugyanis a szerződésben felvállalt jótállás az osztrák jogban megkülönböztetendő a garanciaszerződéstől, amely nem kapcsolódik a hibás teljesítéshez, lásd lent az elhatárolási kérdéseknél.

${ }^{1458}$ Lásd: KSchG $§ 9 b(1)$.

${ }^{1459}$ Lásd: SÄÄF (2005), 60. p.

${ }^{1460}$ Van olyan álláspont, amely szerint ez az elöírás felesleges, mert ez magából az ABGB-ből is következik, lásd: KREJCI (2004), 135. p.
} 
kijelentésekre, reklámokra. ${ }^{1461}$ Mivel a jótállás kötelezettje a fogyasztóvédelmi törvény alapján mindig a vállalkozó (a fogyasztó szerződési partnere), nem vonatkoznak a KSchG szabályai a gyártó vagy forgalmazó által nyújtott jótállásra. ${ }^{1462}$ A gyártói jótállás azonban a gyakorlatban szintén gyakori. ${ }^{1463}$ Amikor csak ilyen gyártói jótállási nyilatkozat (jótállási jegy) kíséri a dolgot, akkor a fogyasztó a fentiek szerint - a német jogtudomány álláspontjával ellentétben - a vállalkozással szemben csak a kellékszavatossági jogait érvényesítheti hibás teljesítés esetén, és a jótállásból fakadó jogainak érvényesítését a gyártótól követelheti. ${ }^{1464}$

A KSchG-be implementálta az osztrák jogalkotó azokat az Irányelvbeli rendelkezéseket, amelyek a vállalkozói jótállás tartalmi követelményeit szabják meg. Ezek szerint a jótállási nyilatkozatnak tartalmaznia kell a jótállás vállalójának a nevét és aláírását, valamint egyszerü és érthető formában a jótállás tartalmát, különösen időbeli és területi hatályát, valamint a jótállási jogok érvényesítéséhez szükséges egyéb adatokat [KSchG § 9b (2)]. A jótállási nyilatkozatot a fogyasztó kérésére írásos formában vagy más tartós adathordozón rendelkezésére kell bocsátani [§ 9b (3)]. Az Irányelvnek megfelelően a fenti formai követelmények nem teljesítése nem érinti a jótállás érvényességét, de az azok megszegéséből eredő fogyasztói károk megtérítéséért a vállalkozó felel [KSchG § 9b (4)]. Ilyen kár lehet például az, ha a nyilatkozaton nem szerepel a jótállásra kötelezett neve, és emiatt a fogyasztónak lényegesen nehezebb kiderítenie, hogy kivel szemben érvényesítheti jogait; az ebből fakadó kárért így helytállással tartozik a kötelezett. ${ }^{1465} \mathrm{Ez}$ a rendelkezés üdvözlendő, mert az Irányelv vonatkozó szabálya lex imperfecta, azaz nem tartalmaz szankciót a rendelkezés megsértése esetére. ${ }^{1466}$

\section{Kellékszavatossági jogok az Európai Bíróság gyakorlatában:}

\section{a kicserélési jog és az arányosság mércéje - a C-65/09. számú egyesített ítélet}

Az Európai Bíróság három ügyben foglalkozott az Irányelv anyagi jogi kérdéseivel. ${ }^{1467}$ Ezek közül a jelen pontban tárgyalandó jogeset kínálkozik részletesebb kifejtésre, ami

\footnotetext{
${ }^{1461}$ Vö. ABGB § 922 (1)-(2).

${ }^{1462}$ Lásd: SÄÄF (2005), 60. p. Vö. Irányelv, 1. cikk (2) bekezdés e. pont.

${ }^{1463}$ FERCH-FISCHER (2011), 15. p.

${ }^{1464}$ FERCH-FISCHER (2011), 15. p.

${ }^{1465}$ Lásd: KREJCI (2004), 135. p.

${ }^{1466}$ Vö. Irányelv, 6. cikk (5) bekezdés. A BGB vonatkozó szabálya is lex imperfecta, vö. § 477 (1)-(3).

1467 Az másik a C-404/06. számú Quelle-ügyben 2008. április 17-én hozott ítélet [EBHT 2008., I-2685.] 33. és 34. pontja. A továbbiakban: Quelle-ügy. Elérhető:
} 
azért indokolt, mert egyrészt a dolgozatban vizsgált német szabályok kapcsán merült fel az ügyben megítélt értelmezési kérdés, másrészt az EuB a főtanácsnoki indítvánnyal és annak meggyőző érvelésével ellentétes precedenst alkotott. Ezen kívül a döntés alapjául szolgáló német tagállami indítványok komplex jogi és jogértelmezési kérdésekre világítanak rá.

\subsection{Az alapügyek és az elözetes döntéshozatal iránti kérelmek}

Az Európai Bíróság két, lényegében azonos tárgyú, német bíróságok által előterjesztett előzetes döntés iránti kérelem egyesített ügyében 2011. június 16-án hozta meg a tárgyalt ítéletét, amely az Irányelv anyagi jogi kérdéseivel, közelebbről a kicserélési joggal, annak tartalmával és a vonatkozó arányossági követelmény mibenlétével foglalkozik.

\subsubsection{A C-65/09. számú ügy}

Az első ügyben Jürgen Wittmer német fogyasztó (Wittmer) a Gebr. Weber GmbH-tól (Weber) 2005 januárjában 45,36 $\mathrm{m}^{2}$ olasz gyártmányú csiszolt járólapot vásárolt 1382,27 euró vételáron, amelyböl $33 \mathrm{~m}^{2}$-t építtetett be a házába. A beépítés után a járólapok felületén szabad szemmel látható foltok jelentek meg, ezért Wittmer független bizonyítási eljárást indított a hiba mibenlétének, okának felderítésére. Ennek során a szakértő arra a következtetésre jutott, hogy a foltok olyan finom mikrocsiszolási nyomok, amelyek kijavítása lehetetlen, így a lehetséges orvoslás csak a járólapok teljes cseréje lehet. A szakértő a költségeket 5830,57 euró összegben állapította meg. Miután Wittmer határidő kitűzése mellett eredménytelenül szólította fel a fentieknek megfelelő teljesítésre a Webert, keresetet indított ellene a Landgericht Kassel előtt, és hibátlan járólapok átadását, valamint

http://curia.europa.eu/juris/document/document.jsf?text=\&docid=71604\&pageIndex=0\&doclang=HU\&mode =lst\&dir=\&occ=first\&part=1\&cid=3363774) (2013. december 11.). Ebben az ügyben a fö jogi probléma az volt, hogy a hibás fogyasztási cikkel okozott érdeksérelmet kicserélés útján orvosló eladó követelheti-e a fogyasztótól az árunak a kicserélésig történő használatának az ellenértékét. Az ügyben egy német bíróság terjesztette elő az előzetes döntéshozatal iránti kérelmet. Az EuB ebben az ügyben is a fogyasztóvédelem maximális érvényesítése mellett érvelt, és kimondta, hogy az Irányelvvel ellentétes az olyan nemzeti szabályozás, amely lehetővé teszi a használat ellenértékének követelését a fogyasztótól.

A harmadik, az Irányelv anyagi jogi kérdéseivel foglalkozó ügy a C-32/12., amelyben spanyol bíróság terjesztett indítványt a Bíróság elé. Az EuB ebben a 2013. októberi ítéletében kimondta, hogy az irányelvet úgy kell értelmezni, hogy azzal ellentétes az a tagállami szabályozás, ,amely - amennyiben a szerződésben meghatározott fogyasztási cikk vételárának megfelelő leszállítására jogosult fogyasztó a bíróság előtt kizárólag a szerződés felbontása iránti igényt érvényesít annak ellenére, hogy arra e fogyasztási cikk hibájának csekély mértéke miatt nincs lehetőség - még akkor sem teszi lehetővé, hogy az eljáró nemzeti bíróság hivatalból leszállítsa a vételárat, ha az említett fogyasztó nem jogosult sem eredeti kérelmének megváltoztatására, sem arra, hogy erre vonatkozóan új keresetet terjesszen elö”. Az ítélet elérhető: http://curia.europa.eu/juris/documents.jsf?num=C-32/12 (2013. december 11.). 
5830,57 euró és kamatai megfizetését követelte. A bíróság árcsökkentést állapított meg ítéletében, és a Webert 273,10 euró kamatokkal való megfizetésére kötelezte, egyebekben a keresetet elutasította. ${ }^{1468}$

Wittmer fellebbezése nyomán az Oberlandesgericht Frankfurt am Main az elsőfokú bíróság ítéletét részben megváltoztatva a Webert 45,36 $\mathrm{m}^{2}$ hibátlan járólap átadására és - a hibás járólapok eltávolításának költségeként - 2122,37 euró és kamatainak megfizetésére kötelezte. ${ }^{1469}$

A német legfelsőbb bírósághoz, a Bundesgerichtshofhoz az ítélet ellen benyújtott felülvizsgálati kérelemben a Weber tiltakozott a 2122,37 euró és kamatainak megfizetése ellen. A Bundesgerichtshof álláspontja szerint a felülvizsgálati kérelemről való döntés attól függ, hogy a másodfokú bíróság jogszerüen állapította-e meg, hogy Wittmer követelheti a Webertől a járólapok eltávolításával járó költségek megtérítését. A Bundesgerichtshof azt hangsúlyozta, hogy - ellentétben az Oberlandesgericht álláspontjával - a német BGB $\S$ 439 (3) bekezdése alapján a Weber jogosan tagadhatta meg a ,pótteljesítésnek” hibátlan járólapok átadása formájában követelt módját, és ezzel a hibás járólapok eltávolítását is az aránytalanságra hivatkozva. Ez ugyanis a Bundesgerichtshof véleménye szerint nem csak akkor érvényesül, ha az utólagos teljesítés vevő által választott módja a másik módjához képest aránytalan költségeket okozna neki (,relatív aránytalanság”), hanem akkor is, ha az utólagos teljesítés választott - vagy egyedüli lehetséges - módja már önmagában aránytalan költségekkel jár (,,abszolút aránytalanság”). ${ }^{1470}$ Mindez pedig a Bundesgerichtshof szerint ellentétben állhat az Irányelv 3. cikk (3) bekezdésével, amely a szóhasználata alapján látszólag csak a „relatív aránytalanság” esetét kívánta szabályozni.

A fentiekre tekintettel a Bundesgerichtshof 2009. január 14-én úgy határozott, hogy az előtte folyamatban lévő eljárást felfüggeszti, és előzetes döntéshozatal céljából az alábbi kérdéseket terjeszti az EuB elé:

„1) Úgy kell-e értelmezni a[z ...] irányelv 3. cikke (3) bekezdésének első és második albekezdését, hogy azzal ellentétes az olyan nemzeti törvényi szabályozás, amely szerint ha az átadott fogyasztási cikk nem felel meg a szerződésnek, akkor az eladó akkor is megtagadhatja a fogyasztó által követelt orvoslási módszert, ha az neki a fogyasztási cikk hibátlan állapotbani értékével és a hiba jelentőségével összehasonlítva ésszerütlen (abszolút aránytalan) költségeket okoz?

2) Az 1) kérdésre adott igenlő válasz esetén: úgy kell-e értelmezni a fenti irányelv 3. cikkének (2) bekezdését és (3) bekezdésének harmadik albekezdését, hogy az eladó a fogyasztási cikk szerződésszerü állapotának kicserélés formájában történő

\footnotetext{
${ }^{1468}$ Az elsőfokú ítélet német nyelven elérhető: http://openjur.de/u/298385.html (2013. december 14.).

1469 A másodfokú ítélet német nyelven elérhető: http://openjur.de/u/300016.html (2013. december 14.).

1470 „,Absolute Unverhältnismäßigkeit”, lásd: LOOSCHELDERS (2011), 32. p.
} 
helyreállítása során viselni köteles a fogyasztó által a fogyasztási cikk természetének és céljának megfelelően beépített, nem szerződésszerü fogyasztási cikknek az eltávolítása során felmerült költségeket?"1471

\subsubsection{A C-87/09. számú ügy}

A másik ügyben Ingrid Putz német fogyasztó (Putz) a Medianess Electronics-szel (Medianess) új mosogatógépre vonatkozóan 9,52 euró összegü szállítási költséggel kiegészülő 367 euró vételáron, interneten keresztül adásvételi szerződést kötött. A mosogatógép házhoz szállítása után Putz beszereltette azt a lakásába, azonban ezután fény derült arra, hogy a készülék - nem a beszerelésével kapcsolatos müveletekre visszavezethető ok miatt - hibás, kijavítása pedig lehetetlen. A felek megállapodtak a mosogatógép kicserélésében. Ez alapján Putz nemcsak új mosogatógép átadását, hanem a hibás készülék eltávolítását, valamint azt is követelte a Medianesstől, hogy szerelje be a csereként átadott készüléket, vagy viselje az eltávolítással és az új, hibátlan gép beszerelésével járó költségeket. Ezt a Medianess megtagadta, és mivel a hozzá intézett felszólító levélre sem válaszolt, Putz elállt az adásvételi szerződéstől, és minderre tekintettel keresetet nyújtott be az Amtsgericht Schorndorfhoz a Medianess-szel szemben a hibás mosogatógép átadásáért cserébe a vételár visszatérítését követelve.

A bíróság úgy foglalt állást, hogy a német jog szerint az adásvételi szerződéstől való elállás érvényessége attól függ, hogy Putz eredménytelenül tüzött-e ki a Medianess felé a szerződés pótteljesítésére határidőt, valamint hogy arra szorítkozott-e, hogy azt követelje, amivel az utóbbi tartozott. Véleménye szerint a jogvita eldöntéséhez tudni kell azt, hogy Putz jogosult volt-e azt követelni a Medianesstől, hogy távolítsa el a hibás készüléket, és szerelje be az újat, vagy vállalja az e müveletekkel kapcsolatos költségeket. Rámutatott arra, hogy a német jog még arra az esetre sem írja elő a nem vétkes eladó tekintetében a hibás fogyasztási cikk eltávolításának vagy a csereként átadott fogyasztási cikk beszerelésének kötelezettségét, ha a fogyasztó a hibás fogyasztási cikket a hiba felmerülése előtt - rendeltetésének megfelelően - már beszerelte. Ugyanakkor úgy vélte, hogy az Irányelvből eredhet ilyen jellegü kötelezettség.

E körülményekre tekintettel az Amtsgericht Schorndorf 2009. február 25-ei határozatával úgy döntött, hogy felfüggeszti az elötte folyó eljárást, és az alábbi - az első

\footnotetext{
${ }^{1471}$ Lásd: az EuB C-65/09. és C-87/09. számú egyesített ügyekben hozott ítéletének 23. pontja. Elérhető: http://curia.europa.eu/juris/document/document_print.jsf?doclang=HU\&text=\&pageIndex=0\&part=1\&mode $=$ lst\&docid=85085\&occ=first \&dir=\&cid=2560395\#Footnote* $(2013$. december 16.).
} 
ügyben feltettekkel majdnem teljes mértékben megegyező - kérdéseket terjeszti az Európai Bíróság elé:

„1) Úgy kell-e értelmezni az [...] irányelv 3. cikkének (2) bekezdését és (3) bekezdésének harmadik albekezdését, hogy azzal ellentétes az olyan nemzeti törvényi szabályozás, amely szerint, ha a beszerelés eredetileg nem volt szerződéses kötelezettség, akkor az eladó a fogyasztási cikk szerződésszerü állapotának kicserélés formájában történő helyreállítása során nem köteles viselni az utólagos teljesítés során átadott fogyasztási cikk fogyasztó által a fogyasztási cikk természetének és céljának megfelelően beszerelt nem szerződésszerü fogyasztási cikk helyére történő beszerelésének a költségeit?

2) Úgy kell-e értelmezni az [...] irányelv 3. cikkének (2) bekezdését és (3) bekezdésének harmadik albekezdését, hogy az eladó a fogyasztási cikk szerződésszerű állapotának kicserélés formájában történő helyreállítása során viselni köteles a fogyasztó által a fogyasztási cikk természetének és céljainak megfelelően beszerelt, nem szerződésszerü fogyasztási cikknek az eltávolításával járó költségeket?"1472

\subsection{Az elözetes kérdések jogi kontextusa}

Az Irányelv megalkotásának fö célja a korábban említetteknek megfelelően „,a fogyasztási cikkek adásvételének egyes vonatkozásait szabályozó tagállami törvényi, rendeleti és közigazgatási rendelkezések közelítése a fogyasztóvédelem egységes minimális szintjének biztosítása érdekében a belső piac keretében". ${ }^{1473}$ A jogszabály azonban a fogyasztói adásvételnek csupán egyes vonatkozásait tárgyalja, így nem rendezi többek között a jelentős gyakorlati relevanciával bíró konkurencia-kérdést a szavatossági/jótállási objektív helytállás és a hibás teljesítés szubjektív jogalapú jogkövetkezménye, a kártérítés között.

\subsubsection{Az 1999/44/EK irányelv és a német BGB}

Az EuB előtti két eljárásban felmerülő jogi kérdések gyakorlatilag azonosak, mindkettőben a kicserélés, mint kellékszavatossági jog és az azzal szemben kifogásként felhozható aránytalanság mércéjének értelmezése a probléma. Az Irányelv 3. cikkében szerepelnek a releváns rendelkezések. A szerződésnek való megfelelés hibája esetén a fogyasztó az eladótól először a fogyasztási cikk térítésmentes kijavítását vagy kicserélését követelheti, kivéve, ha ez lehetetlen vagy aránytalan. Az Irányelv magyar nyelvű szövegváltozata szerint az orvoslás akkor aránytalan, ha az eladónak „más orvoslási módszerrel összehasonlitva ésszerütlen költséget okoz, figyelembe véve a fogyasztási cikk hibátlan

\footnotetext{
${ }^{1472}$ Lásd: az EuB ítéletének 32. pontja.

${ }^{1473}$ Irányelv, 1. cikk (1) bekezdés.
} 
állapotbani értékét, a hiba jelentöségét, és azt, hogy az alternativ orvoslási módszer a fogyasztónak okozott jelentős kényelmetlenség nélkül végrehajtható-e”. ${ }^{1474}$ Ezeket az első lépcsős igényeket ésszerü határidőn belül, a fogyasztót érő jelentős kényelmetlenség nélkül kell elvégezni, figyelembe véve a fogyasztási cikk természetét és a fogyasztó által megkívánt célját [3. cikk (3) bekezdés]. A ,téritésmentes” kijavítás illetve kicserélés fogalma magában foglalja a fogyasztási cikk szerződésszerű állapota helyreállításának szükséges költségeit, különösen a postaköltséget, a munkadíjat és az anyagköltséget [3. cikk (4) bekezdés]. ${ }^{1475}$ Az Irányelv a fogalmi meghatározások között megadja a kijavítás definícióját, ${ }^{1476}$ de a kicserélés mibenlétéről nem ejt külön szót.

A kicserélésre vonatkozó német BGB-beli rendelkezés szerint a jogorvoslat aránytalansága esetén a vevő joga a pótteljesítés másik módjára korlátozódik, de ha az is aránytalannak minősül, akkor az eladó azt is megtagadhatja, és ez esetben a második lépcsős jogok alkalmazhatóak. ${ }^{1477} \mathrm{Az}$ értelmezési vita eldöntésében egyedül az irányelvkonform értelmezés alapelve segíthet. ${ }^{1478}$

\subsubsection{Az EuB hatásköre az ügyben}

Az EUMSz 267. cikke alapján az EuB hatáskörrel rendelkezik előzetes döntéshozatalra valamely irányelv értelmezésének kérdésében. Csak akkor utasíthatja el a kérelmet, ha , $a z$ uniós jog kért értelmezése nyilvánvalóan semmilyen összefüggésben nincs az alapügy tényállásával vagy tárgyával, ha a probléma hipotetikus jellegü, vagy ha nem állnak a Bíróság rendelkezésére azok a ténybeli vagy jogi elemek, amelyek szükségesek ahhoz, hogy az elé terjesztett kérdésekre hasznos választ adhasson". ${ }^{1479}$

A C-65/09. számú ügyben a Bundesgerichtshof kérdéseivel azonban éppen annak meghatározása céljából kérte az Irányelv értelmezését, hogy azzal összeegyeztethető-e a német nemzeti jog, amennyiben az egyrészről nem kötelezi az eladót a nem szerződésszerü

\footnotetext{
${ }^{1474}$ Irányelv, 3. cikk (3) bekezdés.

${ }^{1475}$ E szabálynak megfelel a BGB § 439 (2) rendelkezése.

${ }^{1476}$ Lásd: 1. cikk (1) bekezdés f. pont: „kijavitás: a szerződésnek nem megfelelő fogyasztási cikknek a szerzödésnek megfelelővé tétele".

1477 A Bundesgerichtshof álláspontja, joggyakorlata alapján; lásd az ügyben szereplő indítványokat.

1478 Ezt már a kötelmi jog reformjáról szóló törvény 2001-es javaslata is kimondta, lásd: Entwurf eines Gesetzes zur Modernisierung des Schuldrechts, BT-Drucksache 14/6857, 58. p. [német nyelven elérhető: http://dip21.bundestag.de/dip21/btd/14/068/1406857.pdf (2013. december 15.)], és BT-Drucksache 14/6040, 211. p.

1479 Lásd: EUMSz 267. cikk. Az EuB ítélete e vonatkozásban a következő ügyekben kimondottakra hivatkozik: a Conseil général de la Vienne ügyben (C-419/04. sz.) hozott ítélet 20. pontja; a Lucchini-ügyben (T-91/10. sz.) hozott ítélet 44. pontja; a TeliaSonera-ügyben (C-52/09. sz.) hozott ítélet 16. pontja.
} 
fogyasztási cikk eltávolításával járó költségeinek vállalására, másrészről pedig felkínálja számára azt a lehetőséget, hogy megtagadja a kicserélést, ha az aránytalan költségekkel járna. Az EuB erre figyelemmel elutasította a Weber által előterjesztett elfogadhatósági kifogást. Az eljárási szabályzata 43. cikkének megfelelően - a közöttük lévő összefüggés miatt - egyesítette ezt az ügyet a fent említett C-87/09. számú üggyel.

\subsection{Az EuB elötti eljárás}

\subsubsection{A beadványok és az elöterjesztett álláspontok}

Az ügyben a Weber, a német, a belga, a spanyol, az osztrák és a lengyel kormány, valamint az Európai Bizottság terjesztett elő állásfoglalást. ${ }^{1480}$

A kicserélési jog terjedelme - A Weber, valamint az osztrák, a belga és a német kormány nemleges választ javasolt arra a kérdésre, hogy az Irányelv alapján a fogyasztó követelheti-e a kicserélés révén történő szerződésszerű teljesítés esetén az általa a fogyasztási cikk természetének és céljának megfelelően beépített, nem szerződésszerü fogyasztási cikk eltávolítását és a csereként adott új árucikk beépítését, illetve az ezekkel kapcsolatban felmerült költségeket. A Weber és a német kormány érvei szerint az eladó az Irányelv 3. cikkének (2) és (3) bekezdése alapján arra köteles, hogy egy másik ugyanolyan szerződésszerü árut adjon át, és az eladó kötelezettségeit nem lehet akként kiterjeszteni, hogy azok magukban foglalják a fenti cselekményeket/munkálatokat a fogyasztó által az átadást követően saját belátása szerint felhasznált hibás áru tekintetében. Az átadott árunak a fogyasztó általi felhasználási módja - még ha az meg is felel az áru természetének és céljának - nehezen kalkulálható előre az eladó részéről, így ugyanannak a terméknek az eltávolításával, és az új beszerelésével járó költségek esetről esetre jelentősen eltérhetnek egymástól. Ezen túlmenően véleményük szerint a kérdéses kötelezettség abból sem következik, hogy az Irányelv 3. cikkének (3) és (4) bekezdése értelmében a kicserélést „,éritésmentesen” és „a fogyasztót érő jelentős kényelmetlenség nélkül” kell elvégezni. Ezek a feltételek pusztán az eladó azon kötelezettségére vonatkoznak, hogy új, hibátlan árut adjon át. Végül hangsúlyozták, hogy a szóban forgó hibás áru használata (vagy eltávolítása) folytán bekövetkező károk megalapozhatják a fogyasztó igényét a szerződéses

\footnotetext{
${ }^{1480}$ Logikai érvekre hivatkozva Ján Mazák fötanácsnok a C-65/09. számú ügyben feltett két kérdés közül az áru eltávolításának és a csereként adott hibátlan árucikk beépítésének/beszerelésének kötelezettségére és az abból fakadó költségek megtéritésére vonatkozó második kérdéssel kezdte az értékelését, ezért az ügyben észrevételt elöterjesztettek érvelései is ebben a sorrendben kerülnek bemutatásra.
} 
vagy szerződésen kívüli károkért való felelősségre vonatkozó nemzeti rendelkezések szerint. Az osztrák és a belga kormány csatlakozott ehhez az érveléshez, de a belga kormány azt a pontosítást tette, hogy az eladó köteles viselni a hibás áru szállításával kapcsolatos költségeket.

A spanyol és a lengyel kormány, valamint a Bizottság az igenlő válasz mellett érveltek. A Bizottság álláspontja szerint a kicserélés a hibás áru akkori állapotára és környezetére vonatkozik, amikor a hiba bekövetkezik, és a fogyasztót a kicseréléssel olyan helyzetbe kell hozni, amelyben akkor lett volna, ha részére hibátlan árut adtak volna át, ami azt jelenti, hogy a hibás árut szükség esetén el kell távolítani, a hibátlan árut pedig be kell építeni. Ezt az értelmezést szerintük maga a „kicserélés” szó is alátámasztja. A Bizottság ugyanakkor elismerte, hogy a kicserélés térítésmentességének és a fogyasztót érő jelentős kényelmetlenség elkerülésének követelménye nem bír jelentőséggel a kicserélés jogával összefüggésben felmerülő kötelezettségek meghatározása szempontjából. Bár a spanyol és a lengyel kormány éppen ez utóbbi rendelkezésekre támaszkodott érvelésében, de összességében mégis osztotta a Bizottság álláspontját.

A jogorvoslati módok arányossága - A Weber, valamint a német és az osztrák kormány álláspontja szerint a hibás áru eladója még akkor is, amikor az alternatív orvoslási módszer lehetetlennek látszik, megtagadhatja a fogyasztó által követelt orvoslási módszert, ha az azáltal aránytalan, hogy a szerződésnek megfelelő áru értékéhez képest ésszerütlen költségeket okozna az eladónak. Úgy vélték, hogy a fogyasztó és az eladó érdekei közötti egyensúly megteremtésére törekvő Irányelv szövegezése, rendszere és különösen célja ezt az értelmezést támasztja alá. Előadták, hogy az eladót az Irányelv 3. cikke alapján terhelö kötelezettségeknek minden esetben (még akkor is, ha az orvoslási módszerek alkalmazása lehetetlen) meg kell felelniük az arányosság követelményének. Elismerték, hogy az Irányelv 3. cikk (3) bekezdésének második albekezdése és a Preambulum (11) bekezdése látszólag mindössze az azonos igényérvényesítési „lépcsőben” szereplő másik orvoslási módszerhez viszonyítottan aránytalan orvoslási módszerre vonatkozik. Ennek ellenére úgy vélték, hogy az arányosság általános hatállyal bír, és akkor is irányadó, ha az adott esetben csak egyfajta orvoslási módszer lehetséges. Véleményük szerint, amennyiben a kicserélés vagy a kijavítás lehetetlen vagy aránytalan, az Irányelv megfelelő védelmet biztosít a fogyasztónak azáltal, hogy árleszállítást követelhet, vagy elállhat a szerződéstől. Ezen kívül úgy vélték, hogy mivel az Irányelv szerinti jogok és kötelezettségek nem érintik a szerződéses és a szerződésen kívüli felelősségre vonatkozó nemzeti jogszabályi 
rendelkezéseket és elveket, így a fogyasztó a német polgári jog szabályai szerint aggálytalanul léphet fel kártérítési igénnyel.

A Bizottság, valamint a belga, a lengyel és a spanyol kormány ezzel szemben azt állította, hogy az arányossági vizsgálat mindössze a kicserélés és a kijavítás közötti választásra alkalmazható, tehát nem vezethet az árleszállítás és az elállás alkalmazásához. A Bizottság ezt mindenekelőtt az Irányelv 3. cikke (3) bekezdése második albekezdésének, valamint a Preambulum (11) bekezdésének megszövegezéséből vezette le. ${ }^{1481}$ Ezen túlmenően az Irányelv 3. cikkének rendszerében a szerződés (utólagos) teljesítése előnyt élvez az árleszállítással vagy az elállással szemben, tehát e cikk arányosságra való hivatkozását szerintük megszorítóan kell értelmezni. A Bizottság ugyanakkor nem cáfolta, hogy szélsőséges esetekben, amikor a fogyasztó által igényelt egyetlen lehetséges orvoslási módszer súlyosan aránytalan lenne a fogyasztó adott orvoslási módszer alkalmazásához füződő érdekéhez képest, át lehet térni a második lépcsős jogokra. A belga, a lengyel és a spanyol kormány egyetértett, és úgy vélték, hogy ellentétes lenne az Irányelv által biztosított fogyasztói jogokkal és a védelem magas szintjével, ha az eladó megtagadhatná az egyetlen lehetséges orvoslási módszert azon az alapon, hogy túlságosan magas költségei merülnének fel.

\subsubsection{A fötanácsnoki indítványok}

A kérelmekben feltett kérdésekkel kapcsolatos álláspontját Ján Mazák fötanácsnok a később egyesített két ügyben 2010. május 18-án ismertette, és tekintettel arra, hogy azok értékelő része szinte teljes mértékben azonos, együtt kerülnek bemutatásra. ${ }^{1482}$

A kérdések vizsgálata előtt a főtanácsnok megjegyezte, hogy az EU tagállamaiban nem csak az Irányelv megalkotása előtti, a nemzeti jogok sajátosságából fakadó különbözőségek nehezítették meg a jogalkalmazást, de most, a fogyasztói adásvétel egyes

\footnotetext{
${ }^{1481}$ Irányelv, Preambulum (11) bekezdés: „mivel a fogyasztó elöször az áru kijavitását vagy kicserélését követelheti az eladótól, kivéve, ha az ilyen orvoslás nem lehetséges vagy aránytalan; mivel az orvoslás aránytalan voltát objektiv alapon kell megállapitani; mivel az orvoslás aránytalannak tekintendö, ha annak alkalmazása más orvoslási módszerrel összehasonlitva ésszerütlen költségekkel jár; mivel a költségek akkor ésszerütlenek, ha az egyik orvoslási módszer költségei jelentös mértékben meghaladják a másik orvoslási módszer költségeit...".

1482 A fötanácsnoki indítványok magyar nyelven elérhetőek: C-65/09. számú ügy: http://curia.europa.eu/juris/document/document.jsf;jsessionid=9ea7d0f130d5866087b17f1848d5a28485ef775 d449d.e34KaxiLc3eQc40LaxqMbN4OahmQe0?text=\&docid=79075\&pageIndex=0\&doclang=HU\&mode=1s t\&dir=\&occ=first\&part=1\&cid=2845330 (2013. december 16.);

C-87/09. számú ügy:

http://curia.europa.eu/juris/document/document.jsf?text=\&docid=79074\&pageIndex $=0 \&$ doclang $=H U \&$ mode $=\underline{1 \text { st } \& \text { dir }=\& o c c=\text { first } \& p a r t=1 \& c i d=2845486}$ (2013. december 16.).
} 
szabályaira vonatkozó jogharmonizáció megvalósulásának idején is bizonytalanságok és eltérések mutatkoznak az adásvétel nem szerződésszerü teljesítésével kapcsolatosan, akár egyazon nemzeti jogrendszeren belül is. ${ }^{1483} \mathrm{~A}$ főtanácsnok álláspontja szerint nem lehet pusztán a fogyasztóvédelem magas szintjének elősegítésére irányuló irányelvi törekvésböl ${ }^{1484}$ kiindulni az ügyek tárgyalásakor.

A kicserélési jog tartalma - A főtanácsnok álláspontja szerint az Irányelv 3. cikk (2) és (3) bekezdéseinek szó szerinti értelmezéséből nem lehet megfelelően következtetni arra, hogy a kicserélés joga magában foglalja a fogyasztó jogát arra, hogy az eladótól az áru eltávolítását vagy az ehhez kapcsolódó költségek viselését követelje. Igaz ez különösen azért, mert az Irányelv hivatalos nyelvi változataiban eltérő jelentéstartalmú a kicserélés. Ezen túl a 3. cikk szövegkörnyezete és rendszertani olvasata alapján is nemleges választ kell adni a kérdésre. A 3. cikkben szereplö, a szerződésszerüség követelményéből eredeztethető fogyasztói jogokat a fötanácsnok szerint a konkrét szerződésben foglalt jogokra és kötelezettségekre tekintettel kell értelmezni. Ezen kívül a teljesítés időpontjában meglévő hibákért való helytállást meg kell különböztetni az áru átadását, azaz a teljesítést követő és a fogyasztó akaratától függő felhasználásból fakadó felelősségtől. A főtanácsnok szerint az áru „természetének és céljának megfelelö felhasználása” kitétel pontatlan meghatározás az Irányelvben, ${ }^{1485}$ így az erre alapozott eladói helytállás mértéke sem definiálható megfelelően. Az Irányelvben a kicserélés igényéhez kapcsolódóan a „,éritésmentesség” és a „jelentős kényelmetlenség nélküli” teljesítés követelményei sem értelmezhetőek kiterjesztően Mazák szerint: az utóbbi a hiba orvoslásának módját, és nem annak „fizikai terjedelmét” határozza meg.

Minderre figyelemmel a fötanácsnok nemleges választ adott arra a kérdésre (illetve kérdésekre), hogy a fogyasztó kicseréléshez füződő joga magában foglalja-e azt az igényt, hogy követelje az eladótól a hibás áru eltávolítását és az új árucikk beszerelését, illetve az ezek megvalósításából fakadó költségeket. Nemleges volt a válasza a második ügyben (C-

\footnotetext{
1483 Érdemes megemlíteni, hogy a fötanácsnok indítványaiban Ulpianus és Iulianus neves ókori római jogtudósokra hivatkozva a jogi probléma ókori gyökereiről emlékezik meg: „A jelen ügyben a Bíróság által megítélendő jogi probléma klasszikus kötelmi jogi, illetve pontosabban adásvételi jogi kérdés, amióta római jogtudósok, mint például Iulianus vagy Ulpianus, a „hibás” szarvasmarha ókori piacokon történő értékesítésének jogi következményeiről, nevezetesen az eladónak a hibás áru értékesítésével kapcsolatban fennálló felelősségének mértékéről, illetőleg - a vevő védelme szempontjából - annak kérdéséről értekeztek, hogy milyen orvoslási módszereknek kell a vevő rendelkezésére állnia, ha az eladó olyan árut adott át részére, amelyek nem felelnek meg az adásvételi szerződésnek." Lásd: fötanácsnoki indítvány a C-65/09. sz. ügyben, 23. pont.

${ }_{1484}$ Lásd: Irányelv, Preambulum (1) bekezdés.

${ }^{1485}$ Lásd: Irányelv, 3. cikk (3) bekezdés utolsó mondat.
} 
87/09.) is, azzal kiegészítve, hogy nem követelheti a fentieket a fogyasztó, ha a beszerelés (beépítés) nem képezte a szerződéses kötelezettségek részét.

A jogorvoslati módok arányossága - A főtanácsnok szerint az Irányelv 3. cikk (3) bekezdésben szereplő arányosság követelménye - a szövegezésből fakadóan - mind a kicserélésre, mind a kijavításra vonatkozik. Emellett szól szerinte az is, hogy az arányosság követelményére tekintet nélküli vevői választás esetén a másodlagos jogok alkalmazásának lehetősége rendkívüli módon korlátozódna, ez pedig sértené a felek érdekegyenlőségének követelményét.

A fentiekre figyelemmel a fötanácsnok álláspontja szerint nem ellentétes az Irányelvvel az olyan nemzeti jogszabályi rendelkezés, amely szerint az eladó akkor is megtagadhatja a nem szerződésszerű teljesítésnek a vevő választása szerinti kicserélés általi orvoslását, ha a kijavítás lehetetlen, és a kicserélés maga pedig a szerződésszerűség hiányának jelentőségére és az ugyanolyan hibátlan áru értékére tekintettel neki ésszerütlen és aránytalan költségeket okozna.

\subsection{Az itélet érvelése}

\subsubsection{Az eladó kötelezettségei a kicserélési jog érvényesítése során}

$\mathrm{Az}$ EuB két részletben válaszolt az egyesített ügyekben feltett négy kérdésre. Érvelése elején utalt korábbi joggyakorlatára, és hangsúlyozta, hogy mind az Irányelv 3. cikkének szövegéből, mind annak előkészítő munkáiból kitünik, hogy az uniós jogalkotó az Irányelvben biztosított fogyasztóvédelem alapvető összetevőjének szánta a fogyasztási cikk szerződésszerü állapota eladó általi helyreállításának térítésmentességét. Ez a kötelezettség az EuB szerint a fogyasztót kijavítás és kicserélés esetén is azon pénzügyi terhek veszélyétől kívánja megvédeni, amely e védelem hiányában visszatartaná őt a jogai érvényesítésétől. ${ }^{1486}$ Erre figyelemmel, ha a nem szerződésszerü fogyasztási cikk kicserélése esetén a fogyasztó nem kérhetné az eladótól, hogy vállalja annak eltávolítását arról a helyröl, ahová azt - természetének és céljának megfelelően - beépítették, és hogy ugyanazon a helyen építse be a csereként átadott fogyasztási cikket, úgy a kicserélés olyan pénzügyi többletterheket okozna a fogyasztónak, amelyeket nem kellett volna viselnie, ha az eladó megfelelően teljesített volna.

${ }^{1486}$ Lásd: a Quelle-ügyben hozott ítélet 33. és 34. pontja. 
Az EuB elismerte, hogy a fenti költségek nem szerepelnek az Irányelv 3. cikkének (4) bekezdésében kifejezetten felsoroltak között, amely bekezdés a térítésmentességet „, $a$ fogyasztási cikk szerzödésszerü állapota helyreállitásának szükséges költségeit, különösen a postaköltséget, a munkadijat és az anyagköltséget” tartalmazó elvárásként határozza meg. Visszautalt azonban korábbi döntésére, amelyben kimondta, hogy a „különösen” határozószó az uniós jogalkotásban (is) azt jelzi, hogy e felsorolás csak példálózó, nem kimerítő jellegü. ${ }^{1487}$

Az EuB a Bizottság álláspontjával egyezően úgy vélte, hogy az Irányelv 3. cikk (2) és (3) bekezdésének rendszeréből kitünik, hogy a kicserélés és a kijavítás a fogyasztó azonos szintü védelmére irányul. A kijavításra föszabályként a hiba felmerülésekori helyzetben lévő fogyasztási cikken kerül sor, így a fogyasztót ebben az esetben nem terhelheti semmilyen, az eltávolítással és az újabb beépítéssel járó költség. Analógia útján ez alkalmazandó tehát a kicserélésre is. A hatékony védelem biztosításának jogalkotói szándékára tekintettel „a fogyasztónak okozott jelentős kényelmetlenség nélkül” kifejezésnek az EuB szerint nem lehet a német, a belga és az osztrák kormány által javasolt megszorító értelmezést adni. Elismerte ugyanakkor, hogy a „kicserélés” kifejezés pontos jelentése eltér a különböző nyelvi változatokban. Számos nyelvi változatban, például a spanyol (sustitución), angol (replacement), francia (remplacement), olasz (sostituzione), holland (vervanging) és a portugál (substituição) nyelvi változatokban ez a kifejezés azon mủvelet egészére utal, amelynek végén a nem szerződésszerü fogyasztási cikket ténylegesen ki kell cserélni. ${ }^{1488}$ Más nyelvi változatok - többek között a német is (Ersatzlieferung) - szükebb jelentést sugallhatnak. Azonban az EuB úgy vélte, hogy még az utóbbi nyelvi változatban sem korlátozódik a kicserélés a csereként átadott fogyasztási cikk puszta átadására.

Ezen túlmenően úgy vélte a Bíróság, hogy az Irányelv céljának, azaz a fogyasztóvédelem magas szintje biztosításának is megfelel ez az értelmezés. Véleménye szerint ez objektív alapon sem méltánytalan, mert a kicserélés folyamata az adásvételi szerződésben foglalt kötelezettségének a megsértése miatt vált szükségessé. A fogyasztónak pedig nem lehet felróni, hogy a hiba megnyilvánulása előtt jóhiszemüen beépítette a hibás fogyasztási cikket természetének és a megkívánt célnak megfelelően. Az EuB szerint tehát az ahhoz hasonló helyzetben, amikor a két szerződő fél közül egyik sem járt el felróhatóan, indokolt az eladóra hárítani a kérdéses költségek viselését, mivel ezeket

\footnotetext{
${ }^{1487}$ Lásd: a Quelle-ügyben hozott ítélet 31. pontja.

${ }^{1488}$ Lásd: az ítélet 54. pontja.
} 
a többletköltségeket egyrészről el lehetett volna kerülni, ha az eladó már az elején megfelelően teljesítette volna a szerződést, másrészről pedig szükségesek a fogyasztási cikk szerződésszerü állapotának helyreállításához. A szigorú helytállási kötelezettséget az EuB szerint ellensúlyozza az, hogy az eladó az ugyanazon szerződésláncban korábbi helyet elfoglaló értékesítővel vagy bármely más közvetítővel szemben felléphet. ${ }^{1489}$

Úgy vélte a Bíróság, hogy az Irányelv fenti értelmezése független attól, hogy az eladó - az adásvételi szerződés alapján - köteles lett volna-e beépíteni az átadott fogyasztási cikket. Annak ellenére ugyanis, hogy az adásvételi szerződés meghatározza a fogyasztási cikk szerződésszerüségét, és azt, hogy mi minősül hibának, az eladónak a szerződés hibás teljesítéséből eredő kötelezettségei nem csupán a szerződésből, hanem főként a fogyasztóvédelemmel kapcsolatos szabályokból, és különösen az Irányelv 3. cikkéböl következnek. Ez utóbbiak olyan kötelezettségeket írnak elö, amelyek hatálya független az említett szerződéstől, és amelyek adott esetben meg is haladhatják az abban elöírtakat.

\subsubsection{Az eladó számára aránytalan költségvonzatú jogorvoslati mód}

Az EuB szerint az Irányelv az aránytalan kifejezést kizárólag a másik orvoslási módszerrel összefüggésben határozza meg, ekként a relatív aránytalanság esetére korlátozza azt. A 3. cikk szövegezéséből és rendszeréből, valamint a Preambulum (11) bekezdéséből az EuB szerint egyébként is ez következik. Az utóbbi bekezdés bizonyos nyelvi változatai - így a német is - többes számban „más orvoslási módszerekre” hivatkoznak. Számos nyelvi változatban (angol, francia, olasz, holland és portugál) viszont az arányosság kétségtelenül kizárólag a másik első lépcsős orvoslási módszerre - a kijavításra vagy a kicserélésre vonatkozik. Ezzel szemben az Irányelv 3. cikkének (3) bekezdését minden nyelvi változatban - így a németben is - egyes számban fogalmazták meg. ${ }^{1490}$ Következésképpen, ha e két orvoslási módszer közül csupán az egyik bizonyul lehetségesnek, az eladó nem tagadhatja azt meg, mert a két másodlagos jogorvoslati mód (árleszállítás, elállás) nem teszi lehetővé ugyanazon fogyasztóvédelmi szint biztosítását, mint a fogyasztási cikk szerződésszerü állapotának helyreállítása, azaz az első lépcsős jogok.

\footnotetext{
${ }^{1489}$ Vö. Irányelv, 4. cikk az eladó visszkereseti igényéről.

1490 „Eine Abhilfe gilt als unverhältnismäßig, wenn sie dem Verkäufer Kosten verursachen würde, die... verglichen mit der alternativen Abhilfemöglichkeit unzumutbar wären.".

Vö. a magyar szövegváltozattal: „,Az orvoslást aránytalannak kell tekinteni, ha az az eladónak más orvoslási módszerrel összehasonlitva...", ahol a fogalmazásmód minden igényre utalni látszik.
} 


\subsection{Az ítélet ratio decidendije}

Az EuB 2011. június 16-án meghozott ítéletének rendelkező része két elemből áll. ${ }^{1491} \mathrm{~A}$ ratio decidendi a rendelkező rész fényében az alábbiakban ragadható meg: a fogyasztói adásvétel hibás vagy hiányos teljesítéséből fakadó fogyasztói kicserélési jog terjedelme felöleli a kicserélési procedúra teljes folyamatát, a jóhiszemüen és rendeltetésszerủen beépített illetve beszerelt hibás áru kiszerelésétől egészen az új, csereként adott hibátlan fogyasztási cikk beépítéséig, beszereléséig. Az e folyamatból adódó minden költség - a fogyasztóvédelem magas szintjének biztosítására vonatkozó EU-s elvárásból eredően - az eladót terheli. Az arányosság követelménye, mint a kicserélés illetve kijavítás eladói megtagadásának oka csak e két fogyasztói jog viszonylatában, és a lehetetlenség körülményével együtt értelmezendő. Ez azt jelenti, hogy ha a kettő közül az egyik jog teljesítése lehetetlen vagy aránytalan, akkor az eladó köteles a fogyasztó másik jogát kielégíteni, függetlenül attól, hogy annak teljesítése a költségvonzat tekintetében rá nézve aránytalan-e. Az arányosság azonban mégis érvényesülhet annyiban, hogy a fenti költségek adott esetben az eladó által vállalt arányos összegre korlátozhatóak, ilyenkor viszont a vevő jogát meg kell hagyni arra, hogy a második lépcsős jogokra térjen át.

\subsection{Az EuB érvelésének kritikája}

Kuriózuma az eljárásnak, hogy abban a főtanácsnok javaslatától eltérően érvelt, és eltérő döntést hozott az EuB. Azonban - bár a fogyasztóvédelem nagyon magas szintjét irányozza elő az ítélet - annak érvelése dogmatikailag szerintem mégsem állja meg teljesen a helyét. Ján Mazák fötanácsnok több megállapítása is felhozható a Bíróság érvelésének kritikájaként. Ö már az értékelése elején leszögezte többek között azt, hogy nem lehet egyszerüen a fogyasztóvédelem magas szintjének elősegítését célzó irányelvi törekvésből kiindulni az eset tárgyalásakor, és hangsúlyozta, hogy a jogharmonizáció majdnem tíz évre visszatekintő folyamata ellenére még mindig jelentős bizonytalanságok és eltérések mutatkoznak a fogyasztói adásvétel nem szerződésszerű teljesítésével kapcsolatosan,

\footnotetext{
${ }^{1491}$ A rövidített ítélet elérhető: http://curia.europa.eu/juris/document/document print.jsf?doclang=HU\&text=\&pageIndex=1\&part=1\&mode $=$ req\&docid=112615\&occ=first $\&$ dir $=\&$ cid $=24451777$ (2013. december 17.).
} 
különösen a jogtudományi álláspontok között, akár egyazon nemzeti jogrendszeren belül is. $^{1492}$

$\mathrm{Az}$ ítélet érvelésének kritikájánál a kiindulópont véleményem szerint a fogyasztóvédelem eredendő célja, azaz a felek érdekei közötti egyensúly helyreállításának elve, ${ }^{1493}$ valamint az, hogy mivel a nem szerződésszerü teljesítés jogi kérdés, így mindig esetenként, a konkrét szerződés fényében kell megítélni a vonatkozó jogszabály rendelkezéseit. ${ }^{1494}$ Emellett - ahogyan azt a fötanácsnok is kiemelte -, az ügyben felmerült költségek a nemzeti jogrendszerek nagy hányadában inkább a következménykárokkal kapcsolatos kérdésnek minősülnek. ${ }^{1495}$

\subsubsection{A kicserélési jog tartalma}

Aggályos a Bíróság nyelvi módszerrel való érvelése a kicserélés tartalmára vonatkozóan, ${ }^{1496}$ mivel a különböző hivatalos szövegváltozatok közötti különbségek sokszor kiküszöbölhetetlenek, és az anyagi jogi kérdések megítélése ezektől nem függhet.

Ellentmondásos az érvelés azon pontja is, amely elöször az Irányelv minimumharmonizációs törekvését emeli ki, majd arra hivatkozik, hogy annak rendelkezései a fogyasztóvédelem magas szintjének követelményeit szem elött tartva felülmúlhatják a konkrét szerződés tartalmát is. ${ }^{1497}$ A 3. cikk fogyasztói jogai a szerződésszerü teljesítés fogalmában gyökereznek, és ennek megfelelően azokat az eredeti adásvételi szerződésben megállapított jogokra és kötelezettségekre figyelemmel kell értelmezni. ${ }^{1498}$ A szavatossági jogok célja ugyanis az, hogy a fogyasztó eredeti jogosultságának, a hibátlan áru birtokbavételének a hiányát orvosolják. Ettől viszont elkülönítendő az olyan további munkákért vagy költségekért való helytállás, amely a fogyasztási cikk átadását, valamint a fogyasztó általi felhasználást követően merül fel. ${ }^{1499}$ Itt a fogyasztó felelősségi körébe eső cselekvésből is fakadóan lépnek fel extraköltségek,

\footnotetext{
1492 Lásd fent: fötanácsnoki indítvány a C-65/09. sz. ügyben, 24. pont.

${ }^{1493}$ Lásd már az Irányelv javaslatát is: $\operatorname{COM}(95)$ 520, 7. p. Ezt egyébként az EuB maga is hangsúlyozta az ítélete rendelkező részében, lásd: 75. pont.

${ }^{1494}$ Az ún. szubjektív hibafogalom, lásd többek között: KÄMPF M. (2007), 60-61. p.; LOOSCHELDERS (2011), 11. p.; EMMERICH (2012), 21. p.

1495 Lásd: fötanácsnoki indítvány a C-65/09. sz. ügyben, 29. pont.

1496 Lásd: az ítélet 54. pontja.

${ }^{1497}$ Vö. az ítélet 59. és 60. pontját.

${ }^{1498}$ Erre utal az is, hogy a német jogalkotó a szubjektív hibafogalmat alkalmazta az Irányelv átültetésekor, azaz a hiba elsősorban a szerződésben kialkudottak szerint ítélendő meg, lásd: BT-Drucksache 14/6040, 212.

${ }^{\mathrm{p} .}{ }^{149}$ Lásd: fötanácsnoki indítvány a C-65/09. sz. ügyben, 60. pont.
} 
így az eladó ezekért fennálló felelősségénél már a szubjektív elemek is relevánsak. ${ }^{1500}$ Ezek azonban már (szándékoltan) nem tartoznak az Irányelv hatálya alá. ${ }^{1501}$ Emellett pedig figyelemmel kell lenni a szerződés tartalmára a vonatkozásban is, hogy abban benne volt-e a beépítési/beszerelési kötelezettség az eladó oldalán.

Amint arra a fötanácsnok is rávilágított, az áru „természete és célja szerinti felhasználása" a gyakorlati esetek fényében pontatlan megfogalmazás, hiszen az nagyon gyakran nem határozható meg egyértelműen. ${ }^{1502}$ Ezen kívül a már felhasznált, azaz jelen esetben a beépített illetve beszerelt áru hibáinak a jellege is különbözhet a beépítéstől függetlenül. A hiba jelentősége és jellege pedig az Irányelv szerint mértékadó az arányosság megítélésénél. Erre figyelemmel úgy vélem, hogy a kérdések azonossága ellenére nem ítélhető meg egyformán a két jogeset. A járólapok esetében a hiba nem hat ki a rendeltetésszerü használatra, a mosogatógépnél viszont igen, hiszen ott müködési hiba lépett fel. Természetesen az előbbi esztétikai hiba is okozhat érdeksérelmet. Azonban a járólapok esetében az is kérdésként merül fel, hogy a vevő mikor, a beépítés melyik fázisában észlelhette volna a hibát, azaz megelőzhető lett volna-e a többletköltsége (kára), ha körültekintően jár el. ${ }^{1503}$

\subsubsection{Az arányosság kérdése}

Amennyiben az EuB ítélete alapján csak az első lépcső két jogorvoslatának vonatkozásában érvényesülne az arányosság követelménye, és az egyik lehetetlensége esetén a másikat már ily módon nem lehetne megtagadni, akkor jelentősen leszükülne a második lépcsős jogok alkalmazásának köre, és maga az érdekegyensúly billenne el aránytalanul a fogyasztó javára. ${ }^{1504}$ Itt is hangsúlyozni kell ezért, hogy a hiba illetve a szerződésszegés jellege a legfontosabb mérce.

Az Irányelv nem fogalmaz konkrétan, amikor arról rendelkezik, hogy „, a fogyasztó a vételár megfelelő csökkentését kérheti vagy elállhat a szerződéstöl, ha nem jogosult sem

\footnotetext{
${ }^{1500}$ Lásd: fötanácsnoki indítvány a C-65/09. sz. ügyben, 55. pont.

${ }^{1501}$ Már az Irányelv javaslata is kimondta, hogy az Irányelv semmiképp sem szándékozik szabályozni a felelősséget a lehetséges közvetett és közvetlen károkért, lásd: COM(95) 520, 6. p. Vö. BGB § 437 (3); lásd: SCHULZE (2012), 546. p.

${ }^{1502}$ Minél egyszerübb az áru, illetve minél közelebb áll valamely alkotórészhez vagy nyersanyaghoz, annál több felhasználási módja lehetséges. Ennek fényében az egyes esetekben meglehetősen eltérő lehet az eltávolítási költség hibás termék esetén; lásd: főtanácsnoki indítvány a C-65/09. sz. ügyben, 63. pont.

${ }^{1503}$ Vö. az EuB által kreált minta-fogyasztó kategóriája, lásd: C-210/96. számú ítélet. Lásd: II. rész 1. fejezet 3. pont.

${ }^{1504}$ Lásd: főtanácsnoki indítvány a C-65/09. sz. ügyben, 85. pont.
} 
a fogyasztási cikk kijavitására, sem a kicserélésére...". ${ }^{1505}$ Egyértelmű azonban, hogy ehelyütt az első lépcsős jogok korlátjaiként felsorolt lehetetlenségre és aránytalanságra kell gondolni. Ez pedig arra az értelmezésre vezet, hogy az arányosság kérdése nem csupán az első lépcsős jogok közötti választás esetén, hanem az összes szavatossági jog viszonylatában releváns. ${ }^{1506}$ A BGB kötelmi általános részének szabálya egyébként kimondja, hogy a kötelezett megtagadhatja a teljesítést, amennyiben az olyan költségekkel jár, amely a kötelem tartalmára és a jóhiszemüség és tisztesség elvére tekintettel a jogosult teljesítéshez való érdekével súlyos aránytalanságban áll. ${ }^{1507} \mathrm{Az}$ arányosság kérdésével kapcsolatban sem lehetett volna egyébként csupán az Irányelv megszövegezésére hagyatkozni a nyelvi változatok eltérősége miatt. ${ }^{1508}$

Ítélete indokolásában hangsúlyozta az $\mathrm{EuB}$, hogy a 3. cikk célját, azaz a fogyasztó és az eladó érdekei közötti megfelelő egyensúly megteremtését úgy kell elérni, hogy figyelembe vegyék az eladó által felhozott gazdasági jellegű megfontolásokat is. ${ }^{1509}$ Kimondta ezért, hogy az Irányelvvel nem ellentétes az, hogy a fogyasztónak a fenti költségek megtérítéséhez való jogát - szükség esetén - a fogyasztási cikk hibátlan állapotbani értékével és a hiba jelentőségével arányos összegre korlátozzák, és egyúttal a fogyasztó számára biztosítják a lehetőséget arra, hogy kicserélés helyett a vételár megfelelő csökkentését követelje vagy elálljon a szerződéstől. ${ }^{1510} \mathrm{Az}$ EuB ezen ésszerü, de a többi érvvel ellentmondásba keveredő megállapítása lényegében a főtanácsnok és a fent feltárt kritikai álláspontot igazolják: az arányosság kérdését mindig a konkrét eset körülményeinek megfelelően, a hibátlan fogyasztási cikk értékének és a hiba jelentőségének a figyelembevételével kell megítélni, és az nem korlátozható csupán az első lépcsős igényekre.

\footnotetext{
${ }^{1505}$ Lásd: Irányelv, 3. cikk (5) bekezdés.

${ }^{1506}$ Az osztrák polgári törvénykönyv jó példát szolgáltat az Irányelv rendelkezésének konkrétabb és tisztább átültetésére, vö. ABGB $§ 932$ (4).

1507 Lásd: BGB § 275 (2): „Der Schuldner kann die Leistung verweigern, soweit diese einen Aufwand erfordert, der unter Beachtung des Inhalts des Schuldverhältnisses und der Gebote von Treu und Glauben in einem groben Missverhältnis zu dem Leistungsinteresse des Gläubigers steht...”.

${ }^{1508}$ Az egyik németnyelvü Irányelv-kommentár például többes számban „más jogokhoz” való viszonyítást jelez, nem pedig csupán a másik első lépcsős jogra vonatkozóan tartja az arányosságot irányadónak. Lásd: GRUNDMANN - BIANCA (2002), 180. p.: „,.. die für die Gewährleistung aufzuwendenden Kosten, verglichen mit denjenigen der anderen Gewährleistungsarten, nicht vertretbar erscheinen.”; uo. 187. p.: „,.. Er kann keine Form der Gewährleistung wählen, die im Vergleich zu einer anderen mit unangemessenen Kosten verbunden ist...".

${ }^{1509}$ Lásd: az EuB ítéletének 75. pontja.

${ }^{1510}$ Lásd fent az ítélet rendelkező részét.
} 


\subsection{Az itélet jelentősége}

Az ítélet jelentősége abban rejlik, hogy egyike annak a három, közelmúltban hozott luxemburgi döntésnek, amelyek a fogyasztói adásvételhez kötődő kellékszavatossággal kapcsolatos anyagi jogi kérdéseket tárgyalják. A német joggyakorlatban már hivatkozott is az ítéletre egy legfelsőbb bírósági határozat. ${ }^{1511} \mathrm{Az}$ alapügyekben felmerült fogyasztói jogérvényesítési problémákon keresztül az Európai Bíróság a fogyasztóvédelem nagyon magas szintjének követelményét írja elő benne a tagállami jogalkalmazás és irányelvértelmezés területén. Bár az EuB érvelése dogmatikailag több ponton nem állja meg a helyét, a végeredmény, mint precedens a fogyasztók részére az eddiginél is erőteljesebb védelmet irányoz elő az EU tagállamaiban. A kérdés az, hogy a tagállami bíróságok joggyakorlatában ez mennyire fog megjelenni.

\section{Igényérvényesítési határidők - bizonyítási teher}

\subsection{Németország}

A pandektajogban gyökerező 30 éves általános elévülési határidő 3 évre rövidült a 2002-es kötelmi jogi reform következtében (BGB § 195). Emellett az adásvételi szerződés hibás teljesítése esetén is változtak a speciális igényérvényesítési határidők.

Fontos kérdés, hogy melyik a meghatározó időpont a kellékhiba keletkezése szempontjából. A BGB § 434 (1) bekezdése alapján ez a veszély átszállása, amely akkor következik be, amikor a dolgot átadják a vevőnek: ${ }^{1512}$

„Die Sache ist frei von Sachmängeln, wenn sie bei Gefahrübergang die vereinbarte Beschaffenheit hat..."

„Mit der Übergabe der verkauften Sache geht die Gefahr des zufälligen Untergangs und der zufälligen Verschlechterung auf den Käufer über. Von der Übergabe an Gebühren dem Käufer die Nutzungen und trägt er die Lasten der Sache. Der Übergabe steht es gleich, wenn der Käufer im Verzug der Annahme ist."

Az adásvétel általános szabályai eltérően rendelkeznek ugyan a „helykülönbségi vétel” (Versendungskauf) esetén, ${ }^{1513}$ fogyasztási cikk vételénél azonban - a főszabálytól eltérően

\footnotetext{
${ }^{1511}$ Lásd: BGH 17.10.2012 VIII ZR 226/11. számú ítélet.

1512 Ezen kívül, ha az átadás-átvétel időpontja pontosan meghatározott, viszont a vevő az átvételt elmulasztja, azaz az átvétellel késedelembe esik, akkor is beállnak a jogkövetkezmények, lásd: BGB $\S 446$.

${ }^{1513}$ Vö. BGB $§ 447$ (1).
} 
- minden esetben az árunak a fogyasztó általi átvételekor száll át a veszély, így ez az irányadó időpont a kellékhiány fennállására nézve is [§ 474 (2)].

A kötelmi általános szabályok alapján, amennyiben a vevő késedelembe esik az áru átvételével, akkor - hacsak az eladót nem terheli szándékosság vagy súlyos gondatlanság a vevőre az áru átadására megállapított időben átszáll a veszély. ${ }^{1514}$

\subsubsection{Kellékszavatossági határidők}

A kellékszavatossági igények érvényesítésének általános elévülési ideje a BGB-ben 2 év lett a reform után [§ 438 (1)]. Fogyasztási cikkek adásvétele esetén az eladó hibáról való tájékoztatása előtt csak a fogyasztó előnyére állapodhatnak meg eltérő határidőben, azaz ilyenkor az eltérő kikötés a 2 évnél csak hosszabb lehet [§ 475 (2)]. Használt dolgok esetén - az Irányelv opcionális rendelkezését átvéve - legfeljebb egy évre redukálható a határidő, de ha nem állapodnak meg másban a felek, akkor azokra is a két év lesz az irányadó. ${ }^{1515}$ $\mathrm{Az}$ igények elévülése ingók esetén a dolog „leszállításával” (Ablieferung) veszi kezdetét. $^{1516}$

A bizonyítás általános szabálya értelmében a vevőnek kellene bizonyítania, hogy a hiba már a dolog átadásakor fennállt, de a BGB az Irányelvnek megfelelően megkönnyíti a fogyasztó helyzetét a hibásság vélelmének előírásával:

„Zeigt sich innerhalb von sechs Monaten seit Gefahrübergang ein Sachmangel, so wird vermutet, dass die Sache bereits bei Gefahrübergang mangelhaft war, es sei denn, diese Vermutung ist mit der Art der Sache oder des Mangels unvereinbar. "1517

A rendelkezés alapján, ha a veszély átszállásától számított hat hónapon belül merül fel kellékhiba, akkor úgy kell tekinteni, mintha a dolog már a veszély átszállásakor hibás lett volna. A vélelem joghatása az, hogy megfordul a bizonyítási teher, azaz a hat hónap alatt az eladónak kell az áru hibátlanságát bizonyítania. ${ }^{1518} \mathrm{~A}$ vélelem nem áll fenn azonban akkor, ha az a dolog vagy a hiba jellegével összeegyeztethetetlen. ${ }^{1519}$ A bíróság egy ezzel

\footnotetext{
${ }^{1514}$ BGB $\S 300$ (1): „Der Schuldner hat während des Verzugs des Gläubigers nur Vorsatz und grobe Fahrlässigkeit zu vertreten.”. Fajlagos vételnél a vevő késedelme akkor áll be ('́gy a veszély is akkor száll át rá), amikor a felajánlott (kiválasztott) árut nem veszi át, ezért a kellékhibákra is ez az időpont lesz releváns, lásd: BGB § $300(2)$.

${ }_{1515}$ Lásd: BGB $§ 475$ (2), vö. Irányelv, 7. cikk (1) bekezdés.

${ }^{1516}$ Lásd: 438 § (2): „Die Verjährung beginnt bei Grundstücken mit der Übergabe, im Übrigen mit der Ablieferung der Sache.".

${ }_{1517}^{1517}$ Lásd: BGB $§ 476$.

${ }^{1518}$ CSIZMAZIA (2002), 434. p.

${ }^{1519}$ Vö. Irányelv, 5. cikk (3).
} 
kapcsolatos jogesetben kimondta, hogy a hibásság vélelme az állatok fogyasztói adásvétele esetén ugyan általában alkalmazható, de bizonyos hibák esetén nem. ${ }^{1520}$ A jogeset tényállása szerint egy lótenyésztő eladott egy öt éves lovat 7100 euróért, amely 4 hónap múlva „nyári ekcéma” nevü allergiában szenvedett, ezért a vevő úgy döntött, hogy eláll a szerződéstől; igénye teljesítését azonban az eladó megtagadta. A német Bundesgerichtshof úgy ítélte meg, hogy ez esetben a hiba jellegével nem összeegyeztethetetlen a hat hónapos vélelem, és az az indok, hogy az tipikusan bármikor előfordulhat, nem állja meg a helyét. Az esetben szereplő betegség kialakulásának időpontját nehéz megállapítani, így a bíróság szerint méltánytalan lett volna kizárni a vélelem alkalmazhatóságát. ${ }^{1521}$

Szintén a fordított bizonyítási teherrel függ össze az a jogeset, amelyben a fogyasztó által megvásárolt autó motorjában elszakadt az ékszíj. ${ }^{1522}$ A kereskedő arra hivatkozott, hogy a hibát az okozta, hogy a fogyasztó nagy sebességnél nem a megfelelő sebességi fokozatba kapcsolt, azaz szerinte a hiba a kárveszély átszállásakor még nem volt meg az autóban. Az ügyben jogerős ítéletet hozó legfelsőbb bíróság az elsőfokú eljárásban alkalmazott szakértői véleményre hivatkozott. A szakértő, bár megállapította, hogy az ékszíj lazulása az anyagban lévő hibára és a rendkívül nagy súrlódási kopásra visszavezethető, de azt is előadta, hogy nem zárható ki az sem, hogy a tényleges szakadás a rossz sebességbe kapcsolás miatt következett be: éppen ezért minden kétséget kizáróan nem állapítható meg a hiba eredője. A bíróság végül úgy döntött, hogy a fordított bizonyítási teherre vonatkozó fogyasztóvédelmi elöírást nem lehet kiterjesztően értelmezni, és a fogyasztóra hárul a hiba oka bizonyításának a terhe. Az indoklás szerint a hat hónapos vélelem csapán arra az időszakra vonatkozik, amelyben a hiba fennállhatott, és nem magának a hibának a létezésére. Úgy vélem, hogy ez a jogértelmezés meglehetősen megszorító, nem tükrözi a vélelem jogpolitikai célját, ráadásul nem is egyértelmü az indoklás fogalmazásmódja. ${ }^{1523}$

\footnotetext{
${ }^{1520}$ Lásd: BGH VIII ZR 173/05 (2006) NJW 2250. számú döntés.

${ }^{1521}$ Lásd: MICKLITZ - STUYCK - TERRYN (2010), 337. p.

${ }^{1522}$ Lásd: BGH VIII ZR 329/03 (2004) ZIP 1368. számú ítélet.

${ }^{1523}$ Vö. a BGH VIII ZR 329/03 (2004) számú ítélet rendelkező része: „Macht der Käufer Rechte gemäß § 437 BGB geltend, nachdem er die Kaufsache entgegengenommen hat, trifft ihn die Darlegungs- und Beweislast für die einen Sachmangel begründenden Tatsachen. $\S 476$ BGB enthält insoweit für den Verbrauchsgüterkauf keine Beweislastumkehr. Die Bestimmung setzt einen binnen sechs Monaten seit Gefahrübergang auftretenen Sachmangel voraus und begründet eine lediglich in zeitlicher Hinsicht wirkende Vermutung, daß dieser Mangel bereits im Zeitpunkt des Gefahrübergangs vorlag.”.

Az ítélet német nyelven elérhető: http://autokaufrecht.info/2004/06/darlegungs-und-beweislast-fuer-dieeinen-sachmangel-begruendenden-tatsachen/ (2013. november 18.).
} 
A német legfelsőbb bíróság egy másik ítéletében viszont kiterjesztő értelmezéssel úgy döntött, hogy a vélelem akkor is fennáll, ha az árut egy harmadik, a fogyasztóval szerződéses viszonyban álló fél üzemeli be. ${ }^{1524}$

A német kötelmi általános szabályok szerint, ha a jogosult a nem szerződésszerü teljesítést elfogadta teljesítésként, akkor az a teljesítéssel azonos hatályú, azaz megszünteti a kötelmet. ${ }^{1525}$ Ezért a fenti hat hónap eltelte után a fogyasztói adásvétel esetén is a bizonyítás általános szabálya érvényesül: a fogyasztó köteles bizonyítani, hogy mégsem minősül hibátlan teljesítésnek a szolgáltatás, mert az nem szerződésszerű vagy hiányos. ${ }^{1526}$

A kicserélésről a BGB itt explicite nem rendelkezik, de a jogtudomány álláspontja az, hogy a dolognak vagy egy részének a kicserélése megszakítja az elévülést, így az újrakezdődik. ${ }^{1527} \mathrm{Ez}$ azonban a sorozatos javítások esetén a legfelsőbb bíróság szerint méltánytalan bizonyítási terhet róna az eladókra, így egyik döntésében úgy rendelkezett, hogy az első átadás (teljesítés) időpontja az irányadó minden kicserélési szavatossági igény elévülése és a hibásság vélelme szempontjából. ${ }^{1528} \mathrm{Ez}$ az indoklás szerint nem jelent hátrányt a fogyasztóra nézve, mert az új dolog teljesítése a BGB $§ 212$ (1) értelmében mindenképp megszakítja az elévülést. Kijavítás esetén az elévülés a legfelsőbb bíróság szerint csak a javítással érintett dologrészre vonatkozóan kezdődik újra.

Az elállási és vételárcsökkentési igények elévülésére a BGB utaló szabálya a § 218 alkalmazását írja elő. ${ }^{1529}$ Eszerint e jogok nem gyakorolhatóak, ha a teljesítésre vagy a pótteljesítésre irányuló igény elévült, és a kötelezett erre hivatkozik, valamint akkor sem, ha a kötelezett a teljesítés lehetetlenülése, vagy a pótteljesítés vevő által választott módjának aránytalan költségek miatti megtagadása okán nem teljesít, de egyébként a teljesítésre vagy a pótteljesítésre vonatkozó igény elévült. ${ }^{1530}$

\footnotetext{
${ }^{1524}$ Lásd: BGH 22.11.2004, VIII ZR 21/04.

1525 BGB § 364 (1): „,Das Schuldverhältnis erlischt, wenn der Gläubiger eine andere als die geschuldete Leistung an Erfüllung statt annimmt.".

1526 Lásd: BGB § 363: „Hat der Gläubiger eine ihm als Erfüllung angebotene Leistung als Erfüllung angenommen, so trifft ihn die Beweislast, wenn er die Leistung deshalb nicht als Erfüllung gelten lassen will, weil sie eine andere als die geschuldete Leistung oder weil sie unvollständig gewesen sei.". Vö. BGB § 364 (1).

${ }^{1527}$ LOOSCHELDERS (2011), 53. p.

${ }^{1528}$ Lásd: BGH NJW 2006, 47. számú ítélet.

${ }^{1529}$ Vö. BGB § 438 (4)-(5).

${ }^{1530}$ Vö.: BGB §§ 218 (1), 275 (1)-(3) és 439 (3).
} 


\subsubsection{A hibás teljesítésböl eredö kártérítési igény érvényesítésének határideje}

A „teljesítés helyetti kártérítésre” - jellegéből fakadóan - csak a kellékszavatossági igények érvényesítésére nyitva álló, az általánosnál rövidebb határidők alkalmazandóak a német jogban. ${ }^{1531} \mathrm{Ez}$ azonban arra vezet, hogy gyakran már akkor letelik a határidő, amikor a kár még fel sem merült. ${ }^{1532}$

A „teljesítés melletti kártérítési igény” a kötelmi általános szabályok szerint az általános 3 éves határidő alatt évül el, és ugyanez érvényes a hiábavaló ráfordítások megtérítésére is. ${ }^{1533}$ A fogyasztó számára (is) előnyös, hogy a határidő annak az évnek a végétől indul, amelyben az igény (követelés) létrejött, és amelyben a kártérítési igényt megalapozó körülményekről és a kötelezett személyéről a jogosult, azaz a vevő tudomást szerzett vagy - a súlyos gondatlanság esetén kívül - tudomást kellett volna szereznie. ${ }^{1534}$

Ha az eladó a hibás teljesítés tekintetében csalárdul jár el, akkor a BGB § 438 (3) értelmében a szavatossági igények érvényesítésére ugyancsak az általános három éves elévülési határidő alkalmazandó. ${ }^{1535} \mathrm{E}$ két utóbbi kategória tehát a hibás teljesítés felróhatóságon alapuló szubjektív jogkövetkezménye, amire az igényérvényesítési határidők is utalnak.

\subsection{Ausztria}

Az ABGB is a dolog átadásának idején már fennálló hiba esetén teszi lehetővé a szavatossági igényérvényesítést (§ 924). Az átadáskor meglévő hiba nyilvánvalóan nem jelenti azt, hogy annak már abban az időpontban felismerhetőnek is kell lennie. Ha ugyanis a hiba felismerhető, szemmel látható, és a jogosult mégis elfogadja és átveszi a dolgot, akkor a korábban említettek szerint - a BGB szabályával egyezően - nincs szó hibás teljesítésröl. ${ }^{1536}$

\footnotetext{
${ }^{1531}$ LOOSCHELDERS (2011), 54. p.

${ }^{1532}$ A jogtudomány többségi álláspontja e károk esetén az általános elévülési határidő alkalmazását támogatta a reform során, de a jogalkotó mégis a fenti módon rendelkezett, lásd: LOOSCHELDERS (2011), 54-55. p.

${ }^{1533}$ Lásd: BGB § 195. STÖBER (2005), 40. és 42. p.

1534 Lásd: BGB § 199 (1): „Die regelmäßige Verjährungsfrist beginnt, soweit nicht ein anderer Verjährungsbeginn bestimmt ist, mit dem Schluss des Jahres, in dem der Anspruch entstanden ist und der Gläubiger von den den Anspruch begründenden Umständen und der Person des Schuldners Kenntnis erlangt oder ohne grobe Fahrlässigkeit erlangen müsste.".

1535 LOOSCHELDERS (2011), 53. p.

${ }^{1536}$ Lásd fent: ABGB § 928; PERNER - SPITZER (2007), 167. p.
} 
A hiba kialakulásának időpontját igen nehéz megállapítani a gyakorlatban, így ahhoz gyakran szakértőt kell igénybe venni az igényérvényesítés során. ${ }^{1537}$ A hibásság időpontjával kapcsolatban ezért nem csak a fogyasztói vétel, hanem minden visszterhes jogügylet esetén felállítja az ABGB is az Irányelv hat hónapos megdönthető vélelmét. ${ }^{1538}$ Itt sem alkalmazható azonban a vélelem, ha az a dolog illetve a hiba jellegével összeegyeztethetetlen. ${ }^{1539}$ A vélelem alkalmazása a már említettek szerint a bizonyítási teher megfordulását eredményezi, azaz minden visszterhes szerződés hibás teljesítésével kapcsolatos esetleges jogvitában az átadást követő hat hónap alatt kiütköző hiba esetén a kötelezettnek kell bizonyítania, hogy a hiba a dolog átadásakor még nem állt fenn. ${ }^{1540}$ A jogtudomány és joggyakorlat a fogyasztási cikkek közül különösen müszaki cikkek esetén ítéli nehézkesnek a hiba fennállásának bizonyítását, így azok esetén különösen meghatározó a fenti vélelem jelentősége. ${ }^{1541}$

\subsubsection{Kellékszavatossági határidők}

A kellékszavatossági jogait az ABGB szerint a következő határidőkön belül foganatosíthatja a vevő:

„Das Recht auf Gewährleistung muss, wenn es unbewegliche Sachen betrifft, binnen drei Jahren, wenn es bewegliche Sachen betrifft, binnen zwei Jahren gerichtlich geltend gemacht werden. Die Frist beginnt mit dem Tag der Ablieferung der Sache... "1542

Az ingó dolgok esetén két éves az általános elévülési határidő, amely a dolog átadásától, „leszállításától” (Ablieferung) számítandó. ${ }^{1543}$ Az ABGB tehát az Irányelv fogyasztói adásvételekre irányadó, a megelőző hat hónaposnál jóval hosszabb, 2 évet vezette be általános határidőként a BGB-hez hasonlóan. A határidők (a korábbi jogvesztő határidőktől

\footnotetext{
${ }^{1537}$ Lásd: PIRKER-HÖRMANN - HAMMERL (2004), 22. p.

1538 Lásd: ABGB § 924: „,Der Übergeber leistet Gewähr für Mängel, die bei der Übergabe vorhanden sind. Dies wird bis zum Beweis des Gegenteils vermutet, wenn der Mangel innerhalb von sechs Monaten nach der Übergabe hervorkommt. Die Vermutung tritt nicht ein, wenn sie mit der Art der Sache oder des Mangels unvereinbar ist.”. PIRKER-HÖRMANN - HAMMERL (2004), 23. p.

1539 Így például a gyorsan romló termékek, élelmiszerek esetén. Lásd: EB 422 BlgNR 21. GP 15. számú döntés; KLETECKA (2001), 36. p.

${ }^{1540}$ FERCH-FISCHER (2011), 27. p.

1541 PERNER - SPITZER (2007), 167. p.

1542 Lásd: ABGB § 933 (1).

${ }^{1543}$ Ez a megelőző joggyakorlatot is tükrözi, lásd: Gewährleistungsreform (2001), 4. p.
} 
eltérően) elévülési jellegűek, ami különösen a fogyasztói szerződések esetén történő határidő-hosszabbítás szempontjából releváns. ${ }^{1544}$

A KSchG alapján ennél a kétéves határidőnél rövidebb határidőre vonatkozó kikötés fogyasztói szerződés esetén hatálytalan:

„Die Vereinbarung einer kürzeren als der gesetzlichen Gewährleistungsfrist ist unwirksam, doch kann bei Veräußerung gebrauchter beweglicher Sachen die Gewährleistungsfrist auf ein Jahr verkürzt werden, sofern dies im Einzelnen ausgehandelt wird." 1545

A törvény pusztán használt dolgok elidegenítése esetén teszi lehetővé (az Irányelv opcionális szabályával élve), hogy kifejezett megállapodásban legfeljebb egy évre csökkentsék az időtartamot a felek. Egyes jogtudományi álláspontok szerint a használt dolgok esetén lehetővé tett határidő-rövidítés azért felesleges, mert a használt áruk hibás teljesítéséből fakadó problémák nem az igényérvényesítési határidők hosszából, hanem abból fakadnak, hogy azoknál az új, használatlan állapothoz képest milyen tulajdonságok hiányoznak; ez a kérdés pedig nem szabályozható absztraktan törvényi szinten. ${ }^{1546}$

Egyedi a fogyasztóvédelmi törvény szabályozása, mert speciálisan a használt gépkocsikra vonatkozó fogyasztói ügyleteket illetően úgy rendelkezik, hogy az egy évre rövidített határidő kikötése csak akkor érvényes, ha az első forgalmi engedély napjától számítva már eltelt több mint egy év [KSchG § 9 (1)]. Ez azt jelenti, hogy ha például az első forgalmi engedély kibocsátását követő fél év után adásvétel keretében máris gazdát cserél egy autó, akkor az új tulajdonos szavatossági joga ugyanúgy minimum két éves lesz, mint az új (használatlan) ingó dolog vétele esetén lenne. Tekintve, hogy a gépjármüvek a fogyasztási cikkek piacán jelentős értéket képviselnek, és ezért a hibás voltukból fakadó jogviták is fokozott jelentőségűek, dicséretes ez a speciális rendelkezés. ${ }^{1547}$

A kicserélés mindig a határidő félbeszakadását eredményezi, így az újra kezdődik. Kijavítás esetén pedig a kijavított vagy pótolt dologrész tekintetében indul újra az elévülés. $^{1548}$

\footnotetext{
${ }^{1544}$ Gewährleistungsreform (2001), 5. p.

1545 Lásd: KSchG § 9 (1). Vö. Irányelv, 7. cikk (1) bekezdés.

${ }^{1546}$ Lásd: KREJCI (2004), 131. p.

1547 Természetesen ez sem állja meg mindig a helyét, hiszen a gépjárművek állapotára a koron kívül meghatározóan hat például az is, hogy hány kilométert tettek már meg.

${ }^{1548}$ FERCH-FISCHER (2011), 35. p. Ez megegyezik a német megközelítéssel.
} 


\subsubsection{A hibás teljesítés miatti kártérítés érvényesitésének határideje}

A szavatosság és a teljesítés helyetti kártérítés közötti konkurencia az igényérvényesítési határidőkben nyilvánul meg leginkább az ABGB-ben: ${ }^{1549}$

„Jede Entschädigungsklage ist in drei Jahren von der Zeit an verjährt, zu welcher der Schade und die Person des Beschädigers dem Beschädigten bekannt wurde, der Sache mag durch Übertretung einer Vertragspflicht [...] verursacht worden sein..., 1550

A kártérítési igényérvényesítés elévülésének általános szabálya alapján a szerződésszegéssel okozott károk a kár és a károkozó felismerésétől számított három éven belül évülnek el, csakúgy, mint a német jogban. A felróhatóságot a dolog átadásától számított 10 éven belül vélelmezi a törvény a hibás teljesítésből eredő károknál is, azután azonban már az átvevőt terheli annak bizonyítása [ABGB § 933a (3)]. Ez a meglehetősen hosszú vélelmi időszak egyes vélemények szerint problematikus, mert rendkívül megnehezíti az átadó pozícióját. ${ }^{1551}$ A fenti rendelkezés megfelelően alkalmazandó a következménykárok vonatkozásában is. ${ }^{1552}$

\subsection{Svájc}

Az igényérvényesítési határidők tekintetében a százéves OR elfogadása óta csupán az elmúlt évtizedben történt változás. A kellékhiba keletkezése szempontjából meghatározó időpont az OR § 185 alapján a veszély átszállása a vevőre, akárcsak a BGB szerint.

E vonatkozásban is külön kell azonban választani az egyedi és fajlagos vételt. Egyedi adásvétel esetén a veszély - ellenkező megállapodás hiányában - a szerződés megkötésekor száll át. ${ }^{1553}$ Fajlagos vétel esetén a kiválasztás illetve az elküldés időpontja az irányadó. ${ }^{1554}$ Mindkét esetben a releváns időpontban már fennálló hiba alapozza meg a kellékszavatossági helytállást, mint a német és az osztrák jogban. ${ }^{1555}$

\footnotetext{
${ }^{1549}$ Lásd: PERNER - SPITZER (2007), 174. p.

${ }^{1550}$ Vö. ABGB $§ 1489$.

${ }^{1551}$ Lásd: Gewährleistungsreform (2001), 6. p.

${ }^{1552}$ Lásd: FERCH-FISCHER (2011), 60-61. p.

1553 Lásd: OR § 185 (1): „Sofern nicht besondere Verhältnisse oder Verabredungen eine Ausnahme begründen, gehen Nutzen und Gefahr der Sache mit dem Abschlusse des Vertrages auf den Erwerber über.". ${ }^{1554}$ Lásd: OR § 185 (2): „,Ist die veräusserte Sache nur der Gattung nach bestimmt, so muss sie überdies ausgeschieden und, wenn sie versendet werden soll, zur Versendung abgegeben sein.".

${ }^{1555}$ HONSELL (2010), 85. p.
} 
A bizonyítási teher vonatkozásában - az EU-s szabályozással ellentétben - a hibátlanság vélelmezendő, ${ }^{1556}$ ami az átlagfogyasztóra nézve hátrányt jelent az igényérvényesítés során. Ha a vevő az árut átvette, akkor neki kell bizonyítania, hogy a hiba fennállt már a veszély átszállásakor, ${ }^{1557}$ valamint azt is, hogy a kifogásközlés a megfelelő időben megtörtént. ${ }^{1558}$

Az OR kellékszavatossági igényérvényesítési határidőre vonatkozó, 2013. január 1jétől hatályos rendelkezése szerint: ${ }^{1559}$

„Die Klagen auf Gewährleistung wegen Mängel der Sache verjähren mit Ablauf von zwei Jahren nach deren Ablieferung an den Käufer, selbst wenn dieser die Mängel erst später entdeckt, es sei denn, dass der Verkäufer eine Haftung auf längere Zeit übernommen hat. "1560

Ingók adásvétele esetén általános igényérvényesítési határidőként - a korábbi egy év helyett - két évet szab meg tehát az OR, amely - az ABGB és a BGB szabályaival egyezően - a dolog leszállításától számítandó, akkor is, ha a hiba később jelentkezik. A korábbi egy éves, a római jogban gyökerező határidőt ${ }^{1561}$ épp a kezdő időpont miatt kritizálta a jogtudomány. ${ }^{1562}$

Az új kétéves határidő ráadásul kógens a „fogyasztó” és „,vállalkozás” közötti új ingó árura vonatkozó adásvételnél, használt dolog esetén pedig egy évnél rövidebb határidő nem köthető ki az ilyen szerződésben:

„Eine Vereinbarung über die Verkürzung der Verjährungsfrist ist ungültig, wenn:

a. sie die Verjährungsfrist auf weniger als zwei Jahre, bei gebrauchten Sachen auf weniger als ein Jahr verkürzt;

b. die Sache für den persönlichen oder familiären Gebrauch des Käufers bestimmt ist; und

c. der Verkäufer im Rahmen seiner beruflichen oder gewerblichen Tätigkeit handelt. $" 1563$

\footnotetext{
${ }^{1556}$ HONSELL (2010), 85. p.; BUCHER (1988), 93. p.

${ }^{1557}$ Ez alól nyilvánvaló kivételt képez a német és osztrák joggal egyezően az az eset, amikor a vevő már az átadás alkalmával megtagadja a dolog átvételét annak hibás voltára hivatkozva, vagy a hibásságra vonatkozó fenntartással veszi azt át; ekkor az eladó köteles bizonyítani azt, hogy a veszély átszállásakor a dolog hibátlan volt. Ez már több korai Szövetségi Bírósági döntésböl is egyértelműen kiderül, lásd: HONSELL (2010), 85. p. hivatkozása a BGE 26 II 798. számú döntésre. Az indoklás szerint azért a vevőt terheli a bizonyítási kötelezettség, mert az ö érdekében áll, hogy az áru hibáját a „lehető leghamarabbi kifogásközlés” nyomán orvosolják, lásd: BUCHER (1971), 3. p.

${ }^{1558}$ ZEHNDER (2000), 548. p. A bírósági gyakorlat alapján ez a ZGB $\S 8$ szabályából következik (a bizonyítási teher általános szabálya), lásd: BGer. 4D. 4/2011. számú döntés.

${ }^{1559}$ Lásd: http://www.admin.ch/aktuell//00089/index.html?lang=de\&msg-id=46136 (2014. február 22.).

${ }^{1560}$ OR $\S 210(1)$.

${ }^{1561}$ A határidők ókori gyökereit sok szerző megemlíti, lásd többek között: GIGER (1979), 588-589. p.

${ }^{1562}$ Nagyon gyakran ellehetetlenítette az igényérvényesítést a csak egy év elteltével jelentkező, de már a veszély átszállásakor „lappangó” hiba. A korábbi szabályozás kritikájához lásd többek között: PICHONNAZ (2003), 296-297. p.

${ }^{1563}$ OR $§ 210(4)$.
} 
A rendelkezés feltételei konjunktívak. A törvény nem alkalmazza a fogyasztó kifejezést, de a fogyasztó általános meghatározásának megfelelő fogalmat ad, és ugyanígy a rendelkezésbe építi be a vállalkozó fogalmi meghatározását is. Ez a szabály teljes egészében az Irányelv vonatkozó rendelkezéseit tükrözi. ${ }^{1564}$

A határidő elévülési jellegü, amit elsősorban az igazol, hogy a szavatossági igények kifogásként érvényesítése annak letelte után is lehetséges, feltéve, hogy a vevő a kifogásközlési kötelezettségének e határidőn belül eleget tett. ${ }^{1565} \mathrm{E}$ jellegből fakadóan a határidő nyugodhat és megszakadhat, ${ }^{1566}$ a nyugvás azonban nem áll be amiatt, hogy a hiba bizonyos ideig nem felismerhető. ${ }^{1567}$

A határidő a kellékhiba miatti minden igény érvényesítésére kiterjed, az eladó által ígért tulajdonságokra, valamint egyéb, a szerződésben esetlegesen megállapított igényekre is vonatkozik. Ezen kívül pedig mind a közvetlen károk objektív jogalapú megtérítése, mind pedig az egyéb károk szubjektív jogalapú megtérítése esetén alkalmazandó. ${ }^{1568}$

A jogalkotó a kultúrkincsek védelmében hozott 2003-as törvény nyomán is beépített egy külön rendelkezést a kultúrkincsnek minősülő árucikkekkel kapcsolatban fellépő igények érvényesítési határidejére vonatkozóan az OR-be, amely 2005. június 1-jén lépett hatályba. Bár a kultúrkincsek (régiségek) ${ }^{1569}$ adásvételénél a vételár gyakran nagy értéket képvisel, jellemzően ezek az ügyletek is fogyasztók (műkedvelők) és vállalkozások között bonyolódnak le. A kellékszavatossági határidőt illetően a törvény az adásvétel e speciális tárgyára figyelemmel elévülési és jogvesztő határidőket határoz meg: az elévülési határidő egy év, amely nem a leszállítástól, hanem a hiba felismerésétől számítandó. Az abszolút, jogvesztő határidő kifejezetten hosszú, a törvény ezt a szerződéskötéstől számított 30 évben állapítja meg. ${ }^{1570}$

A határidők a többi kellékszavatossági szabályhoz hasonlóan - a fent említett, a „fogyasztó” javára fennálló klaudikálóan kógens rendelkezés kivételével - diszpozitívek.

\footnotetext{
${ }^{1564}$ Vö. Irányelv, 5. cikk (1) bekezdés és 7. cikk (1) bekezdés. Az OR-t módosító javaslatban többek között az Irányelv elvárásaira, így az európai országok szabályozására, valamint a Bécsi Vételi Egyezményre hivatkoztak a két évre emelendő határidő megalapozottságát illetően, lásd: http://www.parlament.ch/d/suche/seiten/geschaefte.aspx?gesch_id=20060490 (2014. február 11.). ${ }^{1565}$ OR $§ 210$ (5); lásd: HONSELL (2010), 98. p.

${ }^{1566}$ Az OR ezekre vonatkozó, $\S \S 134$ és azt követő rendelkezései alkalmazandóak, HoNSELL (2010), 95. p.

${ }^{1567}$ Az elévülési jelleg tehát e vonatkozásban relatív. Giger úgy fogalmaz, hogy ,atipikus elévülés” áll fenn, a jogvesztő funkció nem zárható ki teljesen, lásd: GIGER (1979), 592. p.

${ }^{1568}$ Lásd a BGE 90 II 88. számú döntés hivatkozását a Szövetségi Bíróság vonatkozó következetes gyakorlatára. Nem vonatkozik azonban a határidő a kellékszavatossági igényekkel konkuráló jogok, az „önálló garanciából” fakadó jogok, az aliud és peius szolgáltatás miatti igények érvényesítésére, valamint a megtévesztés esetére, lásd: HoNSELL (2010), 96. p.

${ }^{1569}$ A Kulturgütertransfergesetz $§ 2$ adja meg a kultúrkincs fogalmát.

1570 OR § 210 (3). Egy festmény, dombormú, stb. nem eredeti jellege például gyakran csak évek múltán derül ki, így ez a 2003-as módosítás nagy előnyt jelent az igényérvényesítésnél.
} 
Ez azt jelenti, hogy a nem „fogyasztói vétel” esetén rövidebb vagy hosszabb, „fogyasztói vétel" esetén pedig hosszabb határidő is kiköthető a szerződésben az igények érvényesítésére. A korábbi többségi tudományos álláspont alapján azonban a hosszabb határidő nem haladhatja meg az OR általános elévülési határidejét, a 10 évet. ${ }^{1571}$

\section{Kellékszavatosság állatok adásvétele esetén}

\subsection{Ausztria}

Az ABGB állatok (jószágok) adásvétele esetén irányadó eredeti szavatossági szabályai több mint kétszáz éve hatályban vannak a szavatosság általános szabályai között. Ezek a speciális rendelkezések a hibásság vélelmére, a hibával kapcsolatos kifogásközlésre, a bizonyítási teherre, és a szavatossági határidőkre vonatkoznak. ${ }^{1572}$ A fogyasztóvédelmi törvény konkrétan úgy rendelkezik azonban, hogy ha a jószág megszerzője fogyasztó, akkor nem alkalmazhatók az ABGB speciális szabályai [KSchG § 9 (2)]. Amennyiben tehát a jószág vétele fogyasztói adásvételnek minősül, akkor a fogyasztói jogügyletekre irányadó általános szabályok alkalmazandóak a határidők esetén, és más tekintetben is.

\subsection{Svájc}

Az OR is külön szabályozza a kellékszavatosságot az állatok (jószágok) adásvételére vonatkozóan (Viehkauf). ${ }^{1573}$ A jószág eladója csak akkor tartozik kellékszavatossággal, ha azt a vevővel szemben írásban vállalta fel, vagy ha a vevőt szándékosan megtévesztette (OR § 198). A kódex az állatszavatossági határidők vonatkozásában diszpozitív szabályt ír elő (§ 202), a fenti új fogyasztóvédelmi kógens határidő fényében azonban értelmezésem szerint a diszpozitivitás nem alkalmazható a fogyasztó és vállalkozás közötti jószágra vonatkozó adásvétel esetén. A probléma azonban az, hogy az OR § 198 szabálya diszpozitív, azaz ha az eladó nem csalárdul jár el, illetve nem vállalja a szavatossági helytállást, akkor nincs ugyan szavatossági kötelezettsége, de a határidőre vonatkozó kógens rendelkezés elviekben fennáll. Remélhetőleg a svájci jogalkotó felfedezi a következetlenséget, és rendezi ezt a kérdést is.

\footnotetext{
1571 GIGER (1979), 592. p.; lásd: BGE 99 II 189. és BGE 56 II 430. számú döntések.

1572 Lásd: ABGB $§ \S 925-927$ és 933 (2). Vö. I. rész 2. fejezet 1.5. pont.

${ }^{1573}$ A rendelkezés értelmében a ló, a szamár, az öszvér, a szarvasmarha, a bárány, a kecske és a sertés tartozik a speciális rendelkezések hatálya alá (Vieh = négylábú haszonállat).
} 


\section{Elhatárolási kérdések}

\subsection{Németország}

Az elhatárolási kérdések a jogirodalomban és a bírói gyakorlatban általában olyan esetek kapcsán merülnek fel, amikor a kellékszavatosság különös részi tényállása konkurenciába kerül valamilyen kötelmi általános részi tényállással.

A német magánjogban tényleges elhatárolást nem, csupán pontosítást igényel a BGB azon szabálya, amely szerint kellékhibának minősül az is, ha az eladó más vagy túl csekély mennyiségü árut szolgáltat: „Einem Sachmangel steht es gleich, wenn der Verkäufer eine andere Sache oder eine zu geringe Menge liefert." ${ }^{1574}$ Ezek szerint a mennyiségi hiány, valamint az aliud szolgáltatás a német jogban ex lege a hibás teljesítés kategóriájába tartozik, bár a jogtudomány ehhez kiegészítést füz. A többségi irodalmi álláspont szerint csak kifejezett kikötés mellett válik egyenértéküvé a kellékhibával az aliud szolgáltatás, a túl nagy mennyiség szolgáltatása pedig a kötelmi általános szabályok hatálya alá tartozik, ami fogyasztói adásvétel esetén nem eredményez jogorvoslatot. ${ }^{1575}$

Nem kellékhibás azonban a teljesítés a korábban említettek szerint, ha a dolgot még nem adták át a vevőnek, mert ő az általa ismert kellékhiba miatt az átvételt visszautasította. Ha a hiba ilyen esetben nem javítható ki, akkor a szolgáltatás lehetetlenültnek minősül. ${ }^{1576}$ Ha a hiba a szerződés megkötése után, de még a veszély átszállása előtt jelentkezik, akkor az eladó szabadul a kötelemböl, de felel a kötelmi általános szabályok alapján a szerződésszegésből eredő kárért, és a lehetetlenült szolgáltatás helyett is keletkezik kártérítési kötelezettsége. ${ }^{1577} \mathrm{Ha}$ a hiba a veszély átszállása után ütközik ki, akkor azonban már egyértelmüen fennáll a kellékszavatossági helytállás. ${ }^{1578}$

A szerződéskötéskori gondosság követelményével, annak elmulasztásával (culpa in contrahendo $)^{1579}$ és a kapcsolódó BGB-beli rendelkezésekkel is konkurenciába léphetnek a kellékszavatossági szabályok. Ez azért jelentős kérdés, mert a culpa in contrahendo szabályaira az általános elévülési határidők irányadóak. ${ }^{1580}$ A kellékszavatossági rendelkezések föszabály szerint prioritást élveznek a culpa in contrahendora

\footnotetext{
${ }^{1574}$ Lásd: BGB § 434 (3).

${ }^{1575}$ Lásd: KÄMPF M. (2007), 131. p.; LoOSCHELDERS (2011), 23. p. Vö. BGB § 241a.

${ }^{1576}$ Lásd: FEZER (2009), 27. p.

${ }^{1577}$ Lásd: BGB $§ \S 275$ (1), 280 (1) és (3), 283.

1578 Lásd: FEZER (2009), 27-28. p.

${ }^{1579}$ Lásd: BGB $\S \S 280$ (1), 311 (2), 241 (2).

${ }^{1580}$ A BGB $§ 195$ alapján a 3 éves általános elévülési határidő; lásd: FEZER (2009), 28. p.
} 
vonatkozóakkal szemben. ${ }^{1581}$ Ha mégis konkurálnak a szabályok, és vitatott, hogy a kellékhiba a culpa in contrahendoból fakad-e, akkor az elhatárolásnál arra kell figyelni, hogy a szerződéskötést megelőző tájékoztatási kötelezettség felróható megszegése olyan körülményre vonatkozik-e, amely a kellékhiba fogalmába tartozó, a minőségre vonatkozó megállapodásnak minősül. ${ }^{1582}$

Az előbbi esettől eltérően, amennyiben az eladó felróhatóan megszegi valamely szerződéses mellékkötelezettségét, az adásvétel tárgya azonban nem kellékhibás, akkor egyértelmüen nincs konkurencia. ${ }^{1583}$ Más azonban a helyzet, ha károk keletkeznek, amelyek a szerződéses mellékkötelezettség megszegéséből és az eladott áru hibájából fakadnak, mert azok esetén a BGB utaló szabálya az általános szerződésszegésből eredő, „teljesítés helyetti” kártérítési szabályokat rendeli alkalmazni. ${ }^{1584}$

\subsection{Ausztria}

$\mathrm{Az}$ alábbi esetek konkurálnak az osztrák kellékszavatossági igényekkel, és az igényérvényesítés szempontjából gyakran kedvezőbbek a szavatossági jogoknál a jogosult számára.

A tévedés (Irrtum) az osztrák magánjogban (is) akarati hiba az ügyletkötésnél, és így azon érvénytelenségi okok egyike, amelyek alapján a szerződés megtámadható (ABGB $\S 871)$. Az olyan hibás teljesítés esetén, amikor a hiba már a szerződéskötéskor fennáll, az átvevő hivatkozhat arra, hogy tévedett az ügylet tárgyát illetően. ${ }^{1585}$ A tévedés miatti megtámadási jog a $§ 1487$-nek megfelelően a szerződéskötéstől számított 3 éven belül évül el, így előnyös lehet az igényérvényesítésnél előtérbe helyezni a tévedés miatti érvénytelenségre vonatkozó kereseti kérelmet. ${ }^{1586}$

Nemteljesítésről abban a fent már említett esetben lehet szó, amikor a vevő a hibát felismerve még a dolog átvétele elött visszautasítja azt. Ilyenkor nem történik teljesítés, ezért amennyiben az eladó egy a vevő által esetlegesen adott póthatáridő alatt sem teljesít szerződésszerűen, a késedelem szabályait kell alkalmazni. ${ }^{1587}$

\footnotetext{
${ }^{1581}$ FEZER (2009), 28. p.

1582 A BGB $§ 434$ (1) alapján, lásd: FEZER (2009), 28. p.

${ }^{1583}$ Lásd: FEZER (2009), 29. p.

1584 Vö. BGB $§ 437$ (3) és $§ 280$ (1); lásd: FEZER (2009), 29. p.

${ }^{1585}$ Ez a „tulajdonságban való tévedés” (Eigenschaftsirrtum) esete, lásd: PERNER - SPITZER (2007), 83. és 177. p.

${ }^{1586}$ PERNER - SPITZER (2007), 87. és 177. p.

${ }^{1587}$ Lásd: FERCH-FISCHER (2011), 84. p. Vö. ABGB § 918.
} 
Amennyiben az eladó teljesen mással teljesít, mint amivel a szerződés alapján teljesítenie kellett volna (aliud), az - a német szabályokkal ellentétben - ugyanúgy nemteljesítésnek minősül, mint a fenti eset. ${ }^{1588}$ Ennek fényében ekkor is a késedelemre vonatkozó rendelkezések nyernek alkalmazást. Az aliud megállapítása az egyedi dolog vételével szemben nehezebb fajlagos vétel esetén: ilyenkor abból kell kiindulni, hogy a szolgáltatott egyedek egyáltalán az adott fajtába tartoznak-e. ${ }^{1589}$

Meg kell különböztetni a jótállást az ABGB-ben szabályozott „garanciaszerződéstől”. ${ }^{1590}$ Ebben a szerződésben a „garantáló” felelősséget vállal a kedvezményezettel szemben egy vállalkozás még bizonytalan sikeréért, illetve egy vállalkozás által okozott károkért. A szerződés a kezességhez nagyon közel álló jogügyletet jelent azzal a jelentős különbséggel, hogy a garanciaszerződés nem járulékos kötelem, mert a garantáló akkor is felel, ha a harmadik személyt felróhatóság nem terheli. ${ }^{1591}$ Ez a szerződés tehát semmilyen kapcsolatban nem áll a hibás teljesítéssel és a kellékszavatossági szabályokkal.

\subsection{Svájc}

A nem egységes szerződésszegési rendszerből fakadóan az elhatárolási kérdések a kellékszavatosság különös részi szabályai és a kötelmi általános részben található szerződésszegési esetekre vonatkozó rendelkezések között merülnek fel a leggyakrabban a svájci magánjogban is. A viszonyukat illetően elméletben három variáció lehetséges a jogtudományi álláspontok szerint: a viszony lehet speciális, alternatív, vagy kumulatív. ${ }^{1592}$ Sok esetben a kellékszavatosság, mint kötelmi különös részi jogintézmény „lerontja” a kötelmi általános rész szabályait, más esetekben pedig az igények alternatív érvényesítésére van lehetőség. A harmadik, kumulatív viszony lehetőségét a Szövetségi Bíróság gyakorlata következetesen elveti. ${ }^{1593}$

Az elhatárolási kérdések gyakorlati jelentősége elsősorban abban rejlik, ami a fogyasztóvédelmi deficitként kezelt kérdések során már említésre került: kellékszavatosság

\footnotetext{
${ }^{1588}$ PERNER - SPITZER (2007), 178. p.

${ }^{1589}$ PERNER - SPITZER (2007), 178. p.

${ }^{1590}$ Lásd: ABGB § 880a. (Garantievertrag). Ehhez a törvényi garanciaszerződéshez képest a jótállást, mint ún. garanciaígéretet (Garantiezusagen) gyakran „,nem valódi garanciának” nevezik, lásd: SÄÄF (2005), 60. p.

1591 Lásd: SÄÄF (2005), 60. p.

1592 Lásd: GINTER (2005), 2. p.

${ }^{1593}$ Lásd: GINTER (2005), 2. p. 4. 1 j.
} 
esetén a vevőt sújtja a szigorú megvizsgálási és kifogásközlési kötelezettség, valamint az általános 10 évesnél rövidebb igényérvényesítési határidő. ${ }^{1594}$

Az OR § 97 (1) bekezdés értelmében, amennyiben a kötelezettség nem vagy nem megfelelően teljesíthető, a kötelezettnek az ebből fakadó károkat meg kell térítenie, kivéve, ha bizonyítja, hogy felróhatóság nem terheli:

„Kann die Erfüllung der Verbindlichkeit überhaupt nicht oder nicht gehörig bewirkt werden, so hat der Schuldner für den daraus entstehenden Schaden Ersatz zu leisten, sofern er nicht beweist, dass ihm keinerlei Verschulden zur Last falle."

E rendelkezés a gyakorlatban úgy értelmezendő, hogy a kötelezett teljesít ugyan, de a kötelezettségének bizonyos eleme(i) sérelmet szenved(nek), viszont a jogosult ennek ellenére elfogadja a teljesítést. ${ }^{1595}$ Hibás áru szolgáltatása esetén az eladó felróhatósága abban áll, hogy a hiba létezéséről tud, vagy gondatlansága miatt nem tud arról. ${ }^{1596}$ A többségi tudományos álláspont és a Szövetségi Bíróság következetes gyakorlata alapján a kellékszavatosságból és a fenti nem- vagy nem megfelelő teljesítésből fakadó igények konkurálnak egymással, így a joggyakorlatban alternatívan alkalmazhatóak. ${ }^{1597} \mathrm{Az}$, hogy adott esetben a két igény (OR §§ 97 és 197) mögötti tényállás megegyezik-e, elsősorban attól függ, hogy az áru minősége szerződési tartalomként kezelendö-e. Itt tehát ismét relevanciát nyer az, hogy a vétel fajlagos vagy egyedi-e, és ezzel összefüggésben eltérő álláspontok ütköznek a jogtudományban. ${ }^{1598}$ A bírói gyakorlat alapján a $§ 97$ alkalmazása esetén alkalmazandóak a kellékszavatosságnál irányadó megvizsgálási- és kifogásközlési, valamint a rövidebb igényérvényesítési határidőre vonatkozó szabályok is. ${ }^{1599}$

A joggyakorlat alapján a tévedés, mint akarathiba esetén fennálló jogosulti igények is alternatívan alkalmazhatóak a kellékszavatossági igények helyett (OR § 24). ${ }^{1600}$ Erre az esetre azonban nem vonatkoznak a megvizsgálási- és kifogásközlési, valamint a rövidebb igényérvényesítési határidő szabályai, ezért előnyösebb lehet a fogyasztó számára. ${ }^{1601}$

Fajlagos vétel esetén merül fel az az elhatárolási kérdés, hogy mikor minősül a teljesítés aliudnak (Falschlieferung), és mikor peiusnak (Schlechtlieferung). A német

\footnotetext{
${ }^{1594}$ Lásd: GINTER (2005), 5. p.

1595 NEUENSCHWANDER (1971), 45. p. A tudomány álláspontja azonban egyáltalán nem egységes a nem megfelelő teljesítés megítélését illetően, lásd: GINTER (2005), 19. p.

${ }^{1596}$ Lásd: BGE 107 II 166; HoNSELL (2010), 117. p.

${ }^{1597}$ Lásd HoNSELL (2010), 116. p. hivatkozását a számos Szövetségi Bírósági döntésre a kérdésben, többek között: BGE 133 III 335 és BGE 58 II 211. számú döntések.

1598 „Erfüllungs-” és ,, Gewährleistungstheorie”" ellentéte, lásd: GINTER (2005), 69. p.

1599 Lásd: OR $\S 201$ (1) és 210. Lásd: BGE 133 III 335. számú ítélet; MÜLLER-CHEN - HuGUENIN GIRSBERGER (2012), 171. p.

${ }^{1600}$ Lásd: BGE 114 II 134. számú ítélet; KÄSER (2000), 42-43. p.

${ }^{1601}$ MÜLLER-CHEN - HUGUENIN - GIRSBERGER (2012), 172. p.; FURRER - SCHNYDER (2012), 139. p.
} 
elnevezések is mutatják, hogy amennyiben teljesen más a szolgáltatott dolog, azaz a fajta sem egyezik a kialkudottal, akkor az - az osztrák joggal egyezően - nemteljesítésnek minősül a svájci jogban. ${ }^{162}$ Amennyiben a fajta egyezik, de kellékhiba áll fenn, akkor peiusnak minősül a szolgáltatás, ami a hibás teljesítés jogkövetkezményeit vonja maga után. ${ }^{1603}$ Azért nehéz a gyakorlatban a kettőt elhatárolni, mert a fajta szüken és tágan is értelmezhető, tetszés szerint megállapítható, ezért attól nem függhet a jogkövetkezmények megállapítása, hanem mindig egyedileg és objektív kritériumok alapján kell mérlegelni a kérdést. ${ }^{1604}$

Elhatárolandó a kellékszavatosság fogalmi körébe tartozó eladói ígérettől az ún. „önálló garancia” (selbständige Garantie). Ez az eladói ígérettel ellentétben - az osztrák jogintézményhez hasonlóan - jövőbeli tulajdonságokra vagy sikerekre vonatkozó ígéret jogintézménye a svájci magánjogban, amelyre ezért nem alkalmazhatóak a kellékszavatosság speciális szabályai. ${ }^{1605}$ A kötelezett ennek keretében olyan tulajdonságokért illetve körülményekért vállal helytállást, amelyek bekövetkezése bizonytalan. ${ }^{1606}$

\section{Összefoglalás}

A fejezet igyekezett bemutatni, hogy a német, az osztrák és a svájci magánjog hogyan közelíti meg a fogyasztói adásvétel hibás teljesítésének kérdését. A német jogalkotó az Irányelv implementálásával egybekötötte a polgári jogi kódex teljes kötelmi jogának reformját. A történeti hagyományokhoz igazodva a BGB adásvételi jogába, - annak speciális fajtájaként - a fogyasztói adásvétel szabályai közé illesztette be a legtöbb implementáló rendelkezést, főként utaló szabályok formájában. Az átfogó kötelmi jogi reform koncepciójának megfelelően azonban például az elállás jogáról, valamint a „pótteljesítésről” (azaz a kijavításról és kicserélésről) is a szerződésszegés általános szabályai között rendelkezik. Ezen kívül minden adásvételi szerződésre kiterjedő hatállyal általánossá tette a két éves elévülési határidőt a hibás teljesítés miatti igényérvényesítésre nézve.

\footnotetext{
1602 HONSELL (2010), 129. p.

${ }^{1603}$ HONSELL (2010), 129. p.

${ }^{1604}$ Lásd: HONSELL (2010), 129-130. p.

${ }^{1605}$ HONSELL (2010), 87. p. Ehhez hasonló jogintézmény az osztrák magánjogban a „, Garantievertrag”, lásd fent: jelen fejezet 11.2. pontja.

${ }^{1606}$ HONSELL (2010), 87. p.
} 
A német megoldás a gyakorlatban véleményem szerint azt eredményezte, hogy a számtalan utaló szabály miatt nagyon gyakran nehezen követhetö, különösen a fogyasztói adásvétel hibás teljesítése esetén, hogy mely szabályok pontosan hogyan alkalmazandóak. Megmutatkozik ez a hibás teljesítés miatti kártérítés esetén is. A jogalkotó a hiba miatt a dologban beálló ún. tapadó károk megtérítését a kellékszavatossághoz hasonló objektív helytállásként, míg az ún. következménykárok megtérítését a hibás teljesítés miatti felróhatósági alapú, szubjektív jogkövetkezményként szabályozza. A koncepció célja egyértelmü, a szabályok azonban gyakran csak nehézkesen követhetőek a BGB-ben az utaló normák sokasága miatt.

Az implementáció megvalósítása után több jogértelmezési és konformitási kérdés is felmerült a német jogalkalmazásban. Ezek többek között a hibásság vélelmével, a használt dolog fogalmával, az egyedi dolog kicserélhetőségével, a jótállási ígéret tartalmával, az eladó kicserélési kötelezettségének terjedelmével és az aránytalan jogorvoslat mércéjével kapcsolatos kérdések. Az utóbbi kettővel kapcsolatban merült fel olyan konformitási kérdés, amely a bíróságot két jogesetben is arra ösztönözte, hogy kérdést terjesszen az EuB elé elözetes döntéshozatal céljából. $\mathrm{Az}$ EuB az egyesített ügyekben úgy döntött, hogy a kicserélés igénye az új, hibátlan áru szolgáltatásának teljes folyamatát felöleli, beleértve a hibás áru eltávolításának és az új dolog beépítésének/beszerelésének a költségeit is. Az arányosság követelményét pedig szűken, csak az első lépcsős kicserélés és kijavítás relációjában ítélte irányadónak. A Bíróság érvelése azonban dogmatikailag nem állja meg a helyét a fejezetben kifejtett véleményem szerint, ezért is kérdéses, hogy a precedens miként fog majd hatni a tagállamok bírósági joggyakorlatára.

Az osztrák jogalkotó az Irányelv implementációjának keretei között a teljes hibás teljesítésre vonatkozó szabályozást megreformálta. A reform célja azonban az volt, hogy a joggyakorlat és a kereskedelmi praxis által kimunkált tradicionális kellékszavatossági szabályok ne menjenek át rendszeridegen változtatáson. Megkönnyítette az Irányelv fogyasztóvédelmi rendelkezéseinek meghonosítását az, hogy az osztrák fogyasztóvédelmi törvény a magánjogi fogyasztóvédelmi célú jogalkotás termékeinek nagy részét már kezdettől fogva magában foglalja. Ennek köszönhetö az, hogy az Irányelv szerinti fogyasztói adásvételi ügyletek kellékhibás teljesítése esetén egyrészt a (kereskedelminek nem minősülő) adásvétel ABGB-beli szabályai, a továbbra is a szerződésszegés közös szabályai között szereplő kellékszavatossági szabályok és az - egyébként minden visszterhes fogyasztói jogügyletre irányadó - fogyasztóvédelmi törvénybeli rendelkezések 
alkalmazandóak. Az osztrák szabályozás véleményem szerint azonban csak látszólag széttagolt, valójában megkönnyíti a jogkeresők és a jogalkalmazók dolgát.

Az osztrák jogalkotó a hibás teljesítésre vonatkozóan több példaértékű szabályt is alkotott. Szankciót füz például a jótállási nyilatkozat kötelező tartalmi elemeinek hiányához, és kellően konkrétan fogalmaz a tekintetben, hogy a jótállási nyilatkozatban miként kell utalni a fogyasztónak a jótállás mellett fennálló, törvényen alapuló kellékszavatossági jogaira. Ezen kívül speciális szabályt ír elő a használt gépjármüvekkel kapcsolatos kellékszavatossági határidő tekintetében, felismerve, hogy e fogyasztási cikkek az átlagfogyasztók körében és a piacon milyen jelentős gazdasági értéket képviselnek.

A svájci magánjogban a fogyasztóvédelmi jogalkotás az elmúlt egy-két évtized folyamán kezdett el kibontakozni a magánjogban, és ez megmutatkozik ez az adásvétel hibás teljesítése szabályozásának körében is. Bár többnyire még a pandektahagyományokat tükröző eredeti (több mint száz évvel ezelőtt megalkotott), egységes, azaz a szerződő felek jogalanyiságától független szabályok vannak hatályban. Ennek köszönhetően számos, a jogtudomány által régóta kritizált fogyasztóvédelmi deficitben szenved az OR szabályozása. Ez megmutatkozik többek között a rendelkezések diszpozitív jellegében, a szigorú megvizsgálási és kifogásközlési kötelezettség elöírásában és a kellékszavatossági kijavítási igény szabályozásának hiányában is. Üdvözlendő azonban, hogy a közelmúlt jogalkotása az igényérvényesítési határidők tekintetében az EU-s Irányelvvel csaknem teljesen megegyező elöírást épített az OR-be ingók „fogyasztói” adásvételének hibás teljesítése esetén. Az új rendelkezés klaudikálóan kógens szabályozása azt mutatja, hogy a svájci jogalkotó is elindult azon az úton, hogy a korunk gazdasági és kereskedelmi folyamatainak nyomán kibontakozó fogyasztóvédelem céljait is érvényesítse a polgári jogi normaalkotásban. 


\section{A FOGYASZTÓ TRADICIONÁLIS JOGAI INGÓ ADÁSVÉTEL HIBÁS TELJESÍTÉSE ESETÉN A MAGYAR JOGBAN - AZ IRÁNYELV IMPLEMENTÁCIÓJA 2002-BEN}

\section{Bevezetés - fogyasztóvédelmi szerződési jog a hazai polgári jogban}

Hazánkban a rendszerváltozás előtt egyedül a belkereskedelemről szóló törvény rendelkezett a fogyasztói érdekvédelemről, azonban ez a jogalkotói és jogpolitikai törekvés a piacgazdasági környezet és a fokozott követelmények következtében gyökeresen megváltozott. Magánjogunkban a rendszerváltozás után, a piacgazdaság kiépülésével összefonódva erősödött a fogyasztók érdekeinek a védelme, a fogyasztóvédelmi politika fontossága és a fogyasztóvédelmi intézményrendszer kiépítésének az igénye. ${ }^{1607}$ A szocialista állami és gazdasági berendezkedésnek köszönhetően kialakult ún. hiánygazdaságban a fogyasztók informáltsága alacsony fokon állt, hiányzott a „fogyasztói öntudat", a vállalkozói oldalon pedig még nem alakult ki az az üzleti etika, amely a megtévesztés és agresszív kereskedői módszerek kizárására törekedett volna. ${ }^{1608}$ Így a fogyasztóvédelemnek a magánjog területén különösen ezen „maradványok” kiküszöbölésére kellett törekednie. ${ }^{1609}$

Az EU-s csatlakozásunkat előkészítő tárgyalásokhoz kapcsolódó jogközelítési és harmonizációs kötelezettségeinknek ${ }^{1610}$ eleget téve 1997-ben megszületett a Fogyasztóvédelmi törvény, amely azonban csak csekély számban tartalmaz speciális polgári anyagi jogi rendelkezéseket. ${ }^{1611}$ A fogyasztóvédelemre vonatkozó jogharmonizációt az EU ún. Fehér Könyve segítette, ${ }^{1612}$ amelynek 23. fejezete az implementálandó irányelveket két csoportba osztva tartalmazta a jogharmonizációra vonatkozó követelményeket: az egyik a termékek minőségi és biztonsági követelményeivel, a másik a fogyasztók gazdasági érdekeinek védelmével kapcsolatos normák köre. ${ }^{1613}$

\footnotetext{
${ }^{1607}$ Lásd: SÁRINÉ DR. SIMKÓ (2000), 25. p.

${ }^{1608}$ SÁRINÉ DR. SIMKÓ (2000), 25. p.

${ }^{1609}$ SÁRINÉ DR. SIMKÓ (2000), 25. p.

1610 1994. évi I. törvény a Magyar Köztársaság és az Európai Közösségek és azok tagállamai között társulás létesítéséről szóló, Brüsszelben, 1991. december 16-án aláírt Európai Megállapodás kihirdetéséröl, a továbbiakban: Európai Megállapodás, 67. cikk. Az EU-s elvárások folyományaként a fogyasztóvédelemmel összefüggö jogszabály-közelítés és jogszabályalkotás tárgykörében több kormányhatározat is született: 2145/1996. (VI. 13.) és 2298/1997. (IX. 30.) Korm. hat.

${ }^{1611}$ 1997. évi CLV. törvény a fogyasztóvédelemröl, a továbbiakban: Fgytv.

${ }^{1612}$ Council Cannes White Paper COM(95) 163 final/2.

1613 A fogyasztóvédelem rendszerváltozást követö fejlődéséhez és a kapcsolódó jogharmonizációs követelményekhez lásd részletesebben: FAZEKAS (2007), 39-44. p. valamint FAZEKAS (2004), 18-29. p.
} 
Az utóbbi kategóriába tartozik az Európai Megállapodást követően, de még hazánk EU-s csatlakozása előtt megalkotott 1999/44/EK Irányelv a fogyasztási cikkek adásvételének és a kapcsolódó jótállásnak egyes vonatkozásairól, amelynek a harmonizációját ugyancsak meg kellett valósítania hazánknak. Az implementációt az egyes fogyasztóvédelmi tárgyú törvények módosításáról szóló 2002. évi XXXVI. törvény vitte véghez, amely a jogalkotói szándéknak megfelelően nagyrészt a Ptk. rendelkezései közé építette be az Irányelv minimumharmonizációs elvárásait, ${ }^{1614}$ ugyanakkor módosította a termékfelelősségről szóló törvény és az Fgytv. egyes rendelkezéseit is. ${ }^{1615}$

\subsection{A fogyasztó fogalma}

A Ptk.-ban az 1997. évi CXLIX. törvény honosította meg a fogyasztó fogalmát, és ugyanebben az évben az Fgytv.-ben is megjelent annak meghatározása. ${ }^{1616}$ A 2002. XXXVI. törvény nyomán fogyasztó „a gazdasági vagy szakmai tevékenység körén kívül eső célból szerződést kötő személy” (Ptk. 685. § d.). Ez a definíció 2003. július 1-jei hatályba lépésekor még hasonult az Fgytv. meghatározásához, ez utóbbi 2008-as módosítása azonban a természetes személyekre korlátozta a fogyasztókat:

„,fogyasztó: az önálló foglalkozásán és gazdasági tevékenységi körén kivül esö célok érdekében eljáró természetes személy, aki árut vesz, rendel, kap, használ, igénybe vesz, vagy az áruval kapcsolatos kereskedelmi kommunikáció, ajánlat cimzettje". 1617

Az Fgytv. fogalmának módosítása a tisztességtelen kereskedelmi gyakorlatokról szóló EUs irányelv nyomán vált szükségessé. ${ }^{1618}$

A fogyasztói szerződések és azok hibás teljesítése esetén a Ptk. fogyasztó-fogalma alkalmazandó. ${ }^{1619} \mathrm{Az}$ e definícióban szereplő ,gazdasági, szakmai, illetve önálló

${ }^{1614}$ Ez megfelelt Vékás Lajos kodifikációs javaslatának, amely a szabályozási tradíciók megtartásával képzelte el az implementációt, lásd: VÉKÁs (2000), 646-659. p. Vékásnak az 1999/44/EK Irányelv implementációjával kapcsolatos további tanulmányai meghatározóan hatottak a szabályozás kialakítására, lásd: VÉKÁs (2000), 646-660. p., VÉKÁS (2001a), 104-035. p., VÉKÁS (2001b), 58-84. p., Vékás (2002), 313. p.

${ }_{1615}$ A jelen fejezetben bemutatott Ptk.-beli rendelkezések a 2013. évi V. törvény (új Ptk.) 2014. március 15-i hatályba lépése előtt kötött szerződések esetén alkalmazandóak, vö. II. rész 4. fejezet.

${ }^{1616}$ A Ptk. eredeti, 1997-es meghatározása szerint: „fogyasztó: a 387-388. \$-ok alkalmazása kivételével a gazdasági vagy szakmai tevékenység körén kivül szerzödést kötö személy.". Ugyancsak 1997-ben a gazdasági reklámtevékenységröl szóló 1997. évi LVIII. törvény is meghatározta a fogyasztó fogalmát: 2 . § f) pont: „Fogyasztó: minden olyan természetes és jogi személy, valamint jogi személyiség nélküli gazdasági társaság, aki felé a reklám irányul.".

${ }_{1617}^{1617}$ Fgytv. 2. § a) pont.

1618 2005/29/EK irányelv a belső piacon az üzleti vállalkozások fogyasztókkal szemben folytatott tisztességtelen kereskedelmi gyakorlatairól. Lásd: HÁMORI (2009), 88. p. 
foglalkozáson kívüli tevékenységi kör" a legtöbb speciális jogszabály fogyasztófogalmában is megtalálható. ${ }^{1620} \mathrm{Ez}$ a fogalmi elem a fogyasztóvédelmi magánjogi szabályozás ún. relációs jellegére utal: mindig az adott jogviszony relációjában vizsgálandó a jogalanyok szerződéskötési célja. ${ }^{1621}$

Az egymás mellett létező jogszabályi fogyasztó-fogalmak mellett a legnagyobb ellentmondást a Ptk. generálja azzal, hogy csupán „személyt” említ, azaz a fogalmába nem csak természetes személyek tartozhatnak bele. A Ptk. definícióját annak ellenére fogalmazta meg így a jogalkotó, hogy az 1999/44/EK Irányelv csak a természetes személyeket tekinti fogyasztónak. ${ }^{1622}$ A fogyasztó-fogalom természetes személyekre korlátozása Hámori Antal szerint a „fogyasztóvédelmi jogalkotás régi dilemmája” és a „fogyasztóvédelmi hatósági gyakorlat kitartó vágya”. ${ }^{1623}$ Hámori utal a fogyasztóvédelmi szabályozás korszerüsítésének koncepciójáról, valamint az azzal kapcsolatos további feladatokról szóló 2145/1996. (VI. 13.) Kormányhatározatra, amely szintén a természetes személy fogyasztókra utalt, bár rámutatott arra, hogy mindig az adott fogyasztóvédelmi rendelkezés fényében kell vizsgálni, hogy mennyiben terjeszthető az ki a nem természetes személyekre. ${ }^{1624} \mathrm{Az}$ új Polgári Törvénykönyv T/5949. számú, 2006. évi törvényjavaslatának indokolása úgy fogalmaz, hogy a „fogyasztóvédelmi magánjog szabályai - már csak kógens jellegüknél fogva is - a magánjogtól idegen szabályozási módszert alkalmaznak, és ezért ezt a különös védelmet csak kivételesen [...] szabad megadni.",1625

A Kúria szerint a legfontosabb követelmény a fogyasztói minőség megállapításánál az, hogy a dolog megszerzése, használata és így a szerződés célja a dolog végső felhasználása legyen. ${ }^{1626}$ Így a nem természetes személy is lehet fogyasztó, ha az áru végső felhasználója. ${ }^{1627}$ A kapcsolódó jogesetben egy kft. vásárolt telefonkészüléket, majd az

\footnotetext{
1619 A Fővárosi Ítélőtábla egy ítéletében kifejezetten kimondta, hogy a Ptk. alkalmazási körében nem az Fgytv., hanem a Ptk. fogyasztó-fogalmából kell kiindulni, lásd: Fővárosi ÍT 6.Pf.20.911/2008/7. számú ítélet. ${ }^{1620}$ Vö. például: a fogyasztókkal szembeni tisztességtelen kereskedelmi gyakorlat tilalmáról szóló 2008. évi XLII. törvény, 2. § a) pont.

${ }^{1621}$ HÁMORI (2009), 88. p.

${ }^{1622}$ Vö.: Irányelv 1. cikk (2) bekezdés a): ,fogyasztó: minden olyan természetes személy, aki az ezen irányelv hatálya alá tartozó szerzödések tekintetében gazdasági vagy szakmai tevékenysége körén kivül esö célból jár el".

${ }_{1623}$ HÁMORI (2009), 89. p.

${ }^{1624}$ Lásd: HÁMORI (2009), 89. p. utalása a 2145/1996. (VI. 13.) kormányhatározat 1.1. a) pontjára.

${ }^{1625}$ Lásd: HÁMORI (2009), 93. p.

${ }^{1626} \mathrm{BH}$ 2006. 343.

${ }^{1627}$ EBH 2004. 1093. A döntések rövid elemzését lásd: HAJNAL (2010), 41-43. p., valamint OszToviTs (2013b), 65-66. p.
} 
eredménytelen fogyasztóvédelmi hatósági eljárás ${ }^{1628}$ után a bírósághoz fordult a közigazgatási szerv ellen, és az elsőfokú bíróság az utóbbival szemben a kft. kereseti kérelmének adott helyt, a felperest fogyasztónak minősítve. A felülvizsgálati kérelem folytán a Kúria az elé került ügyben úgy döntött, hogy mivel a felperes kft. nem a továbbértékesítése céljából, hanem annak végső felhasználása végett vásárolta meg a telefont, fogyasztónak minősül. Véleményem szerint a fogyasztói minőség meghatározásához mind a végső felhasználás (mint szerződési cél), mind a gazdasági, szakmai illetve foglalkozási célú tevékenységi körön kívüli használat szükséges kritérium. E két feltétel együttesen az esetek nagyon nagy hányadában - a gyakorlatban - a természetes személy szerződéskötő felek esetén áll csupán fenn, ezért ennek és a fogyasztóvédelem jogpolitikai céljának fényében magam is a fogalom természetes személyekre szükítését tartom kívánatosnak. ${ }^{1629}$

\subsection{A fogyasztói szerzödés fogalma}

A 2002-es módosítások értelmében 2003. július 1-jétől fogyasztói szerződésnek minősül a Ptk. szerint „, az a szerződés, amely fogyasztó és olyan személy között jön létre, aki (amely) a szerződést gazdasági vagy szakmai tevékenysége körében köti” (685. § e) pont). A Ptk. tehát nem adja meg külön a fogyasztóval szerződést kötő fél fogalmát, hanem azt a fogyasztói szerződés fogalmába integrálja. A fogyasztói szerződés fogalmába olyan szerződéstípusok tartoznak, amelyek dogmatikailag besorolhatók valamelyik általános szerződési típusba. ${ }^{1630}$

A Ptk. speciális rendelkezése szerint a jótállásra és kellékszavatosságra vonatkozó szabályok alkalmazásában az a szerződés minősül fogyasztói szerződésnek, amelynek tárgya ingó dolog. Kivételt képez a villamos energia, a - tartályban, palackban vagy egyéb módon korlátozott mennyiségben vagy meghatározott ürtartalommal ki nem szerelt - víz és gáz, továbbá a végrehajtási eljárás vagy más hatósági intézkedés folytán eladott dolog, valamint az olyan árverésen eladott használt dolog, amelyen a fogyasztó személyesen részt vehet. ${ }^{1631}$ A kivételek között nem szereplő ingó dolgok minősülnek tehát fogyasztási cikknek. E meghatározás teljes mértékben megfelel az Irányelv előírásának, azzal a

\footnotetext{
${ }^{1628}$ Az eljáró közigazgatási szerv a Fgytv. akkor még csupán „személyt” említő fogyasztó-fogalmát szüken, csak a természetes személyekre szorítva értelmezte.

${ }^{1629}$ Ezt meg is valósította az új Ptk., lásd: II. rész 4. fejezet 2. pont.

${ }^{1630}$ Lásd: FAZEKAS (2007), 137. p.

${ }^{1631}$ Vö. Irányelv, 1. cikk (2) bekezdés b. pont és (3) bekezdés.
} 
kivétellel, hogy a magyar jogalkotó a szabályozási koncepciónak és a hibás teljesítés illetve kellékszavatosság rendszerbeli elhelyezésének megfelelően - az osztrákhoz hasonlóan ${ }^{1632}$ - kiterjeszti a „fogyasztói” visszterhes szerződésekre a speciális fogyasztói szabályok hatályát.

\section{A hibás teljesítés rendszere és a „fogyasztói adásvétel” a Ptk.-ban}

A 2003. július 1-jén hatályba lépett Ptk.-beli módosítások a koncepciónak megfelelően a hibás teljesítés dogmatikai rendszerének koherenciáját és tradícióit sértetlenül hagyva ${ }^{1633} \mathrm{a}$ kódex kötelmi általános részébe épültek be, amelyeket kiegészíti a fogyasztó és a fogyasztói szerződés fent ismertetett fogalma az értelmező rendelkezések között. ${ }^{1634}$ A rendszerbeli elhelyezésnek megfelelően a módosult szabályok a legtöbb esetben nem csak a „fogyasztói adásvételi szerződések”, hanem továbbra is minden visszterhes szerződés hibás teljesítése esetén alkalmazandóak. ${ }^{1635}$

\subsection{Az adásvételi szerzödés tartalma és teljesítése}

A Ptk. 365. § (1) bekezdése az árucsere alapjogviszonya, az adásvétel fogalmának meghatározásánál dolog tulajdonának és birtokának vételár ellenében történő átruházásáról rendelkezik. A felek a jogszabályok biztosította korlátokon belül bármilyen forgalomképes dolgot kiköthetnek az adásvétel tárgyaként, és a szerződés tárgyát meghatározhatják egyedileg és fajlagosan is. A fajlagos vétel tárgya általában, de nem szükségszerüen helyettesíthető dolog. ${ }^{1636} \mathrm{Az}$ is a felek szerződési szabadságához tartozik, hogy szerződéses érdekeiknek megfelelően meghatározhatják a dolog tulajdonságait. ${ }^{1637}$ A jogtudomány szerint az eladó főkötelezettségei közé tartozik a szerződés tárgyának megfelelőségéért fennálló „feltétlen helytállási kötelezettség”. ${ }^{1638}$ A teljesítéssel összefüggő mellékkötelezettsége az eladónak, hogy tájékoztassa a vevőt a szerződés minden lényeges eleméről, a dolog tulajdonságairól és az azzal kapcsolatos egyéb körülményekről is. A tájékoztatás az együttmüködési kötelezettség konkrét megnyilvánulása, amely kötelezi az

\footnotetext{
${ }^{1632}$ Lásd: II. rész 2. fejezet 3.2. pont.

${ }^{1633}$ Lásd: FAZEKAS (2007), 47. p.

${ }^{1634}$ A 2003-tól hatályos rendelkezésekhez részletesen lásd: CSÉCSY (2008), 131-158. p.

1635 A szabályozás kritikáját lásd többek között: KOVÁCS (2005), 433. p., FAZEKAS (2007), 48. p.

${ }^{1636}$ KISFALUDI (2003), 66. p. Az egyedi és fajlagos vételre vonatkozó korábban említett megfontolások a hatályos jogban is megfelelően irányadóak.

${ }^{1637}$ KISFALUDI (2003), 61. p.

${ }^{1638}$ Lásd: BíRÓ (2011), 45. p. Ugyanúgy, mint a német és svájci felfogás szerint.
} 
eladót a szerződés megkötésétől a teljesítésig, és olyan részletességgel várható el tőle az információnyújtás, ,ahogy az az adott helyzetben általában elvárható”. ${ }^{1639}$

A teljesítést megelőző eladói kötelezettségek tehát a szerződésszerü teljesítés kikényszerítésére, az azok ellenére hibás, nem szerződésszerü teljesítéshez füződő jogkövetkezmények pedig a szerződésszegésből eredő érdeksérelem kiküszöbölésére hivatottak a mindenkori magánjogban. ${ }^{1640}$

A piacgazdaságra jellemző tömegtermelés és rohamosan gyarapodó kínálat hívta életre a standardizált ún. blankettaszerződéseket, amelyek révén a gyakorlatban a szerződéskötés nem csak egyedileg meghatározott, hanem általános szerződési feltételekkel is történhet. ${ }^{1641} \mathrm{Az}$ ilyen, a feltételek alkalmazója által egyoldalúan, elöre, több szerződés megkötése céljából, a másik fél közremüködése nélkül meghatározott, és egyedileg meg nem tárgyalt szerződési tartalom ${ }^{1642}$ esetén akarategység helyett inkább „fiktív konszenzusról” beszélhetünk. ${ }^{1643} \mathrm{Ez}$ a fogyasztókra nézve fokozott veszélyt jelent korunkban, mert tipikusan a fogyasztókkal kötött szerződések esetén alkalmazzák őket a piacon nagyobb gazdasági erővel bíró jogalanyok. ${ }^{1644}$ A fokozott hátrányt többek között az jelenti, hogy gyakran fel sem hívják a figyelmet a vállalkozások az ÁSZF létezésére, vagy azt a szerződéskötés alkalmával - annak nagy terjedelme miatt - el sem tudja olvasni a fogyasztó, vagy ha el is tudja, értelmezése a bonyolult terminológia miatt nehézkes számára; mindez a fogyasztó szerződési szabadságát a szerződés meg vagy meg nem kötésére redukálja. ${ }^{1645}$ Erre figyelemmel a Ptk. így rendelkezik:

„,Tisztességtelen az általános szerzödési feltétel, illetve a fogyasztói szerzödésben egyedileg meg nem tárgyalt szerzödési feltétel, ha a feleknek a szerzödésböl eredö jogait és kötelezettségeit a jóhiszemüség és tisztesség követelményének megsértésével egyoldalúan és indokolatlanul a szerzödési feltétel támasztójával szerzödést kötö fél hátrányára állapítja meg. "1646

Az ÁSZF-jelleget nélkülöző szerződési feltétel tisztességtelen volta is tiltott tehát a fogyasztói szerződésekben. A Ptk. 209. § (3) bekezdése által adott felhatalmazás alapján a 2/2006. (I. 4.) Korm. rendelettel módosított 18/1999. (II. 5.) Kormányrendelet

\footnotetext{
${ }^{1639}$ Lásd: BíRÓ (2011), 46. p. Vö. Ptk. 277. § (4) bekezdés.

${ }^{1640}$ Bíró (2010), 410. p.

${ }^{1641}$ Lásd például: NAGY - PECZE (2007), 267. p.

${ }^{1642}$ Az ÁSZF hatályos fogalmát az 1993/13/EGK irányelvnek megfelelően megalkotott 2006. évi III. törvény 3. § (2) bekezdése nyomán a Ptk. 2006. március 1-jétől hatályos 205/A. § (1) bekezdése adja meg, további szabályait pedig a 205/B-C. $\S \S$-ban találjuk.

${ }^{1643}$ NAGY - PECZE (2007), 267. p. Lásd még: BíRÓ (2010), 279. p.

${ }^{1644}$ Lásd ehhez Fazekas Juditnak a már 1995-ben a témát tárgyaló tanulmányát: FAZEKAS (1995a), 660. p.

1645 Lásd: NAGY - PECZE (2007), 267. p.

${ }^{1646}$ Ptk. 209. § (1) bekezdés.
} 
határozza meg a fogyasztóval kötött szerződések tekintetében azt, hogy mely szerződési feltételek minősülnek tisztességtelennek. ${ }^{1647}$ A jogszabály először egy példálózó felsorolást ad, majd katalógust állít az olyan szerződési feltételekről, amelyek vélelmezendően tisztességtelenek. ${ }^{1648}$ A hibás teljesítéssel összefüggésben kiemelendő, hogy tipikusan tisztességtelen az a kikötés, mely ,a kizárólagosan a fogyasztóval szerződő felet jogositja fel annak megállapitására, hogy teljesitése szerződésszerü-e”; ${ }^{649}$ amely „kizárja vagy korlátozza a fogyasztó jogszabályon vagy a felek közötti megállapodáson alapuló igényérvényesitési lehetöségeit”; ${ }^{1650}$ valamint amely a bizonyítási terhet a fogyasztó hátrányára változtatja meg. ${ }^{1651}$; Az Európai Bíróság következetes gyakorlata alapján a nemzeti bíróságok hivatalból is kötelesek vizsgálni a fogyasztó és az eladó vagy a szolgáltató között megkötött szerződésben alkalmazott valamely feltétel tisztességtelen jellegét. ${ }^{1652}$

$\mathrm{Az}$ adásvételi szerződés teljesítésére speciális rendelkezések hiányában a szerződések teljesítésének általános szabálya alkalmazandó, amely a 2003 előttihez képest nem változott. ${ }^{1653}$ Az Irányelv elvárásainak megfelelően kiegészült azonban a fenti szabály a szolgáltatás minőségi kritériumait, szerződésszerüségét illetően:

„A szolgáltatásnak a teljesités idöpontjában a) alkalmasnak kell lennie azokra a célokra, amelyekre más, azonos fajtájú szolgáltatásokat rendszerint használnak, és

b) rendelkeznie kell azzal a minöséggel, illetve nyújtania kell azt a teljesitményt, amely azonos fajtájú szolgáltatásoknál szokásos, és amelyet a jogosult elvárhat, figyelembe véve a szolgáltatás természetét, valamint a kötelezettnek, a gyártónak, az importálónak vagy ezek képviselojjének a szolgáltatás konkrét tulajdonságaira vonatkozó - különösen reklámban vagy az áru címkéjén megjelenö - nyilvános kijelentését, és

c) alkalmasnak kell lennie a jogosult által meghatározott célra, ha azt a jogosult a szerzödéskötés idöpontjában a kötelezett tudomására hozta, és abba a kötelezett beleegyezett, valamint

d) rendelkeznie kell a kötelezett által adott leírásban szereplö, és az általa a jogosultnak mintaként bemutatott szolgáltatásban lévő tulajdonságokkal. "1654

1647 18/1999. (II. 5.) Korm. rendelet a fogyasztóval kötött szerződésben tisztességtelennek minősülő feltételekről, a továbbiakban: 18/1999. Kormányrendelet

${ }^{1648}$ Lásd: 18/1999. Kormányrendelet, 1-2. $\S$.

1649 18/1999. Kormányrendelet, 1 . $(1$ (1) bekezdés b) pont.

1650 Kivéve, ha azt egyben más, jogszabályban meghatározott vitarendezési móddal helyettesíti, lásd: 18/1999. Kormányrendelet, $1 . \S(1)$ bekezdés i) pont.

${ }^{1651}$ Lásd: 18/1999. Kormányrendelet, 1. § (1) bekezdés j) pont.

1652 Lásd: a C-243/08. számú „Pannon” és a C-137/08. számú „VB Pénzügyi Lízing” ügyekben hozott EuBítéletek.

${ }^{1653}$ Lásd: Ptk. 277. § (1) bekezdés: „A szerzödéseket tartalmuknak megfelelöen, a megszabott helyen és idöben, a megállapitott mennyiség, minöség és választék szerint kell teljesiteni.”.

1654 Ptk. 277. § (1) bekezdés. 
A részletes definíció teljes mértékben az Irányelv elöírásait tükrözi. Ezt egészíti ki az a szabály, hogy ha a felek fajta és mennyiség szerint, de a minőség meghatározása nélkül jelölik meg a szerződés tárgyát, akkor a ,forgalomban szokásos jó minőségü dolgokkal kell teljesíteni ". 1655

E követelmények egy része immanens része a szerződésnek (hallgatólagos megállapodás), azaz a felek nyilvánvalóan azonos módon értelmezik az adott szerződéses kötelezettség tartalmát - egy bicikli két kereke, az ebédlőasztal legalább négy lába például evidens minőségi paraméterek. ${ }^{1656}$ A követelmények másik része bizonyos nyilatkozatokat tételez fel a minőségre vonatkozó szerződéses kötelezettség keletkeztetéséhez. ${ }^{1657}$ Amennyiben a szerződés tárgya használt dolog, akkor a korábbi joggyakorlat szerint is árnyaltabb minőség-meghatározás szükséges. Irányadó az a követelmény, hogy a használt dolgokra irányuló szerződéseknél a dolog minőségi megfelelőségénél mindig a szerződéssel elérni kívánt cél mérvadó, és a használt állapot nem jelent egyben automatikusan használhatatlanságot. ${ }^{1658}$

A kötelezett, illetve a gyártó és forgalmazó által tett nyilvános kijelentések szintén tartalmazhatnak a dolog minőségére vonatkozó paramétereket, amelyek az Irányelvnek megfelelően a szerződéses kötelezettet kötik. A szabály jogpolitikai indoka az, hogy a gyártók és kereskedők reklám- és marketing-tevékenysége a szerződéskötési szándék befolyásolásának jellemző eszköze korunkban. ${ }^{1659}$ A kötelezett csak a konkrét, tényszerü kijelentésért áll helyt, ami egyértelmü a jogszabály által meghatározott minőségi paraméterek esetén. ${ }^{1660}$ Egyéb kijelentéseknél pedig mindig a dolog jellegét és az eset összes körülményét kell figyelembe venni. ${ }^{1661} \mathrm{Az}$ eladó a nem általa, hanem a gyártó illetve forgalmazó által tett nyilvános kijelentésekért való helytállás alól bizonyos körülmények bizonyításával kimentheti magát. ${ }^{1662}$

\footnotetext{
${ }^{1655}$ Lásd: Ptk. 288. §.

${ }^{1656}$ BÁRTFAI (2004), 14. p.

${ }^{1657}$ BÁRTFAI (2004), 14. p.

${ }^{1658}$ Lásd többek között: BH 1984/12. 490., BH 1995/2. 92., BDT 2001/12. 192. számú döntések.

${ }^{1659}$ BÁRTFAI (2004), 15. p.

${ }^{1660}$ BÁRTFAI (2004), 15. p.; BACHER (2005), 652. p. Ilyen például a lábbelik címkézéséről szóló 4/1998 (I. 6.) IKIM rendelet 3. § (3) bekezdése, vagy a 12/2002. (III. 14.) GM-KöViM-KöM együttes rendelet az új személygépkocsik üzemanyag-gazdaságossági és szén-dioxid-kibocsátási adatainak közzétételéről (4-5. §§). ${ }^{1661}$ BACHER (2005), 653. p.

${ }^{1662}$ Lásd: Ptk. 277. § (2) bekezdés: „A szolgáltatásnak nem kell megfelelnie az (1) bekezdés b) pontjában emlitett nyilvános kijelentésnek, ha a kötelezett bizonyitja, hogy a nyilvános kijelentést nem ismerte, és azt nem is kellett ismernie, vagy a nyilvános kijelentést a szerzödéskötés idöpontjáig már megfelelö módon helyesbitették, vagy a nyilvános kijelentés a jogosult szerződéskötési elhatározását nem befolyásolhatta.".
} 
Harmathy Attila szerint a bíróságnak a szerződéses szolgáltatás minőségével kapcsolatos jogvitában „mindig az adott szolgáltatás minőségi viszonyait kell alapul venni, s úgy mérlegelni, hogy a döntés ösztönözzön a minőséget javító, de az önköltséget csökkentő intézkedésekre, magasfokú és reális igényeket támasztani”. 1663

A továbbiakban a hibás teljesítésre vonatkozó Ptk.-beli szabályok a „fogyasztói adásvételi szerződés” tekintetében kerülnek bemutatásra. Kétségtelen, hogy a „fogyasztói adásvételi szerződés" fogalmát a Ptk. nem alkalmazza. A dolgozatban a tárgyi kör szükítése érdekében használom azt, figyelemmel a fent tárgyalt Ptk.-beli fogyasztói szerződés speciális - kellékszavatosság és jótállás esetén alkalmazandó - fogalmára.

\subsection{Kellékszavatosság és hibafogalom}

Az eladó főkötelezettségei közé tartozik a fent említetteknek megfelelően a megfelelőségért fennálló „feltétlen helytállási kötelezettség”, amely többek között a kellékszavatosságban testesül meg, de ,az eladó jogszabályi előíráson túl is vállalhat garanciát (jótállást) a szolgáltatott dolog rendeltetésszerü használatra alkalmasságáért”. ${ }^{1664}$ „A szavatosság a hibás teljesítés objektív, kimentést nem türő jogkövetkezménye."1665 A Ptk. rendelkezése szerint: „A kötelezett a hibás teljesitésért felelösséggel tartozik (kellékszavatosság)."1666 A Ptk. 2003. előtti rendelkezéseiből megmaradt hibás teljesítésért való „felelősség” kifejezést továbbra sem tartom adekvátnak: a „helytállás” szó alkalmazása dogmatikailag helytállóbb lenne. A Ptk. 2003-ban módosult szabálya részletes hibafogalmat határoz meg:

„Olyan szerzödés alapján, amelyben a felek kölcsönös szolgáltatásokkal tartoznak, a kötelezett hibásan teljesit, ha a szolgáltatott dolog a teljesités idöpontjában nem felel meg a jogszabályban vagy a szerzödésben meghatározott tulajdonságoknak."

A meghatározás a módosítás előtti szöveget csupán annyiban változtatta meg, hogy törvényes tulajdonság helyett a jogszabály terminus technikust használja.

A hibás teljesítés a bírói gyakorlat szerint is ,jogi kategória: lehetséges, hogy a dolog köznapi értelemben hibás, a szerződés keretei között még sincs hibás teljesítésről

\footnotetext{
1663 Lásd: TÖRÖK (2006), 564. p. hivatkozása Harmathy Attila professzor úrra.

${ }^{1664}$ Lásd: BÍRÓ (2011), 45. p.

1665 Lásd: BíRÓ (2010), 426-427. p. Vö. FAZEKAS (1995b), 150. p. egyes szerzők álláspontjainak összevetése.

${ }^{1666}$ Ptk. 305. § (3) bekezdés

${ }^{1667}$ Ptk. 305. § (1) bekezdés.
} 
szó" ${ }^{1668}$ Lehetséges, hogy a felek hibás dolog vételében állapodtak meg, illetve előfordulhat az is, hogy a kifogástalan minőségű dolog a szerződésben külön kikötött tulajdonságoknak, jogosulti igényeknek nem felel meg, ezért jogi értelemben a teljesítés hibás. ${ }^{1669}$ A Ptk. szabálya szerint a szerződésszerüség továbbra is kettős aspektusú: a szolgáltatás akkor nem hibás, ha megfelel (1) a jogszabályban és (2) a szerződésben meghatározott tulajdonságoknak.

A jogszabályi kellékek a joggyakorlat szerint három szinten jelennek meg. ${ }^{1670} \mathrm{Az}$ első a Ptk. kötelmi általános részi szabálya a teljesítés módjáról, a szolgáltatás rendeltetésszerűségéről. ${ }^{1671}$ Különösen releváns a fogyasztói adásvételi szerződés esetén a Ptk. alábbi rendelkezése:

„A kötelezett, dolog szolgáltatására irányuló szerzödés esetén, köteles a dolgot - a jogszabályok rendelkezéseinek és a szakmai szokásoknak megfelelöen azonositásra alkalmas jelzéssel ellátni és a dologról a rendeltetésszerü használathoz, a felhasználáshoz szükséges tájékoztatást megadni. Ha a kötelezett gazdálkodó szervezet, a dolog minöségének tanúsitására is köteles. "1672

Külön jogszabályok is előírhatnak minőségi követelményeket. ${ }^{1673}$ A Szegedi Ítélőtábla szerint „a hibás teljesítés szempontjából a termékek törvényes tulajdonsága egyfelöl azt jelenti, hogy ha a termék müszaki paramétereit szabványok vagy más müszaki előírások kötelezően határozzák meg, és a termék ezeknek nem felel meg, akkor hibás teljesítés

${ }^{1668}$ Lásd: Szegedi Ítélőtábla Polgári Kollégiumának 1/2004. évi (VI. 17.) számú kollégiumi ajánlása a hibás teljesítés egyes jogértelmezési kérdéseiről (megjelent: Bírósági Döntések Tára 2004. évi 9. szám), a továbbiakban: Szegedi ÍT 1/2004. Elérhető:

http://szegediitelotabla.birosag.hu/sites/szegediitelotabla.birosag.hu/files/field_attachment/ajanlas_20041.pdf (2013. október 16.).

A téma jogalkalmazás-központú fejtegetéseihez rendkívül hasznos anyagot nyújt ezen kívül a Szegedi Ítélőtábla 2/2004. (VI. 17.) számú kollégiumi ajánlása, a továbbiakban: Szegedi ÍT 2/2004. Elérhető: http://szegediitelotabla.birosag.hu/sites/szegediitelotabla.birosag.hu/files/field_attachment/ajanlas_2004-

2.pdf (2013. 12. 07.);

a Pécsi Ítélőtábla 2011.EL.II.C.25. számú összefoglaló kollégiumi anyaga, a továbbiakban: Pécsi ÍT 2011.EL.II.C.25. Elérhető:

http://www.pecsiitelotabla.hu/docs/szakmai/polgari/Hibas_teljesites20111015.pdf (2013. 12. 06.);

a Debreceni Ítélőtábla 2010.El.II.C.54/5. számú polgári kollégiumi anyaga [a továbbiakban Debreceni ÍT 2010.El.II.C.54/5. Elérhető: http://www.debreceniitelotabla.hu/doc/polgari/HibasTeljesites.pdf (2013. 12. 06.); és

a Kúria 1/2004. (XII. 2.) számú Polgári Kollégiumi véleménye (a továbbiakban: 1/2004. PK), valamint a legfrissebb 1/2012. (VI. 21.) számú Polgári Kollégiumi véleménye a hibás teljesítés jogalkalmazási kérdéseiről, a továbbiakban: 1/2012. PK. Elérhető: http://www.lb.hu/hu/kollvel/12012-vi-21-pk-velemenyhibas-teljesitessel-kapcsolatos-egyes-jogalkalmazasi-kerdesekrol (2013. 12. 06.).

1669 Lásd: 1/2004. PK 1. pont indokolás, Pécsi ÍT 2011.EL.II.C.25. 15. p., Szegedi ÍT 1/2004. 1. pont indokolás. Ez megfelel a német, osztrák és svájci magánjogi dogmatika felfogásának, az ún. szubjektív hibafogalomnak.

${ }^{1670}$ Lásd: Szegedi ÍT 2/2004. 3. p.; Pécsi ÍT 2011.EL.II.C.25. 12. p.; 1/2012. PK vélemény 1. pont indokolása.

${ }^{1671}$ A fent részletezett Ptk. 277. § (1)-(2) bekezdések. Lásd: 1/2012. PK.

1672 Ptk. 277. § (6) bekezdés.

${ }^{1673}$ Szegedi ÍT 2/2004. 3. p.; 1/2012. PK 1. pont indokolása. 
történt. Kötelező szabvány hiányában is hibás azonban a termék, ha a szerződéssel elérni kívánt célnak megfelelő felhasználásra bármely okból nem alkalmas. A nem kötelező szabványban elöírt követelmények abból a szempontból jelentősek a hibás teljesítés megítélése során, hogy az adott termék alkalmas-e a rendeltetésszerü használatra."1674 A szabványok is a jogszabály által elöírt tulajdonságok köréhez tartoznak tehát, de amint azt a Pécsi Törvényszék napkollektorok hibás teljesítése ügyében hozott ítéletében kimondta, ilyen esetben sem ,a szabványhoz viszonyított megfelelőség, hanem az általában elvárható szintű, jó minőségü, a cél elérésére alkalmas szolgáltatás mércéje alapján kell elbírálni” az ügyet. $^{1675}$

A jogszabály által meghatározott tulajdonságok harmadik körét a használati, kezelési útmutatók, árujelzők, megfelelőséget tanúsító dokumentumok alkotják. ${ }^{1676}$ Ezek alkalmazása egyes termékek esetén jogszabály által kötelezővé tehető a Fgytv. alapján [12. $\S$ (1) bekezdés]. A még mindig hatályos 2/1984. (III. 10.) BkM-IpM együttes rendelet szerint a használati-kezelési útmutató a termék rendeltetésszerü használatához, müködtetéséhez, kezeléséhez, eltarthatóságához, felhasználhatóságához szükséges feltételeket és ismereteket foglalja magában, a minőségtanúsítás pedig a terméknek a vásárló számára lényeges tulajdonságait, főbb minőségi, műszaki és egyéb jellemzőit, minőségi osztályát tartalmazza [2. § (2)-(3) bekezdések].

A szerződéses tulajdonságok alkotják a hibás teljesítés másik aspektusát a Ptk. szabályozása szerint, amelyek a szerződés konkrét tartalmától függően adott esetben meg is elözhetik a jogszabályban meghatározott tulajdonságokat és minőségi követelményeket. Ezért állapítja meg a Pécsi Ítélőtábla, hogy nagyon fontos jogalkalmazási feladat, hogy a bíróság mindig részletesen feltárja a konkrét szerződés tartalmát és a felek szerződéssel elérni kívánt célját. ${ }^{1677}$ A Veszprémi Törvényszék egy ítéletében megállapította, hogy ha a szerződő fél olyan célt kívánt elérni, ami az adott szerződés természetéből automatikusan nem következik, azt már a szerződés megkötésekor közölnie kell, mert az e tájékoztatás elmaradása miatti szubjektív hiba miatt nem tekinthető jogi értelemben hibásnak a teljesítés. ${ }^{1678}$ Az Irányelv nyomán a hibás teljesítés fogalma a Ptk.-ban az alábbi esettel egészült ki:

\footnotetext{
${ }^{1674}$ Lásd: BDT2004. 1072.

${ }^{1675}$ Lásd: Pécsi Törvényszék, 2. Pf. 20.194/2010. Az 1995. évi XXVIII. törvény 2002. január 1-jétől hatályos 6. § (1) bekezdése értelmében már nem létezik kötelező szabvány, lásd: Pécsi ÍT 2011.EL.II.C.25., 13.p.

${ }^{1676}$ Pécsi ÍT 2011.EL.II.C.25., 13. p.; 1/2012. PK 1. pont.

${ }^{1677}$ Pécsi ÍT 2011.EL.II.C.25., 14. p.

1678 A jogesetben a csomagolóanyag csúszós felülete jelentette a hibát a kereseti kérelem szerint. A Veszprémi Törvényszék nem publikált határozatára való utalást lásd: Pécsi ÍT 2011.EL.II.C.25., 15. p.
} 
„Hibás teljesitésnek minösül a szolgáltatott dolog szakszerütlen összeszerelése is, ha a szerelés szerzödéses kötelezettség, és azt a kötelezett vagy olyan személy végezte el, akinek magatartásáért a kötelezett felelös. A kötelezett felel akkor is, ha a szolgáltatott dolog összeszerelését a szerzödésnek megfelelöen a jogosult végezte el, és a szakszerütlen összeszerelés a használati útmutató hibájára vezethetö vissza." 1679

A külföldi jogirodalomban IKEA-klauzulának nevezett rendelkezés ${ }^{1680}$ relevanciája valószínűleg valóban a darabokban megvásárolható, és otthon összeszerelhető bútorok adásvétele esetén a legnagyobb. Ha az összeszerelést a vevő-fogyasztó végzi el, akkor a használati útmutató leírása szolgál segítségül, és méltányos, hogy ha annak hibája okozza az összeszerelt dolog hibáját, akkor az eladónak ezért helyt kell állnia. Ennek fényében a jogalkotó fogyasztói szerződés esetén az e szabállyal ellentétes kikötéshez a semmiség joghatását füzi [Ptk. 305. (2) bekezdés]. A használati útmutatóra visszavezethető hiba miatti helytállást egyébként már a korábbi bírói gyakorlatunk is megállapította. ${ }^{1681}$

\subsection{A szabályozás kógens jellege}

Az Irányelv úgy rendelkezik, hogy „az eladóval a megfelelés hibájáról való értesitését megelözöen kötött olyan szerzödési kikötés vagy megállapodás, amely az ezen irányelvben biztositott jogokat közvetve vagy közvetlenül elvonja vagy korlátozza, a fogyasztót a nemzeti jogban szabályozottak szerint nem köti”. ${ }^{1682}$ A hibás teljesítés klaudikálóan kógens szabályait azok jogpolitikai céljának megfelelően a magyar jogalkotó nyilvánvalóan a fogyasztói szerződésekre kívánta ilyen kötőerővel kiterjeszteni, ezért mindig az egyes rendelkezések utáni külön szabállyal rendeli el azt. ${ }^{1683}$ Az Irányelvnél szigorúbb azonban a magyar szabályozás annyiban, hogy nem csupán a kötelezettnek a hibáról történő értesítése előtti, hanem valamennyi megállapodás esetén tilos eltérni a rendelkezésektől a fogyasztó hátrányára. ${ }^{1684}$ Figyelemre méltó, hogy Fazekas Judit az 1994-es kandidátusi értekezésének téziseiben - már az Irányelv megszületése és a magyar fogyasztóvédelmi magánjog intézményesülésének hajnalán - ugyanezt a szabályozási megoldást javasolta. ${ }^{1685}$ Korábbi

\footnotetext{
${ }^{1679}$ Ptk. 305. § (2) bekezdés.

${ }^{1680}$ Lásd többek között: KLETECKA (2001), 97. p.

1681 Lásd: BH 1981. 466.

1682 Lásd: Irányelv, 7. cikk (1) bekezdés.

${ }^{1683}$ Lásd: Ptk. 305. (2) bekezdés, 305/A. § (2) bekezdés, 306. § (5) bekezdés, 307. § (2) bekezdés, 308. $\S(4)$ bekezdés, 308/A. $\S(2)$ bekezdés, 309. $§(1)$ bekezdés.

${ }^{1684}$ A fogyasztói szerződésnek nem minősülő jogügyleteknél továbbra is a polgári jogra jellemző diszpozitív szabályozás érvényesül.

${ }^{1685}$ Lásd: FAZEKAS (1994), 19. p.
} 
magánjogunk tapasztalatai alapján többek között Zoltán Ödön is megfogalmazta már a kógens szabályozás iránti igényt. ${ }^{1686}$

\subsection{A hiba vevö általi ismerete - az eladó „mentesülése”}

A korábbi szabályozást fenntartva a kódex úgy rendelkezik, hogy „, a kötelezett mentesül a szavatossági felelösség alól”, ha a jogosult „a hibát a szerzödéskötés időpontjában ismerte, vagy azt ismernie kellett". ${ }^{1687}$ A hiba ismerete a Ptk.-ban kezdettől fogva mentesülési okként van feltüntetve, pedig fel sem merülhet a szerződésszegés, ha a jogosult a hiba ismeretében veszi át a dolgot. ${ }^{1688} \mathrm{Ha}$ a hibát/hibás állapotot a teljesítés alkalmával mégis kifogásolja, és azt nem akarja elfogadni teljesítésként, akkor a jóhiszeműség és tisztesség általános követelményének megfelelően azt nyomban vissza kell utasítania. Ezt támasztja alá a 316. § (1) bekezdés is:

„Ha a jogosult a teljesitést a szerződésszegésről tudva elfogadja, a szerzödésszegésböl igényt utóbb csak akkor támaszthat, ha erre irányuló jogait fenntartotta."

A szerencsésebb megfogalmazás véleményem szerint az lenne, hogy „nem minősül hibásnak a teljesítés, ha a jogosult a hibát a szerződéskötés időpontjában ismerte, vagy azt ismernie kellett". ${ }^{1689}$ A Kúria szerint, ha a jogosult a hiba ismeretében köt szerződést, az azt jelenti, hogy „a felek szerződési akarata ténylegesen az adott fogyatékossággal rendelkező szolgáltatás nyújtására irányult", ${ }^{1690}$ és ilyen esetben a hibás teljesítés nem következik be. ${ }^{1691}$ A Szegedi ÍT és a Kúria is úgy vélekedik, hogy a hiba ismerete nem csak a szavatossági, hanem a hibátlan teljesítésért fennálló jótállási és a hibás teljesítésből eredő kártérítési igények érvényesítését is kizárja. ${ }^{1692}$ Az Irányelv szerint a szerződéskötés időpontja a meghatározó a hiba ismeretére vonatkozóan, és így rendelkezik a Ptk. is. A Pécsi Ítélőtábla hangsúlyozza, hogy a szerződéskori és a teljesítéskori ismeret a hibára vonatkozóan nem azonos, és a kettőt szigorúan el kell különíteni, mert a jogosultnak nem

\footnotetext{
${ }^{1686}$ Lásd: ZOLTÁN (1970b), 345. p.

${ }^{1687}$ Lásd: Ptk. 305/A. § (1) bekezdés.

${ }^{1688}$ Lásd: Szegedi ÍT 1/2004. 5. p.; 1/2012. PK 2. pont indokolása; TÖRÖK (2006), 631. p.

1689 Így rendelkezik egyébként az Irányelv, 2. cikk (3) bekezdése is: „E cikk alapján nem minösül a megfelelés hibájának, ha a szerzödés megkötésének idöpontjában a fogyasztó a hibáról tudott vagy arról ésszerüen eljárva tudnia kellett...". Az új Ptk. is hasonlóan fogalmaz, lásd később: II. rész 4. fejezet 4. pont.

$16901 / 2012$. PK 1. pont indokolása.

1691 1/2012. PK 2. pont indokolása; Pécsi ÍT 2011.EL.II.C.25., 23. p.

${ }^{1692}$ Lásd: Szegedi ÍT 1/2004. I. pont.; 1/2004. PK 1. pont indokolása.
} 
kötelezettsége az, hogy a dolgot már a szerződéskötéskor körültekintően megvizsgálja (sokszor nincs is rá alkalma - az mindig a körülményektöl függ). ${ }^{1693}$

A hibát „,ismernie kellett” fordulatot a 2002. évi XXXVI. tv. építette be a Ptk.-ba, de annak értelmezése a jogalkalmazásra és a jogtudományra maradt. A Szegedi ÍT, a Pécsi ÍT és a Kúria is egyértelműen úgy ítéli meg, hogy ebből a fordulatból és az Irányelvből sem vonható le olyan következtetés, hogy a jogosultnak bármilyen megvizsgálási kötelezettsége lenne. ${ }^{1694}$ A Kúria szerint a Ptk. 305/A. § (1) bekezdésének alkalmazását az alapozza meg, ha a jogosultnak a hibát „a szolgáltatás jellege, természete (pl. használt dolgok) vagy a szerződéskötés körülményei alapján számításba kellett vennie, fel kellett ismernie", ${ }^{1695}$ a Szegedi ÍT pedig úgy fogalmaz, hogy a fordulat azt jelenti, hogy a jogosultnak ,a teljesítéskori hibára ésszerüen számítania kellett”. ${ }^{1696}$ A Pécsi ÍT a fordulatot úgy értelmezi, hogy a szolgáltatásnak azon hibája, ,amelyek észlelése a jogosulttól ésszerü eljárás mellett elvárható lett volna, hibás teljesítés hiányában nem alapozhat meg szavatossági igényt”. ${ }^{167}$ A kérdés az, hogy a fenti meghatározások alapján a mérce objektív (azaz mindenkinek fel kellene ismernie a hibát) vagy szubjektív (azaz a jogosulttól lett volna elvárható, hogy ő felismerje).

Czuczai Jenő, a Pécsi ÍT és a Kúria megállapításai alapján két irányban releváns az „, ismernie kellett” fordulat. ${ }^{1698}$ „Ésszerü eljárás mellett” elvárható a hiba ismerete a vevő részéről azon adásvételek körében, amelyek esetén a szerződés megkötése és teljesítése időben egybeesik, valamint a használt dolgok adásvételénél is. ${ }^{1699}$ Ezt az álláspontot az alábbi két rövid példa szemlélteti. A szerződéskötéskor azonnal teljesedésbe megy az ügylet, ha például valaki szőnyeget vásárol és azt azonnal haza is viszi az üzletből az adásvétel megkötése után. A körültekintő és ésszerüen eljáró vevőtől elvárható, hogy szemügyre vegye a megvásárolni kívánt szőnyeget, így rögtön láthatja, ha a vadonatúj (de leértékelt vételárú) szőnyeg egyik sarkánál (szövési hiba miatt) jóval világosabb a minta, mint a többi helyen. E hiba miatt a vétel lebonyolítása és a szőnyeg elszállítása után a fentiek értelmében szavatossági igényt később nem támaszthat. A másik esetkörhöz kapcsolódóan, ha például a vevő egy használtruha-üzletben egy használt kosztümöt kíván megvenni, körültekintő eljárásához hozzátartozik, hogy megnézze, hogy van-e rajta

\footnotetext{
${ }^{1693}$ Pécsi ÍT 2011.EL.II.C.25., 23. p. Ellentétben például a svájci joggal.

${ }^{1694}$ Pécsi ÍT 2011.EL.II.C.25., 23. p.; Szegedi ÍT 1/2004. 4. p.; 1/2012. PK vélemény 2. pont indokolása.

1695 1/2012. PK vélemény 2. pont.

1696 Szegedi ÍT 1/2004. 1-2. pontok.

1697 Pécsi ÍT 2011.EL.II.C.25., 25. p.

${ }^{1698} \mathrm{E}$ fordulat az ún. nyílt, azaz azonnal felfedezhetö hibákhoz kapcsolódhat, lásd: TÖRÖK (2006), 632. p., Pécsi ÍT 2011.EL.II.C.25., 23. p.; 1/2012. PK 2. pont indokolása.

${ }^{1699}$ Lásd: TÖRÖK (2006), 632. p., Pécsi ÍT 2011.EL.II.C.25., 23. p.
} 
valamilyen folt vagy szakadás, hiszen ezek a ruhahasználattal velejáró körülmények. Amennyiben felfedez bármilyen „szépséghibát”, akkor rajta múlik, hogy annak tudatában is megveszi-e a használt kosztümöt. E hiba miatt később, a vétel lebonyolítása és a ruha elvitele után szavatossági igényt az elöbbi példához hasonlóan nem támaszthat. Erre vonatkozóan a használtruha-üzletek gyakorlata általában az, hogy jól látható helyre kifüggesztik, hogy az ilyen jellegü, a használt állapotból eredő hibákért kizárják a helytállást.

A bírósági joggyakorlatban gyakori a használat gépkocsi adásvételének hibás teljesítésével kapcsolatos jogvita. A Pécsi Törvényszék egyik ítéletében elutasította a hibás teljesítésre alapított keresetet abban a jogesetben, amelyben az eladó felajánlotta a felperesnek, hogy az adásvétel tárgyát képező használt gépkocsit egy szerelőmühelyben megvizsgálhatja, de ő ezzel a lehetőséggel nem élt. ${ }^{1700}$ A törvényszék érvelése szerint, ha élt volna e lehetőséggel a vevő, akkor a keresetben felhívott összes hibát felismerhette volna. Ez az indoklás azonban véleményem szerint túl általános, és az ilyen eset megítélése attól függ, hogy milyen komoly a felmerülö hiba.

Nehezebb volt a döntés abban az ügyben, amelyben egy totálkáros gépkocsit értékesítettek, és az a jogi probléma merült fel, hogy a totálkárosság jelenti-e egyben a teljes üzemképtelenséget is. ${ }^{1701}$ A bíróság nemleges válaszában azt állapította meg, hogy mivel a motor rejtett hibája okozta az üzemképtelenséget, így ez esetben is felléphet a vevő a kellékszavatossági igényekkel annak ellenére, hogy tudott a gépkocsi totálkáros voltáról.

A kérdéskörhöz kapcsolódik az a bírósági döntés is, amelynek rendelkező része szerint „a vevőt a megvizsgálási kötelezettség nem a szerződés megkötése előtt terheli, hanem a vevőnek a teljesítéskor (azt követően) kell a legrövidebb időn belül a szerződésszerü teljesítésről megbizonyosodnia. Amennyiben azonban a szerződéskötés és a teljesítés időben lényegében egybeesik, a vevő a szerződéskötés előtt a megvásárolni kívánt gépkocsit ténylegesen megtekinti, és ehhez képest nyilatkozik vételi szándékáról, vélelmezni lehet, hogy azokat a hibákat, amelyeket a kellően gondos, ésszerü eljárás mellett felismerhetett, „ismernie kellett”, ennélfogva a (nyílt) hiba (vélelmezett) ismeretében vette meg a gépkocsit." ${ }^{1702}$ Figyelemre méltó, hogy a Ptk. eredeti szabályai között még szereplő „nyílt hiba” kérdésköre - közvetett módon bár, de - visszaköszön a 2003 utáni szabályozásban.

\footnotetext{
${ }^{1700}$ Lásd: Pécsi Törvényszék 2. Pf. 20.032/2009.

1701 Zalaegerszegi Törvényszék 3. Pf. 20.116/2009/3.

${ }^{1702}$ BDT2006. 1510.
} 


\subsection{A hibás teljesítésböl fakadó jogkövetkezmények}

A Ptk. alapján hibás a teljesítés jogkövetkezményei elsősorban az objektív jogalapú kellékszavatossági igények, amelyek függetlenek a kötelezett, az eladó felróhatóságától és tudattartalmától is. ${ }^{1703}$ Ezen kívül azonban a jogosult a hibás teljesítésből eredő kárának megtérítését is követelheti, és jótállás esetén az abból fakadó jogok is megilletik. ${ }^{1704}$

A 2002-es módosítások a többi EU-s tagállamhoz hasonlóan hazánkban is a kellékszavatossági igények ún. lépcsős érvényesítésének rendszerét vezették be: a jogosult elsősorban a szerződésnek megfelelő állapot térítésmentes helyreállítását követelheti a kijavítás és kicserélés igényének érvényesítésével, másodsorban pedig árleszállítást kérhet, vagy a szerződéstől elállva az eredeti állapot helyreállítását követelheti (Ptk. 306. §). A Kúria ötödik szavatossági igényként nevezi meg a kijavítási költségek követelését a második lépcsős jogok között. ${ }^{1705}$

A jogorvoslatok lépcsős rendszere a megelőző szabályozáshoz és joggyakorlathoz annyiban hasonló, hogy a reális teljesítés elvének megfelelően korábban szintén előtérbe kerültek a reparatív jellegü jogosulti igények. Fogyasztói szerződések, így fogyasztói adásvétel esetén is a fogyasztó javára eltérhetnek tőle a felek, a fogyasztó hátrányára eltérő rendelkezés azonban semmis (klaudikáló kógencia, Ptk. 306. § (5) bekezdés).

\subsubsection{Elsö lépcsöben érvényesíthető igények - kijavítás, kicserélés}

„Hibás teljesités esetén a jogosult elsösorban - választása szerint - kijavítást vagy kicserélést követelhet, kivéve, ha a választott szavatossági igény teljesitése lehetetlen, vagy ha az a kötelezettnek a másik szavatossági igény teljesitésével összehasonlitva aránytalan többletköltséget eredményezne, figyelembe véve a szolgáltatott dolog hibátlan állapotban képviselt értékét, a szerződésszegés súlyát, és a szavatossági jog teljesitésével a jogosultnak okozott kényelmetlenséget." A kijavitást vagy kicserélést - a dolog tulajdonságaira és a jogosult által elvárható rendeltetésére figyelemmel - megfelelö határidön belül, a jogosultnak okozott jelentös kényelmetlenség nélkül kell elvégezni. "1706

\footnotetext{
1703 TÖRÖK (2006), 636. p.; BESENYEI (2012), 163. p. Vö. 305. § (3) bekezdés, lásd fent.

${ }^{1704}$ Lásd: BíRÓ (2010), 410-413. p.; TÖRÖK (2006), 591. p.; Szegedi ÍT 2/2004. 4. p. Vö. Ptk. 248. § és 310. $\S$. ${ }^{1705}$ Lásd: 1/2012. PK 3. és 8. pont.

${ }^{1706}$ Lásd: Ptk. 306. $§$ (1) bekezdés a) pont és (2) bekezdés.
} 
Az elsődlegesen alkalmazandó szavatossági igények közé a kijavítás és a kicserélés tartozik: e jogok tehát a hiba természetbeni orvoslására hivatottak. ${ }^{1707}$ A két igény közötti választás elvben megengedett, gyakorlatilag azonban két korlátot is felállít a törvény: ha a választott igény teljesítése lehetetlen (például egy meghatározott festmény, antik bútordarab, vagy más egyedi dolog kicserélése), vagy ha a kötelezettnek - meghatározott körülmények figyelembevételével - aránytalan költségeket okozna, akkor nem illeti meg a választás joga a jogosultat. Az arányosság feltétele a felek érdekeinek egyensúlyát hivatott biztosítani, ${ }^{1708}$ ami megfelel a magánjogi fogyasztóvédelmi szabályozás céljainak. Egyetértek Czuczai Jenő azon megállapításával, hogy az aránytalansággal kapcsolatos szabályozás azt célozza, hogy a kijavításra nagy értékü, a kicserélésre pedig kisebb értékü dolog esetén kerüljön sor. ${ }^{1709}$

Az arányosság értékelésénél irányadó szempontokat is meghatározza a Ptk. az Irányelvnek megfelelően: figyelembe kell venni a szolgáltatott dolog hibátlan állapotban képviselt értékét, a szerződésszegés súlyát, és a szavatossági jog teljesítésével a jogosultnak okozott kényelmetlenséget. Amennyiben a választott első lépcsős igény ezek fényében aránytalan költséget okozna az eladónak, akkor csak a másik elsőlépcsős igény áll a jogosult rendelkezésére. Értelmezésem szerint, ha az sem tesz eleget a fenti kívánalmaknak, azaz teljesítése lehetetlen vagy aránytalan költésekkel jár a kötelezett oldalán, akkor az igények a második lépcsős jogokra korlátozódnak. Úgy ítélte meg a Kúria is, hogy az arányosság követelményét „az eltérő lépcsőkbe tartozó jogok közötti választás során is vizsgálni kell”. 1710

Előfordulhat, hogy a kijavítás igényének érvényesítése után a dologban mégis fennmarad olyan hiba, amely vagy a rendeltetésszerü használatra való alkalmasságát befolyásolja hátrányosan, vagy az értékét csökkenti, vagy az esztétikai jellemzőire hat negatívan. A Kúria szerint, ha ennek ellenére a jogosult továbbra is ragaszkodik a dologhoz, akkor megengedett az, hogy árleszállításra is igényt tartson a kijavítás mellett. ${ }^{1711}$

Különösen a részletvétel esetén releváns a Ptk.-nak az a szabálya, amely szerint „, $a$ jogosult a kijavitásig vagy kicserélésig az ellenszolgáltatás arányos részét

\footnotetext{
${ }^{1707}$ Pécsi ÍT 2011.EL.II.C.25., 27. p.; 1/2012. PK 3. pont indokolása.

1708 TÖRÖK (2006), 643. p.

1709 TÖRÖK (2006), 643. p.

${ }^{1710}$ Lásd: 1/2012. PK vélemény 4. pont. Ezzel ellentétesen döntött azonban az EuB a dolgozat II. rész 2. fejezet 8. pontjában tárgyalt ítéletében (C-65/09.).

${ }^{1711}$ Lásd: $1 / 2012$. PK 7. pont indokolása.
} 
visszatarthatja.". ${ }^{1712} \mathrm{Ez}$ a ius retentionis csak a természetbeni reparációt biztosító első lépcsős jogok esetén alkalmazható. A Kúria szerint kicserélés esetén akár a teljes vételár is, kijavítás esetén pedig a javítás előrelátható költségeihez viszonyított arányos összeg tartható vissza. ${ }^{1713}$

A megfelelő határidőn belüli és a jogosultnak a lehető legkevesebb érdeksérelmet okozó kicserélés szabálya a kellékszavatosság rendeltetéséből fakadó követelmény. Kicserélés (és elállás) esetén a fogyasztó nem köteles a dolognak azt az értékcsökkenését megtéríteni, amely a rendeltetésszerű használat következménye [Ptk. 309. § (2) bekezdés]. E rendelkezés arra szolgál, hogy az eladót a követelt igény minél hamarabbi teljesítésére sarkallja. ${ }^{1714}$ Ebből egyértelmüen következik, hogy kicserélés esetén az igény foganatosításáig történő rendeltetésszerü használatért sem köteles ellenértéket fizetni a fogyasztó. ${ }^{1715}$

\subsubsection{Második lépcsőben érvényesíthetö igények - árleszállitás és elállás}

„Hibás teljesités esetén a jogosult [...] ha sem kijavitásra, sem kicserélésre nincs joga, vagy ha a kötelezett a kijavitást, illetve a kicserélést nem vállalta, vagy e kötelezettségének a (2) bekezdésben irt feltételekkel nem tud eleget tenni választása szerint - megfelelö árleszállitást igényelhet vagy elállhat a szerzödéstöl. Jelentéktelen hiba miatt elállásnak nincs helye."

Ha a kötelezett a dolog kijavitását megfelelö határidőre nem vállalja, vagy nem végzi el, a jogosult a hibát a kötelezett költségére maga kijavithatja vagy mással kijavittathatja." 1716

Az árleszállítás és az elállás ${ }^{1717}$ feltételei a rendelkezés alapján a következőek: (1) a kijavítás/kicserélés lehetetlen, (2) aránytalan, (3) a kötelezett ezen igények teljesítését nem vállalja, illetve (4) nem tudja ezeket megfelelő időn belül teljesíteni. Az utóbbi két feltétel érvényesül a kijavítás költségeinek megtérítésére vonatkozó követelés esetén is. Ezen felül az elállás joga nem gyakorolható jelentéktelen hiba esetén, amely a rendeltetésszerü

\footnotetext{
1712 Ptk. 306. $\S(4)$ bekezdés.

${ }^{1713}$ Lásd: $1 / 2012$. PK 10. pont indokolása.

${ }^{1714}$ Ez a Ptk. 4. § (4) bekezdéséből is levezethető, lásd: GELLÉRT (2007), 1117-1118. p.

${ }^{1715}$ Ezt mondta ki az EuB is a Quelle-ügyben, illetve a jóval korábbi hazai bírói gyakorlat is ezt az álláspontot képviselte, lásd például: P. törv. IV. 20211/1972. és 1971. El. II. D. 22. számú tanácselnöki értekezleti vélemény; GELLÉRT (2007), 1119. p.

${ }^{1716}$ Ptk. 306. $\S$ (1) bekezdés b) pont és (3) bekezdés.

1717 Érdekesség, hogy Besenyei Lajos tankönyvében ezen igények neve mellé a római jogból ismert latin elnevezéseket is hozzátoldotta, lásd: BESENYEI (2012), 164. p.
} 
joggyakorlás elvéből, a joggal való visszaélés tilalmából, és az első lépcsős szavatossági jogok esetén alkalmazandó arányosság elvéből is levezethető rendelkezés. ${ }^{1718}$

A Kúria úgy ítélte meg, hogy a sorrendiség nem feltétlenül jelenti azt, hogy a második lépcsős jogok érvényesítése előtt a jogosultnak eredménytelenül fel kell hívnia a kötelezettet a dolog kijavítására vagy kicserélésére, ${ }^{1719}$ mert e nélkül is sikeresen bizonyíthatja, hogy a dolog tulajdonságaira és az elvárható rendeltetésére figyelemmel megfelelő határidőn belül, vagy a neki okozott jelentős kényelmetlenség nélkül a kötelezett nem fogja tudni teljesíteni az igényt. Ez a helyzet többek között akkor is, ha a kötelezett magát a hibás teljesítés tényét is vitatja. ${ }^{1720}$ A bizonyítás azonban a gyakorlatban nehézségeket okozhat a fogyasztónak.

A korábbi joggyakorlatnak megfelelően az árleszállítás mértékénél az arányos számítási módszert alkalmazzák a hazai joggyakorlatban. ${ }^{1721} \mathrm{Ez}$ azt jelenti, hogy azt vizsgálják, hogy a dolog hibás állapotban milyen értéket képvisel, és az arányos leszállításnál a vételár összege is viszonyítási pont. E számítási módszer indoka az, hogy hibás teljesítés esetén a szolgáltatás-ellenszolgáltatás viszonyában „értékeltolódás” lép fel, és az árleszállításnak ezt az értékaránytalanságot kell kiküszöbölnie. ${ }^{1722}$

A szerződés megszűnésének egyes esetei című fejezetben a Ptk. úgy rendelkezik, hogy aki „jogszabálynál fogva elállásra jogosult, e jogát a másik félhez intézett nyilatkozattal gyakorolja. Az elállás a szerzödést felbontja”. ${ }^{1723}$ Ez a szabály tehát a kellékszavatosságból fakadó törvényi elállási jog esetén is irányadó. A felbontás jogkövetkezménye az, hogy a szerződés a keletkezésére visszamenő hatállyal szünik meg (ex tunc),${ }^{1724}$ azaz ez esetben helyre kell állítani az akkori állapotot. Ez azt jelenti, hogy a feleknek a már nyújtott szolgáltatásokat kölcsönösen vissza kell téríteniük. ${ }^{1725}$ A Kúria álláspontja szerint a mortuus redhibetur esetén, azaz amikor a jogosult a dolgot - ,,a hibás teljesítés miatt vagy a kötelezett érdekkörébe tartozó bármely más okból” - csak értékcsökkent állapotban, vagy a megsemmisülés miatt egyáltalán nem tudja visszaadni,

\footnotetext{
${ }^{1718}$ Vö. Ptk. 2. § (2) bekezdés és 4. § (1) bekezdés és 5. § (1) bekezdés; lásd: BÁRTFAI (2004), 22. p.; 1/2012. PK 4. pont indokolása.

${ }^{1719}$ Ez sok esetben elöírás a német jogban.

$17201 / 2012$. PK 3. pont indokolása.

${ }^{1721}$ Lásd: GELLÉRT (2007), 1098. p.; BESENYEI (2012), 167. p.

${ }^{1722}$ Lásd: BESENYEI (2012), 167. p. Irányadóak tehát a korábbi kapcsolódó bírósági döntések, lásd: I. rész 4. fejezet 6.2.1. pont. Nem olyan egzakt azonban az árleszállítás mértékének számítása, mint ahogyan az a BGB nyomán a vizsgált külföldi magánjogi dogmatikában és bírói gyakorlatban jellemző.

${ }^{1723}$ Ptk. 320. § (1) bekezdés.

1724 Vö. Ptk. 319. § (3) bekezdés.

${ }^{1725}$ Lásd: 1/2010. (VI. 28.) PK vélemény 4. pont.
} 
gyakorolható az elállási jog. ${ }^{1726}$ Ilyenkor azonban annak jogkövetkezménye az eredeti állapot helyreállítása helyett a jogalap nélküli gazdagodás elve alapján az ellenszolgáltatás nélkül maradt szolgáltatás ellenértékének pénzbeli megtérítése. ${ }^{1727}$

A Kúria a második lépcsős jogok közé illeszti be a kijavítási költségek követelésének jogát. ${ }^{1728}$ Abból indul ki e kategorizálásnál, hogy ezt az igényt a Ptk. külön nevesíti, és nem az elsőlépcsős jogok feltétel nélküli alkalmazásához hasonlít az érvényesítése, hanem a második lépcsőben szereplö jogokkal egyezően, csak bizonyos feltételek teljesülése mellett élhet ezzel a jogosult. Ezt kiegészítve a Kúria álláspontja szerint nem csak akkor követelheti a kijavítási költségek megtérítését a vevő, ha a dolog kijavítását megfelelő határidőre nem vállalja, vagy nem végzi el az eladó, hanem akkor is, ha „a hibás teljesítés körülményei, illetve a kötelezett magatartása miatt a jogosultnak megalapozottan megrendül a bizalma abban, hogy a kötelezett a javítást az ő méltányos érdekeinek sérelme nélkül el tudja végezni”. ${ }^{1729}$ Azért is helyes a Kúria tipizálása, mert a kijavítási költségek megtérítésének igénye nem azonosítható az árleszállítás igényének gyakorlati jogkövetkezményéhez sem, hiszen ott arányosan, több tényezöre tekintettel történik az árcsökkentés összegének megállapítása.

Minden szavatossági igény teljesítésénél irányadó szabálya a Ptk.-nak, hogy a kapcsolódó költségek, különösen az anyag-, munka- és továbbítási költségek a kötelezettet terhelik. Fogyasztói szerződés esetén a felek ettől eltérő megállapodása semmisnek minősül [309. (1) bekezdés]. A fenti felsorolás csupán példálózó, a kapcsolódó költségeket mindig az adott eset függvényében kell vizsgálni. ${ }^{1730}$

\subsubsection{Kártérítés}

A kártérítés a hibás teljesítés szubjektív jogalapú jogkövetkezménye. Míg az objektív jogalapú kellékszavatossági jogok a szolgáltatás hibájában beálló érdeksérelem, azaz maga a hiba természetbeni orvoslására irányulnak elsődlegesen, addig a kártérítés a hibás teljesítéssel okozott vagyoni érdeksérelem pénzbeli reparációjára hivatott elsősorban. ${ }^{1731}$ Ezen igény korábbi magánjogunkban gyakran vitatott jogalapját és a kellékszavatossági igényekhez való viszonyát a Ptk. egyértelmüen szabályozza:

\footnotetext{
${ }^{1726}$ Lásd: 1/2012. PK 9. pont.

${ }^{1727}$ Lásd: 1/2012. PK 9. pont indokolása.

${ }^{1728} 1 / 2012$. PK 8. pont.

${ }^{1729} 1 / 2012$. PK 8. pont. indokolás.

${ }^{1730}$ Erre a kérdésre is irányadó az EuB C-65/09. számú döntése.

${ }^{1731}$ Lásd: Szegedi ÍT 2/2004. 6-7. p.
} 
„, Szavatossági jogainak érvényesitésén kivül a jogosult a hibás teljesitésböl eredő kárának megtéritését is követelheti a kártérités szabályai szerint."

A kártérítés szabályainak alkalmazása azt jelenti, hogy a kötelezett hibás teljesítés esetén ez alól az igény alól mentesülhet, ha bizonyítja, hogy a hibátlan teljesítést illetően „úgy járt el, ahogy az az adott helyzetben általában elvárható”. ${ }^{1733}$ Másrészt a jogosult, azaz a fogyasztó hibás teljesítés esetén „a kár elháritása, illetöleg csökkentése érdekében úgy köteles eljárni, ahogy az az adott helyzetben általában elvárható" (kárenyhítési kötelezettsége van). ${ }^{1734}$ A polgári jogi dogmatika szerint a kártérítés általános feltételei a következők: a hibás teljesítésből fakadó kár a jogosult oldalán (ami a hibás teljesítéssel bizonyított okozati összefüggésben van) és a kár felróhatósága a kötelezettnek. ${ }^{1735}$

A hazai joggyakorlatban és jogtudományban a hibás teljesítés miatt felmerülő károk két fajtáját különítik el: ${ }^{1736}$ a jogosultnak a dolog hibájában megvalósuló, értékcsökkenést eredményező teljesítési érdeksérelme jelenti az ún. tapadó károkat, és a dolog hibájával okozati összefüggésben, de azon kívül keletkező vagyoni hátrány alkotja az ún. következménykárok körét. ${ }^{1737}$ A Szegedi Ítélőtábla a megtérítendő károk és a kártérítés módja tekintetében e két kárfajtának megfelelően differenciál vonatkozó állásfoglalásában. Úgy ítéli meg, hogy a kártérítéssel a szavatosság intézménye az általános-különös viszonyában van: a szavatosság céljának és jogalapjának a természetbeni orvoslási módok felelnek meg, amelyek a tapadó károk megtérítését szolgálják, míg a szubjektív jogalapú kártérítés esetén tipikusan a következménykárok pénzbeli megtérítésére van lehetőség. ${ }^{1738}$ E megfontolások alapján kerülhető el az, hogy a jogosult adott esetben a már elévült kellékszavatossági igény helyett, azzal gyakorlatilag azonos tartalmú kártérítési igényt érvényesítsen. ${ }^{1739}$ A Szegedi ÍT szerint a tapadó károk esetén kártérítés csak akkor érvényesíthető, ha a jogosult a hiba miatti értékcsökkenés megtérítését pénzben követeli, vagy ha a hiba javításának költségeire tart igényt. ${ }^{1740} \mathrm{Az}$ utóbbi esetben a kártérítés általános szabályának fényében a fogyasztó a hiba ésszerü kijavíttatásával összefüggésben

\footnotetext{
${ }^{1732}$ Ptk. 310. §.

1733 Vö. Ptk. 339. § (1) bekezdés. A szubjektív jogalap másik következménye az igényérvényesítési határidőkhöz kapcsolódik, lásd később.

${ }^{1734}$ Ptk. 340. § (1) bekezdés.

${ }^{1735}$ Lásd: TÖRÖK (2006), 666. p. Vö. Ptk. 339. §; lásd: uo. 779-781. p.

${ }^{1736}$ A német, osztrák és svájci magánjogi dogmatikával megegyezően.

${ }^{1737}$ Lásd: Szegedi ÍT 2/2004. 6-7. p.; 1/2012. PK 14. pont indokolása.

1738 Lásd: Szegedi ÍT 2/2004. 6-7. p. Erre utal az 1/2012. PK 14. pont indokolása is, a Ptk. 355. § (2) bekezdésre hivatkozva (, A kárt pénzben kell megtériteni, kivéve, ha a körülmények a kár természetben való megtéritését indokolják...").

${ }^{1739}$ Szegedi ÍT 2/2004. 6. p.

1740 Szegedi ÍT 2/2004. 7. p.
} 
indokoltan felmerült költségei megtérítésére tarthat csak igényt, azaz releváns, hogy ő a kijavíttatás költségeinek csökkentése érdekében úgy járt-e el, ahogy az az adott helyzetben általában elvárható volt. ${ }^{1741}$ Egyetértek a Szegedi ÍT fenti megfontolásaival, mert ily módon a szavatossági igények által és a kártérítés keretei között érvényesíthető károk köre világosan elkülöníthető.

A két jogintézmény közötti átfedés a dolog hibájának pénzbeli megtérítése körében fordulhat elö, mert a vételár arányos leszállítása szavatossági igény is lehet, és ahhoz tartalmilag nagyon hasonló az értékcsökkenés címén érvényesíthető kártérítés. ${ }^{1742} \mathrm{~A}$ Debreceni Ítélőtábla azonban rámutat, hogy míg az árleszállítás szavatossági igényének mértéke a vételárhoz is arányosan igazodik, addig az értékcsökkenés kártérítési igényénél a dolog forgalmi értékéből kell kiindulni (azaz a felek közötti alkutól független lesz a marasztalás). ${ }^{1743}$

A Szegedi ÍT álláspontjától a Kúria véleménye annyiban tér el, hogy mivel a kártérítés módjának meghatározása során a bíróság a felek kérelméhez kötve nincs, ezért a Kúria úgy véli, hogy a bíróságnak azt a módot kell mindig meghatároznia ítéletében, amellyel „a teljes jóvátétel elvének gyakorlati érvényesülését a legcsekélyebb sérelemmel és a legeredményesebben biztosítja". ${ }^{1744}$

\subsection{Jótállás}

A Ptk. a 2002-es módosítások után is a szerződésre vonatkozó általános szabályok között, a szerződést biztosító mellékkikötések címü fejezetben szabályozza a jótállást, amely így bármilyen szerződésszegés esetén alkalmazható. Tipikus esete azonban továbbra is a hibátlan teljesítésért fennálló jótállás, ${ }^{1745}$ amit jelez többek között a Pécsi Ítélőtábla megállapítása is, miszerint „a jótállás a szavatosság és kártérítés mellett a hibás teljesítés harmadik jogkövetkezménye". ${ }^{1746}$ A Ptk. szerint:

„aki a szerződés hibátlan teljesitéséért szerzödés vagy jogszabály alapján jótállásra köteles, ennek idötartama alatt a felelösség alól csak akkor mentesül, ha bizonyitja, hogy a hiba oka a teljesités után keletkezett."

\footnotetext{
${ }^{1741}$ Szegedi ÍT 2/2004. 8. p. Vö. Ptk. 340. § (1) bekezdés.

${ }^{1742}$ Szegedi ÍT 2/2004. 8. p.

${ }^{1743}$ Lásd: Debreceni ÍT 2010.El.II.C.54/5., 20. p.

1744 Lásd: 1/2012. PK 14. pont indokolása. Vö. 44. számú PK.

1745 GELLÉRT (2007), 933. p.

${ }^{1746}$ Lásd: Pécsi ÍT 2011.EL.II.C.25., 45. p.

${ }^{1747}$ Ptk. 248. § (1) bekezdés.
} 
A jótállási kötelezettség ${ }^{1748}$ alapja a korábbi szabályozással egyezően továbbra is lehet szerződés (önkéntesen vállalt jótállás), és - a magyar jogrendszer kuriózumaként hazánkban jogszabály kötelezővé is teheti a jótállás vállalását. Ezen kívül új rendelkezés, hogy a dologra vonatkozó reklám is megalapozhatja a jótállást [Ptk. 248. § (2) bekezdés].

Az Irányelv csak az önkéntesen felvállalt jótállás szabályairól rendelkezik, és célja, hogy a fogyasztót korrekt módon tájékoztassa a szerződési partnere. ${ }^{1749}$ Az implementáció során vita tárgyát képezte, hogy kikerüljön-e a magyar magánjogi szabályozásból a kötelező jótállás. A jogintézmény azonban 1968 óta annyira beleivódott a hazai kereskedelmi kultúrába, hogy végül a jogalkotó érintetlenül hagyta az erre vonatkozó rendelkezést. ${ }^{1750}$

A megelőző szabályozással megegyezően a jótállás a kellékszavatossággal azonos jogalapú, de annál szigorúbb helytállást keletkeztet: a jogalkotó a „kimentést” továbbra is csak akkor teszi lehetővé, ha a jótállásra kötelezett bizonyítja, hogy a hiba oka a teljesítés után keletkezett. A „felelősség alóli mentesülés” kifejezés alkalmazása véleményem szerint továbbra sem helytálló, mert a hiba okának keletkezése egy teljesen objektív körülmény.

Újdonság a szabályozásban 2003. július 1. óta, hogy a Ptk. elrendeli: „A jótállás a jogosultnak a törvényböl eredö jogait nem érinti”. ${ }^{1751} \mathrm{Ez}$ mindenekelött a törvényen alapuló kellékszavatossági igényekre való utalásként értelmezendő, illetve az egyéb szerződésszegésből eredő jogkövetkezmények érvényesítési lehetőségének a sértetlenségét jelzi.

Az Irányelv előírásait valósítja meg az a speciálisan a fogyasztói szerződésekre vonatkozó rendelkezés, amely a jótállási nyilatkozat kötelező tartalmi elemeit sorolja fel. A nyilatkozatnak eszerint magába kell foglalnia a jótállás kötelezettjének nevét és címét, a jótállás tartalmát, időtartamát, területi hatályát, a jótállásból fakadó jogok érvényesítésének módját, és utalnia kell arra a fenti rendelkezésre, hogy a jótállás a fogyasztó törvényből eredő jogait nem érinti [Ptk. 248. § (3) bekezdés]. Az Irányelv által támasztott követelményeknek megfelel a rendelkezés, ${ }^{1752}$ annak hủ átvétele a jótállási nyilatkozatban azonban az átlagemberek számára nem mindig világít rá a helyes tartalom tényleges jelentésére. A jótállás „tartalma” helyett egyértelmübb lenne a jótállás alapján érvényesíthető jogok meghatározásának követelménye. A „fogyasztó törvényböl eredő

\footnotetext{
${ }^{1748}$ A köznyelvben és a kereskedelmi kommunikációs zsargonban a garancia szó a jótállás szinonimájaként használatos.

1749 BÁrTFAI (2004), 46. p.

${ }^{1750}$ Lásd: BÁRTFAI (2004), 46. p.; Pécsi ÍT 2011.EL.II.C.25., 46. p.

1751 Ptk. 248. § (1) bekezdés 2. mondat.

1752 Vö. Irányelv, 6. cikk (2) bekezdés.
} 
jogait nem érinti" fordulattal kapcsolatban a személyes tapasztalatom az, hogy a kereskedők gyakran állítanak ki olyan jótállási jegyet, amely konkrétan a törvényszöveget ismétli meg, mert a jótállásra kötelezett elsődleges célja nyilvánvalóan a jogszabályok követelményeinek kielégítése; a Ptk. szövegének hü megismétlése ennek az elvárásnak maradéktalanul eleget tesz. Ez azonban aligha közvetíti azt a fogyasztó felé, hogy neki a jótállás mellett törvényen alapuló kellékszavatossági jogai is vannak, és azokat nem érinti a jótállás. A „nem érinti” szókapcsolat sem adekvát, mert nem érzékelteti kellően, hogy az azt jelenti, hogy a fogyasztót illeti meg a választási jog, hogy a törvényen alapuló kellékszavatossági igényeit vagy a jótállási jogait érvényesíti-e, illetve hogy az egyik határidejének lejártával a másik adott esetben még érvényesíthető lehet. Így a fenti helyett véleményem szerint helyesebb lett volna, ha a Ptk. azt írja elő, hogy a fogyasztó az őt a törvény alapján megillető kellékszavatossági és egyéb jogokat a jótállástól függetlenül érvényesítheti. ${ }^{1753}$

A 2002. évi XXXVI. törvény nyomán született meg a 151/2003. (IX. 22.) Kormányrendelet az egyes tartós használatra rendelt termékek jótállási kötelezettségeiről, ${ }^{1754}$ amely a Ptk. értelmében fogyasztói szerződésnek minősülő egyes termékek adásvétele esetén kötelező jótállást ír elő. ${ }^{1755}$ A rendelet melléklete tartalmazza a hatálya alá tartozó dolgokat, így ilyen tartós fogyasztási cikknek minősül például az új (használatlan) hütőgép, a mosógép, a személygépkocsi, a motorkerékpár, a 10000 Ft bruttó vételár feletti személyi számítógép, mp3-lejátszó, óra és bútor is, stb.

A rendelet célja a mellékletében található új termékekre vonatkozó kötelező legkisebb jótállási idő meghatározása: erre egy évet határoz meg a jogalkotó, amely az átadástól, illetve az üzembe helyezéstől számítandó [2. § (1)-(2) bekezdések]. A fogyasztó hátrányára eltérő kikötések semmisek, és helyükbe a rendelet szabályai lépnek [1. § (2) bekezdés]. A jogszabály rendelkezései szinte teljes egészében a megelőző 117/1991. Kormányrendelet szabályozását tükrözik. ${ }^{1756}$

\footnotetext{
${ }^{1753}$ Ez fogyasztói adásvétel esetén természetesen tovább konkretizálható a fogyasztó törvényen alapuló kellékszavatossági igényeire utalással. Az Irányelv egyébként úgy fogalmaz, hogy „, a jótállásnak utalnia kell arra, hogy a fogyasztót a fogyasztási cikkek adásvételét szabályozó hatályos nemzeti jog szerint törvényen alapuló jogok illetik meg, és nyilvánvalóvá kell tennie, hogy ezeket a jogokat a jótállás nem érinti”, lásd: 6. cikk (2) bekezdés.

Jó minta lenne a szabályozás módosítására az osztrák fogyasztóvédelmi törvény rendelkezése e körben, lásd: $\mathrm{KSchG} \S 9 \mathrm{~b}(1)$; II. rész 2. fejezet 7.5.2. pont.

${ }^{1754}$ A továbbiakban: 151/2003. Korm. rend.

1755 A kormányrendelet melléklete 2005. június 1-jei hatállyal tartalmazza azt a 25 termékkategóriát, amelyekre kiterjed a hatálya.

1756 Lásd ezen kívül az egyes javító-karbantartó szolgáltatásokra vonatkozó kötelező jótállásról szóló 249/2004. (VIII. 27.) Kormányrendelet szabályait.
} 
A Ptk. szerinti fogyasztói szerződés hatálya alá eső, de a 151/2003. Korm. rend. szerinti tartós fogyasztási cikknek nem minősülő szerződés esetén tehát a fogyasztóval szerződő félen múlik, hogy vállal-e jótállást, a kormányrendelet alá tartozó adásvételi szerződések ${ }^{1757}$ esetén viszont kötelező jótállást vállalnia. Az előbbi esetben a fogyasztó kérésére, kötelező jótállás esetében pedig külön kérés nélkül is át kell adnia írásbeli vagy más maradandó formában a jótállási nyilatkozatát. ${ }^{1758}$ A nyilatkozatnak azonban mindkét esetben meg kell felelnie a jogszabályi tartalmi követelményeknek. Ehhez nyújt segítséget az a minta, amit a Nemzeti Fogyasztóvédelmi Hatóság 2012-ben készített el. ${ }^{1759}$ A minta megalkotásának a célja az volt, hogy a forgalmazók (akik a terméket a fogyasztó részére közvetlenül értékesítik) ${ }^{1760}$ rendelkezésére álljon egy olyan dokumentum, amelyet valamennyi, a Kormányrendelet alapján kötelező jótállás alá eső termék értékesítése esetében használhatnak, alkalmazása azonban nem kötelező, csupán útmutatóul szolgál. ${ }^{1761}$

\subsection{Igényérvényesítési határidők - bizonyitási teher}

A hibás teljesítésből eredő igények érvényesítésével kapcsolatos első releváns kérdés az, hogy melyik az az időpont, amikor a teljesítés már hibásnak minősül. A Ptk. 305. § (1) bekezdése alapján a dolognak a teljesítés időpontjában kell megfelelnie a szerződésnek és a jogszabályi előírásoknak. A teljesítés időpontja a „bolti vétel” esetén általában egybeesik a szerződéskötés időpontjával: a teljesítés az átadással és a vételár egyidejü kifizetésével azonnal végbemegy (készvétel). A Ptk. kötelmi általános szabályai szerint, ha a dolgot a kötelezett lakóhelyétől/székhelyétöl különböző helyre kell küldeni (ún. helyközi teljesítés ${ }^{1762}$ ), akkor fogyasztói szerződés esetén az előbbivel egyezően szintén mindig az átadással valósul meg a teljesítés [278. § (2) bekezdés]. E szabály a kárveszélyviselés és a hibás teljesítés tekintetében is előnyt jelent a fogyasztónak. ${ }^{1763}$

\footnotetext{
1757 A 151/2003. Korm. rend. csupán utaló szabályt tartalmaz a Ptk. fogyasztói szerződésre vonatkozó rendelkezésre, azonban hatályát illetően az „étékesítés” szóból véleményem szerint a fogyasztói adásvételi szerződésre kell következtetni.

${ }^{1758}$ Vö.: Ptk. 248. § (3) bekezdés és 151/2003. Korm. rend. 3. § (1) bekezdés. Az utóbbi az alakiságok tekintetében nem tartalmaz elöírást.

${ }^{1759}$ A jótállási minta elérhető:

http://www.nfh.hu/magyar/hasznos/szavatossag/szav_letoltheto/letolt_jotallasijegy.html (2013. december 8.). ${ }^{1760}$ Lásd: 151/2003. Korm. rend. 1. § (3) bekezdés.

1761 Lásd: Általános információk a jótállási jegy minta alkalmazásával kapcsolatban: http://www.nfh.hu/data/cms74914/minta jotallasi_jegy.pdf (2013. október 16.).

${ }^{1762}$ Lásd: TÖRÖK (2006), 530. p.

1763 Vö. Ptk. 279. § (2) bekezdés: „A teljesitéssel a kárveszély - ha a törvény kivételt nem tesz - a másik szerzödö félre száll át.".
} 
A hibával kapcsolatos kifogását a jogosultnak általában ,a hiba felfedezése után a körülmények által lehetővé tett legrövidebb időn belül” kell bejelentenie [Ptk. 307. § (1) bekezdés]. A fogyasztó számára azonban könnyítést jelent a törvény kógens rendelkezése, miszerint ö „, a hiba felfedezésétöl számitott két hónapon belül” bármikor megteheti a bejelentést [307. $§(2)$ bekezdés]. A kifogás közlésére nem ír elő speciális formai követelményeket a törvény, ezért az szóban és írásban is megtehetö, de nyilvánvalóan megkönnyíti a bizonyítást az írásbeli forma. ${ }^{1764}$ A Ptk. előírása nem jelenti azonban a hibás teljesítés miatti esetleges perindítás előfeltételét: a joggyakorlat szerint a kifogásközléssel egyenértékủ az, ha a benyújtott keresetlevelet a kötelezettnek kézbesítik. ${ }^{1765}$ Ezen kívül a késedelmes közlésnek sincs jogvesztő hatálya, csupán azt eredményezi, hogy a jogosult köteles a kötelezettnek ebböl a késedelemböl eredő kárát megtéríteni [Ptk. 307. § (3) bekezdés].

A hiba leggyakrabban csak a teljesítést követően ütközik ki, de ha az már a teljesítéskor „lappangott”, akkor is helytállással tartozik az eladó. ${ }^{1766}$ Ilyen esetben a hibásság megdönthető vélelmének kógens szabálya érvényesül a fogyasztói szerződés esetén:

„... az ellenkezö bizonyitásáig vélelmezni kell, hogy a teljesitést követö hat hónapon belül felismert hiba már a teljesités idöpontjában megvolt, kivéve, ha e vélelem a dolog természetével vagy a hiba jellegével összeegyeztethetetlen. A felek ettöl eltérö megállapodása semmis.

Ennek a szabálynak a legfontosabb következménye a bizonyítási tehernek a fogyasztó számára kedvező megfordulása, amely őt a jótállás jogosultjáéval azonos helyzetbe hozza. ${ }^{1768}$ A Szegedi ÍT álláspontja szerint - e hasonlóság miatt is - a jogosultnak a bizonyítási teher alóli mentesüléshez a hat hónapon belül közölnie kell a felismert hibát és a szavatossági kifogását. ${ }^{1769}$ Eltérő álláspontot képvisel ebben a kérdésben Wellmann György, aki szerint a hat hónapos határidő csupán a hiba felismerésére vonatkozik, és a vélelem nem követeli meg, hogy a kifogásközlés is megtörténjen a határidőn belül. ${ }^{1770} \mathrm{Az}$ utóbbi álláspont a törvény szövegezéséböl kiindulva helytállónak tünhet, én mégis a Szegedi ÍT álláspontját osztom, ugyanis ha a jogosult nem jelentené be kifogását a hat

\footnotetext{
${ }^{1764}$ A Ptk. 199. § és 216. § (1) bekezdése alkalmazandóak, lásd: TÖRÖK (2006), 646. p.

${ }^{1765}$ Lásd: TÖRÖK (2006), 646. p.

1766 BÍRÓ (2010), 429. p.

${ }^{1767}$ Lásd: Ptk. 305/A. $§(2)$ bekezdés.

1768 TÖRÖK (2006), 633. p.; Szegedi ÍT 1/2004. 6. p.

${ }^{1769}$ Szegedi ÍT 1/2004. 7. p.

${ }^{1770}$ Lásd: WELLMANN (2004), 12. p.
} 
hónapon belül, akkor méltánytalan bizonyítási teher hárulna a kötelezettre. A Szegedi ÍT értelmezését követve így a vélelem maximum a teljesítést követő nyolc hónapban „védi” a fogyasztót: a hibának a teljesítést követő hat hónapon belül kell jelentkeznie, és a fogyasztónak ettől számított két hónapon belül kell megtennie az azzal kapcsolatos kifogását. ${ }^{1771}$

\subsubsection{Szavatossági határidők}

Az igényérvényesítési határidők speciális, komplex rendszere, elévülési és jogvesztő határidők találhatóak a Ptk.-ban, amelyek gyakran nem csak a jogkereső magánszemélyek, de a jogalkalmazók dolgát is megnehezítik. Ezen nem segít az a gyakorlat sem, amely különösen a ruházati üzletekben jellemző, hogy az eladó a fizetéskor azt a tájékoztatást adja, hogy hat hónapos szavatosság áll fenn az áru esetleges hibáiért. A kellékszavatossági határidőkről így rendelkezik a Ptk.:

„Fogyasztói szerzödés esetében a fogyasztó [...] a teljesités időpontjától számitott kétéves elévülési határidö alatt érvényesitheti szavatossági igényét. Az ennél rövidebb elévülési határidőt megállapitó kikötés semmis. Ha a fogyasztói szerzödés tárgya használt dolog, a felek rövidebb határidöben is megállapodhatnak, egy évnél rövidebb elévülési határidö azonban ebben az esetben sem köthetö ki. "1772

A teljesítés időpontjától számítandó két éves határidő tehát elévülési jellegü, ami azt jelenti, hogy vonatkoznak rá az elévülés nyugvásának és félbeszakadásának általános szabályai. ${ }^{1773}$ Ezek szerint a teljesítésére irányuló írásbeli felszólítás, a követelés bírósági úton való érvényesítése vagy megegyezéssel való módosítása, és a tartozásnak a kötelezett részéről való elismerése esetén a határidő félbeszakad, és újra kezdődik [Ptk. 327. (1) bekezdés]. Ezen kívül „, a szavatossági jog érvényesithetőségének határideje a dolognak vagy jelentösebb részének kicserélése (kijavitása) esetén a kicserélt (kijavitott) dologra (dologrészre), valamint a kijavitás következményeként jelentkezö hiba tekintetében újból kezdödik", 1774

Az elévülés nyugvására az alábbi általános szabály irányadó:

„Ha a követelést a jogosult menthető okból nem tudja érvényesiteni, az akadály megszünésétöl számított egy éven belül [...] a követelés akkor is érvényesithetö, ha

\footnotetext{
${ }^{1771}$ Vö.: Ptk. 305/A. § (2) bekezdés és 307. § (2) bekezdés. Ezt az álláspontot képviseli a Pécsi ÍT 2011.EL.II.C.25., 26. p. is.

${ }^{1772}$ Lásd: Ptk. 308. § (4) bekezdés.

${ }^{1773}$ Lásd: Ptk. 326-327. §§.

${ }^{1774}$ Lásd: Ptk. 308. § (3) bekezdés.
} 
az elévülési idö már eltelt, vagy abból egy évnél, illetöleg három hónapnál kevesebb van hátra..."1775

Ez tehát azt jelenti, hogy ha a fogyasztó a szavatossági jogait azért nem tudja korábban érvényesíteni, mert például a hiba a teljesítéstől számított két év után ütközik csak ki, akkor az igényeit a hiba felmerülésétől számított egy éven belül még minden esetben érvényesítheti. ${ }^{1776}$ Természetesen ilyenkor már öt terheli a bizonyítás kötelezettsége, hogy a hiba már a teljesítéskor megvolt a dologban, mert a hibásság vélelme csak a teljesítés utáni hat hónapon belül áll fenn.

A kijavítás szavatossági jogának elévülési határidejébe a korábbi szabállyal egyezően továbbra sem számít bele „, a kijavitási időnek az a része, amely alatt a jogosult a dolgot nem tudja rendeltetésszerüen használni,", ${ }^{177}$ azaz az elévülés nyugszik.

A fogyasztók javára érvényesülő klaudikálóan kógens szabály értelmében, ha a fogyasztói adásvétel tárgya állat, akkor nem érvényesül az a speciális szabály sem, miszerint az állatszavatossági igények érvényesítési határideje 60 nap [Ptk. 308. § (2) bekezdés]. Azaz ha például egy fogyasztó saját használatra lovat vásárol egy állattenyésztéssel és értékesítéssel üzletszerűen foglalkozó személytől, akkor ő mindenféle állat-, illetve ló-specifikus hiba (betegség) esetén is a teljesítéstől számított két éven belül érvényesítheti a szavatossági igényeit. Kérdésként merül fel, hogy egy állat mikor minősül használt dolognak, azaz mikor köthető ki a rövidebb, de minimum egy éves határidő. Iránymutatásul szolgálhat a német bírói gyakorlat, amely szerint nem tekinthető használtnak egy állat nyomban a születése után, és mindig egyedileg vizsgálandó ez a kérdés. ${ }^{1778}$

A jogvesztő határidőkről a Ptk. az alábbi módon rendelkezik:

„Ha a jogosult igényét menthetö okból nem tudja érvényesiteni, igy különösen, ha a hiba a jellegénél vagy a dolog természeténél fogva a 308. \$-ban meghatározott határidőn belül nem volt felismerhetö, a szavatossági jogok érvényesitésének határideje a teljesités idôpontjától számított egy év, tartós használatra rendelt dolog esetében három év. Ha a kötelezö alkalmassági idö három évnél hosszabb, az igény érvényesitésére ez a határidö az irányadó. E határidők elmulasztása jogvesztéssel jár.

Fogyasztói szerzödésben az (1) bekezdésben megállapitott hároméves határidönél rövidebb határidö kikötése semmis. ",1779

\footnotetext{
1775 Ptk. 326. $\S(2)$ bekezdés.

${ }^{1776}$ BÁRTFAI (2004), 30. p.

${ }^{1777}$ Lásd: Ptk. 308. § (3) bekezdés.

${ }^{1778}$ Lásd: a lovak adásvételével kapcsolatos OLG Braunschweig 20.02.2006, 3U 42/05. és OLG Oldenburg 9 O 2979/05, 2006. számú ítéletek; II. rész 2. fejezet 3.1. pont.

${ }^{1779}$ Lásd: Ptk. 308/A. § (1)-(2) bekezdés.
} 
Ez a rendelkezés a korábbi szabályozásban is szerepelt. Új az a fogyasztói adásvétel esetén kógens rendelkezés, amely alapján a teljesítéstől számított egy éves, míg tartós használatra rendelt dolgok adásvétele esetén 3 éves jogvesztő határidő érvényesül, ha pedig a kötelező alkalmassági idő 3 évnél is hosszabb, akkor ez a határidő minősül jogvesztő határidőnek az igényérvényesítés tekintetében.

A Ptk. megfogalmazása a fogyasztói szerződések esetén nem egyértelmü: a nem tartós használatra rendelt dolgok esetén irányadó egy éves jogvesztő határidő irrelevánsnak tünik fogyasztói szerződés esetén, hiszen azoknál az elévülési idő eleve két év. Bártfai Judit két lehetséges jogértelmezést vázol fel e tekintetben: az egyik szerint fogyasztói szerződések esetén a két éves elévülési határidő egyben jogvesztő határidőnek is tekintendő. ${ }^{1780} \mathrm{Ha}$ nem így lenne, akkor előfordulhatna, hogy a nem tartós használatra rendelt dolgok vevője a tartós használatra rendelt dolgokkal kapcsolatos szavatossági igények érvényesítési határidejénél hosszabb ideig érvényesíthetné kellékszavatossági jogait. ${ }^{1781}$ A másik lehetséges értelmezés szerint a fogyasztói ügyletek esetén az egy éves jogvesztő határidő kizárja az elévülés nyugvásának általános szabályát kellékszavatossági igényérvényesítés esetén. ${ }^{1782}$ A Szegedi Ítélőtábla egy harmadik - általam is képviselt álláspontot vázolt fel. ${ }^{1783}$ Úgy véli, hogy mivel a jogvesztő határidő általános célja az, hogy megadja az elévülés nyugvásának illetve félbeszakadásának a végső határidejét, ezért fogalmilag kizárt az elévülési idővel azonos tartamú jogvesztő határidő. Álláspontja szerint a jogalkotó feltehető akarata az volt, hogy az egyébként csak tartós használatra rendelt dolgok esetén érvényesülő három éves jogvesztő határidő fogyasztói szerződéseknél általános jogvesztő határidő legyen. ${ }^{1784}$

Tartós használatra rendelt dolgok esetén a jogvesztő igényérvényesítési határidő fogyasztói adásvétel esetén egyértelmüen a teljesítéstől számított 3 év, ennél rövidebb nem köthető ki a szerződésben. Következetlen azonban a fenti rendelkezés, mert nem adja meg a „tartós használat” fogalmát, így problémát jelent a gyakorlatban, hogy melyek tartoznak a tartós használatra rendelt dolgok közé. Emiatt az nyilvánvalóan mindig egyedi elbírálás tárgya, és megítélésénél az áru értékének figyelembe vétele mellett az általános

\footnotetext{
${ }^{1780}$ BÁRTFAI (2004), 30. p.

${ }^{1781}$ BÁRTFAI (2004), 30. p.

1782 BÁRTFAI (2004), 30. p.

${ }^{1783}$ Lásd: Szegedi ÍT 1/2004. 3. pont indokolása.

${ }^{1784}$ Lásd: Szegedi ÍT 1/2004. 3. pont indokolása. Ugyanígy: FAZEKAS (2007), 126. p.
} 
fogyasztási, használati szokások lehetnek mérvadóak. ${ }^{1785}$ A fogyasztási cikkek tekintetében irányadó az 151/2003. Kormányrendelet, mivel azonban ez a jogszabály sem adja meg a tartós használatra rendeltség kritériumát illetve fogalmát, a mellékletében szereplő egyes konkrét új fogyasztási cikkek tekinthetőek csak jogszabályi alapon tartós használatra rendelt dolgoknak. A másik irányadó jogszabály, az egyes épületszerkezetek és azok létrehozásánál felhasználásra kerülő termékek kötelező alkalmassági idejéről szóló rendelet $^{1786}$ a „fogyasztói adásvételek” esetén nem annyira releváns, konkrétan úgy rendelkezik azonban, hogy a hatálya alá tartozó dolgok tartós használatra rendeltek (2. §). A mellékletében szereplő dolgok esetén 5 illetve 10 éves kötelező alkalmassági időt ír elö. ${ }^{1787}$

A Ptk. lehetővé teszi a jogosultnak az egyik választott szavatossági jogról a másikra való áttérést (306/A. §). Ennek eljárásjogi kérdéseit is tárgyalta a Kúria, és megállapította, hogy a jogosult a bírósági perben azokban a határidőkben és feltételek mellett térhet át egyik választott szavatossági jogról a másikra, amelyeket a Polgári Perrendtartás a keresetváltozatás esetén elöír. ${ }^{1788} \mathrm{Ha}$ azonban az áttérést az időközben bekövetkezett objektív körülmények vagy a kötelezett magatartása tette indokolttá, akkor az nem minősül keresetváltoztatásnak, azaz a jogosult szabadon áttérhet egy másik szavatossági jogra. ${ }^{1789}$

\subsubsection{A hibás teljesítés miatti kártérítés érvényesítésének határideje}

A Ptk. 310. §alapján a hibás teljesítés miatti szubjektív jogalapú kártérítés a szavatossági jogokkal ellentétben az általános elévülési időn, azaz a kár bekövetkezésétől számított öt éven belül érvényesíthető. ${ }^{1790}$ Erre is irányadóak ennek megfelelően az elévülés nyugvásának és félbeszakadásának általános szabályai.

Az igényérvényesítés kapcsán az a jogértelmezési kérdés merült fel a gyakorlatban, ha a határidők nem egyeznek, a hibásság hat hónapos vélelme akkor is alkalmazható-e; és ezáltal a fordított bizonyítási teher érvényesül-e a teljesítéstől számított hat hónapon belül felmerülő hibás teljesítés miatti kártérítési igény esetén. A Szegedi Ítélőtábla a kérdésre

\footnotetext{
${ }^{1785}$ CSÉCSY (2010), 83. p.

${ }^{1786}$ Az egyes épületszerkezetek és azok létrehozásánál felhasználásra kerülő termékek kötelező alkalmassági idejéről szóló 11/1985. (VI. 22.) ÉVM-IpM-KM-MÉM-BkM együttes rendelet.

${ }^{1787}$ Hatálya kiterjed például a nyílászárókra, a csapadékvíz-elvezető szerkezetekre, stb.

1788 1/2012. PK 5. pont indokolása. Vö. Polgári Perrendtartás (a továbbiakban: Pp.) 146. § (1) bekezdés és 146/A. § (1), (3)-(4) bekezdések.

${ }^{1789}$ Vö. Pp. 146. § (5) bekezdés b. pont; 1/2012. PK 5. pont indokolása.

${ }^{1790}$ Lásd: Ptk. 324. § (1) bekezdés és 326. § (1) bekezdés. TÖRÖK (2006), 669. p.; GELLÉRT (2007), 1121. p.
} 
igenlő választ adott. ${ }^{1791}$ Ezen álláspontját azzal indokolta, hogy ellentmondás állna fenn, ha ugyanazon hibás dolog tekintetében a szavatossági jogok esetén a teljesítéstől számított hat hónapon belül a kötelezettre hárulna a bizonyítás, kártérítés esetén viszont a jogosult viselné a bizonyítás terhét a hiba fennállására vonatkozóan. ${ }^{1792} \mathrm{Ez}$ azt eredményezné, hogy a teljesítést követő hat hónapon belül ugyanazon dologra vonatkozóan egyszerre kellene megállapítani a hibás teljesítés tényét a szavatossági jogok tekintetében, és annak hiányát a kártérítés vonatkozásában. ${ }^{1793}$ A Debreceni Ítélőtábla kollégiumi anyaga arról nyújt tájékoztatást, hogy a hibásság vélelmének hibás teljesítés miatti kártérítés esetén való alkalmazása tekintetében a bírói gyakorlat nem mutat egységes képet. ${ }^{1794}$ Én egyetértek a Szegedi Ítélőtábla meglátásaival, és úgy vélem, hogy ez a jogértelmezés a Ptk. szövegezéséből is levezethető, hiszen a kódex nem az egyes hibás teljesítésből fakadó igényekkel és azok érvényesítésével, hanem magával a hibás teljesítéssel összefüggésben szól a vélelemről. Ily módon az bármely, a hibás teljesítésből fakadó jogorvoslat esetén alkalmazandó.

\subsubsection{Jótállási határidó}

A jótállás határidejének magában a jótállást keletkeztető nyilatkozatban illetve szerződésben kell szerepelnie, a jótállási igények érvényesítésére tehát az a határidő lesz irányadó. A jótállási határidő a jogtudomány álláspontja szerint azonban voltaképpen nem igényérvényesítési határidőt jelent, hanem a jogintézmény céljának megfelelően azt jelzi, hogy a kötelezettet mely határidő alatt felmerülő hibákra nézve terheli a helytállási kötelezettség. ${ }^{1795}$ Ebből mindenekelőtt az a következtetés vonható le, hogy nem alkalmazhatóak rá az elévülés nyugvásának és félbeszakadásának szabályai, így inkább jogvesztő jellegünek tekinthető. ${ }^{1796}$ Speciális jellegét mutatja azonban az a jogalkotói szándék, ami a jótállási igények gyakorlására a szavatossági jogok gyakorlásának szabályait rendelte megfelelően alkalmazni [Ptk. 248. § (5) bekezdés]. Ez a gyakorlatban azt jelenti, hogy a határidő a kvázi jogvesztő jellege ellenére is meghosszabbodik a jótállás alapján érvényesített kijavítás idejének azon részével, amely alatt a fogyasztó a dolgot nem

\footnotetext{
${ }^{1791}$ Lásd: Szegedi ÍT 1/2004. 2. pont indokolása.

1792 Lásd: Szegedi ÍT 1/2004. 2. pont indokolása.

1793 Lásd: Szegedi ÍT 1/2004. 2. pont indokolása.

${ }^{1794}$ Lásd: Debreceni ÍT 2010.El.II.C.54/5., 24. p.

1795 Lásd: Pécsi ÍT 2011.EL.II.C.25., 50. p.

${ }^{1796}$ Pécsi ÍT 2011.EL.II.C.25., 50. p.; VÉKÁS (2000), 656. p.
} 
tudta rendeltetésszerüen használni; illetve kicserélés esetén a határidő félbe is szakad; valamint a jogosult kifogásként is érvényesítheti jótállási igényeit. ${ }^{1797}$

A jótállás kellékszavatosságnál szigorúbb jellege megmutatkozik a joggyakorlatnak abban az álláspontjában, hogy a kötelezett „kimentésére” vonatkozó szabályból fakadóan a határidő teljes tartama alatt az általánossal ellentétes bizonyítási teher, vagyis a hibásság vélelme érvényesül. ${ }^{1798}$

A fentiek alapján el kell különíteni a jótállási igények bírósági érvényesíthetőségének a határidejét. A 2002-es módosítás miniszteri indokolása szerint a kifogás közlésének eredménytelensége esetén az általános elévülési időn belül fordulhat bírósághoz a jogosult. ${ }^{1799}$ A bírósági igényérvényesítés azonban más esetben is felmerülhet: vizsgálandó az eredményes kifogásközlés (esetleges egyezség), az eredménytelen kifogásközlés és a kifogásközlés nélküli bírósági igényérvényesítés esetköre is.

Az utolsó eset ellenkező rendelkezés hiányában lehetséges, hiszen a Ptk. csak annyit rendel el, hogy „, a jogosult a jótállási határidő alatt bármikor közölheti kifogását a kötelezettel”. ${ }^{1800}$ Ha a jogosult közvetlenül a bírósági igényérvényesítés mellett dönt, akkor a jótállási határidőn belül bármikor bírósághoz fordulhat. ${ }^{1801}$ A jogirodalom szerint a határidőn belül benyújtott illetve az azon belül a kötelezettnek kézbesített keresetlevél kellő időben érvényesített jótállási igénynek tekintendő. ${ }^{1802}$

Azzal az esettel kapcsolatban, ha a jogosult a kifogását eredménytelenül közli a kötelezettel, azaz a kötelezett nem reagál arra, a Kúria egyik régebbi, precedensértékü határozatát hívja fel a jogtudomány. ${ }^{1803}$ Ebben az ügyben a Kúria úgy döntött, hogy a szavatosság és a jótállás jogintézményi hasonlóságaiból fakadóan a jótállási határidő alatt megtett kifogás esetén a jótállási jogok a határidő alatt bármikor érvényesíthetőek, annak letelte után azonban legkésőbb három hónapon belül érvényesíteni kell a követelést bírói úton, az azon túl beérkező kereset elkésettnek tekintendő.

Amennyiben a jogosult kifogását a jótállási időn belül eredményesen közölte a jótállás kötelezettjével, azaz a kötelezett vállalta az igény érvényesítését, de az mégis

\footnotetext{
${ }^{1797}$ Erre utalt a 2002. évi XXXVI. törvény 2. § miniszteri indokolása is.

${ }^{1798}$ Lásd: Szegedi ÍT 1/2004. 2. pont és indokolása.

${ }^{1799}$ Lásd: Pécsi ÍT 2011.EL.II.C.25., 50. p.

${ }^{1800}$ Ptk. 248. § (4) bekezdés.

${ }^{1801}$ Lásd: GELLÉRT (2007), 937. p.

1802 Lásd: GELLÉRT (2007), 937. p.

${ }^{1803}$ Lásd: P. törv. III. 20 277/1989., BH 1989.6. 228.; GELLÉRT (2007), 938. p.
} 
eredménytelen maradt, a jogosult az általános elévülési időn belül élhet a bírósági igényérvényesítés lehetőségével. ${ }^{1804}$

Üdvözlendő, hogy kikerült a Ptk. szabályozásából az a rendelkezés, amely a kötelező jótállás tartama alatt felmerülő kellékszavatossági igények rendezését a jótállásra vonatkozó szabályok szerint rendelte intézni. ${ }^{1805}$ A szabályozás és a joggyakorlat szerint így nincs akadálya annak, hogy a jótállási határidő alatt felmerülő hibával kapcsolatos igényeit a fogyasztó nem jótállási, hanem kellékszavatossági vagy kártérítési alapon érvényesítse. $^{1806}$

A fogyasztói szerződés keretében érvényesített szavatossági és jótállási igények speciális szabályait rendezi 4/1978. BkM rendeletet felváltó 49/2003. (VII. 30.) GKM rendelet. ${ }^{1807}$ A jogszabály klaudikálóan kógens rendelkezései a szavatossági vagy jótállási igényként közvetlenül a fogyasztási cikk eladójával (forgalmazójával) szemben érvényesített kicserélés és kijavítás intézéséről szólnak. A fogyasztó e jogait a vásárlás tényéről szóló bizonylat felmutatásával tudja érvényesíteni. ${ }^{1808}$ A rendelet szabályozza a fogyasztói kifogásról minden esetben kötelezően felveendő jegyzőkönyv tartalmi elemeit [3. § (1) bekezdés]. Az igényérvényesítés módját rendező (a korábbi rendeletnél véleményem szerint enyhébb) szabálya szerint a "forgalmazónak törekednie kell arra, hogy a kijavitást vagy kicserélést legfeljebb tizenöt napon belül elvégezze". ${ }^{1809}$ A forgalmazónak amellett, hogy a fogyasztó kifogásáról felvett jegyzőkönyv egy másolatát a fogyasztónak át kell adnia, tájékoztatnia kell őt arról is, hogy a kijavítást vagy kicserélést a termék tulajdonságaira és a fogyasztó által elvárható rendeltetésére figyelemmel megfelelő határidőn belül, és a neki okozott jelentős kényelmetlenség nélkül kell elvégeznie. ${ }^{1810}$ Úgy vélem, hogy mivel e tájékoztatásra vonatkozóan semmilyen alakiságot nem ír elö a jogszabály, így annak kikényszeríthetősége lehetetlen. A fogyasztó viszont a hosszadalmas igényérvényesítés miatt érdeksérelmet szenvedhet. Ezt valamelyest kompenzálhatja az a rendelkezés, amely szerint a javításra átvett dologról elismervényt kell

\footnotetext{
${ }^{1804}$ Lásd: GELLÉRT (2007), 938. p.; Pécsi Ítélőtábla BDT 2006.1302. számú, és a Szegedi Ítélőtábla BDT 2009.2088. számú döntései.

${ }^{1805}$ A korábbi szabályozás elvetését javasolta e vonatkozásban Vékás az implementáció során, lásd: VÉKÁS (2000), 655. p.

${ }^{1806}$ Lásd: 1/2012. PK 15. pont indokolása.

${ }^{1807}$ A továbbiakban: 49/2003. GKM rend.

1808 49/2003. GKM rend. 2. §.

1809 49/2003. GKM rend. 4. § (2) bekezdés. Vö. 4/1978. BkM rend. 5. § (1) bekezdés: „A hibás áru kijavitását legkésőbb a hiba bejelentésétől számitott 8 napon belül el kell végezni”. Erre BÁRTFAI (2004), 39. p. is utal.

${ }^{1810}$ Lásd: 49/2003. GKM rend. 3. § (3) bekezdés és 4. § (1) bekezdés. Vö. Ptk. 306. § (2) bekezdés.
} 
adni, amelynek többek között tartalmaznia kell azt az időpontot, amikor a fogyasztó a kijavított terméket átveheti (5. §).

Nem rendezi a rendelet az üzleti gyakorlatban gyakran előforduló cserekészülék kérdéseit sem, ${ }^{1811}$ amely gyakori például a mobiltelefon-adásvétel hibás teljesítésének orvoslása esetén. Személyes tapasztalataim szerint a mobilszolgáltatóknál kötött adásvételi szerződések kellékhibás teljesítésére (például a megvásárolt telefon szoftverhibájára) vonatkozó kifogás esetén a vevőnek automatikusan a telefon kijavítását ajánlják fel. Ezt az igényt azonban gyakran nem is a mintaboltban, hanem az adott telefon márkaszervizében foganatosítják. Ez máris kellemetlenséget okozhat a vevőnek, hiszen egyik helyröl a másikra kell járnia, ami időt vesz igénybe. A másik probléma az, hogy a kijavítás ideje alatt nem tudja használni a telefont, ami adott esetben a vevő fontos munkaeszköze is lehet. Ezt orvosolandó teszi lehetővé gyakran a szolgáltató, hogy a kijavítás idejére a vevő cserekészüléket kapjon. Az ilyen szerződés gyakorlatilag haszonkölcsön, mert a szolgáltató ingyenesen biztosítja a cserekészülék használatát, ilyenkor is felelős azonban a rendeltetésellenes vagy szerződésellenes használatból eredő kárért a vevő. A cserekészülékkel kapcsolatos másik kellemetlenség, hogy bár az a telefonálás céljaira alkalmas, de gyakran a kijavítandónál régebbi típusú, így nem alkalmas azon többletfunkciók ellátására, amelyek miatt az adásvétel tárgyát képező (hibás) telefont a vevő megvette. ${ }^{1812}$

A 49/2003. GKM rendelet szerint, ha a forgalmazó a kifogás bejelentésekor nem tud nyilatkozni a kért igény teljesítéséről, akkor azt legkésőbb 3 munkanapon belül meg kell tennie [3. § (3) bekezdés]. Lehetősége van azonban arra, hogy a kívánt igénytől eltérjen, de az eltérést meg kell indokolnia [3. § (4) bekezdés].

Az Országos Fogyasztóvédelmi Egyesület készített egy, a fogyasztói minőségi kifogásról szóló jegyzőkönyv-mintát, amely a rendelet elvárásait maradéktalanul tükrözi, és a kereskedőknek segítségül szolgálhat. ${ }^{1813}$

\footnotetext{
${ }^{1811}$ A 117/1991. Korm. rend. 3. § rendezte a kérdést, lásd: I. rész 4. fejezet 6.4. pont.

1812 Összehasonlításképp vö. a Telenor, a T-mobil és a Vodafone interneten elérhető tájékoztatását a szavatosságot, különösen a kijavítást, valamint a jótállást illetően: http://www.telenor.hu/ugyfelszolgalat/technikai/keszulekek, http://www.t-mobile.hu/lakossagi/ugyintezes/vasarlasi_utmutato/hasznos tudnivalok/garancia, https://segithetunk.vodafone.hu/system/selfservice.controller?CONFIGURATION=1000\&PARTITION_ID= 1\&USERTYPE $=1 \&$ LANGUAGE=hu\&COUNTRY $=$ hu\&CMD=BROWSE TOPIC\&requestedPage=SERVI CE\&TOPIC_ID=58854\&LEFT_NAV_ID=0\&MODE=NONJS (2013. október 21.).

1813 Lásd: http://www.ofe.hu/inet/ofe/hu/menu/ujjogi/mintalev/mint07/object/jegyzokonyv.pdf (2013. december 9.).
} 


\subsection{Elhatárolási kérdések}

A joggyakorlatban a mennyiségi hiba és a más dolog, azaz aliud szolgáltatásának kérdése vitára adott okot. Abban az esetben, ha az eladó mást szolgáltat, mint amit a szerződés alapján szolgáltatnia kellett volna, akkor aliud szolgáltatásról van szó. Egyedi szolgáltatás esetén az aliud nyilvánvalóan fennáll, ha más dolgot szolgáltat az eladó, ezért az ilyen esetben jogi értelemben nem is történik teljesítés. A kérdés megítélése a helyettesíthető dolgoknál illetve fajlagos vétel esetén problematikusabb. Az aliud szolgáltatás problémája így mindig esetenként megítélendő kérdés, és azt kell mérlegelni, hogy mennyiségben, minőségben és fajtában nyilvánul-e meg a teljesítés hibája, és hogy mennyiben elégíti ki a dolog a szerződés eredeti célját, azaz rendeltetésszerüen használható-e. ${ }^{1814}$ Ha még a fajta sem egyezik, akkor az az esetek többségében nemteljesítést jelent. ${ }^{1815}$

A mennyiségi hiba esetén releváns kérdés az, hogy a dolog osztható szolgáltatásnak minősül-e. Ha igen, akkor a mennyiségi hiba (a kevesebb mennyiség) a Ptk. 317. § értelmében részteljesítésnek minősül: ${ }^{1816}$

„(1) Osztható szolgáltatás egy részére vonatkozó szerzödésszegés esetében a szerzödésszegés következményei csak erre a részre következnek be. A jogosult azonban a szerzödésszegésböl eredö jogait az egész szerzödésre nézve gyakorolhatja, ha bizonyitja, hogy a további teljesités a szerzödésszegés következtében már nem áll érdekében.

(2) Ha a szerzödésszegés oszthatatlan szolgáltatás egy részére vonatkozik, következményei az egész szerzödésre beállnak.”.

Ha tehát a szolgáltatás osztható, például a vevő egy asztalt rendelt hat székkel, de egy szék a kiszállításkor hiányzik, akkor a nemteljesítés következményei állnak be, de nyilvánvalóan csak a hiányzó székre vonatkozóan. Ha nem osztható a szolgáltatás, akkor beállnak az egészre nézve a hibás teljesítés jogkövetkezményei. ${ }^{1817}$ Figyelemmel arra, hogy az alkatrész a fődolog részét képezi és osztja annak sorsát, a hibás alkatrész okozta kellékhiba is kihat az egész szolgáltatásra. ${ }^{1818}$

\footnotetext{
${ }^{1814}$ BÍRÓ (2010),

1815 BESENYEI (2012), 161. p. Ez az elhatárolási kérdés a svájci magánjogtudományban is vitatott, lásd: II. rész 2. fejezet 11.3. pont.

${ }^{1816}$ GELLÉRT (2007), 1090. p.

1817 GELLÉRT (2007), 1090. p.

1818 GELLÉRT (2007), 1090. p.
} 


\section{Összefoglalás}

A magyar jogalkotó az osztrák megoldáshoz hasonlóan úgy valósította meg az Irányelv implementációját a Ptk.-ban, hogy a reform a hibás teljesítés átfogó módosításához vezetett. Így számos rendelkezés minden visszterhes szerződésre nézve alkalmazandó, a fogyasztói adásvételre vonatkozó EU-s szabályok pedig - bizonyos kivételekkel - minden ingó dologra vonatkozó fogyasztói szerződésre nézve hatályosak. Míg a szabályozás számos ponton szó szerint tükrözi az Irányelv megoldásait, addig több olyan rendelkezés is szerepel a kódexben, amely a jogtudomány és a bírói gyakorlat értelmezésére szorult. A kutató számára (is) nagy segítséget nyújtanak ezért a téma vizsgálatához a vonatkozó hazai bírói gyakorlatról szóló, a közelmúltban született állásfoglalások és kollégiumi anyagok.

Értelmezési kérdések merültek fel - többek között - azzal kapcsolatban, hogy a jogosultnak a hibát mikor „kell ismernie”; hogyan ítélendő meg a kijavítási költségek követelésének az igénye; az arányosság mércéjét miként kell alkalmazni az igényérvényesítés során; hogyan ítélendő meg a hibás teljesítés miatti kártérítési igény kérdése; milyen tágan értelmezhető a hibásság vélelme; valamint, hogy milyen határidőn belül léphet fel igényével a jótállás jogosultja a bíróság előtt. A fentiek mellett kritika érte a szabályozást az igényérvényesítési határidők bonyolult rendszere miatt, ezen kívül a jótállás rendszerbeli elhelyezése továbbra is vita tárgyát képezte.

Az utolsó fejezet arra hivatott, hogy bemutassa, miként igyekezett a felmerülő jogértelmezési kérdéseket orvosolni a magyar jogalkotó az új Polgári Törvénykönyv megalkotása során. 


\section{AZ ÚJ PTK. RENDELKEZÉSEI A HIBÁS TELJESÍTÉSRŐL - KÜLÖNÖS TEKINTETTEL A FOGYASZTÓ ÉS VÁLLALKOZÁS KÖZÖTTI ADÁSVÉTELRE}

\section{A kodifikációs folyamat}

Az új magyar magánjogi kódex iránti jogalkotási igény már 1989-ben felmerült, de az akkori kezdeményezés és a Harmathy Attila, Vékás Lajos és Sárközy Tamás elnökletével alakult kodifikációs bizottság hamar beszüntette tevékenységét. Az első releváns kormányzati döntés, az 1050/1998. (IV. 24.) Kormányhatározat alapján kezdödött meg ténylegesen a kodifikációs folyamat. ${ }^{1819}$ A koncepció és tematika publikálása után a Szerkesztőbizottság 2006 végén tette hozzáférhetővé az első tervezet és indokolás teljes szövegét. Az ahhoz füződő számos tartalmi véleménykülönbség következtében a kormány döntése alapján a Tervezet elkészítése az Igazságügyi és Rendészeti Minisztérium (IRM) hatáskörébe került. Az IRM munkája mellett azonban a Vékás Lajos professzor által vezetett szerkesztőbizottság nem hivatalos, átdolgozott tervezete is elkészült 2008-ra. Az IRM második normaszöveg-tervezetét a kormány 2008. május 28-án fogadta el, amely alapján az Országgyülés 2009. szeptember 21-én szavazta meg a Polgári Törvénykönyvről szóló 2009. CXX. törvényt, amely végül mégsem lépett hatályba. ${ }^{1820}$

A 1129/2010. (VI. 10.) Kormányhatározat újfent Vékást bízta meg a kodifikációs bizottság elnökletével. Az új Ptk. újabb javaslatát a Polgári Jogi Kodifikációs Főbizottság 2011. december 16-án fogadta el, a végleges törvényszöveget pedig 2013. február 11-én fogadta el az Országgyülés. Az így megszületett 2013. évi V. törvény a Polgári Törvénykönyvről 2014. március 15-én lépett hatályba. ${ }^{1821}$ A hatálybalépésével összefüggő átmeneti és felhatalmazó rendelkezésekről szóló 2013. évi CLXXVII. törvény ${ }^{1822}$ szerint az új Ptk. hatálybalépésekor már fennálló kötelmekkel kapcsolatos, de az új Ptk. hatálybalépését követően keletkezett tényekre és megtett jognyilatkozatok esetén - az e tények, illetve jognyilatkozatok által keletkeztetett újabb kötelmeket is beleértve - az új

\footnotetext{
${ }^{1819}$ A kodifikáció folyamatának ismertetését lásd: SZIKORA (2013), 133-142. p.

1820 Lásd: SZIKORA (2013), 135-138. p. Az Alkotmánybíróság alkotmányellenesnek találta, és megsemmisítette a hatálybalépéséről és végrehajtásáról szóló törvény 1 . § (1) bekezdését és 208 . §-át, lásd: 436/B/2010. AB határozat. A 2009. évi CXX. törvény tervezetének hibás teljesítést érintő szabályaihoz lásd: CSÉCSY (2008), 264-278. p.

${ }^{1821}$ 2013. évi V. törvény a Polgári Törvénykönyvröl, a továbbiakban: új Ptk. Ennek megfelelően e fejezetben az 1959. évi IV. törvényre ,régi Ptk.”-ként hivatkozom. Az új kódexet a Magyar Közlöny 2013. évi 31. számában hirdették ki. Szövege elérhető: http://www.kozlonyok.hu/nkonline/MKPDF/hiteles/MK13031.pdf (2014. április 23.).

1822 2013. évi CLXXVII. törvény a Polgári Törvénykönyvről szóló 2013. évi V. törvény hatálybalépésével összefüggő átmeneti és felhatalmazó rendelkezésekről, a továbbiakban: új Ptké. Elérhető: http://www.complex.hu/kzldat/t1300177.htm/t1300177.htm (2014. március 13.).
} 
Ptk. hatálybalépése előtt hatályos jogszabályok rendelkezéseit kell alkalmazni [új Ptké. 50. $\S$ (1) bekezdés]. A felek természetesen megállapodhatnak abban is, hogy az új Ptk. hatálybalépése előtt kötött szerződésüket teljes egészében az új kódex hatálya alá helyezik [új Ptké. 50. § (2) bekezdés].

\section{Fogyasztóvédelmi magánjog és fogyasztófogalom az új Ptk.-ban}

Már az új Ptk. 2002-es koncepciója is a fogyasztóvédelmi magánjog integrációjára törekedett. ${ }^{1823}$ Ennek megvalósításnál mégis a minimalizmus és szelektivitás érvényesül az új Ptk.-ban, és az Európai Unió fogyasztóvédelmi magánjogának csak a „magja” került integrálásra. ${ }^{1824} \mathrm{Az}$ új Ptk. javaslatának ,általános indokolása” a kódex fogyasztóvédelmi magánjogi célkitüzéseivel kapcsolatban így fogalmaz:

„A fogyasztókat a magánjogi szerződésekben védő jogalkotás az elmúlt negyedszázadban fokozatosan az európai uniós szervek hatáskörébe került. Az egyre intenzívebb fogyasztóvédelmi irányelvalkotás a tagállamok számára csak az irányelvek átültetése keretében biztosít némi önállóságot. Ebben az egyre szükülö tagállami hatáskörben a Javaslat azt a kiindulópontot választotta, hogy a fogyasztóvédelmi szerződési jogból csak az irányelvek maradandó magját építi be tematikusan a kódexbe...". ${ }^{1825}$

A fogyasztóvédelmi irányelvek e magját a tisztességtelen szerződési feltételekről szóló 1993/13/EGK irányelv és a fogyasztói adásvételről szóló 1999/44/EK Irányelv jelenti. ${ }^{1826}$ Az integráció ennek megfelelően háromféle módon valósul meg: az új Ptk. egyrészt átvesz a Ptk.-ban már szereplő intézményeket (többek között a kellékszavatosságot és a jótállást is); másrészt integrálja a Ptk.-ban eddig nem szereplő, de a magyar jogrendszerben már meglévő intézményeket (például a termékfelelösséget és a tisztességtelen szerződési feltételeket); harmadrészt pedig új jogintézményeket épít be a szabályozásba (például a hibás teljesítéshez kapcsolódó termékszavatosságot). ${ }^{1827}$

A régi Ptk. fogyasztó-fogalmával kapcsolatban a legtöbb aggályt az váltotta ki a jogirodalomban és a joggyakorlatban is, hogy amikor nem természetes személyek kötnek

\footnotetext{
${ }^{1823}$ Az 1009/2002. (I. 31.) Kormányhatározat fogadta el. Megjelent: Magyar Közlöny 2002. 15. szám, 2. kötet. 4. p.

${ }^{1824}$ Lásd: Prof. Dr. Fazekas Judit: Az új Ptk. fogyasztóvédelmi aspektusai című előadása (a továbbiakban: Fazekas Judit előadás). Elhangzott: „A magánjog oktatása - tekintettel az Alaptörvényre és az új Ptk-ra” címủ konferencián, 2013. június 14-én Győrött. Lásd továbbá: FAZEKAS (2013), 46-47. p.

${ }^{1825}$ Lásd: T/7971. számú törvényjavaslat a Polgári Törvénykönyvröl (2012. július) és annak általános indokolása, 563. p. A továbbiakban: új Ptk. javaslat. Elérhető:

http://www.parlament.hu/irom39/07971/07971.pdf (2013. december 10.).

${ }^{1826}$ Új Ptk. javaslat, 563. p.

${ }^{1827}$ Lásd: Fazekas Judit előadás, valamint FAZEKAS (2013), 47. p.
} 
szerződést, akkor nehéz megítélni, hogy az ügylet gazdasági, szakmai illetve önálló foglalkozásukon kívüli tevékenyéghez kapcsolódó, vagy azon kívüli célból jön-e létre. ${ }^{1828}$ Vékás több tanulmányában kifejezésre juttatta, hogy a fogyasztóvédelem szerződési szabadságot korlátozó speciális magánjogi szabályozási módszere, a kógencia miatt csak különösen indokolt esetben szabad megadni a többletvédelmet meghatározott jogalanyoknak. ${ }^{1829}$

Az új Ptk. a fogyasztó definícióját a megelőző jogtudományi kritikának és dogmatikai megfontolásoknak megfelelöen részben megújította:

„,fogyasztó a szakmája, önálló foglalkozása vagy üzleti tevékenysége körén kívül eljáró természetes személy", ${ }^{1830}$

Ez a megoldás egyébként összhangban áll az EU-s fogyasztóvédelmi irányelvekben használt fogalmi meghatározásokkal is. ${ }^{1831}$ A fent említett aggályok tehát az új fogalomnak köszönhetően megszünni látszanak.

Osztovits András megfogalmazza azt a kívánalmat, hogy az új Ptké. egyértelmúen rendelkezzen arról, hogy hogyan minősülnek a még a régi Ptk. alapján megkötött, de már az új Ptk. hatályba lépése után teljesedésbe ment, nem természetes személyek által kötött fogyasztói szerződések. ${ }^{1832}$ Az új Ptké. azonban csupán felhatalmazza a jogalkotót, hogy rendeletben rendelkezzen a fogyasztó és vállalkozás közötti szerződések szabályairól [új Ptké. 66. § (1) bekezdés d. pont]. A felhatalmazáson alapuló új jogszabály a 45/2014. Kormányrendelet, amely 2014. június 13 -án lép hatályba. ${ }^{1833}$ A rendelet sem rendezi a fenti kérdést, csupán azt mondja ki, hogy a hatálybalépése után kötött szerződésekre terjed ki a szabályainak hatálya (32. §).

Az új Ptk. már nem alkalmazza a korábbi fogyasztói szerződés kategóriáját, hanem következetesen fogyasztó és vállalkozás közötti szerződésről rendelkezik. ${ }^{1834}$ Ennek

\footnotetext{
${ }^{1828}$ Lásd: OsZTOvits (2013a), 2. p., valamint OsZTOviTs (2013b), 64. p.

${ }^{1829}$ Lásd többek között: VÉKÁs (2008), 757. p. Vékás a Szakértöi Javaslatban kifejtette, hogy a természetes személyeknek is csak meghatározott élethelyzetekben, az adott magánjogi ügylet személyes szükségletek kielégítésére irányuló célja esetén jár a többletvédelem.

${ }^{1830}$ Lásd: új Ptk. 8:1. § (1) bekezdés 3. pont.

${ }^{1831}$ Ezt maga az új Ptk. javaslata is kimondja, 696. p. Az egyetlen kivétel, amely a természetes személyeken kívüli jogalanyokra is kiterjeszti hatályát, az a szervezett utazási formákról szóló 1990/314/EGK tanácsi irányelv. A kollíziót az új Ptk. úgy kerüli el, hogy az utazási szerződés szabályai a fogyasztó fogalma helyett a megrendelő kifejezés alkalmazása által nem redukálják csupán a fogyasztói szerződésekre az utazási szerződés hatályát, lásd: új Ptk. 6:254. §.

${ }_{1832}$ OsZTOVITS (2013a), 3. p., valamint OsZTOVITS (2013b), 67. p.

${ }^{1833}$ Lásd: 45/2014. (II. 26.) Kormányrendelet a fogyasztó és a vállalkozás közötti szerződések részletes szabályairól. A Magyar Közlöny 2014. évi 30. számában (2014. február 26.) került kihirdetésre. Elérhető: http://www.kozlonyok.hu/nkonline/MKPDF/hiteles/MK14030.pdf (2014. március 13.). A jogszabály elsősorban a 2011/83/EU irányelv implementációját valósítja meg (lásd: 33. §).

${ }^{1834}$ FAZEKAS (2013), 45. p. 4. lj.
} 
megfelelően a vállalkozás fogalmát a fogyasztó ellentettjeként határozza meg: , vállalkozás a szakmája, önálló foglalkozása vagy üzleti tevékenysége körében eljáró személy”. ${ }^{1835}$

Ez a fogyasztó és vállalkozás közötti szerződésre vonatkozó jogalkotói megoldás a szerződési jogon belüli fogyasztói és nem fogyasztói szerződésekre tagolást előzi meg, és kifejezi a fogyasztóvédelmi magánjog már említett ún. relációs jellegét. ${ }^{1836}$ Wellmann György úgy véli, hogy a Kúriának a Ptk. szerinti fogyasztói szerződés érvénytelenségéről szóló 2/2011. (XII. 12.) Polgári Kollégiumi véleménye ${ }^{1837}$ az új. Ptk. fogyasztó és vállalkozás közötti szerződéseire megfelelően felhívható. ${ }^{1838}$ Ennek megfelelően a bíróságnak hivatalból kell észlelnie, hogy az előtte folyó ügyben fogyasztó és vállalkozás közötti szerződéses jogviszony áll fenn a felek között, de kétség esetén a fogyasztónak kell ezt bizonyítania. ${ }^{1839}$ Ezzel összefüggésben - Osztovits véleményét osztva - szükségesnek találom annak a kérdésnek az egyértelmü rendezését, hogy a gazdasági, szakmai tevékenység körét hogyan kell értelmezni. ${ }^{1840}$

\section{A hibás teljesítés rendszere - a fogyasztó és vállalkozás között kötött ingó adásvétel hibás teljesítése}

Az új Ptk. a régi Ptk.-val egyezően a kötelmi általános részben helyezte el a hibás teljesítésre vonatkozó rendelkezéseket, köztük az Irányelv előírásait is. Bár az adásvételről szóló szakaszok tartalmaznak néhány speciális, a fogyasztó és a vállalkozás közötti szerződést érintő szabályt, azok nem az Irányelvből fakadnak. ${ }^{1841}$

Az új kódex a szerződésszegés szabályain belül - a régi Ptk.-val ellentétben elsőként a szerződésszegés általános szabályait, majd annak egyes eseteit tárgyalja. ${ }^{1842}$ Elöírja, hogy „, a szolgáltatást a kötelem tartalmának megfelelöen kell teljesíteni”, és ennek megfelelően szerződésszegésnek minősíti „bármely kötelezettség szerződésszerü teljesitésének elmaradását”. ${ }^{1843} \mathrm{Az}$ egyik legfontosabb újítás a szerződésszegés szabályozásában, hogy az új Ptk. alkotói kidolgozták a szerződésszegéssel okozott károk

\footnotetext{
${ }^{1835}$ Lásd: új Ptk. 8:1. § (1) bekezdés 4. pont. OszTOVITS (2013a), 2. p.; Javaslat, 696. p.

${ }^{1836}$ WELLMANN (2013), 155. p.

${ }^{1837}$ A továbbiakban: 2/2011. PK.

${ }^{1838}$ WELLMANN (2013), 155. p.

${ }^{1839}$ Lásd: $2 / 2011$. PK 1. pont.

1840 OsZTOVITS (2013b), 67. p

${ }^{1841}$ Lásd: a kárveszély átszállása (6:220. §), valamint az eladó késedelmének jogkövetkezményei fogyasztói adásvétel esetén $(6: 221$. $)$.

${ }^{1842}$ Lásd: $6: 138-153$. $\S$.

${ }^{1843}$ Lásd: új Ptk. 6:34. § és 6:137. §.
} 
kategóriáját, ${ }^{1844}$ elkülönítve azt a szerződésen kívüli, deliktuális károkozás szabályaitól. E rendelkezések relevánsak hibás teljesítés esetén is.

Az új kódex hibás teljesítésre vonatkozó rendelkezései strukturális újítást tükröznek. Az új Ptk. elkülöníti a hibás teljesítés fogalmát és annak jogkövetkezményeit a szabályozásban, és a fogalmat kiterjeszti a visszterhes szerződéseken kívül az ingyenesekre is: ${ }^{1845}$

„A kötelezett hibásan teljesit, ha a szolgáltatás a teljesités időpontjában nem felel meg a szerzödésben vagy jogszabályban megállapított minöségi követelményeknek." $" 1846$

Jogkövetkezményeket azonban csak a visszterhes szerződés hibás teljesítéséhez füz a kódex, amelyek között már nem csupán a kellékszavatosságról rendelkezik, hanem a jogalkotó a több mint ötven éve vitatott elhelyezését megszüntetve ide helyezi a jótállás szabályait is, megteremti a speciális hatályú termékszavatosság jogintézményét, valamint a hibás teljesítés jogkövetkezményeként rendelkezik a jogszavatosságról is. Az új szabályozási struktúra véleményem szerint áttekinthetőbbé teszi a hibás teljesítésböl eredő jogkövetkezményeket, és ezzel növeli a fogyasztó érdekérvényesítési esélyeit. ${ }^{1847}$

A szerződések érvénytelenségének szabályairól szóló fejezetben található általános rendelkezés alapján a fogyasztó és vállalkozás közötti ingó adásvétel esetén is semmis az olyan kikötés, amely az új Ptk.-nak a fogyasztó jogait megállapító rendelkezéseitől a fogyasztó hátrányára eltér (6:100. §). A következőkben az új Ptk.-nak a korábbi szabályozástól eltérő, valamint a teljesen új, a fogyasztó és vállalkozás közötti ingó adásvételi szerződések esetén releváns rendelkezéseit ismertetem.

\section{Hibafogalom}

Az új Ptk.-ban a jogalkotó a fent említettek szerint külön pontokban határozza meg a hibás teljesítés általános szabályait és annak jogkövetkezményeit. A hibás teljesítésre vonatkozó fogalmi meghatározás tágabb a régi Ptk.-énál:

„A kötelezett hibásan teljesit, ha a szolgáltatás a teljesités idöpontjában nem felel meg a szerzödésben vagy jogszabályban megállapitott minöségi követelményeknek. Nem teljesit hibásan a kötelezett, ha a jogosult a hibát a szerzödéskötés időpontjában ismerte, vagy a hibát a szerzödéskötés időpontjában ismernie kellett.

\footnotetext{
${ }^{1844}$ Lásd: 6:143. $\S$.

1845 VÉKÁS (2013), 620. p.; FAZEKAS (2013), 47. p.

${ }^{1846}$ Lásd: új Ptk. 6:157. § (1) bekezdés.

${ }^{1847}$ Ugyanígy véli FAZEKAS (2013), 58. p. is.
} 
Fogyasztó és vállalkozás közötti szerzödésben semmis az a kikötés, amely e fejezetnek a kellékszavatosságra és a jótállásra vonatkozó rendelkezéseitöl a fogyasztó hátrányára tér el." 1848

Az egyik eltérés a régi Ptk. szabályozásától a minőségi követelményekre utalás a tulajdonságok helyett, amely azonban dogmatikailag nem hoz változást. Továbbra is a konkrét szerződés kikötéseinek és a jogszabályi előírásoknak a hiánya jelenti a hibátlan teljesítés alapját. A jogszabályi elöírások tekintetében továbbra is elsősorban a szolgáltatás minőségére vonatkozó új Ptk.-beli elöírások irányadóak, amelyek nagyrészt megfelelnek a régi Ptk. rendelkezéseinek. ${ }^{1849}$ A szerződéses kikötések tekintetében a bírói gyakorlat által kialakított elvek továbbra is irányadónak tekinthetőek. ${ }^{1850} \mathrm{Az}$ új Ptk. a hibás teljesítés kapcsán megismétli a szerződések fent említett általános szabályát a fogyasztókra irányadó klaudikáló kógenciával kapcsolatban. ${ }^{1851}$

Üdvözlendő, hogy az új kódex - dogmatikailag helyesen - többé nem kimentési oknak tekinti, hanem nem értékeli hibás teljesítésként azt az esetet, amikor a jogosult a hibát a szerződéskötés időpontjában ismerte vagy azt ismernie kellett. A kötelezett ilyen esetben tehát nem csak a szavatossági helytállás, de a hibás teljesítés többi jogkövetkezménye alól is mentesül. ${ }^{1852}$

Hiányzik az új Ptk.-ból a régi Ptk.-ban szereplő szabály, miszerint a szakszerütlen kötelezetti, illetve a hibás útmutató szerinti jogosulti összeszerelésből eredő hiba keletkezése is hibás teljesítésnek számít, így közvetlenül nem érvényesül az Irányelv előírása. ${ }^{1853}$ A jogalkotó az ún. IKEA-klauzula kihagyását azzal indokolja, hogy az összeszerelés is a szerződésnek és a jogszabályoknak megfelelö teljesítés körében értékelendő, mert ha a kötelezetti összeszerelés szerződéses kötelezettség, akkor annak hibája magától értetődően hibás teljesítést jelent jogilag, ha pedig a jogosult maga végzi azt el, és a hiba a helytelen szerelési útmutató miatt következik be, az is a hibás teljesítés általános szabálya alá tartozik. ${ }^{1854}$ Az új szöveg tehát ez esetben kerüli a kazuisztikát, és absztraktabban rendelkezik.

\footnotetext{
${ }^{1848}$ Új Ptk. 6:137. § (1)-(2) bekezdések.

${ }^{1849}$ Vö.: régi Ptk. 277. § (1)-(6) bekezdések és 288. §, valamint új Ptk. 6:123. § (1)-(5) bekezdések. A régi és az új Ptk. szabályainak összevetéséhez rendkívül hasznos a „Ptk. Fordítókulcs. Oda-vissza” című mű, lásd: GADÓ - NÉMETH - SÁRINÉ SIMKÓ (2013).

${ }^{1850}$ Vö.: Szegedi ÍT 1/2004; Pécsi ÍT 2011.EL.II.C.25.; 1/2012. PK.; Debreceni ÍT 2010.El.II.C.54/5.; lásd: II. rész 3. fejezet 2.2. pont.

${ }^{1851}$ Vö. új Ptk. 6:100. §.

${ }^{1852}$ GADÓ - NÉMETH - SÁRINÉ SIMKÓ (2013), 314. p.

${ }^{1853}$ Lásd: Irányelv, 2. cikk (5) bekezdés. A szabályozási hiány problematikájára utal FAZEKAS (2013), 48. p. is.

${ }^{1854}$ Lásd: GADÓ - NÉMETH - SÁRINÉ SIMKÓ (2013), 314. p.; VÉKÁS (2013), 625. p.
} 


\section{A hibás teljesítésből fakadó jogkövetkezmények}

\subsection{Kellékszavatosság}

A kellékszavatosság a hibás teljesítésnek továbbra is a centrális jogkövetkezménye, és az új kódex nem változtat sokat a jogosult kellékszavatossági jogainak korábbi szabályozásán. A kellékszavatossági jogok egyetlen szisztematikus változása az, hogy a bírói gyakorlatnak és a Kúria kifejezett álláspontjának megfelelően az új Ptk. a második lépcsős igények között rendelkezik a dolog kijavításával illetve kijavíttatásával felmerülő költségek követeléséről [6:159. § (2) bekezdés b. pont]. Ez a gyakorlatban azt jelenti, hogy a fogyasztó e költségeket csak akkor követelheti, ha a kijavítás első lépcsős igényének teljesítését a vállalkozás nem vállalta, vagy nem tud annak eleget tenni a fogyasztó érdekeinek kíméletével, illetve megfelelő határidőn belül. ${ }^{1855}$ Minden esetben a javítás/javíttatás során felmerült indokolt költségeket követelheti a jogosult. ${ }^{1856} \mathrm{Ha}$ a javítást maga végzi el, akkor Farkas Attila szerint követelheti a készkiadások mellett azt a munkadíjat is, amit a javításért a piaci árakon a szakembernek fizetett volna. ${ }^{1857}$ Ha mással végezteti a javítást, akkor a javítást végző szakembernek fizetett ellenértéket követelheti, de a bíróságnak mindkét esetben vizsgálnia kell az összeg szükségességét és reális voltát. $^{1858}$

A második lépcsőbe tartozó elállási jog gyakorlására a szerződésszegés általános szabályai között szereplő elállásra illetve felmondásra vonatkozó rendelkezéseket megfelelöen alkalmazni kell (6:140. §). Ez azt is jelenti, hogy ha a szerződéskötést megelőző eredeti állapot természetben nem állítható helyre, akkor a fogyasztó felmondhatja az adásvételt. Ez a szabály tipikusan akkor kerülhet alkalmazásra, amikor a hibás dolog megsemmisül, azaz a fogyasztó a kifizetett vételárért cserébe nem tudja azt visszaszolgáltatni az eladónak. Ilyen esetben az új kódex alábbi szabálya irányadó:

„A kötelezett nem követelheti az ellenszolgáltatás nélkül maradt szolgáltatás ellenértékének pénzbeni megtéritését, ha a jogosult bizonyitja, hogy a számára teljesitett szolgáltatást visszatéríteni olyan okból nem tudja, amelyért a kötelezett felelös. Ha a jogosult a szolgáltatás ellenértékét megfizette, kérheti annak visszatéritését akkor is, ha ö a számára teljesitett szolgáltatást visszatériteni nem

\footnotetext{
${ }^{1855}$ Vö.: új. Ptk. 6:159. § (2) bekezdés b) pont és (4) bekezdés.

1856 VÉKÁS (2013), 629. p.

1857 WELLMANN (2013), 297. p.

${ }^{1858}$ WELLMANN (2013), 298. p.
} 
tudja, és bizonyítja, hogy ennek oka olyan körülményre vezethetö vissza, amelyért a kötelezett felelös. "1859

A kódex a megsemmisült áru visszaszolgáltatásának kérdését a fentiek szerint felróhatósági alapon, az elvárható magatartás alapelve szerint rendezi. ${ }^{1860}$ Fogyasztói adásvétel esetén tehát, ha az eladó a hibátlan teljesítést illetően nem úgy járt el, ahogy az az adott helyzetben általában elvárható, és ezért semmisül meg a vétel tárgya, akkor a már kifizetett vételár visszajár a fogyasztónak, a ki nem fizetett vételárat pedig nem lehet tőle követelni. A felróhatóság bizonyításának kötelezettsége azonban a fogyasztót terheli.

A kellékszavatossági igények érvényesítését érintő új rendelkezés a bírói gyakorlatot tette jogszabállyá:

„A bíróság a jogosult kérelméhez nincs kötve, de nem kötelezhet olyan kellékszavatossági jog teljesitésére, amely ellen mindegyik fél tiltakozik."1861

Eljárásjogi szempontból ez a rendelkezés kivételt enged a kereseti kérelemhez kötöttség elve alól. ${ }^{1862}$ Akkor releváns, amikor a jogosult illetve jogi képviselője olyan szavatossági jogot jelöl meg a keresetben, amelyről utóbb kiderül, hogy nem teljesíthető vagy aránytalan, esetleg ellentétben áll a jóhiszemüség és tisztesség követelményével. ${ }^{1863}$ Ilyenkor, ha van másik olyan kellékszavatossági jog, amelynek érvényesítési feltételei fennállnak, és alkalmas is az érdeksérelem orvoslására, akkor a bíróság azt elrendelheti, és ezzel véglegesen lezárhatja a jogvitát - kivéve természetesen, ha mindkét fél tiltakozik az alternatív megoldás ellen. ${ }^{1864}$

Az új Ptk. teljesen új szabálya így rendelkezik:

„, ha a dolog meghibásodásában a jogosultat terhelö karbantartási kötelezettség elmulasztása is közrehatott, a szavatossági kötelezettség teljesitésével felmerült költségeket közrehatása arányában a jogosult köteles viselni, ha a dolog karbantartására vonatkozó ismeretekkel rendelkezett, vagy ha a kötelezett e tekintetben tájékoztatási kötelezettségének eleget tett. "1865

A rendelkezés jogpolitikai indoka az, hogy korunkban különösen a tartós használatra rendelt dolgok (például gépkocsik, motorkerékpárok, háztartási gépek, stb.) rendeltetésszerü használatához szükséges a megfelelő karbantartás (szervizelés), és ha ez a

\footnotetext{
${ }^{1859}$ Új Ptk. 6:140. § (3) bekezdés.

1860 Vö. új Ptk. 1:4. § (1) bekezdés: „Ha e törvény eltérő követelményt nem támaszt, a polgári jogi viszonyokban úgy kell eljárni, ahogy az az adott helyzetben általában elvárható. ”.

${ }^{1861}$ Lásd: új Ptk. 6:161. §. Vö. BDT2007. 1543.

${ }^{1862}$ WeLLMANN (2013), 302. p. Ilyen lehetőséget biztosít a svájci kódex is, vö. OR $§ 215$ (2); lásd: II. rész 2. fejezet 7.3.3. pont.

${ }^{1863}$ WELLMANN (2013), 302. p.; VÉKÁS (2013), 630. p.

1864 WELLMANN (2013), 302. p.; VÉKÁS (2013), 630. p.; FAZEKAS (2013), 51. p.

1865 Lásd: új Ptk. 6:166. $\S(2)$ bekezdés.
} 
jogosult részéről nem valósul meg, az a dolog élettartamát jelentősen rövidítheti, illetve a kellékhibák felmerülését hamarabb előidézheti. ${ }^{1866}$ Ezért méltányos, hogy az ebből eredő hibák a jogosult terhére essenek, amennyiben ő megfelelő tájékoztatást kapott a karbantartás módjáról. Kemenes István véleményével egyetértve ezért tartom fontosnak, hogy a gyártók/forgalmazók olyan részletes használati-kezelési útmutatót mellékeljenek a termékhez, amely a karbantartási kötelezettség tartalmáról, a javítás és az esetleges csere várható idejéről, valamint a dolog előrelátható élettartamáról is tájékoztatást nyújt. ${ }^{1867}$

\subsection{Termékszavatosság}

Kifejezetten a fogyasztó és a vállalkozás között kötött ingó dolgok adásvételének hibás teljesítése esetére konstruál új jogintézményt az új Ptk.:

„Vállalkozás által fogyasztónak eladott ingó dolog (ezen alcím alkalmazásában: termék) hibája esetén a fogyasztó követelheti a gyártótól, hogy a termék hibáját javitsa ki, vagy - ha a kijavitás megfelelö határidön belül, a fogyasztó érdekeinek sérelme nélkül nem lehetséges - a terméket cserélje ki. A termék akkor hibás, ha nem felel meg a terméknek a gyártó által történt forgalomba hozatalakor hatályos minöségi követelményeknek, vagy nem rendelkezik a gyártó által adott leírásban szereplö tulajdonságokkal.",1868

A termékszavatosság jogintézményének rendeltetése az, hogy biztosítsa a fogyasztó számára a termék hibájában megtestesülő vagyoni érdeksérelem orvoslását közvetlenül a gyártóval/forgalmazóval szemben, lehetővé téve ezzel a hiba szakszerübb és gyorsabb kiküszöbölését. ${ }^{1869}$ Érdemes megemlíteni, hogy az Irányelv előmunkálatai során elkészített Zöld Könyv is felvetette és támogatta a termékszavatosság bevezetését. ${ }^{1870} \mathrm{Az}$ Európai Bizottság azzal indokolta a jogintézmény létjogosultságát, hogy a fogyasztói társadalmakra jellemző tömegtermelés körülményei között a fogyasztóknak gyakran nagyobb bizalma van a gyártóban, mint a szerződési partner kereskedőben, emellett a gyártóval szembeni közvetlen igényérvényesítés lehetősége az uniós belső piacon belüli ún. cross-border vásárlásra is jobban ösztönözne. ${ }^{1871}$

\footnotetext{
1866 VÉKÁS (2013), 633. p.

${ }^{1867}$ Lásd: VÉKÁs (2013), 633. p.

$18686: 168$. $§(1)$ bekezdés.

1869 VÉKÁS (2013), 634. p.; WELLMANN (2013), 312. p. Gyártónak a termék előállítója és forgalmazója minősül, lásd: $6: 168$. $\S(2)$ bekezdés.

${ }^{1870}$ Lásd: Zöld Könyv [COM(93) 509], 86-88. p.; FAZEKAS (2013), 54. p.

1871 Zöld Könyv, 86. p. Az EU tagállamai közül például Portugália és Spanyolország végül be is vezette a termékszavatosság intézményét, lásd: FAZEKAS (2013), 54. p.
} 
Az új jogintézmény rendszerbeli elhelyezése vitatható a speciális hatály miatt. Az új Ptk. kötelmi különös része a speciális adásvételi fajták között nem tárgyalja a fogyasztó és vállalkozás között kötött adásvételt, de az adásvétel általános szabályaiban rendelkezik például a fogyasztói adásvétel esetén irányadó kárveszély-átszállási szabályokról és az ilyen szerződés esetén felmerülő eladói késedelemről is, ezért véleményem szerint a termékszavatossági rendelkezések is jobban illenének dogmatikailag az adásvételi szabályai közé.

Termékhiba akkor áll fenn, ha a fogyasztónak eladott ingó dolog nem felel meg a forgalomba hozatal időpontjában irányadó minőségi követelményeknek, vagy a gyártói leírásban szereplő tulajdonságoknak. Mivel a termékszavatosság a „szerződésen átívelő” jogintézmény, és a fogyasztóval kötelmi viszonyban nem álló gyártó oldalán keletkeztet helytállást, így a szerződéses tulajdonságok hiánya értelemszerűen nem tartozik a hibafogalomba. ${ }^{1872}$ A hiba szempontjából releváns időpont a forgalomba hozatal, hiszen akkor még a gyártó ellenőrzése alatt áll a termék; ${ }^{1873}$ a később keletkezett hibákért való felelősségre vonás értelemszerüen méltánytalan lenne.

A hiba természetbeni orvoslásának célját ${ }^{1874}$ tükrözi az, hogy a fogyasztó a gyártótól termékszavatossági igényként elsődlegesen a termék kijavítását kérheti, és csak akkor, ha az nem lehetséges megfelelő határidőn belül illetve fogyasztói érdeksérelem nélkül, akkor követelheti a dolog kicserélését. Nem csak a jogorvoslatok tekintetében jelent kevésbé szigorú helytállást a termékszavatosság a kellékszavatosságnál. A jogintézmény objektív jogalapú ugyan, de nem feltétlen, ${ }^{1875}$ a gyártó ugyanis három esetben mentesülhet e törvényi kötelezettsége alól:

„A gyártó mentesül a termékszavatossági kötelezettség alól, ha bizonyítja, hogy a) a terméket nem üzleti tevékenysége vagy önálló foglalkozása körében gyártotta vagy forgalmazta;

b) a termék forgalomba hozatalának idöpontjában a hiba a tudomány és a technika állása szerint nem volt felismerhetö; vagy

c) a termék hibáját jogszabály vagy kötelezö hatósági elöírás alkalmazása okozta. "1876

Ha tehát a terméket például szívességből állították elő, akkor a gyártó nyilvánvalóan nem köteles helytállni. A második kimentési okot illetően pedig nem a gyártó tényleges ismeretei relevánsak, hanem általában a tudomány és technika adott állása. ${ }^{1877}$

\footnotetext{
1872 VÉKÁS (2013), 634. p.; WELLMANN (2013), 312. p.

${ }^{1873}$ WELLMANN (2013), 312. p.

${ }^{1874}$ Lásd: új Ptk. javaslat, 595. p.; VÉKÁS (2013), 635. p

1875 FAZEKAS (2013), 54. p.

${ }^{1876} 6: 168$. $\S(3)$ bekezdés.
} 
A termékszavatosság egyik fontos rációja abban rejlik, hogy tulajdonváltozást türő jogintézmény, azaz ha a termék első vevője átruházza a dolog tulajdonjogát, akkor az új tulajdonos is érvényesítheti a termékszavatossági jogokat a gyártóval szemben (új Ptk. 6:170. §). Arról nem rendelkezik kifejezetten a törvény, hogy az új tulajdonosnak is fogyasztónak kell-e minősülnie, de a jogintézmény jogpolitikai céljából véleményem szerint ez következik. ${ }^{1878}$

A termékszavatosság jogintézményének másik rációja az, hogy lehetővé teszi a fogyasztó számára a választást a kellék- és termékszavatosság, azaz a kereskedővel vagy közvetlenül a gyártóval szembeni igényérvényesítés között. ${ }^{1879}$ Hátránya az előbbivel szemben, hogy ez esetben nem érvényesül a hibásság hat hónapos vélelme, amelyet a kellékszavatosság esetén az új Ptk. szabályozása továbbra is fenntart (6:158. §), illetve csak a kijavítás és - feltételhez kötötten - a kicserélés jogait foglalja magában. A két jogintézmény közti viszonyról kifejezetten is rendelkezik a törvény:

„Csere esetén a kicserélt termékre, kijavitás esetén a termék kijavitással érintett részére vonatkozó kellékszavatossági kötelezettség a gyártót terheli. "1880

Ez a szabály megkötött szerződés nélkül kötelmi helytállással terheli a gyártót, azaz úgy tekinti, mintha a kijavítás és kicserélés - az eladót kiiktatva - új szerződést keletkeztetne közte és a fogyasztó között. ${ }^{1881}$

Kérdésként merül fel a termékszavatossági szabályok tényleges alkalmazhatóságának kezdete. A fogyasztóra nézve valószínüleg az a megoldás lenne kedvezőbb, ha a jogalkotó a termékszavatossági rendelkezések hatályát az új. Ptk. hatályba lépése után megvásárolt minden termékre kiterjesztené, a gyártóknak azonban vélhetően az kedvezne, ha csak az új kódex hatályba lépése után gyártott, illetve Magyarországon forgalomba hozott termékekre nézve állna fenn a termékszavatossági kötelezettségük. ${ }^{1882}$

\subsection{Jótállás}

A jótállásra vonatkozó szabályozás legfontosabb újítása, hogy az 1959-es Ptk. hatályba lépésétől kezdve vitatott rendszerbeli elhelyezést megreformálva a jogalkotó a hibás

\footnotetext{
${ }^{1877}$ Lásd: WELLMANN (2013), 312-313. p.

1878 Így vélekedik MOLNÁR Sz. (2013), 1. p. is. A cikk elérhető: http://www.vg.hu/kozelet/jog/termekszavatossag-az-uj-ptk-ban-412758 (2014. január 7.).

${ }^{1879}$ GADÓ - NÉMETH - SÁRINÉ SIMKÓ (2013), 317. p.; új Ptk. javaslat, 595. p.; FAZEKAS (2013), 55. p.

${ }^{1880} 6: 168 . \S(4)$ bekezdés.

${ }^{1881}$ VÉKÁS (2013), 635. p.

${ }^{1882}$ MolnÁr Sz. (2013), 1. p. A kérdésről az új Ptké. nem rendelkezik.
} 
teljesítés jogkövetkezményei közé helyezte azt át, így - az indokolás fogalmazásával élve - „a kellékszavatosság és a jótállás rendszertani kapcsolata és közös elvi alapja egyértelművé válik". ${ }^{1883}$ Az új kódex az alábbiak szerint rendelkezik:

„,Aki a szerzödés teljesitéséért jótállást vállal vagy jogszabály alapján jótállásra köteles, a jótállás időtartama alatt a jótállást keletkeztetö jognyilatkozatban vagy jogszabályban foglalt feltételek szerint köteles helytállni a hibás teljesitésért. Mentesül a jótállási kötelezettség alól, ha bizonyítja, hogy a hiba oka a teljesités után keletkezett.",1884

A rendelkezés lényegi változtatást annyiban tartalmaz, hogy mellőzi a reklámra, mint jótállási kötelezettséget keletkeztető nyilatkozatra utalást, mivel a jogalkotó azt is jognyilatkozatnak minősíti. ${ }^{1885}$ Nem tartalmazza ezen kívül az Irányelv által a fogyasztó és a vállalkozás közötti szerződés esetére előírt kötelező tartalmi elemeket sem. ${ }^{1886}$ Az utóbbi hiányosságnak az oka egyrészt az lehet, hogy már a régi Ptk. (és az Irányelv) is kimondta, hogy a kötelező tartalmi elemek elmaradása a jótállási nyilatkozatban nem érinti a jótállás érvényességét. Másrészt az egyes tartós használatra rendelt fogyasztási cikkekre vonatkozó kötelező jótállás vonatkozásában a jogalkotó külön rendelkezik a jótállási nyilatkozat kötelező tartalmi kellékeiről. ${ }^{1887}$ Kemenes megállapítja, hogy az Irányelv nyomán implementálandó rendelkezés tulajdonképpen lex imperfecta, azaz be nem tartása nem eredményez semmilyen szankciót, ezért került ki az új Ptk.-ból. ${ }^{1888}$ Véleményem szerint ennek ellenére is kívánatos lenne az Irányelvi rendelkezést továbbra is beépíteni a kódexbe, hiszen az az önkéntesen, szerződésben vállalt jótállást szabályozza, és célja, hogy az ilyen kötelezettségvállalást a transzparencia elve vezérelje, és az esetleges igényérvényesítést minden szempontból megkönnyítse. Megfontolandó lenne az osztrák fogyasztóvédelmi törvényhez hasonlóan szankciót is füzni a kötelező tartalmi elemek elmaradása esetére. ${ }^{1889}$ Emellett kívánatos lenne beépíteni a szabályozásba egy ugyancsak az osztrák megoldáshoz hasonló egyértelmü rendelkezést is arra nézve, hogy a jótállási nyilatkozatban utalni kell arra, hogy a fogyasztónak a törvényen alapuló kellékszavatossági jogai is vannak, amelyekkel a jótállás fennállása esetén is szabadon élhet. ${ }^{1890}$ A magyar előírás tartalmazhatná a kellékszavatosságra és termékszavatosságra való kifejezett utalást

\footnotetext{
${ }^{1883}$ Lásd: új Ptk. javaslat, 596. p.

${ }^{1884} 6: 171$. $§(1)$ bekezdés.

1885 GADÓ - NÉMETH - SÁRINÉ SIMKÓ (2013), 317. p.; VÉKÁS (2013), 637. p.

${ }^{1886}$ Vö. Irányelv, 6. cikk (2) bekezdés és Ptk. 248. § (3) bekezdés.

1887 Lásd: 151/2003. Kormányrendelet, 3. §.

1888 Lásd: VÉKÁS (2013), 637. p.; FAZEKAS (2013), 52. p.

${ }^{1889}$ Vö. KSchG $\S 9$ b (4); lásd: II. rész 2. fejezet 7.5.2. pont.

${ }^{1890}$ Vö. KSchG $§ 9 b$ (1)-(2); lásd: II. rész 2. fejezet 7.5.2. pont.
} 
a törvényhelyek megjelölésével együtt, hogy minél konkrétabb tájékoztatást nyújtson a fogyasztók választható jogairól.

A jótállási nyilatkozat esetleges hiányai (tipikusan a jótállási igények megnevezésének hiánya) esetén a kommentár szerint úgy kell tekinteni, hogy a jogosult a kellékszavatosságból fakadó jogokkal azonos tartalmú igényeket érvényesíthet, mivel azok a jótállással egyezően a teljesítési érdek védelmét szolgálják. ${ }^{1891}$

A kellékszavatossággal szemben továbbra is előnyt jelent a fogyasztó számára az, hogy jótállás esetén annak teljes tartama alatt a hibás teljesítés vélelme áll fenn, azaz a fordított bizonyítási teher érvényesül: a jogosultnak csak azt kell bizonyítania, hogy a jótállás és a kellékhiba fennáll. ${ }^{1892}$ A jótállási helytállás alóli mentesüléshez a kötelezettnek kell ellenben bizonyítania azt, hogy a hiba oka a teljesítés után keletkezett. ${ }^{1893}$ Ezen bizonyítási könnyebbség ellenére is választhatja a fogyasztó a kellékszavatossági igények érvényesítését a jótállási jogok helyett. Ez általában akkor kedvezőbb, ha a jótállási jogok körét a jótállási nyilatkozat vagy jogszabály a kellékszavatosságnál szükebben határozza meg, vagy ha az csak a dolog egyes konkrét kellékhibáira terjed ki, a fogyasztónál azonban attól eltérö hiba jelentkezik. ${ }^{1894}$

Vitás lehet annak megítélése, hogy miként érvényesül a fordított bizonyítási teher akkor, ha a jótállási nyilatkozat illetve az azt keletkeztető jogszabály a jótállás tartalmát nem határolja be. Az 1/2012. PK szerint ,a jótállás szigorúbb felelősséget eredményező szabályai csak a jótállás alapján érvényesített igények elbírálása során alkalmazhatóak" ${ }^{1895}$ Kemenes szerint ezzel a megállapítással ellentétes az új Ptk. szabályozása, mert a hibás teljesítésnek a jogkövetkezményektől elkülönült fogalma miatt a bizonyítási teher megfordítása a hibás teljesítés, mint szerződésszegés tényére és így annak összes jogkövetkezményére vonatkozik. ${ }^{1896}$ Kemenes egy bírósági döntésre hivatkozik, amely szerint nem állhat elő olyan helyzet, amelyben a hibás teljesítés hiányát a jótállásra kötelezettnek, a hibás teljesítés tényét viszont jótállási alapon kártérítést követelve a jogosultnak kelljen bizonyítani. ${ }^{1897}$ Én ez utóbbi állásponttal értek egyet azon esetben tehát, amikor a jótállás tartalma, azaz az abból fakadó igények nincsenek konkretizálva a jótállási nyilatkozatban.

\footnotetext{
${ }^{1891}$ WELLMANN (2013), 315. p.

1892 VÉKÁS (2013), 636. p.; WELLMANN (2013), 316. p.

${ }^{1893}$ WELLMANN (2013), 316. p.

${ }^{1894}$ WELLMANN (2013), 316. p.

1895 Lásd: 1/2012. PK 15. pont.

1896 Lásd: VÉKÁS (2013), 637. p.

${ }^{1897}$ Lásd: VÉKÁS (2013), 637. p.; vö. BH2012. 99.
} 
A termékszavatossághoz hasonlóan a jótállást is tulajdonváltozást türő jogintézménnyé tette a jogalkotó az új Ptk.-ban (6:172. §), ami azt jelenti, hogy a jótállás a szerződéstől függetlenedhet, és a „szerződésen átívelő” viszonyt hoz létre a jótállásra kötelezett és a dolog mindenkori tulajdonosa között. ${ }^{1898}$

\subsection{Kártérítési igény}

Fontos változást hozott a hibás teljesítés jogkövetkezményeinek szabályozásában is az a jogalkotói lépés, amely a német BGB-vel egyezően, a bécsi vételi egyezmény mintájára elkülöníti az új Ptk.-ban a szerződésszegéssel okozott károkért való felelősséget a szerződésen kívüli kártérítési felelősségtől. ${ }^{189}$ Az új Ptk. reformját a jogalkotó így indokolja:

„A kártérítési felelősségnek eltérőek a gyökerei szerződésen kívüli jogellenes károkozó magatartás és szerződésszegésnél esetében... Kontraktuális felelősség esetében [...] a károkozást megelőzően is fennáll egy relatív szerkezetü jogviszony a felek között: a szerződés, amely meghatározza a felek egymással szembeni jogait és kötelezettségeit...

Kontraktuális felelősségnél [...] a károkozó magatartás egy szerződésben önként vállalt kötelezettség megszegését jelenti... A döntő különbség [...] az, hogy a kontraktuális felelősséget egy önként, tudatosan, átgondoltan vállalt szerződéses kötelezettségvállalás megszegése alapozza meg...”.

A felróhatóság középpontba állítása ,individuális magatartási rendellenességet” feltételez a polgári jogi felelősségre vonásnál, azonban a jogalkotó szerint szerződésszegés esetén inkább abból kell kiindulni, hogy „valamely tevékenység üzletszerü folytatása szükségszerü kockázatvállalást jelent, és az esetleges konfliktus feloldása nem a magatartás utólagos értékelésével, hanem a tevékenységgel együtt járó kockázat telepítése útján célszerü". 1901

Mindezekre figyelemmel az új Ptk. úgy rendelkezik, hogy a szerződésszegéssel okozott károk megtérítése alóli mentesüléshez három konjunktív körülményt kell a kötelezettnek bizonyítania:

„,Aki a szerzödés megszegésével a másik félnek kárt okoz, köteles azt megtériteni. Mentesül a felelösség alól, ha bizonyítja, hogy a szerzödésszegést ellenörzési körén

\footnotetext{
${ }^{1898}$ Lásd: VÉKÁS (2013), 637. p.

1899 A régi Ptk. egységes kártérítési rendszert alkalmazó szabályozása a hibás teljesítésből eredő károk megtérítésére még a deliktuális kártérítés szabályait rendelte alkalmazni, lásd: II. rész 3. fejezet 2.5.3. pont. ${ }^{1900}$ Lásd: új Ptk. javaslat, 585-586. p.

${ }^{1901}$ Lásd: új Ptk. javaslat, 586. p.
} 
kívül esö, a szerzödéskötés időpontjában elöre nem látható körülmény okozta, és nem volt elvárható, hogy a körülményt elkerülje vagy a kárt elhárítsa. "1902

A rendelkezés természetesen alkalmazandó hibás teljesítés esetén is, ahol a jogalkotó úgy rendelkezik, hogy „a kötelezett köteles megtéríteni a jogosultnak a hibás teljesitésböl eredő kárát”. ${ }^{1903}$ A vállalkozásnak ez alapján a felelősség alóli mentesüléshez a fogyasztóval szembeni, ingó adásvétel hibás teljesítéséből eredő jogvitában azt kell bizonyítania, hogy (1) a szerződésszegést az ellenőrzési körén kívül eső olyan körülmény (például vis maior, behozatali-kiviteli tilalmak, súlyos üzemzavarok) okozta, amely (2) a szerződéskötés időpontjában nem volt előre látható, amely előre láthatóságnak objektíve a szerződésszerü teljesítést akadályozó körülményre kell vonatkoznia, és (3) nem volt elvárható, hogy a körülményt elkerülje vagy a kárt elhárítsa. ${ }^{1904}$ Az utolsó feltételnek az indokolás szerint nem a szerződéskötés, hanem a szerződésszegés időpontjában kell fennállnia. ${ }^{1905}$ A jelenlegi jogalkalmazási álláspontoknak és az új Ptk. nyelvtani illetve logikai értelmezésének megfelelően a hibás teljesítés hat hónapos vélelme ${ }^{1906}$ a hibás teljesítésből eredő kártérítés esetén is fennáll, azaz a teljesítést követő 6 hónap alatt a kötelezettet a fentieken kívül annak bizonyítási kötelezettsége is terheli, hogy a dolog a teljesítés időpontjában nem volt hibás. ${ }^{1907}$ Csak mindezen fenti bizonyítási kötelezettségének eleget téve mentesülhet a kártérítési kötelezettség alól.

Már a szerződésszegéssel okozott károk általános szabálya is elkülöníti a hibás teljesítésből eredő kártérítés kapcsán a jogalkalmazás és jogtudomány által régóta megkülönböztetett tapadó károk és következménykárok kategóriáját (új Ptk. 6:143. §). A hibás teljesítésről szóló speciális rendelkezések kifejezetten csak a tapadó károkról ejtenek szót:

„A hibás teljesitéssel a szolgáltatás tárgyában bekövetkezett károk megtérítését a jogosult akkor követelheti, ha kijavitásnak vagy kicserélésnek nincs helye, vagy ha a kötelezett a kijavitást vagy a kicserélést nem vállalta, e kötelezettségének nem tud eleget tenni, vagy ha a jogosultnak a kijavitáshoz vagy kicseréléshez füzödö érdeke megszünt...". 1908

\footnotetext{
1902 Lásd: új Ptk. 6:142. §.

${ }^{1903}$ Lásd: új Ptk. 6:174. § (1) bekezdés.

${ }^{1904}$ Lásd: új Ptk. javaslat, 587-588. p.; WELLMANN (2013), 232-235. p.

${ }^{1905}$ Lásd: új Ptk. javaslat, 588. p.

1906 Az új Ptk. e szabálya tartalmilag azonos a régi Ptk.-val, vö.: új Ptk. 6:158. § és Ptk. 305/A. § (2) bekezdés; GADÓ - NÉMETH - SÁRINÉ SIMKÓ (2013), 314. p.

${ }^{1907}$ Vö. Szegedi ÍT 2004/1.; WELLMANN (2013), 229. p.; VÉKÁS (2013), 639. p.

${ }^{1908}$ Lásd: új Ptk. 6:174. $\S(2)$ bekezdés.
} 
A rendelkezésben felsorolt három vagylagos feltétel esetén követelheti tehát a jogosult a tapadó, azaz a hibás teljesítés miatt magában a dologban beálló károkat. E feltételek gyakorlatilag teljesen azonosak a második lépcsős kellékszavatossági igények alkalmazhatóságára vonatkozó feltételekkel. Az új Ptk. tehát rendezi a kellékszavatosság és a tapadó károk megtérítésének viszonyát. Ennek lényege, hogy a tapadó károk megtérítésének igénye az első lépcsős szavatossági igényekhez képest ugyancsak másodlagos igénynek, a másodlagos kellékszavatossági igények mellett pedig alternatív jogorvoslati módnak tekinthető. ${ }^{1909}$ A tapadó kár megtérítéseként a dolognak a hiba miatti értékcsökkenésére, vagy a dolog kijavításának költségére tarthat igényt a jogosult. ${ }^{1910}$ Farkas a fentiek alapján úgy véli, hogy a gyakorlatban ilyen igényt ténylegesen nem fognak érvényesíteni, mert az objektív jogalapú öt kellékszavatossági igény megfelelően képes orvosolni a teljesítési érdeksérelmet. ${ }^{1911}$

Mivel a következménykárokról a hibás teljesítés vonatkozásában külön nem rendelkezik az új Ptk., azok megtérítésére a szerződésszegéssel okozott károk általános szabálya alkalmazandó:

„A szerzödésszegés következményeként a jogosult vagyonában keletkezett egyéb károkat és az elmaradt vagyoni elönyt olyan mértékben kell megtériteni, amilyen mértékben a jogosult bizonyítja, hogy a kár mint a szerzödésszegés lehetséges következménye a szerzödés megkötésének időpontjában elöre látható volt.",1912

A szabályban megjelenő ún. előreláthatósági korlát célja „,a szolgáltatás, ellenszolgáltatás és a kötelezett által vállalt kockázatok egyensúlyának megteremtése". ${ }^{1913}$ Az új Ptk. indokolása szerint az előreláthatóság akkor is fennáll, ha a szerződésszegés lehetséges következménye a szerződésszegő fél által látható ténylegesen előre (például a fogyasztó közölte az eladóval a megvásárolni kívánt dolog konkrét használati célját); valamint akkor is, ha egy hasonló helyzetben lévő, ,ésszerüen gondolkodó és cselekvő személy” számára lett volna előrelátható (ún. elvárható előreláthatóság). ${ }^{1914} \mathrm{Az}$ indokolás azt is kiemeli, hogy a fenti elöreláthatósági korlát nem azonos a szerződésszegéssel okozott károk alóli kimentés szabályában szereplő előreláthatósággal: az előbbi, következménykárok esetén alkalmazandó előreláthatóság nem terjed ki a szerződésszegés lehetőségére és annak

\footnotetext{
${ }^{1909}$ Lásd: WELLMANN (2013), 320. p.; VÉKÁS (2013), 639. p.

${ }^{1910}$ WeLlMANN (2013), 320. p.

${ }^{1911}$ Lásd: WELLMANN (2013), 320. p.

1912 Lásd: új Ptk. 6:143. § (2) bekezdés.

1913 WELLMANN (2013), 241. p.

${ }^{1914}$ Lásd: WellmanN (2013), 241. és 243. p., valamint új Ptk. javaslat, 589. p.
} 
előfeltételeire, hanem csupán a jogosultnál esetlegesen bekövetkező kárra és annak nagyságrendjére vonatkozik. ${ }^{1915}$

Üdvözlendő, hogy az új Ptk. külön rendelkezik a teljesítés során, de a szerződésen kívül okozott károk megtérítéséről. Ez a kérdés az osztrák magánjogban például nem törvényi szinten került rendezésre, hanem a jogtudomány és joggyakorlat állásfoglalása révén. ${ }^{1916}$ Az új Ptk. a következő szabályt írja elő:

„A jogosult a vagyonában a szerzödés teljesitése során a kötelezett által okozott kár megtéritését a szerzödésszegéssel okozott károkért való felelösség szabályai szerint követelheti. ",1917

A deliktuális és kontraktuális kártérítési felelősségi tényállások metszeteként jelentkező esetben a jogalkotó tehát csakis a szerződésszegéssel okozott károk megtérítésére irányadó szabályok alkalmazását rendeli el olyan esetekben, amikor például a megvett bútor leszállításakor a kötelezett vagy alkalmazottai kárt tesznek valamelyik, a jogosult lakásában lévő bútordarabban vagy a parkettában. Ezzel a szabállyal elkerülhető az, hogy különböző felelösségi rendszerben kelljen értékelni ugyanannak a káreseménynek a következményeit, attól függően, hogy a jogosult szerződéses vagy egyéb érdeke szenvedett-e sérelmet. ${ }^{1918}$

\section{Igényérvényesítési határidők}

\subsection{Kellékszavatosság}

A kellékszavatossági igényérvényesítési határidők egyszerüsödnek az új Ptk.-ban, mert a jogalkotó megszünteti az elévülési és jogvesztő határidők kettősségét. A jogvesztő határidők előírása a régi Ptk.-ban jogalkalmazási bizonytalanságot okozott, ezért vette ki a jogalkotó azokat a szabályozásból. ${ }^{1919}$ Nem tartotta fenn a speciális állatszavatossági 60 napos elévülési és egy éves jogvesztő határidőt sem a jogalkotó, mert azt szükségtelennek vélte. $^{1920}$

\footnotetext{
1915 Lásd: új Ptk. javaslat, 589. p. A fogyasztó és vállalkozás között kötött ingó adásvételi szerződések körében tipikus példa lehet a következménykárra a felrobbant televíziókészülék által a lakásban lévő bútorokban okozott kár, vagy a gépjármüben lévő hibás alkatrész miatti üzemképtelenségből eredő jogosulti kár, lásd: WELLMANN (2013), 240-241. p.

${ }^{1916}$ Lásd: II. rész 2. fejezet 7.4.2. pont (Begleitschaden).

${ }^{1917}$ Lásd: új Ptk. 6:146. §.

${ }^{1918}$ Lásd: VÉKÁS (2013), 610. p.

${ }^{1919}$ FAZEKAS (2013), 50. p.

${ }^{1920}$ FAZEKAS (2013), 50. p.
} 
A fogyasztó és vállalkozás közötti szerződések esetén továbbra is fenntartja az új kódex azt a szabályt, hogy a hiba felfedezésétől számított két hónapon belüli hibaközlés illetve kifogás kellő időben megtettnek minősül ilyen ügyletek esetén. ${ }^{1921}$ Az a szabály sem változik, miszerint a fogyasztó és vállalkozás közötti szerződések esetén a fogyasztónak a teljesítéstől számított két év áll rendelkezésre az igényérvényesítésre, és annak elmulasztása esetén kifogásként továbbra is érvényesítheti kellékszavatossági jogait az ugyanazon szerződésből eredő követeléssel szemben. ${ }^{1922}$ Használt dolgok esetén a felek kiköthetnek két évnél rövidebb határidőt is, de annak tartama ez esetben az Irányelvnek megfelelően továbbra sem lehet egy évnél kevesebb [6:163. § (2) bekezdés]. Mindezek mellett a teljesítéstől számított hat hónapon belül a hibásság vélelme ugyancsak fennáll továbbra is $(6: 158 . \S)$.

A határidők elévülési jellegéből adódóan azokat a bíróság hivatalból nem észlelheti [6:23. § (4) bekezdés], és azokra a régi Ptk.-val egyező szabályozás szerint alkalmazandóak az elévülés nyugvásának és félbeszakadásának szabályai is. ${ }^{1923} \mathrm{~A}$ félbeszakadást előidéző körülmények tekintetében kiemelést érdemel, hogy az új Ptk. már nem tartalmazza a követelés teljesítésére irányuló írásbeli felszólítást, új félbeszakító ok azonban a követelés csődeljárásban történő bejelentése és a kötelem megegyezéssel történő módosítása. ${ }^{1924}$

Az elévülés nyugvására vonatkozó új rendelkezések szerint a fogyasztó és vállalkozás közötti szerződésnél irányadó két éves elévülési határidő menthető okból való nyugvása esetén az objektív akadály megszűnésétől számított egy évig a kellékszavatossági igényeket még akkor is érvényesítheti a fogyasztó, ha az elévülési határidőből egyébként egy évnél kevesebb van hátra [6:24. § (2) bekezdés]. A korábbi jogbizonytalanságot megszüntetendő, az új Ptk. úgy rendelkezik, hogy a fenti egy éves időtartam alatt újból nem nyugszik az elévülés; az elévülés megszakítására irányadó szabály pedig csak erre a nyugvás következtében beálló egy éves határidőre alkalmazható. $^{1925}$

\footnotetext{
${ }^{1921}$ Vö.: új Ptk. 6:162. § (2) bekezdés és régi Ptk. 307. § (2) bekezdés; GADÓ - NÉMETH - SÁRINÉ SIMKÓ (2013), 315. p.

${ }^{1922}$ Vö.: új Ptk. 6:163. § (2) bekezdés és régi Ptk. 308. § (4) bekezdés, valamint 6:164. § és 308/C. §; GADÓNÉMETH - SÁRINÉ SIMKÓ (2013), 315-316. p.

${ }^{1923}$ Lásd: új Ptk. 6:24. és 6:25. §§.

${ }^{1924}$ Vö.: új Ptk. 6:25. § (1) bekezdés és régi Ptk. 327. § (1) bekezdés.

${ }^{1925}$ Lásd: új Ptk. 6:24. § (2) bekezdés; GADÓ - NÉMETH - SÁRINÉ SIMKÓ (2013), 280. p.
} 


\subsection{Termékszavatosság}

A termékszavatosság speciális jogintézménye speciális igényérvényesítési határidőt kíván meg:

„A gyártót a termékszavatosság az adott termék általa történö forgalomba hozatalától számitott két évig terheli. E határidö eltelte jogvesztéssel jár."1926

A termékszavatossági igény érvényesítésére nyitva álló két éves jogvesztő határidő letelte szempontjából az igényérvényesítésre irányuló bírósági eljárás megindításának kezdete az irányadó, más jogvesztő határidőkkel egyezően. ${ }^{1927}$ Nem alkalmazandó a termékszavatosságra a hibás teljesítés többi jogkövetkezménye esetén irányadó hibásság vélelme, mert az csak a fogyasztó és vállalkozás közötti kötelmi jogviszonyban érvényesül a kódex megfogalmazása alapján. ${ }^{1928}$ Ennek értelmében a fogyasztónak kell bizonyítania a termékhibát, azaz azt, hogy a dolog nem felel meg a forgalomba hozatalkor hatályos minőségi követelményeknek illetve a gyártó leírásának. A termékszavatossági igényérvényesítés vonatkozásában is érvényesül azonban az a szabály, hogy a hiba felfedezésétől számított két hónapon belüli kifogásközlés (illetve kifogásközlés nélküli keresetindítás) kellő időben megtettként értékelendő. ${ }^{1929}$

\subsection{Jótállás}

Jótállás esetén a jótállási nyilatkozatban illetve a jótállási helytállást keletkeztető jogszabályban elöírt határidőn belül érvényesítheti igényeit a fogyasztó a jótállás kötelezettjével szemben $\left[6: 173\right.$. § (1) bekezdés]. Ez a határidő jogvesztő jellegü. ${ }^{1930} \mathrm{~A}$ jótállási igény bírósági érvényesítését illetően a Kúria korábbi precedensértékü döntését ${ }^{1931}$ emelte törvényi erőre a jogalkotó minden olyan esetben, amikor a jogosult közli a hibát és felhívja a kötelezettet a jótállási igénye teljesítésére, aminek a kötelezett mégsem tesz eleget:

\footnotetext{
${ }^{1926}$ Lásd: új Ptk. 6:169. § (2) bekezdés.

1927 Lásd: VÉKÁs (2013), 636. p.

${ }^{1928}$ Lásd: új Ptk. 6:158. §: „Fogyasztó és vállalkozás közötti szerzödés esetén az ellenkező bizonyitásáig vélelmezni kell, hogy a teljesitést követö hat hónapon belül a fogyasztó által felismert hiba már a teljesités idöpontjában megvolt, kivéve, ha e vélelem a dolog természetével vagy a hiba jellegével összeegyeztethetetlen.".

${ }^{1929}$ Lásd: új Ptk. 6:169. § (1) bekezdés; WELLMANN (2013), 313-314. p.

${ }^{1930}$ FAZEKAS (2013), 53. p.

${ }^{1931}$ Vö. BH 1989.6., P. törv. III. 20 277/1989.; lásd: II. rész 3. fejezet 2.7.3. pont.
} 
„....Ha a jótállásra kötelezett kötelezettségének a jogosult felhívására - megfelelö határidöben - nem tesz eleget, a jótállási igény a felhívásban tüzött határidö elteltétöl számított három hónapon belül akkor is érvényesithetö bíróság elött, ha a jótállási idő már eltelt. E határidő elmulasztása jogvesztéssel jár." 1932

A kisegítő szabály alkalmazására a fentiek értelmében csak akkor van lehetőség, ha a jogosult megfelelő - azaz a dolog és a hiba jellegére figyelemmel elegendő - határidőt tüz az igénye teljesítésére, de az eredménytelenül telik el. ${ }^{1933}$

A jótállás továbbra is a kellékszavatosságnál szigorúbb szankciója a hibás teljesítésnek, ami főként abban nyilvánul meg, hogy a jótállási alapú követelés esetén a jótállási határidő teljes tartama alatt a fordított bizonyítási teher elve érvényesül a bírósági eljárásban [6:171. § (1) bekezdés].

Az új Ptk. a korábbi szabályozással egyezően továbbra is elrendeli, hogy a jótállási igény érvényesítésére megfelelően alkalmazandóak a kellékszavatossági jogok gyakorlására vonatkozó rendelkezések [6:173. § (2) bekezdés]. Ez azt jelenti, hogy a jogosult a választott jótállási igényről áttérhet egy másik jótállási igényre (6:160. §). Továbbá a bíróság eltérhet a kereseti kérelemben megjelölt jótállási igénytől, és egy másik jótállási igényt ítélhet meg, ha az indokolt, fennállnak annak alkalmazási feltételei és nem tiltakoznak ellene a felek (6:161. §). További követelmény, hogy a dolognak a kicseréléssel/kijavítással érintett részét illetően a jótállási határidő újraindul [6:163. § (5) bekezdés]; a jótállási igény teljesítésével kapcsolatos költségek a kötelezettet terhelik (6:166. §); a kötelezett a részére a kicserélés/kijavítás következtében visszaadott dolog rendeltetésszerü használatáért használati díjat nem követelhet, és az ilyen használatból eredő értékcsökkentés megtérítését sem követelheti (6:167. §). ${ }^{1934}$

\subsection{Kártérítés}

A hibás teljesítésből eredő kártérítési követelés érvényesítési határideje vonatkozásában - a kártérítés mértékének megállapításához hasonlóan - különbséget kell tenni a tapadó károk és a következménykárok kategóriája között. A tapadó károk esetén az új Ptk. a kellékszavatossági igények érvényesítésére irányadó elévülési határidő alkalmazását rendeli el [6:174. § (2) bekezdés]. Eszerint a fogyasztó és a vállalkozó közötti ingó adásvétel esetén a már említett feltételek mellett, a dologban a hibás teljesítés miatt beálló

\footnotetext{
${ }^{1932}$ Lásd: új Ptk. 6:173. § (1) bekezdés.

${ }^{1933}$ WeLlMANN (2013), 318. p.

1934 Lásd: WELLMANN (2013), 316. p.; VÉKÁS (2013), 639. p.
} 
károkat illetően az igényérvényesítés a teljesítéstől számított két évre, illetve használt dolgok esetén az opcionálisan kikötött minimum egy évre korlátozódik. Ezt az indokolja, hogy ez esetben a vagyoni hátrány a dolog teljesítés idején fennálló minőségi fogyatékosságában áll, csakúgy, mint kellékszavatosság esetén. ${ }^{1935}$

A következménykárok szavatossági igények keretében nem lennének érvényesíthetőek, ezért ezek megtérítésének követelése - speciális rendelkezés hiányában a rendes öt éves elévülési időn belül lehetséges, amely a kár bekövetkezésétől számítandó [6:22. § (1)-(2) bekezdések]. A Szegedi Ítélőtábla korábbi álláspontjának megfelelően úgy vélem, hogy továbbra is alkalmazandó a hibásság hat hónapos vélelme a hibás teljesítésből eredő kártérítési követelésre irányuló bírósági eljárásokban is. ${ }^{1936}$ 


\section{Befejező gondolatok}

A dolgozat első, jogtörténeti részének első fejezete igyekezett bemutatni, hogy az ókori Rómában a spontán kialakult piaci szokások nyomán az áru minőségéhez füződő vevői érdek védelme miként materializálódott a piaci adásvételről szóló aediliszi edictumban. A kérdéskör szabályozásának alábbi jellemzői már az ókori megoldásokban megjelentek:

1. a caveat emptor elve, azaz a készvétel esetén a vevő körültekintő eljárásának követelménye;

2. ezzel összefüggésben az áru minőségi hibájára utaló külső jelek és a rejtett minőségi hibák relevanciája, azaz a kockázattelepítés a szerződő felek között;

3. a minőséget már az adásvétel megkötése előtt demonstráló, tisztességes eladói gyakorlat kívánalma;

4. az áru rendeltetésszerü használatát befolyásoló és piaci értékére is kiható kellékhibák relevanciája;

5. a gyakran tájékozatlan vevőnek a hivatásos (furfangos) kereskedőkkel szembeni védelme;

6. az újkorban jótállásnak nevezett jogintézmény előképe az áru tulajdonságaiért önkéntesen felvállalt eladói ígéret formájában;

7. az objektív kellékszavatossági és a hibás teljesítés miatti szubjektív kártérítési igények párhuzamossága és a vevő igények közötti választási joga.

A dolgozat a továbbiakban igyekezett rávilágítani arra, hogy a fenti jellemzők az ingó adásvétel hibás teljesítéséért fennálló eladói helytállási kötelezettségnek korokon átívelő szabályozásában minduntalan fellelhetőek.

A római jog recepciója a hazánk magánjogi fejlődésére meghatározóan ható német és osztrák polgári jogi kódexek hibás teljesítésre vonatkozó szabályozásában is nyomon követhető. A dolgozat első részének második fejezete e két kodifikációt vizsgálta. Az ABGB és a BGB eredeti szabályozási koncepciói eltérően közelítették meg a kellékhibás teljesítést: az előbbi minden visszterhes szerződésre kiterjedő hatállyal, az utóbbi azonban csak az adásvételi szerződésre vonatkozóan alakította ki a rendelkezéseket. Míg az osztrák törvény meglehetősen absztraktan fogalmazott, a BGB alkotói igyekeztek minden, az adásvétel kellékhibás teljesítése kapcsán potenciálisan felmerülő részletkérdést a pandektahagyományoknak megfelelően rendezni. 
Az ABGB szükszavú szabályozása miatt vitatott volt a korabeli jogtudományban és a joggyakorlatban is a hibás teljesítés miatti kártérítés jogalapja. A vevő nem rendelkezett a római jogból ismert árleszállítási igénnyel, valamint az igények közötti választási joga sem volt. Ezen kívül vitatott volt az igényérvényesítési határidők jogi jellege is.

A BGB nagyrészt a pandektisták munkája nyomán letisztult római jogi megoldásokat vezette be az adásvétel kellékhibás teljesítésének részletes szabályozásában. $\mathrm{Az}$ aediliszi kellékszavatossági igényeken kívül fajlagos vétel esetén szabályozta a kicserélés jogát, és egyértelműen meghatározta a hibás teljesítés miatti kártérítés jogalapját is. A két kódex a különbségek mellett azonban hasonlóan szabályozta a nagy gazdasági jelentőséggel bíró állatok adásvétele esetén fennálló kellékszavatosság kérdését.

A fenti két magánjogi kódex kellékhibás teljesítésre vonatkozó rendelkezései elsősorban a tanult hazai jogtudósok közvetítő munkájának eredményeképp - tükröződtek a XIX-XX. századi magyar jogéletben. A kellékszavatosság az ún. köztörvényi vételek esetén nem nyert hatályos szabályozást a dolgozat első rész harmadik fejezetében vizsgált időszakban (1853-1959.), ezért gyakran nagy zavart okozott a kodifikáció hiánya a hibás teljesítés illetve annak centrális jogintézménye, a kellékszavatosság megítélésében. A helyzetet segítette az 1875 . évi Kereskedelmi törvény megalkotása, amelynek a kellékhibás teljesítésre vonatkozó rendelkezéseit azonban csak analógia útján lehetett a kereskedelmi vételnek nem minősülő ingó adásvételi ügyletekben alkalmazni.

Változást az 1928-ra megalkotott Magánjogi Törvényjavaslat hozott, amely nagyban tükrözte a kellékhibás teljesítésre vonatkozó korábbi magyar bírói gyakorlatot. Annak ellenére, hogy nem lépett hatályba, szabályai a megalkotása utáni időszakban nagy hatást gyakoroltak a bírói jogalkalmazásra. A kellékhibás teljesítésre vonatkozó rendelkezések az adásvétel jogában kaptak helyet az Mtj.-ben, és e rendszerbeli elhelyezés mellett a kérdéskör szabályozási koncepciója és részletes tárgyalása is a pandektajog és a BGB hatását mutatja.

A kellékhibás teljesítés szabályai az 1959-ben elfogadott magyar Polgári Törvénykönyvben váltak egységes, hatályos törvényi rendelkezésekké. Az első rész negyedik fejezete a kellékhibás teljesítés magyar fejlődésének bemutatását folytatta az ezt követő időszakban. A Ptk. - az ABGB mintáját követve - a visszterhes szerződések hibás teljesítéséről rendelkezett a szerződésszegés egyes esetei körében. Bár annak centrális jogkövetkezményeként a kellékszavatosságot jelölte meg, a szerződésen kívüli károkozás szabályainak alkalmazásával lehetővé tette a hibás teljesítés miatti kártérítés követelését is a jogosult számára. Ezen igény jogalapja azonban - a szükszavú rendelkezésnek is 
köszönhetően - vita tárgyát képezte a jogtudományban. A jótállásról rendszertanilag ugyancsak vitatott módon - a szerződést biztosító mellékkikötések körében rendelkezett a kódex, de annak a legnagyobb relevanciája kezdettől fogva a hibás teljesítés esetén volt a gyakorlatban. A Ptk. nyomán alkotott speciális jogszabályok meghonosították jogrendszerünkben a kötelező, jogszabályon alapuló jótállást, amely a minőségvédelem fontos eszközeként funkcionált a kereskedelmi forgalomban eladott ingó dolgok esetén. A szabályozás azonban dogmatikai zavart okozott a kellékszavatosság és a jótállás elhatárolásánál.

A XX. század második felében felmerülő gazdasági, társadalmi és jogpolitikai elvárásoknak az 1959-es szabályok több ponton nem tettek eleget, ezért került sor a hibás teljesítés és a jótállás szabályainak megreformálására is az 1977-es Ptk.-novella keretei között. A belkereskedelemről szóló 1978. évi I. törvény már külön fejezetben foglalkozott a „fogyasztói érdekvédelem” és a kereskedelmi forgalomban árusított ingó dolgok minőségvédelmének kérdésével. A vásárlói („fogyasztói”) érdekvédelem jegyében a Ptk. felhatalmazása alapján megalkotott egyes speciális jogszabályok a vásárló javára már a magánjogi diszpozitivitástól eltérően klaudikálóan kógens rendelkezéseket tartalmaztak.

Ez a hazai szabályozási megoldás mintegy átvezet a dolgozat második, az ingó adásvétel hibás teljesítésének hatályos szabályait tárgyaló részébe. Az 1957-ben létrehozott Európai Gazdasági Közösségben a szabad piac kiépítésének igényei nyomán kibontakozó gazdasági és társadalmi célkitűzések az 1970-es évek közepére a szupranacionális jogalkotó fogyasztóvédelmi célú normaalkotásához vezettek.

Az 1990-es években az Európai Unió fogyasztóvédelmi szerződési jogot érintő jogalkotásának keretei között a fogyasztási cikkek adásvételének és a kapcsolódó jótállásnak egyes vonatkozásairól szóló 1999/44/EK Irányelv is megszületett. A jogszabály célja az volt, hogy a tagállami jogszabályi és közigazgatási rendelkezések közeledjenek egymáshoz a fogyasztóvédelem egységes minimális szintjének biztosítása érdekében.

A dolgozat első részének első fejezetében vázoltak közül az alábbi történeti jellemzők tükröződése figyelhető meg az Irányelvben:

1. a gyengébb gazdasági pozícióban lévő fél védelmének jogpolitikai célja [Preambulum (21)-(24) bekezdések; 1. cikk (1) bekezdés],

2. emellett az elöírásokban fellelhető a fogyasztó eljárását illetően a caveat emptor elve [2. cikk (3) bekezdés],

3. a vevő által nem ismert, rejtett kellékhibák relevanciája [2. cikk (3) bekezdés], 
4. a dolog szerződésszerü használhatóságának kritériuma [2. cikk (1)-(2) bekezdések],

5. az objektív jogalapú helytállás [Preambulum (9) bekezdés; 3. cikk (1) bekezdés], valamint

6. a tisztességes eladói eljárás, a transzparencia követelménye [Preambulum (21) bekezdés; 6 . cikk (1)-(4) bekezdések].

A hibás teljesítés miatti kártérítés szabályozását tagállami hatáskörben hagyta az EU-s jogalkotó. A tagállami implementációk mellett a dolgozat célul tüzte ki az e kártérítési igény szabályozási megoldásainak összehasonlító vizsgálatát is, hiszen az jól szemlélteti, hogy az egyes államok egyéni magánjogi hagyományokra is támaszkodó jogalkotása milyen eltérően valósulhat meg.

Az Irányelv által meghatározott, a fogyasztóvédelem gazdasági, társadalmi és jogi koncepciójának megfelelő klaudikáló kógencia előírása jelentette a legnagyobb változást a korábbi tagállami magánjogi szabályozáshoz képest. A második rész második fejezetének tanúsága szerint a német jogalkotó az Irányelv implementálásával egybekötötte a polgári jogi kódex teljes kötelmi jogának reformját. A történeti hagyományokhoz igazodva a BGB adásvételi jogába, annak speciális fajtája, a fogyasztói adásvétel szabályai közé illesztette be a legtöbb implementáló rendelkezést, főként utaló szabályok formájában. Az átfogó kötelmi jogi reform koncepciójának megfelelően azonban például az elállás jogáról, valamint a kijavításról és a kicserélésről is a szerződésszegés általános szabályai között rendelkezett. Minden adásvételi szerződésre kiterjedő hatállyal általánossá tette a két éves elévülési határidőt a hibás teljesítés miatti igényérvényesítésre nézve.

A német megoldás számtalan utaló szabályt tartalmaz, ami a gyakorlatban véleményem szerint azt eredményezte, hogy nagyon gyakran nehezen követhető különösen a fogyasztói adásvétel hibás teljesítése esetén -, hogy mely szabályok hogyan és mely esetben alkalmazandóak. A jogalkotó a hiba miatt a dologban beálló ún. tapadó károk megtérítését a kellékszavatossághoz hasonló objektív helytállásként, míg az ún. következménykárok megtérítését a hibás teljesítés miatti felróhatósági alapú, szubjektív jogkövetkezményként szabályozza. A koncepció célja egyértelmü, a szabályok azonban gyakran ez esetben is csak nehézkesen követhetőek az utaló normák sokasága miatt.

Az implementáció megvalósítása után több jogértelmezési és konformitási kérdés is felmerült a német jogalkalmazásban és jogtudományban a hibásság vélelmével, a használt dolog fogalmával, az egyedi dolog kicserélhetőségével, a jótállási ígéret tartalmával, az eladó kicserélési kötelezettségének terjedelmével és az aránytalan jogorvoslat mércéjével 
kapcsolatosan. Az utóbbi két kérdéshez kapcsolódik az Európai Bíróságnak a fejezetben tárgyalt precedens értékü döntése, amely szerint a kicserélés igénye az új, hibátlan áru szolgáltatásának teljes folyamatát felöleli, beleértve a hibás áru eltávolításának és az új dolog beépítésének/beszerelésének a költségeit is. Az arányosság követelményét pedig szüken, csak az első lépcsős kicserélés és kijavítás relációjában ítélte irányadónak az EuB. Bár az ítélet érvelése véleményem szerint dogmatikailag több ponton nem állja meg a helyét, a végeredmény mintegy precedensként a fogyasztók részére az eddiginél is erőteljesebb védelmet irányoz elő a tagállamokban.

Az osztrák jogalkotó az Irányelv implementációjának keretei között a teljes hibás teljesítésre vonatkozó szabályozást úgy reformálta meg, hogy a joggyakorlat és a kereskedelmi praxis által kimunkált tradicionális kellékszavatossági szabályok ne menjenek át rendszeridegen változtatáson. Megkönnyítette a fogyasztóvédelmi rendelkezések meghonosítását az, hogy az osztrák fogyasztóvédelmi törvény a magánjogi fogyasztóvédelmi célú jogalkotás termékeit már a módosítás előtt is magában foglalta. Az Irányelv szerinti fogyasztói adásvételi ügyletek kellékhibás teljesítése tekintetében egyrészt az adásvétel ABGB-beli szabályai, a továbbra is a szerződésszegés közös szabályai között szereplö kellékszavatossági szabályok és a (minden visszterhes fogyasztói jogügyletre irányadó) fogyasztóvédelmi törvénybeli rendelkezések alkalmazandóak. A szabályozás azonban csak látszólag széttagolt; véleményem szerint valójában megkönnyíti a jogkeresők és a jogalkalmazók dolgát is. Az osztrák jogalkotó a hibás teljesítést illetően több ponton is példaértékủ szabályokat alkotott. Szankciót füz például a jótállási nyilatkozat kötelező tartalmi elemeinek hiányához, és kellően konkrétan fogalmaz a tekintetben, hogy a jótállási nyilatkozatban miként kell utalni a fogyasztónak a jótállás mellett fennálló, törvényen alapuló kellékszavatossági jogaira.

A svájci magánjogban a fogyasztóvédelmi jogalkotás az utóbbi bő egy évtized eredményeként kezdett el kibontakozni. Megmutatkozik ez az ingó adásvétel hibás teljesítésére vonatkozó szabályok körében is. Ennek ellenére többnyire még mindig a pandekta-hagyományokat tükröző eredeti, száz évvel ezelőtt megalkotott, egységes - a szerződő felek jogalanyiságától független - szabályok vannak hatályban. Ennek köszönhetően számos, a jogtudomány által régóta kritizált fogyasztóvédelmi deficitben szenved az OR szabályozása. Ez megmutatkozik többek között a rendelkezések diszpozitív jellegében, a szigorú megvizsgálási és kifogásközlési kötelezettség előírásában és a kellékszavatossági kijavítási igény szabályozásának hiányában is. Üdvözlendő azonban, hogy a közelmúlt jogalkotása az igényérvényesítési határidők tekintetében az EU-s 
Irányelvvel csaknem teljesen megegyező, klaudikálóan kógens előírásokat épített az OR-be ingók „fogyasztói” adásvételének hibás teljesítése esetére.

A jogösszehasonlítás során nyilvánvalóvá vált számomra, hogy a modern német és osztrák dogmatika az eltérő implementálási koncepciók ellenére is milyen sok ponton egyezik a vizsgált területen. A svájci kódex jórészt a történeti hagyományokat tükrözi, így fogyasztóvédelmi szempontból lemarad a fenti két szabályozás mögött.

A fogyasztó és a vállalkozás egységes magánjogi fogalmát a német jogban a BGB, az osztrákoknál a fogyasztóvédelmi törvény tartalmazza, a svájci jogban viszont nincs egységes fogalmi meghatározás. Az osztrák jog tágan értelmezi a fogyasztót, szemben a BGB-vel, amely a természetes személyekre szükíti a fogalmat.

A német és az osztrák jogrendszer elkülönülten szabályozza a kereskedelmi, illetve az annak nem minősülő (,egyszerü”) adásvétel rendelkezéseit. A fogyasztói adásvétel kategóriája az adásvétel egyik speciális fajtája a BGB-ben, az osztrák jogalkotó viszont a legtöbb implementáló rendelkezés hatályát kiterjesztette a fogyasztó és a vállalkozás között kötött minden jogügyletre. A svájci jogban bármely jogalanyok közötti adásvételre egységes szabályok alkalmazandóak, a fogyasztói adásvétel így csupán elméleti kategória, amelyre egyedül a 2013-tól hatályos szavatossági határidő utal jogszabályi szinten.

A szubjektív kellékhiba-fogalom relevanciája érvényesül mindhárom vizsgált jogrendszerben, azaz a szerződő felek alkuja és megállapodása az elsődleges a kellékhiba fennállásának megállapításánál. A hibás teljesítés központi jogkövetkezménye, a kellékszavatosság mindhárom jogrendszerben objektív jogalapú, az osztrák és a svájci jogban azonban az egyes tulajdonságokra vonatkozó eladói ígéret, valamint az eladó csalárd magatartása szubjektív jogalapon is megtorlást nyer a szabályozásban, ami a történeti hagyományokat tükrözi. A svájci jog differenciál az egyedi és a fajlagos vétel, illetve a nyílt és rejtett kellékhibák között, a német és az osztrák magánjogban ilyen különbségtételek nincsenek.

A fogyasztóknak kedvez a klaudikálóan kógens szabályozás a német és az osztrák jogban. A svájci OR rendelkezései ellenben diszpozitívak, és emellett a kódex a szigorú megvizsgálási és haladéktalan kifogásközlési kötelezettség elöírása is megnehezíti a fogyasztók igényérvényesítését. Következetes mindhárom szabályozás abban, hogy nem értékeli hibás teljesítésként azt, ha a kellékhibáról a jogosult tudott a szerződéskötéskor.

A kellékszavatossági igények lépcsős rendszerét szabályozza a német és az osztrák jog az Irányelvnek megfelelően: elsősorban a hibás teljesítést természetben orvosló kijavítás és kicserélés igényét érvényesítheti a fogyasztó, második lépcsőben - bizonyos 
feltételekkel - pedig árleszállítást kérhet vagy elállhat a szerződéstől. A svájci jogban az általános az utóbbi két szavatossági igény, a kicserélés csak fajlagos vétel esetén lehetséges, a kijavításról pedig egyáltalán nem rendelkezik az OR. A vételárcsökkentés számításának részletes BGB-beli szabályát a német mellett az osztrák és a svájci joggyakorlat is alkalmazza. A kellékszavatossági igényérvényesítés elévülési határideje mind a német, mind az osztrák jogban két év, amely ingók esetén a dolog leszállításától indul, és használt dolgok adásvétele esetén legkevesebb egy évre csökkenthető. A bizonyítás terhének könnyítésére mindkét jogban fennáll a hibásság hat hónapos - az ABGB-ben minden visszterhes szerződésre is alkalmazandó - vélelme. Svájcban a határidő 2013-tól „fogyasztói adásvétel” esetén szintén két év, de az OR nem állítja fel a hibásság vélelmét.

A hibás teljesítés miatt kártérítést is érvényesíthet a fogyasztó mindhárom nemzeti magánjog szerint, de a szabályozási megoldások eltérnek egymástól e kérdésben. Annyiban egyezik a három megközelítés, hogy mind megkülönbözteti a hibás teljesítéssel közvetlenül okozott (tapadó) károkat a közvetett (következmény-) károktól. Az elöbbit a német jog objektív jogalapon a kellékszavatossági határidőkön belül, az utóbbit felróhatósági alapon, az általános három éves határidőn belül teszi lehetővé, de mindkettő a kellékszavatosság melletti alternatív jogorvoslat.

Az osztrák szabályozás is objektív jogalapon biztosítja a tapadó károk követelését, amely csak a kellékszavatossági igények helyett lehetséges, és a kódex meghatározza a kártérítés feltételesen választható módjait is. A következménykárok megtérítésének szubjektív a jogalapja az osztrák jogban is, segíti azonban az igényérvényesítést, hogy ilyen károk keletkezésénél az eladó felróhatósága vélelmezendő. További különbség a némethez képest, hogy mindkét kárfajta megtérítését a kötelmi általános három éves elévülési időn belül lehet követelni.

A svájci jogban ugyancsak objektív a tapadó károk, és szubjektív a következménykárok megtérítésének jogalapja, az utóbbi a jogirodalomban azonban nem egyértelmü, mert vitatott a pozitív és negatív interesse megítélése. A kétéves határidő „fogyasztói adásvétel” esetén a hibás teljesítés miatti kár bármely fajtájának megtérítése esetén is irányadó, amely jelentősen nehezíti a fogyasztó igényérvényesítését.

Mindent összevetve az osztrák magánjog szabályozási koncepcióját és megoldásait tartom a legvilágosabbnak, és e szabályok között találtam a legtöbb példaértéküt, amelyek a magyar jogalkotásban de lege ferenda megfontolandóak lehetnek. 
A dolgozat második részének harmadik fejezete a magyar implementáció kérdéseit tárgyalja az 1959. évi IV. törvény (régi Ptk.) 2003-ban módosult szabályait vizsgálva. Az osztrák megoldáshoz hasonlóan számos rendelkezés minden visszterhes szerződésre nézve alkalmazandó, a fogyasztói adásvételre vonatkozó EU-s szabályok pedig - bizonyos kivételekkel - minden ingó dologra vonatkozó fogyasztói szerződésre alkalmazandóak. Míg a régi Ptk. szabályozása számos ponton szó szerint tükrözi az Irányelv megoldásait, addig több olyan rendelkezés is szerepelt a kódexben, amely a jogtudomány és a bírói gyakorlat értelmezésére szorult. Ilyen értelmezési kérdések merültek fel többek között azzal kapcsolatban, hogy a jogosultnak a hibát mikor „kell ismernie"; hogyan ítélendő meg a kijavítási költségek követelésének az igénye; az arányosság mércéjét miként kell alkalmazni az igényérvényesítés során; hogyan ítélendő meg a hibás teljesítés miatti kártérítési igény kérdése; milyen részletszabályai lehetnek a hibásság vélelmének. Kritika érte a szabályozást az igényérvényesítési határidők bonyolult rendszere miatt is, ezen kívül a jótállás rendszerbeli elhelyezése is további vita tárgyát képezte.

A második rész utolsó, negyedik fejezete azt mutatja be, hogy a magyar jogban felmerülő jogalkalmazási és jogértelmezési kérdéseket miként orvosolta a jogalkotó az új Polgári Törvénykönyv idén hatályba lépett szabályozásában. Az új kódex nagy eredménye többek között, hogy a kellékhibás teljesítés három (tradicionális) jogkövetkezménye - törvényileg is nevesítve - a kellékszavatosság, a jótállás és a kártérítés lett. A külön jogszabályok és a Fgytv. meghatározásával harmóniába került az új Ptk. csak természetes személyekre kiterjedő fogyasztó-fogalma. Dogmatikailag letisztult a jogkövetkezmények elkülönítése a jogalap és az igényérvényesítési határidők tekintetében is. Különösen üdvözlendő a szerződésszegéssel és a szerződésen kívül okozott károk német mintát is követő - elkülönített szabályozása. A hibás teljesítés miatti kártérítési rendelkezések is új alapokra helyeződtek a tapadó károk és a következménykárok eltérő jogi értékelése nyomán.

Az új Ptk. kétségtelenül számos ponton letisztult szabályokat tartalmaz a fogyasztó és a vállalkozás között kötött adásvételi szerződés hibás teljesítése tekintetében is. A dolgozat hatályos nemzetközi jogösszehasonlító fejezetének megállapításait és tanulságait szem előtt tartva mégis a következő, kiegészítő de lege ferenda javaslatokkal élek.

1. A kellékszavatosság kapcsán megfontolandónak tartom az árleszállítás számítási módszerének törvényi meghatározását. Ennek két módját tartom lehetségesnek: a magyar jogalkotó átveheti a több becslőeljárást feltételező, a német dogmatikában kidolgozott 
relatív számítási módszer szabályát; ${ }^{1937}$ vagy a magyar bírói joggyakorlat által kidolgozott elveket felsorolva is meghatározhatja az árleszállítás kiszámításakor irányadó szempontokat. Ilyen lehet a kijavítás költségének, a hiba rendeltetésszerü használatot befolyásoló jellegének, a dolog elhasználódását felgyorsító mivoltának az együttes mérlegelése, valamint annak figyelembe vétele, hogy a hiba miatt mekkora a dolog természetes elhasználódáshoz viszonyított értékcsökkenése. ${ }^{1938}$

2. Megfontolandó lenne az osztrák fogyasztóvédelmi törvényhez hasonló módon rendezni a Ptk.-ban - vagy a fogyasztó és a vállalkozás közötti szerződések részletes szabályairól szóló 45/2014. (II. 26.) Kormányrendeletben - a kicserélés és a kijavítás foganatosításának részletszabályait (helyszínét, tételes költségviselését, stb.) az igényérvényesítés megkönnyítése érdekében. ${ }^{1939}$

3. Megfontolandónak tartom annak a német szabálynak az átvételét, amely szerint megdönthető vélelem áll fenn amellett, hogy a kijavítási igény teljesítése a második sikertelen kísérlet után meghiúsult. ${ }^{1940} \mathrm{Ez}$ véleményem szerint megelőzné a sokszoros kijavításból eredő jogosulti kellemetlenséget és közvetett károkat.

4. Megfontolandónak tartom a termékszavatosság rendszerbeli elhelyezésének módosítását. Az új Ptk. kötelmi általános része a szerződésszegésekről rendelkezik, a termékszavatosság azonban egy kötelmi jogviszonyon kívüli, de a fogyasztási célra vásárolt ingó dolgok adásvételéhez közvetetten mégis kapcsolódó helytállási kötelezettség. Az adásvétel általános szabályaiban rendelkezik a kódex többek között a fogyasztó és a vállalkozás közötti adásvétel esetén irányadó kárveszély-átszállási szabályokról és az e szerződés esetén felmerülő eladói késedelemről is, ezért véleményem szerint a

\footnotetext{
${ }^{1937}$ BGB $§ 441$ (3)-(4): „Vételárcsökkentés esetén a vételárat olyan arányban kell leszállitani, amilyen arányban a hibátlan áru szerzödéskötéskori értéke az áru tényleges értékéhez viszonyulna... Amennyiben a vevö a csökkentett vételárnál többet fizetett, az eladó köteles a különbözetet a vevö részére visszatéríteni..." (saját fordítás).

${ }^{1938}$ Vö.: BH 1985. 320., BH 1985. 394., BH 1988.182., BH 1995. 92., BH 1995. 212. Lásd: I. rész 4. fejezet 6.2.1. pont.

${ }^{1939}$ Vö. KSchG § 8 (1)-(2): „Ha a vállalkozó kicserélésre vagy kijavitásra kötelezett, akkor azt 1. az átadás helyén kell foganatositani; ha a dolgot a vállalkozó a szerzödésnek megfelelöen valamely belföldi helyre küldte vagy szállitotta, akkor ez minösül az átadás helyének; vagy ha a fogyasztó azt kéri, akkor

2. azon a helyen kell foganatositani, ahol a dolog szokásosan található, amennyiben az belföldön van, az a vállalkozónak nem „meglepö”, és amennyiben a dolognak a vállalkozóhoz szállitása a fogyasztó által a dolog jellege miatt lehetetlen, különösen, ha a dolog hatalmas, nehéz, vagy beépités folytán ingatlanná vált. Amennyiben azonban a dolog elküldése a fogyasztó által megvalósitható, akkor a vállalkozó kérheti ezt. Az elküldéssel járó veszélyt azonban a vállalkozó viseli." (saját fordítás).

${ }^{1940}$ BGB § 440. 2. mondat: „A kijavitás a második sikertelen kísérlet után meghiúsultnak tekintendö, hacsak különösen a dolog vagy a hiba jellegéböl, illetve az egyéb körülményekböl más nem következik." (saját fordítás).
} 
termékszavatossági rendelkezések is jobban illenének dogmatikailag az adásvétel szabályai közé.

5. A jótállással kapcsolatban is példaértékünek tartom az osztrák fogyasztóvédelmi törvény rendelkezéseit. ${ }^{1941}$ Bár a magyar jogalkotó nem építette be az új kódexbe, én mégis szükségesnek tartom a jótállás kötelező tartalmi elemeinek rendezését az Irányelv elöírásának és a régi Ptk.-nak megfelelően, szankciót is füzve a rendelkezések be nem tartásához. Ennek fényében a következő kiegészítő szövegjavaslattal élek:

új Ptk. 6:171. § (3) bekezdés: „A fogyasztó és a vállalkozás között kötött szerzödés esetén a jótállásnak tartalmaznia kell azt, hogy a fogyasztót a Polgári Törvénykönyv 6:159-6:170. §-ai szerint kellékszavatossági és termékszavatossági jogok illetik meg, és nyilvánvalóvá kell tennie azt, hogy ezek a jogok a jótállás fennállása esetén attól függetlenül is érvényesithetöek. A jótállásnak világosan és közérthetöen meg kell határoznia a jótállás tartalmát és igénybevételének feltételeit, különösen a jótállás idötartamát és területi hatályát, valamint a jótállásra kötelezett nevét és cimét."

(4) bekezdés: „A (3) bekezdésben foglalt követelmények megsértése a jótállás érvényességét nem érinti, a kötelezett azonban az ebböl eredö, a jogosultat ért károk megtéritésére köteles."

6. Megfontolandónak tartom a jótállás vonatkozásában annak a német jogtudományi álláspontnak és bírói gyakorlatnak a 45/2014. Kormányrendeletbe integrálását, amely szerint a fogyasztási cikkhez nyújtott gyártói jótállás a fogyasztó és a vállalkozás közötti adásvételi szerződés megkötése után a kereskedőt is automatikusan, ugyanolyan tartalommal köti. ${ }^{1942}$ Ez véleményem szerint egyszerübbé tenné az igényérvényesítést.

7. Megfontolandónak tartom a használt tartós fogyasztási cikkek hibás teljesítése miatti kellékszavatosság érvényesítésének határidejére vonatkozó speciális rendelkezés megfogalmazását ugyancsak az osztrák magánjogi példa alapján. ${ }^{1943}$ Ez a kérdés komplex, ezért megvalósításához azt is szükségesnek tartom, hogy a jogalkotó rendezze azt a kérdést, hogy mely ingók minősülnek tartós fogyasztási cikknek. Erre a legjobb megoldást az új Ptk. értelmező rendelkezései közé ékelt szabály jelentené. Kielégítő lehet azonban az a megoldás is, ha az egyes tartós fogyasztási cikkekre vonatkozó kötelező jótállásról szóló 151/2003. Kormányrendeletben rendelkezik konkrétan a tartós fogyasztási cikkek fogalmi köréröl a jogalkotó.

\footnotetext{
${ }^{1941}$ Lásd: KSchG § 9b. (1)-(4).

${ }^{1942}$ Lásd: II. rész 2. fejezet 7.5.1. pont.

1943 KSchG § 9 (1): „... A törvényesnél rövidebb kellékszavatossági határidő kikötése hatálytalan, de használt ingó dolgok értékesitése esetén egy évre csökkenthetö a határidö, amennyiben azt a felek egyedileg megtárgyalják. Gépjármüvek esetén egy ilyen rövidítés csak akkor hatályos, ha az elsö forgalmi engedély kibocsátása óta több mint egy év eltelt." (saját fordítás).
} 
A dolgozat a vizsgált tág időintervallum keretei között igyekezett bemutatni azt, hogy az ingó adásvétel hibás teljesítésének szabályozása és a szerződésszerü teljesítéshez füződő érdek védelme mindig az adott kor gazdasági, társadalmi körülményei és jogpolitikai célkitüzései szerint alakul a jogi szabályozásban. A jogtörténeti és jogösszehasonlító következtetésekkel remélhetőleg sikerült azonban rámutatni arra, hogy az ókortól egészen napjainkig a jogalkotási elvek, a dogmatikai jellemzők és a mindenkor vitatott kérdések milyen sok ponton mutatnak szembetünő funkcionális hasonlóságot. 


\section{Hivatkozott Digesta-helyek}

D. $2,14,31$

D. $4,3,1,1$

D. $4,3,37$

D. $18,1,43$ pr.

D. $18,5,6$

D. $19,1,11$ pr.

D. $19,1,11,1$

D. $19,1,11,8$

D. $19,1,13 \mathrm{pr}$.

D. $19,1,13,1$

D. $19,1,13,2$

D. $19,1,13,3$

D. $19,1,4$ pr.

D. $19,1,4,1$

D. $19,1,6$ pr.

D. $19,1,6,8$

D. $21,1,1,1$

D. $21,1,1,2$

D. $21,1,1,3$

D. $21,1,1,7$

D. $21,1,1,8$

D. $21,1,1,9$

D. $21,1,1,10$

D. $21,1,1,11$

D. $21,1,4,1$

D. $21,1,4,3$

D. $21,1,5$

D. $21,1,6$ pr.

D. $21,1,10$ pr.

D. $21,1,12,1$

D. $21,1,14,10$

D. $21,1,17 \mathrm{pr}$.

D. $21,1,17,1$

D. $21,1,17,14$

D. $21,1,17,17$

D. $21,1,17,20$

D. $21,1,18 \mathrm{pr}$.

D. $21,1,18,1-2$

D. $21,1,19$ pr.

D. $21,1,19,1$

D. $21,1,19,2$

D. $21,1,19,3$ 

D. $21,1,19,6$
D. $21,1,21 \mathrm{pr}$.
D. $21,1,23,2$
D. $21,1,23,3$
D. $21,1,23,4$
D. $21,1,23,5$
D. $21,1,23,7$
D. $21,1,23,8$
D. $21,1,23,9$
D. $21,1,25$ pr.
D. $21,1,25,1-4$
D. $21,1,25,9$
D. $21,1,25,10$
D. $21,1,31,11$
D. $21,1,31,16$
D. $21,1,31,21$
D. $21,1,31,22$
D. $21,1,32$ pr.
D. $21,1,33$ pr.
D. $21,1,37$
D. $21,1,38$ pr.
D. $21,1,38,7$
D. $21,1,48,2$
D. $21,1,48,5$
D. $21,1,48,8$
D. $21,1,52$
D. $21,1,53$
D. $21,2,31$
D. $21,2,32,1$
D. $21,31,16$ pr. 


\section{Hivatkozott bírósági határozatok, állásfoglalások}

\section{Magyarország}

- 621/1882. sz. hat.

- 1886. 01.26.6222. sz. curiai hat.

- 193/1897. sz. döntés

- 1887. 12. 7., 917. sz. a. curiai hat.

- 866/1889. sz. curiai hat.

- 1295/1889. sz. curiai hat.

- 7157/1890. sz. curiai hat.

- 3672/1891. sz. curiai hat.

- 1893.04. 17. 3604. sz. a. curiai hat.

- 1895 12. 18. 1367/94. sz. a. curiai hat.

- 1897. 06. 24. 5178. sz. curiai hat.

- 51/78/1897. sz. hat.

- 1897. 10. 29. 463. sz. a. curiai hat.

- D3f. 5/339.

- D3f. 6/34.

- D3f. $8 / 34$.

- D3f. 9/44.

- D3f. 10/155.

- D3f. 10/349.

- D3f. 17/100.

- D3f. 17/245.

- D3f. 18/32.

- D3f. 18/50.

- D3f. 19/61.

- D3f. 22/80.

- D3f. 24/43.

- D3f. 25/140.

- D3f. 26/79.

- D4f. 1/125.

- D4f. $1 / 88$.

- D4f. $2 / 131$.

- D4f. $2 / 32$.

- D4f. 3/47.

- D4f. 4/133.

- D4f. 4/140.

- Drf. 21/60.

- Drf. 23/59.

- Drf. 27/43.

- Duf. 4/159.

- Duf. 5/81.

- Duf. 9/19.

- Duf. 20/28.

- Duf. 25/102.

- Duf. 30/56.

- Duf. 30/69.

- Duf. 31/46. 
- Duf. 35/76.

- Duf. 37/38.

- Duf. 39/37.

- Duf. 40/48.

- D. új f..40/171.

- 187/1901.

- 5949/1901. (Dt. 3. f. XXII. 40.)

- I. G. 651/1901. (Dt. 3. f. XXII. 178.)

- 80/1902. (Dt. 3. f. XXII. 194.)

- 173/1902.

- G. 87/1904. (Dt. 3. f. XXVII. 128.)

- 4706/1904. (Dt. 4. f. IV. 140.)

- 4502/1905. (MD. I. 16.)

- 5437/1908. (PHT. 116., MD. III. 178.)

- 308/1909. (MD. III. 163.)

- 2456/1913. (Gr. XV. 497.)

- 3849/1916. (MD. XI. 11.)

- 6673/1917. (PHT. 661.)

- P. II. 2348/1917. (MD. XI. 227.)

- 55/1917. (MD. XI. 226.)

- P. VII. 3483/1917. (MD. XII. 16.)

- 1891/1917. (MD. XI. 159.)

- 7091/1917. (MD. XII. 115.)

- 1071/1918. (MD. XII. 177.)

- 469/1919.

- P. II. 5445/1921. (MD. XVI. 11.)

- P. IV. 6063/1922. (MD. XVI. 98.)

- P. II. 2103/1922. (MD. XVI. 87.)

- 5840/1924. (Gr. XIX. 579.)

- 1690/1925.

- P. II. 513/1927. (Grill XXI. 746.)

- P. V. 5828/1928. (MD. XXIII. 118.)

- P. IV. 698/1928. (PHT. 848.)

- P. V. 3778/1929. (MD. XXIII. 73.

- P. II. 7999/1929. (Grill XXIV. 582.)

- P. VI. 226/1931. (MD. XXIV. 122)

- P. VI. 1776/1931. (MD. XXVI. 121.)

- PJD. IV. 116.

- LB. P. törv. I. 22.044/1960.

- 55. Pf. 30.857/1960.

- P. II. 25.817/1961.

- 16. P. 29.855/1961.

- 16. P. 86.721/1961.

- Pf. IV. 22.202/1961.

- 43. Pf. 27.657/1961.

- Fővárosi Bíróság Táj. 29/848. 1963.

- Kecskeméti Járásbíróság P. 22.919/1963.

- BH. 1964. 4. 3948.

- P. törv. IV. 20211/1972.

- BH 1980/1/26.

- BH 1981. 466.

- BH 1982. 522. 
- BH 1984.12. 490.

- BH 1985. 320.

- P. törv. III. 21 143/1985.

- P. törv. III. 20 112/1985.

- BH 1985. 394.

- BH 1986. 10.

- BH 1986.2. 60., PJD XI. 130.

- BH 1986. 430.

- BH 1987.1., LB Gf. I. 30 274/1986.

- BH 1988. 41.

- BH 1988. 182.

- BH 1989. 6. 228., P. törv. III. 20 622/1988.

- BH 1990. 387.

- BH 1990. 4. 138., P. törv. III. 20 277/1989.

- BH 1990. 9. 346., LB Gf. V. 31 815/1989.

- BH 1991. 10. 404., LB Gf. I. 31 970/1990.

- BH 1992. 263.

- BH 1992. 10. 654., LB Gf. V. 32 327/1991.

- LB Gf. III. 31 401/1992.

- BH 1994. 608.

- BH 1995.2. 92.

- BH 1995. 92.

- BH 1995. 154.

- BH 1995. 212.

- BH 1995. 638.

- BH 1995. 706.

- BH 1995. 724.

- BDT 2001.12. 192.

- EBH 2004. 1093.

- BDT 2004. 1072.

- BH 2006. 343.

- BDT 2006. 1510.

- BDT 2006. 1302.

- Fővárosi Ítélőtábla 6. Pf. 20.911/2008/7.

- Pécsi Törvényszék 2. Pf. 20.032/2009.

- BDT 2009. 2088.

- Zalaegerszegi Törvényszék 3. Pf. 20.116/2009/3.

- Pécsi Törvényszék 2. Pf. 20.194/2010.

- 1971. El. II. D. 22. számú tanácselnöki értekezleti vélemény

- GKT 31/1973. sz. állásfoglalás

- GKT 63/1973. sz. állásfoglalás

- GKT 75/1973. sz. döntés

- XXX. Polgári Elvi Döntés

- XXXI. Polgári Elvi Döntés

- 35. számú PK állásfoglalás

- 44. számú PK. állásfoglalás

- 56. számú PK állásfoglalás

- 12. számú GKT állásfoglalás

- 72. számú GKT állásfoglalás

- 31/1973. számú GKT állásfoglalás

- 63/1973. számú GKT állásfoglalás 
- 1. számú PED-GED

- Kúria 1/2004. (XII. 2.) számú Polgári Kollégiumi véleménye

- Szegedi Ítélőtábla Polgári Kollégiumának 1/2004. évi (VI. 17.) számú kollégiumi ajánlása a hibás teljesítés egyes jogértelmezési kérdéseiről

- Szegedi Ítélőtábla 2/2004. (VI. 17.) számú kollégiumi ajánlása

- Debreceni Ítélőtábla 2010.El.II.C.54/5. számú polgári kollégiumi anyaga

- 1/2010. (VI. 28.) PK vélemény

- Pécsi Ítélótábla 2011.EL.II.C.25. számú összefoglaló kollégiumi anyaga

- 2/2011. (XII. 12.) Polgári Kollégiumi vélemény

- Kúria 1/2012. (VI. 21.) számú Polgári Kollégiumi véleménye

- 14/1991. (IV. 13.) AB határozat

- 436/B/2010. AB határozat

\section{Európai Unió}

- C-470/93. sz. ítélet

- C-210/96. sz. ítélet

- C-220/98. sz. ítélet

- C-541/99 és C-542/99. sz. egyesített ítélet

- C-404/06. sz. ítélet

- C-137/08. sz. ítélet

- C-243/08. sz. ítélet

- C-65/09. és C-87/09. sz. egyesített ítélet

- C-32/12. sz. ítélet

\section{Németország}

- RG. 3/216.1. számú döntés

- OLG Oldenburg 22.09.2003, 9 W 30/03.

- OLG Celle, ZGS 2004, 474.

- $\quad$ BGH VIII ZR 329/03 (2004) ZIP 1368.

- BGH 22.11.2004, VIII ZR 21/04.

- OLG Braunschweig 20.02.2006, 3U 42/05.

- OLG Oldenburg 9 O 2979/05, 2006.

- BGH VIII ZR 173/05 (2006) NJW 2250.

- BGH NJW 2006, 47.

- BGH NJW 2006, 434.

- BGH NWJ 2006, 2251

- BGH NJW 2009, 3780.

- BGH, NJW 2010, 148.

- BGH, 13.07.2011, VIII ZR 215/10.

- BGH 17.10.2012 VIII ZR 226/11.

\section{Ausztria}

- $\mathrm{OGH} 4514$

- OGH 1761

- OGH 1148.

- OGH 1597

- OGH 4862 
- OLG Wien KRES 1a/22.

- OLG Wien KRES 1a/23.

- SZ 63/134.

- JAB 1223 BlgNR 14. GP 2.

- Erl 422 BlgNR 21. GP 23.

- EB 422 BlgNR 21. GP 15.

- OGH 27.4.1976 EvBl 1976/238.

- EvBl 1989/116.

- OGH 7.3.1990 SZ 63/37.

- 3 Ob 547/93 wobl 1994, 230.

- 7 Ob 155/03z JB1 2004, 183.

- 3 Ob 58/05h ÖBA 2006, 461.

- 2 Ob 191/07p ecolex 2008, 1014.

\section{Svájc}

- BGE 26 II 194.

- BGE 26 II 798.

- BGE 56 II 430.

- BGE 67 II 137.

- BGE 81 II 210.

- BGE 87 II 245.

- BGE 88 II 365.

- BGE 88 II 416.

- BGE 90 II 86.

- BGE 91 II 344.

- BGE 99 II 189.

- BGE 104 II 357.

- BGE 109 II 24.

- BGE 111 II 162.

- BGE 113 II 78.

- BGE 114 II 134.

- BGE 135 III 7.

- BGer 4C. 395/2001.

- BGer. 4A. 70/2011.

- BGer. 4A. 272/2011.

- BGer. 4D. 4/2011. 


\section{Hivatkozott jogszabályok, jogszabálytervezetek}

\section{Magyarország}

$>$ 1848. évi XV. törvénycikk az ösiség eltörléséről

> 1875. évi XXXVII. törvénycikk: a kereskedelmi törvény

> 1876. évi XVI. törvénycikk a végrendeletek alaki kellékeiröl

> 1877. évi XX. törvénycikk a gyámságról és gondnokságról

$>$ 1894. évi XXXI. törvénycikk a házassági jogról

$>$ 1900. évi polgári törvénykönyv tervezet

$>$ 1913. évi polgári törvénykönyv tervezet

$>$ 1923. évi V. törvénycikk a tisztességtelen versenyröl

> 1923. évi X. törvénycikk az állatforgalmi szavatosságról

$>$ 1934/1923. M. E. sz. rendelet

> Magyarország Magánjogi Törvénykönyvének Javaslata, 1928.

> 1950. évi 30. számú törvényerejü rendelet a tervszerü devizagazdálkodással kapcsolatos szabályokról

> 1952. évi III. törvény a Polgári Perrendtartásról

> A Magyar Népköztársaság Polgári Törvénykönyvének tervezete, 1957.

$>$ 1959. évi IV. törvény a Magyar Népköztársaság Polgári Törvénykönyvéröl (jelenleg: 1959. évi IV. törvény a Polgári Törvénykönyvröl)

$>$ 21/1959. (IV. 23.) Korm. rendelettel módosított 29/1958. (IV. 15.) Kormányrendelet

$>$ 1959. évi 23. törvényerejű rendelet a szőlö-, gyümölcs- és borgazdálkodásról

> 1960. évi 11. számú törvényerejü rendelet a Polgári Törvénykönyv hatálybalépéséröl és végrehajtásáról (Ptké.)

> A 3/1961. (XII. 14.) Élm. M.-Bk. M. sz. együttes rendelettel módosított 2/1961. (VI. 15.) Élm. M.-Bk. M. sz. együttes rendelet

$>1 / 1964$ (I. 11.) BkM rendelet

$>$ 56/1967. (XII. 19.) Kormányrendelet az árszabályozásról

$>$ 1/1968. (VI. 8.) ÁH sz. rendelkezés az árhatósági hatáskörökröl

$>$ 5/1968. (I. 27.) PM sz. rendelet a jótállási alap képzéséröl és a jótállási költségek elszámolásáról

$>$ 7/1968. (I. 30.) Korm. sz. rendelet a tartós fogyasztási cikkek jótállási kötelezettségéröl

$>$ 4/1969. (III. 30.) BkM - KGM - KipM - KkM - NIM sz. együttes rendelet az egyes tartós fogyasztási cikkek jótállásának legkisebb kötelező mértékéről

$>$ 1977. évi IV. törvény a Magyar Népköztársaság Polgári Törvénykönyvéről szóló 1959. évi IV. törvény módosításáról és egységes szövegéröl

$>$ 1978. évi 2. törvényerejü rendelet az 1977. évi IV. törvény hatálybalépéséről és végrehajtásáról (Ptké. II.)

$>$ 1978. évi IV. törvény a belkereskedelemröl

$>$ 4/1978. (III. 1.) BkM rendelet a vásárlók minőségi kifogásainak intézéséről

$>$ 2/1984. (III. 10.) BkM-IpM együttes rendelet

$>$ 11/1985. (VI. 22.) ÉVM-IpM-KM-MÉM-BkM együttes rendelet az egyes épületszerkezetek és azok létrehozásánál felhasználásra kerülő termékek kötelező alkalmassági idejéről

> 1988. évi IV. törvénnyel módosított 1976. évi IV. törvény az élelmiszerekröl 
> 10/1988. (VI. 30.) MÉM-SZEM egyesített rendelet a 1976. évi IV. törvény módosításáról

$>$ 117/1991. (IX. 10.) Kormányrendelet az egyes tartós használatra rendelt termékek jótállási kötelezettségéröl

$>$ 1994. évi I. törvény a Magyar Köztársaság és az Európai Közösségek és azok tagállamai között társulás létesítéséről szóló, Brüsszelben, 1991. december 16-án aláírt Európai Megállapodás kihirdetéséről (Európai Megállapodás)

$>$ 2145/1996. (VI. 13.) Kormányhatározat

$>$ 2298/1997. (IX. 30.) Kormányhatározat

> 1997. évi LVIII. törvény a gazdasági reklámtevékenységről

$>$ 1997. évi CLV. törvény a fogyasztóvédelemről

$>$ 1997. évi CXLIX. törvény

> 1997. évi LVIII. törvény a gazdasági reklámtevékenységről

> 4/1998 (I. 6.) IKIM rendelet a lábbelik címkézéséről

$>$ 1050/1998. (IV. 24.) Kormányhatározat

$>$ 1009/2002. (I. 31.) Kormányhatározat

$>$ 12/2002. (III. 14.) GM-KöViM-KöM együttes rendelet az új személygépkocsik üzemanyag-gazdaságossági és szén-dioxid-kibocsátási adatainak közzétételéről

> 2002. évi XXXVI. törvény a Polgári Törvénykönyv módosításáról

$>$ 49/2003. (VII. 30.) GKM rendelet a fogyasztói szerződés keretében érvényesített szavatossági és jótállási igények intézéséről

$>$ 151/2003. (IX. 22.) Kormányrendelet az egyes tartós használatra rendelt termékek jótállási kötelezettségeiröl

$>$ 249/2004. (VIII. 27.) Kormányrendelet az egyes javító-karbantartó szolgáltatásokra vonatkozó kötelező jótállásról

> T/5949. számú törvényjavaslat az új Polgári Törvénykönyvröl (2006.)

$>$ 2/2006. (I. 4.) Korm. rendelettel módosított 18/1999. (II. 5.) Kormányrendelet a fogyasztóval kötött szerződésben tisztességtelennek minősülő feltételekről

$>$ 2006. évi III. törvény a Polgári Törvénykönyvröl szóló 1959. évi IV. törvény, valamint egyes törvények fogyasztóvédelemmel összefüggő jogharmonizációs célú módosításáról

$>$ 2008. évi XLII. törvény a fogyasztókkal szembeni tisztességtelen kereskedelmi gyakorlat tilalmáról

$>$ 2009. CXX. törvény a Polgári Törvénykönyvröl (hatályba nem lépett)

$>$ 1129/2010. (VI. 10.) Kormányhatározat

> T/7971. számú törvényjavaslat az új Polgári Törvénykönyvröl (2012.)

> 2013. évi V. törvény a Polgári Törvénykönyvröl.

\section{Európai Unió}

$>$ Római Szerződés, 1957.

$>$ Resolution 543 (1973) on a Consumer Protection Charter (17.05.1973). Angol nyelven elérhető:

http://www.assembly.coe.int/Mainf.asp?link=/Documents/AdoptedText/ta73/ERES543.ht

$\underline{m}$

$>$ Council Resolution of 14 April 1975 on a preliminary programme of the European Economic Community for a consumer protection and information policy. Angol nyelven elérhető: 
http://eur-

lex.europa.eu/LexUriServ/LexUriServ.do?uri=CELEX:31975Y0425(01):EN:NOT

$>$ 85/374/EGK irányelv a termékfelelősségröl

$>$ Egységes Európai Okmány, 1986.

$>$ 1987/102/EGK Irányelv a fogyasztói hitelre vonatkozó tagállami törvényi, rendeleti és közigazgatási rendelkezések közelítéséről

> 1990/314/EGK Irányelv a szervezett utazási formákról

$>$ Proposal for a Council Directive on unfair terms in consumer contracts, COM(90) 322. Angol nyelven elérhető: http://aei.pitt.edu/5704/1/5704.pdf

$>$ Maastrichti Szerződés, 1992.

$>$ Council Resolution of 13 July 1992 on future priorities for the development of consumer protection policy (92/C 186/01). Angol nyelven elérhető:

http://eur-

lex.europa.eu/LexUriServ/LexUriServ.do?uri=CELEX:31992Y0723(01):EN:HTML

$>$ Green Paper on Guarantees for consumer goods and after-sales services, COM(93) 509. Angol nyelven elérhető: http://eur-lex.europa.eu/LexUriServ/LexUriServ.do?uri=COM:1993:0509:FIN:EN:PDF

$>$ 1993/13/EGK Irányelv a fogyasztókkal kötött szerződésekben alkalmazott tisztességtelen feltételekröl

$>$ 1994/47/EK Irányelv az ingatlanok időben megosztott használati jogának megszerzésére irányuló szerződések egyes szempontjai vonatkozásában a fogyasztók védelméről

$>$ Council Cannes White Paper, $\operatorname{COM}(95) 163$ final/2

$>$ Proposal for a European Parliament and Council Directive on the sale of consumer goods and associated guarantees, $\operatorname{COM}(95)$ 520. Angol nyelven elérhetö:

http://eur-lex.europa.eu/LexUriServ/LexUriServ.do?uri=COM:1995:0520:FIN:EN:PDF

$>$ 1998/6/EK Irányelv a fogyasztók számára kínált termékek árának feltüntetésével kapcsolatos fogyasztóvédelemről

$>$ Amended proposal for a European Parliament and Council Directive on the sale of consumer goods and associated guarantees, $\operatorname{COM}(1998) 217$. Angol nyelven elérhető: http://eur-lex.europa.eu/LexUriServ/LexUriServ.do?uri=COM:1998:0217:FIN:EN:PDF

$>$ 1999/44/EK Irányelv a fogyasztási cikkek adásvételének és a kapcsolódó jótállásnak egyes vonatkozásairól

$>$ Decision 283/1999/EC establishing a general framework for Community activities in favour of consumers. Angol nyelven elérhetö: http://eur-lex.europa.eu/LexUriServ/LexUriServ.do?uri=CELEX:31999D0283:EN:HTML

> 2000/31/EK Irányelv a belső piacon az információs társadalommal összefüggő szolgáltatások, különösen az elektronikus kereskedelem, egyes jogi vonatkozásairól

$>$ 2002/65/EK Irányelv a fogyasztói pénzügyi szolgáltatások távértékesítéssel történő forgalmazásáról, valamint a 90/619/EGK tanácsi irányelv, a 97/7/EK irányelv és a 98/27/EK irányelv módosításáról

> 2005/29/EK Irányelv a belső piacon az üzleti vállalkozások fogyasztókkal szemben folytatott tisztességtelen kereskedelmi gyakorlatairól, valamint a 84/450/EGK tanácsi irányelv, a 97/7/EK, a 98/27/EK és a 2002/65/EK európai parlamenti és tanácsi irányelvek, valamint a 2006/2004/EK európai parlamenti és tanácsi rendelet módosításáról

$>$ Közösségi fogyasztóügyi politikai stratégia 2007-2013”, $\operatorname{COM(2007)~99.~Elérhető:~}$ http://ec.europa.eu/consumers/overview/cons_policy/doc/cps 0713 hu.pdf

$>$ Az Európai Unió Müködéséről szóló Szerződés (EUMSz)

$>$ Draft Charter of Fundamental Rights of the European Union (Convent 34). 
Angol nyelven elérhető:

http://www.europarl.europa.eu/charter/activities/docs/pdf/convent34 en.pdf

$>$ Az Európai Unió Alapjogi Chartája

$>$ 2011/83/EU irányelv a fogyasztók jogairól, a 93/13/EGK tanácsi irányelv és az 1999/44/EK európai parlamenti és tanácsi irányelv módosításáról, valamint a 85/577/EGK tanácsi irányelv és a 97/7/EK európai parlamenti és tanácsi irányelv hatályon kívül helyezéséröl.

\section{Németország}

$>$ Bürgerliches Gesetzbuch für das Deutsche Reich (,,alte Fassung”)

$>$ 1899. III/27. császári rendelet

$>$ Bürgerliches Gesetzbuch (,neue Fassung”)

$>$ Deutscher Bundestag Drucksache 14/6040

$>$ Deutscher Bundestag Drucksache 14/6857

Dinführungsgesetz zum Bürgerlichen Gesetzbuch

$>$ Verordnung über Informations- und Nachweispflichten nach bürgerlichem Recht (BGBInfoV).

\section{Ausztria}

Allgemeines Bürgerliches Gesetzbuch für die gesammten deutschen Erbländer der Österreichischen Monarchie (,alte Fassung”)

$>$ Allgemeines Bürgerliches Gesetzbuch (,neue Fassung”)

$>$ Konsumentenschutzgesetz, BGBl 1979/140

$>$ Unternehmensgesetzbuch

$>$ Bundesgesetz, mit dem das Gewährleistung im Allgemeinen Bürgerlichen Gesetzbuch und im Konsumentenschutzgesetz sowie das Versicherungsvertragsgesetz geändert werden, BGB1 2001/48.

\section{Svájc}

$>$ Zivilgesetzbuch

$>$ Obligationenrecht

$>$ Bundesverfassung der Schweizerischen Eidgenossenschaft

$>$ Bundesgesetz über den Gerichtsstand in Zivilsachen

$>$ Bundesgesetz über Konsumkredit

$>$ Bundesgesetz gegen den unlauteren Wettbewerb

$>$ Botschaft zur Änderung des Bundesgesetzes gegen den unlauteren Wettbewerb

$>$ Bundesgesetz über die Information der Konsumentinnen und Konsumenten

$>$ Kulturgütertransfergesetz

$>$ Entwurf über das Bundesgesetz über den elektronischen Geschäftsverkehr (Teilrevisionen des Obligationenrechts und des Bundesgesetzes gegen den unlauteren Wettbewerb). 


\section{Irodalomjegyzék}

AdomeIT, Klaus - HÄHNCHEN, Susanne: Caveat emptor oder Käuferschutz um jeden Preis? In: Muscheler, Karlheinz (Hrsg.): Römische Jurisprudenz - Dogmatik, Überlieferung, Rezeption. Festschrift für Detlef Liebs zum 75. Geburtstag (Duncker \& Humblot, Berlin, 2011.), 1-9. p.

A Magyar Népköztársaság Polgári Törvénykönyve. Tervezet (Igazságügyminisztérium, Atheneum, Budapest, 1957.)

A Magyar Népköztársaság Polgári Törvénykönyve: Az 1959. évi IV. törvény és a törvény javaslatának miniszteri indokolása, továbbá a Polgári törvénykönyv hatálybalépéséröl és végrehajtásáról szóló 1960. évi 11. számú törvényerejü rendelet (Közgazdasági és Jogi Könyvkiadó, Budapest, 1963.)

A Polgári Törvénykönyv törvényjavaslatának tárgyalása a képviselőház külön bizottságában (Grill Károly Könyvkiadóvállalata, Budapest, 1915.). Elérhető: http://brittlebooks.library.illinois.edu/brittlebooks_open/Books201109/anon0001apolto/anon0001apoltov00001/anon0001apoltov00001.pdf

AKERLOF, George A.: The Market for "Lemons": Quality Uncertainty and the Market Mechanism. In: The Quarterly Journal of Economics, Volume 84, Issue 3 August, 1970, 488-500. p. Elérhetö: http://qje.oxfordjournals.org/content/84/3/488.full.pdf+html

ARLT, Claudia: Verbraucherschutz im reformierten Kaufrecht (Peter Lang, Frankfurt am Main, 2010.)

BACHER Gusztáv: A reklámban tett kijelentések és a hibás teljesítés. Magyar Jog 2005. LII. évfolyam 11. szám, 650-662. p.

BALÁSFALVI KISS Albert: A római jog receptiója a germán jogban s annak hatása az európai jogfejlődésre (M. Kir. Ferencz József Tud. egyet., Szeged, 1937.)

BALDUS, Christian: Una actione experiri debet? Zur Klagenkonkurrenz bei Sachmängeln im römischen Kaufrecht. Orbis Iuris Romani (OIR) 5 (1999) 20-83. p.

BARANYAI János - FLUCKNÉ DR. PAPÁCSY Edit - DR. ZOLTÁN Ödön (szerk.): A Polgári Törvénykönyv (Közgazdasági és Jogi Kiadó, Budapest, 1985.)

BÁRDos Benő: Szavatosság. In: Meszlényi Artur (szerk.): Magyar Jogászegyleti Értekezések, 1914. aug.-okt. hó, új folyam X. kötet, 63-66. füzet: Bíráló vélemények a Polgári Törvénykönyv törvényjavaslatáról (összegyüjtötte a Magyar Jogászegylet). IV. füzet. Kötelmi jog második fele (Franklin-Társulat Könyvnyomdája, Budapest, 1914.), 61-71. p.

BÁRDOs Péter: Kárfelelősség a Polgári Törvénykönyv rendszerében (HVGOrac, Budapest, 2001.)

BÁRTFAI Judit - BOZZAY Erika - KERTÉSZ Ágnes - WALLACHER Lajos: Új szavatossági és jótállási szabályok. Fogyasztóvédelmi jogharmonizáció a polgári jogban és a polgári eljárásjogban (HVGOrac, Budapest, 2004.)

Beckmann, Roland Michael (Hrsg.): BGB Juris Praxiskommentar. Schuldrecht, Band 2.2. (Juris, Saarbrücken, 2010.)

BENACCHIO, Giannantonio: Az Európai Közösség magánjoga (Földi András - Csizmazia Norbert ford., Osiris, Budapest, 2003.) 
BENEDEK Ferenc - PóKecz KovÁcs Attila: Római magánjog (Dialóg Campus, Budapest Pécs, 2013.)

BenedeK Károly - VilÁGHY Miklós: A Polgári Törvénykönyv a gyakorlatban. Magyar Jog 1962. IX. évfolyam 3. szám, 102-110. p.

BENEDEK Károly - VILÁGHY Miklós: A Polgári Törvénykönyv a gyakorlatban. Száz jogeset (Közgazdasági és Jogi Könyvkiadó, Budapest, 1965.)

BERÉNYI Pál: Kereskedelmi Jog. In: Stampfel-féle Tudományos Zseb-könyvtár 84. (Stampfel Károly Kiadása, Pozsony - Budapest, 1904.)

BESENYEI Lajos: Kötelmi jog. Általános rész (Pólay Elemér Alapítvány, Szeged, 2012.)

BIERMANN Mihály: Megjegyzések a magyar magánjogi törvénykönyv tervezetének a kötelmi jogot tárgyazó részére. Magyar igazságügy, 22. kötet, 1884. 1-17. p.

BíRÓ György: Kötelmi jog. Közös szabályok, szerződéstan (Novotni Alapítvány a Magánjog Fejlesztéséért, Miskolc, 2010.)

BíRÓ György: Szerződési alaptípusok (Novotni Alapítvány a Magánjog Fejlesztéséért, Miskolc, 2011.)

BLuNTSCHLI, Johann Caspar: Privatrechtliches Gesetzgebung für den Kanton Zürich (Schultheß, Zürich, 1855.)

BLUTMAN László: Az Európai Unió joga a gyakorlatban (HVGOrac, Budapest, 2010.)

BÓNIS Péter: Az ausztriai polgári törvénykönyv és polgári jogunk (Az ABGB jelentősége és hatása a magyar bírói gyakorlatra és jogfelfogásra). De iurisprudentia et iure publico, 2011. V. évf. 1. szám, 1-11. p.

BozóKY Alajos: Az ausztriai magánjog rendszere (Pallas Irodalmi és Nyomdai Részvénytársaság, Budapest, 1891.)

BRADLEY, Keith: Slavery in the Roman Republic. In: Bladley, Keith - Cartledge, Paul (ed.): The Cambridge World History of Slavery. Vol. I. (Cambridge University Press, Cambridge, 2011.), 241-264. p.

BRUNNER, Alexander: Konsumverträge - Begriff, Typologie und wirtschaftliche Bedeutung. In: Brunner, Alexander - REHBinder, Manfred - Stauder, Bernd (Hrsg.): Jahrbuch des Schweizerischen Konsumentenrechts 2004. (Stäpfli, Bern, 2007.), 3-45. p.

BuCHER, Eugen: Der benachteiligte Käufer. Schweizerische Juristen Zeitung, 1971, 11. 16., 17-24. p. Elérhető: http://www.eugenbucher.ch/pdf_files/12.pdf

BUCHER, Eugen: Schweizerisches Obligationenrecht. Besonderer Teil (Schulthess, Zürich, 1988.)

Bundesminister der Justiz (Hrsg.): Abschlußbericht der Kommission zur Überbereitung des Schuldrechts (Bundesanzeiger, Cologne, 1992.)

BÜHLER, Gregor - STÄUBER, Richard: Die AGB-Kontrolle gemäss dem revidierten Art. 8 UWG - Anmerkungen zum intemporalen Recht. Zeitschrift für juristische Weiterbildung und Praxis. 2012, 2-3., 86-90. p. Elérhetö:

http://www.homburger.ch/fileadmin/publications/recht_02-03_2012.pdf

Bürgerliches Gesetzbuch. Textausgabe mit ausführlichem Sachverzeichnis und einer Einführung von Universitätsprofessor Dr. Helmut Köhler (Deutscher Taschenbuch, München, 2010.) 
CAMOdECA, Giuseppe: Tabulae Herculanenses: riedizione delle emptiones di schiavi (TH 59-62). In: Manthe, Ulrich - Wolf, Joseph Georg - Krampe, Christoph (Hrsg.): Festschrift für Joseph Georg Wolf zum 70. Geburtstag (Duncker \& Humblot, Berlin 2000.), 53-76.

CANARIS, Claus-Wilhelm: Die Nacherfüllung durch Lieferung einer mangelfreien Sache beim Stückkauf. Juristenzeitung 2003, 58., 831-837. p.

CANARIS, Claus-Wilhelm: Die richtlinienkonforme Auslegung und Rechtsfortbildung im System der juristischen Methodenlehre. In: Koziol, Helmut - Rummel, Peter (Hrsg.): Im Dienst der Gerechtigkeit: Festschrift für Franz Bydliński (Springer, Wien, 2002.), 47-105. p.

CANARIS, Claus-Wilhelm: Schuldrechtsmodernisierung 2002 (C.H. Beck, München, 2002.)

CETINER, Bilgehan: Die Sachmängelhaftung des Verkäufers im UN-Kaufrecht und im neuen deutschen Schuldrecht (Peter Lang, Frankfurt am Main, 2006.)

Chapman, Kenneth - Meurer, Michael J.: Efficient remedies for breach of warranty. Law and Contemporary Problems, Volume 52, Number 1, Winter 1989, 107-133. p. Elérhetö:

http://scholarship.law.duke.edu/cgi/viewcontent.cgi?article=3984\&context=lcp

CHRISTIAN vON BAR, Osnabrück: A European Civil Code, international agreements and European directives (2002). Elérhető: http://www.cisg.law.pace.edu/cisg/biblio/vonbar1.html

CSÉCSY Andrea: A szerződések hibás teljesítése, szavatosság, jótállás, minőségi kifogások intézése. In: Szikora Veronika (szerk.): Magyar fogyasztóvédelmi magánjog európai kitekintéssel (FOME, Debrecen, 2010.), 71-96. p.

CSÉCSY Andrea: A szerződésszegés jogkövetkezményeinek összehasonlító jogi elemzése. Doktori értekezés (Miskolc, 2008.). Elérhető:

http://193.6.1.94:9080/JaDoX_Portlets/documents/document_5691_section_1123.pd f

CsIZMAZIA Norbert: A fogyasztói vételről szóló 1999/44/EK Irányelv és a német kötelmi jog reformja. Magyar Jog 2002. 7. szám, 429-442. p.

DAUNER-LIEB, Barbara: Das Schuldrechtsmodernisierungsgesetz in Wissenschaft und Praxis - Versuch einer Bestandsaufnahme. In: Dauner-Lieb, Barbara - Konzen, Horst - Schmidt, Karsten (Hrsg.): Das neue Schuldrecht in der Praxis (Carl Heymanns, Köln, 2003.), 3-24. p.

DAunER-LiEB, Barbara - KonZEN, Horst - SchmidT, Karsten (Hrsg.): Das neue Schuldrecht in der Praxis. Akzente - Brennpunkte - Ausblick (Heymanns, Köln, 2003.)

DELI Gergely: Az időtényező a kellékszavatosság szabályozásában. Miskolci Jogi Szemle 2008. III. évfolyam 2. szám, 30-57. p. Elérhetö:

http://www.mjsz.uni-miskolc.hu/200802/5_Deli.pdf

DENKINGER, Fleur: Der Verbraucherbegriff. Schriften zum Europäischen und Internationalen Privat-, Bank- und Wirtschaftsrecht. Band 22. (De Gruyter, Berlin, 2007.)

DONADIO, Nunzia: Garanzia per i vizi della cosa e responsabilità contrattuale. In: Jakab, Eva - Ernst, Wolfgang (Hrsg.): Kaufen nach Römischem Recht (Springer, Berlin, 2008.), 61-82. p. 
DONADIO, Nunzia: La tutela del compratore tra actiones aediliciae e actio empti (Giuffré, 2004.)

DREXL, Josef: Die wirtschaftliche Selbstbestimmung des Verbrauchers: eine Studie zum Privat- und Wirtschaftsrecht unter Berücksichigung gemeinschaftsrechtlicher Bezüge (Mohr Siebeck, Tübingen, 1998.)

ECK, Ernst: Vortrage über das Recht des Bürgerlichen Gesetzbuchs, 1. Band (J. Guttentag, Berlin, 1903.)

EMMERICH, Volker: BGB-Schuldrecht. Besonderer Teil (C. F. Müller, Heidelberg, 2012.)

EÖRSI Gyula: A polgári jogi kártérítési felelősség kézikönyve (Közgazdasági és Jogi Könyvkiadó, Budapest, 1966.)

ERNST, Wolfgang: Kleine Geschichte des Kaufrechts (Auszug). In: Schmoeckel, Mathias Rückert, Joachim - Zimmermann, Reinhard (Hrsg.): Historisch-kritischer Kommentar zum BGB. Band III. Schuldrecht Besonderer Teil §§ 433-853. (Mohr Siebeck, Tübingen, 2013.), 34-162. p.

FABER, Wolfgang: Handbuch zum neuen Gewährleistungsrecht (Neuer Wissenschaftlicher, Wien, 2001.)

FAZEKAS Judit: A fogyasztói szerződések tisztességtelen szerződési feltételeit szabályozó új európai uniós irányelv és a magyar jog. Magyar Jog 1995a. XLII. évfolyam 11. szám, 660-668. p.

FAZEKAS Judit: A fogyasztóvédelem jogi eszközei különös tekintettel a polgári jogi intézményekre. Kandidátusi értekezés tézisei (Miskolc, 1994.)

FAZEKAS Judit: A hibás teljesítés szabályozása az új Polgári Törvénykönyvben. In: GradGyenge Anikó (szerk.): Szociális elemek az új Ptk.-ban (Károli Gáspár Redormátus Egyetem Állam- és Jogtudományi Kar, Budapest, 2013.), 45-58. p.

FAZEKAS Judit: Fogyasztói jogok - fogyasztóvédelem (Közgazdasági és Jogi Könyvkiadó, Budapest, 1995b.)

FAZEKAS Judit: Fogyasztóvédelmi jog (Complex, Budapest, 2007.)

FAZEKAS Judit: Jogharmonizációs feladatok a csatlakozás után. Európai Tükör 2004. IX. évfolyam 3. szám, 18-29. p.

FERCH-FISCHER, Gerda (Hrsg.): Gewährleistung und Garantie (Service-GmbH der Wirtschaftskammer Österreichs, 2011.)

FEZER, Karl-Heinz: Klausurenkurs zum Schuldrecht. Besonderer Teil (Carl Heymanns, München, 2009.)

FINKENAUER, Thomas: Vererblichkeit und Drittwirkungen der Stipulation im klassischen römischen Recht (Mohr Siebeck, Tübingen, 2010.)

FINLEY, Moses I.: Die antike Wirtschaft (Deutscher Taschenbuch Verlag, München, 1977.)

FöLDI András: A jóhiszeműség és tisztesség elve (ELTE Állam- és Jogtudományi Kar, Budapest, 2001.)

FÖLDI András: A másért való felelősség a római jogban (Rejtjel, Budapest, 2004.)

FöLDI András - HAMZA Gábor: A római jog története és institúciói (Nemzedékek Tudása Tankönyvkiadó, Budapest, 2013.)

FÖLDI András (szerk.): Összehasonlító jogtörténet (ELTE Eötvös Kiadó, Budapest, 2012.) 
FurRer, Andreas - SCHNYDER, Anton K. (Hrsg.): Handkommentar zum Schweizer Privatrecht. Obligationenrecht, Allgemeine Bestimmungen (Schulthess, ZürichBasel-Genf, 2012.)

GAdó Gábor - NÉmeth Anita - SÁriné Simkó Ágnes: Ptk. Fordítókulcs. Oda-vissza (HVGOrac, Budapest, 2013.)

GAMAUF, Richard: Ad statuam licet confugere (Peter Lang, Franfurt am Main, 1999.)

GAMAUF, Richard: Iudicium: Die Denunziation von flüchtigen Sklaven im Spiegel der römischen Jurisprudenz. In: Gamauf, Richard (Hrsg.): Festschrift für Herbert Hausmaninger zum 70. Geburtstag (Manzsche, Wien, 2006.), 91-108. p.

GAROFALO, Luigi: Studi sull'azione redhibitoria (Cedam, Padova, 2000.)

GELLÉRT György - ZoLTÁN Ödön (szerk.): Polgári Törvénykönyv (Közgazdasági és Jogi Könyvkiadó, Budapest, 1975.)

GELLÉRT György (szerk.): A Polgári Törvénykönyv magyarázata 1. kötet (Complex, Budapest, 2007.)

GIGER, Hans: Berner Kommentar zum Schweizerischen Privatrecht. Band VI. 1. Teilband: Kauf und Tausch - Die Schenkung (Stämpfli \& Cie, Bern, 1979.)

GINTER, Petra: Verhältnis der Sachgewährleistung nach Art. $197 \mathrm{ff}$. OR zu den Rechtsbehelfen in Art. 97 ff. OR. (St. Galler Schriften zur Rechtswissenschaft. Band 11. (Schulthess, Zürich-Basel-Genf, 2005.)

GINYOVSZKY József (szerk.): Az osztrák polgári törvénykönyv hatásában a magyar magánjogra. Dr. Szladits Károly ny. r. egyetemi tanár előadásainak jegyzete (Politzer, Budapest, 1932.)

GoTTL Ágost (szerk.): A magyar kir. Curia felülvizsgálati tanácsa által a sommás eljárásról szóló törvény alapján hozott határozatoknak gyüjteménye. 6-9. kötetek (Franklin Társulat, Budapest, 1902-1905.)

GRECSÁK Károly - SÁNDOR Aladár (szerk.): Grill-féle döntvénytár. XXI. kötet (Grill Károly Könyviadóvállalata, Budapest, 1916.)

Grundmann, Stefan - Bianca, Cesare Massimo (Hrsg.): EU-Kaufrechts-Richtlinie. Kommentar (Dr. Otto Schmidt, Köln, 2002.)

GRUNEWALD, Barbara: Kaufrecht (Mohr Siebeck, Tübingen, 2006.)

GULDIMANN, Beat: Der Nachbesserungsanspruch von Käufer und Besteller im Schweizerischen Recht unter besonderer Berücksichtigung der Allgemeinen Geschäftsbedingungen und der internationalen Kaufrechtabkommen (Dissertation, Basel, 1986.)

HAJNAL Zsolt: A 169. cikk. In: Osztovits András (szerk.): Az Európai Unióról és az Európai Unió Müködéséről szóló Szerződések magyarázata. 3. kötet: Az Európai Unió működéséről szóló szerződés magyarázata II. (Complex, Budapest, 2011.), 2425-2433. p.

HAJNAL Zsolt: A fogyasztói jogok egységes európai szabályozásának lehetséges irányai. Doktori értekezés (Debrecen, 2013.). Elérhető: http://jog.unideb.hu/documents/doktori_nyilvanosvita/hajnal-ertekezes.pdf

HAJNAL Zsolt: A fogyasztóvédelem alanya: a fogyasztó. In: Szikora Veronika (szerk.): Magyar fogyasztóvédelmi magánjog - európai kitekintéssel (FOME, Debrecen, 2010.), 39-52. p. 
HAJNAL Zsolt: A fogyasztóvédelem alapjai. In: Szikora Veronika (szerk.): Magyar fogyasztóvédelmi magánjog - európai kitekintéssel (FOME, Debrecen, 2010.), 1517. p.

HÁMORI Antal: A „fogyasztó”-fogalom „dilemmái” különös tekintettel az Fgytv. módosításában és az új Ptk.-javaslatban foglaltakra. Magyar Jog 2009. LVI. évfolyam 2. szám, 88-97. p.

HAMZA Gábor: Az európai magánjog fejlődése: a modern magánjogi rendszerek kialakulása a római jogi hagyományok alapján (Nemzeti Tankönyvkiadó, Budapest, 2002.)

HAUSMANingeR, Herbert - SelB, Walter: Römisches Privatrecht (Böhlau, Wien-KölnWeimar, 1997.)

HoMOKI NAGY Mária: A magyar magánjogi kodifikáció első lépései. In: Szeged, Acta Juridica et Politica, Tom. LIII. Fasc. 11. (Szeged, 1998.), 149-160. p.

HoMOKI NAGY Mária: A magyar magánjog történetének vázlata 1848-ig (JatePress, Szeged, 2005.)

HoMOKI NAGY Mária: Die Gewährleistung für Rechtsmängel im ungarischen Privatrecht des 18 Jhs. In: Eva Jakab - Wolfgang Ernst (Hrsg.): Kaufen nach Römischem Recht (Springer, Berlin-Heidelberg, 2008.), 105-121. p.

Honsell, Heinrich - PIETRUSZAK, Thomas: Der Vernehmlassungsentwurf zu einem Bundesgesetz über den elektronischen Geschäftsverkehr. AJP (2001) 7, 771-790. p.

HONSELL, Heinrich: Quod interest im bonae-fidei-iudicium. Studien zum römischen Schadenersatzrecht (C. H. Beck, München, 1969.)

HoNSELl, Heinrich: Schweizerisches Obligationenrecht. Besonderer Teil (Stämpfli, Bern, 2010.)

Huber, Eugen: System und Geschichte des Schweizerischen Privatrechtes. Band 4. (C. Detloff, Basel, 1893.)

ILLÉS József: A magyar szerződési jog az árpádok korában. In: Magyar Jogászegyleti Értekezések XXII. kötet 4. füzet (Franklin-Társulat Könyvnyomdája, Budapest, 1901.)

Indokolás Magyarország magánjogi törvénykönyvének a m. kir. igazságügyminiszter által 1928. március 1-én az országgyülés elé terjesztett törvényjavaslatához. I. kötet (A M. Kir. Igazságügyminisztérium, Budapest, 1929.)

JAKAB Éva: Apropó jogharmonizáció: gondolatok az ókori kellékszavatossági modell kapcsán. In: Tóth Károly (szerk.): In memoriam Nagy Károly egyetemi tanár: 19322001. Acta juridica et politica, Tom. 61. Fasc. 1-26. (Szegedi Tudományegyetem Állam- és Jogtudományi Kar, Szeged, 2002.), 225-237. p.

JAKAB Éva: Az árleszállítás mértéke a szavatossági perben. Jogtudományi Közlöny 2000. LV. évfolyam 9. szám, 325-333. p.

JAKAB Éva: Chirographum in Theorie und Praxis. In: Muscheler, Karlheinz (Hrsg.): Römische Jurisprudenz - Dogmatik, Überlieferung, Rezeption. Festschrift für Detlef Liebs zum 75. Geburtstag (Duncker \& Humblot, Berlin, 2011.), 275-288. p.

JAKAB Éva: Diebische Sklaven, marode Balken: Von den römischen Wurzeln der Gewährleistung für Sachmängel. In: Martin Schermaier (Hrsg.): Verbraucherkauf in 
Europa. Altes Gewährleistungsrecht und die Umsetzung der Richtlinie 1999/44/EG (Sellier, München, 2003.), 27-53.

JAKAB Éva: Forum Romanum. Jogesetek és szerződési minták római jogból (Leges, Diligens, Szeged, 2012.)

JAKAB Éva: Humanizmus és jogtudomány. Brissonius szerződési formulái I. (Pólay Elemér Alapítvány, Szeged, 2013.)

JAKAB Éva: Kellékszavatosság és jótállás. In: Hamza Gábor - Kajtár István - Zlinszly János (szerk.): Tanulmányok Benedek Ferenc tiszteletére, Studia Iuridica 123 (JPTE ÁJK, Pécs, 1996.), 113-123. p.

JAKAB Éva: Stipulationes aediliciae, Acta juridica et politica, Tom. 44. Fasc. 7. (JATE ÁJK, Szeged, 1993.)

Jogtudományi Közlöny. Hetilap a jog- és államtudományok köréből (Dr. Dárdai Sándor szerk.), 1888. XXIII. évfolyam 7. szám (február 17.), melléklet: Curiai Határozatok, és 1894. XXIX. évfolyam 21. szám (május 25.), melléklet: Curiai Határozatok (Magyar Irodalmi Intézet és Könyvnyomda, Budapest).

JózSA Mihály: A kellékszavatosság vitás elvi kérdései. Jogtudományi Közlöny 1968. XXIII. évfolyam 11-12. szám, 603-610. p.

JUSZTINGER János: A vételár meghatározás és szolgáltatása a konszenzuális adásvétel római jogi forrásaiban. Doktori értekezés (Pécs, 2012.). Elérhető: http://doktoriiskola.ajk.pte.hu/files/tiny_mce/File/Archiv2/jusztinger/jusztinger_ertekezes_nyilv.p $\underline{\mathrm{df}}$

KALLÓs Lajos: A magyar polgári jog alapelvei (Telegdi K. Lajos, Debreczen, 1865.)

KÄMPF M., Hanno: Gewährleistung und Verbraucherschutz. Europa auf dem Weg zu einheitlichem Zivilrecht (Nomos, Baden-Baden, 2007.)

KARVASY Ágost: Az ausztriai általános polgári törvénykönyv (Eggenberger, Pest, 1870.)

KÄSER, Andreas: Die Abtretung von Gewährleistungsansprüchen bei Kauf- und Werkvertrag (Schulthess, Zürich, 2000.)

KASER, Max - KNÜTEL, Rolf: Römisches Privatrecht (C. H. Beck, München, 2014.)

KASER, MAX: Das römisches Privatrecht. Das altrömische, das vorklassische und klassische Recht (C. H. Beck, München, 1971.)

KaSER, Max: Die Jursidiction der kurulischen Ädilen, in: Philippe Meylan. Vol. 1. (Imprimerie Centrale de Lausanne, 1963.), 173-191. p.

KATONA Mór: A mai érvényü magyar magánjog vezérfonala. In: Stampfel-féle Tudományos Zseb-könyvtár 31-34. (Stampfel Károly Kiadása, Pozsony - Budapest, 1904.)

KECSKÉS László: A polgári jog fejlődése a kontinentális Európa nagy jogrendszereiben (HVGOrac, Budapest, 2009.)

KELLER, Max - SIEHR, Kurt: Kaufrecht: Kaufrecht des OR und Wiener UN-Kaufrecht (Schulthess, Zürich, 1995.)

KEMENES Béla: A fogyasztó érdekvédelmének egyes polgári jogi kérdései hibás teljesítés esetén. Jogtudományi Közlöny 1974. XXIX. új évfolyam 3. szám, 124-134. p.

KEMENES Béla: A jótállási rendszer néhány időszerü elvi kérdése. Jogtudományi Közlöny 1973b. XXVIII. új évfolyam 2. szám, 64-73. p. 
KEMENES Béla: A jótállási igények és érvényesítésük módja, különös figyelemmel az állampolgárok vételi ügyleteire. Jogtudományi Közlöny 1973c. XXVIII. új évfolyam 3. szám, 124-134. p.

KEMENES Béla: A Ptk. kellékszavatossági rendszere korszerüsítésének kodifikációs kérdései. Állam- és Jogtudomány 1973a. XV. évfolyam 4. szám, 207-233. p.

KISFALUDI András: Az adásvételi szerződés (KJK-Kerszöv, Budapest, 2003.)

KLAMERT, Marcus: Richtlinienkonforme Auslegung und unmittelbare Wirkung von EGRichtlinien in der Rechtsprechung der österreichischen Höchstgerichte. Juristen Blätter 130. (2008), 158-170. p.

KLETECKA, Andreas: Gewährleistung neu (Verlag Österreich, Wien, 2001.)

KolmaSch, Wolfgang: Das neue Gewährleistungsrecht (Orac, Wien, 2001.)

KOLOSVÁRY Bálint: A magyar magánjog tankönyve, 2. kötet. Kötelmi jog. Családjog. Öröklési jog. (Politzer Zsigmond és Fia Könyvnyomdája, Budapest, 1904.)

KovÁcs László: A polgári jogi szabályok harmonizálásának buktatói. Magyar Jog 2005. LII. évfolyam 7. szám, 425-433. p.

Koziol, Helmut - Bydlinsky, Peter - Bollenberger, Raimund (Hrsg.): Allgemeines Bürgerliches Gesetzbuch. Kommentar (Springer, Wien-New York, 2010.)

KRAINZ, Josef: System des österreichischen Privatrechts, 2. Band (Manz, Wien, 1900.)

KRAMER, Ernst A.: Die konsumentenrechtlichen Defizite des schweizerischen Kaufrechts vor dem Hintergrund der europäischen Rechtsentwicklung. In: Jahrbuch des Schweizerischen Konsumentenrechtes, 1998. 205-237. p.

KrAMER, Ernst A.: Obligationenrecht - Allgemeiner Teil (Helbing Lichtenhahn, Basel, 2009.)

KREJCI, Heinz: Konsumentenschutz und Gewährleistung. In: Reiffenstein, Maria et al. (Hrsg.): Konsumentenpolitik im Spannungsfeld von Liberalisierung und sozialer Verantwortung. Festschrift für Gottfried Mayer (Neuer Wissenschaftlicher, WienGraz, 2004.), 127-135. p.

KREJCI, Heinz: Privatrecht (Manzsche, Wien, 2007.)

KULCSÁRNÉ DR. BUZÁs Gizella (et al.): Vásárlás előtt és után - fogyasztói tudnivalók és érdekvédelem. Fogyasztói tájékoztató füzetek 8. (Országos Fogyasztóvédelmi Egyesület, Budapest, 2010.). Elérhető:

http://tamop.ofe.hu/inet/osszefogas/hu/documents/vasarlas/object/vasarlas_elott_utan .pdf

KuNCZ Ödön: A magyar kereskedelmi- és váltójog vázlata (Grill Károly Könyvkiadóvállalata, Budapest, 1922.)

KunCZ Ödön - BALÁs P. Elemér: A tisztességtelen verseny. Az 1923 : V. törvénycikk magyarázata, kiegészítve a törvényt végrehajtó rendeletekkel (Politzer Zsigmond és fia kiadása, Budapest, 1924.)

LÁNYI Márton (szerk.): Magánjog. A személyjogra, a házassági törvényre, a házassági vagyonjogra, a rokonságra, a gyámságra és gondnokságra, a dologi jogra, a kötelmi jogra, az öröklési jogra vonatkozó felsőbírósági határozatok. 2. kötet (Grill Károly Könyvkiadóvállalata, Budapest, 1911.)

LAUTNER, Julius: Grundsätze des Gewährleistungsrechtes (Polygraphischer, Zürich, 1937.) 
LEDERLE, Rosalie: Mortuus redhibetur. Die Rückabwicklung nach Wandlung im römischen Recht (Duncker \& Humblot, Berlin, 1983.)

LOOSCHELDERS, Dirk: Schuldrecht. Besonderer Teil (Franz Vahlen, München, 2011.)

LURGER, Brigitta - AUGENHOFER, Susanne: Österreichisches und Europäisches Konsumentenschutzrecht (Springer, Wien, 2005.)

LuSZCZ Viktor: A szavatosság egy módosított EK-irányelvtervezet tükrében. Gazdaság és Jog 1999. VII. évfolyam 5. szám, 15-18. p.

MÁDL Ferenc: Néhány gondolat a BGB hatásáról a magyar magánjog fejlődésére. In: Sárközy Tamás - Vékás Lajos (szerk.): Eörsi Gyula emlékkönyv (HVGOrac, Budapest, 2002.), 67-72. p.

MANTHE, Ulrich: Zur Wandlung des servus fugitivus. The Legal History Review XLIV 1976. 133-146. p.

MÁRKus Dezső (szerk.): Magyar Jogi Lexikon, VI. kötet. Pergátló kifogás - Zsupán. (Pallas Irodalmi és Nyomdai Részvénytársaság, Budapest, 1907.)

MARÓTI Egon: A déloszi rabszolgapiac és a kalózkodás. Antik tanulmányok 1. (1962.)

MEDICUS, Dieter: Das Schuldrechtsmodernisierungsgesetz - behutsame Weiterwicklung oder Systemwechsel? In: Dauner-Lieb, Barbara - Konzen, Horst - Schmidt, Karsten (Hrsg.): Das neue Schuldrecht in der Praxis (Carl Heymanns, Köln, 2003.), 61-70. p.

MEMMER, Michael: Der „schöne Kauf” des ,guten Sklaven”. Zum Sachmängelrecht im Syrisch-römischen Rechtsbuch. Zeitschrift der Savigny-Stiftung für Rechtsgeschichte 107 (1990), 1-45. p.

MEYER, Jürgen (Hrsg.): Charta der Grundrechte der Europäischen Union (Nomos, BadenBaden, 2006.)

Micklitz, Hans-W - STUYCK, Jules - TERryn, Eveline (ed.): Cases, Materials and Text on Consumer Law (Hart Publishing, Oxford-Portland, 2010.)

MisERA, Karlheinz: Der Kauf auf Probe im klassischen römischen Recht. ANRW II/14 (1982), 524-582. p.

MOLNÁR Imre - JAKAB Éva: Római jog (Leges, Diligens, Szeged, 2012.)

MolnÁr Sz. Bence: Termék-szavatosság az új Ptk.-ban. Világgazdaság online (2013). Elérhető: http://www.vg.hu/kozelet/jog/termek-szavatossag-az-uj-ptk-ban-412758

Müller-Chen, Markus - Huguenin, Claire - GiRsberger, Daniel (Hrsg.): Handkommentar zum Schweizer Privatrecht. Vertragsverhältnisse Teil 1: Innominatkontrakte, Kauf, Tausch, Schenkung, Miete, Leihe (Schulthess, ZürichBasel-Genf, 2012.)

NAGY Ferenc: A magyar kereskedelmi jog kézikönyve. Különös tekintettel a bírói gyakorlatra és a külföldi törvényhozásokra, II. kötet (8. átdolgozott kiadás, Az Athenaeum Irodalmi és Nyomdai R.-T. Kiadása, Budapest, 1913.)

Nagy Éva - Pecze Dóra: Polgári jog I. (Dialóg Campus, Budapest-Pécs, 2007.)

NÉMETH Gábor (szerk.): A Polgári Törvénykönyv és gyakorlata. II. rész: Kötelmi jog általános rész (Kézirat, 1982.)

NEUENSCHWANDER, Markus: Die Schlechterfüllung im schweizerischen Vertragsrecht (Dissertation, Bern, 1971.) 
OszTovits András (szerk.): Az Európai Unióról és az Európai Unió Működéséről szóló Szerződések magyarázata. 3. kötet: Az Európai Unió működéséről szóló szerződés magyarázata II. (Complex, Budapest, 2011.)

OszTovits András: A fogyasztó fogalma az új Ptk.-ban (2013a.). Elérhető: http://ptk2013.hu/szakcikkek/osztovits-andras-a-fogyaszto-fogalma-az-uj-ptk$\underline{\text { ban } / 2267}$

OszTOVITS András: Tisztességtelen feltételek fogyasztói szerződésekben. In: Grad-Gyenge Anikó (szerk.): Szociális elemek az új Ptk.-ban (Károli Gáspár Redormátus Egyetem Állam- és Jogtudományi Kar, Budapest, 2013b.), 59-67. p.

PÁlfalvi József: Szavatosság, jótállás, felelősség. Magyar Jog 1975. XXII. évfolyam 11. szám, 661-663. p.

PARISI, Francesco: The Harmonization of Legal Warranties in European Law: an Economic Analysis. American Journal of Comparative Law, Volume 52, Number 2, Spring, 2004, 1-43. p. Elérhetö:

http://www.law.gmu.edu/assets/files/publications/working_papers/01-20.pdf

PEKARY, Thomas: Die Wirtschaft der griechisch-römischen Antike (Wiesbaden, 1979.)

PERNER, Stefan - SPITZER, Martin: Bürgerliches Recht (Manzsche, Wien, 2007.)

PETERS, Frank: Die Rücktrittsvorbehalte des römischen Kaufs (H. Böhlau, Köln-Wien, 1973.)

PETRIK Ferenc (szerk.): Szavatosság és jótállás (Közgazdasági és Jogi Könyvkiadó, Budapest, 1990.)

PETRIK Ferenc (szerk.): Szavatosság, jótállás és jogyasztóvédelem (Közgazdasági és Jogi Könyvkiadó, Budapest, 1995.)

PETRUCCI, Aldo: Per una storie della protezione dei contraenti con gli imprenditori I. (G. Gioppichelli, Torino, 2007.)

PICHONNAZ, Pascal: Die Schweiz und das Römische Recht (Sonderdruck). In: Fargnoli Iole - Rebenich, Stefan (Hrsg.): Das Vermächtnis der Römer. Ein Bild in groben Zügen (Haupt, Bern, 2012.), 21-46. p.

PichonNAZ, Pascal: Überlegungen zur „,autonomen” Umsetzung der Richtlinie 1999/44/EG den Verbrauchsgüterkauf in der Schweiz. In: Schermaier, Martin (Hrsg.): Verbraucherkauf in Europa. Altes Gewährleistungsrecht unf die Umsetzung der Richtlinie 1999/44/EG (Sellier, München, 2003.), 287-301. p.

PIRKER-HÖRMANN, Beate - HAMMERL, Alexandra: Das neue Gewährleistungsrecht (Verlag Österreich, Wien, 2004.)

Plate, Jürgen: Das gesamte examensrelevante Zivilrecht (Springer, Heidelberg, 2011.)

PóKECZ KovÁCs Attila: A szerződéstől való elállás az adásvétel mellékegyezményeinél a római jogban és továbbélése során (Pécsi Tudományegyetem Állam- és Jogtudományi Kar, Pécs, 2012.)

PÓLAY Elemér: A dáciai viaszostáblák szerződései (Közgazdasági és Jogi Könyvkiadó, Budapest, 1972.)

PÓLAY Elemér: Az eladói kellékszavatosság a preklasszikus római jogban, Acta Juridica et Politica, Tom. 11. Fasc. 9. (JATE ÁJK, Szeged, 1964.) 
PóLAY Elemér: Az eladói kellékszavatosság szabályozásának első megjelenése a római jogban. In: A Szegedi Tudományegyetem Állam- és Jogtudományi Karának Évkönyve. Red. E. Schultheisz (Budapest, 1953.), 115-136. p.

PólAY Elemér: Die Rolle der Stipulation in den Urkunden der Siebenbürgischen Wachstafeln. JJP 15 (1965), 185-220. p.

PRIEST, George L.: A Theory of the Consumer Product Warranty. Yale Law Journal, Volume 90, Number 6, May 1981, 1297-1352. p. Elérhető: http://digitalcommons.law.yale.edu/cgi/viewcontent.cgi?article $=1570 \&$ context $=$ fss_p apers

RAFFAY Ferencz: A magyar magánjog kézikönyve. II. kötet: Dologi jog, Kötelmi jog és Öröklési jog (Benkő Gyula CS. És Kir. Udv. Könyvkereskedése, Budapest, 1909.)

Rechtsanwaltskanzlei Foglar - Deinhardstein \& Brandstetter KEG: Gewährleistungsreform - Warranty Reform (Wien, Juni 2001). Elérhető:

http://www.fdblawyers.com/PDF/newsletter_01.pdf

ReETZ, Peter - ZimMERLI, Christoph: Kauffertrags-, Werkvertrags- und Auftragsrecht. Entwicklungen 2011. (Stämpfli, Bern, 2012.)

REICH, Norbert - MickLiTZ, Hans-W.: Europäisches Verbraucherrecht (Nomos, BadenBaden, 2003.)

REMIEN, Oliver: Zwingendes Vertragsrecht und Grundfreiheiten des EG-Vertrages (Mohr Siebeck, Tübingen, 2003.)

RIESENHUBER, Karl: Europäisches Vertragsrecht (De Gruyter Recht, Berlin, 2003.)

Rogerson, A.: Implied Warranty against Latent Defects in Roman and English Law. In: Daube, David (ed.): Studies in the Roman Law of Sale (Clarendon Press, Oxford, 1959.), 112-131. p.

RosentHAL, Heinrich: Bürgerliches Gesetzbuch: gemeinverständlich erläutert unter besonderer Berücksichtigung der Rechtsverhältnisse des täglichen Lebens (Heymann, Berlin, 1927.)

RоTH, Wulf-Henning: Die Europäisierung des Bürgerlichen Gesetsbuchs. In: Dauner-Lieb, Barbara - Konzen, Horst - Schmidt, Karsten (Hrsg.): Das neue Schuldrecht in der Praxis (Carl Heymanns, Köln, 2003.), 25-39. p.

RÖSLER, Hannes: Europäisches Konsumentenvertragsrecht (C. H. Beck, München, 2004.)

RUSZOLY József: Európai jog- és alkotmánytörténelem (Pólay Elemér Alapítvány, Szeged, 2011.)

SÄÄF, Johannes: Leistungsstörungen im Kauf- und Werkvertragsrecht - Landbericht Österreich. In: DACH Europäische Anwaltsvereinigung e.V. (Hrsg.): Gewährleistungsrecht im Kauf- und Werkvertrag (Schulthess, Zürich, 2005.), 49-62. p.

SAN NiCOLO, Mariano: Die Schlussklauseln der altbabylonischen Kauf und Tauschverträge (O. Beck, München, 1922.)

SÁRINÉ DR. SimKÓ Ágnes (szerk.): Szerződési jog - fogyasztóvédelem (HVGOrac, Budapest, 2000.)

Schulte-Nölke, Hans - Twigg-Flesner, Christian - Ebers, Martin (ed.): EC Consumer Law Compendium. The Consumer Aquis and its transposition in the Member States (Sellier, Munich, 2008.) 
SchUlze, Reiner - GRzIWOTZ, Herbert - LAUdA, Rudolf: Bürgerliches Gesetzbuch (Nomos, Baden-Baden, 2011.)

SCHUMACHER, Leonard: Sklaverei in der Antike. Alltag und Schicksal der Unfreien (C. H. Beck, München 2001.)

SchWARZ Gusztáv: Ujabb magánjogi fejtegetések (Politzer, Budapest, 1901.)

Schwimann, Michael: Praxiskommentar zum ABGB. Band 5. (Orac, Wien, 1997.)

SELB, Walter: Das prätorische Edikt: Vom rechtspoltischen Programm zur Norm. In: Benöhr, Hans-Peter - Hackl, Karl - Knütel, Rolf - Wacke, Andreas (Hrsg.): Iuris Professio. Festgabe für Max Kaser zum 80. Geburtstag (Hermann Böhlhaus, WienKöln-Graz, 1986.), 259- 272. p.

SivesAnd, Hanna: The Buyers' Remedies for Non-Conforming Goods (Sellier, Munich, 2005.)

SteIN, Peter: Medieval Discussions of the Buyer's Actions for Phisical Defects. In: Daube, David (ed.): Studies in the Roman Law of Sale (Clarendon Press, Oxford, 1959.), 102-111. p.

STIASSNY József: A mindennapi élet jogi problémái. A magyar polgári magánjog gyakorlati kézikönyve (Székely Nyomda és Könyvkiadó Vállalat, Budapest, 1904.)

STÖBER, Michael: Beschaffenheitsgarantien des Verkäufers (Duncker \& Humblot, Berlin, 2005.)

STÖCKLI, Hubert: Der neue Art. 8 UWG - offene Inhaltskontorlle, aber nicht für alle. In: BR/DC Zeitschrift 4/2011. 184-188. p. Elérhető:

http://www.unifr.ch/zrhr/assets/files/Documents/Publikationen/Stoeckli/Aufsatz_BR \%201.pdf

SUHAYDA János: A magyar polgári anyagi magánjog rendszere. Az Országbírói Értekezlet által megállapított szabályokhoz alkalmazva (A magyar királyi egyetemi nyomdából, Buda, 1869.)

SzIKORA Veronika: A fogyasztóvédelmi jog történeti kialakulása Európában, különös tekintettel a magánjog-egységesítési folyamatokra. In: Szikora Veronika (szerk.): Magyar fogyasztóvédelmi magánjog - európai kitekintéssel (FOME, Debrecen, 2010.), 19-29. p.

SzIKORA Veronika: Az új magyar Polgári Törvénykönyv kodifikációja és társasági jogi összefüggései (nemzetközi kitekintéssel). In: Szalma József (szerk.): A Magyar Tudomány Napja a Délvidéken: 2012. (Újvidék: Vajdasági Magyar Tudományos Társaság, 2013.), 133-158. p. Elérhetö:

http://www.vmtt.org.rs/mtn2012/133_158_Szikora_A.pdf

SzLADITS Károly (szerk.): A magyar magánjog. IV. kötet: Kötelmi jog különös rész (Grill Károly Könyvkiadóvállalata, Budapest, 1942.)

SzLADITS Károly: A magyar magánjog vázlata. II. kötet (Grill Károly Könyvkiadóvállalata, Budapest, 1933.)

SzLADITS Károly: Az eladó felelőssége az eladott dolog minőségéért. (Kellékszavatosság). In: Almási Antal et al. (szerk.): Emlékkönyv Nagy Ferenc huszonöt éves egyetemi tanárságának megünneplésére (Athenaeum, Budapest, 1906.), 285-383. p.

SZLADITS Károly - FÜRST László: A magyar bírói gyakorlat. Magánjog. II. kötet (Grill Károly Könyvkiadóvállalata, Budapest, 1935.) 
SzLADITS Károly - FÜRST László - DR. UJLAKI Miklós: Magyar magánjog mai érvényében. Kötelmi jog. II. kötet (Grill Károly Könyvkiadóvállalata, Budapest, 1934.)

TÁRCZY Edit: Milyen változást hoz a fogyasztók jogairól szóló irányelv (a tájékoztatás és az elállás vonatkozásában)? Fogyasztóvédelmi Szemle 2012. májusi szám. Elérhető: http://www.fvszemle.hu/aktualis_szam/2012_majus/kilato/fogyasztoi_iranyelv/

TEMESVÁRI Jenő: Jótállás - szavatosság - alkalmassági idő (Novorg, Budapest, 1996.)

ThiElmanN, Georg: 'Actio redhibitoria' und zufälliger Untergang der Kaufsache (mit Beiträgen zur Frage der Pönalität der ädilizischen Klagen). In: Studi in onore di Edoardo Volterra. Vol. 2. (Giuffré, Milano, 1971.), 487-520. p.

TóTH Lajos: Magyar magánjog. Kötelmi jog (Magyar Tudományos Akadémia, Debrecen, 1938.)

TöRÖK Gábor (szerk.): A Polgári Törvénykönyv magyarázata. 3. kötet, Kötelmi jog: általános rész (Magyar Hivatalos Közlönykiadó, Budapest, 2006.)

VAVRIK Béla - GYOMAI Zsigmond (szerk.): Grill-féle döntvénytár. Magánjog. II. kötet 2. rész: Családjog és kötelmi jog (Grill Károly Könyvkiadóvállalata, Budapest, 1906.)

VÉKÁS Lajos (szerk.): Szakértői Javaslat az új Polgári Törvénykönyv tervezetéhez (Complex, Budapest, 2008.)

VÉKÁS Lajos: A fogyasztói adásvételről szóló irányelv és átültetése a magyar polgári jogba. Magyar Jog 2000. XLVII. évfolyam 11. szám, 646-659. p.

VÉKÁS Lajos: A hibás teljesítés tényállása és a reális teljesítés alapelve Polgári Törvénykönyvünkben. In: Acta Facultatis Politico-Iuridicae Universitatis Scientiarium Budapestinensis de Rolando Eötvös Nominatae. Tom. IX. (Tankönyvkiadó, Budapest, 1967.), 195-211.p.

VÉKÁS Lajos (szerk.): A Polgári Törvénykönyv magyarázatokkal (Complex, Budapest, 2013.)

VÉKÁS Lajos: Az európai közösségi magánjog sajátos alanyáról: a „fogyasztó” fogalmáról. Európai Jog 2002. II. évfolyam 5. szám, 3-13. p.

VÉKÁS Lajos: Az új Polgári Törvénykönyv elméleti elökérdései (HVGOrac, Budapest, 2001a.)

VÉKÁS Lajos: Európai közösségi fogyasztóvédelmi magánjog. In: Vékás Lajos (szerk.): Európai közösségi jogi elemek a magyar magán- és kereskedelmi jogban (KJKKerszöv, Budapest, 2001b.), 58-84. p.

VILÁGHY Miklós - EÖRSI Gyula: Magyar polgári jog. II. kötet (Tankönyvkiadó, Budapest, 1962.)

VILLÁNYI László: A magyar magánjog rövid tankönyve (Grill Károly Könyvkiadóvállalata, Budapest, 1941.)

WACKE, Andreas: Die Menschenwürde von Sklaven im Spiegel des Umgehungsgeschäfts nach Sextus Pedius. Si alii rei homo accedat und D. 21,1,44 pr. In: Martin J. Schermaier - J. Michael Rainer - Laurens C. Winkel (Hrsg.): Iurisprudentia universalis. Festschrift für Theo Mayer-Maly (Böhlau, Köln-Weimar-Wien, 2001.), 811-836. p.

WAGNER, Gerhard: Mortuus redhibetur in neuen Schuldrecht? In: Baums, Theodor Huber, Ulrich - Wertenbruch, Johannes - Lutter, Marcus - Schmidt, Karsten 
(Hrsg.): Festschrift für Ulrich Huber: zum siebzigsten Geburtstag (Mohr Siebeck, Tübingen, 2006.), 591-624. p.

WeBER, Rolf H.: Berner Kommentar, Bd. VI/1/5, Die Folgen der Nichterfüllung, Art. 97109 OR (Stämpfli, Bern, 2000.)

Wellmann György: A hibás teljesítés egyes jogértelmezési kérdései I. Gazdaság és Jog 2004. XII. évfolyam 11. szám, 10-14. p.

Wellmann György: Az új Ptk. magyarázata V/VI. Kötelmi jog első és második rész (HVGOrac, Budapest, 2013.)

WestermanN, William L.: The Slave Systems of Greek and Roman Antiquity (Philadelphia, 1955.)

WIEACKER, Franz: Privatgeschichte der Neuzeit (Vandenhoeck \& Ruprecht, Göttingen, 1967.)

WINDSCHEID, Bernhard: Lehrbuch des Pandektenrechts, 2. Band (Bütten und Loening, Frankfurt/Main, 1891.)

ZEHNDER, Hannes: Die Mängelrüge im Kauf-, Werkvertrags- und Mietrecht. Schweizerische Juristen-Zeitung, 96 (2000) 23. 545-550. p. Elérhető: http://www.avsz.ch/fileadmin/Dateien/Publikationen/zehnder.pdf

ZERRES, Thomas: Bürgerliches Recht (Springer, Heidelberg, 2010.)

ZIMMER, Daniel: Das geplante Kaufrecht. In: Ernst, Wolfgang - Zimmermann, Reinhard: Zivilrechtswissenschaft und Schuldrechtsreform (Mohr Siebeck, Tübingen, 2001.), 191-204. p.

ZimmermanN, Peter: Leistungsstörungen im Kauf- und Werkvertagsrecht - Landbericht Deutschland. In: DACH Europäische Anwaltsvereinigung e.V. (Hrsg.): Gewährleistungsrecht im Kauf- und Werkvertrag (Schulthess, Zürich, 2005.), 25-48. p.

ZIMMERMANN, Reinhard: Comparative Foundations of a European Law of Set-Off and Prescription (Cambridge University Press, Cambridge, 2002.)

ZimmermanN, Reinhard: Contract Law Reform: The German Experience. In: Vogenauer, Stefan - Weatherill, Stephen: The Harmonisation of European Contract Law (Hart Publishing, Oxford-Portland-Oregon. 2006a.), 71-87. p.

ZimmermanN, Reinhard: The Law of Obligations. Roman Foundations of the Civilian Tradition (Oxford University Press, New York, 1996.)

ZimMERMANN, Reinhard: The New German Law of Obligations (Oxford University Press, Oxford-New York, 2006b.)

ZLINSZKY Imre: A magyar magánjog mai érvényében. Különös tekintettel a gyakorlat igényeire (Franklin Társulat, Magyar Irodalmi Intézet és Könyvnyomda, Budapest, 1899.)

ZoLTÁN Ödön: Adásvétel és csere (Közigazgatási és Jogi Könyvkiadó, Budapest, 1962.)

ZoLTÁN Ödön: A hibás teljesítéssel okozott kárért való felelősség és a jótállás új szabályozásáról. Jogtudományi Közlöny 1970c. XXV. új évfolyam 9. szám, 480-484. p.

ZoLTÁN Ödön: A szavatossági jogok érvényesítésének szabályozásáról. Jogtudományi Közlöny 1970b. XXV. új évfolyam 7. szám, 341-346. p. 
ZOLTÁN Ödön: A szavatossági jogok új szabályozásáról. Jogtudományi Közlöny 1970a. XXV. új évfolyam 2-3. szám, 69-75. p.

ZsÖGÖD Benö: Fejezetek kötelmi jogunk köréböl. II. kötet (Athenaeum, Budapest, 1900.) 